Renato Vilela Faria

\title{
NATUREZA JURÍdiCA dA RETENÇÃO NA FONTE DO IMPOSTO SOBRE A RENDA.
} SÃO PAULO - JANEIRO DE 2012 
RENATO VILELA FARIA

\title{
NATUREZA JURÍDICA DA RETENÇÃO NA FONTE DO IMPOSTO SOBRE A RENDA
}

\author{
Dissertação apresentada como requisito para \\ habilitação ao título de Mestre em Direito, sob a \\ orientação do Prof. Dr. Luís Eduardo Schoueri, \\ na área de Direito Econômico, Financeiro e \\ Tributário da Faculdade de Direito da \\ Universidade de São Paulo
}

Faculdade de Direito da Universidade de São Paulo

São Paulo - Janeiro de 2012 


\section{DEDICATÓRIA}

Para Carolina, meu porto seguro e meu amor, que, pacientemente, compreendeu e apoiou as longas horas de distância e de privação; ao pequeno príncipe Gabriel, que sem saber direito os porquês de minha ausência, me fortalecia a cada dia com suas risadas e seus choros, sempre me recebendo com muito amor e carinho; e à pequena Alice, que em breve chegará nesse mundo, e completará o principal tripé da minha vida.

Essa dedicatória é o mínimo que posso oferecer. 


\section{AGRADECIMENTOS}

Ao Professor Luís Eduardo Schoueri, fonte de inspiração, por meio de inigualável exemplo de dedicação à vida acadêmica, com o aperfeiçoamento e o enriquecimento constantes do universo tributário no Brasil e no mundo. Mais do que um orientador e mais do que um professor, Luís Eduardo Schoueri foi um grande mestre e amigo, com o qual tive a enorme felicidade de conhecer um novo (e melhor) Direito Tributário, além dos livros e além das leis. Qualquer tentativa de resumir em palavras o agradecimento pelas inúmeras oportunidades oferecidas ao longo dos últimos anos será diminuta. Agradeço pela acolhida no Mestrado na Faculdade de Direito da Universidade de São Paulo, pelos debates, pelo estímulo e pelo tempo dispendido em revisões, reuniões e orientações.

Aos Professores Paulo Ayres Barreto e Guilherme Adolfo dos Santos Mendes, pelas valiosas lições e contribuições proporcionadas na Banca de Qualificação e em debates ocasionais.

Se é verdade que o período em que estamos imersos em um curso de Mestrado nos isolamos e nos privamos daquilo de melhor que temos em nossas vidas, a família e os amigos, não é menos verdade que nesse período construímos uma importante rede de amigos que, ao menos por um tempo, tornam-se nossa segunda família, com a qual espero sempre estar por perto de agora em diante. Foram várias famílias acadêmicas que participei e convivi nesses anos.

Agradeço aos colegas professores-monitores que, juntos, tivemos a oportunidade mais que especial de participar da formação do Curso de Especialização em Direito Tributário, já em sua segunda turma. Agradecimentos especiais aos guerreiros acadêmicos Alberto Macedo e Rodrigo de Freitas.

Aos colegas Carlos Otávio e Lucas Bevilacqua, por compartilhar de momentos importantes de nossas obrigações acadêmicas no dia a dia do Mestrado.

Ao grande amigo Ricardo Maitto, primeiro incentivador para meu ingresso nessa empreita acadêmica. Agradeço aos exemplos dados, aos trabalhos de revisão, às dicas fruto da experiência e, mais que tudo, à amizade.

Ao amigo e, hoje, mestre, Luís Flávio Neto, pelas oportunas palavras de incentivo, pela amizade construída nesses anos e, também, pela paciência e pela ajuda na revisão deste texto.

Aos amigos, de Passos e de São Paulo, do Mackenzie e da USP, do meio jurídico ou não que, de uma forma ou de outra, contribuíram para a realização desse trabalho.

Aos colegas da Navarro Advogados, pelas contribuições diárias, seja por meio de debates sobre temas técnicos do Imposto de Renda, seja por meio de palavras de incentivo, em especial ao Tadeu Navarro, que proporcionou um ambiente profissional de tranqüilidade e confiança, sem o qual a conclusão desta etapa acadêmica seria muito mais árdua. 
Por fim, e mais importantes, agradeço a meus pais e meus irmãos. À minha querida e saudosa mãe, Siomara Lage Villela Faria, exemplo primeiro e único de ser humano e fonte de inspiração pela vida docente. A meu pai, Sebastião Oliveira Faria, meu grande herói e meu grande amigo, por sempre apoiar meu crescimento pessoal, profissional e acadêmico. Aos meus irmãos, por simplesmente serem as pessoas maravilhosas que são. 


\section{RESUMO}

No contexto do sistema tributário nacional, a tributação da renda obriga o legislador não apenas a obedecer aos princípios abrigados sob o manto da Constituição Federal, mas também ao atendimento dos valores impregnados na sociedade, de forma que seus trabalhos sejam orientados por meio da ponderação de prioridades. O princípio da praticabilidade é tomado neste estudo como a pedra de toque no debate sobre a validade da incidência do Imposto de Renda na Fonte. A praticabilidade, elevada ao grau de princípio, é confrontada com outros princípios constitucionais, em especial com a capacidade contributiva, a vedação ao confisco, o mínimo existencial e a segurança jurídica. Focado nos aspectos material, temporal e quantitativo da regra matriz do Imposto Sobre a Renda, o presente estudo procura identificar os regimes jurídicos aplicáveis a cada uma das situações onde este imposto incide, de forma antecipada e isolada, por meio do conceito da retenção na fonte, com a transferência da responsabilidade por seu pagamento para a fonte pagadora. O tema é examinado sob a ótica do Imposto de Renda na Fonte, sobretudo no tocante às pessoas físicas, onde surge um campo maior de questionamentos. A presente abordagem percorre, primeiro, o campo específico do Imposto sobre a Renda e, em um segundo momento, descortina o aspecto subjetivo deste imposto. Na primeira parte, amparados pela Constituição Federal e pela legislação infraconstitucional, busca-se a identificação do conceito de renda e dos principais aspectos de seu fato gerador, com ênfase na disponibilidade ou realização dessa renda e na aquisição de um acréscimo patrimonial. A relevância do aspecto temporal se dá no confronto com as regras de retenção do imposto na fonte, na medida em que determina que o pagamento do imposto seja realizado de forma antecipada e isolada dos demais rendimentos. Na segunda parte, o foco é direcionado para a responsabilidade tributária, com a discussão acerca da classificação dos possíveis sujeitos passivos indiretos, com ênfase nas figuras do substituto tributário e do agente de retenção e a relação com o contribuinte, ora excluindo sua responsabilidade ora a mantendo, de forma supletiva. Ao final, além de propor regras gerais aplicáveis a cada um dos dois regimes jurídicos próprios do Imposto de Renda na Fonte, são analisados casos práticos que revelam características daqueles dois regimes.

Palavras-chaves: 1. Direito tributário - Imposto de Renda. 2 Imposto de Renda - Direito tributário. 3. Imposto de Renda na Fonte. 4. Sujeição Passiva - Substituição Tributária. 5. Agente de Retenção 


\begin{abstract}
In the context of the Brazilian tax system, taxation of income demands the legislator not only to obey the principles sheltered under the mantle of the Federal Constitution, but also to meet the values imbued within the society, so that his activities shall be guided by means of consideration of priorities. The Principle of Praticability in this study is taken as the touchstone in the debate on the validity of the applicability of the withholding tax. Praticability, raised at a principle level, is considered before other constitutional principles, specially the ability to pay, the prohibition of confiscation, the minimum existence and legal certainty, Focusing on the material, temporal and quantitative aspects of the rulearray of the income tax, the present study aims to identify the legal regimes applicable to each of the situations where said tax is levied, in advance and isolated through the so called source concept, with the transfer of the tax liability to the source payer. The issue is examined before the perspective of the withholding tax, especially with regard to the individuals, where it seems to appear a larger field of challenges. This approach runs, firstly, the specific field of the income tax and, secondly, reveals the subjective aspect of such tax. In the first part, supported by the Federal Constitution and by the infraconstitutional law, seeks to identify the concept of income and the main aspects of its taxable event, with emphasis on the availability or realization of said income and the acquisition of an equity increase. The relevance of the temporal aspect operates when confronting with the rules of the withholding tax, as this determines that the payment must be realized in advance and isolated from other income. In the second part, the focus is driven to the tax liability, through the discussion on the classification of the possible indirect taxpayers, with emphasis to the figures of the Tax Substitution and the withholding agent and the relationship with the taxpayer, sometimes excluding his tax liability and sometime keeping his tax liability, in a supplementary manner. At the end, besides in proposing general rules applicable to each of the two legal regimes of the Withholding Tax, there is the examination of case studies which reveals characteristics from both regimes.
\end{abstract}

Keywords: 1. Tax Law - Income Tax. 2 Income Tax - Tax Law. 3. Withholding Income Tax. 4. Taxable Person - Tax Substitution. 5. Withholding Agent. 


\section{NATUREZa JURÍdica da RETENÇão Na Fonte DO IMPOSTO SOBRE A RENDA.}

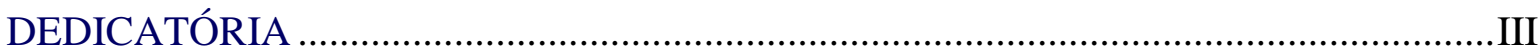

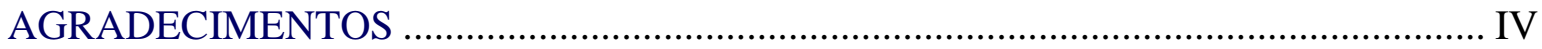

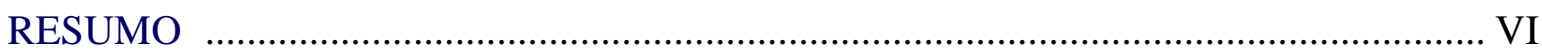

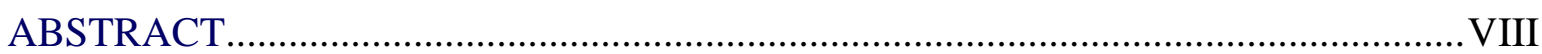

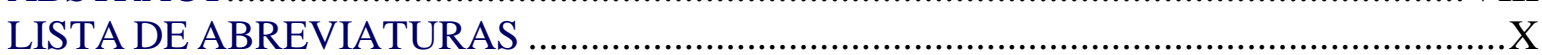

\section{Sumário}

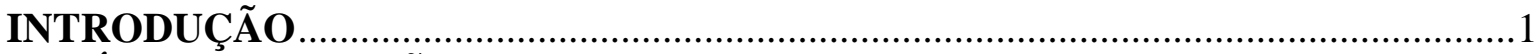

CAPÍTULO I - NOÇÕES PRELIMINARES E PREMISSAS ................................. 15

1.1. $\quad$ O Estado de Direito e a Relação Jurídica Tributária............................................15

1.2. O Antecedente e o Consequente da Regra Matriz ..........................................19

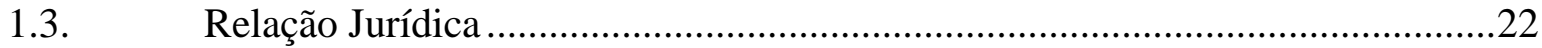

1.4. Obrigação Tributária (Principal) e Deveres Instrumentais ................................26

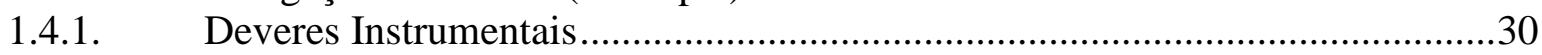

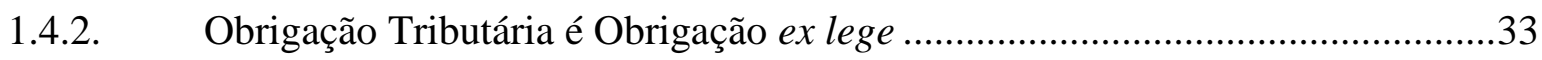

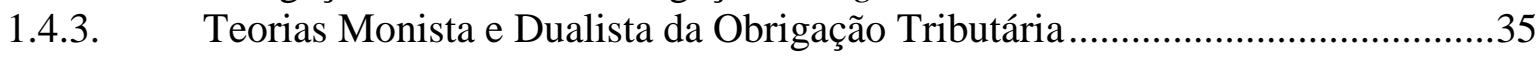

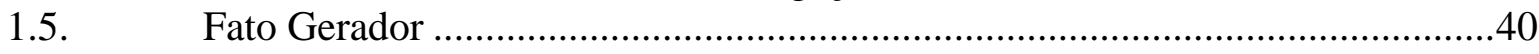

CAPÍTULO II - O IMPOSTO SOBRE A RENDA E O IMPOSTO SOBRE A RENDA COBRADO NA FONTE .......................................................4

1.6. Os Princípios Gerais Constitucionais Informadores da Hipótese Tributária do

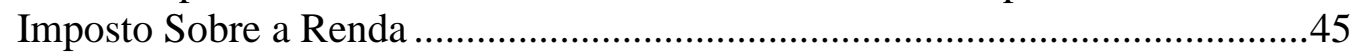

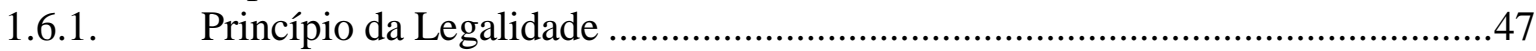

1.6.2. Princípio da Igualdade e da Capacidade Contributiva e o Mínimo

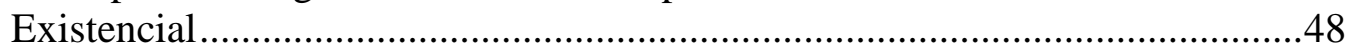

1.6.3. Certeza do Direito e Segurança Jurídica ......................................................52

1.6.4. A Justiça Fiscal como Denominador Comum ...................................................53

1.7. Universalidade, Generalidade e Progressividade - Os Princípios

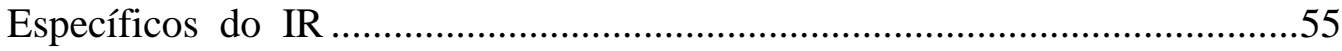

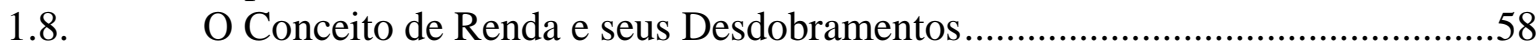

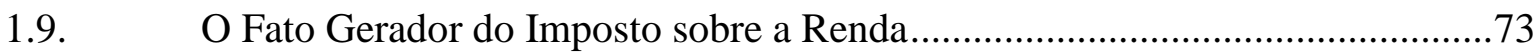

1.9.1. Aquisição da Disponibilidade Econômica ou Jurídica ........................................75

1.9.2. Disponibilidade como sinônimo de Realização ...............................................78

1.9.3. Aquisição de Aumento Patrimonial e o Aspecto Temporal................................82

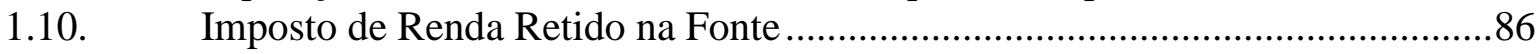

1.10.1. Breve Contexto Histórico no Direito Comparado - A Experiência Anglo-

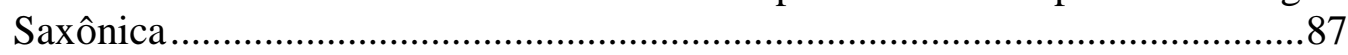

1.10.2. Regime de Tributação na Fonte em Outros Países ............................................91

1.10.3. A Origem da Tributação do IRF no Brasil e seus Regimes Jurídicos ...............93

1.10.3.1. Sistemática de Tributação do Imposto de Renda antes do IRF .........................99

1.10.3.2. Regime de Retenção Exclusiva na Fonte .....................................................101

1.10.3.3. Regime de Retenção na Fonte como Antecipação do IR Devido .....................110

1.10.4. A Natureza Jurídica do IRF sob a ótica do CTN ............................................117

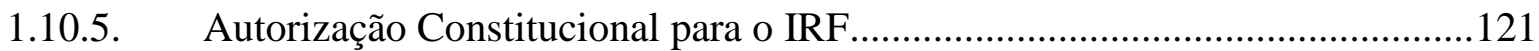

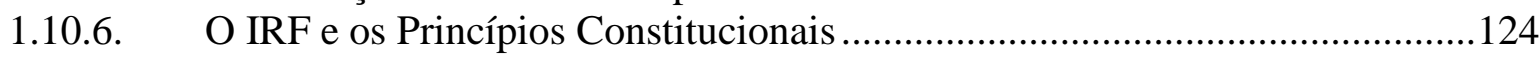




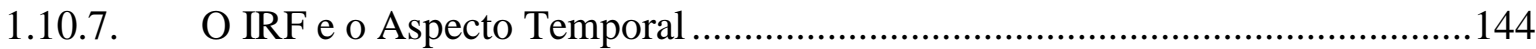

1.10.8. Capacidade Contributiva e a Retenção ............................................................153

CAPÍtULO III - O ASPECTO SUBJETIVO DO FATO GERADOR DA OBRIGAÇÃO TRIBUTÁRIA ....................................................................155

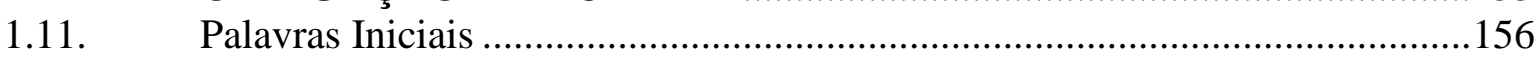

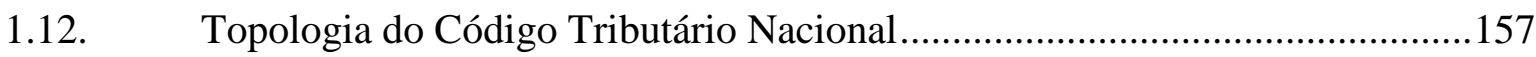

1.13. A Constituição Federal como Elemento Limitador ........................................158

1.13.1. Posicionamento Doutrinário com Relação aos Limites Constitucionais para Eleição do Sujeito Passivo .........................................................................160

1.13.2. Limitações Constitucionais como Critérios Informadores da Condição de Contribuinte e como Critérios para a Eleição do Sujeito Passivo ....................162

1.13.2.1. O Princípio da Legalidade e a Competência Tributária.....................................164

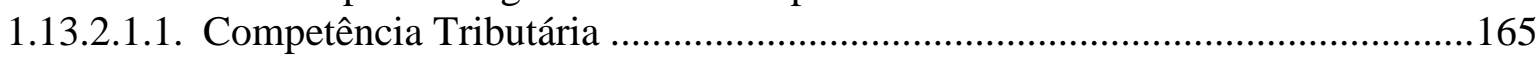

1.13.2.2. O Princípio da Capacidade Contributiva .......................................................167

1.13.2.3. O Princípio da Vedação de Tributo com Efeito de Confisco..............................172

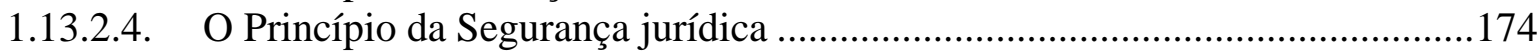

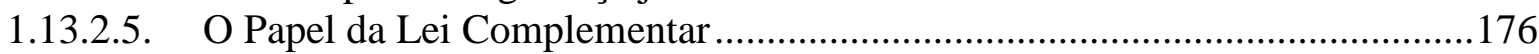

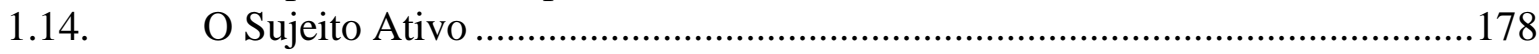

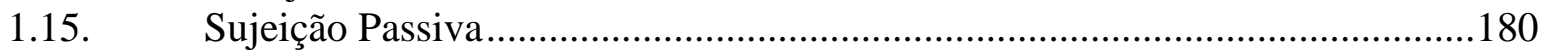

1.15.1. Sujeição Passiva Direta - O Contribuinte da Obrigação Tributária .................183

1.15.2. Sujeição Passiva Indireta da Relação Jurídica Tributária ................................186

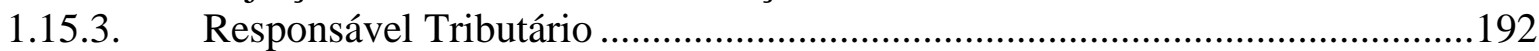

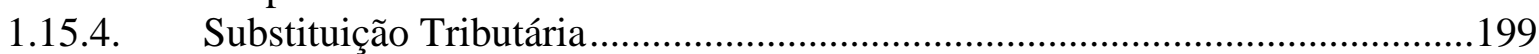

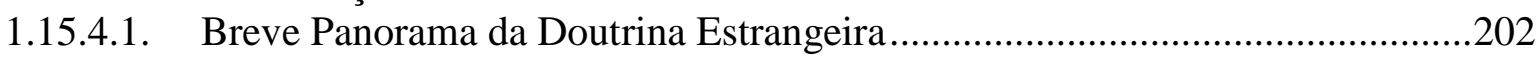

1.15.4.2. Outras Divergências Doutrinárias e Teorias sobre o Responsável Tributário e sobre o Substituto Tributário ......................................................................204

1.15.4.3. Imprecisão Técnica e Terminológica do artigo 128, do Código Tributário

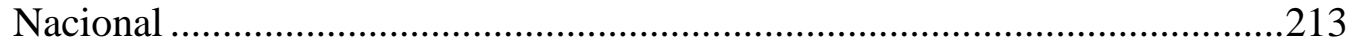

1.15.4.4. Repercussão Econômica do Tributo - Outro Critério Diferenciador ...............215

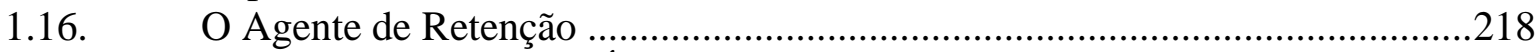

1.16.1. Análise do Tema sob a Ótica das Penalidades Aplicáveis................................232

CAPÍTUlO IV - DEBATE SOBRE OS DIFERENTES CENÁRIOS DE APLICAÇÃO PRÁTICA DO IRF ……………………………………........239

1.17. O Parecer Normativo COSIT $n^{\circ}$ 01, de 2002 - Regras Gerais ..........................240

1.18. O Regime Jurídico do IRF como "antecipação do devido" .............................242

1.19. O Regime Jurídico do IRF “exclusivo de fonte” "........................................248

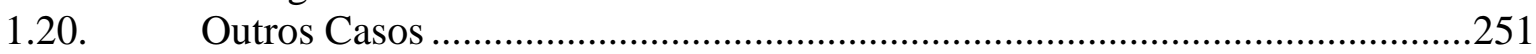

1.20.1. Responsabilidade tributária no caso de não retenção por força de decisão

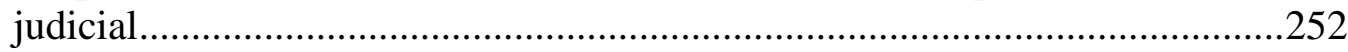

1.20.2. Gratificação Natalina e Participação nos Lucros e Resultados..........................253

1.20.3. IRF sobre o Ganho de Capital do Não Residente ...........................................256

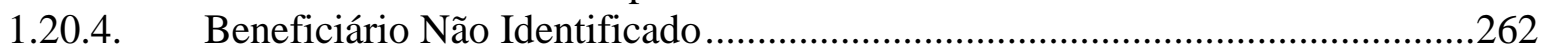

1.20.5. Aplicações Financeiras de Renda Variável....................................................264

1.20.6. Prêmios Distribuídos em Dinheiro ou em Bens..............................................267

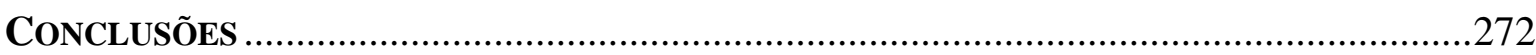

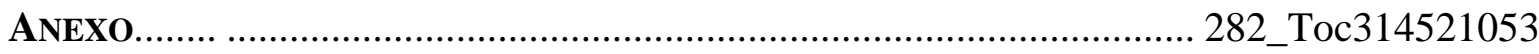

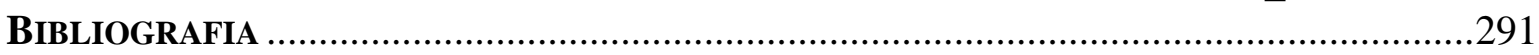




\section{LISTA DE ABREVIATURAS}

CF - Constituição Federal de 1988

COSIT - Coordenação-Geral do Sistema de Tributação

CTN - Código Tributário Nacional

DCTF - Declaração de Créditos e Tributos Federais

DIRF - Declaração do Imposto de Renda na Fonte

DIRPF - Declaração de Ajuste Anual do Imposto de Renda da Pessoa Física

IR - Imposto Sobre a Renda

IRF (IRRF) - Imposto de Renda (Retido) na Fonte

IRPF - Imposto de Renda da Pessoa Física

IRPJ - Imposto de Renda da Pessoa Jurídica

PN - Parecer Normativo

RE - Recurso Extraordinário

RFB - Receita Federal do Brasil

RIR - Regulamento do Imposto de Renda

RMIT - Regra Matriz de Incidência Tributária

SRF - Secretaria da Receita Federal

SRRF - Superintendência Regional da Receita Federal

STF - Supremo Tribunal Federal

STJ - Superior Tribunal de Justiça

TRF - Tribunal Regional Federal 


\section{INTRODUÇÃO}

O Direito Tributário constitui o ramo da ciência jurídica que estuda as relações de direito que surgem entre as entidades com capacidade tributária ativa e as pessoas, físicas ou jurídicas, em consequência da cobrança das prestações que aquelas entidades exigem, segundo normas genéricas, em razão de vínculos políticos, sociais e econômicos ${ }^{1}$.

Como é sabido de longa data pelo estudioso da seara financeira e tributária, parcela significativa dos institutos ${ }^{2}$, conceitos e elementos presentes e identificados no seio do Direito Tributário decorrem, de forma direta ou indireta, das noções de obrigação tributária e do fato gerador. Por sua vez, não é demasiado afirmar que o estudo da responsabilidade tributária lato sensu requer que a investigação tenha como ponto de partida aquela mesma obrigação tributária, com enfoque nas relações jurídicas tributárias que dela originam ${ }^{3}$. Mais importante ainda é ter clara a ideia de que sem a ocorrência do fato gerador não há se falar em relação jurídica tributária.

Em apertada e preliminar síntese, fato gerador ${ }^{4}$ pode ser conceituado como a ocorrência no mundo fenomênico (mundo das coisas, mundo real) que se amolda a uma determinada prescrição abstrata definida e eleita pelo legislador como sendo a situação que dá ensejo ao surgimento do direito (poder-dever) subjetivo do Estado-Fisco de exigir e cobrar o recolhimento ou o pagamento de tributos. Não se trata de querer redefinir o que Código Tributário Nacional (Lei no 5.172/66 - CTN) já fez, apenas realçar que a relevância

${ }^{1}$ Cf. VANONI, Ezio. Natureza e Interpretação das Leis Tributárias (Título Original: Natura ed Interpretazione Delle Leggi Tributairie) Tradução de Rubens Gomes de SOUSA. São Paulo: Edições Financeiras S.A., 7932 P. 12.

${ }^{2}$ Em certo momento de seu Curso de Direito Tributário, RuY BARBosa NogueIRA se questiona o que é instituto jurídico: "Que é instituto jurídico? As disposições do direito objetivo nada mais são que comandos, ordenações normativas, visando regular relações de fato. Acontece que, às vezes, uma dada situação ou relação de fato exige várias disposições legais para poder ser integralmente regulada. Embora essas disposições possam estar esparsas em várias leis ou regulamentos, elas guardam afinidades, se entrelaçam e se completam no escopo comum de regular o mesmo objeto material. São exatamente as normas girando em torno da mesma relação fática, ou melhor, visando a regular as mesmas relações humanas, que formam um todo lógico, denominado instituto jurídico. Portanto, instituto jurídico é a disciplina integral da mesma relação de fato, pelas normas objetivas do Direito." (destaques no original) (Cf. NOGUEIRA, Ruy Barbosa. Curso de Direito Tributário. $15^{\mathrm{a}}$ ed. São Paulo: Saraiva, 1999. P. 39).

${ }^{3}$ Cf. FERRAGUT, Maria Rita. Responsabilidade tributária e o Código Civil de 2002. 2a ed. São Paulo: Noeses, 2009. P. 25.

4 À guisa da bivalência que a expressão "fato gerador" oferece, ora se referindo à hipótese abstratamente definida em lei, ora se referindo ao fato concreto, o Professor LUIS EDUARDO SCHOUERI dá preferência, na medida do possível, às expressões "hipótese tributária", para a situação abstrata, e "fato jurídico tributário", para o fato, situação ou acontecimento concreto (Cf. SCHOUERI, Luis Eduardo. Direito Tributário. São Paulo: Saraiva, 2011. P. 426;434). 
conceitual da expressão "fato gerador". Daquele "processo de amoldamento", chamado de subsunção no universo jurídico, dá-se o nascimento da obrigação tributária ${ }^{5}$.

Idealmente, a cobrança de tributos pela Administração Pública deveria se manifestar, formal e materialmente, em razão da pessoa que incorreu naqueles fatos, atos, negócios ou situações escolhidas pelo legislador como suficientes para dar ensejo a essa atividade estatal. Em outras palavras, em um cenário ideal, o tributo deveria ser cobrado (e pago) do (e pelo) indivíduo que praticou, incorreu ou se colocou em uma posição que caracterizasse o fato gerador prescrito em lei, dando origem à obrigação tributária.

Entretanto, por questões diversas, dentre elas a otimização dos recursos (humanos e materiais) da Administração e da eficiência da função arrecadadora, por vezes o legislador define e indica pessoa diversa para fazer o recolhimento e o pagamento do tributo, pessoa essa que não se confunde com aquela que deu causa ao processo e ao fenômeno da tributação. As correntes doutrinárias mais modernas do Direito Tributário usualmente têm chamado esse conjunto de fatores (otimização dos recursos e eficiência da administração tributária) de princípio da praticabilidade, ora divergindo se haveria ou não base constitucional que resguarde essa assertiva $^{6}$, ora afastando a classificação dessa "praticabilidade" como sendo um princípio jurídico?

\footnotetext{
${ }^{5}$ ALCIDES JORGE COSTA afirma que a relação jurídica tributária nasce com a obrigação tributária, chamando esta última de "dever positivo de uma prestação de dar" (Cf. COSTA, Alcides Jorge. Contribuição ao Estudo da Obrigação Tributária. Edição Especial para a Jornada de Direito Tributário em Homenagem ao Professor Alcides Jorge Costa. São Paulo: IBDT, 2003. P. 31).

${ }^{6}$ Misabel Abreu Machado Derzi, citando Klaus TiPKe, ensina que o Princípio da Praticidade (ou praticabilidade, como preferimos), é mais um princípio técnico do que um princípio ético ou de valor, como se vislumbra no caso da igualdade, da segurança jurídica ou mesmo da capacidade contributiva. Afirma que o princípio da praticabilidade serve não apenas à igualdade, mas, também, abranda o princípio da capacidade contributiva, na medida em que proporciona uma execução simplificada, econômica e viável da lei (Cf. BALEEIRO, Aliomar. Limitações Constitucionais ao Poder de Tributar. Atualizadora: Misabel Abreu Machado Derzi. $8^{\text {a }}$ ed. Rio de Janeiro: Editora Forense, 2010. P. 1249 e ss.). Regina HelEnA Costa postula que a praticabilidade é um autêntico princípio já que ostenta as seguintes características: (i) elevado grau de generalidade e abstração, irradiando seus efeitos sobre múltiplas normas; e (ii) contempla valor considerado fundamental para a sociedade, qual seja, a viabilização do atingimento do interesse público objetivado nos atos estatais, no campo tributário. Para a autora, o princípio da praticabilidade funciona como limite objetivo na realização de diversos valores e como ferramenta obrigatória a ser utilizada pelos agentes públicos na interpretação e na aplicação das normas tributárias (Cf. COSTA, Regina Helena. Praticabilidade e Justiça Tributária. São Paulo: Malheiros, 2007. P. 388/390.)

${ }^{7}$ Cf. COELHO, Sacha Calmon Navarro. Curso de Direito Tributário Brasileiro. Rio de Janeiro: Editora Forense, 2001.
} 
Em tempo, devem ser analisadas, com cuidado, as vozes que julgam que essa transferência da obrigação de recolher o imposto devido por outrem para pessoa diversa seria mera comodidade fiscal, em prejuízo de outros alicerces jurídicos. É de se questionar se, nos dias de hoje, é possível afastar essa tal comodidade fiscal, especialmente com relação ao tema da substituição tributária do ICMS que vem ganhando cada vez mais força. Aliás, em verdade, de quem seria essa comodidade: do Fisco, reduzindo o foco de sua função fiscalizadora, ou do contribuinte, reduzindo drasticamente o número de pessoas obrigadas aos deveres de apuração e recolhimento de tributos e demais deveres instrumentais de prestar informação ao Estado?

O estudo que se propõe percorrer no presente trabalho insere-se na linha de pesquisa do Direito e do Desenvolvimento Econômico, valendo-se, para tanto, da legislação tributária em vigor.

O tema escolhido, apresentado na presente dissertação está relacionado com o Direito Tributário e com a legislação tributária federal, mais especificamente à temática da sujeição passiva tributária à luz do CTN, com ênfase nos casos típicos do Imposto de Renda na Fonte (IRF). Com suporte no alicerce conceitual que se almeja abordar no presente trabalho, exemplos diversos colhidos da legislação tributária federal, tanto em transações locais como internacionais, serão apresentados, de forma a enfrentar a validade dos argumentos e a aplicabilidade a diferentes realidades práticas.

A legislação tributária normatizada, no âmbito infraconstitucional, através do CTN, aponta, a princípio, em seu artigo 121, as espécies de sujeitos passivos para fins tributários: (i) contribuinte e (ii) responsável tributário.

Com foco na tributação do Imposto sobre a Renda, particularmente nas situações de retenção do imposto cobrado na fonte, o presente estudo tem por mote a perquirição da condição da fonte pagadora da renda que, por força de lei, promove a retenção do imposto. É objeto do presente trabalho identificar a natureza jurídica da fonte pagadora, i.e., se promove a retenção do IR na qualidade de substituta tributária ou como mero agente de retenção. Para parte dos doutrinadores que sustentam a teoria do agente de retenção, essa figura sequer assume a natureza de um responsável tributário, tendo em vista que sua 
condição de devedor do imposto não decorre de uma relação jurídica tributária, ainda que indiretamente vinculada ao fato gerador, mas, sim, de uma função administrativa, como veículo arrecadador.

Neste sentido, de extrema relevância se apresenta o recente julgado do Supremo Tribunal Federal (STF), de relatoria da Ministra Ellen Gracie, cuja ementa assim dispõe, verbis:

“EMENTA: DIREITO TRIBUTÁRIO. SUBSTITUIÇÃO TRIBUTÁRIA. RETENÇÃO DE 11\% ART. 31 DA LEI 8.212/91, COM A REDAÇÃO DA LEI 9.711/98. CONSTITUCIONALIDADE. 1. Na substituição tributária, sempre teremos duas normas: a) a norma tributária impositiva, que estabelece a relação contributiva entre o contribuinte e o fisco; b) a norma de substituição tributária, que estabelece a relação de colaboração entre outra pessoa e o fisco, atribuindo-lhe o dever de recolher o tributo em lugar do contribuinte. 2. A validade do regime de substituição tributária depende da atenção a certos limites no que diz respeito a cada uma dessas relações jurídicas. Não se pode admitir que a substituição tributária resulte em transgressão às normas de competência tributária e ao princípio da capacidade contributiva, ofendendo os direitos do contribuinte, porquanto o contribuinte não é substituído no seu dever fundamental de pagar tributos. A par disso, há os limites à própria instituição do dever de colaboração que asseguram o terceiro substituto contra o arbítrio do legislador. A colaboração dele exigida deve guardar respeito aos princípios da razoabilidade e da proporcionalidade, não se lhe podendo impor deveres inviáveis, excessivamente onerosos, desnecessários ou ineficazes. 3. Não há qualquer impedimento a que o legislador se valha de presunções para viabilizar a substituição tributária, desde que não lhes atribua caráter absoluto. 4. A retenção e recolhimento de $11 \%$ sobre o valor da nota fiscal é feita por conta do montante devido, não descaracterizando a contribuição sobre a folha de salários na medida em que a antecipação é em seguida compensada pelo contribuinte com os valores por ele apurados como efetivamente devidos forte na base de cálculo real. Ademais, resta assegurada a restituição de eventuais recolhimentos feitos a maior. 5. Inexistência de extrapolação da base econômica do art. 195, I, a, da Constituição, e de 
violação ao princípio da capacidade contributiva e à vedação do confisco, estampados nos arts. 145, $\S 1^{o}$, e 150, IV, da Constituição. Prejudicados os argumentos relativos à necessidade de lei complementar, esgrimidos com base no art. 195, § 4º com a remissão que faz ao art. 154, I, da Constituição, porquanto não se trata de nova contribuição. 6. Recurso extraordinário a que se nega provimento. 7. Aos recursos sobrestados, que aguardavam a análise da matéria por este STF, aplica-se o art. 543-B, $\S 3^{\circ}$, do CPC." (grifamos)

(RE $\mathrm{n}^{\circ}$ 603.191/MT. Relatora Min. Ellen Gracie. Tribunal Pleno. DJe 05.09.2011)

Como se vê, a despeito de tratar de hipótese de retenção na fonte sob o regime de antecipação de valores devidos a título de contribuição previdenciária, o exame crítico da decisão torna-se obrigatório, na medida em que classifica essa sistemática de retenção na fonte como hipótese típica, constitucionalmente válida, de substituição tributária.

Também serão alvo de nossa perquirição as noções de sujeição passiva indireta e seus diferentes desdobramentos, aqui genericamente denominados por "responsabilidade tributária" e "substituição tributária", que correspondem justamente às situações em que o legislador determina que o pagamento do tributo seja realizado por pessoa diversa daquela que realizou o fato gerador.

Em tempo, alertamos que não será alvo de nossas ponderações e análises o instituto da substituição tributária próprio do ICMS e do PIS/Cofins, comumente conhecida como "substituição tributária para frente". Como é sabido, trata-se de ferramental jurídico apoiado na ideia do fato gerador presumido (artigo $150, \S 7^{\circ}$, da Constituição Federal $^{8}$ ), onde se exige pagamento do imposto com base na mera expectativa de ocorrência de um determinado número de potenciais fatos geradores futuros ${ }^{9}$.

\footnotetext{
${ }^{8}$ Cf. ROTHMANN, Gerd Willi. Prefácio In Planejamento Tributário: Análise de Casos. Organizador Leonardo Freitas de Moraes e Castro. São Paulo: MP Ed., 2010. P. 15.

${ }^{9}$ MARIA RITA FERRAGUT entende tratar-se de técnica incompatível com os princípios da segurança jurídica e da capacidade contributiva (Cf. FERRAGUT, Maria Rita. Op. cit. (nota 03), P. 64/66). LUís CESAR SoUZA DE QUEIROZ entende também que aqui se revela hipótese de manifesta inconstitucionalidade, por ofender aos princípios constitucionais da igualdade, da capacidade contributiva objetiva e capacidade contributiva subjetiva (direitos fundamentais do sistema jurídico brasileiro) (Cf. QUEIROZ, Luís Cesar Souza de. Imposto sobre a renda: requisitos para uma tributação constitucional. Rio de Janeiro, Forense. 1996. P. 310). PAULO VictOR VIEIRA DA RochA, em excelente dissertação tratando ao assunto, conclui que o regime
} 
Não apenas pelo fato de fugir ao escopo do presente trabalho, mas, também, principalmente, por se tratar de hipótese, a nosso ver, que não se amolda ao instituto da substituição tributária, definido na presente dissertação a partir da interpretação conjunta dos artigos 121 e 128, ambos do CTN, e da estrutura conceitual do fato gerador da obrigação tributária, a tal "substituição tributária para frente" não será objeto de nossos estudos.

Conforme teremos a oportunidade de demonstrar, o presente estudo não tem por objetivo, nem de forma superficial, negar a validade de outras contribuições doutrinárias na seara do Direito Tributário, nem mesmo reduzir-lhes a importância a que fazem jus. Algo nesse sentido seria não apenas sobremodo pretensioso, mas até mesmo impossível. Pelo contrário, apoiado no brilhantismo do caminho outrora percorrido por esses verdadeiros desenvolvedores do Direito enquanto ciência, utilizaremo-nos desse material, aproveitando aquilo que de melhor eles têm a oferecer e que melhor se amolda aos entendimentos e conclusões que aqui serão expostos.

O artigo 128, do CTN, que é elemento nuclear do presente estudo, apresenta, a nosso ver, imprecisão técnica ao misturar características concernentes ao instituto da "substituição tributária" dentro do Capítulo V, intitulado como "Responsabilidade Tributária", Título II, Livro Segundo, do Código Tributário Nacional. Divergências doutrinárias à parte que, frisamos, serão trazidas a lume, refletem a importância na delimitação conceitual desses temas. Igualmente, as expressões "relação pessoal e direta com a situação que constitua o respectivo fato gerador" e "terceira pessoa, vinculada ao fato gerador da respectiva

de tributação chamado de substituição tributária "para frente" por fato gerador "presumido", próprio dos impostos plurifásicos como é o caso do ICMS, foi autorizado por regra constitucional que, interpretada em conjunto com as demais normas constitucionais, coloca-se como regra excepcional com relação à aplicabilidade do princípio da capacidade contributiva. Este mesmo autor conclui, ainda, que a regra contida no artigo $150, \S 7^{\circ}$, da $\mathrm{CF}$, é resultado da ponderação dos princípios da capacidade contributiva e da praticabilidade. Dessa ponderação, o autor passa a discutir, após caracterizada sua adequação e necessidade, se a regra de tributação por fato gerador "presumido" é válida diante do teste de proporcionalidade em sentido estrito, devendo ser verificado se em cada setor econômico o ganho econômico em praticabilidade justifica a intervenção sobre a capacidade contributiva (ROCHA, Paulo Victor Vieira da. A Proporcionalidade na Tributação por Fato Gerador Presumido (Artigo 150, § $7^{\circ}$, da Constituição Federal). Dissertação apresentada como parte dos requisitos para habilitação ao título de Mestre em Direito, sob a orientação do Prof. Dr. Luís Eduardo Schoueri, na subárea de Legislação Tributária, integrada ao Departamento de Direito Econômico e Financeiro da Faculdade de Direito da Universidade de São Paulo USP. São Paulo: 2010. Acesso em 28.12.2011. Disponível em: http://www.teses.usp.br/teses/disponiveis/2/2133/tde-06072011-164915/). 
obrigação" contidas, respectivamente, nos artigos 121 e 128, ambos do CTN, serão enfrentadas a fundo.

Conforme se apontará, as doutrinas pátria e estrangeira divergem em muitos pontos e estão longe de chegar a um consenso, não apenas no que se refere à nomenclatura adequada para identificar essas espécies de sujeição passiva tributária indireta. A divergência vai muito além do emprego de uma ou outra terminologia, chegando alguns até mesmo a negar a existência dessas espécies de sujeição passiva indireta ${ }^{10}$.

Não se negue a importância do correto e rigoroso uso da terminologia adequada e apropriada para a identificação de um ou outro conceito jurídico que, certamente, terão o condão de deflagrar diferentes consequências. Nesse sentido, lembrando as notáveis contribuições que os Professores Geraldo Ataliba e Paulo de Barros Carvalho já tiveram a oportunidade de prestar para a precisão conceitual e terminológica do Direito Tributário, o professor argentino de Direito Tributário, HeCTOR VILLEGAS ${ }^{11}$, assim disse: "E a precisão terminológica é uma exigência fundamental para a construção de toda ciência".

E não pode ser diferente de forma alguma para a ciência do Direito.

A utilização da expressão "responsabilidade tributária", da forma genérica como é feita pelo legislador, não se restringe aos limites do CTN, alcançando as legislações estaduais e municipais e toda a sorte de demais atos normativos infralegais. É mesmo a partir da leitura de atos interpretativos e declaratórios expedidos por órgãos técnicos da administração tributária do País que se nota a completa falta de harmonia e sintonia formal e substancial dos conceitos atrelados a essa chamada "responsabilidade tributária".

\footnotetext{
${ }^{10}$ O Professor PAUlo de Barros CARVAlHo, acompanhando a ideia desenvolvida pelo Professor Pedro LUCIANO MARREY JUNIOR, chegou a afirmar que, nos casos de substituição tributária, a relação jurídica não chegaria a nascer para o contribuinte, dito destinatário legal tributário, dado que em nenhum momento, nem por um segundo, esse primeiro seria obrigado, não sendo possível, em seu entender, falar--se em substituição (in Aula Magna - Exposição de VILLEGAS, Hector. Destinatário Legal Tributário - Contribuinte e sujeitos passivos na obrigação tributária. Revista de Direito Público. Julho/Agosto de 1974. Revista dos Tribunais $n^{\circ} 30$. P. 283/284).

${ }^{11}$ Cf. VILLEGAS, Hector. Op. cit. (nota 10), P. 272.
} 
Não apenas a fonte doutrinária se mostra como não pacífica acerca do tema da sujeição passiva indireta mas, também, em grau menos técnico e menos uniforme, a jurisprudência nacional, seja no âmbito das decisões judiciais, seja com relação às decisões exaradas no âmbito administrativo.

Não raras vezes, o que se tem visto é a aplicação das normas que tratam da sujeição passiva tributária sem qualquer apego ao exame técnico de uma determinada ocorrência da vida e sem qualquer padronização e uniformização dos conceitos jurídicos utilizados por estes julgadores. A consequência disso é a total insegurança jurídica por parte de contribuintes e administradores de empresas que, vez e outra, são incluídos, de forma solidária, supletiva ou subsidiária, como queira, como suscetíveis para serem afetados pelo ônus do encargo tributário, às vezes com o seu próprio patrimônio pessoal.

Sob a perspectiva do Imposto sobre a Renda (IR), o cenário de preocupação, mormente quanto a situações que ensejam a retenção do imposto pela fonte pagadora, ganha traços mais interessantes. Neste momento, arrimados nas conclusões a que chegaremos sobre o fato gerador do IR, a relevância do instituto da retenção da fonte e as diferentes formas em que ocorre, analisando se o alcance de seu caráter impõe reflexos jurídicos, i.e., se a retenção na fonte faz parte da relação jurídica tributária, ou se seus efeitos são meramente econômicos, será igualmente relevante o exame do espectro conceitual do substituto tributário, nos moldes do artigo 128, do CTN.

A busca em definir se a fonte pagadora seria um mero agente de retenção, ou se, de fato, integra a relação jurídica tributária como substituto tributário, permitirá indicar os limites a que essa responsabilidade (Haftung) estará adstrita. Exaurir essas questões é criar mecanismos que permitirão indicar, com razoável segurança, a quem compete a obrigação pelo pagamento de determinado crédito, assim como definir o responsável pelo pagamento das penalidades de caráter moratório, se devidas.

A análise jurisprudencial permite afirmar que o tema ainda carece de um posicionamento definitivo e de instrumentos jurídicos que possam conferir eficiência e eficácia na aplicação dos conceitos de responsabilidade tributária e substituição tributária e, até mesmo, para a figura do agente de retenção. 
Some-se a isso o fato de que as leis tributárias surgem em razão de necessidades e situações da vida social e, por isso, caso sua interpretação seja considerada de forma rígida e cristalizada, não será possível atingir as novas manifestações da vida social e econômica, sempre evoluídas, renovadas e transformadas.

Em suma, é neste contexto que se justifica o exame científico dos diversos desdobramentos que (i) a sujeição passiva tributária indireta e (ii) a natureza jurídica da retenção na fonte do Imposto sobre a Renda oferecem, tendo o CTN como ponto de partida e como principal fonte de positivação sobre esses temas no Brasil. Busca-se, a partir da pesquisa das origens históricas e da definição de premissas e pressupostos, fixar os limites claros e objetivos que deverão ser observados pelo Estado e pelos demais agentes fiscalizadores no exercício da função pública, na definição legal das situações em que uma determinada pessoa será obrigada a pagar tributo devido originalmente por um terceiro.

No Capítulo I, serão assumidas as premissas referentes aos conceitos de relação jurídica e de relação jurídica tributária e às noções de antecedente e consequente da regra matriz e de fato gerador que, nas lições colhidas de AMÍLCAR ARAÚJO FALCÃO ${ }^{12}$, é o ponto de partida para o desencadeamento de diversas outras figuras do Direito Tributário. Mais ainda, o doutrinador assevera que, dentre os efeitos irradiados a partir da ocorrência do fato gerador definido em lei, deflagra-se a determinação do sujeito passivo principal da obrigação tributária.

Assim é que conhecer as premissas e as razões que motivaram as decisões, bem como o entendimento e a compreensão sobre um determinado assunto permitem uma melhor assimilação e aceitação muito mais sólida sobre o tema.

Prosseguindo, já imergindo nos fios condutores de nossas análises, antes de procurar preencher o conteúdo dos institutos e conceitos centrais deste trabalho, é fundamental que se alerte que qualquer estudo, obra ou pesquisa que se propõe a identificar a natureza de alguma coisa, estará, em síntese, procurando identificar em que cenário uma determinada

\footnotetext{
${ }^{12}$ Cf. FALCÃO, Amílcar de Araújo. Fato gerador da obrigação tributária. $4^{a}$ ed. São Paulo: Editora Revista dos Tribunais, 1976. P. 31 e ss.
} 
coisa, objeto ou ser se encaixa, se enquadra ou se classifica e quais as consequências que essa classificação implica.

Na ciência do Direito, identificar a natureza jurídica de algo é precisar qual o regime jurídico que lhe será aplicável.

PONTES DE MiRANDA ${ }^{13}$ já ensinava que os sistemas jurídicos são sistemas lógicos, compostos de proposições, ou melhor, de regras jurídicas que se referem a situações da vida, criadas pelos mais diversos interesses. Essas regras jurídicas é que dizem o que é jurídico ou não e permitem diminuir os efeitos arbitrários da vida em sociedade, a desordem dos interesses e dos movimentos do homem e do Estado conforme razões de mera conveniência ou oportunidade.

As regras jurídicas não são diferentes de outras proposições da vida; empregam-se conceitos para indicar que, incidindo [A], ter-se-á [A'] como consequência. Para a identificação ou definição de qual regra jurídica incidiu é preciso saber o que diz cada uma dessas regras, função que não cabe a outra pessoa que não ao intérprete.

Analisar essas regras jurídicas passa, dentre outras coisas, pela verificação dos conceitos com que aquelas regras jurídicas se formularam e como esses conceitos se relacionam com outros conceitos formuladores de outras regras jurídicas, formados a partir dos processos de interpretação e integração.

Pensando no âmbito do Direito Tributário, seara na qual se debruça a presente dissertação, e previamente ao estudo da interpretação, aplicação e/ou integração da legislação tributária, i.e., da análise focada nas regras jurídicas contidas no texto de lei, mais especificamente a lei tributária, há, em grau de maior relevância, necessária e cronologicamente, a análise fática.

Por sua vez, da apreciação dos fatos ocorridos na vida social, opera-se o que LUIS EduARdo Schoueri (in Direito Tributário. Op. cit. (nota 04). P. 608/610) chamou de

\footnotetext{
${ }^{13}$ Cf. MIRANDA, Pontes de. Tratado de Direito Privado - Parte Geral. Tomo 1. Atualizado por Vilson Rodrigues Alves. Campinas: Bookseller, 1999. Prefácio.
} 
"processo de qualificação", por meio do qual também são identificados conceitos. As características relevantes identificadas nestes conceitos serão comparadas, em grau de subordinação, com os conceitos identificados nas normas jurídicas, desencadeando o fenômeno da subsunção.

O Direito Tributário tributa fatos econômicos; a nossa função, como intérpretes e aplicadores do Direito, é lidar com fatos. Não é suficiente a interpretação dos fatos à luz da norma tributária, é imprescindível interpretar o próprio fato e, desse processo de interpretação, identificar as características ou os elementos que mais sobressaltam, autorizando, com isso, a aplicação da regra jurídica construída por meio dos processos de interpretação e integração.

"Por onde se vê que não é de admitir-se, em ciência, que se comece a exposição, a falar-se dos efeitos, da eficácia (direitos, deveres ou dívidas; pretensões, obrigações; ações e exceções), antes de se descrever como os elementos do mundo fático penetram no mundo jurídico."14

Mais à frente, ao analisarmos o nascimento da relação jurídica pelo fenômeno da subsunção, voltaremos a abordar a relevância desses processos de identificação dos conceitos inseridos nos fatos da vida social e na própria regra jurídica.

Para MARIA HELENA DinIz" 15 , natureza jurídica é a "afinidade que um instituto tem em diversos pontos, com uma grande categoria jurídica, podendo nela ser incluído o título de classificação". Portanto, determinar a natureza jurídica de um instituto consiste em determinar sua essência para classificá-lo dentro do universo de figuras existentes no Direito. Trata-se, em verdade, de um exercício de topologia, como se um instituto quisesse saber a qual gênero ele pertence, é a espécie procurando o gênero; é a subespécie procurando a espécie.

A palavra natureza designa tanto o conjunto de seres e coisas (mares, montanhas, árvores, animais etc.) existentes no universo ou no mundo natural, como também o caráter, o tipo

\footnotetext{
${ }^{14}$ Cf. MIRANDA, Pontes de. Op. cit. (nota 13), Prefácio, P. 21.

${ }^{15}$ Cf. DINIZ, Maria Helena. Dicionário Jurídico Universitário. $1^{\text {a }}$ ed. São Paulo: Saraiva, 2010.
} 
ou a espécie de uma determinada coisa (tangível ou intangível) ou mesmo de um ser. No universo jurídico, natureza assinala a essência ou substância de um objeto, de um ato, de um instituto ou até mesmo de um ramo da ciência jurídica.

Assim, encontrar a natureza jurídica de um ramo do Direito consiste em determinar sua essência para classificá-lo dentro do universo de figuras existentes no Direito. Tradicionalmente, e como exemplo básico dessa exposição, o Direito tem sido dividido em dois grandes grupos: Público e Privado. Por conseguinte, fixar a natureza de um dos ramos da ciência jurídica é estabelecer de qual dos grandes grupos clássicos se aproxima.

Fixada a natureza jurídica a que pertence um determinado instituto ou regra jurídica, simultaneamente, e como noção dos efeitos e consequências então aplicáveis, tem-se o regime jurídico no qual são definidos o plexo de direitos, deveres e demais parâmetros que devem regular aquele(s) instituto(s) ou regra(s) jurídica(s).

O regime jurídico é o conjunto de direitos, deveres, garantias, vantagens, proibições e penalidades aplicáveis a determinadas relações sociais qualificadas pelo Direito, i.e., definidas pelas regras jurídicas que marcam tais situações, coisas ou objetos como sendo jurídicos. Sendo assim, o regramento conferido pelos diversos diplomas jurídicos instaura uma linha de conduta a ser seguida e raciocinada dentro de certos parâmetros, premissas, conceitos, ideias e valores (SILVA, De Plácido e. Vocabulário Jurídico Conciso. Atualizadores Nagib Salibi Filho e Gláucia Carvalho. 2a ed. Rio de Janeiro: Forense, 2010. P. 645).

Falar em natureza jurídica da retenção na fonte do Imposto sobre a Renda é, em primeira instância, identificar os regimes jurídicos em que essa sistemática de pagamento do imposto se opera ${ }^{16}$. Mais ainda, identificado esse primeiro conjunto de regimes jurídicos que amoldam o IRF, que, como veremos, são dois, resta perquirir os regimes jurídicos aplicáveis não à forma como essa retenção ocorre, mas, em outra perspectiva, ao sujeito que realiza essa retenção, daí se invocando os efeitos jurídicos aplicáveis ao responsável tributário stricto sensu, ao substituto tributário e ao agente de retenção.

\footnotetext{
${ }^{16}$ RICARDO MARIZ DE OLIVEIRA explica que o IRF não é um tipo específico de imposto de renda, mas, sim, apenas uma técnica de arrecadação, sem alteração da natureza jurídica do imposto. (Cf. OLIVEIRA, Ricardo Mariz de. Fundamentos do Imposto de Renda. São Paulo: Quartien Latin, 2008. P. 499).
} 
Discorrerá a primeira parte deste trabalho dobre os regimes jurídicos em que se opera a retenção na fonte do Imposto sobre a Renda, após profícua busca dos conceitos relevantes que permeiam os aspectos material, temporal e quantitativo do fato gerador do IR. Estes regimes, conforme veremos, são dois: (i) regime de retenção por antecipação e (ii) regime de retenção isolada e exclusiva na fonte. Na segunda parte, pautada nos aspectos subjetivos da regra matriz e com foco na figura do sujeito passivo, cuidaremos de precisar os conceitos dos regimes jurídicos concernentes à pessoa que promove aquela retenção.

Sob a ótica da legislação tributária constitucional e, principalmente, infraconstitucional, através do CTN e também das valiosas construções doutrinárias e jurisprudenciais, é que será analisado o aspecto pessoal ou subjetivo dessa relação jurídica tributária, com ênfase no processo de conformação e configuração legal da sujeição passiva indireta.

O Capítulo II será dedicado à análise do IR, onde teremos a oportunidade de indicar qual a natureza jurídica associada ao papel exercido pela fonte pagadora, com a identificação do conjunto conceitual e da base legal que emoldura aqueles dois regimes jurídicos próprios da sistemática de retenção na fonte do IR. Nossa abordagem será focada na análise dos elementos e princípios que perfazem o fato gerador do IR e os diferentes regimes de retenção na fonte.

Partindo das premissas desenvolvidas e assumidas no primeiro capítulo e com foco na disciplina contida nos artigos 121 e 128, ambos do CTN, procuraremos avaliar no Capítulo III, de forma bastante objetiva, as nuances entre responsabilidade tributária e substituição tributária, bem como as principais características que identificam e diferenciam cada um desses institutos jurídicos e cada uma das situações em que se aplicam. O exame segue com a identificação do perfil legal próprio da figura do agente de retenção, a partir da qual, em comparação aos perfis traçados de responsável e substituto tributário, será possível desenhar os regimes jurídicos pertinentes a cada situação. Os contornos conceituais dessas figuras serão analisados sobretudo à luz da sistemática de retenção na fonte aplicável ao IR, conforme se depreende do artigo 45, também do CTN. 
No Capítulo IV serão abordados alguns casos especiais e problemáticas em que se vislumbram as figuras do responsável tributário stricto sensu, do substituto tributário e do agente de retenção, tanto a partir da análise literal da redação da lei, como também por meio dos conceitos teóricos e do ferramental prático construídos no presente trabalho.

O último Capítulo será dedicado à apresentação das conclusões obtidas a partir dos conceitos definidos no presente estudo e das regras práticas que permitem identificar um ou outro instituto jurídico atrelado à retenção na fonte do Imposto sobre a Renda. 


\section{CAPÍTULO I - NOÇÕES PRELIMINARES E PREMISSAS ${ }^{17}$}

Neste primeiro Capítulo será apresentado um breve histórico de como evoluiu o conceito de relação jurídica tributária e qual a relevância dessa evolução sob a ótica do Direito e diante das relações entre o Estado, representado pelo Fisco, e a sociedade, na figura do contribuinte.

O debate será encaminhado pela abordagem das noções de antecedente e consequente da regra matriz tributária, permitindo, com isso, a descrição das premissas que aqui serão assumidas. A extensão dessa análise necessariamente conduzirá ao exame conceitual de obrigação tributária principal e "acessória" e ao debate existente entre as teorias monista e dualista da relação obrigacional.

Traçadas essas primeiras matizes, o desfecho deste Capítulo I culminará no exame do fato gerador, já destacando a relevância que este instituto terá no desdobramento das questões relacionadas com a responsabilidade tributária e os diferentes tipos de contato que a fonte pagadora exerce diante das complexas situações provocadas pelo fato gerador do Imposto sobre a Renda.

\subsection{O Estado de Direito e a Relação Jurídica Tributária}

Por relação jurídica tributária decorrem, primeiramente, duas observações importantes: a primeira é que se trata de uma relação de natureza obrigacional entre o Estado (Fisco) e o particular; a segunda, e como consequência da anterior, é que se trata de uma relação obrigacional cujo cunho patrimonial é materializado pelo pagamento de tributo em virtude da existência de uma legislação tributária em sentido estrito.

\footnotetext{
${ }^{17}$ Sobre a importância de serem assumidas premissas em qualquer estudo científico, o Professor GENARO R. CARRIÓ ensina com maestria: "Para que cualquier discusión sobre las caracteristicas de los fenomenos designados por ella sea una genuina discrepancia - y no el fruto de um simple equivoco verbal - tiene que mediar acuerdo previo sobre el significado que, en la disputa, damos a las palavras claves (...)" (Cf. CARRIÓ, Genaro R. Notas sobre Derecho y Lenguaje. $4^{\circ}$ ed. Buenos Aires: Editora Abeledo-Perrot, 1990).
} 
Essa obrigação implica um vínculo entre o Estado, sujeito ativo, e o particular, aqui chamado de sujeito passivo, colocado na posição de devedor ou responsável pelo recolhimento de tributo. Nesse sentido, a didática oferecida pelo artigo 113, do CTN, é bastante esclarecedora, evidenciando-se que a obrigação tributária, que implica um vínculo, que nada mais é que a relação jurídica tributária formada entre credor (Estado) e devedor e que surge com a ocorrência do fato gerador ${ }^{18}$.

Essas conclusões, todavia, nem sempre foram pacíficas. EzIO VANONI ${ }^{19}$ explica que esse vínculo obrigacional já foi entendido como uma situação de poder, de opressão ou de sujeição. É nesta seara que passamos a analisar a evolução do pensamento que conduziu ao desenho do que se compreende por relação jurídica tributária nos dias de hoje.

Junto com a chamada Teoria da Supremacia do Estado $^{20}$ vinha a ideia de uma patente injustiça fiscal e social, ao vincular a tributação à localização dos indivíduos e não em razão de sua capacidade contributiva. Atribuía-se importância somente ao elemento formal, desconsiderando o elemento material (conteúdo) como, por exemplo, no caso da tributação dos estrangeiros que era devida simplesmente pelo fato de se encontrarem no território do Estado tributante, independentemente da utilização e/ou fruição dos serviços públicos disponibilizados.

Em decorrência do radicalismo da corrente defendida por OTTO MAYER no final do século XIX (MAYER, Otto. Derecho administrative alemán. Trad. Horacio H. Heredia y Ernesto Krotoschin. Buenos Aires: Depalma, 1949) que se passa a difundir a ideia de que a

${ }^{18}$ Cf. SCHOUERI, Luis Eduardo. Op. cit. (nota 04), P. 413/414.

${ }^{19}$ Cf. VANONI, Ezio. Op. cit. (nota 01), P. 90 e ss.

${ }^{20}$ Para uma visão mais abrangente e detalhada sobre a profusão de teorias e correntes doutrinárias que procuraram explicar a natureza da fenomenologia da tributação, confira a obra-prima de EzIO VANONI. A partir da análise como os povos enxergavam o poder exacional exercido pelo Estado, passando por São Tomás de Aquino, Robespierre, Adam Smith e por diversos outros juristas e pensadores do Direito das escolas italiana e germânica, o jurista italiano ilustra como a atividade tributária e administrativa exercida pelo ente tributante saiu de uma posição odiosa e limitadora dos direitos, garantias e liberdades individuais, até assumir o lugar de previsão estritamente legal e tuteladora daqueles mesmos direitos, liberdades e garantias, exercendo função limitadora, ao contrário, à atividade vinculada do Estado, autorizando a instituição e a cobrança de tributos desde que em conformidade com todo o ordenamento jurídico. O Estado deixa a posição de ente supremo ou superior, tornando-se uma pessoa (pessoa jurídica de direito público), dotada de direitos subjetivos, equiparando-se ao contribuinte, pessoa - física ou jurídica - obrigada ao recolhimento e ao pagamento do tributo. Estado e contribuinte passam a ser encarados em pé de igualdade, dando surgimento a uma relação jurídico-tributária: o indivíduo só deveria pagar tributo, e somente se, caso incorresse/praticasse um determinado ato ou fato (realização fenomênica), que já estivesse previamente previsto em lei. (Cf. VANONI, Ezio. Op. cit. (nota 01), 345 p.). 
supremacia do Estado só se faz valer quando formalizada na forma de uma lei tributária. O vínculo tributário entre o ente público e o indivíduo deixa de ser uma relação de supremacia e passa a ser uma relação de direito, em consonância com as então recentes elucubrações sobre a ideia do Estado de Direito.

É neste contexto, com a evolução da ideia do Estado de Direito, já existente à época, e da representatividade política dos cidadãos que se abre espaço para a formalização de normas tributárias que passaram a tratar o vínculo entre Estado e súdito como relações jurídicas, com identificação de direitos, deveres e obrigações recíprocos. E é essa norma tributária que passa a disciplinar o nascimento, o desenvolvimento e a extinção da relação tributária.

Toda essa evolução dá espaço ao surgimento da personalidade jurídica do Estado, como ente dotado de interesses, de direitos e de deveres. O Estado passa a ser visto como o autor do ordenamento jurídico e, ao mesmo tempo, como ente sujeito às diretrizes desse próprio ordenamento jurídico. Melhor dizendo, o soberano não poderia exigir tributos simplesmente conforme a sua vontade, mas somente nos estritos termos e limites da lei. O tributo, para ser válido, deveria ser constituído em razão de uma finalidade pública, de forma que o Estado utilizasse esses recursos econômicos para fazer frente à prestação dos serviços de utilidade pública.

RUBENS GOMES DE SOUSA ${ }^{21}$, apoiado nas lições do jurista alemão NAVIASKY, argumenta que a relação de soberania do Estado é objetivada até o momento da elaboração da lei, sendo certo que, uma vez promulgada a lei, o Estado se submete integral e invariavelmente aos seus efeitos.

É com a evolução e a exteriorização do Estado de Direito que se permite afirmar, que ao mesmo tempo em que a norma tributária outorgava ao Estado o direito de exigir os sacrifícios dos cidadãos mediante o pagamento de tributos, inclusive fornecendo ferramentas de sanção nos casos de inadimplência, cobrava-se a responsabilidade do Estado e o dever de empregar tais recursos em favor da coletividade, através da prestação de serviços públicos.

${ }^{21}$ Cf. SOUSA, Rubens Gomes de. Compêndio de Legislação Tributária. $2^{\mathrm{a}}$ ed. Rio de Janeiro: Edições Financeiras S.A., 1954. P. 48/49. 
EZIO VANONI ${ }^{22}$ afirma, ainda, que este elemento material é o produto de diferentes tendências, interesses e fatores intrínsecos a um determinado Estado e em um dado momento histórico. A atividade financeira do Estado, exteriorizada pelo fenômeno da tributação, ou melhor, da legislação tributária, nada mais é que a resultante dos fatores econômicos, sociais, políticos, históricos e religiosos.

Para o jurista e hermeneuta italiano, bastava que existisse um Estado organizado como um Estado de Direito para que já existisse, ética e moralmente, o dever do indivíduo de pagar o tributo e o direito do Estado de exigi-lo. Essa relação de fato deverá ser formalizada por meio de lei que, necessariamente, refletirá as características econômicas, sociais, políticas, históricas e religiosas desse Estado. A norma tributária passa a definir, além do comportamento humano tributável (aspectos material e pessoal), o momento e a medida da imposição (aspectos temporal e quantitativo).

Como se vê, a tributação deixa de ser um simples processo de obtenção de receitas e assume a natureza de um procedimento orientado para o recebimento de receitas exclusivamente para fazer frente às necessidades públicas, sem que isso corresponda a um nexo de causalidade, já que as necessidades públicas podem ser atendidas por outros meios que não as receitas de origem tributária.

A lei se torna o produto resultante da causa social que dá origem a uma situação definida como uma relação jurídico-tributária. O legislador "escolhe" determinados fatos da vida social e lhes confere caracteres de juridicidade. Com efeito, a lei passa a promover o elo entre esse determinado evento da vida social e a obrigação de pagar imposto. É o início das noções sobre obrigação tributária e fato gerador.

${ }^{22}$ Cf. VANONI, Ezio. Op. cit. (nota 01), P. 153 e ss. 


\subsection{O Antecedente e o Consequente da Regra Matriz}

Antecedente e consequente são os elementos componentes da estrutura da norma tributária. A hipótese ou suposto, abstratamente definidos, fará alusão a um fato, ao passo que o consequente apontará para a relação jurídica que se vai instaurar e os correspondentes efeitos jurídicos que serão desabrochados. PAULO DE BARROS CARVALHO, certamente um dos maiores estudiosos do fenômeno que vincula o Estado e o particular a partir da materialização prevista em uma norma jurídica e a sua correspondente consequência, é o responsável pela criação da expressão "regra matriz da incidência tributária" (RMIT), consolidando, num único momento, o antecedente e o consequente ${ }^{23}$.

Sobre a separação analítica proposta pelo esquema da RMIT, LUÍs EDUARDO SCHOUERI explica que esse desmembramento em antecedente e consequente se faz por esquema lógico-normativo, mas adverte que, não raras vezes, haverá vínculos entre ambos. Exemplo disso é a própria base de cálculo (aspecto quantitativo do consequente) que corresponderá à própria medida numérica da hipótese tributária ${ }^{24}$. A identificação do aspecto subjetivo no antecedente, como veremos a seguir, não revela outra coisa senão o vínculo entre a hipótese e a relação jurídica tributária que se forma.

Ao analisar a decomposição da norma tributária nestes dois elementos, RICARDO LOBO TORRES aponta que a expressão "fato gerador" deve ser reservada ao antecedente, correspondente ao que a doutrina alemã chama de Tatbestand, expressão não exclusiva do direito tributário alemão ${ }^{25}$. Para o Professor carioca, a expressão "fato gerador", amoldada no antecedente, corresponde à situação necessária e suficiente ao nascimento da obrigação tributária (artigo 114, do CTN), abrangendo o objeto, o sujeito e o tempo do fato gerador ${ }^{26}$.

${ }^{23}$ Cf. CARVAlHO, Paulo de Barros. Curso de Direito Tributário. 23ª ed. São Paulo: Saraiva, 2011. P. 298/300.

${ }^{24}$ Cf. SCHOUERI, Luís Eduardo. Op. cit. (nota 04). P. 422.

${ }^{25}$ Cf. TORRES, Ricardo Lobo. Curso de Direito Financeiro e Tributário. $17^{\mathrm{a}}$ ed. Rio de Janeiro: Renovar, 2010. P. 245.

${ }^{26}$ Diverso é o entendimento de Paulo de Barros Carvalho, que sustenta que no antecedente da regra matriz são identificados apenas os aspectos material, temporal e espacial (Cf. CARVALHO, Paulo de Barros. Op. cit. (nota 23), P. 299; 352/368). Por sua vez, o Professor LUIS EDUARDO SCHOUERI ensina que, a partir do estudo do fato gerador da obrigação tributária, é possível identificar os demais aspectos/critérios da regra matriz na hipótese, tal qual o elemento subjetivo em estreita conexão com a figura do contribuinte (Cf. SCHOUERI, Luís Eduardo. Fato Gerador da Obrigação Tributária. in Direito Tributário - Homenagem a Alcides Jorge Costa. Vol. 1. Coordenação Luís Eduardo Schoueri. São Paulo: Quartier Latin, inverno de 2003. P. 147). 
Guardadas as devidas ressalvas, mormente no tocante à bivalência que a expressão comporta, LUÍS EDUARDO SCHOUERI adota o mesmo sentido para a expressão fato gerador, de forma a abranger apenas a hipótese abstrata, compreendendo o plexo de prescrições encampadas pelo legislador ${ }^{27}$. Em sua mais recente obra, ao explicar sobre a relação entre regra matriz e legalidade, o autor defende que, sob a égide do disposto no inciso III, do artigo 97, do CTN, a expressão fato gerador compreende o antecedente da regra matriz e não apenas a sua materialidade ${ }^{28}$.

Parece-nos válido dizer que no antecedente, onde repousa o critério material, não encontramos outra coisa senão o comportamento de uma pessoa - o contribuinte -, correspondente à realização do fato gerador. Em outras palavras, esse comportamento corresponderá à realização ou promoção do verbo contido no fato gerador (hipótese abstrata: "auferir renda"; "prestar serviço"; vender mercadoria"; "industrializar ou importar produto"), podendo ou não corresponder a uma movimentação voluntária, mas, sempre, invariavelmente, em função da pessoa do contribuinte.

Neste sentir, interessante a observação de PAULO DE BARROS CARVALHO ${ }^{29}$ ao relatar que o verbo será obrigatoriamente pessoal, pois vai se referir ao sujeito e/ou a um comportamento do sujeito, revelando, a nosso ver, a presença do elemento subjetivo igualmente no antecedente da regra matriz. É fundamental que se alerte, no entanto, que o autor não identifica dentre os presentes no antecedente da RMIT o aspecto pessoal. Para este autor, o consequente ou prescritor da norma tributária, implicado na hipótese, fornece os elementos necessários à identificação do vínculo obrigacional formado e retrata a relação jurídica, aí sim, com a identificação dos sujeitos (credor e devedor) e do objeto da prestação.

É, portanto, oportuno o comentário de LUís EDUARDO SCHOUERI ${ }^{30}$, ao notificar o alerta nesse sentido, esclarecendo que o critério pessoal não pode ser considerado irrelevante para a configuração da hipótese tributaria, já que muitas vezes, será este o que determinará

\footnotetext{
${ }^{27}$ Cf. SCHOUERI, Luís Eduardo. Op. cit. (nota 26), P. 138; 147; 167.

${ }^{28}$ Cf. SCHOUERI, Luís Eduardo. Op. cit. (nota 04). P. 423/424.

${ }^{29}$ Cf. CARVALHO, Paulo de Barros. Op. cit. (nota 23), P. 324/327.

${ }^{30}$ Cf. SCHOUERI, Luís Eduardo. Op. cit. (nota 04). P. 421.
} 
a própria hipótese. Para fundamentar sua visão, cita como exemplo os casos de imunidade subjetiva para os quais, verificados os critérios material, espacial e temporal, só haverá falar-se em obrigação tributária na hipótese de se tratar de pessoa não imune (critério subjetivo); caso contrário, a verificação dos critérios anteriores torna-se inócua.

Também JosÉ ARTUR LiMA GONÇALVES ${ }^{31}$, ao defender a ideia do destinatário constitucional do Imposto sobre a Renda, parece caminhar em linha com o quanto exposto acima, identificando a presença do aspecto subjetivo no antecedente, ante a sua estreita conexão com a materialidade do imposto. Explica que há uma conexão, necessária, do substantivo "renda" com o verbo "auferir", o que o leva a concluir que só pode ser obrigado a pagar IR a pessoa que realizou tal verbo, ou seja, que auferiu a renda. Há, portanto, além da própria materialidade envolta à palavra "renda", questões gramaticais conexas ao verbo transitivo "adquirir".

Assim é que, verificado o aspecto material do fato gerador, será possível, regra geral, identificar o contribuinte, como sendo a pessoa responsável pela realização/promoção do verbo nuclear que corresponde à hipótese abstrata do fenômeno da tributação.

Continuando a análise da estrutura normativa tributária, temos o consequente ${ }^{32}$, como sendo, nas lições de RICARDO LOBO TORRES, a determinação do dever de pagar o tributo, representado pelo aspecto quantitativo (base de cálculo + alíquota) ${ }^{33}$. A despeito da valiosa construção promovida por este Professor carioca, no que diz respeito ao antecedente da norma tributária (regra matriz), ousamos divergir por ele não destacar, a nosso ver, a clara presença do elemento subjetivo no consequente, seio onde se estabelece a relação jurídica.

Se estamos lidando com entidades lógicas (contribuinte e responsável, em sua acepção lata), parece-nos autorizado valermos da abstração em separar tais momentos para o fim metodológico que aqui pretendemos alcançar. Corrobora o entendimento a própria estrutura da relação jurídica, formada por dois sujeitos, o credor (accipiens) e o devedor

\footnotetext{
${ }^{31}$ Cf. GONÇALVES, José Artur Lima. Imposto sobre a Renda - Pressupostos Constitucionais. $1^{\mathrm{a}}$ ed, $2^{\mathrm{a}}$ tiragem. São Paulo: Malheiros, 2002. P. 187/188.

32 PAUlo de Barros CARVAlHo faz análise de forma aritmética, sugerindo uma sequência lógica entre antecedente e conseqüente (Cf. CARVALHO, Paulo de Barros. Op. cit. (nota 23), P. 317/319).

${ }^{33}$ Cf. TORRES, Ricardo Lobo. Op. cit. (nota 25), P. 246.
} 
(solvens). É da relação jurídica, portanto consequência do fato gerador, sua natureza subjetiva, por abrigar os sujeitos ativo e passivo, sendo certo que este último não necessariamente se confundirá com a figura do contribuinte.

\subsection{Relação Jurídica}

Etimologicamente a expressão "relação" exprime a ideia de vínculo, elo, ligação que se estabelece entre coisas, fatos, lugares ou pessoas.

"RELAÇÃO s.f. 1 Ato de relatar; relato, informação, descrição 2 consideração que resulta da comparação de dois ou mais objetos 3 lista, listagem, rol 4 semelhança, parecença 5 vinculação de alguma ordem entre pessoas, fatos ou coisas; ligação, conexão, vínculo 6 cotejo entre duas quantidades mensuráveis 7 situação de um órgão comparativamente aos que the são adjacentes (anatomia) 8 caráter de dois ou mais objetos de pensamento compreendidos num só ato intelectual (filosofia) 9 antiga denominação comum aos tribunais de justiça (jurídico) 10 interdependência entre dois ou mais elementos linguísticos (linguagem) 11 condição que liga dois ou mais objetos lógicos (lógica) 12 condição que liga os valores de duas ou mais grandezas (matemática) 13 intervalo entre dois sons; ligação harmônica entre duas notas executadas uma após a outra.

RELAÇÕES s.f.pl. 14 pessoas com as quais se cultiva trato de cortesia ou de amizade. RELAÇÃO JURÍDICA - a que une duas pessoas em razão da ocorrência de um fato com relevância jurídica, em que uma das partes (sujeito ativo) possui direito subjetivo em relação à outra (sujeito passivo), que tem o dever de realizar a devida prestação." 34

Quando se fala em relações jurídicas trata-se de relações entre pessoas, físicas ou jurídicas, ou entre pessoas e bens, coisas ou objetos. Para os fins do presente trabalho, importam as

\footnotetext{
${ }^{34}$ Cf. HOUAISS, Antônio; VILLAR, Mauro de Salles. Dicionário Houaiss da língua portuguesa. Instituto Houaiss de Lexicografia e Banco de Dados da Língua Portuguesa S/C Ltda. Rio de Janeiro: Objetiva, 2009. P. 1638.
} 
relações obrigacionais, entre pessoas, tendo em vista que somente estes entes são capazes de certos direitos, deveres, pretensões, obrigações, ações e exceções ${ }^{35}$.

Assim, as relações jurídicas obrigacionais nada mais são do que os vínculos interpessoais instaurados a partir da subsunção dos fatos ${ }^{36}$ à norma jurídica que trata daqueles fatos ${ }^{37}, 0$ que significa dizer que a incidência não ocorre de maneira infalível e/ou automática; pelo contrário, é o homem que dita a sua ocorrência, produção e materialização, por ato próprio. Diante disso, não nos parece apropriado falar em hipótese de incidência, caso contrário estar-se-ia admitindo a abstração da participação do homem, passando a ideia, já ultrapassada entre nós, de que a regra jurídica "cairia" sobre um determinado fato (sentido inverso $)^{38}$.Ilustrativamente assim teríamos:

\section{Figura 1}

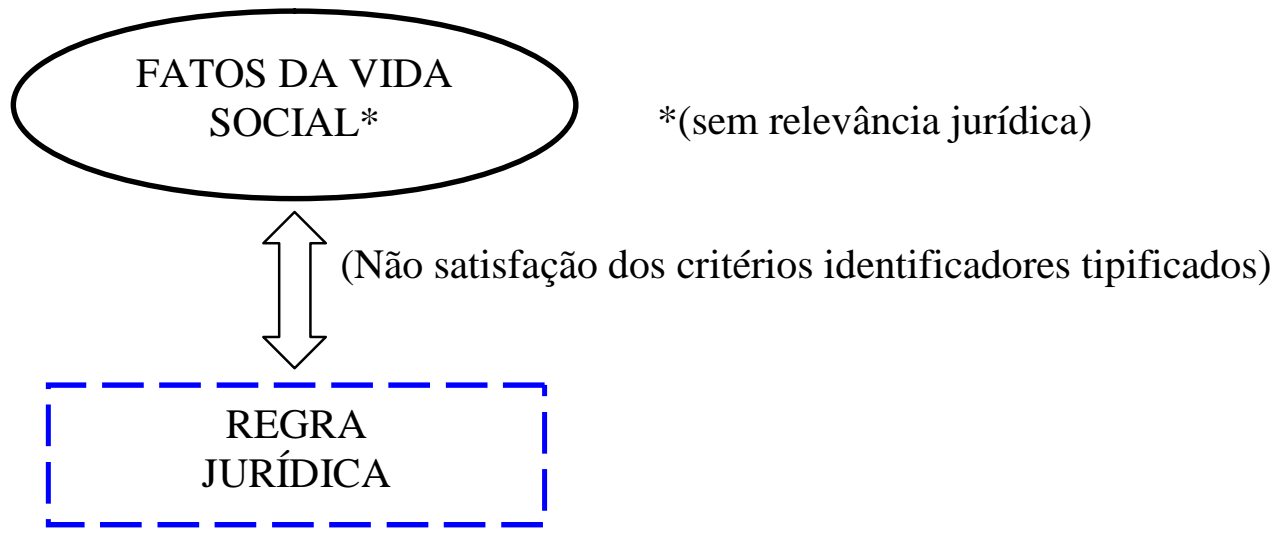

Nesta primeira figura, o que se quer mostrar é que o fato realizado pelo homem, representado acima pela caixa com listras contínuas, não corresponde à descrição contida na hipótese tributária, representada pela caixa com listras tracejadas, não podendo se falar em subsunção.

\footnotetext{
${ }^{35}$ Cf. MIRANDA, Pontes de. Op. cit. (nota 13), P. 169 e ss.

${ }^{36}$ RUY BARBOSA NOGUEIRA lembra que os fatos ou situações ocorridos na vida social, quando disciplinados em lei, ganham "potência jurídica" (contornos de juridicidade), mas nem por isso perdem sua essência fática (Cf. NOGUEIRA, Ruy Barbosa. Op. cit. (nota 02), P. 48).

${ }^{37}$ Cf. CARVALHO, Paulo de Barros. Op. cit. (nota 23), P. 315/319.

${ }^{38}$ Em crítica à idéia de infalibilidade sustentada pelos adeptos da teoria da incidência José WILSON FERREIRA SOBRINHO aponta que se a norma jurídica (re)cair sobre um determinado fato, de forma inexorável e infalível, então o homem será mero expectador. Significa dizer que, em que pese o Direito ser um produto do homem, o próprio Direito exclui o homem de sua formação, na medida em que a relação jurídica nasce com a incidência da norma jurídica e essa incidência seria infalível e inexorável (Cf. SOBRINHO, José Wilson Ferreira. Imunidade tributária. $1^{a}$ ed. Porto Alegre: Sergio Antonio Fabris, 1996. P. 49 e ss.).
} 


\section{Figura 2}

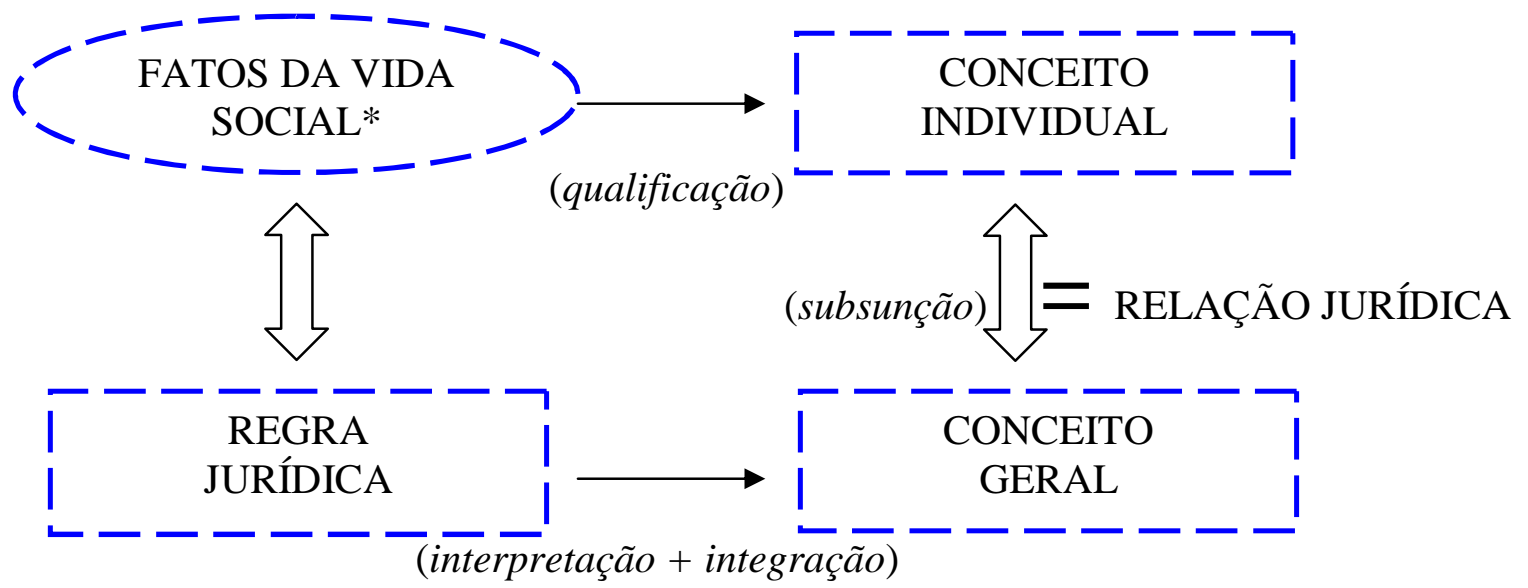

Neste segundo desenho, a incidência está igualmente prevista na regra jurídica (hipótese tributária), representada pela caixa com listas tracejadas. Com isso, sendo de seu conhecimento a descrição contida naquela "caixa", o homem realiza um fato que corresponde exatamente à hipótese (linhas tracejadas), permitindo a subsunção daquela concretude à regra jurídica, fazendo nascer a relação jurídica.

A lógica que se estabelece é no sentido de que a regra jurídica compreende um conjunto de características mais abrangentes, sendo que o todas essas características são identificadas naquele fato da vida social, cuja abrangência é menor. Simultaneamente à identificação de um conceito geral abstrato formulado a partir da interpretação e integração da regra jurídica, constroem-se, por um processo de qualificação, conceitos individuais, de modo que a aplicação da norma já deverá levar em conta o conceito geral identificado abstratamente (in SCHOUERI, Luis Eduardo. Op. cit. (nota 04). P. 607/610).

A subsunção ocorre por meio dos processos de interpretação, integração e qualificação, permitindo, com isso, a construção da norma jurídica. Diante das figuras iguais projetas por tais processos, dá-se a subsunção, fazendo nascer a relação jurídica. Somente a partir dessa situação é que se pode afirmar que a incidência será incondicional, automática e infalível, evidenciando, em momento lógico-normativo anterior, a imprescindibilidade de um comportamento humano. 
As ilustrações acima apontam que as relações jurídicas obrigacionais são a juridicização dos fatos do mundo e das relações interpessoais. Somente após a juridicização desses fatos da vida social, traduzidos pelo fenômeno da subsunção, é possível falar em relação jurídica, entendida como ponto de partida para a geração de direitos, deveres e obrigações recíprocos.

Portanto, é possível falar em sujeito de direitos e de deveres somente depois de estabelecida a relação de direito; antes disso o que existe são apenas fatos do mundo, em grande parte sem qualquer relevância para o universo do Direito, ou meras previsões abstratas descritas na letra latente da lei.

O caráter subjetivo da relação jurídica obrigacional (consequente) é o seu principal traço. Pode-se afirmar que as relações jurídicas são autônomas, singulares, únicas e insubstituíveis. Tanto é que uma determinada relação jurídica obrigacional formada entre os indivíduos A e B nunca será equivalente ao elo formado entre A e C, mesmo que se tome o mesmo evento ${ }^{39}$ econômico e esteja inserido em idênticas condições, ainda que o indivíduo $\mathrm{C}$ substitua $\mathrm{B}$, ocupando-lhe o lugar. A relação jurídica é outra, i.e., trata-se de uma nova relação jurídica.

Situações há em que o sujeito de direito toma duas ou mais posições numa mesma relação jurídica, como no caso de uma transação de compra e venda entre os sujeitos A (vendedor) e B (comprador): o sujeito A se coloca na posição de entregar bem ou coisa objeto de transação comercial e o sujeito B se coloca na posição de receber a coisa ou o bem adquirido. Concomitante, nesta mesma transação, dá-se a situação de A para receber o

\footnotetext{
${ }^{39}$ PAULO DE BARROS CARVALHO faz distinção entre "evento" e "fato", preferindo, na delimitação às noções de "fato gerador" e "subsunção", a expressão "fato jurídico", cuja construção hermenêutica se dá no seio das estruturas do significado - conduta humana, na vida social - e significação - juízos lógicos formados a partir da estrutura do suporte físico (texto de lei) e aquelas condutas humanas. O evento é, assim, a faceta da realidade, a partir do qual poderão ser construídos tanto o fato jurídico, como o fato contábil ou mesmo o fato econômico, tudo dependendo do corte epistemológico que se fez. Os fatos que se descortinam são meras construções metafóricas do próprio evento, ou seja, desde que o universo ou realidade a que pertençam seja o jurídico, estar-se-á diante de um fato jurídico. Para o Direito, e mais especificamente para o Direito Tributário, só os fatos jurídicos importam; os fatos não jurídicos (contábeis ou econômicos) não terão qualquer relevância para fins de subsunção, ou seja, não será capaz de implicar no consequente da regra matriz. O evento descrito no consequente da regra matriz tem conteúdo econômico e de possível ocorrência no mundo concreto, somente se transformando em fato jurídico quando relatado em linguagem competente, não se confundindo, assim, com o fato da vida real, que seriam as outras possíveis construções de um mesmo evento. (Cf. CARVALHO, Paulo de Barros. Op. cit. (nota 23), P. 301/310).
} 
preço ajustado entre as partes, ao passo que B se coloca na posição de entregar os recursos financeiros, objeto daquele ajuste.

Para os fins do presente trabalho e dos conceitos teóricos que serão aqui construídos, relação jurídica (ou simplesmente consequente da regra matriz) é o fenômeno do surgimento e da instauração de direitos, deveres e obrigacões recíprocos, entre duas ou mais pessoas, que ocorre a partir da subsunção de uma conduta humana à descrição contida na hipótese tributária (regra jurídica) e que perdura até a sua extinção.

GIORGIO LAZARRO ${ }^{40}$ lembra que a noção clássica do conceito trazido pela expressão "relação jurídica" traduz uma concepção originária do Direito Privado, onde prevalecem relações negociais, para as quais a lei surge como garantia e instrumento de tutela da autonomia contratual.

Diferente é o cenário vislumbrado no Direito Tributário, para o qual a relação jurídica nasce a partir da subsunção de um fato do mundo (conduta humana) à lei, de forma exclusiva. Por isso se diz que a obrigação é ex lege.

Todavia, conforme passaremos a demonstrar, sem embargo de sua origem privatística, o conceito de "relação jurídica" (tributária) encontra sólida guarida no seio do Direito Tributário.

\subsection{Obrigação Tributária (Principal) e Deveres Instrumentais}

Obrigação tributária é a relação jurídica (tributária) que se estabelece com a concretização da hipótese legalmente prevista (na norma jurídica) para seu surgimento. Assim, obrigação tributária e relação jurídica tributária não querem dizer coisas diferentes, i.e., ambas as expressões se reportam ao vínculo criado entre o Estado e o particular.

O termo "obrigação" presta-se a designar a relação, de cunho patrimonial, que é criada entre duas ou mais pessoas. A etimologia da palavra traz insigne a ideia de ligação entre

${ }^{40}$ apud COSTA, Alcides Jorge. Op. cit. (nota 05), P. 21. 
partes antagônicas que, de um lado, revela o dever de prestar (comportamento comissivo ou omissivo) e, de outro, o poder de exigir.

Neste sentido, LUÍS EDUARDO SCHOUERI ensina que uma “obrigação" implica um vínculo jurídico que une duas ou mais pessoas, por meio do qual o devedor (na posição de sujeito passivo) deve efetuar uma prestação de natureza patrimonial (dar, fazer ou não fazer) em favor do credor (sujeito ativo) e, se aquele primeiro não cumprir com sua obrigação, o credor pode pleitear, junto ao Poder Judiciário, o seu constrangimento para que o devedor cumpra aquela obrigação ${ }^{41}$.

Apoiado no trabalho de HENRI DE PAGE (Traité Elémentaire de Droit Civil Belge. Bruxelas, Établissements Emile Bruylant, 1948, 2ª edição, Tomo III, p. 388 e ss.), ALCIDES JORGE COSTA explica que a obrigação tende unicamente à execução de uma prestação por parte de uma pessoa, o devedor, em proveito de outra, o credor. Este direito de crédito, traço característico da obrigação, que distingue este tipo de relação do direito real (havido sobre a coisa), é exercido contra uma ou várias pessoas determinadas, das quais se obtém a execução de uma prestação, através do poder de coação conferido ao credor, inclusive ${ }^{42}$.

A obrigação é, assim, um tipo de vínculo jurídico transitório e de conteúdo econômico, por meio do qual alguém (sujeito ativo) pode forçar outro alguém (sujeito passivo) a honrar o cumprimento de uma determinada prestação, ou mesmo alcançar o patrimônio de um outro alguém de forma a satisfazer aquele direito de crédito ${ }^{43}$

Para fins do Direito Tributário, a obrigação tributária é bastante semelhante às demais obrigações que exprimem a ideia de uma relação jurídica. A característica singular que individualiza a obrigação tributária é o seu objeto, que é e sempre será o tributo ${ }^{44}$.

\footnotetext{
${ }^{41}$ Cf. SCHOUERI, Luís Eduardo. Op. cit. (nota 04), P. 413.

${ }^{42}$ Cf. COSTA, Alcides Jorge. Op. cit. (nota 05), P. 32/33.

${ }^{43}$ Cf. GRECO, Marco Aurélio. Dinâmica da Tributação e Procedimento. São Paulo: Editora Revista dos Tribunais, 1979. P. 182.

${ }^{44}$ Ao utilizarmos a palavra "tributo" não intencionamos afastar as penalidades da obrigação tributária. Absolutamente! Quer-se apenas dar ênfase de que se trata de uma relação jurídica cujo objeto não é um dinheiro qualquer ou outra coisa que não o pagamento de débito representado por um crédito tributário, cuja origem se dá com a ocorrência do fato gerador. LUIS EDUARDO SCHOUERI pondera que a opção pelo adjetivo "tributária" pelo legislador complementar não foi para qualificar o conteúdo da obrigação (que seria uma obrigação unicamente de pagar tributo), mas, sim, com o intuito de identificar sua origem, qual seja, uma obrigação de pagar (sem especificar), em virtude da legislação tributária, assegurando, dessa forma, que a
} 
Assim é que a relação jurídica tributária nada mais é do que uma espécie do gênero relação jurídica. Nada mais óbvio. AlCIDES JoRGE COSTA ${ }^{45}$, trazendo o entendimento da doutrina estrangeira, comenta que, para WINDSCHEID, há dois tipos de relação jurídica: uma relação da vida a que o direito adere (prioritariamente de natureza privada) e uma relação criada pelo ordenamento jurídico. A relação jurídica tributária - obrigação tributária - encontra-se nesse segundo grupo.

Só é possível conhecer a individualização da relação jurídica tributária a partir da análise conceitual de seu objeto, que é a prestação de entregar tributo como registra o artigo $3^{\circ}$, do CTN, verbis:

\begin{abstract}
"Art. $3^{o}$ Tributo é toda prestação pecuniária compulsória, em moeda ou cujo valor nela se possa exprimir, que não constitua sanção de ato ilícito, instituída em lei e cobrada mediante atividade administrativa plenamente vinculada."
\end{abstract}

Note, com isso, que o conceito de tributo, objeto nuclear da relação jurídica tributária, traz implícitos caracteres de extrema relevância, como é o caso de "prestação pecuniária" que, por si só, revela a natureza patrimonial e obrigacional da espécie de relação jurídica em comento. Não se olvide também da parte que menciona que o tributo não constitui sanção de ato ilícito, afastando, de vez, qualquer vinculação conceitual entre tributo e multa.

Ao comentar sobre a relação jurídica tributária, BLUMENSTEIN fala em duas relações: a relação de débito (cunho patrimonial) e a relação de "accertamento", que corresponderia às obrigações do indivíduo de cooperação com o ente público na prestação de informações para fins de fiscalização e lançamento ${ }^{46}$.

Por sua vez, HENSEL ensina que a relação obrigacional é uma relação jurídica entre duas pessoas e, como tal, o credor tem o direito de exigir uma prestação do devedor. Afirma,

instituição e cobrança de multas estaria sujeita ao mesmo regime jurídico dos tributos (Cf. SCHOUERI, Luís Eduardo. Op. cit. (nota 04), P. 414/415).

${ }^{45}$ Cf. COSTA, Alcides Jorge. Op. cit. (nota 05), P. 24.

${ }^{46}$ Cf. BLUMENSTEIN, Ernst. Sistema di Diritto delle Imposte. Trad. Italiana. Milão: Ed. Giuffrè, 1954. 
ainda, que, ao lado dessa prestação pecuniária, existe uma série de outras prestações, igualmente devidas, por força de lei, quando ocorre o fato típico ${ }^{47}$.

Interessantes são as lições trazidas por JOSÉ LuIS PEREZ DE AYALA ${ }^{48}$ ao tratar das diferentes e divergentes correntes doutrinárias, no tocante à obrigação tributária e às relações que dela se emanam, dividindo-as em quatro grupos:

a. Teoria da pluralidade de relações jurídicas tributárias, que julga artificiosa;

b. Teoria da relação jurídica tributária complexa e única ${ }^{49}$;

c. Teorias que distinguem relação tributária e obrigação tributária;

d. Teoria de uma relação jurídica tributária não complexa, de direito material.

Sobre o tema, ALCIDES JORGE COSTA conclui afirmando que a relação jurídica tributária é de ordem complexa, pois, ao lado de uma obrigação/prestação de dar (usualmente chamada de obrigação tributária ou obrigação tributária principal), existem outros deveres/prestações conexos, decorrentes daquela mesma prestação positiva. O autor esclarece, também, que a relação jurídica tributária não existe antes do fato gerador (entendimento comungado por ANTONIO BERLIRI que mencionou que a relação jurídica tributária só se constitui onde existe uma obrigação tributária ${ }^{50}$ ).

Sobre o assunto também se pronunciou SACHA CALMON NAVARRO COELHO ${ }^{51}$, apontando que a obrigação tributária se distingue das obrigações contratuais, pois aquela seria "acontratual" e distingue-se das multas e da indenização por estar calcada na tipicidade e na licitude. Arrola, ainda, dentre as distinções identificáveis, o fato de que o credor, na obrigação tributária, é sempre a Administração, ainda que tal função seja delegada, por exemplo, aos tabeliães, e nas demais obrigações seria sempre uma pessoa natural.

\footnotetext{
${ }^{47}$ apud COSTA, Alcides Jorge. Op. cit. (nota 05), P. 12/13.

${ }^{48}$ Cf. AYALA, Jose Luis Perez de. Derecho Tributário I. Serie IV - Tratados de Derecho Financeiro y de Hacienda Publica. Vol. XIII. Madrid: Editorial de Derecho Financeiro, 1968. P. 140/147.

${ }^{49}$ Para MARIO PUGLIESE a obrigação tributária é unitária e está constituída somente pela relação fundamental de dívida que se desenvolve entre o Estado e o contribuinte de direito (Cf. ). Os demais preceitos de fazer, não fazer e tolerar ou suportar (estes dois últimos não presentes no Direito Tributário Brasileiro, conforme noticia a doutrina nacional, que amplamente acolheu as lições de RUBENS GOMES DE SOUSA, imantadas no CTN), dirigidos ao sujeito passivo, visam apenas garantir a execução daquela obrigação fundamental de dar (pagar tributo).

${ }^{50}$ Cf. COSTA, Alcides Jorge. Op. cit. (nota 05), P. 14.

${ }^{51}$ Cf. COELHO, Sacha Calmon Navarro. Op. cit. (nota 07).
} 
Assim é que a relação jurídica tributária, insculpida no consequente da regra matriz, corresponde, em verdade, às situações que decorrem dos direitos e deveres das pessoas que integram os dois polos (bilateralidade) dessa relação. Com foco no polo devedor, a situação por excelência que decorre desse cenário é o fato de que um alguém, chamado sujeito passivo, na condição de obrigado ou, genericamente falando, de um terceiro obrigado, responsável tributário, deverá pagar tributo, mediante a entrega de recursos financeiros em favor dos cofres públicos.

São essas situações, vislumbradas exclusivamente quando da instauração da relação jurídica tributária, que serão examinadas no presente trabalho.

\subsubsection{Deveres Instrumentais}

Além da obrigação de pagamento de tributo, incumbem aos contribuintes, e mesmo a terceiros designados por lei, a prestação de informações com o objetivo de averiguar a existência de situações que conduzem à obrigação de recolhimento de tributo, mas também à determinação de sua exata medida ou mesmo evitar ou reprimir situações ensejadoras de fraude fiscal. Trata-se de deveres que visam auxiliar a Administração Tributária em suas diversas atividades de cobrança e fiscalização das receitas tributárias ${ }^{52}$.

O artigo 113, do CTN, assevera que a obrigação tributária é principal ou acessória. Diz-se principal a obrigação que surge com a ocorrência do fato gerador e tem por objeto o pagamento de tributo ou penalidade pecuniária e extingue-se juntamente com o crédito dela decorrente. Por sua vez, revelando o caráter complexo que JOSE LUIZ PEREZ DE AyALA destacou, a obrigação acessória será aquela que decorra da legislação tributária e tem por objeto as prestações, positivas ou negativas, previstas no interesse da Administração Tributária.

\footnotetext{
${ }^{52}$ MANUEL PIRES chama essas prestações de "deveres auxiliares" (Cf. PIRES, Manuel; PIRES, Rita Calçada. Direito Fiscal. $4^{a}$ ed. Coimbra: Almedina, 2010. P. 253/255).
} 
HELENÍlson CUNHA PONTES ${ }^{53}$ descreve essa definição com maestria, explicando que o CTN (artigo 113) preferiu classificar como obrigação tributária tanto o dever principal de recolher o tributo devido, como os deveres instrumentais ligados àquele dever principal, tais como a escrituração de livros e o preenchimento de declarações fiscais.

Entretanto, apoiados nas premissas construídas acima e diante da redação contida no artigo 113, do CTN, as diferenças entre obrigação tributária principal e a "obrigação acessória" evidenciam-se com clareza. Primeiramente, quanto à fonte de produção, aquela primeira, por estar vinculada ao fato gerador, dependerá de lei, submetendo-se, pois, ao princípio da legalidade, tema que será analisado no subitem seguinte. As "obrigações acessórias", por seu turno, decorrem da legislação tributária, cingindo-se ao que delimita o disposto no artigo 100 , do $\mathrm{CTN}^{54}$, inclusive por meio de atos infralegais ${ }^{55}$.

As diferenças, contudo, não param por aí. Como se apontou no subitem anterior, a característica marcante das obrigações em geral é seu caráter ou conteúdo patrimonial. Nas obrigações tributárias (principais), isto se revela pela própria natureza do tributo, que corresponde a uma prestação pecuniária. $\mathrm{O}$ mesmo não se pode dizer com relação às ditas “obrigações acessórias”, daí se questionar a expressão obrigação.

Em que pese a notória limitação à liberdade do contribuinte, tais "obrigações" acessórias não causam constrangimento ou ingerência sobre o seu patrimônio como ocorre com

\footnotetext{
${ }^{53}$ Cf. PONTES, Helenílson Cunha. Revisitando o Tema da Obrigação Tributária. in Direito Tributário Homenagem a Alcides Jorge Costa. Vol. 1. Coordenação Luís Eduardo Schoueri. São Paulo: Quartier Latin, inverno de 2003. P. 107/108.

${ }^{54}$ Cf. SCHOUERI, Luís Eduardo. Op. cit. (nota 04), P. 414. "Art. 100. São normas complementares das leis, dos tratados e das convenções internacionais e dos decretos:

I - os atos normativos expedidos pelas autoridades administrativas;

II - as decisões dos órgãos singulares ou coletivos de jurisdição administrativa, a que a lei atribua eficácia normativa;

III - as práticas reiteradamente observadas pelas autoridades administrativas;

IV - os convênios que entre si celebrem a União, os Estados, o Distrito Federal e os Municípios.

Parágrafo único. A observância das normas referidas neste artigo exclui a imposição de penalidades, a cobrança de juros de mora e a atualização do valor monetário da base de cálculo do tributo."

${ }^{55}$ A instituição de deveres instrumentais por ato normativo com hierarquia inferior a lei em sentido estrito é perfeitamente possível e constitui-se em uma prerrogativa do sujeito ativo. Neste sentido vide manifestações do STJ: $1^{\text {a }}$ T, REsp 724.779/RJ, Rel Min. Luiz Fux, set/06; $1^{\text {a }}$ T, REsp 866.851/RJ, Rel Min. Luiz Fux, ago/08. Reproduzimos o mais recente, apenas no trecho que nos interessa: “(...)5. A Municipalidade é a entidade legiferante competente para a instituição do tributo em tela (ISSQN), exsurgindo, como consectário, sua competência para, mediante legislação tributária (inclusive atos infralegais), atribuir ao contribuinte deveres instrumentais no afã de facilitar a fiscalização e arrecadação tributárias, minimizando a ocorrência da sonegação fiscal."
} 
relação à obrigação principal de pagar tributo. Traduzem-se, as "obrigações" acessórias, em deveres formais, de fazer, não fazer ou tolerar, sempre no interesse da fiscalização e da arrecadação, por meio da facilitação (critérios de simplicidade e segurança) e regulamentação da operacionalidade da tributação em si, por isso não existir necessidade de lei em sentido estrito para regulamentar tais deveres formais ${ }^{56}$.

A ausência de cunho patrimonial decorre da sua própria natureza de não visar uma indenização ou uma reparação atrelada ao direito de um determinado alguém (credor) ${ }^{57}$.

Não são poucas as vozes nesse sentido, ora alegando que a própria ausência de transitoriedade lhes retira a natureza de obrigações propriamente ditas ${ }^{58}$, já que as (obrigações) principais dissolvem-se, sobretudo, quando do pagamento ${ }^{59}$, ora explicando que, aos atos de escrituração de livros, emissão de notas fiscais, entrega de declarações ou qualquer outra forma de prestação de informações e até mesmo a manutenção e guarda de documentos à disposição da fiscalização carece o conteúdo de dimensão econômica, não sendo correto, portanto, falar-se em natureza obrigacional ${ }^{60}$.

Se a inaplicabilidade da palavra "obrigação" parece ser mais clara, dada a ausência do caráter patrimonial em tais deveres, a palavra "acessória" não revela a mesma uniformidade. Entre seus defensores, encontramos HUGO DE BRITO MACHADO ${ }^{61}$, que não aceita a crítica quanto à utilização da palavra "acessória", sob o argumento de que decorreria de uma visão privatista. Para este autor, o adjetivo "acessória" que qualifica aquelas "obrigações" encontra significação totalmente diferente da encampada no Direito Privado.

\footnotetext{
${ }^{56}$ Cf. PAULSEN, Leandro. Direito Tributário: Constituição e Código Tributário à Luz da doutrina e da jurisprudência. 11 a ed. Porto Alegre: Livraria do Advogado; EMAFE. P. 902/903.

${ }_{57}$ Cf. SCHOUERI, Luís Eduardo. Op. cit. (nota 04), P. 414.

${ }^{58}$ Cf. COSTA, Alcides Jorge. Op. cit. (nota 05), P. 21.

${ }^{59}$ Cf. BASTOS, Celso Ribeiro. Comentários ao Código Tributário Nacional. Vol. 2. $3^{\mathrm{a}}$ ed. Coord. Ives Gandra da Silva Martins. São Paulo: Saraiva, 2002. P. 154.

${ }^{60}$ Cf. CARVALHO, Paulo de Barros. Op. cit. (nota 23), P. 359/362.

${ }^{61}$ Cf. MACHADO, Hugo de Brito. Curso de Direito Tributário. $21^{\mathrm{a}}$ ed. revista, atualizada e ampliada. São Paulo: Malheiros, 2002. P. 111/112.
} 
CELSO RIBEIRO BASTOS ${ }^{62}$ sustenta que o adjetivo "acessória" deve ser interpretado no sentido de desempenhar uma função auxiliar, afastando-se a noção de subordinação ou de dependência da obrigação tributária principal.

Não obstante os entendimentos acima, a doutrina tem se manifestado mais favoravelmente à expressão "instrumentais", já que tais deveres existem independentemente da ocorrência do fato gerador, logo, do surgimento efetivo da obrigação tributária principal ${ }^{63}$.

Tais deveres não correspondem a meros apêndices, acessórios à obrigação principal ${ }^{64}$, e sua suposta "acessoriedade" subsiste ainda que a obrigação à qual se liga ou parece ligar-se inexista, por exemplo, em decorrência de uma imunidade ${ }^{65}$, uma não-incidência ou uma isenção $^{66}$. A prestação de informações ao Fisco, mesmo numa situação em que não há imposto a pagar ou sequer houve a incidência, subjaz mais a uma ideia de instrumentalizar todo o processo de controle e fiscalização por parte da Administração do que a um vínculo a uma suposta obrigação tributária principal.

Diante dos argumentos expostos acima, relevantes, inclusive, para nossas conclusões acerca da natureza jurídica da retenção na fonte do IR, para os fins da presente dissertação adotaremos a expressão “deveres instrumentais".

\subsubsection{Obrigação Tributária é Obrigação ex lege}

Como vimos, a manifestação da soberania do Estado culmina com a elaboração da lei. É exatamente essa característica que identifica as obrigações tributárias e as distingue das obrigações privadas e até mesmo dos deveres instrumentais. Assim é que, reconhecido o vínculo obrigacional, Fisco e particular se põem sujeitos à lei, i.e., seus direitos e deveres

\footnotetext{
${ }^{62}$ Cf. BASTOS, Celso Ribeiro. Op. cit. (nota 59), P. 155.

${ }^{63}$ Cf. CARVALHO, Paulo de Barros. Op. cit. (nota 23), P. 359/362.

${ }^{64}$ Cf. SCHOUERI, Luís Eduardo. Op. cit. (nota 04), P. 416/417.

${ }^{65}$ Cf. FERRAZ, Tércio Sampaio. Obrigação Tributária Acessória e Limites de Imposição. in Teoria Geral da Obrigação Tributária - Estudos em Homenagem ao Professor Souto Maior Borges. São Paulo: Malheiros, 2005. P. 267.

${ }^{66}$ Neste sentido é o entendimento de José EDUARDO SOARES DE MELO, que destaca que o rótulo "acessório" não é o mais adequado para tais deveres instrumentais, haja vista que, explica, nem sempre têm conexão com uma efetiva obrigação principal (Cf. MELO, José Eduardo Soares de. Curso de Direito Tributário. São Paulo: Dialética, 2002. P. 178).
} 
decorrerão da lei, colocando-se em pé de igualdade, abandonando de vez a pretensa ideia de subordinação ou autoritarismo que vigeu no passado.

A Teoria Legalista exerceu enorme influência no Brasil, conforme se constata da própria redação do artigo 114, do CTN, o qual, por sua vez, foi influenciado por RUBENS GOMES DE SousA, um dos principais autores do Anteprojeto (na década de 1950, foi elaborado um anteprojeto do CTN sob a responsabilidade do tributarista RUBENS GOMES DE SOUSA. Durante anos, o Anteprojeto foi analisado e debatido. O CTN só seria transformado em lei mais de dez anos depois, logo após a Emenda Constitucional $n^{\circ} 18 / 65$, que instituiu um novo sistema tributário, com profundas mudanças em todos os níveis de tributação, em especial na tributação sobre o consumo e sobre a renda).

HELENÍlson CUNHA PONTES ${ }^{67}$, analisando a evolução das ideias que tentaram conceituar a natureza da relação entre ente tributante e sujeito passivo, lembra que o Estado foi, aos poucos, deixando de ocupar o papel protagonista no fenômeno da tributação (posição ocupada, antes do Estado de Direito, pelo Estado Supremo ou Estado Soberano), cedendo espaço para a consolidação da obrigação tributária como sendo uma obrigação ex lege. Em suas importantes manifestações doutrinárias, o tributarista chega a afirmar que a obrigação tributária não é apenas ex lege, mas, também, que se deve buscar sua origem constitucional uma vez que, na medida em que o texto constitucional contempla um rol de regras e princípios norteadores da atividade impositiva, é na própria Constituição Federal que se encontram os direitos e garantias individuais, tendo, neste segundo rol, dentre as suas finalidades, a proteção do indivíduo contra o exercício desmesurado do poder tributário.

Quer-se acreditar que a definição e o regramento (aspectos gerais e principais) da obrigação tributária sedimentam-se em plano necessariamente infraconstitucional ${ }^{68} \mathrm{e}$ obrigatoriamente legal.

\footnotetext{
${ }^{67}$ Cf. PONTES, Helenílson Cunha. Op. cit. (nota 53), P. 95-116.

${ }^{68}$ Há que se observar, neste caso, o que disciplina o artigo 146, II, "b", da Constituição Federal, ao afirmar que caberá ao legislador complementar estabelecer normas gerais em matéria tributária, especialmente no que se refere à obrigação tributária. Desloca-se, assim, para o âmbito infra-constitucional, a definição legal e abstrata das situações escolhidas pelo legislador como aptas a dar nascimento à obrigação de pagar tributo. $\mathrm{O}$ Código Tributário Nacional, recepcionado pela Constituição Federal de 1988 como Lei Complementar (neste sentido, veja ADI-MC 1911, cuja ementa segue: "CRÉDITO TRIBUTÁRIO - EXTINÇÃO. As formas de extinção do crédito tributário estão previstas no Código Tributário Nacional, recepcionado pela Carta de 1988 como lei complementar. Surge a relevância de pedido formulado em ação direta de
} 
Em sendo a obrigação tributária uma forma de relação jurídica entre sujeitos (ativo e passivo), certo é que, por estar inserida no universo do Direito Tributário, trata-se de uma obrigação ex lege, i.e., que decorre da lei. A relação jurídica tributária, na medida em que corresponde ao consequente da regra matriz, é, na realidade, a concretização do fato gerador da obrigação tributária (antecedente).

Chama-se assim a atenção para a forma como as obrigações tributárias são originadas: diferente de uma obrigação de natureza cível ou comercial, por exemplo, para as quais, na maioria das vezes, a manifestação de vontade das partes será fator determinante e fulcral, a obrigação tributária nasce, com a mera ocorrência de determinados fatos previamente descritos de forma abstrata na lei $^{69}$ (denominamos estes acontecimentos de fatos geradores).

\subsubsection{Teorias Monista e Dualista da Obrigação Tributária}

MARIA HELENA DinIz ${ }^{70}$, ao ensinar sobre os elementos constitutivos da relação obrigacional, lembra que, ao lado dos elementos pessoal e material, há o vínculo jurídico, que sujeita o devedor à realização de um ato positivo ou negativo no interesse do credor. Para explicar este fenômeno a autora afirma que existem 3 (três) teorias.

Uma das teorias que explicam o fenômeno causado por este vínculo jurídico é a teoria monista. Para a civilista MARIA HelenA DINIZ, a teoria monista vislumbra na obrigação

\footnotetext{
inconstitucionalidade considerada lei local prevendo nova forma de extinção do crédito tributário na modalidade civilista da dação em pagamento. Suspensão de eficácia da Lei Ordinária do Distrito Federal de $n^{o}$ 1.624/97." - grifos nossos), cumpre, com rigor, esse papel, ao prescrever, ao longo de seus 218 artigos, a definição dos tributos e suas espécies, suas hipóteses de incidência e as hipóteses de constituição, suspensão e extinção do crédito tributário, dentre muitos outros aspectos e institutos relacionados com o fenômeno da tributação. À Constituição Federal coube tão somente disciplinar sobre os limites ao poder de tributar, através da normatização de princípios constitucionais tributários, bem como à definição e divisão das competências tributárias entre as pessoas jurídicas de Direito Público, representadas pela União, pelos Estados, pelo Distrito Federal e pelos Municípios.

${ }^{69}$ Neste sentido vale ressaltar o magistério do Professor LUCIANO AMARO: “O nascimento da obrigação tributária independe de manifestação do sujeito dirigida à sua criação, (...) ainda que o devedor ignore ter nascido a obrigação tributária, esta o vincula e o submete ao cumprimento da prestação que corresponda ao seu objeto." (Cf. AMARO, Luciano. Direito Tributário Brasileiro. 13 a edição. São Paulo: Saraiva, 2007. P. 246).

${ }^{70}$ Cf. DINIZ, Maria Helena. Curso de Direito Civil Brasileiro. V. 2 - Teoria Geral das Obrigações. $22^{\mathrm{a}}$ ed. Revista e atualizada. São Paulo: Saraiva, 2007. P. 30/39.
} 
uma só relação jurídica vinculando credor e devedor, cujo objeto é a prestação. Na obrigação há o dever de prestar do devedor e o direito de exigir do credor; porém, o direito de exigir está inserido no dever de prestar; assim, o direito do credor insatisfeito de exigir execução do patrimônio do devedor não integra a essência da obrigação, por ser questão, dizem uns autores ${ }^{71}$, meramente processual, não havendo qualquer diferença entre o cumprimento voluntário da prestação pelo devedor e sua execução forçada, no caso de inadimplemento.

PAUlO DE BARROS CARVALHO ${ }^{72}$ parece trilhar a linha de uma visão monista ao não reconhecer a segregação das relações entre debitum e obligatio, supostamente por se tratar de uma distinção de natureza econômica. Para o autor não haveria, em termos propriamente jurídicos, sujeitos passivos diretos e indiretos, aqueles representados pelos contribuintes, e estes, pelos responsáveis. Para PAUlO DE BARros CARVAlHO tal orientação estaria impregnada pela influência de categorias de natureza econômica. $\mathrm{O}$ jurista leciona que, do ponto de vista jurídico-tributário, o que importa é quem integra o vínculo obrigacional. Logo, nos casos de substituição tributária, o sujeito passivo eleito pela norma como obrigado ao recolhimento do tributo, i.e., que integra a relação jurídica tributária, é o único sujeito passivo enxergado pelo Direito. O outro sujeito, chamado de sujeito passivo direto, sequer existiria, pois sua relevância, para este autor, estaria adstrita a um plano pré-legislativo.

É fácil perceber, todavia, que o legislador tributário nacional quebrou a sujeição passiva em dois momentos distintos, separando as noções de débito e de responsabilidade. Tal segregação se concretiza em, pelo menos, duas figuras distintas: o contribuinte e o responsável tributário.

A simples leitura do artigo 121, do CTN, nos leva a crer que as visões de PAULO DE BARROS CARVALHO $^{73}$, desenvolvida acima, e as de DINO JARACH ${ }^{74}$, ambos afiliados à

\footnotetext{
${ }^{71}$ Neste sentido, segundo MARIA Helena Diniz: SERPa LoPes (Curso de Direito Civil. $4^{\mathrm{a}}$ ed. Freitas Bastos, 1996. V. 2. P. 12 e ss.); Washington de Barros Monteiro (Curso de Direito Civil. 17 a ed. São Paulo: Saraiva, 1982. V. 4. P. 22-7); MARCo AurÉLIO GRECO (Op. cit. (nota 43). P. 182 e ss.).

${ }^{72}$ Cf. CARVALHO, Paulo de Barros. Op. cit. (nota 23), P. 389/396 (391).

${ }^{73}$ Ibidem, Op. cit. (nota 23), 389/396 (391).

${ }^{74} \mathrm{O}$ jurista argentino afirmava que o contribuinte é aquele que está obrigado ao pagamento do tributo por um débito próprio, evidenciando, desta forma, o vínculo obrigacional (pagamento do tributo) e vínculo com o
} 
Teoria Monista, parecem, a nosso ver, não refletir a melhor interpretação do caso brasileiro. Nessa corrente, também chamada de voluntarista ou clássica, a obrigação tem por conteúdo a submissão da vontade do devedor à do credor e, por objeto, um ato daquele mesmo devedor.

Preleciona o mesmo artigo 121 que, não raras vezes, o tributo deverá ser arcado por um terceiro, diferente do contribuinte e que não tenha relação/vínculo direto com o fato gerador. A obrigação de pagar o imposto decorre, nestes casos, exclusivamente de imposição legal, e por uma conduta humana própria desse terceiro, como se observa na perspectiva do contribuinte (sujeito passivo direto).

Para explicar o fenômeno jurídico a que se refere o indigitado artigo 121, ou seja, a situação descrita quando o imposto deve ser pago/assumido por um terceiro que não tenha vínculo direto e pessoal com o fato gerador, i.e., que não tenha dado causa ou promovido o nascimento da obrigação tributária, Alcides JoRge $\operatorname{CostA}^{75}$ faz uso da Teoria Dualista. Para o jurista, fortemente apoiado na monografia de FÁBIO KONDER COMPARATO (Essay d'Analyse Dualiste de l'Obligation em Droit Privé), distinguem-se, na obrigação, dois elementos: o dever (debitum; Schuld), que corresponde ao dever de executar a prestação, e a responsabilidade (obligatio; Haftung $)^{76}$.

Nessa mesma linha caminha MARCO AURÉLIO GRECO ${ }^{77}$, reconhecendo uma decomposição em duas relações ${ }^{78}$ distintas, a relação de débito (rapporto di debito) e a relação de responsabilidade (rapporto di rispondenza):

"Nessa parte o CTN realmente contém previsão que nos autoriza dizer que pode ser utilizada a teoria dualista para explicar nosso Direito positivo, posto

\footnotetext{
fato gerador (débito por título próprio) concentrados no mesmo indivíduo. Existe apenas uma única relação jurídica, que é aquela que se estabelece entre credor e devedor, sendo que o momento (e até mesmo a forma) como ocorre a afetação do patrimônio da pessoa é irrelevante (Cf. JARACH, Dino. O Fato Imponível. in Teoria Geral do Direito Tributário Substantivo. São Paulo: Editora Revista dos Tribunais, 1989. P. 156).

${ }^{75}$ Cf. COSTA, Alcides Jorge. Noção de Tributo. Imposto. Taxa. Contribuição. Preços Públicos. Noção de Direito Tributário. in Curso de Direito Tributário. São Paulo: s.d. Editora FIESP. 69 p.

${ }^{76}$ Cf. COSTA, Alcides Jorge. Op. cit. (nota 05), P. 34.

${ }^{77}$ Cf. GRECO, Marco Aurélio. Op. cit. (nota 43), P. 186.

${ }^{78}$ Lembrando que relação jurídica pressupõe alteridade, contraposição de partes, i.e., pessoas situadas em posições opostas umas às outras. Em sintonia com o que se convencionou afirmar, diz-se contraposição entre os lados ativo e passivo da relação jurídica.
} 
que o art. 121, parágrafo único - dentro do largo espectro do que designou "sujeito passivo" (que corresponderia ao lado positivo da obrigação) contempla as figuras do contribuinte e do responsável. De fato, pode a legislação prever que o contribuinte seja titular da dívida (deve ter a prestação) enquanto ao responsável reserva-se a conseqüência do inadimplemento. Neste sentido, somente a visão dualista explicaria com clareza como duas pessoas, uma vinculada pessoal e diretamente ao fato gerador $e$ outra não, possam ser ambas colocadas perante o mesmo credor e presas à mesma prestação.

(...)

Em conclusão, temos duas relações, a primeira cujo conteúdo é a prestação de dar dinheiro, e a segunda que nasce do inadimplemento da primeira, mediante a qual o credor alcançara um patrimônio para garantir a prestação. "

Com efeito, a análise exige que se reconheça de um lado a obrigação, de outro, a responsabilidade. Enxerga a Teoria Dualista a obrigação tributária como sendo uma relação composta de duas relações diversas e independentes ${ }^{79}$.

A relação de obrigação diz respeito ao débito $(S c h u l d)$ e reporta-se exclusivamente ao contribuinte, que é quem guarda relação pessoal e direta com a causa jurídica do tributo (que é o próprio fato gerador). A capacidade contributiva a ser mensurada para identificação do quantum debeatur (aspecto quantitativo) deverá tomar em consideração somente e tão somente essa primeira relação, tendo em vista que o imposto deverá gravar o patrimônio pessoal do contribuinte.

\footnotetext{
${ }^{79}$ A bem da verdade, aplicando a Teoria Dualista para o âmbito da obrigação tributária, o que se verifica é a formação de duas relações. Na relação de débito teríamos: a sujeição do devedor original (contribuinte), justamente em razão daquela previsão abstrata da lei que se dirige justamente a esse indivíduo, e, por sua vez, a legítima expectativa do Estado (credor) de receber aquela prestação. Na relação de responsabilidade: a obrigação de retenção, pagamento ou de recolhimento, deslocada para o sujeito passivo indireto, contra crédito correspondente de titularidade do Estado. Uma terceira relação poderia ser detectada, que seria aquela entre o obrigado e o responsável: o obrigado (contribuinte) estaria sujeito a arcar com o ônus financeiro gerado pelo encargo tributário, e o responsável guardaria o direito de não sacrificar seu patrimônio próprio mediante retenção de quantia suficiente e necessária para recolhimento aos cofres públicos, e extinção do crédito tributário.
} 
A segunda relação diz respeito à responsabilidade (Haftung) que nada mais é do que a determinação/definição em lei de um terceiro (responsável tributário, genericamente falando) para pagar o tributo por conta e em nome do contribuinte.

É o que explica FÁBIO KONDER COMPARATO ${ }^{80}$ em artigo sobre a teoria dualista da obrigação no direito privado:

"Le grand rapport de la théorie dualiste de l'obligation à la doctrine juridique contemporaine a été de démonstrer que l'obligation n'est pas un rapport simple et unitaire, mais qu'elle se compose de deux éléments: la relation de créance et de dette (Schuld), que nous appelerons devoir, et la relation de contrainte et de responsabilité (Haftung), que nous appelerons engagement.

(...)

Lê second type de rapport constitutif de l'obligation, dans l'ancien droit germanique, serait um rapport de responsabilité (Haftung), en vertu duquel une personne ou une chose se truveraient assujetties à la domination d'une autre personne, comme garantie de la réalisation d'un événement quelconque."

Convém ressaltar que, em que pese toda a construção da doutrina dualista da obrigação ter sido desenvolvida em ambiente do Direito Privado, é perfeitamente possível sua aplicação no Direito Tributário, tendo em vista que, estruturalmente, a obrigação tributária é igual à de direito privado. Trata-se, contudo, de divergência doutrinária relevante, cuja problemática não se encontra definitivamente superada, tanto sob a perspectiva da doutrina como também a partir da legislação nacional ${ }^{81}$.

${ }^{80}$ Cf. COMPARATO, Fábio Konder. Essai d'Analyse Dualiste de l'Obligation en Droit Privé. Paris: Librairie Dalloz, 1964. Em tradução livre: "A grande contribuição da teoria dualista da obrigação à doutrina jurídica contemporânea foi demonstrar que a obrigação não é uma relação simples e unitária, mas que ela se compõe de dois elementos: a relação de crédito e débito (Schuld), que chamamos de dever, e a relação de constrangimento e de responsabilidade (Haftung), que chamamos de obrigação. (...) o segundo tipo de relação constitutiva da obrigação, no direito germânico antigo, seria uma relação de responsabilidade (Haftung), em que uma pessoa ou uma coisa se tornariam sujeitos à dominação de uma outra pessoa, como garantia da realização de um evento qualquer."

${ }^{81}$ As objeções e críticas contra a identidade das obrigações de Direito Público, onde se encontra a obrigação tributária, e as obrigações de Direito Privado, não dizem respeito à estrutura jurídica intrínseca de ambas. Nesse sentido é a opinião de A.D. GIANINI, para quem a obrigação tributária, considerada sob a perspectiva de sua estrutura intrínseca, não se diferencia de qualquer outra obrigação, segundo esquema tradicional elaborado no Direito Privado. Na mesma linha, GIORGIO TESORO ao afirmar que as características que diferenciam uma obrigação da outra não têm a força de modificar a unidade conceitual da estrutura íntima do instituto jurídico da obrigação (apud COSTA, Alcides Jorge. Op. cit. (nota 05), P. 39/45). 
Pois bem. O fato de não coincidir na mesma pessoa as relações de obrigação (debitum; Schuld) e responsabilidade (obligatio; Haftung) não significa dizer que não há consequências de ordem jurídica e econômico-financeiras ao contribuinte ${ }^{82}$, inclusive a própria afetação de seu patrimônio pessoal.

Tanto é assim que, nos casos em que o contribuinte recolhe o tributo voluntariamente, mesmo quando a lei determinava que se tratava de uma responsabilidade de um terceiro, não há se falar em direito de restituição (repetição de indébito) do contribuinte, tendo em vista que nada mais fez do que pagar débito próprio. Sobre este ponto, em crítica à teoria dualista e preferência por uma terceira corrente, MARIA HELENA DINIZ aponta que pecam as teorias que priorizam o debitum em prejuízo da obligatio, valorizando, demasiadamente, a responsabilidade, esquecendo que o adimplemento da obrigação é a regra, e o seu inadimplemento, a exceção. Sustenta que o debitum e a obligatio são essenciais e se completam, constituindo uma unidade com o dever primário do sujeito passivo de satisfazer a prestação e o correlato direito do credor de exigir judicialmente o seu cumprimento, investindo contra o patrimônio do devedor, visto que o mesmo fato gerador do débito produz a responsabilidade ${ }^{83}$.

Assim é que o Código Tributário Nacional, fonte fundamental do Direito Tributário no Brasil, no que se refere ao tema da obrigação tributária e da sujeição passiva tributária, optou por acolher a Teoria Dualista, com a segregação de duas relações jurídicas distintas.

\subsection{Fato Gerador}

Em artigo intitulado "Fato Gerador da Obrigação Tributária", o Professor Luís EDUARDo SCHOUERI ${ }^{84}$ destaca, em suas palavras iniciais, a relevância do tema fato gerador, pois é a partir dele que se desencadeiam diversas noções fundamentais do Direito Tributário, tais

\footnotetext{
${ }^{82}$ Cf. SCHOUERI, Luís Eduardo. (nota 26), P. 166. Neste mesmo sentido veja TORES, Ricardo Lobo. Op. cit. (nota 25), P. 228.

${ }^{83}$ Cf. DINIZ, Maria Helena. Op. cit. (nota 70), P. 30/39.

${ }^{84}$ Cf. SCHOUERI, Luís Eduardo. Op. cit. (nota 26), P. 126.
} 
como a identificação do momento do nascimento/surgimento da obrigação tributária, a identificação/determinação do sujeito passivo, dentre muitos outros efeitos ${ }^{85}$.

Afirma-se que foi GASTÓN JÈZE o precursor na utilização da expressão "fato gerador”, que, rapidamente, foi acolhida e assumida pela doutrina nacional, seja em razão da boa sintonia acadêmica, seja em razão de sua adequação prática. Certamente, essa assimilação contumaz que se operou no Direito brasileiro se deve, em muito, ao magistério de RUBENS GOMES DE SOUSA, influenciado tanto pelo magistério de GASTÓN JÈZE quanto pela doutrina de EZIO VANONI ${ }^{86}$.

Essa forte influência refletiu-se no principal diploma jurídico-tributário existente no País ${ }^{87}$ que é o Código Tributário Nacional, tendo em vista que o próprio RUBENS GOMES DE

${ }^{85}$ Como é sabido, o fato gerador é analisado sob diversas óticas. Diz-se aspectos do fato gerador a análise de cada uma dessas óticas, que são: aspecto material - corresponde ao núcleo ou objeto para o qual se direciona a regra tributária; aspecto espacial - reporta-se ao âmbito de jurisdição e aplicabilidade de uma determinada regra tributária, que poderá ser federal, estadual ou municipal; aspecto temporal - refere-se ao exato momento a partir do qual determinado tributo passa a ser devido e deve ser recolhido em favor dos cofres públicos; aspecto pessoal - corresponde às pessoas que deverão integrar os polos ativo e passivo de uma determinada relação jurídica tributária, foco do presente estudo; aspecto quantitativo - noções referentes ao quantum debeatur, ao valor que será devido a título de tributo, que, regra geral, é formado pela combinação de dois elementos: base de cálculo e alíquota. Para uma completa visão sobre os aspectos do fato gerador confira em: SCHOUERI, Luís Eduardo. Op. cit. (nota 26), P. 146:168; Cf. CARVALHO, Paulo de Barros. Fundamentos Jurídicos da Incidência. $8^{\mathrm{a}}$ ed. São Paulo: Saraiva, 2010. Capítulos II e III; Cf. ATALIBA, Geraldo. Hipótese de Incidência Tributária. $6^{\text {a }}$ edição. $5^{\text {a }}$ tiragem. São Paulo: 2004. Malheiros. P. 89-94.

${ }^{86}$ Também sob forte influência do professor francês, GERALDO ATALIBA assevera que a expressão fato gerador é equívoca, eis que ora referindo-se à hipótese abstrata descrita em lei, ora ao acontecimento fático abstratamente previsto. É nesse sentido que GERALDO ATALIBA prefere, respectivamente, o uso das expressões "hipótese de incidência" e "fato imponível". Em que pese, sob a ótica da doutrina local, o pioneirismo do autor no que se refere à utilização dessas expressões, observam-se duras críticas por boa parcela da doutrina. LUIS EDUARDO SCHOUERI esclarece que, na origem, envolto por seu posicionamento constitutivista (do lançamento), o jurista francês GASTÓN JÈZE entendia que o fato gerador era do "imposto" e não da obrigação tributária (Cf. SCHOUERI, Luís Eduardo. Op. cit. (nota 26), P. 127).

Afirma-se que a utilização da expressão hipótese de incidência não se sustentava com base na teoria da incidência, sob o argumento de que a incidência, i.e., a situação da norma/regra jurídica recair sobre o fato de forma infalível e inexorável (instauração da relação jurídica tributária, seguindo as preliminares noções traçadas no subitem 2.3.) teria força própria, ou seja, aconteceria independentemente da realização ou da prática de um determinado ato ou fato pelo homem (independe da vontade do homem) (nesse sentido, confira-se SOBRINHO, José Wilson Ferreira. Op. cit. (nota 38).

A crítica doutrinária à corrente perseguida por GERALDO ATALIBA continua com relação à expressão fato imponível, utilizada para designar a ocorrência fática no mundo fenomênico da previsão abstrata disposta em lei. Contra a utilização dessa expressão, DINO JARACH afirma que os adjetivos terminados em "vel” indicam mera possibilidade. Como já dito, o nascimento da obrigação tributária, portanto da relação jurídica tributária, independe da vontade do homem, basta a efetivação da subsunção do fato à hipótese descrita em lei.

${ }^{87}$ Para uma visão sobre a problemática que a expressão "fato gerador" tem provocado no Direito Comparado confira trabalho sobre a origem dessa bivalência in SCHOUERI, Luís Eduardo. Op. cit. (nota 26), P. $127 / 146$. 
SousA foi um dos coautores do Anteprojeto que deu origem ao Código atual, publicado em 1966.

Considerando a suposta bivalência ou ambiguidade que a expressão fato gerador revela, ora se referindo à previsão legal, ora se referindo ao acontecimento real e efetivo (situação fática), quer-se crer que o emprego das expressões "fato gerador abstrato" (fattispecie astratta) e "fato gerador concreto" (fattispecie concreta) seriam suficientes para sanar a problemática terminológica em questão. Aquele primeiro designaria a situação abstrata descrita na letra da lei (em estado latente) e o segundo conceito corresponderia à realização, no mundo fático, de um determinado comportamento (de dar, fazer, ou não fazer). A utilização dessas expressões, contudo, a nosso ver, além de repetitiva, não tem o condão de afastar a problemática imantada à expressão "fato gerador".

Em brevíssima síntese, e para os fins do presente estudo, assume-se que fato gerador (fattispecie concreta) é a ocorrência de uma determinada hipótese/situação prevista em lei que dá origem à obrigação tributária. É a partir desse exato instante que se constitui a obrigação tributária $^{88}$ (relação jurídica tributária).

Não se discute a relevância do fato gerador, já que é a partir de suas características que será possível distinguir um tributo do outro. Assim é que quando um determinado dispositivo legal se refere ao fato gerador, em que pese a penosa e problemática bivalência (ou polivalência) gerada por essa expressão, ela quer, em verdade, referir-se à sua

\footnotetext{
${ }^{88}$ Foge ao escopo do presente trabalho a identificação da problemática sobre a natureza declaratória ou constitutiva do lançamento, que certamente implica diferentes conclusões e consequências no que se refere à identificação do sujeito passivo da relação jurídica tributária. Muito embora, assume-se que o fato gerador tem natureza constitutiva, sendo o lançamento meramente declaratório. Sobre esse assunto, em consonância com a posição aqui assumida, confira-se: RUY BARBOSA NOGUEIRA: "Ora, o lançamento não pode criar, modificar ou extinguir direitos, ele é apenas declaratório da obrigação tributária apurada em face da lei e frente à ocorrência do fato gerador. Os efeitos do ato declaratório são 'ex tunc', isto é, eles retroagem. (...) Blumenstein, na Suíça, esclarece: 'O vínculo do lançamento do imposto com o direito tributário material caracteriza-se na resposta à pergunta se o lançamento faz parte ou não dos fundamentos do nascimento do crédito tributário. Embora a esta pergunta se respondesse afirmativamente na mais antiga literatura do Direito tributário, hoje a doutrina e prática são de opinião oposta. Os elementos materiais do nascimento do crédito do imposto (sujeição subjetiva ao poder de imposição e relação com o fato gerado do imposto) existem desde o princípio e, por isso, ao lançamento do imposto como tal, não pode caber nenhum efeito de produção do nascimento (efeito constitutivo)."” (Cf. NOGUEIRA, Ruy Barbosa. Op. cit. (nota 02), P. 223/224). Nesse sentido é a posição do mestre ALIOMAR BALEEIRO: "Recorde-se que o C.T.N. adere à teoria que reconhece ao lançamento o caráter meramente declaratório da obrigação tributária nascida do fato gerador. Este é o ato constitutivo. Por outro lado, segundo o C.T.N., crédito resulta do procedimento administrativo oriundo dessa situação constitutiva.”. (Cf. BALEEIRO, Aliomar. Direito Tributário Brasileiro. $11^{\mathrm{a}}$ ed. Rio de Janeiro: Forense, 2002).
} 
materialidade e não aos demais aspectos do antecedente da RMIT. No final do dia, será o aspecto material que diferenciará uma tributação da outra ${ }^{89}$.

Importante, pois, essa composição, ao se ter em mente o disposto no artigo 128, do CTN, que disciplina sobre espécie de terceiro obrigado ao cumprimento de obrigação tributária para a qual mantenha relação (de forma indireta) com o respectivo fato gerador. Este terceiro estará vinculado, de alguma forma, necessariamente indireta, aos elementos formadores da materialidade do tributo, participando, de forma assessória, no e do momento lógico-normativo em que o fato gerador ocorre, por uma conduta ou situação direta e pessoal do contribuinte.

Para fins da presente dissertação e na medida do possível, utilizaremos a expressão hipótese tributária para designar a previsão abstrata e, para nos referirmos à situação concreta, daremos preferência à expressão "fato gerador", cientes, contudo, dos penosos óbices que a sua utilização costuma gerar. Assim, no decorrer da presente dissertação, conforme passamos a expor, ao nos referirmos ao fato gerador do IR, é pressuposto que, neste momento de concretização, todos os aspectos da regra matriz já terão sido observados. Significa dizer que o fato gerador somente ocorre e se aperfeiçoa quando são verificados todos os aspectos que compõem a sua estrutura, o que resulta concluir que não basta verificar a quase totalidade dos aspectos, ainda que já existam condições razoavelmente seguras para acionar o gatilho da tributação.

\footnotetext{
${ }^{89}$ Este, como vimos, não é exatamente o entendimento do Professor Luís EDUARDO SCHOUERI, que vê, na expressão "fato gerador", o antecedente da regra matriz e não apenas a sua materialidade ${ }^{89}$ (Cf. SCHOUERI, Luís Eduardo. Op. cit. (nota 04), P. 447).
} 


\section{CAPÍTULO II - O IMPOSTO SOBRE A RENDA E O IMPOSTO SOBRE A RENDA COBRADO NA FONTE}

Apoiado nas premissas delineadas no Capítulo I e considerando as diferentes correntes doutrinárias que tratam da extensão do conceito de renda, a análise que propomos percorrer agora é direcionada para a identificação desse conceito. Arrimados nos estudos desenvolvidos neste capítulo, pretendemos, no Capítulo IV, relacionar os correspondentes desdobramentos nas situações observadas no plano do comportamento das pessoas.

Verificar a existência, ou não, de um conceito constitucional de renda será fundamental. Identificados os contornos oferecidos pelo conceito de renda, estaremos muito próximos do ponto nuclear dessa exação, momento em que deverão ser examinados, com profundidade, os aspectos material, temporal e quantitativo do IR. Também será objeto de estudo como estes aspectos se comportam em relação aos princípios informadores do IR, permitindo avaliar se tais princípios são respeitados ou, ao contrário, acabam se desfigurando ou tendo seu conteúdo esvaziado quando da tal concretização, no plano da realidade ventilado acima.

Suportado pelos matizes perfilados nestes pontos, passaremos à abordagem do ponto central deste Capítulo III, o Imposto de Renda na Fonte (IRF), avaliando sua adequação, enquanto sistemática de pagamento, com a hipótese tributária do IR e seu comportamento diante dos princípios que o fundamentam. Para tanto, apoiados no Direito Comparado, traremos o pano de fundo histórico em que surgiu a tributação da renda na fonte e seu contexto legislativo vigente no Brasil. Somente após esse exame é que poderemos dissecar os regimes jurídicos próprios da sistemática de pagamento definida pelo IRF e, com isso, delimitar as consequências jurídicas em cada cenário.

Fundamentalmente, apoiado nos mais elevados níveis do sistema tributário nacional e nas legislações infraconstitucionais que desenham o percurso da concretização da tributação pelo IR, a questão central analisada neste capítulo consiste na identificação conceitual a 
que corresponde o IRF, sua adequação constitucional e a delimitação dos efeitos para os regimes jurídicos que definem a sua natureza jurídica.

\subsection{Os Princípios Gerais Constitucionais Informadores da Hipótese Tributária do Imposto Sobre a Renda}

Diante da fúria arrecadatória de que tanto se fala a respeito da postura do Fisco brasileiro, não podemos perder de vista a preponderância do Sistema Constitucional brasileiro, não apenas no conjunto formado pelos dispositivos compreendidos entre os artigos 145 e 169, mas, em verdade, em toda a Constituição Federal de 1988, como se observa a partir do artigo $1^{\circ}$, que traz as noções quanto à dignidade humana e o mínimo existencial, e do artigo $3^{\circ}$, que traz as expressões dos princípios de justiça, solidariedade e erradicação da pobreza e, também, apenas como exemplo, o artigo 170, que informa quanto à função social da propriedade.

Nos dias de hoje, é de se questionar se, favorecendo uma função exclusivamente exacional, o IR vem sendo utilizado como um instrumento para atingir os fins por ele visados, tais como a redistribuição de riquezas, a promoção do bem estar social e da justiça fiscal, a realização da igualdade e seu corolário, a capacidade contributiva ${ }^{90}$.

A despeito das conclusões que chegaremos a seguir, no tocante à definição do conceito de renda e sua origem exclusivamente constitucional ou não, parece ser consenso que os princípios constitucionais, explícitos e implícitos ${ }^{91}$, são peças-chave na formação dos conceitos e na definição dos parâmetros mínimo e máximo que levam à construção das regras matrizes dos tributos. E com o IR não é diferente.

\footnotetext{
${ }^{90} \mathrm{Cf}$. QUEIROZ, Mary Elbe. Imposto sobre a renda e proventos de qualquer natureza. Barueri/SP: Manole, 2004. Introdução. P. XXIX.

${ }^{91}$ Humberto Ávila, apoiado nas lições de Aliomar BaleEIro e José SOUTO MaIOr Borges, ensina que os princípios explícitos e implícitos diferenciam-se apenas quanto à forma de exteriorização, mas não quanto à sua eficácia jurídica. O mesmo autor complementa que, nos últimos anos, as Cortes Superiores do País têm dado maior ênfase aos postulados da razoabilidade, proporcionalidade e da proibição do excesso, sabidamente implícitos, e que vêm sendo cada vez mais largamente utilizados como fundamentos justificadores para distinções entre os contribuintes. (Cf. ÁVILA, Humberto. Sistema Constitucional Tributário. $3^{\mathrm{a}}$ ed. São Paulo: Saraiva, 2008. P. 7/10).
} 
Desconsiderar a importância dos princípios significa dizer que o legislador infraconstitucional não tem quaisquer amarras, podendo, ilimitadamente, travestir as noções dos conceitos hoje existentes ou definir-lhes novos valores, alterando-lhes o significado, sua extensão e seus efeitos.

O Direito Positivo é altamente impregnado de conteúdo axiológico, sendo certo que os valores que informam o ordenamento jurídico aparecem sob a roupagem de princípios, os quais influenciam e regem todo aquele sistema jurídico, já que são dotados de força vinculante. Significa dizer que eles estão incrustados na consciência ético-moral de uma sociedade, revelando-lhe seu perfil, daí se afirmar que nem o legislador constitucional nem o infraconstitucional poderão se afastar daquela carga valorativa informadora. Assim é que, no tocante à atividade de incidência dos tributos, no bojo dos princípios constitucionais, deverão ser levados em conta tanto os interesses dos contribuintes como os do Fisco, de forma a buscar a necessária harmonização no emprego dessas cláusulas pétreas.

Neste tópico, valendo-se do senso comum extraído da jurisprudência e da doutrina especializadas, analisaremos os princípios constitucionais que guardam maior contato e mais se identificam à hipótese tributária do IR e aos propósitos para os quais acreditamos que direcionam, ou devem direcionar, as políticas atreladas à tributação da renda das pessoas físicas e jurídicas. Serão analisados apenas os principais princípios de caráter geral que informam o IR, reservando tópico separado para análise dos princípios específicos do IR, a saber: universalidade, generalidade e progressividade. Conforme se perceberá, não são raras as situações em que os valores e os conceitos gravados no âmago de cada um dos princípios se entrecruzam e se confundem, traduzindo a unicidade que se espera do ordenamento jurídico ${ }^{92}$.

\footnotetext{
${ }^{92}$ Humberto Ávila ensina que os princípios buscam um estado ideal das coisas e, por conta disso, vinculam-se mais intensamente entre eles e com os quais mantêm relação de complementariedade, especialmente porque a própria Constituição Federal estabelece o dever de buscar ou preservar vários ideais ao mesmo tempo (Ibidem, Op. cit. (nota 91), P. 39).
} 


\subsubsection{Princípio da Legalidade}

Como já dissemos no início desta dissertação, foi a consagração da legalidade, elevada à categoria de um ato ou procedimento obrigatório por parte do Estado em relação aos seus súditos, que permitiu consolidar a noção de Estado de Direito. Trata-se de uma garantia individual dos contribuintes contra atos e atitudes arbitrárias por parte do Estado, de forma a evitar abusos do Fisco.

Em matéria tributária, o princípio basilar da legalidade apresenta-se como uma garantia dos contribuintes, na medida em que o Estado só poderá atingir-lhes o patrimônio nos precisos moldes definidos na lei e desde que essa lei seja anterior à ocorrência do fato ou à determinada situação ensejadora de evento tributário definido naquela mesma lei.

A legalidade se manifesta de tal forma que nenhum tributo poderá ser criado ou aumentado sem que lei assim o estabeleça. Editada lei nesse sentido, a ocorrência fática deverá subsumir-se inteiramente à hipótese tributária definida em lei.

No esteio do que dissemos acima quanto à necessidade de harmonização dos princípios, a legalidade é exemplo típico, ao se apresentar como comando polivalente, direcionado tanto para o Estado quanto para o contribuinte. Do contribuinte será exigido o cumprimento da prestação tributária tão logo ocorra o nascimento da obrigação tributária, assim como lhe deve ser assegurado o direito de inviolabilidade e certeza dos atos praticados em conformidade com aquela tal legalidade. É pressuposto dessa conformidade com a legalidade o agir com boa-fé e a adequação dos atos às formalidades prescritas em lei.

Ao Estado, por sua vez, é-lhe assegurado o direito (dever) de exigir aquela prestação tributária, tão logo se torne exigível. Ainda, obriga-se o Estado a respeitar os atos praticados pelo contribuinte dentro da legalidade.

O princípio da legalidade deve ter em alta conta uma de suas principais feições, que deve ser, nessa ordem, porém sempre de forma conjunta, (i) a conformidade da tributação com o fato gerador - é dizer que, regra geral, os tributos somente podem ser arrecadados depois 
de ocorrido o fato gerador ao qual a lei vincula a obrigação tributária ${ }^{93}$, e (ii) a finalidade da lei - a lei tributária deverá ser interpretada através do emprego conjunto dos métodos sistemático e teleológico. Diz-se regra geral, porque, justamente em função do grau de flexibilidade próprio da natureza jurídica dos princípios, a tributação poderá ocorrer antes do aperfeiçoamento completo do fato gerador, em prestígio de outras justificativas de natureza constitucional, igualmente relevantes.

\subsubsection{Princípio da Igualdade e da Capacidade Contributiva e o Mínimo Existencial}

Da leitura do preâmbulo da Constituição Federal já se observa a expressão igualdade, sendo possível afirmar que se trata de um sobreprincípio, com funções inclusive de informar os outros princípios.

A relevância desse sobreprincípio não passou despercebida por MARY ELBE QUEIROZ ${ }^{94}$, que ensina que sua magnitude é tamanha que, se subtraído fosse do ordenamento jurídico, outros princípios perderiam sua amplitude, como a legalidade, na medida em que a mesma lei poderia ser aplicada de forma diferente para contribuintes que se encontrassem na mesma situação, bem como a capacidade contributiva, por meio da exigência em medidas diferentes de tributo perante contribuintes que se encontrassem em situações idênticas.

Na doutrina, é RUY BARBosA ${ }^{95}$, em sua Orações aos Moços, apoiado nos eruditos pensamentos de Aristóteles, que, com eloquência, detalha o campo de atuação e emprego deste princípio, valendo a transcrição de suas palavras:

\footnotetext{
93 “Em matéria tributária, e como corolário dos três princípios acima descritos, encontramos finalmente o princípio específico da conformidade da tributação com o fato gerador. Segundo este princípio, os tributos somente podem ser arrecadados depois de ocorrido o fato gerador ao qual a lei vincula a obrigação tributária. O nascimento da obrigação tributária está subordinado ao princípio da legalidade, na forma específica de conformidade com o fato gerador.

Assim, por força do princípio da legalidade tributária, exige-se que a lei formal determine todos os elementos constitutivos da obrigação tributária, ou seja, todos os aspectos do fato gerador. Uma lei que autoriza a cobrança de tributos não pode deixar a critério da administração a diferenciação objetiva. Ela própria tem que realizar esta diferenciação." (Cf. ROTHMANN, Gerd Willi. O princípio da legalidade tributária. São Paulo: Revista Forense Vol. 248, 1974. P. 41).

${ }^{94}$ Cf. QUEIROZ, Mary Elbe. Op. cit. (nota 90), P. 18.

95 Cf. BARBOSA, Rui. Oração aos Moços. Ed. Popular anotada. Rio de Janeiro: Fundação Casa de Rui Barbosa, 1980.
} 
"A regra da igualdade não consiste senão em quinhoar desigualmente os desiguais, na medida em que se desigualam. Nesta desigualdade social, proporcionada à desigualdade natural, é que se acha a verdadeira lei da igualdade. O mais são desvarios da inveja, do orgulho ou da loucura. Tratar com desigualdade a iguais, ou a a desiguais com igualdade, seria desigualdade flagrante, e não igualdade real."

Há que se alertar, contudo, que definir o que é igual ou desigual (diferente) é tarefa que só se faz por meio de critérios de classificação, sendo certo que a escolha e a definição desses critérios de discrímen competem exclusivamente ao homem. Daí se dizer que um mesmo objeto pode ser igual ou desigual em relação a outro conforme seja o critério de classificação adotado.

Luís CESAR SOUZA DE QueIROZ cita alguns exemplos de critérios que não podem ser utilizados para fins classificatórios: origem, raça, cor, religião, convicção filosófica ou política, estado civil, espécie de trabalho e de vínculo trabalhista. E como exemplos que podem ser adotados como critérios de discrímen: a quantidade de patrimônio e o porte de uma empresa. Há, todavia, critérios camaleões, como é o caso da idade ou faixa etária dos indivíduos e a espécie de nacionalidade, que poderão, em algumas situações, ser utilizados como critérios classificatórios e, em outras, não ${ }^{96}$.

Conforme se verá, especificamente com relação ao IRF, o legislador infraconstitucional trata de forma diferente a renda produzida pelo trabalho e a renda com origem no capital. Resta saber se o critério de discrímen eleito encontra suporte constitucional.

Para os fins da atividade tributária, o que se deve ter em conta é que o princípio constitucional da igualdade, como elemento limitador do conteúdo inserido na hipótese tributária, deve ser entendido de tal forma que seja conferido tratamento igual aos iguais e desigual aos desiguais, desde que os critérios eleitos para determinação dessas igualdades ou desigualdades encontrem amparo na Constituição, notadamente em seus princípios.

${ }^{96}$ Cf. QUEIROZ, Luis Cesar Souza de. Op. cit. (nota 09), P. 95/99. 
O princípio da igualdade é analisado, também, sob a ótica de vetor de realização do princípio da capacidade contributiva, e este, por sua vez, é vetor de realização do princípio do mínimo existencial e da proibição constitucional de matéria tributária com efeito de confisco. Na verdade, não há uma sequência lógica a ser seguida; como já se disse, por vezes, diante do caso concreto, esses princípios se entrecruzam e se confundem.

PASQUALE RUSSO ${ }^{97}$ ensina que, para definir capacidade contributiva em termos propriamente jurídicos, não se pode limitar a referir-se apenas à capacidade econômica, mas somente àquela capacidade suscetível de fornecer ao sujeito gravado (contribuinte e responsável) os meios financeiros necessários para absorção da prestação pecuniária com o pagamento de tributos. Mais especificamente quanto à ideia do mínimo existencial, assim revela o autor:

"B) Os recursos econômicos que não revelam capacidade para contribuir, $e$ por isso não são destináveis à realização da prestação pecuniária porque indispensáveis ao atendimento a necessidades fundamentais do sujeito passivo, não podem ser submetidos à tributação. É o caso do assim chamado mínimo vital, com cuja expressão se costuma designar aquela faixa de riqueza que não pode ser atingida pela arrecadação sem comprometer a própria sobrevivência do contribuinte e, portanto, sem arranhar a tutela dos direitos invioláveis da pessoa proclamada pelo art. $2^{\circ}$, parágrafo $1^{\circ}$ da Constituição."

O autor completa esclarecendo que aquela "faixa de segurança" pode ser preservada tanto com a indicação de alíquotas mínimas, como também com a concessão de deduções adequadas da base tributável.

Neste sentido, e consoante disposto no artigo 145, da Constituição Federal, o Estado deve buscar, sempre que possível, aferir a real capacidade contributivo-econômica dos contribuintes.

${ }^{97}$ Cf. RUSSO, Pasquale. Os Princípios Fundamentais (Título Original: I Principi Fondamentali - Capítulo do livro "Manuale di Duitto Tributario: parte generale", Milano: Giuffrè, 2002, p. 39-73). Tradução de Dalton Dallazem. in Princípios e Limites da Tributação. Coord. Roberto Catalano Botelho Ferraz. São Paulo: Quartir Latin, 2005. P. 396/399. 
A expressão "sempre que possível", presente na redação do texto constitucional, parece trazer a própria tônica ínsita aos princípios constitucionais, no sentido de um ideal a ser alcançado, como uma obrigação a ser perseguida arduamente, flexibilizada, porém, por outras questões com maior prioridade para uma situação em específico. Essas outras razões necessariamente deverão revestir-se de natureza e origem constitucional, de forma a justificar sua prioridade em relação a outro princípio constitucional.

Sob outra ótica, aquela expressão deverá ser entendida como uma garantia constitucional do contribuinte, de forma a considerar sua obrigação de pagar imposto em comparação à sua condição sócio-econômica. É neste cenário que a capacidade contributiva exerce papel protagonista. Na medida em que pressupõe a capacidade econômica ${ }^{98}$, considerando, neste universo, o mínimo existencial, estaria realizado o ideal de justiça fiscal. É dizer que a capacidade contributiva não deve se ater à regra matemática para cobrança de tributos, mas, sim, considerar outros fatores de ordem não tributária.

KLAUS TIPKE ensina que ao Estado Social de Direito deve corresponder o princípio da capacidade contributiva. Postula que o tributo somente pode ser exigido daquele que pode pagá-lo, e somente na exata proporção dessa possibilidade, é dizer que somente pode ser tributado o que for além do mínimo existencial ${ }^{99}$.

É imperativo que a capacidade contributiva seja analisada como efetiva capacidade econômica, no sentido de que se deve contribuir para as despesas públicas, através do pagamento de tributos, de acordo com o rendimento ou riqueza ajustados para o pagamento de tributos. Se o Estado não provê aquele mínimo existencial, correspondente às necessidades fundamentais do homem (saúde, segurança, educação, moradia, condições de emprego, dentre outros), transferindo esse ônus aos particulares, sob grave prejuízo à

\footnotetext{
98 "A capacidade contributiva é o princípio segundo o qual cada cidadão deve contribuir para as despesas públicas na exata proporção de sua capacidade econômica. Isto significa que os custos públicos devem ser rateados proporcionalmente entre os cidadãos, na medida em que estes tenham usufruído da riqueza garantida pelo Estado. Também aceita como capacidade contributiva a divisão equitativa das despesas na medida da capacidade individual de suportar o encargo fiscal. Este conceito se traduz na necessidade de separar, com justiça, a porção necessária à sobrevivência do cidadão daquela sujeita a ser utilizada no custeio dos custos públicos. Essa separação seria feita sob um critério de distinguir a capacidade econômica da capacidade contributiva." (Cf. ZILVETI, Fernando Aurélio. Capacidade Contributiva e Mínimo Existencial. in Direito Tributário - Estudos em Homenagem a Brandão Machado. Coordenação: Prof. Luis Eduardo Schoueri e Prof. Fernando Aurélio Zilveti. São Paulo: Dialética, 1998. P. 36/37).

${ }^{99}$ Cf. TIPKE, Klaus, e YAMASHITA, Douglas. Justiça Fiscal e Princípio da Capacidade Contributiva. São Paulo: Malheiros Editores, 2002. P. 29.
} 
maior parcela da população carente, muitas vezes inviabilizando o acesso a tais recursos, a capacidade econômica para pagamento de tributos deveria corresponder àquela riqueza ou renda líquida, ou seja, à renda deduzida das despesas que o contribuinte tem que arcar com a provisão e subsistência próprias e de sua família, diante da inércia e da omissão do Estado $^{100}$.

\subsubsection{Certeza do Direito e Segurança Jurídica}

A segurança jurídica, por sua vez, significa a exigência de certeza quanto à existência e aplicabilidade dos direitos do cidadão, traduzindo-se, também, na mútua confiança que se faz nascer a partir da relação entre Fisco e contribuinte. Ambos, justiça e segurança jurídica, concretizam-se, em menor ou maior grau, conforme o caso, através dos princípios da legalidade, tipicidade, irretroatividade, anterioridade, vedação à analogia e ao confisco $^{101}$.

Valendo-se dos métodos sistemático e teleológico, a interpretação da segurança jurídica deve buscar as causas da regra de incidência e exigência de tributo, para que sejam colocados na balança, de um lado, os ideais de justiça e do imposto justo, e de outro lado, os princípios que informam o Direito Tributário ${ }^{102}$.

Acreditamos que a solução para esse pseudoparadoxo, com vistas a evitar maior insegurança jurídica, deve colimar pela simplificação, coesão, coerência, concisão e unidade do sistema, explicado a seguir ${ }^{103}$.

${ }^{100}$ Cf. FARIA, Renato Vilela. Noções de Justiça Fiscal e o Planejamento Tributário. in Revista de Direito Tributário Atual. Vol. 23. Coord. Alcides Jorge Costa, Luis Eduardo Schoueri e Paulo Celso Bergstrom Bonilha. São Paulo: Dialética-IBDT, 2009. P. $427 / 448$ (440).

${ }^{101}$ Nesse sentido: "Os postulados da segurança jurídica e da proteção da confiança, enquanto expressões do Estado Democrático de Direito, mostram-se impregnados de elevado conteúdo ético, social e jurídico, projetando-se sobre as relações jurídicas, inclusive as de direito público, sempre que se registre alteração substancial de diretrizes hermenêuticas, impondo-se à observância de qualquer dos Poderes do Estado e, desse modo, permitindo preservar situações já consolidadas no passado e anteriores aos marcos temporais definidos pelo próprio Tribunal. Doutrina. Precedentes. - A ruptura de paradigma resultante de substancial revisão de padrões jurisprudenciais, com o reconhecimento do caráter partidário do mandato eletivo proporcional, impõe, em respeito à exigência de segurança jurídica e ao princípio da proteção da confiança dos cidadãos, que se defina o momento a partir do qual terá aplicabilidade a nova diretriz hermenêutica." (Pleno do STF. Rel. Min. Celso de Mello. MS no 26603/DF. D.J.e 19/12/2008).

102 Cf. FARIA, Renato Vilela. Op. cit. (nota 100), P. 436.

${ }^{103}$ Ibidem, Op. cit. (nota 100), P. 441. 
Simplificação consiste na imediata diminuição do número de normas que a cada dia se multiplicam e na redução do volume de deveres instrumentais acometidas ao contribuinte, causando-lhe confusão na interpretação e aplicação da lei tributária e frustração, tanto pelas dificuldades enfrentadas nessa seara quanto pelo aumento nos custos (pessoal e infraestrutura) que essas tarefas ensejam.

Coesão, coerência, concisão e unidade são máximas a serem perseguidas pela harmonia e lógica do ordenamento. Some-se, acentuando mais a ineficiência de um sistema jurídico, o fato de que regras conflitantes ou situações de lacuna na lei são causa de insegurança jurídica, além de contribuir para a propagação de situações de desrespeito à lei e de tentativas de burlar o ordenamento ${ }^{104}$.

\subsubsection{A Justiça Fiscal como Denominador Comum}

É imprescindível que a justiça, igualmente prevista como sobreprincípio no preâmbulo da Constituição, descrita como justiça fiscal no âmbito do Direito Tributário, deve ser um objetivo, tanto ou mais importante que a própria arrecadação, a ser buscado pelo legislador.

A justiça fiscal, todavia, não pode ser analisada isoladamente, somente a partir de uma perspectiva meramente tributária. É imprescindível que os olhares se voltem para a problemática social, daí se falar numa justiça sócio-tributária. Acreditamos que não é possível dissociar o sinalagma entre estas duas realidades, já que ambos se referem a um único valor: justiça. Este sistema cíclico de justiça nada mais é do que o resultado derivado do liame entre a justiça fiscal e a justiça social. Desprezá-lo significa mergulhar em ambiente de injustiças, incertezas e arbitrariedades ${ }^{105}$.

\footnotetext{
${ }^{104}$ Exemplo atual de norma de difícil compreensão e aplicação é o recente Regime Tributário de Transição, o qual prevê, para aqueles contribuintes pessoas jurídicas que o adotarem, que as novas regras trazidas pela Lei $\mathrm{n}^{\circ}$ 11.638/07, que alterou drasticamente a Lei das Sociedades Anônimas (Lei ${ }^{\circ}$ 6.404/76), não deverão ser aplicados aos novos critérios de reconhecimento de receitas, custos e despesas, devendo ser adotados os métodos e critérios contábeis vigentes em 31 de dezembro de 2007, alguns deles expressamente revogados pela própria Lei $\mathrm{n}^{\circ} 11.638 / 07$.

${ }^{105}$ Cf. FARIA, Renato Vilela. Op. cit. (nota 100), P. 432 e ss.
} 
No sistema cíclico de justiça devem prevalecer a mútua confiança, operacionalizada pela contrapartida automática das partes, em termos quantitativos e qualitativos, valendo destacar os seguintes pontos ${ }^{106}$ :

a. Em um Estado de Direito é imperioso que a solidariedade e a liberdade dos contribuintes em exercer, organizar, administrar, planejar e gerir suas atividades e negócios sejam sempre temperadas, equanimemente, lado a lado da igualdade e da solidariedade. $\mathrm{O}$ resultado dessa receita é uma sociedade que privilegia a segurança jurídica (noções de justiça fiscal);

b. Ao passo que é exigida uma determinada soma de dinheiro dos cidadãos enquanto contribuintes, o Estado deve cobrar somente daqueles que gozem de condições mínimas e suficientes para pagar aquele tributo, de forma proporcional, racional e satisfatória (noções de tributo justo);

c. Diante do pagamento/recolhimento do tributo justo, o Estado está obrigado a investir aquele capital em favor da coletividade, através da prestação de serviços públicos e do fomento e desenvolvimento de obras públicas.

Assim, o dever de pagar imposto não deve ser enxergado como um sacrifício, mas, sim, como um dever necessário para que o Estado possa cumprir suas tarefas no interesse do proveitoso convívio de todos os cidadãos ${ }^{107}$. Lastreado nessa necessária contribuição arrecadada dos contribuintes, o Estado estará obrigado e vinculado a empregar tais recursos em investimentos públicos, infraestrutura, programas governamentais e na prestação dos diversos serviços públicos colocados à disposição da sociedade, tais como: segurança pública, educação, saúde, moradia, transporte, condições dignas para a velhice, emprego, atividades de esporte e lazer em geral etc.

A justiça sócio-tributária, ou o sistema cíclico de justiça a que nos referimos acima, associada à segurança jurídica são os vetores que permitirão conduzir a verificação e aplicação dos demais princípios constitucionais às situações concretas, especialmente àquelas limítrofes, dando espaço ao que a doutrina chama de técnica de sopesamento dos

\footnotetext{
${ }^{106}$ Ibidem, Op. cit. (nota 100), P. 432.

${ }^{107}$ Cf. TIPKE, Klaus, e YAMASHITA, Douglas. Op. Cit. (nota 99), P. 15
} 
princípios. Trataremos deste tema no subitem 1.10.6., tendo por mote o cruzamento das normas tributárias do IRF em contraposição às noções conceituais do fato gerador do IR.

\subsection{Universalidade, Generalidade e Progressividade - Os Princípios Específicos do IR}

Além da gama de princípios constitucionais, explícitos e implícitos, que regem o sistema tributário nacional, o IR demanda, ainda, a presença simultânea de outros princípios específicos para sua formulação: a universalidade, a generalidade e a progressividade.

O primeiro ponto a ser destacado, em consonância com o pensamento de RICARDO MARIZ OLIVEIRA $^{108}$, é que os “critérios" (inciso I, $\S 2^{\circ}$, do artigo 153, da CF) da universalidade, da generalidade e da progressividade são verdadeiros princípios, aos quais se aplicam quaisquer dos efeitos próprios do regime jurídico dos princípios. Refoge ao escopo desta dissertação dissecar esse regime jurídico, bastando, por ora, atentar que, entre regras e princípios, temos tratamentos distintos quando estamos diante de (aparente) conflito entre regras ou entre vários princípios entre si.

Pois bem. Diante da incontestável importância que estes princípios exercem na definição dos contornos do IR, passamos, apoiados na melhor doutrina sobre o tema ${ }^{109}$, a elucidar os principais aspectos conceituais presentes nesses três princípios:

Generalidade: basicamente, a generalidade está ligada às pessoas; a universalidade, como ilustraremos a seguir, às rendas. Pelo princípio da generalidade, objetiva-se afastar qualquer tipo de discriminação ou privilégios pessoais, independentemente de seu perfil (sexo, estado civil, raça, função profissional etc.). Significa tratar todas as situações sob uma norma geral, no sentido de ser aplicável a todos os contribuintes e em contraposição à seletividade. A generalidade é tomada, sob essa perspectiva, como um vetor da realização do primado da igualdade, de forma que o imposto deve tratar por igual todo $e$ qualquer contribuinte que tenha obtido um aumento patrimonial sujeito à tributação pelo $I R$, independentemente de quaisquer outras circunstâncias externas ao contexto da

\footnotetext{
${ }^{108}$ Cf. OLIVEIRA, Ricardo Mariz de. Op. cit. (nota 16). P. 250/252.

109 Cf. OLIVEIRA, Ricardo Mariz de. Op. cit. (nota 16). P. 253/260; Cf. QUEIROZ, Mary Elbe. Op. cit. (nota 90), P. 35/42; Cf. QUEIROZ, Luis Cesar Souza de. (nota 09), P. 95/99.
} 
hipótese tributária. Alguns autores chegam a afirmar que não há como dissociar a generalidade da universalidade, daí se dizer que tais conceitos costumam se confundir, ou, mais propriamente, igualar-se. É importante que fique claro que a generalidade refere-se à totalidade das pessoas e universalidade, à totalidade da rendas.

Universalidade: A universalidade refere-se, assim, ao alcance do conjunto de todas as espécies de rendas e de todas as espécies de proventos, independentemente de sua origem e de sua fonte de produção. Esse conjunto, em regra, deverá ser considerado englobadamente, de forma que eventual exceção deverá condicionar-se e justificar-se na exata extensão dos demais princípios constitucionais. Queremos crer, desde que observados os critérios de discrímen eleitos pelo legislador sob a ótica constitucional e de forma a atender aos objetivos de facilitação na execução das leis, que a universalidade poderá permitir a existência de diferentes tipos de tributação em razão do tipo de renda. $\mathrm{O}$ princípio está intimamente ligado aos aspectos material, na medida em que todo patrimônio do contribuinte deve ser considerado na sua integralidade, sem qualquer fracionamento, e quantitativo, tendo em vista que quanto maior o volume de rendas, receitas e rendimentos a serem considerados, maior será a base de cálculo. Este princípio requer que sejam considerados todos os fatores positivos e negativos que compõem o patrimônio no início e no final do período de apuração, bem como a universalidade de todos os fatores que o aumentem ou diminuem dentro desse período de tempo fixado pela lei (...), durante o seu transcurso com todos os fatores de mutação dessa universalidade; o princípio da universalidade se amolda à natureza pura do imposto de renda, incidente que é sobre acréscimo patrimonial, revelando sua intimidade e coordenação com a capacidade contributiva.

Progressividade: este princípio, por sua vez, está vinculado quase que exclusivamente a um dos aspectos quantitativos da regra matriz, a alíquota. A progressividade, junto com a pessoalidade, são vetores que permitem a realização da capacidade contributiva na hipótese tributária do IR, i.e., são técnicas de graduação da capacidade contributivo-econômica dos contribuintes. Assim é que quanto maior a renda, maior a base tributável e, proporcionalmente, exigem-se alíquotas maiores quanto maiores sejam as bases de cálculos. Seu requisito de validade exige que haja uma variação ascendente, à medida que a base de cálculo aumente. Ao ser acolhido como princípio pela $\mathrm{CF}$, a progressividade 
somente se mostra eficiente se for associada aos princípios da generalidade e da universalidade; exatamente por isso, a consideração da progressividade, juntamente com a generalidade e a universalidade, atende à exigência do princípio da isonomia, da capacidade contributiva e da justiça fiscal, tratando por igual os contribuintes que se encontrem em igual montante de aumento dos seus patrimônios, além de que também observa o princípio da pessoalidade, dado que possibilita um tratamento mais equitativo entre pessoas de diferentes níveis de riqueza, tributando mais onerosamente os de maior capacidade econômica $^{110}$. Impostos com alíquotas progressivas (crescentes) atuam como vetores da igualdade, afastam as injustiças tributárias e permitem que o Estado remova, em parte, as desigualdades econômicas existentes entre as pessoas, ao menos na extensão da carga tributária que lhes é atribuída ${ }^{111}$.

Sem querer afastar a importância desses princípios no desenho do fato gerador do IR, é importante ter em mente que, diferentemente das regras em que se chega ao limite de ter que decidir pela sua aplicação ou não, ou, nas palavras de LUís EDUARDO SCHOUERI ${ }^{112}$, baseado nas lições de EROS RobERTO GRAU e DwORKIN, onde as questões se resolvem no critério do "tudo ou nada", os princípios não se aplicam automática e necessariamente quando as condições previstas para sua aplicação se manifestam. Diversamente, os princípios, dada sua dimensão de importância, refletem um estado ideal, algo a ser alcançado na maior medida possível ${ }^{113}$.

\footnotetext{
${ }^{110}$ Contra a progressividade levantam-se, todavia, os argumentos no sentido de que essa técnica tende a (i) desestimular os mais esforçados ou mais eficientes, sendo punidos com uma tributação mais gravosa em vez de serem recompensados; (ii) não atrair o ingresso de novos capitais e incentivar a saída dos aqui existentes, sob a alegação de procurar um ambiente fiscalmente menos hostil, prejudicando o incremento da produção nacional; (iii) redução do desenvolvimento nacional, em função do menos esforço e da menor eficiência; (iv) e tudo isso prejudica o processo de distribuição de riquezas nacionais e agrava a situação de subdesenvolvimento econômico-social ou desenvolvimento precário de um determinado país ou região (Cf. QUEIROZ, Luís Cesar Souza de. Op. cit. (nota 09), P. 96). Fernando AuRÉLIo ZilvetTi já se manifestou contrariamente à ideia de que a progressividade seria um dos vetores de realização da capacidade contributiva e afirmou não existir qualquer relação entre estes princípios, revelando até mesmo um grau de incompatibilidade (Cf. ZILVETTI, Fernando Aurélio. Progressividade, justiça social e capacidade contributiva. in Revista Dialética de Direito Tributário no 76. São Paulo: Dialética, 2002. P. 29/32).

${ }^{111}$ Cf. CARRAZZA, Roque Antonio. Curso de Direito Constitucional Tributário. $19^{\mathrm{a}}$ edição. $3^{\mathrm{a}}$ tiragem. São Paulo: Malheiros, 2003. P. 79.

${ }^{112}$ Cf. SCHOUERI, Luis Eduardo. Op. cit. (nota 04), P. 266.

${ }^{113}$ Cf. SCHOUERI, Luis Eduardo. O Mito do Lucro Real na Passagem da Disponibilidade Jurídica para a Disponibilidade Econômica. in Controvérsias Jurídico-Contábeis (Aproximações e Distanciamentos). Coord.s Roberto Quiroga Mosquera e Alexsandro Broedel Lopes. São Paulo: Dialética, 2010. P. 263.
} 
Queremos crer que os princípios da universalidade, generalidade, progressividade e todos os demais princípios constitucionais, explícitos ou implícitos, devem ser analisados e utilizados sob essa perspectiva. Voltaremos a essa análise quando analisarmos o comportamento dos princípios constitucionais que informam IR diante da sistemática do IRF.

\subsection{O Conceito de Renda e seus Desdobramentos}

A problemática acerca do conceito de "renda" não é uma exclusividade do cenário brasileiro. Na Alemanha, por exemplo, segundo WofGANG SchÖN ${ }^{114}$, com foco na tributação da pessoa física, renda pode ser definida como um lucro, i.e., como a diferença entre o montante líquido dos ativos negociais no final do exercício fiscal e no final do exercício fiscal anterior, mais alguns ajustes de adição e exclusão. Em outros casos, "renda" pode ser definida como o excesso de recebimentos sobre os gastos para aquisição e/ou manutenção de receita, baseado, portanto, na aplicação de um método de caixa, mais a dedução de algumas depreciações. A principal diferença entre essas duas categorias é que, no primeiro caso, todos os ganhos e perdas relacionados com a liquidação de ativos são incluídos na base de cálculo; na segunda categoria, os ganhos de capital podem se valer de incentivos fiscais somente em determinadas condições.

JOHN TILEY indica que provavelmente um dos maiores legados da história do imposto de renda britânico seja a análise do escopo da "renda" e a distinção entre renda e capital. Quando o IR inglês foi primeiramente introduzido em 1799, não apenas as formas existentes de capital já estavam sujeitas a outros tributos, mas havia também uma área relevante do Direito - a que lidava com os Trusts - onde uma precisa distinção entre renda e recebimentos do capital havia sido então desenhada ${ }^{115}$.

O conceito de renda pode ser analisado sob diversas óticas: produção, repartição ou distribuição, consumo. Ainda, não é menos acertado falar-se em renda imputada, renda

\footnotetext{
${ }^{114}$ Cf. SCHÖN, Wofgang. Germany. in Comparative Income Taxation - A Structural Analysis. Second Editions. Coords. Hugh J. Ault. Brian J. Arnold. Kluwer Law Internationl - Aspen Publishers. 2004. P. 58/59. ${ }^{115}$ Cf. TILEY, John. United Kingdom. in Comparative Income Taxation - A Structural Analysis. Second Editions. Coords. Hugh J. Ault. Brian J. Arnold. Kluwer Law Internationl - Aspen Publishers. 2004. P. 115/116.
} 
psíquica, ou mesmo analisar o seu conceito a partir das Teorias da Fonte ou do Acréscimo Patrimonial $^{116}$.

Alcides Jorge CoSta, citando Walter Ryser, ensina que, sob a ótica da produção, a noção de renda traduz-se como sendo fruto periódico de uma fonte permanente. Mais à frente, o tributarista lembra que, sob essa ótica, aparece clara a contraposição entre capital e renda e, também, a conexão entre ambos, esclarecendo que renda não é a totalidade do produto de uma atividade, uma vez que dele deve ser apartado o que é conservação do capital. Sob a ótica da distribuição, a renda constitui-se como o produto da atividade da empresa distribuído aos diversos agentes da produção. E, por último, sob a ótica do consumo, considera-se renda o que uma pessoa consome efetivamente ${ }^{117}$.

Ainda, acerca das teorias da fonte e do acréscimo patrimonial, Alcides JORGE CostA assim elucida: "À teoria da fonte opõe-se a do acréscimo patrimonial (...) constitui renda, para todos os indivíduos e para as sociedades, o acréscimo dos ativos num determinado período de tempo e renda tributável o crescimento líquido do patrimônio calculado deduzindo-se do valor bruto as perdas de capital, os gastos gerais e de manutenção, os juros e, em certos casos, as obrigações passivas." ${ }^{118}$.

Sobre a renda imputada e a renda psíquica, THOMAS CHANCELlOR ${ }^{119}$ destaca que os serviços prestados a si próprio, o tempo dedicado ao ócio ou a utilização de ativos próprios promovem satisfação ou benefícios ao indivíduo. Entretanto, não representam aumento do poder de compra do indivíduo para adquirir (outros) produtos/serviços no mercado e, consequentemente, não gerariam receita/renda. $\mathrm{O}$ autor aponta que a renda poupada é uma

\footnotetext{
${ }^{116}$ O STJ já se manifestou no sentido de que não importa o nome ou a natureza jurídica de determinado rendimento ou verba recebida, mas, sim, se houve acréscimo patrimonial: "Ementa: TRIBUTÁRIO. IMPOSTO DE RENDA. INCIDÊNCIA. INDENIZAÇÃO POR HORAS EXTRAS. TRABALHADAS - IHT. PETROBRÁS. EMBARGOS DE DIVERGÊNCIA PROVIDOS. (...) 2. Não é o nomen juris, mas a natureza jurídica da verba que definirá a incidência tributária ou não. $O$ fato gerador de incidência tributária sobre renda e proventos, conforme dispõe o art. 43 do CTN, é tudo que tipificar acréscimo ao patrimônio material do contribuinte." (STJ. Primeira Seção. EREsp no 979.765/SE. Rel. Min. Mauro Campbell Marques. DJ 01/09/2008).

${ }^{117}$ Cf. COSTA, Alcides Jorge. Conceito de Renda Tributável. in Estudos sobre o Imposto de Renda (Em Memória de Henry Tilbery). Coord. Ives Gandra da Silva Martins. São Paulo: Editora Resenha Tributária, julho/1994. P. 20/21.

${ }_{118}$ Cf. COSTA, Alcides Jorge. Op. cit. (nota 117), P. 20/21.

${ }^{119}$ Cf. CHANCELLOR, Thomas. Imputed Income and the Ideal Income Tax. 67 Or. L. Ver. 561 (1998). in Federal Income Tax Anthology. CARON, Paul L.; BURKE, Karen C.; MCCOUCH, Grayson M. P. P. 114/115.
} 
escolha da pessoa para ser utilizada em outros propósitos, sendo certo que a não realização de uma despesa não constitui uma receita. Ainda, o autor esclarece seu ponto de vista no sentido de que essas satisfações não são renda passível de tributação: o indivíduo, por exemplo, poderia ter a satisfação de ter sua casa pintada por um pintor contratado, da mesma forma como poderia alcançar resultado semelhante caso ele mesmo pintasse a casa, situação, neste último caso, que não seria passível de avaliação.

VICTOR THURONYL ${ }^{120}$ oferece crítica ao conceito utilizado por Haig-Simons (Sistema SHS), que teria buscado fundamento na teoria econômica e não jurídica. $\mathrm{O}$ autor explica, ademais, que sua exposição é lastreada naquele mesmo Sistema SHS, com a diferença de que as relações que envolvem alguma riqueza relacionada com o conceito de renda são mais bem explicitadas a partir do valor justiça e sua mensuração, sem que isso represente um obstáculo à praticabilidade e/ou à Administração.

Não se nega a extrema importância do estudo do conceito de renda, perquirição percorrida por incontáveis doutrinadores dos mais diversos campos de atuação, jurídico (fiscalmente como também sob a perspectiva cível), financeiro, econômico e contábil. Merece destaque a obra de KEVIN HoLMES ${ }^{121}$ que, com maestria, trouxe o detalhamento do conceito de renda, com irrepreensível e singular análise do chamado "Sistema SHS", valendo-se, inclusive, de testes empíricos e comparativos entre países como Reino Unido, Austrália, Nova Zelândia e Estados Unidos.

Conforme ventilou-se, sob o ponto de vista econômico, as teorias que se propuseram a definir o conceito de renda se subdividem em "renda-produto" e "renda-acréscimo" 122.

Para a teoria da renda-produto ou teoria da fonte, considera-se renda o fruto periódico de uma fonte permanente, sendo certo falar em renda quando este fruto se destaca (realização) dessa fonte (a fonte seria o capital). Para a teoria da renda-acréscimo patrimonial, o

\footnotetext{
${ }^{120}$ Cf. THURONYL, Victor. The Concept of Income. 46 Tax. L. Ver. 45 (1990). in Federal Income Tax Anthology. CARON, Paul L.; BURKE, Karen C.; MCCOUCH, Grayson M. P. P. 107/108

${ }_{121}$ Cf. HOLMES, Kevin. The Concept of Income - A multidisciplinary analysis. Doctoral Series 1 Academic Council. Amsterdam, The Netherlands: IBFD Publications BV, February 2000.

${ }^{122}$ Cf. COSTA, Alcides Jorge. Op. cit. (nota 117), P. 20/21.
} 
conceito de renda define-se a partir da comparação entre um momento inicial e um momento final.

Há, ainda, a teoria legalista, para a qual renda é aquilo que a lei disser que é, conforme orientação já adotada pelo STF, na decisão do Recurso Extraordinário nº 201/465-6/MG, de relatoria do Ministro Marco Aurélio (DJ em 17.10.2003). Após extensa e valiosa análise da evolução legislativa sobre o tema, o Ministro Nelson Jobim, em seu voto-vista, mais especificamente no item 5.2., aponta que o conceito de renda é um conceito legal. afirma, primeiramente, que o substantivo "renda" foi utilizado na CF sem qualquer adjetivação. Afirma, também, que o CTN, ao delimitar a hipótese tributária do IR, conceituou, em seu artigo 43, renda como sendo o produto do capital, do trabalhos ou da combinação de ambos. Observa, ainda, que ao definir as diferentes bases de cálculo no artigo 44, a legislação ordinária passa a utilizar, para uma dessas hipóteses de base de cálculo, a expressão "lucro real" no lugar da expressão constitucional "renda". Arremata que a adjetivação "real" é fruto da legislação infraconstitucional ordinária e que não estaria nem na CF nem no CTN e que, por tudo isso, o conceito de renda, ou melhor, de lucro real tributável, é puramente legal e decorre exclusivamente da lei, sujeito, contudo, a um juízo de proporcionalidade. Desta forma, no entendimento do Ministro Nelson Jobim, não haveria um conceito de "lucro real" que estivesse ínsito ao conceito de renda.

Em tempo, voltando às teorias da fonte e do acréscimo patrimonial e afastada as noções sustentadas pela teoria legalista, com a qual não compaginamos, já que confere ampla liberdade ao legislador infraconstitucional sem qualquer equilíbrio e respeito às balizas constitucionais, em especial o que vimos no item 1.6., é fundamental que fique claro que tanto a CF quanto o CTN, ao regulamentar o fato gerador do IR, nos termos do artigo 146 da Magna Carta, autorizam que a renda poderá ser tributada ou sob a ótica da rendaproduto ou sob o amparo da teria do acréscimo patrimonial ou sob a ótica de ambos, de forma simultânea.

Com isso, da leitura do inciso II, do artigo 43, do CTN, verifica-se que este dispositivo limita-se, exclusivamente, às situações onde se verifica a existência de acréscimo patrimonial. Não é, todavia, a leitura que fazemos do inciso I do mesmo artigo. O inciso II, ao mencionar "assim entendidos os acréscimos patrimoniais não compreendidos n inciso 
anterior", revela que, no inciso I, compreendem-se não apenas a renda-produto (do capital, do trabalho ou da combinação de ambos) mas, também, outras hipóteses de acréscimos patrimoniais. É verdade, entretanto, que o legislador infraconstitucional optou por tributar a renda-produto quando se verificam, também, acréscimos patrimoniais, mas isso não significa que, nos dias de hoje, não poderia aquele mesmo legislador disciplinar hipótese de tributação da renda-produto que não fosse medida a partir de um acréscimo patrimonial, como um recebimento eventual onde houvesse mera recomposição do status quo patrimonial do beneficiário ${ }^{123}$.

Opondo-se à ideia de tributação do capital pelo IR, na teoria da fonte-produto há necessidade de recomposição do patrimônio como fonte periódica da renda e de eventuais reconstruções do próprio capital. Esta mesma ideia se aplica à teoria do acréscimo patrimonial, tendo em vista que não será equivalente a acréscimo patrimonial a mera recuperação de uma perda sofrida ou de um dano (patrimonial) ocorrido ${ }^{124}$.

Paralelamente ao que disciplinam essas teorias, há, também, que se questionar acerca de um conceito constitucional de renda.

Para Roberto QuiRoga MosquerA ${ }^{125}$, os termos "renda" e "proventos de qualquer natureza", da forma como utilizados na Constituição Federal, seriam vagos e ambíguos, visto que há imprecisão quanto ao seu significado denotativo e conotativo, respectivamente $^{126}$. Este mesmo autor demonstra, ainda, que a palavra "renda" apresenta

${ }^{123}$ Cf. SCHOUERI, Luis Eduardo. Op. cit. (nota 113), P. 243. Para este autor, tais teorias fariam parte do grupo das teorias econômicas. MARY ELBE QUEIROZ classifica as mesmas correntes dentro do grupo das teorias fiscais, chamando de teoria econômica aquela que visualiza a renda como uma riqueza nova derivada de fonte produtiva, considerando-se como tal a renda líquida (renda bruta menos despesas para a produção dos rendimentos) (Cf. QUEIROZ, Mary Elbe. Op. cit. (nota 90), P. 68/69). Já há algum tempo, JOÃo DÁCIO RoLIM apontava que, entre nós, a idéia proclamada por um suposto conceito legalista (fiscalista) de renda era noção ultrapassada e superada pelo STF, não merecendo maior acolhida de nossa parte, embora tenha encontrado eco em parte da doutrina (Cf. ROLIM, João Dácio. O Conceito de Renda e Proventos de Qualquer Natureza: Alguns Casos Concreto - Adições e Exclusões ao Lucro Real. in Imposto de Renda Questões Atuais e Emergentes. Coord. Valdir de Oliveira Rocha. São Paulo: Dialética, 1995. P. 85/95).

${ }^{124}$ Cf. ROLIM, João Dácio. A Compensação de Prejuízos Fiscais - Condições de Juridicidade $e$ Necessidade - $O$ Direito Comparado e o Direito Brasileiro. in Imposto de Renda e ICMS - Problemas Jurídicos. Coord. Valdir de Oliveira Rocha. São Paulo: Dialética, 1995. P. 12.

${ }^{125}$ Cf. MOSQUERA, Roberto Quiroga. Renda e proventos de qualquer natureza - o imposto e o conceito constitucional. São Paulo: Dialética, 1996. P. 36.

${ }^{126}$ Apesar de suas severas críticas quanto à confusão conceitual existente entre "renda" e "proventos de qualquer natureza", MISABEL ABREU MACHADO DERZI alerta que há, na doutrina e na jurisprudência, certos pontos pacíficos que merecem ser destacados: “a) renda é o produto, fluxo ou acréscimo patrimonial, 
cinco diferentes acepções dentro do texto constitucional, em mais de 20 aparições em suas formas singular e plural, de forma que o próprio ordenamento constitucional dá a sua definição, sem que se faça necessário recorrer ao texto do $\mathrm{CTN}^{127}$. ROBERTO QUIROGA MOSQUERA sustenta que o CTN contém uma apresentação didática daquilo que estaria contido na $\mathrm{CF}$, uma vez que sua redação já teria levado em conta o arquétipo definido na Constituição de 1946 e que, de certa forma, o arquétipo da CF atual manteve aquilo que foi construído nos textos constitucionais anteriores ${ }^{128}$.

Antes de identificar aquelas cinco acepções diferentes, vale destacar que ROBERTO QUIROGA MosQUeRA ${ }^{129}$ entende claramente que a CF define "renda" como algo derivado do trabalho e do capital e que tanto "renda" como "proventos de qualquer natureza" traduzem a ideia de acréscimo patrimonial.

Primeiramente, com foco nos artigos 30 , inciso $\mathrm{I}^{130}$, e $48^{131}$, ambos da CF, ROBERTO QUIROGA MOSQUERA ${ }^{132}$ evidencia que "renda", nessas hipóteses, equipara-se à noção de receita ou ingresso, abrigando todo tipo de receita pública e não apenas aquelas derivadas de tributos, como é o caso do IR. Nos artigos $43^{133}$, 192, inciso VII (atualmente revogado

inconfundivel com o patrimônio de onde promana, assim entendido o capital, o trabalho ou a sua combinação; b) provento é forma específica de rendimento tributável, tecnicamente compreendida como o que é 'fruto não da realização imediata e simultânea de um patrimônio, mas sim, do acréscimo patrimonial resultante de uma atividade que já cessou, mas que ainda produz rendimentos', como os benefícios de origem previdenciária, pensões e aposentadoria. Já proventos em acepção ampla, como acréscimos patrimoniais não resultantes do capital ou do trabalho, são todos aqueles de 'origem ilícitas e bem aqueles cuja origem não seja identificável ou comprovável'; c) os acréscimos patrimoniais sempre pressupõem a disponibilidade econômica ou jurídica, sendo certo que, mesmo não havendo a jurídica, a incorporação física e material ao patrimônio do contribuinte é sempre necessária; d) no Brasil, tradicionalmente, quer na Constituição quer nas leis, tem-se feito a mesmo diferenciação e, somente a propósito da pessoa jurídica, fala-se em patrimônio fixo e circulante, capital próprio e alheio, a fim de distingui-los da renda tributável." (BALEEIRO, Aliomar. Op. cit. (nota 88), P. 291).

${ }_{127}$ Cf. MOSQUERA, Roberto Quiroga. Op. cit. (nota 125), P. 48/50.

${ }^{128}$ Ibidem, Op. cit. (nota 125), P. 49.

${ }^{129}$ Ibidem, Op. cit. (nota 125), P. 49.

130 “Art. 30. Compete aos Municípios:

(...)

III - instituir e arrecadar os tributos de sua competência, bem como aplicar suas rendas, sem prejuízo da obrigatoriedade de prestar contas e publicar balancetes nos prazos fixados em lei;" (grifamos)

131 "Art. 48. Cabe ao Congresso Nacional, com a sanção do Presidente da República, não exigida esta para o especificado nos arts. 49, 51 e 52, dispor sobre todas as matérias de competência da União, especialmente sobre:

I - sistema tributário, arrecadação e distribuição de rendas;" (grifamos)

${ }_{132}$ Cf. MOSQUERA, Roberto Quiroga. Op. cit. (nota 125), P. 50.

133 "Art. 43. Para efeitos administrativos, a União poderá articular sua ação em um mesmo complexo geoeconômico e social, visando a seu desenvolvimento e à redução das desigualdades regionais. (...) 
pela Emenda Constitucional $n^{\circ} 40$, de 2003) ${ }^{134}$ e 201, inciso II (cuja redação foi radicalmente alterada pela Emenda Constitucional $n^{\mathbf{o}} 20$, de 1998) ${ }^{135}$, todos também da Magna Carta, o autor demonstra que o vocábulo, nestes casos, teria sido empregado no sentido de renda nacional, regional ou de uma determinada classe econômica, todos com a ideia de uma "renda per capita". "Rendas", nestes casos, apresenta um conteúdo altamente econômico, caracterizando-se como ferramenta utilizada para a concessão de benefícios econômicos e direcionamento de programas voltados para a política social e econômica e de ações comunitárias ${ }^{136}$.

Nos artigos 157 , inciso $\mathrm{I}^{137}$, e 158 , inciso $\mathrm{I}^{138}$, que serão analisados mais detidamente em tópico apartado, aquele mesmo autor limita-se a dizer que, nestes casos, "renda" corresponde a um somatório de rendimentos ${ }^{139}$. Tomando estes dispositivos como gancho, o autor passa a precisar o conceito de "renda" como algo derivado do rendimento do trabalho e do capital.

JosÉ LuIZ BulHõEs PEDREIRA ensinava que haveria três conceitos econômicos de renda e um financeiro, sendo os três primeiros formados com abstração da sua organização jurídica e somente o conceito financeiro pertencia ao plano em que o Direito distribui, entre as pessoas, poder sobre os recursos, sobre a moeda e/ou sobre o resultado da atividade

\footnotetext{
$\S 2^{\circ}$ Os incentivos regionais compreenderão, além de outros, na forma da lei:

(...)

IV - prioridade para o aproveitamento econômico e social dos rios e das massas de água represadas ou represáveis nas regiões de baixa renda, sujeitas a secas periódicas."

134 "Art. 192. O sistema financeiro nacional, estruturado de forma a promover o desenvolvimento equilibrado do País e a servir aos interesses da coletividade, será regulado em lei complementar, que disporá, inclusive, sobre:

(...)

VII - os critérios restritivos da transferência de poupança de regiões com renda inferior à média nacional para outras de maior desenvolvimento;"

${ }_{135}$ “Art. 201. Os planos de previdência social, mediante contribuição, atenderão, nos termos da lei, a:

(..)

II - ajuda à manutenção dos dependentes dos segurados de baixa renda;",

${ }^{136}$ Cf. MOSQUERA, Roberto Quiroga. Op. cit. (nota 125), P. 51/52.

137 “Art. 157. Pertencem aos Estados e ao Distrito Federal:

I - o produto da arrecadação do imposto da União sobre renda e proventos de qualquer natureza, incidente na fonte sobre rendimentos pagos, a qualquer título, por eles, suas autarquias e pelas fundações que instituírem e mantiverem;"

138 "Art. 158. Pertencem aos Municípios:

I - o produto da arrecadação do imposto da União sobre renda e proventos de qualquer natureza, incidente na fonte sobre rendimentos pagos, a qualquer título, por eles, suas autarquias e pelas fundações que instituírem e mantiverem;"

${ }^{139}$ Cf. MOSQUERA, Roberto Quiroga. Op. cit. (nota 125), P. 51/52.
} 
econômica. Com isso, o objeto do imposto não seria a renda consumida nem a produzida, mas sim a renda das pessoas, sujeitos de direito. Individualmente, o conceito de renda estava vinculado à ideia de monetarização. Afirmava que a renda financeira não consistia nos direitos, mas, sim, no objeto desses direitos, sendo certo que tais direitos seriam instrumentos para distribuir a renda entre as pessoas ${ }^{140}$.

Diante do disposto no inciso II, do $\S 2$, do artigo $153^{141}$, da CF, ROBERTO QUIROGA MoSQUERA identifica "renda" como algo derivado do produto do trabalho, como resultado de uma atividade laboral por meio da qual o homem recebe uma contraprestação que se qualifica como "rendimentos". Nessa mesma linha, o autor nos remete ao artigo $7^{\circ}$, também da CF, referindo-se aos alicerces jurídicos dos direitos sociais do trabalho. Todos aqueles direitos (salário, seguro desemprego, décimo terceiro salário ou verba natalina, salário-mínimo, salário-família, férias, remuneração por serviços extraordinários ou atividades insalubres, aviso-prévio etc.) estão traduzidos em remunerações, em dinheiros ou em valores recebidos pelos trabalhadores/empregados em decorrência do trabalho. Tais valores, dinheiros ou remunerações representam os rendimentos do trabalho, alvo de tributação do IR, nos termos do artigo $153, \S 2^{\circ}$, da $\mathrm{CF}^{142}$.

Por fim, mas longe de querer esgotar o assunto, este mesmo autor aponta, nos artigos 151, inciso $\mathrm{II}^{143}$, e 163 , inciso $\mathrm{IV}^{144}$, os contornos quanto à definição da possibilidade de tributar a "renda" derivada de outras fontes que não o trabalho. Ilustra, ainda, que no texto constitucional vigente antes da Emenda Constitucional n ${ }^{\circ} 3$, de 1993, que determinou a

\footnotetext{
${ }^{140}$ Cf. PEDREIRA, José Luiz Bulhões. Imposto Sobre A Renda - Pessoas Jurídicas. Vol. 1. Rio de Janeiro: Justec-Editora Ltda., 1979. P. 167/176.

141 “Art. 153. Compete à União instituir impostos sobre: (...)

III - renda e proventos de qualquer natureza; (...)

$\S 2^{\circ}$ O imposto previsto no inciso III: (...)

II - não incidirá, nos termos e limites fixados em lei, sobre rendimentos provenientes de aposentadoria e pensão, pagos pela previdência social da União, dos Estados, do Distrito Federal e dos Municípios a pessoa com idade superior a sessenta e cinco anos, cuja renda total seja constituída, exclusivamente, de rendimentos do trabalho."

${ }^{142}$ Cf. MOSQUERA, Roberto Quiroga. Op. cit. (nota 125), P. 53/57.

143 “Art. 151. É vedado à União:

(...)

II - tributar a renda das obrigações da dívida pública dos Estados, do Distrito Federal e dos Municípios, bem como a remuneração e os proventos dos respectivos agentes públicos, em níveis superiores aos que fixar para suas obrigações e para seus agentes;"

144 “Art. 163. Lei complementar disporá sobre:

(...)

IV - emissão e resgate de títulos da dívida pública;"
} 
extinção da competência dos Estados e do Distrito Federal cobrarem o "adicional estadual sobre a renda e proventos de qualquer natureza", era patente a clareza quanto à possibilidade de tributar os rendimentos de capital. Argumenta que o fato daquela Emenda Constitucional $n^{\circ}$ 3/93 ter excluído a competência dos Estados e do Distrito Federal não significa que o texto constitucional não mais traz a ideia de tributação da renda derivada do capital $^{145}$.

José ARTUR Lima GONÇALVES sustenta que o conceito está (ou é) constitucionalmente pressuposto e que sua definição não está à disposição do legislador infraconstitucional. $\mathrm{O}$ conceito não está explicitado, por isso diz impor-se deduzir um conceito pressuposto ${ }^{146}$.

Primeiramente, JOSÉ ARTUR LIMA GONÇALVES ${ }^{147}$ sustenta que toda a radicação do sistema tributário é constitucional. Diz, ainda, que, do mesmo modo que se assentou na doutrina a noção constitucionalmente pressuposta de tributo, é possível delimitar no mesmo sentido para "renda". Para tanto, vale-se da mesma técnica, estremando o conceito de renda de outras entidades próximas. Com isso, o exercício feito pelo autor é no sentido de que "renda" não se confunde com os conceitos de "faturamento", "patrimônio", "capital", "lucros", "ganho" e "resultado".

Sobre essa técnica de identificação por exclusão, VICTOR BORGES POLIZELLI ${ }^{148}$ oferece crítica no sentido de que, embora consista num certo exercício de definição (no sentido de “dizer os fins, os contornos”), pouco oferece de conteúdo específico quanto ao que seja renda."

\footnotetext{
${ }^{145}$ Assim constava da redação do artigo 155, inciso II, da CF: “Art. 155. Compete aos Estados e ao Distrito Federal instituir:

(...)

II - adicional de até cinco por cento do que for pago à União por pessoas físicas ou jurídicas domiciliadas nos respectivos territórios, a título do imposto previsto no artigo 153, III, incidente sobre lucros, ganhos e rendimentos de capital." (grifamos) (Cf. MOSQUERA, Roberto Quiroga. Op. cit. (nota 125), P. 57/59).

${ }_{146}^{14}$ Cf. GONÇALVES, José Artur Lima. Op. cit. (nota 31), P. 174.

${ }^{147}$ Ibidem, Op. cit. (nota 31), P. 176.

${ }^{148}$ Cf. POLIZELLI, Victor Borges. O Princípio da Realização da Renda e sua Aplicação no Imposto de Renda de Pessoas Jurídicas. Dissertação apresentada como parte dos requisitos para habilitação ao título de Mestre em Direito, sob a orientação do Prof. Dr. Luís Eduardo Schoueri, na subárea de Legislação Tributária, integrada ao Departamento de Direito Econômico e Financeiro da Faculdade de Direito da Universidade de São Paulo - USP. São Paulo: 2009. P. 79.
} 
Apartados esses conceitos próximos, sem, contudo, perder de vista a crítica acima, JosÉ ARTUR LIMA GonçALVES ${ }^{149}$ parte, em um segundo exercício, a identificar os parâmetros mínimos necessários ao conceito constitucionalmente pressuposto de renda, ainda que genéricos e carregados de incertezas. Para o autor, esses parâmetros mínimos são: (i) saldo positivo do (ii) confronto entre certas entradas e certa saídas, (iii) ocorridas ao longo de um dado período.

Por saldo positivo (i) deve-se compreender o acréscimo patrimonial, entendido como incremento (material ou imaterial) ao conjunto líquido de direitos de um dado sujeito. Por seu turno, o confronto (ii) entre elementos positivos (ingressos) e negativos (saídas; desembolsos), juntamente com o item (i) anterior, correspondem à ideia de um ganho efetivo, na medida em que só terá relevância o saldo positivo resultante do confronto entre elementos que "acrescem" e "subtraem" ao patrimônio. Todavia, explica JosÉ ARTUR LiMA GONÇALVES, nem todo ingresso nem toda saída são relevantes para o conceito de renda. Impõe-se selecionar somente aquelas entradas e saídas relevantes na alteração patrimonial para cima. Assim é que elementos que representem mera re-arrumação patrimonial ou substituição de ativos devem ser desprezados ${ }^{150}$.

Por fim, o lapso de tempo (iii) compreende o período entre um dado marco inicial (situação patrimonial prévia), a partir do qual serão confrontadas aquelas entradas e saídas juridicamente relevantes, até um dado marco final (situação patrimonial final). Este período nada mais é do que um corte necessário para a implementação daquele confronto.

Apoiado na ideia de ingressos e saídas relevantes destacada acima e lembrando o papel informador realizado pelos princípios constitucionais, LUís CESAR SOUZA DE QUEIROZ define o conceito constitucional de "renda e proventos de qualquer natureza" nos seguintes termos: acréscimo de valor patrimonial, representativo da obtenção de produto ou de simples aumento no valor do patrimônio, apurado, em certo período de tempo, a partir da combinação de todos os fatos que contribuem para o acréscimo de valor do patrimônio (fatos-acréscimos) com certos fatos que, estando relacionados ao atendimento das necessidades vitais básicas ou à preservação da existência, com dignidade, tanto da

\footnotetext{
${ }^{149}$ Cf. GONÇALVES, José Artur Lima. Op. cit. (nota 31), P. 175/187.

${ }^{150}$ Ibidem, Op. cit. (nota 31), P. 175/187.
} 
própria pessoa quanto de sua família, contribuem para o decréscimo de valor do patrimônio (fatos-decréscimos) ${ }^{151}$.

Note-se que, para Luís CeSAR SouZA DE QueIroz, a definição de renda dá-se, dentre outras situações, com o acréscimo patrimonial por meio de mero aumento no valor do patrimônio, sugerindo a ideia de prescindibilidade da realização da renda.

Arraigada à sua visão constitucionalista, MARY ELBE QUEIROZ lembra, inicialmente, que o legislador infraconstitucional, ao disciplinar acerca do Imposto de sobre a Renda e Proventos de Qualquer Natureza, distingue o tratamento entre pessoas jurídicas e pessoas físicas: para aquelas, considera-se como a hipótese tributária o lucro (receitas menos custos e despesas e ajustes definidos pela legislação) e para o segundo grupo - pessoas físicas -, a tributação recairia sobre o rendimento bruto (total de ingressos, derivados do capital, do trabalho ou da combinação de ambos). De tal constatação, aponta a autora que só faz sentido buscar o conceito de "renda" e "proventos de qualquer natureza" para as pessoas físicas $^{152}$.

Independentemente do que se queira classificar como "renda" e "proventos de qualquer natureza", tais conceitos ou situações sempre deverão revelar acréscimos patrimoniais ${ }^{153}$. Nessa linha, MARY ELBE QUEIROZ ${ }^{154}$ conclui que o IR incide sobre as rendas e proventos de qualquer natureza que constituam acréscimos patrimoniais, sobre os quais o beneficiário haja adquirido e detenha a respectiva posse ou propriedade e estejam à sua livre disposição, econômica ou juridicamente, sendo certo que tais acréscimos patrimoniais devem ser dimensionados, levando em consideração a periodicidade necessária à sua quantificação.

A tributação pelo IR pressupõe não apenas uma riqueza nova, havida em momentos distintos, medida ao longo de um determinado período de tempo. Há que se experimentar

\footnotetext{
${ }^{151}$ Cf. QUEIROZ, Luis Cesar Souza de. Op. cit. (nota 09), P. 247.

152 Cf. QUEIROZ, Mary Elbe. Op. cit. (nota 90), P. 65.

${ }^{153}$ LEANDRO PAULSEN sintetiza que renda é o acréscimo patrimonial positivo do capital ou do trabalho,e proventos são o acréscimo patrimonial decorrente de uma atividade que já cessou e que o artigo 43, do CTN, trata o acréscimo patrimonial como elementos comum e nuclear do conceito de renda e de proventos (Cf. PAULSEN, Leandro. Op. cit. (nota 56), P. 292).

${ }^{154}$ Cf. QUEIROZ, Mary Elbe. Op. cit. (nota 90), P. 88/89.
} 
(o contribuinte) um acréscimo patrimonial, ações que revelem mais valias que incrementem a capacidade contributiva, i.e., realidades econômicas novas que se incorporam ao patrimônio da pessoa ${ }^{155}$.

Na mesma linha, o Professor PAUlo Ayres BARreto ${ }^{156}$ entende que há um conceito constitucional de renda, já que, ao contrário, haveria muita liberdade ao legislador ordinário, que poderia dizer que renda é qualquer coisa. Aponta que o conceito constitucional corresponderia ao conceito de renda existente à época de promulgação da Constituição Federal de 1988, incorporando-se tal conceito no seio constitucional, razão pela qual não haveria dissonância entre o conceito constitucional de renda e o artigo 43, do CTN. Em tempo, este conceito constitucional de renda corresponderia a um acréscimo patrimonial, observado em um lapso temporal, através do cotejo entre determinados ingressos e desembolsos.

Algumas dúvidas se colocam nessa senda:

(i) o conceito vigente à época da Magna Carta atual não era outro que não aquele estampado no CTN. Assumindo a incorporação desse conceito, questiona-se se o conteúdo do que se escreveu em 1966, em 1988 e o que vige atualmente, ainda que tenham escrito da mesma forma, tratam da mesma coisa ou seriam conteúdos diferentes?;

(ii) a CF é algo sujeito à evolução, já que muita coisa ocorreu desde 1988, ou, na visão de Humberto ÁvILA ${ }^{157}$, seria algo estático, assumindo os conceitos que já existiam no ordenamento jurídico até então, como é o caso do CTN? O Direito se renova?

Em excelente dissertação apresentada em conclusão de seu mestrado em Direito Tributário, VICTOR BORGES POLIZELLI ${ }^{158}$ adverte que, ao se falar em um conceito de renda presente no texto constitucional, deve-se ter em mente que esse conceito apresenta um grau relativo de

\footnotetext{
${ }^{155}$ Cf. CARRAZZA, Roque Antonio. A natureza meramente interpretativa do art. 129 a Lei $n^{\circ}$ 11.196/05, o imposto de renda, a contribuição previdenciária e as sociedades de serviços profissionais. in Revista Dialética de Direito Tributário no 154. São Paulo: Dialética, 2008. P. 110/111).

${ }^{156}$ Cf. BARRETO, Paulo Ayres. Imposto Sobre a Renda e Preços de Transferência. São Paulo: Dialética, 2001. P. 61/78.

${ }^{157}$ Cf. ÁVILA, Humberto. Op. cit. (nota 91).

${ }^{158}$ Cf. POLIZELLI, Victor Borges. Op. cit. (nota 148), P. 75/76.
} 
indeterminação, aproximando-se mais da ideia de um tipo ou de uma noção. $O$ autor sustenta que a Carta Constitucional "deve limitar-se a descrever características gerais do que seja renda para fins de tributação, estando sujeito a algumas variações na sua definição, a serem determinadas pelo legislador competente no momento histórico pertinente, podendo absorver as concepções econômicas predominantes e, bem assim, as condições materiais de desenvolvimento da sociedade etc." (destaques no original).

VICTOR BoRges POLIZELli ${ }^{159}$ explica que, assim como o tema da definição dos limites a um conceito constitucional de renda encontra dificuldades, a imposição de restrições muito específicas (como a não tributação de valores que não se traduzem em ingressos capazes de gerar acréscimo patrimonial, chamados pelo autor de ganhos de detenção) também deve ser afastada. E assim arremata:

"A noção constitucional de renda deve limitar-se a descrever as propriedades $e$ características gerais do termo renda, abdicando-se de construir algum conceito muito específico ou erigir limitações definitivas que decorram da aplicação, em termos abstratos, de princípios constitucionais específicos. Os aspectos gerais da noção constitucional de renda retratam o reconhecimento dos princípios da renda líquida, da realização, da apuração periódica e da monetarização da renda. Até aí se pode chegar na leitura do texto constitucional. Inferir algo além disso é sobejar o tema da distribuição rígida de competências e implica obscurecer a delegação dada pela própria CF 1988 ao legislador complementar para o trato da matéria." (destaque no original)

Luís EDUARDO SCHOUERI ${ }^{160}$ é expresso ao afirmar que não existe um conceito constitucional de renda, ainda que existam algumas balizas nesse sentido (argumentos histórico e sistemático).

Queremos crer que a razão assiste a esses dois últimos autores, no sentido de que a Constituição Federal, por meio dos princípios ali enraizados, tais quais a segurança jurídica, a praticabilidade, a isonomia, a capacidade contributiva, a vedação de tributo com

\footnotetext{
${ }^{159}$ Ibidem, Op. cit. (nota 148), P. 77/85.

${ }^{160}$ Cf. SCHOUERI, Luis Eduardo.. Op. cit. (nota 113), P. 245.
} 
efeitos de confisco e outros vetores lá definidos, traz apenas uma noção (aproximação tipológica), cujos princípios (vetores) da universalidade, generalidade e praticabilidade exigem uma maior amplitude do conceito de renda, bem como um núcleo, informado por aqueles próprios vetores, do qual o legislador infraconstitucional não poderá se afastar. Renda é um tipo para o qual a Constituição Federal mantém um núcleo mínimo semântico, sem, contudo, a existência de travas ou limites, salvo com relação àquele núcleo, que é a exata medida que impede que a definição do conceito de renda possa ficar à disposição do legislador infraconstitucional, de forma livre ou sem a existência de contornos mínimos. Referido núcleo é composto pelo conjunto de significação proposto e informado pelos princípios constitucionais, específicos e não específicos do IR, bem como pelos princípios da razoabilidade e da proporcionalidade, que impedem que se chame de renda aquilo que, em linguagem e senso comuns, não é.

O artigo 146, inciso III, da Constituição Federal, é o vetor que faz o elo entre aquele núcleo constitucional e o espaço destinado ao legislador infraconstitucional, de modo a buscar a realização dos princípios constitucionais em razão direta da evolução social, política e econômica pela qual uma sociedade passa. Afastar essa prerrogativa é impor fardo por demais pesado ao legislador, que terá condições muitíssimo limitadas na harmonização do ordenamento jurídico-tributário com a realidade,

MARY Elbe QueIroz, em que pese sua visão constitucionalista acerca do conceito de renda, lembra que a própria expressão "de qualquer natureza”, que acompanha o vocábulo "proventos", serve para conferir-lhe uma maior amplitude, no sentido de englobar, no aspecto material da hipótese de incidência do imposto, quaisquer tipos de proventos, independentemente da natureza de que eles se revistam ${ }^{161}$.

Considerando seu entendimento sobre o sentido da palavra "proventos", como sendo os rendimentos recebidos pelo ser humano provenientes da aposentadoria, ROBERTO QUIROGA MOSQUERA aponta que a locução adjetiva (ampliativa), diferentemente das palavras "renda" e "proventos", não possui uma definição expressa no texto constitucional, revelando tão somente a dimensão de significação que lhe é própria dentro do universo da língua portuguesa. Para o autor, referida locução adjetiva altera o conceito isolado do

${ }^{161}$ Cf. QUEIROZ, Mary Elbe. Op. cit. (nota 90), P. 70. 
substantivo "proventos", dando-lhe uma significação muito mais ampla e extensa. Autoriza-se, com isso, a tributação pelo IR não apenas de valores ou dinheiros provenientes do trabalho, do capital ou da aposentadoria, mas de todo e qualquer rendimento/valor, de qualquer espécie, independentemente de sua origem, i.e., sem que haja necessidade de que tais vantagens derivem, exclusivamente, do trabalho, do capital ou da aposentadoria ${ }^{162}$.

RICARDO MARIZ OLIVEIRA, ao analisar a expressão "na forma da lei", contida na parte final do artigo $153, \S 2^{\circ}$, inciso II, da CF, aponta para uma série de minudências que devem ser disciplinadas no âmbito infraconstitucional e que tal expressão traria a impressão que o conceito de renda não estaria adstrito ao texto constitucional ${ }^{163}$. Entretanto, sob outra perspectiva, apoiado fortemente em seu entendimento de que a hipótese tributária do IR resume-se à tributação dos acréscimos patrimoniais, este mesmo autor afirma ser o patrimônio um conceito de direito privado, justificando a aplicação do artigo 110, do CTN, já que o conceito de patrimônio teria sido absorvido implicitamente pela $\mathrm{CF}$, para definir ou limitar a competência tributária. Este entendimento, porém, confronta-se, por exemplo, com a competência outorgada constitucionalmente pelo artigo 156, inciso II, em que há imposto incidindo sobre os efeitos dos fatos em relação ao patrimônio ${ }^{164}$.

Nessa linha de raciocínio, inserido em uma ampla noção econômica de renda, ainda que inexista este conceito de forma expressa na Constituição Federal, como pensamos não existir, o legislador complementar (artigo 43, do CTN), ao definir o conceito de renda e proventos de qualquer natureza, valeu-se das teorias da renda-produto (teoria da fonte) e da renda-acréscimo patrimonial. O conceito de renda, todavia, é delimitado pela natureza das coisas (noção geral e comum de renda) e pelas próprias balizas impostas pela $\mathrm{CF}$, notadamente os princípios explícitos (por exemplo, a capacidade contributiva, no sentido de tributar sinais de capacidade e signos presuntivos de densidade econômica, até mesmo para que existam recursos para fazer frente ao pagamento dos impostos) e implícitos (razoabilidade, proporcionalidade, mínimo existencial, praticabilidade), assim como pelos

\footnotetext{
${ }^{162}$ Cf. MOSQUERA, Roberto Quiroga. Op. cit. (nota 125), P. 64/67.

${ }^{163}$ Cf. OLIVEIRA, Ricardo Mariz de. Op. cit. (nota 16). P. 267.

${ }^{164}$ Ibidem, Op. cit. (nota 16). P. 52/54.
} 
limites à competência da União, de forma a não invadir a competência conferida a outro ente $^{165}$.

\subsection{O Fato Gerador do Imposto sobre a Renda}

RICARDO MARIZ DE OLIVEIRA ${ }^{166}$ ensina que a complexidade do IR se deve, em grande parte, à circunstância de que seu fato gerador deve atender a três condições: realização da renda, acréscimo patrimonial medido em um determinado período de tempo e aquisição de disponibilidade econômica e/ou jurídica, esta última indissociável da primeira (realização). Somente quando atendidas essas características de forma conjunta é que o imposto se torna devido. Sob outra perspectiva, tais condições correspondem aos próprios aspectos material, temporal e quantitativo da regra matriz do Imposto sobre a Renda.

Como fato gerador instantâneo ${ }^{167}$ que é, o fato gerador do IR somente se materializa quando todos os seus aspectos ali estiverem presentes. Significa dizer que não basta apurar se existe uma renda tributável ou se o quantum dessa renda tributável representa a aquisição de um acréscimo patrimonial, sem que tais expedientes estejam dentro de um contexto temporal. Significa dizer, também, que o tal confronto de entradas e saídas, a que se referiu José ARTUR LIMA GONÇALVES ${ }^{168}$, ou aos fatos-acréscimos e fatos-decréscimos, referidos por LUÍS CESAR SOUZA DE QUEIROZ ${ }^{169}$, perde qualquer significado jurídico comparativo sem a noção de um período de tempo. A indissociabilidade desses aspectos deve ser dura de tal forma que, não identificada a presença de um deles, não estaremos diante do fato gerador do IR, ainda que, como veremos, existam autorizações constitucionais para tributar em momentos distintos do marco final daquele lapso temporal.

Neste sentido posiciona-se MARY ELBE QUEIROZ ${ }^{170}$ :

"Em relação ao Imposto sobre a Renda, tendo em vista que a hipótese abstrata da lei está visceral e intrinsecamente ligada à aquisição da disponibilidade da

\footnotetext{
${ }^{165}$ Nesse sentido vide SCHOUERI, Luís Eduardo. Op. cit. (nota 113), P. 242/253.

${ }^{166}$ Cf. OLIVEIRA, Ricardo Mariz de. Op. cit. (nota 16).

${ }^{167}$ Cf. BARRETO, Paulo Ayres. Op. cit. (nota 156), P. 83.

${ }^{168}$ Cf. GONÇALVES, José Artur Lima. Op. cit. (nota 31), P. 182/184.

${ }^{169}$ Cf. QUEIROZ, Luis Cesar Souza de. Op. cit. (nota 09), P. 247/248.

${ }^{170}$ Cf. QUEIROZ, Mary Elbe. Op. cit. (nota 90), P. 120/121.
} 
renda como riqueza nova que caracterize acréscimo patrimonial, em conseqüência, somente poderá dar-se por ocorrido o fato gerador do imposto no preciso momento em que se puder aferir e quantificar o montante desse acréscimo, bem como já tenha havido a respectiva aquisição da disponibilidade, como prevista na lei, quer sejam pessoas físicas quer sejam pessoas jurídicas."

A rápida análise histórica sobre as origens do IR revela não apenas a importância que este tributo representa dentre as fontes de receita derivada do Estado, mas também a complexidade que permeia cada uma de suas particularidades, como os conceitos das expressões indicadas na letra da lei ao definir o alcance de seu fato gerador, os princípios constitucionais de direito tributário que devem ser justapostos aos demais princípios de natureza exclusiva do IR, assim como os fatos e atos que deverão dar ensejo à sua incidência.

Cumpre chamar a atenção, desde já, para o fato de que as bases de fundamentação do IR deverão alicerçar-se nos princípios que o regem, buscando sua validade no texto constitucional, como se observa na leitura do artigo 153, inciso III, da CF, ao outorgar competência tributária à União para a instituição do imposto sobre a renda e os proventos de qualquer natureza ${ }^{171}$. Mas a atribuição de validade a que nos referimos não para por aí.

A própria Constituição Federal, em seu artigo 146, determina que lei complementar definirá os fatos geradores, bases de cálculo e os respectivos contribuintes, que é exatamente a função exercida pelo CTN. Não basta analisar as leis ordinárias para depreender o espectro global do IR; imperioso se faz compulsar o CTN, mormente seu artigo 43, que elucida mais detidamente o fato gerador do $\operatorname{IR}^{172}$.

\footnotetext{
${ }^{171}$ Cf. OLIVEIRA, Ricardo Mariz de. Princípios Fundamentais do Imposto de Renda. in Direito Tributário - Estudos em Homenagem a Brandão Machado. São Paulo: Dialética, 1998. P. 197/198.

${ }^{172}$ É exatamente esse o sentido da manifestação de MISABEL ABREU MACHADO DERZI: “Assim, por meio de simples lei ordinária, falece competência à União para miscigenar os conceitos de renda e patrimônio para fins de imposição tributária." (Cf. DERZI, Misabel Abreu Machado. Princípio de cautela ou não paridade de tratamento entre o lucro e o prejuizo. in Estudos de Direito Tributário em Homenagem á Memória de Gilberto Ulhôa Canto. Rio de Janeiro: Forense, 1998. P. 256).
} 
Da leitura do CTN, observa-se que o legislador procurou cercar, de forma bastante ampla, as situações passíveis de tributação pelo IR, seja qual for a origem da renda. Analisaremos, a seguir, qual o alcance da afirmação que prescreve que o imposto incide sobre a aquisição da disponibilidade econômica ou jurídica da renda. Para tanto, apoiamo-nos nas conclusões a que chegamos acima, a partir do exame crítico e conceitual do que vem a ser renda.

Por ora, tenhamos em mente que o fato gerador do Imposto sobre a Renda só ocorre quando vislumbrados todos os aspectos de sua regra matriz, em especial o elemento temporal, considerando que, como veremos, o legislador constituinte abre possibilidades de tributação de forma antecipada àquele marco final.

\subsubsection{Aquisição da Disponibilidade Econômica ou Jurídica}

A palavra "aquisição" vem do latim (acquisitio) e significa aumento, processo ou ação de adquirir, tornar-se proprietário ou estar na posse de algo (tomar a posse de algo), ainda que não possa usufruir, tirar proveito ou destinar. Por seu turno, disponibilidade, cujo radical é “disponível”, também deriva do latim (disponibilis) e traduz-se como a possibilidade de que se pode dispor livremente de algum bem ${ }^{173}$.

Assim, isoladamente, tais expressões não informam a realidade da materialidade do IR. É preciso que a tal disponibilidade seja adquirida, revelando, com isso, uma transferência de titularidade, uma transferência de direitos. Juntos, na forma da expressão "aquisição da disponibilidade", permitem uma das exatas noções moldadas no aspecto material do IR.

Para MARY Elbe QueIROZ, o melhor significado para disponibilidade é de liberdade necessária à normalidade dos negócios, caracterizando-se como a situação que possibilita ao titular poder dar destinação livre e imediata à renda ou provento recebido, não alcançando a disponibilidade apenas potencial. Para a maioria da doutrina, o que corresponde à disponibilidade sob o aspecto econômico, como a posse do numerário e o recebimento financeiro, seria, na visão da autora, a disponibilidade financeira, aplicável exclusivamente às pessoas físicas, em estrita consonância com ideia de regime de caixa. Por disponibilidade econômica entender-se-ia a percepção efetiva da renda ou provento. A

${ }^{173}$ Cf. HOUAISS, Antônio; VILLAR, Mauro de Salles. Op. cit. (nota 34), P. 169;696. 
aquisição se dá pelo fato material, independentemente da legalidade, ou não, do modo de obtenção, estendendo-se, com isso, à tributação de renda auferida ilicitamente. Já a disponibilidade jurídica é a posse do direito, i.e., diz respeito à aquisição de um título jurídico que confere direito de percepção de um valor definido, ingresso de forma legal, no patrimônio $^{174}$.

Não são poucas as controvérsias suscitadas pelas expressões que dão título a este subitem, seja em razão dos seus respectivos conceitos, seja em razão do alcance da palavra “disponibilidade" isoladamente considerada ${ }^{175}$. Tradicionalmente, a chamada aquisição da disponibilidade jurídica corresponderia à percepção ou aquisição do direito à renda, sem que, necessariamente, essa aquisição comportasse uma percepção em dinheiro ou em valores suscetíveis de avaliação em dinheiro, ao que chamaríamos de disponibilidade econômica $^{176}$.

Em seus estudos sobre o tema, que podem ser apreendidos a partir da leitura de diversos Pareceres, RuBENS GOMES DE SOUSA parece entender que bastaria a disponibilidade econômica da renda para que se pudesse falar em tributação pelo IR, que corresponderia, de fato, à realização de um bem (fluxo monetário) ${ }^{177}$. Por seu turno, AlCIDES JoRGE CostA, em linha com a redação do CTN, entende que se tratam de disponibilidades alternativas, bastando uma ou outra para que se opere a incidência ${ }^{178}$.

RICARDO MARIZ DE OLIVEIRA opina no sentido de que para os fatos regrados pelo Direito, no exato momento em que determinadas fontes produtoras promovem uma operação ou transação, já se dá a aquisição da disponibilidade jurídica, de onde pode surgir o acréscimo patrimonial, sendo irrelevante a indagação do recebimento do dinheiro ${ }^{179}$. Sob outra

\footnotetext{
${ }^{174}$ Cf. QUEIROZ, Mary Elbe. Op. cit. (nota 90), P. 72.

${ }^{175}$ Cf. OLIVEIRA, Ricardo Mariz de. Op. cit. (nota 171), P. 203.

${ }^{176}$ Ibidem, Op. cit. (nota 171), P. 204,

${ }^{177}$ Cf. SOUSA, Rubens Gomes de. A evolução do conceito de rendimento tributável. in Revista de Direito Público, vol. 14. P. 339/346, apud COSTA, Alcides Jorge. Op. cit. (nota 117), P. 25; 29/31.

${ }^{178}$ Cf. COSTA, Alcides Jorge. Op. cit. (nota 117), P. 29/31.

${ }^{179}$ Cf. OLIVEIRA, Ricardo Mariz de. Op. cit. (nota 171), P. 205. O tributarista esclarece ainda que antes de realizada, por exemplo, uma determinada operação ou transação comercial, não há direito, ao recebimento do preço, assumindo que a mercadoria não foi entregue ou o serviço não foi prestado. Com isso, o preço, se pago em momento prévio à ocorrência daqueles eventos, caracteriza-se como um mero adiantamento, ao que RICARDO MARIZ DE OLIVEIRA, arraigado em sua visão civilista acerca do acréscimo patrimonial, chama de mera disponibilidade financeira, não podendo falar-se em disponibilidade econômica, justamente pelo fato de que aquele dinheiro ainda não integra o patrimônio do vendedor ou prestador.
} 
perspectiva, a disponibilidade econômica ganha relevância para as chamadas situações de fato, isto é, para as situações não regradas ou contrárias ao Direito. Para estes casos, como, por exemplo, o produto obtido por roubo a um banco, não há se falar em aquisição de direitos, mas, tão somente, no efetivo recebimento de quantias em dinheiro ${ }^{180}$.

BRANDÃO MACHADO ${ }^{181}$ parece chegar ao mesmo resultado, concluindo que o que importa é que se verifique um acréscimo patrimonial. O celebrado autor percorre, no entanto, caminho diferente ao afirmar que a expressão "disponibilidade econômica ou jurídica" seria dispensável, seja porque se caracteriza como um complicador na precisão do alcance e do momento de sua incidência, seja porque bastaria dizer que o fato gerador do IR é a aquisição de acréscimos de direitos reais ou pessoais. Oportuna se faz a transcrição de alguns trechos:

"Ligeira leitura do texto mostra que há nele palavras que, na verdade, não exercem nenhuma função definitória. É a expressão disponibilidade econômica ou jurídica, que, efetivamente, está na definição, mas pode dela ser retirada sem prejuízo para sua inteligência. Fica difícil explicar uma disponibilidade econômica de acréscimo de direitos. Se o acréscimo é sempre de direitos, não há como conceber que possam estar economicamente disponíveis. Todo acréscimo de direitos (reais ou pessoais e, portanto, patrimoniais) estará necessariamente disponível, pelo fato singular de que os direitos acrescem ao patrimônio. Aquela expressão é excrescente e tem uma gênese que, afinal, pode encontrar-se na sistemática que o autor de seu anteprojeto pretendia imprimir no Código Tributário, sob a inspiração do direito tributário alemão, que dá maior relevo ao aspecto econômico do que ao jurídico na conceituação da hipótese de aplicabilidade da norma tributária e do vínculo entre a hipótese e o sujeito passivo." (grifamos)

\footnotetext{
${ }^{180}$ Ibidem, Op. cit. (nota 171), P. 207. "Disponibilidade econômica, portanto, a todo rigor, somente existe nos aumentos patrimoniais derivados de causas não jurídicas, quando é necessário dispor do dinheiro ou dos bens representativos do acréscimo para que a materialidade da hipótese de incidência esteja completa." ${ }^{181}$ Cf. MACHADO, Brandão. Breve Exame Crítico do Art. 43 do CTN. in Imposto de Renda - Conceitos, Princípios e Comentários. Coord. Ives Gandra da Silva Martins. São Paulo: Atlas, 1996. P. 101.
} 
Diferentemente do raciocínio perfilado por BRANDÃO MACHADO, LUís EDUARDO SCHOUERI entende que o CTN não trata apenas de "acréscimos patrimoniais", mas, em verdade, que há dois conceitos de renda (renda-produto e renda-acréscimo) que se aglutinam. Entende que é irrelevante a discussão se devem tributar "fenômenos econômicos" ou "fenômenos jurídicos", na medida em que o evento econômico, ao ser regrado em lei, torna-se um "fenômeno jurídico"182. O que se vislumbra, a rigor, é que o CTN utilizou dois adjetivos para qualificar uma mesma situação, a disponibilidade ${ }^{183}$.

Em arremate ao exposto até aqui, é possível apontar que o fato gerador do IR depende da aquisição de uma disponibilidade, jurídica ou econômica, conforme a natureza do direito envolvido, desde que essa disponibilidade represente um acréscimo patrimonial e esteja efetivamente disponível em favor do beneficiário daquela renda.

\subsubsection{Disponibilidade como sinônimo de Realização}

É possível dissociar a disponibilidade, seja ela econômica ou jurídica, da realização? Queremos crer que não e vamos além, enxergamos a aquisição da disponibilidade como sinônimo de realização (ou princípio da realização), no sentido de que uma pressupõe a outra, ou seja, não há disponibilidade sem realização, assim como não há como se falar em realização da renda sem a sua disponibilidade.

Henry TILBERY ${ }^{184}$ e Gilberto DE UlhôA CANTO ${ }^{185}$ parecem entender que, com foco no conceito de disponibilidade econômica, a percepção de rendimentos, representada, contudo, por quaisquer entradas, ou seja, os meros fluxos financeiros, seria suficiente para caracterização da existência de renda passível de tributação, independentemente de sua potencial realização.

\footnotetext{
${ }^{182}$ Cf. SCHOUERI, Luis Eduardo. Op. cit. (nota 113), P. 245/252.

${ }^{183}$ Cf. POLIZELLI, Victor Borges. Op. cit. (nota 148), P. 109.

${ }^{184}$ Cf. TILBERY, Henry. Comentários aos artigos 43 a 45 do Código Tributário Nacional, atualizados por José Ruben Marone. in Comentários ao Código Tributário Nacional: Volume I. Coord. Ives Gandra da Silva Martins. $3^{\text {a }}$ Ed. São Paulo: Saraiva, 2002. P. 328 e ss.

185 Cf. CANTO, Gilberto de Ulhôa. A Aquisição da Disponibilidade e o Acréscimo Patrimonial no Imposto sobre a Renda. in Imposto de Renda - Conceitos, Princípios e Comentários. Coord. Ives Gandra da Silva Martins. São Paulo: Editora Atlas, 1996. P. 38 e ss.
} 
KEVIN HOLMES ${ }^{186}$ parece adotar uma postura de que o que importa é a ocorrência de uma renda econômica, no sentido de um fato/operação/transação ocorrida no mercado, e somente após essa verificação é que se olha para a realização, que pode ou não ocorrer. Para os países que adotam o Sistema SHS, costuma-se dizer que o efeito nocivo deste modelo é o fato de que o acréscimo patrimonial verificado seria apenas potencial/virtual ${ }^{187}$, com base em avaliações por quanto aquele bem ou direito, se colocado no mercado, seria alienado, ou seja, qual o seu valor passível de conversão em dinheiro, independentemente de sua realização. Parece, neste cenário, aproximar-se da ideia de "renda imputada" ou "renda psíquica" medida de acordo com a satisfação pessoal de cada indivíduo, para os casos de utilização de um ativo de sua titularidade ou prestação de serviços a si próprio para estes casos, além da não existência do elemento "realização", válida também, como já nos referimos anteriormente, é a lição de THOMAS CHANCELLOR ${ }^{188}$, para quem essas situações não atendem ao conceito de renda, justamente pela impossibilidade de sua mensuração.

Há, ainda, outros autores, como é o caso de LUCIANO AMARO ${ }^{189}$, para quem os termos “disponibilidade econômica" e "disponibilidade jurídica" servem apenas para causar confusão, pois, de fato, o que importa é a aquisição de uma riqueza nova, integrada ao patrimônio do contribuinte, doutrina da qual parece aproximar-se o mestre BRANDÃo MACHADO, conforme já destacamos.

RICARDO MARIZ DE OLIVEIRA ${ }^{190}$, como se observa a seguir, ao tratar do tema da disponibilidade, traz importante lição, especialmente quando tratarmos dos pagamentos de natureza antecipatória do IR via retenção, ou seja, antes do ciclo completo do período de apuração:

\footnotetext{
${ }^{186}$ Cf. HOLMES, Kevin. Op. cit. (nota 121), P. 117/118; 178/179.

187 ANDRÉ MARTINS DE ANDRADE explica que a disponibilidade jurídica ocorre com o nascimento de um direito, normalmente um direito de crédito, e a disponibilidade econômica ocorre quando se materializa um ganho econômico, que pode ser o recebimento de uma prestação daquele direito de crédito, sendo certo que em qualquer situação a renda deve estar disponível e não corresponder a uma mera expectativa de disponibilidade (Cf. ANDRADE, André Martins. Efeitos Jurídicos da Inconstitucionalidade do Imposto de Renda sobre o Lucro Líquido - ILL. in Imposto de Renda - Questões Atuais e Emergentes. Coord. Valdir de Oliveira Rocha. São Paulo: Dialética, 1995. P. 14).

${ }^{188}$ Cf. CHANCELLOR, Thomas. Op. cit. (nota 119), P. 114/115.

${ }^{189}$ Cf. AMARO, Luciano. Imposto sobre a Renda e Proventos de Qualquer Natureza. in O Fato Gerador do Imposto sobre a Renda e Proventos de Qualquer Natureza. Coord. Ives Gandra da Silva Martins. São Paulo: Centro de Estudos de Extensão Universitária e Resenha Tributária, 1986. P. 388 e ss.

${ }^{190}$ Cf. OLIVEIRA, Ricardo Mariz de. Op. cit. (nota 171), P. 225.
} 
"Neste sentido, realização confunde-se com aquisição de disponibilidade econômica ou jurídica, pois essa aquisição marca o instante a partir do qual há acréscimo patrimonial e o imposto pode ser exigido, e quando se fala em "realização da renda", como princípio informador do fato gerador do imposto de renda, se está falando no momento a partir de quando a renda está consumada e pode ser tributada.

(...)

Com isto, cada fato aquisitivo de renda ou provento, de per si, não é suficiente para fazer nascer a obrigação tributária, que somente estará completa quando estiver completo o ciclo de formação do acréscimo patrimonial. Todavia, cada fato aquisitivo de renda ou provento, de per si, é elemento relevante e indispensável para a formação e complementação do fato gerador.

Portanto, as aquisições de disponibilidade econômica ou jurídica de rendas $e$ proventos não correspondem exatamente ao elemento temporal do fato gerador, mas se constituem em fatos participantes do próprio aumento patrimonial, indicadores da circunstância de que cada um desses fatos está completo, tendo produzido aumento patrimonial." (grifamos)

Conforme dissemos acima, a realização é aqui tomada como um dos princípios que faz o papel de vetor na determinação do formato final do que seja renda tributável. VICTOR BoRges POLIZELLI ${ }^{191}$ expõe que, ao lado do princípio da realização, outros três princípios defluem do conceito constitucional de renda, a saber: monetarização, apuração periódica e renda líquida. Para o autor, o entrelaçamento desses princípios oferece os elementos mínimos, que compõem a estrutura mais básica do imposto de renda.

O princípio da monetarização determina uma simplificação da noção de renda, limitandoa a fatos objetivamente observáveis e mais facilmente mensuráveis. Tem por objetivo final o afastamento da ideia de se querer tributar as pessoas com base nos níveis subjetivos de bem-estar (renda psíquica).

${ }^{191}$ Cf. POLIZELLI, Victor Borges. Op. cit. (nota 148), P. 90. 
O princípio da apuração periódica não é outra coisa senão a necessidade de uma dimensão temporal para que se possa comparar o patrimônio no início e no final de um dado período, caso contrário a noção de acréscimo patrimonial seria esvaziada de sentido. A rigor, valendo-se dos ensinamentos de BRIAN J. ARNOLD, VICTOR BORGES POLIZELLI ${ }^{192}$ pondera que o ideal seria que este período coincidisse com a vida de uma pessoa, evitando-se a tributação de resultados transitórios, todavia, razões mais preponderantes, sobretudo de ordem prática, demandaram que a apuração da renda (ou mesmo dos resultados de um negócio ou atividade) fosse dividida e demonstrada em períodos temporais menores.

Por fim, o princípio da renda líquida reflete o ideal de que o imposto de renda afete apenas o acréscimo patrimonial real, isto é, retrata um mandamento para que sejam considerados, dentro do respectivo período de apuração, os valores despendidos para produção de novos ingressos ${ }^{193}$.

Examinados estes três primeiros princípios, passa-se para a definição do que vem a ser o princípio da realização, elevado à categoria constitucional ${ }^{194}$. Não é foco do presente trabalho o detalhamento da extensão desse conceito, pois disso cuidaram outros trabalhos $^{195}$.

Outrossim, de forma a não deixar o tema sem definição, optamos pelas lições trazidas por VICTOR BORGES POLIZELLI ${ }^{196}$ para quem a realização da renda acontece no tempo da aquisição das disponibilidades, econômica ou jurídica, de acréscimo patrimonial. Ademais, ainda que não contenha uma definição explícita do princípio da realização, o artigo 43, do CTN, orienta, razoavelmente, para que se assimilem os regimes de competência e de caixa como métodos contábeis apropriados para a apuração da renda.

\footnotetext{
192 Ibidem, Op. Cit. (nota 148), P. 92/93.

${ }^{193}$ Ibidem, Op. cit. (nota 148), P. 93/94.

${ }^{194}$ Diversos autores corroboram a assertiva, neste sentido: HUMBERTo ÁvILA, ao afirmar que a "capacidade produtiva não deve ser tributada, mas somente a riqueza efetivamente recebida" (Cf. ÁVILA, Humberto. Teoria da igualdade tributária. São Paulo: Malheiros, 2008. P. 161); RoQUE ANTONIO CARRAZZA defende que a renda, para ser tributada, deve estar disponível ao seu titular, isto é, não pode ser uma renda potencial, ainda não realizada (Cf. CARRAZZA, Roque Antonio. Imposto sobre a renda: perfil constitucional e temas específicos. $2^{\text {a }}$ ed. São Paulo: Malheiros, 2006. P. 35/41).

${ }^{195}$ Cf. POLIZELLI, Victor Borges. Op. cit. (nota 148); Cf. SILVEIRA, Ricardo Maitto. O princípio da realização da renda no direito tributário brasileiro. in Revista de Direito Tributário Atual. Vol. 21. São Paulo: Dialética-IBDT, 2007, P. 317/344; Cf. MACHADO, Brandão. Op. cit. (nota 181), P. 108; Cf. OLIVEIRA, Ricardo Mariz de. Op. cit. (nota 171) P. 224/226.

${ }^{196}$ Cf. POLIZELLI, Victor Borges. Op. cit. (nota 148), P. 108; 112.
} 
Conclui "que o fato gerador do imposto de renda acontece no exato momento da aquisição de acréscimo patrimonial apurado por meio dos regimes de competência ou caixa" (destaques no original ${ }^{197}$, que se dá, necessariamente, ao término do período de apuração.

Ciente da relevância do princípio da realização, conforme alerta VICTOR BORGES POLIZELli, somos da opinião de que a corrente defendida por ALCIDES JORGE COSTA ${ }^{198}$, FERNANDO AURÉlio ZILVETI ${ }^{199}$ e LUÍS EDUARDo SCHOUERI ${ }^{200}$, para quem o IR só é devido após a realização da renda, como sinônimo de disponibilidade, é a que melhor atende à inteligência insculpida na sistemática deste imposto, bem como aos conceitos de disponibilidade, seja ela econômica ou jurídica, mas sempre com a ideia de uma renda disponível.

\subsubsection{Aquisição de Aumento Patrimonial e o Aspecto Temporal ${ }^{201}$}

Não é demais afirmar que o momento em que o fato gerador do IR poderá ocorrer será qualquer um, desde que após verificada a materialidade que lhe dá ensejo, qual seja, a aquisição de uma disponibilidade econômica ou jurídica que se traduza na realização de um acréscimo patrimonial. De fato, o que se vê é o deslocamento desse momento para uma data futura, permitindo, com isso, a mensuração da evolução ou mutação patrimonial, computada em prazos pré-definidos que a lei estabelece, através da comparação de um mesmo patrimônio mensurado em momentos diferentes.

\footnotetext{
${ }^{197}$ Ibidem, Op. cit. (nota 148), P. 117.

198 Cf. COSTA, Alcides Jorge. Imposto sobre a Renda: a Aquisição da Disponibilidade Jurídica ou Econômica como seu Fato Gerador - Limite de sua Incidência. Revista de Direito Tributário no 40 . Vol. 11. São Paulo: 1987. P. 105.

199 Cf. ZILVETI, Fernando Aurélio. O Princípio da Realização da Renda. in Direito Tributário Homenagem a Alcides Jorge Costa. Coordenação Luís Eduardo Schoueri. São Paulo: Quartier Latin, inverno de 2003.

${ }^{200}$ Cf. SCHOUERI, Luis Eduardo. Imposto de Renda e os Lucros Auferidos no Exterior. in Grandes Questões Atuais de Direito Tributário. Vol. 7. Coord. Valdir de Oliveira Rocha. São Paulo: Dialética, 2003. P. 323 e ss.

${ }^{201}$ A leitura dos REsp no 329.160, no 329.367 e no 346.467, todos do Distrito Federal e todos de 23.04.2003, revela que é entendimento da $1^{\mathrm{a}}$ Turma do STJ que o conceito de renda envolve necessariamente um período de tempo. Neste sentido, confira-se: "A retenção do imposto de renda na fonte cuida de mera antecipação do imposto devido na declaração anual de rendimentos, uma vez que o conceito de renda envolve necessariamente um período, que, conforme determinado na Constituição Federal, é anual. A hipótese de incidência do aludido imposto é complexa, cuja ocorrência dá-se apenas ao final do ano-base, quando se verifica o último dos fatos requeridos pela hipótese de incidência do tributo. Dessarte, consumado o fato gerador ao final do ano base, a extinção do direito de pleitear a restituição ocorrerá após 05 (cinco) anos, contados da data da declaração do imposto de renda referente ao ano-base anterior, acrescidos de mais 05 (cinco) anos da homologação." (EREsp 346.467/DF. Rel Min. Franciulli Neto. D.J. 30/06/2003).
} 
LUCIANO AMARO enumera que (i) o acréscimo patrimonial carece, para fins de sua mensuração, da noção de "períodos de tempo"; (ii) a adequação da tributação do IR à capacidade contributivo-econômica pressupõe que os fluxos de ingressos financeiros de uma pessoa sejam mensurados em um período razoável de tempo; (iii) um ingresso isolado certamente dará a ideia distorcida daquela capacidade contributivo-econômica; (iv) a mensuração dos dispêndios necessários à percepção da renda não pode, igualmente, ser tomada de forma instantânea. Conclui o autor que não vê inconstitucionalidades na ideia de tributação na fonte nem na definição, por lei, de período de tributação com prazos mais curtos (um mês, por exemplo), desde que se estabeleçam regras de ajustes como mecanismos de adequação aos princípios constitucionais ${ }^{202}$.

Assim, o legislador escolhe dois momentos que no Direito brasileiro, para a pessoa física, correspondem aos marcos inicial e final do ano civil. Durante esse lapso, chamado de período-base ou período de apuração, é verificado se houve um acréscimo do patrimônio comparado ao seu estágio patrimonial inicial e, em caso positivo, incide o IR sobre aquela variação.

LUÍs CESAR SOUZA DE QUEIROZ ${ }^{203}$ aponta, com perspicácia, que, para a construção do conceito de "acréscimo patrimonial", que nada mais é do que a junção de parte do aspecto material com o aspecto quantitativo do IR, não basta a simples comparação do valor do patrimônio em dois momentos diferentes (marcos inicial e final). É fundamental que, para tanto, sejam considerados os fatos-acréscimos e fatos-decréscimos relevantes, realizados neste interregno, que informarão ou não a existência de acréscimo patrimonial tributável.

$\mathrm{O}$ autor prossegue explicando que em que pese, para a pessoa física, todos os fatosacréscimos serem considerados para fins de mensuração da base de cálculo do IR, há uma especificidade no exercício dessa apuração no sentido de que, para os fatos-decréscimos, só serão considerados aqueles relacionados ao atendimento das necessidades vitais

\footnotetext{
${ }^{202}$ Cf. AMARO, Luciano. Questões Sobre a Periodicidade da Apuração do Imposto de Renda. in Imposto de Renda e ICMS - Problemas Jurídicos. Coord. Valdir de Oliveira Rocha. São Paulo: Dialética, 1995. P. $41 / 42$.

${ }^{203}$ Cf. QUEIROZ, Luis Cesar Souza de. Op. cit. (nota 09), P. 247/248.
} 
básicas ou à preservação da existência, com dignidade, tanto da própria pessoa quanto de sua família ${ }^{204}$.

A despeito da descrição apontada pelo autor, onde há certo grau de subjetivismo quanto ao conteúdo dos conceitos de "necessidades vitais básicas", "preservação da existência" e/ou "dignidade", o que releva concluir é que alguns fatos-decréscimos não serão dedutíveis para fins de apuração da base de cálculo do IR, ainda que, no final do exercício (marco final para os contribuintes pessoas físicas), tais fatos tenham colaborado para redução do valor do patrimônio ${ }^{205}$.

Para a pessoa jurídica, a regra é o período trimestral (Lei $\mathrm{n}^{\circ}$ 9.430/96, artigo $1^{\circ}$ ). Portanto, dentre de um mesmo ano civil haverá quatro datas diferentes ( 31 de março, 30 de junho, 30 de setembro e 31 de dezembro) em que se verificará a ocorrência do fato gerador do IRPJ, com a apuração de resultados definitivos em conformidade com as legislações contábil, societária e fiscal. Opcionalmente, o contribuinte poderá adotar o regime de apuração anual, com o fato gerador ocorrendo no dia 31 de dezembro, cenário em que a pessoa jurídica fica obrigada a promover recolhimentos mensais, com base em estimativas (balancetes de suspensão ou redução), a título de antecipações (Lei no 9.430/96, artigo $2^{\circ}$ ).

Todas essas datas querem demonstrar a natureza do fato gerador do IR como um fato gerador instantâneo. Excetuadas as hipóteses de antecipação de recolhimento do imposto, constitucional e legalmente definidas, conforme veremos a seguir, somente naqueles precisos instantes (datas definidas acima) é que estará concretizado o fato gerador do IR, permitindo aferir e mensurar o acréscimo patrimonial, se é que houve.

Não se trata de dizer que a escolha desses momentos reveste-se de natureza fictícia, sob a alegação de que, a rigor, a mensuração definitiva da variação patrimonial de uma pessoa só seria possível quando de sua morte, se pessoa física, ou quando de sua extinção, se pessoa jurídica, e somente então seria possível verificar se haveria materialidade apta a ser tributada, ou se, ao contrário, não houve qualquer acréscimo passível de tributação. Já abordamos o tema nos subitens 1.8. e 1.9.2. ao tratarmos dos princípios da realização da

${ }^{204}$ Ibidem, Op. cit. (nota 09), P.249.
${ }^{205}$ Ibidem, Op. cit. (nota 09), P.249/250. 
renda e do princípio da apuração periódica, destacando que questões de maior prioridade, sobretudo de ordem prática e de financiamento da máquina estatal, demandam a instituição de um corte artificial como medida necessária para a comparação e mensuração da evolução (e, se houver, do acréscimo), de um determinado patrimônio. A eleição daqueles marcos temporais é técnica legislativa que permite operacionalizar a quantificação da base de cálculo, logo, confere condições à operacionalização da tributação do Imposto sobre a Renda.

Por óbvio, o raciocínio quanto à definição do aspecto temporal coincidindo com a morte da pessoa física ou extinção da pessoa jurídica não é válido, porquanto privilegia uma perspectiva estritamente econômica em demérito de outros valores imprescindíveis. Com isso, além das questões práticas e operacionais, tais como (i) a impossibilidade de verificação e mensuração dessa evolução patrimonial assumindo um lapso temporal demasiadamente extenso; (ii) a necessidade de o ente público angariar recursos para seu funcionamento, para a prestação de serviços públicos em prol da comunidade e para o pagamento de despesas em periodicidade inferior a um ano (por exemplo, os salários dos servidores públicos, em periodicidade mensal); (iii) a necessidade de se compararem períodos não tão curtos e nem tão longos, de forma a neutralizar influências sazonais e permitir a comparabilidade entre exercícios sucessivos ${ }^{206}$, dentre outros fatores que abordaremos com maior propriedade no subitem, é imprescindível a delimitação de prazos menores para tributação da renda.

Por se tratar de um conceito eminente e essencialmente dinâmico, a noção de patrimônio sempre estará vinculada à sua variabilidade no tempo, i.e., a algum parâmetro temporal de comparação $^{207}$. Vale dizer que essa variabilidade atingirá exatamente o aspecto quantitativo do fato gerador do IR, permitindo afirmar que, em que pese tratar-se de um fato gerador instantâneo, cuja concretização ocorre em um preciso instante determinado pela lei, é bastante complexa a formação, mensuração e aferição de sua base de cálculo. É durante aquele intervalo de tempo que se apura a base de cálculo, valendo-se, para isso, de

\footnotetext{
${ }^{206}$ Conforme explica o jurista português Freitas Pereira (A periodização do lucro tributável. Lisboa. Centro de Estudos Fiscais, 1988) Apud BALEEIRO, Aliomar. Op. cit. (nota 88), P. 325.

${ }^{207}$ Cf. CANTO, Gilberto de Ulhôa; SOUZA, Antônio Carlos Garcia; MUNIZ, Ian de Porto Alegre. Imposto sobre a Renda e Proventos de Qualquer Natureza. in O Fato Gerador do Imposto sobre a Renda e Proventos de Qualquer Natureza. Coord. Ives Gandra da Silva Martins. Centro de Estudos de Extensão Universitária e Resenha Tributária. São Paulo: 1986. P. 8/10.
} 
complexas fórmulas com adições, exclusões, deduções, presunções, cálculos de valores adicionais etc.

Não se quer dizer que, diante de tal variabilidade no tempo que um determinado patrimônio não possa alterar em apenas um dia, o que é materialmente possível. A periodicidade a ser considerada deve ser de tal forma que o lapso temporal permita aferir, suficientemente, o cotejo dos eventos ocorridos para verificar se houve aquisição de um acréscimo patrimonial e evitar períodos muito curtos que desvirtuariam a possibilidade de aferição e deixariam de observar os pressupostos da capacidade contributiva, da pessoalidade e da progressividade, princípios ínsitos ao $\mathrm{IR}^{208}$. É preciso haver uma razoável certeza de que um determinado ingresso financeiro líquido pode ser considerado incorporado ao patrimônio do contribuinte para que sobre ele incida o $\mathrm{IR}^{209}$.

\subsection{Imposto de Renda Retido na Fonte}

Entramos na questão central desta dissertação, que permitirá definir as características próprias dos regimes jurídicos em que navega a sistemática de retenção na fonte do IR. $\mathrm{O}$ IRF não corresponde, a nosso ver, a uma espécie tributária autônoma, com hipótese tributária própria e distinta do IR das pessoas físicas e jurídicas ${ }^{210}$. Trata-se de uma técnica de pagamento antecipado do $\mathrm{IR}^{211}$ devido pelas pessoas físicas e jurídicas, que atende, na maior medida possível, aos moldes definidos pelo fato gerador do IR.

Antes, contudo, de nos atermos aos regimes jurídicos do IRF, faremos um breve, porém necessário, esboço histórico da evolução do sistema de retenção na fonte, tanto no Brasil como em outros países, e, com isso, identificar a extensão daqueles regimes, a saber: o

\footnotetext{
${ }^{208}$ Cf. QUEIROZ, Mary Elbe. Op. cit. (nota 90), P. 129/131.

${ }^{209}$ Cf. AMARO, Luciano. Op. cit. (nota 202), P. 42.

210 ROBERTO QUIROGA MOSQUERA sustentou que o IRF corresponderia a uma regra matriz tributária particular e distinta da regra matriz do IR das pessoas físicas e jurídicas (Cf. MOSQUERA, Roberto Quiroga. Tributação no Mercado Financeiro e de Capitais. São Paulo: Dialética, 1998. P. 142). Acerca desse entendimento, PAULO AYRES BARRETO aponta valiosa crítica no sentido de que, admitir-se tal manifestação como correta, equivaleria a dizer que no sistema de retenção na fonte o imposto incidiria sobre o ato de "pagar renda", que, além de não revelar e demonstrar a capacidade econômica, desvirtuaria todo o conjunto de regras e princípios que definem a tributação da renda, i.e., a tributação sobre o beneficiário que aufere renda (Cf. BARRETO, Paulo Ayres. Op. cit. (nota 156), P. 87/88).

${ }^{211}$ Com foco nas retenções na fonte, o Professor da Universidade Lusíada, em Lisboa, Dr. MANUEL PIRES diz que, no direito português, essas antecipações estão sujeitas ao princípio do imediatismo, face à produção do rendimento (PIRES, Manuel; PIRES, Rita Calçada. Op. cit. (nota 52), P. 349).
} 
regime de tributação exclusiva e o regime de antecipação do imposto devido, ambos através da retenção na fonte.

Diante dos conflitos gerados entre essa sistemática de pagamento antecipado do IR, via retenção na fonte, e o plexo de definições e situações desenhadas pelos aspectos material, temporal e quantitativo do fato gerador do IR, nosso estudo irradiará seu alcance de forma a identificar se há autorização constitucional para o IRF ou mesmo se os princípios constitucionais, específicos e não específicos do IR, autorizam essa sistemática de tributação.

Ao final, pretende-se verificar a constitucionalidade e a legalidade desses regimes e como eles se comportam diante dos princípios constitucionais. No capítulo final, nossa tarefa será ilustrar quais efeitos emanam desses regimes de retenção na fonte sobre situações práticas específicas regradas pelo legislador infraconstitucional.

\subsubsection{Breve Contexto Histórico no Direito Comparado - A Experiência Anglo- Saxônica ${ }^{212}$}

O primeiro registro do emprego da renda como índice de tributação data do final do século XVIII quando, diante dos altos custos da guerra contra Napoleão Bonaparte, o Primeiro Ministro britânico, William Pitt, lançou mão de tal imposto, em caráter emergencial e provisório $^{213}$.

\footnotetext{
${ }^{212}$ MEADE EMORY, analisando a herança trazida para os dias de hoje do primitivo imposto sobre a renda britânico, afirmou que a extrema complexidade e as constantes alterações na legislação desse gravame, aliadas aos incontáveis impactos que esse imposto causava na vida das pessoas, implicam a busca das origens históricas dos conceitos que hoje informam a sofisticada e complexa legislação contemporânea do imposto sobre a renda (Cf. EMORY, Meade. The Early English Income Tax: A Heritage for the Comtemporary. Philadelphia: 1965. The American Journal of Legal History. Volume 9. Temple University School of Law. P. 286/319). A origem do imposto sobre a renda remonta a uma gama diversa de razões, desde as já conhecidas justificativas de manutenção da máquina pública, representada já nos primórdios na figura do Estado, até a acontecimentos de conotação estritamente política ou estratégica, como as guerras entre nações, ocorridas de tempo em tempo nos séculos passados.

${ }^{213}$ Cf. GROSSFELD, Bernhard; BRYCE, James D. A Brief Comparative History of the Origins of the Income Tax in Great Britain, Germany an the United States. P. 219/220.
} 
Nos Estados Unidos, inicialmente adotou-se um imposto sobre a renda dos indivíduos em 1864 para financiar a Guerra Civil ${ }^{214}$. Somente em $1913^{215}$, o imposto sobre a renda ganhou o status de principal e mais importante fonte de renda fiscal da estrutura administrativa norte-americana.

Desde então, assim como ocorreu em outros países ${ }^{216}$, a legislação do imposto sobre a renda americano sofreu diversas alterações, muitas delas motivadas pelas guerras, que sempre eram motivo para a majoração da carga tributária.

Do lado britânico, o IR foi introduzido em 1798 e, exceto no período entre 1816 e 1842 , permaneceu e permanece válido desde então. Em 1803, o IR foi completamente revisto, com a introdução de um sistema de tributação da renda, progressivo e fortemente lastreado no regime de retenção na fonte ${ }^{217}$.

Em brilhante trabalho sobre as origens da tributação das riquezas na fonte no Reino Unido, PIROSKA E. SoOs ${ }^{218}$, antes de identificar a evolução histórica desse imposto ${ }^{219}$, traz uma

${ }^{214}$ Cf. REPETTI, James R. The United States. in Comparative Income Taxation - A Structural Analysis. Second Editions. Coords. Hugh J. Ault. Brian J. Arnold. Kluwer Law Internationl - Aspen Publishers. 2004, P. 173.

${ }^{215}$ Em que pese a origem do IR norte-americano datar de época mais remota - em 1861 o Congresso publicou o Revenue Act of 1861, que passou a incluir um imposto sobre as rendas pessoais com o objetivo de obter receita para custear os gastos com a Guerra Civil, porém o imposto foi declarado inconstitucional -,

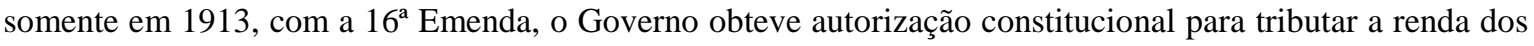
indivíduos.

${ }^{216} \mathrm{Na}$ Austrália, segundo o Professor Richard VANN, da Universidade de Sidney, em 1984, portanto anterior à idéia de federação, já existia um IR na Austrália do Sul, sendo que, em 1907 todos os Estados já tinham seu próprio IR. Somente em 1915 o IR deixou de ser um tributo estadual e passou a ter status federal, como uma medida para financiar a Guerra. BRIAN J. ARNOLD informa que no Canadá o IR federal foi primeiramente imposto como uma medida provisória para financiar a $1^{\text {a }}$ Guerra Mundial - antes disso, as principais fontes de receitas federais eram os impostos aduaneiros e os impostos sobre a circulação de produtos. Por sua vez, a história moderna da tributação sobre a renda na Alemanha começa com o Regulamento do IR da Prússia de 1891, que introduziu uma sistemática baseada na tributação da renda na origem. Posteriormente, em função da pesada carga financeira da $1^{\mathrm{a}}$ Guerra Mundial, houve uma mudança no poder legislativo, trocando-se a Constituição do Reich de 1871, que determinava que somente os Estados poderiam cobrar IR mas não o Reich por ele próprio, para a a Constituição de Weimar de 1919, com a introdução do Regulamento do IR de 1920 (Cf. todos VANN, Richard J. Australia. ARNOLD, Brian. Canada. J. SCHÖN, Wolfgang. Germany. in Comparative Income Taxation - A Structural Analysis. Second Editions. Coords. Hugh J. Ault. Brian J. Arnold. Kluwer Law Internationl - Aspen Publishers. 2004., P. $3 ; 23 ; 53)$.

${ }^{217}$ Cf. TILEY, John. Op. cit. (nota 115), P. 115.

${ }^{218}$ Cf. SOOS, Piroska E. The Origins of Taxation at Source in England. Amsterdam, The Netherlands: 1997. IBFD Publications. $242 \mathrm{p}$.

${ }^{219}$ ALFRED P. KOCH e CARL L. MOORE, em excelente artigo sobre o histórico do imposto sobre a renda na Inglaterra, informam que esse tributo tem suas origens mais remotas à época da Guerra Civil, nos idos de 1861 a 1865, com o primeiro ato normativo sobre o imposto de renda aprovado em 1861 ("Income Tax Act of 
importante conceituação entre as duas modalidades de retenção na fonte até então existentes na Inglaterra ${ }^{220}$. Dada a importância que esse paralelo histórico refletirá aos nossos estudos, torna-se relevante trazer a lume tais conceitos. Vejamos.

O primeiro desses conceitos refere-se ao que PIROSKA E. SoOs chamava de "taxation at the source", que pode ser entendido, em uma tradução livre, como a "tributação na origem" ou “tributação na fonte (pagadora)". Nas situações ocorridas sob essa modalidade, o imposto era cobrado na origem ou na fonte pagadora da receita (também entendido como renda ou rendimento) e, como consequência, essa fonte pagadora ficava autorizada a (se sub-rogava no direito de) recuperar esse imposto pago através da dedução do exato montante, quando do pagamento à pessoa intitulada a receber referida receita.

Na taxation at the source, a fonte ou o pagador teria que pagar o imposto na data devida, recuperando esse dispêndio quando fizesse os pagamentos, via retenção. Apoiado na análise dos sistemas de tributação vislumbrados na atualidade, o autor explica que essa sistemática de tributação funciona melhor nos países que adotam uma alíquota padrão e uniforme para os diversos contribuintes e para toda a sorte de tipos de renda.

A segunda forma de manifestação de tributação sobre a renda foi identificada como sendo o "withholding tax" - imposto retido na fonte -, que corresponde, na verdade, a uma modalidade mais globalmente conhecida e de mais fácil identificação, tanto nas operações internas de cada país, como nas relações jurídico-tributárias entre os países, regularmente normatizadas, em muitos casos, através dos acordos internacionais para evitar a dupla tributação.

1861") (Cf. KOCH, Alfred P. e MOORE, Carl L. Income Taxes and Their Impact on the Individual since 1913. TAXES - The Tax Magazine, by Benjamin M. Becker: 1954. Mahoning Law Library Associaton. P. 462/472).

${ }^{220}$ Conforme veremos, o estudo da origem da legislação que trata do imposto sobre a renda fornece elementos interessantes nesse sentido. Perquirições de cunho acadêmico e científico mostram que desde o século XII já era possível identificar formas primitivas de tributação das riquezas, ou de um determinado fato econômico, em sua origem, i.e., na ponta de onde tais riquezas ou dinheiros provinham. Assim era no período do feudalismo (período que compreende o século XI e se faz sentir até próximo do ano de 1500, em países como Inglaterra e Alemanha). À época, o líder de um determinado grupo era o responsável, para fins fiscais, perante a Coroa, e esta quase não tinha contato direto com os demais indivíduos daquele grupo. Esse sistema ficou conhecido como "tributação na cabeça" ("taxation at the head"). Em alusão, referido tributo também era conhecido como "capitação" ou "por cabeça", correspondendo a um imposto pago por cada membro da família (ônus financeiro; relação de débito), porém recolhido aos cofres reais pelo líder daquele grupo (ônus obrigacional; relação de responsabilidade). 
Para PIROSKA E. Soos, nas situações operacionalizadas através do withholding tax, a tributação é realizada pelo que o autor nomeou como "agentes de retenção", eleitos legalmente para recolher o imposto. Neste caso, após o pagamento ao credor de determinada renda tributável, já líquida do imposto devido, o agente deve remeter tais montantes, anteriormente retidos, aos cofres públicos.

$\mathrm{O}$ autor lembra que as operações sujeitas à retenção na fonte sob a modalidade do withholding tax funcionam melhor nos países que adotam alíquotas progressivas, com tributação diferenciada para rendas ou rendimentos de naturezas distintas ${ }^{221}$ e cuja engenharia de tributação da renda autoriza o cômputo de algumas deduções, tributando, com isso, a renda líquida ("net income"). Observa, ainda, o autor, que, na Inglaterra, a sistemática de retenção do imposto na fonte adaptou-se de forma mais uniforme ao princípio PAYE (“pay-as-you-earn"), i.e., o imposto é pago à medida que os pagamentos são realizados.

JOHN TILEY comenta que a sistemática do PAYE, introduzida durante a $2^{\text {a }}$ Guerra Mundial, tinha sido, talvez, a característica mais importante do IR britânico. Pelo PAYE todos os tipos de rendas do trabalho passaram a ser tributadas na fonte. Diz-se que este sistema impôs um custo extrassubstancial nos empregadores (a fonte), mas revelou-se como uma excelente ferramenta para a Administração. Ainda, esta sistemática livrou os contribuintes de fazer a apuração eles próprios e, com isso, forçá-los à interpretação de leis e métodos razoavelmente complexos ${ }^{222}$.

Importante notar que o grau de responsabilidade das partes envolvidas, numa e noutra modalidade, é distinto. Na modalidade taxation at the source, na qual a fonte paga o

221 A tributação em cédulas pode ser entendida como 'diferentes para rendas ou rendimentos de naturezas distintas, seja através da aplicação de alíquotas menores ou de isenções, seja através da autorização de certas deduções, proporcionando a redução das bases tributáveis. A cedularização nada mais é do que a escolha de determinadas realidades pinçadas pelo legislador que, por revestirem características próprias, demandam tratamento separado das demais hipóteses ou da regra geral. Assim é que os ganhos de capital são tributados à parte, da mesma forma como as pessoas jurídicas possuem tratamento em separado de seus acionistas pessoas físicas. O "regresso" à cedularização, se é que assim podemos dizer, na verdade, constitui uma tendência mundial, misturado aos ingredientes da proporcionalidade e da progressividade e corresponde a uma prática cujo ideal é buscar a tributação mais próxima possível da realidade, sem, contudo, descuidar da capacidade contributiva e do princípio da "renda líquida" que necessariamente devem informar a tributação do imposto de renda.

${ }^{222}$ Cf. TILEY, John. Op. cit. (nota 115), P. 130. 
imposto com recursos próprios primeiro, para, depois, quando do pagamento da renda, deduzir aquele dispêndio já realizado, o Estado só pode exigir e cobrar administrativamente da própria fonte pagadora. Aparentemente, o autor reflete a ideia de que, nessa modalidade, a fonte pagadora estaria pagando o imposto como se fosse uma obrigação própria, como se aquela riqueza tributada estivesse dentro do campo lógicoobrigacional de sua capacidade contributiva ${ }^{223}$.

Nas situações sob o regime do withholding tax, o agente de retenção (withholding agent), na linguagem utilizada por PIROSKA E. $\operatorname{SoOs}^{224}$, tem a obrigação de reter e fazer o pagamento. Na hipótese de essa retenção e de o pagamento não ocorrerem, o Estado poderá ir atrás tanto do beneficiário da renda, quanto da própria fonte. $\mathrm{Na}$ hipótese de o agente efetuar a retenção, mas, por alguma razão, deixar de efetuar a remessa/pagamento de tais valores aos cofres públicos, o Estado só poderá fazer qualquer exigência perante aquele agente pagador.

Neste último caso, PIROSKA E. SoOs ${ }^{225}$ conduz sua exposição para o entendimento de que a fonte estaria cumprindo uma obrigação alheia, aproximando-se do IRF brasileiro.

\subsubsection{Regime de Tributação na Fonte em Outros Países}

Segundo o Professor GUY Gest, da Universidade de Paris, França, nas rendas submetidas à tributação progressiva, o IR é retido somente em alguns casos de receitas de valores

\footnotetext{
${ }^{223}$ Situação parecida, no cenário brasileiro, parece ocorrer com a tributação na fonte prevista para os casos de rendimentos pagos a beneficiário não identificado, conforme disciplinado no artigo 674 do Regulamento do Imposto de Renda (Decreto $n^{\circ} 3.000 / 99$ - RIR). Voltaremos a essa hipótese em capítulo seguinte, quando analisarmos outras hipóteses de tributos sujeitos à retenção na fonte.

${ }^{224}$ No original, mais completo: "As to the legal obligations of the parties involved, the specifies vary, and reference must be made to the particular provision for taxation at source or withholding. As a general rule, however, under taxation at source, the payer is legally obliged to pay the tax on the income with regard to which he is the source, and he is the subject to the same enforcement procedures (e.g. seizure and sale of goods) as other taxpayers. The government may collect the tax only from the payer and generally has no recourse against the recipient of the income. The payer is authorized to recover the tax he paid by deducting it from the payment made to the income recipient, and the latter is obliged to allow the deduction. Under withholding, the payer, as withholding agent, is required to withhold tax and remit it to the government, but the income recipient is in principle ultimately liable for the tax. The payer is liable for the tax withhold an may also be subject to penalties for failure to withhold or remit the tax on time. If the payer fails to withhold tax, the government may usually proceed against either the payer or income recipient. If, however, the payer withhold tax but does not remit it to the government, the government may, in many cases, proceed only against the payer." (grifamos) (Cf. SOOS, Piroska E. Op. cit. (nota 218), P. 12-13).

${ }^{225}$ Ibidem, Op. cit. (nota 218), P. 13.
} 
mobiliários fixos e em certos casos de rendimentos de não-residentes. Informa, também, que não há IRF sobre salários e pensões, todavia, para os casos de alíquotas fixas, há retenção na fonte para a maioria dos rendimentos ${ }^{226}$. A doutrina revela que, naquele país, algumas receitas são tributadas isoladamente por meio de alíquotas fixas (flat rates), não submetidas, portanto, à tabela progressiva aplicável aos demais rendimentos dos indivíduos.

$\mathrm{Na}$ Alemanha, as rendas decorrentes do emprego (salários, principalmente) estão sujeitas à tributação na fonte e isso é um dos maiores inibidores de medidas tendentes à redução da carga tributária. A retenção na fonte do IR alemão é um assunto sério, exigindo fiscalização em campo realizada periodicamente pelos agentes do governo ${ }^{227}$.

Conforme noticiam os Professores Minoru NAKAZATo, Mark RAMSEYer e YASUTAKa NISHIKORI, uma das características mais marcantes da tributação da renda das pessoas físicas no Japão é que ela está pesadamente baseada na sistemática de tributação na fonte. Diz-se que aproximadamente $80 \%$ do IRPF é coletado via retenção na fonte. Interessante notar que justamente em função dessa sistemática do IRF exercer papel tão relevante, os indivíduos acabam ficando livres, na maioria das vezes, da entrega de uma declaração ao Fisco japonês, desde que, no final do exercício fiscal, sejam feitos os ajustes necessários ${ }^{228}$.

Os ganhos de capital em ativos mobiliários, por exemplo, não estão sujeitos à sistemática de tributação na fonte. Tais ganhos são totalizados separadamente de outros tipos de rendas e são tributados de acordo com alíquotas específicas. Diz-se, por um lado, que a teoria por trás desse esquema cedular estaria relacionada com a capacidade contributiva própria de cada categoria de renda. Por outro lado, tal sistema facilitaria a adoção de técnicas de planejamento fiscal no sentido de alterar a característica de uma renda familiar ${ }^{229}$.

\footnotetext{
${ }^{226}$ Cf. GEST, Guy. France. in Comparative Income Taxation - A Structural Analysis. Second Editions. Coords. Hugh J. Ault. Brian J. Arnold. Kluwer Law Internationl - Aspen Publishers. 2004, P. 48/49.

${ }^{227}$ Cf. SCHÖN, Wolfgang. Op. cit. (nota 114), P. 67/69.

${ }^{228}$ Cf. NAKAZATO, Minoru. RAMSEYER, Mark. NISHIKORI, Yasutaka. in Comparative Income Taxation - A Structural Analysis. Second Editions. Coords. Hugh J. Ault. Brian J. Arnold. Kluwer Law Internationl - Aspen Publishers. 2004, P. 78/79.

${ }^{229}$ Ibidem, Op. cit. (nota 228), P. 78/79.
} 
Nos Estados Unidos, o sistema tributário para as pessoas físicas é largamente baseado em informações colhidas através do Fisco americano, indicando os montantes pagos para cada um de seus empregados e, também, ficam obrigados à retenção do IR sobre aqueles montantes ${ }^{230}$. O volume de receitas derivadas do IRF nos Estados Unidos é realmente relevante: para o exercício fiscal americano de 2010, representou 38,4\% da carga tributária arrecadada e $76,6 \%$ da tributação da renda das pessoas físicas ${ }^{231}$.

\subsubsection{A Origem da Tributação do IRF no Brasil e seus Regimes Jurídicos}

O instituto da retenção é um velho conhecido no Brasil. Acreditamos datar de 1923 a primeira vez em que foi por aqui empregado. Através do Decreto $\mathrm{n}^{\circ} 4.682$, publicado no D.O.U. de 28/01/1923, também conhecido como a Lei Eloy Chaves ${ }^{232}$, determinou-se que, (artigos $3^{\circ}$ e $4^{\circ}$ ) sobre a contribuição mensal dos empregados, as empresas ferroviárias estavam obrigadas a descontar 3\% dos respectivos vencimentos.

MARY ELBE QUEIROZ ${ }^{233}$ aponta que a incidência do IRF resulta da obrigatoriedade, imposta por lei ordinária, para que terceira pessoa, física ou jurídica, na qualidade de fonte pagadora de rendimentos ou valores a outras pessoas, físicas ou jurídicas, no momento escolhido pela lei para entrega dos rendimentos ou valores aos beneficiários, efetue a retenção de uma determinada quantia e, posteriormente, proceda ao recolhimento de tributo aos cofres públicos.

Interessante notar a redação utilizada pela autora, frontalmente contra a sistemática de pagamento do IRF, ao tratar os valores recebidos pelo beneficiário como rendimento e não como renda. Por ora, concentremos nossa atenção em qual (quais) seria(m) este(s) momento(s) para que a retenção do IRF ocorra.

\footnotetext{
${ }^{230}$ Ibidem, Op. cit. (nota 228), P. 150.

${ }^{231}$ Cf. Internal Revenue Service Data Book, 2010. October $1^{\text {st }}, 2009$ to September 30 ${ }^{\text {th }}, 2010$. P. 3. Disponível em http://www.irs.gov/pub/irs-soi/10databk.pdf. Acesso em 02/11/2011.

${ }^{232}$ Disponível em: http://www81.dataprev.gov.br/sislex/paginas/23/1923/4682.htm. Acesso em 23.10.2011. Referido Decreto criou, em cada uma das empresas de estradas de ferro existentes no País, uma Caixa de Aposentadoria e Pensões para os respectivos empregados.

233 Cf. QUEIROZ, Mary Elbe. Op. cit. (nota 89), P. 384.
} 
Para uma análise da origem da tributação da renda na fonte no Brasil, é preciso ter em mente que os momentos que têm sido historicamente eleitos pelo legislador infraconstitucional como suficientes para incidência do IRF são outros, que não exatamente aqueles estampados na CF e no artigo 43, do CTN (conforme expusemos no item 1.8.).

Assim é que para o IRF bastará a realização de um dos seguintes eventos para acionar o gatilho da retenção: pagamento, crédito, emprego, entrega ou remessa.

Como se diz, a técnica de arrecadação do IR pela retenção na fonte se dá sobre fatores isolados de acréscimo patrimonial, bem como através da alteração da pessoa obrigada a recolher o imposto, com a "substituição" do contribuinte pela fonte pagadora da renda ${ }^{234}$. Vejamos então cada um desses cinco eventos e sua relação com o aspecto temporal do IRF:

Pagamento: este é o evento por excelência desencadeador da realidade expressiva da noção de "retenção na fonte" ou "desconto na fonte", na medida em que, mediante o pagamento de uma determinada renda, a fonte se desincumbe de sua obrigação de direito privado, disponibilizando, juridicamente, uma determinada quantia, líquida do imposto (retido/deduzido), ao beneficiário daquela renda. Com o pagamento, há extinção do vínculo obrigacional e liberação das partes $^{235}$. O pagamento torna-se, assim, parte integrante e necessária para o nascimento da obrigação tributária de realização de tais antecipações. No exato momento do pagamento, além da notória existência de uma disponibilidade financeira, há, também, de forma prévia ou simultaneamente, uma disponibilidade jurídica, na medida em que este evento reflete a obrigação da fonte ao credor (beneficiário) da renda. Quer-se dizer com isso que não é qualquer pagamento que faz nascer a obrigação tributária correspondente ao IRF, mas somente aquele pagamento de uma renda em que exista ou já tenha ocorrido uma disponibilidade ${ }^{236}$, conforme discorremos no subitem 1.9.1.

\footnotetext{
${ }^{234}$ OLIVEIRA, Ricardo Mariz. Op. cit. (nota 16), P. 499.

235 Cf. QUEIROZ, Mary Elbe. Op. cit. (nota 90), P. 203.

236 RICARDO MARIZ DE OLIVEIRA entende que essa disponibilidade deve ser jurídica. OLIVEIRA, Ricardo Mariz. Op. cit. (nota 16), P. 500/510.
} 
Crédito: trata-se de um quase-pagamento, que consiste numa dívida vencida, a qual é creditada ao beneficiário para que a receba quando quiser. O crédito deve, contudo, corresponder, necessariamente, a um débito, representativo de obrigação de direito privado (vencida), já existente para a fonte pagadora. Corresponde, em suma, a um ato da fonte pagadora de colocar a renda à disposição do respectivo beneficiário, para que este receba o que lhe é devido no momento em que comparecer perante a fonte ${ }^{237}$. É o direito subjetivo de um sujeito ativo (credor; beneficiário) de uma obrigação que lhe possibilita poder exigir o objeto prestacional do sujeito passivo (devedor; fonte pagadora) ${ }^{238}$. Assim como o pagamento, a disponibilidade jurídica ocorre desde o momento em que o beneficiário estiver em condições de exigir que lhe seja creditada/paga uma determinada renda ${ }^{239}$. Vale destacar que o simples crédito contábil não tem o condão de extinguir nem de antecipar a exigibilidade de uma determinada obrigação de direito privado ${ }^{240}$. Essa é inclusive a posição da Administração Tributária, conforme se confere do Parecer Normativo $\mathrm{n}^{\circ} 121$, de $1973^{241}$. O registro na contabilidade não tem o poder de gerar qualquer disponibilidade

\footnotetext{
${ }^{237}$ Ibidem, Op. cit. (nota 16), P. 511/512.

${ }^{238}$ Cf. QUEIROZ, Mary Elbe. Op. cit. (nota 90), P. 203.
}

239 TILBERY, Henry. Imposto sobre a Renda e Proventos de Qualquer Natureza (artigos 43, 44 e 45). in Comentários ao Código Tributário Nacional - Vol. 1. Coords. Hamilton Dias de Souza; Henry Tilbery; Ives Gandra da Silva Martins. Editora Bushatsky, 1975. P. 92.

${ }^{240}$ Estas lições podem ser extraídas de diversos acórdãos do CARF, à época sob a denominação de Conselho de Contribuintes: Acórdão no 103-07602, de 13/10/1986; Acórdão n ${ }^{\circ}$ 104-21549, em 27.04.2006. Transcrevemos o mais recente: "IMPOSTO DE RENDA RETIDO NA FONTE - JUROS E CORREÇÃO PELA VARIAÇÃO CAMBIAL DECORRENTE DE EMPRÉSTIMO DE PESSOA JURIDICA SITUADA NO EXTERIOR COM CLÁUSULA DE VENCIMENTO EM 10 ANOS - ENCARGOS FINANCEIROS LANÇADOS ATRAVÉS DE CRÉDITOS CONTÁBEIS REGISTRADOS EM DATA ANTERIOR AO VENCIMENTO DO EMPRÉSTIMO - FATO GERADOR - Não há fato gerador do imposto de renda incidente na fonte quando os juros e a correção pela variação cambial são contabilmente creditados ao beneficiário do rendimento em data anterior ao vencimento da obrigação. $O$ simples crédito contábil, antes da data aprazada para seu pagamento, não extingue a obrigação nem antecipa a sua exigibilidade pelo credor. O fato gerador do imposto na fonte, pelo crédito dos rendimentos, relaciona-se, necessariamente, com a aquisição da respectiva disponibilidade econômica ou jurídica. Recurso provido."

241 “EMENTA - Não integram o rendimento bruto, no cálculo da renda líquida imponível, as parcelas creditadas que não estejam juridicamente à disposição do contribuinte.

Os saldos remanescentes desses créditos, mesmo quando pagos após a rescisão do contrato individual de trabalho, sujeitam-se à retenção do imposto de renda na fonte, previsto no art. 107. do Regulamento do Imposto de Renda, aprovado pelo Decreto $n^{\circ} 58.400$, de 10 de maio de 1966, com a alteração introduzida pelos arts. $7^{\circ}$ do Decreto-Lei $n^{\circ} 401 / 68$ e $7^{\circ}$ do Decreto-Lei $n^{\circ} 1.198 / 71$.

Dispõe o art. 118. do Regulamento do Imposto de Renda, aprovado pelo Decreto $n^{\text {oo }} 58.400$, de 10 de maio de 1966, que o imposto sobre os rendimentos do trabalho assalariado deverá ser recolhido pela fonte pagadora dentro do mês seguinte àquele em que houver sido efetuado o pagamento ou o crédito aos beneficiários.

Claro está que o Regulamento aí se refere aos créditos incondicionais, não sujeitos a termo, e portanto, inteiramente à disposição do beneficiário, e não aos condicionados ou com vencimento previamente ajustado, porque estes não estão, ainda, juridicamente, à disposição do contribuinte.

Por conseguinte as comissões de empregados da empresa, condicionadas nos termos do art. 466. da CLT, a ultimação do negócio, somente após o implemento dessa condição é que se tornarão exigíveis e sujeitas ao imposto de renda na fonte de que trata o art. 107. do Regulamento do Imposto de Renda, aprovado pelo 
que configure benefício do credor (beneficiário do rendimento), de forma que este possa se apropriar e dispor livremente de tais quantias creditadas $^{242}$. Há a necessidade de um facere, de uma atitude positiva por parte da fonte pagadora, i.e., a inteligência correta a ser dada à palavra crédito não é no sentido de um mero lançamento contábil ou mesmo o direito de haver prestação contratual (vencida); se o substantivo "crédito" gera esse duplo sentido, o verbo "creditar" não, exigindo uma atividade específica por parte da fonte pagadora, sem a qual não surgirá a obrigação pertinente ao $\operatorname{IRF}^{243}$. Sob a perspectiva das pessoas físicas, considerando que o regime de tributação consagrado por lei é o regime de caixa, o entendimento mais adequado é no sentido de que o crédito, como evento desencadeador do IRF, deverá necessariamente estar acompanhado da efetiva disponibilidade financeira, daí se dizer que o crédito é um quase-pagamento;

RICARDO MARIZ DE OLIVEIRA ${ }^{244}$ ensina que os três próximos eventos - remessa, entrega e emprego - correspondem a espécies de efetivação do pagamento e, como tal, amoldam-se à disciplina contida no artigo 304, do Código Civil ${ }^{245}$. Não é verdade, entretanto, que estes três eventos são a mesma coisa.

Veja, por exemplo, o caso da Instrução Normativa SRF $\mathrm{n}^{\circ}$ 38/96, que procurou constitucionalizar a tributação dos lucros auferidos no exterior, trazendo situações que não foram previstas na Lei $\mathrm{n}^{\circ}$ 9.249/95, sem, contudo, qualquer base constitucional, tendo em vista que a Lei de 1995 não previa o conceito do que era lucro disponibilizado. Com vistas a regularizar essa atrapalhada situação, foi editada a Lei $n^{\circ}$ 9.532/95, criando hipóteses de disponibilização do lucro, conforme se depreende de seu artigo $1^{\circ}$.

Decreto $n^{\circ} 58.400$, de 10 de maio de 1966, com as alterações introduzidas pelos arts. $7^{\circ}$ do Decreto-Lei $n^{o}$ $401 / 68$ e $7^{\circ}$ do Decreto-Lei $n^{\circ} 1.198 / 71$.

Conseqüentemente, o saldo remanescente dessas comissões, mesmo após o rompimento do vínculo empregatício, será tributado, à medida que se liberar, na forma acima exposta." (grifamos)

${ }^{242}$ Cf. QUEIROZ, Mary Elbe. Op. cit. (nota 90), P. 204/206.

${ }^{243}$ CANTO, Gilberto Ulhôa. Estudos e Pareceres de Direito Tributário - Imposto de Renda. São Paulo: Revista dos Tribunais, 1975. P. 376.

244 OLIVEIRA, Ricardo Mariz de. Op. cit. (nota 16), P. 513/514.

245 “Art. 304. Qualquer interessado na extinção da dívida pode pagá-la, usando, se o credor se opuser, dos meios conducentes à exoneração do devedor.

Parágrafo único. Igual direito cabe ao terceiro não interessado, se o fizer em nome e à conta do devedor, salvo oposição deste." 
Desse emaranhado normativo vale questionar: emprego é disponibilização? Isto é, o emprego de lucros do exterior em uma operação igualmente no exterior corresponde a uma disponibilização ou a uma forma de pagamento? Vejamos a decisão abaixo:

\section{“LUCROS AUFERIDOS POR INTERMÉDIO DE CONTROLADA NO EXTERIOR. DISPONIB ILIZAÇÃOEMPREGO DO VALOR LUCRO.}

A expressão "o emprego do valor, em favor da beneficiária" contida no artigo $1^{\circ}, \S 2^{\circ}$, " $b^{\prime}$, item 4, da Lei 9.532/1997 abrange os casos em que o emprego do valor foi feito pela própria beneficiária. Como regra geral, na utilização de participação societária da controlada que auferiu lucros no exterior, para integralização de capital em outra pessoa jurídica ocorre o "emprego de valor" que caracteriza a disponibilização, para fins de tributação, salvo na hipótese em que a tal integralização de quotas se dá na própria controladora da beneficiária e, portanto, detentora, indiretamente, por equivalência patrimonial, dos lucros acumulados na investida estrangeira. Nesse caso, não se configura o"emprego de valor" caracterizador da disponibilização."

( $1^{\circ}$ Conselho de Contribuintes. $1^{\text {a }}$ Câmara. Acórdão n• 101-97.032. Sessão de 13.11.2008)

Neste caso, ficou demonstrado que o fato da beneficiária ser controladora da matriz brasileira que, por sua vez, era controladora da empresa estrangeira, implicando na titularidade indireta pela beneficiária, por meio de equivalência patrimonial, dos lucros auferidos pela controlada indireta no exterior, determinou que a utilização da participação societária na empresa estrangeira para integralização no capital da beneficiária, por meio de cisão parcial, caracterizou modalidade de "emprego do valor", sem, contudo, que tenha ocorrido uma efetiva disponibilização dos lucros auferidos no exterior e sem que tenha ocorrido qualquer modalidade de pagamento.

Em suma, tais eventos, portanto, terão o condão de extinguir a relação obrigacional formada entre credor (beneficiário do rendimento) e devedor (fonte pagadora) e, com isso, desencadear a ocorrência da obrigação tributária do IRF. 


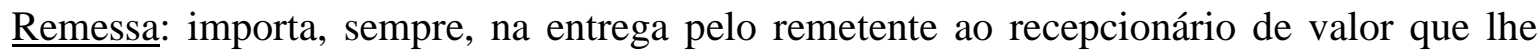
deve ser creditado $^{246}$. Consiste no envio de dinheiro para o beneficiário de um pagamento normalmente este termo é reservado para situações que envolvam transferência de moeda para o exterior, para o país onde se encontra o beneficiário ${ }^{247}$. Tais situações se enquadram mais perfeitamente ao conceito do withholding tax, visto acima, e que também estão largamente regradas no âmbito dos Acordos para Evitar Dupla Tributação;

Entrega: traz o sentido de tradição, por meio do qual se passa para as mãos de outrem o que se tinha ${ }^{248}$. Corresponde ao ato físico de passar o dinheiro do pagamento para as mãos do beneficiário, geralmente na condição de não residente ${ }^{249}$, ou de alguém por ele autorizado a receber (procurador) ${ }^{250}$;

Emprego: significa usar, utilizar ou aplicar o dinheiro do pagamento em alguma finalidade de interesse do beneficiário. Como se vê, corresponde a um ato da fonte pagadora de dar uso ao dinheiro por conta e ordem do beneficiário, conforme instruções deste último ${ }^{251}$.

Para fins do IR, a primeira notícia que se tem da utilização dessa sistemática, especificamente com relação ao pagamento de rendimentos a não residentes do País, parece ter ocorrido por meio do artigo 174, do Decreto $\mathrm{n}^{\circ} 17.390$, de 26.07.1926 (Regulamento do Imposto de Renda) ${ }^{252}$.

\footnotetext{
${ }^{246}$ Cf. QUEIROZ, Mary Elbe. Op. cit. (nota 90), P. 206.

${ }^{247}$ OLIVEIRA, Ricardo Mariz de. Op. cit. (nota 16), P. 513.

248 Cf. QUEIROZ, Mary Elbe. Op. cit. (nota 90), P. 206.

${ }^{249}$ Ibidem, Op. cit. (nota 90), P. 206.

${ }^{250}$ OLIVEIRA, Ricardo Mariz de. Op. cit. (nota 16), P. 513.

251 Ibidem, Op. cit. (nota 16), P. 513.

252 “Art. 174. Quem pagar rendimentos a residentes fóra do paiz responde pelo imposto devido por estes $(\$$ $2^{\circ}$ da lei numero 4.783, de 31 de dezembro de 1923).

$\S 1 .^{\circ} O$ disposto neste artigo não comprehende os devedores que se obrigaram a pagar juros livres de impostos. ou houverem pago o imposto sem deducção dos rendimentos distribuídos a terceiros.

$\S 2 .^{\circ}$ A importancia correspondente ao imposto será recolhida antes de effeetuada a remessa ou o pagamento da renda.

$\S 3 .^{\circ}$ São competentes para receber a importancia do imposto retido:

a) as repartições arrecadadoras dos Estados;

b) a Recebedoria do Districto Federal, mediante guia da Delegacia Geral do Imposto sobre a Renda;

c) a Delegacia Geral do Imposto sobre a Rénda, quando a importancia fôr recolhida por cheque.

$\S 4 .^{\circ} O$ pedido de guia para recolher o imposto será feito contendo a discriminação da categoria de rendimentos e das Importancias respectivas. Nos Estados far-se-ha o recolhimento mediante guia com as indicações acima.

$\S 5^{\circ}$ As importancias retidas e que não forem recolhidas ás estações fiscaes, dentro de 30 dias, serão cobradas com multa de $12 \%$."
} 
Em 1930, com o Decreto $n^{\circ} 19.550$, que trouxe grandes alterações para o imposto cedular, o tema ganhou contornos, com menção novamente à sistemática de tributação na fonte, em se tratando de remessas de rendimentos para residentes no estrangeiro.

Em 22.03.1939, observa-se, no artigo 21, do Decreto-lei n 1.168, a determinação de que os procuradores e representantes de residentes fora do País responderiam pelo imposto por estes devidos, quando à fonte dos pagamentos não coubesse a dedução do tributo. Atualmente, em redação de duvidosa validade, essa sistemática de retenção na fonte vem insculpida no artigo 26 , da Lei $\mathrm{n}^{\circ} 10.833 / 03$, que será objeto de análise mais à frente, no Capítulo IV.

É, contudo, no Decreto-lei no 5.844, de 1943, que o legislador pátrio dedicou um tópico inteiro ao IRF, reservando-lhe treze artigos para tratar especificamente das situações sujeitas a essa sistemática de pagamento do imposto.

Assim é que, com relação aos rendimentos percebidos por beneficiários residentes ou domiciliados no exterior, o artigo 100 daquele Decreto-lei $n^{\circ} 5.844 / 43$ já disciplinava que a retenção do imposto competia à fonte quando pagar, creditar, empregar, remeter ou entregar rendimento a tais pessoas. Estes normativos dão notícia de um dos regimes do IRF, que é o de tributação exclusiva na fonte. Passemos à sua análise.

\subsubsection{Sistemática de Tributação do Imposto de Renda antes do IRF}

Como se viu, no Brasil a sistemática de tributação na fonte do IR começou, primeiramente, com relação aos beneficiários de renda não residentes no País. Tal sistemática, como veremos no item seguinte, está intimamente vinculada ao regime de retenção exclusiva na fonte. Sob a perspectiva do regime de retenção como antecipação do imposto devido, que analisaremos logo a seguir, a incidência do IRF só veio surgir no ano de 1954, por meio da Lei $\mathrm{n}^{\mathrm{o}}$ 2.354. Neste sentido, passamos a apontar a sistemática de pagamento do IR ao tempo do Regulamento do Imposto de Renda de 1947 (Decreto-lei no 24.239/47), vigente até o ano de 1954. 
À época, com foco nos contribuintes pessoas físicas, os rendimentos eram classificados em 8 (oito) cédulas, que se coordenavam pelas primeiras letras do alfabeto (Cédulas A, B, C, $\mathrm{D}, \mathrm{E}, \mathrm{F}, \mathrm{G}, \mathrm{e} \mathrm{H})$. Os artigos $3^{\circ}$ a $10^{\circ}$ do Decreto-lei $\mathrm{n}^{\circ} 24.239 / 47$ detalhavam o que deveria ser incluído em cada uma das cédulas. Assim, por exemplo, na Cédula A classificavam-se os rendimentos do capital aplicado em títulos nominativos de dívidas públicas federais, estaduais ou municipais; na Cédula $\mathrm{C}$, os rendimentos do trabalho e afins; na Cédula $\mathrm{E}$, os rendimentos de capitais imobiliários, tais como o aluguel etc.

Observadas algumas regras especiais e exceções específicas, as importâncias computadas em cada uma das cédulas denominavam-se rendimento bruto, sobre o qual poderiam ser deduzidas algumas despesas necessárias à percepção dos rendimentos, individualizadas para cada cédula (artigos 11 a 17, do Decreto-lei $\mathrm{n}^{\circ}$ 24.239/47). A diferença entre o rendimento bruto e as deduções constitui o rendimento líquido (artigo 18) e por renda bruta tinha-se a somatória dos rendimentos líquidos das cédulas (artigo 19). Da renda bruta ainda eram autorizados alguns abatimentos, constituindo-se como renda líquida a diferença ora obtida (artigo 20 e 21).

A incidência do imposto subdividia-se em cedular (aplicável às cédulas A, B, C, D, E e H) e complementar (cédulas F e G). Ao imposto cedular aplicavam-se taxas proporcionais, tendo como base o rendimento líquido definido no artigo 18 do Decreto-lei $\mathrm{n}^{\circ}$ 24.239/47. Por sua vez, o cálculo do imposto complementar era realizado pela aplicação de taxas progressivas (artigos 24 a 26).

As pessoa jurídicas, por sua vez, eram tributadas de acordo com os lucros verificados anualmente, segundo o balanço e a demonstração da conta de lucros e perdas.

Tanto as pessoas físicas (desde que seus rendimentos excedessem a um parâmetro mínimo) como as pessoas jurídicas deveriam apresentar, até o dia 30/04 de cada ano, declaração de rendimentos, conforme modelos aprovados pelo diretor do Imposto de Renda, devidamente assinadas pelos contribuintes ou por seus representantes (artigos 63 e 64). Após, as declarações eram revisadas pelos agentes fiscais, culminando com o lançamento do imposto e a notificação do contribuinte do débito apurado (artigo 76). 
O imposto apurado poderia ser pago à vista ou em 4 parcelas, observado um valor mínimo. O pagamento deveria ser realizado, em dinheiro ou em cheque, nas Recebedorias, Federais, Alfândegas, Mesas de Rendas e Coletorias Federais. A arrecadação começava a partir de 01\%/06 e no prazo de 20 dias contados da notificação de lançamento (artigos 85 a 90, todos do Decreto-lei no 24.239/47).

Como se vê, diferentemente da sistemática vigente nos dias de hoje, com tributação em bases correntes, i.e., com a antecipação dos recursos financeiros devidos a título de IR, o imposto apurado em um determinado ano era recolhido somente no exercício seguinte, e ainda assim com uma carência superior a 6 (seis) meses.

\subsubsection{Regime de Retenção Exclusiva na Fonte}

A tributação de determinados tipos de rendimentos e ganhos, de forma separada das demais rendas submetidas ao regime de apuração progressiva, não é, como se viu, uma exclusividade do Brasil. Na França, por exemplo, alíquotas fixas e uniformes (flat rates) são aplicadas para diferentes tipos de rendimentos do capital ou ganhos no lugar da tabela progressiva, tanto de forma automática e compulsória, como ocorre nos ganhos de capital em negócios de longo prazo e ganhos de capital na venda de valores mobiliários de forma não profissional ou, opcionalmente, nos rendimentos de juros em títulos de renda ${ }^{253}$.

Nos Estados Unidos, os ganhos de capital e dividendos são tributados separadamente por meio de alíquotas preferenciais, não superiores a $15 \%$, sendo certo que na tabela progressiva essa seria a alíquota mínima, com uma carga máxima podendo chegar a $35 \%{ }^{254}$.

No Brasil, no regime de retenção exclusiva (e definitiva) do IRF, o legislador destaca um determinado tipo de rendimento para que ele seja tributado separadamente das demais rendas do contribuinte. Assim, valendo-se de metodologia que atenda ao efeito da cedularização das rendas e dos rendimentos, por se tratar de situações que, geralmente,

\footnotetext{
${ }^{253}$ Cf. GEST, Guy. Op. cit. (nota 226), P. 37/51.

${ }^{254}$ Cf. REPETTI, James R. Op. cit. (nota 214), P. 139/144.
} 
demandam tratamento separado, o legislador escolhe, discricionariamente, as espécies de rendimento que passarão a pertencer a esse grupo especial.

O montante tributado nestes casos não se comunica com a renda (demais rendimentos) quando do ajuste ao final do exercício para as pessoas físicas, ficando, tais rendimentos, à margem da apuração final e definitiva (ajuste). Tanto os valores referentes aos rendimentos percebidos como o imposto retido são apenas informados na declaração, sem qualquer relevância prática para fins de cálculo do imposto a pagar ${ }^{255}$.

Diferentemente do que se vislumbra com relação ao regime de "antecipação do devido", aplicável largamente tanto às pessoas físicas como às pessoas jurídicas, o regime do IRF de tributação exclusiva é próprio das pessoas físicas, pessoas jurídicas isentas e dos beneficiários residentes ou domiciliados no exterior. Durante um tempo, quando da publicação da Lei $n^{\circ} 9.249 / 95$, vigeu, em seu artigo $9^{\circ}$, $\S 3^{\circ}$, inciso II, o tratamento específico para o IRF incidente sobre os Juros Sobre Capital Próprio (JSCP), pagos ou creditados para beneficiário pessoa jurídica não tributada com base no lucro real, de forma que o IRF era considerado como tributação definitiva. Em que pese tal dispositivo não ter sido revogado expressamente, o artigo 51, da Lei $n^{\circ}$ 9.430/96, parece ter sanado a questão, esclarecendo que o IRF sobre os rendimentos decorrentes de JSCP seria considerado como antecipação do devido, inclusive para as pessoas jurídicas tributadas com base no lucro resumido ou arbitrado.

Nesse sentido, confira-se a decisão a seguir:

"ASSUNTO: Imposto sobre a Renda de Pessoa Jurídica - IRPJ EMENTA: ALEGADA COMPENSAÇÃO DO DÉBITO COM IRRF REFERENTE A JUROS SOBRE CAPITAL PRÓPRIO RECEBIDOS.

$O$ imposto retido na fonte relativo aos juros sobre capital próprio recebidos será considerado antecipação do devido na declaração de rendimentos, no caso de beneficiário pessoa jurídica tributada com base no lucro real, presumido ou arbitrado, podendo ser deduzido do imposto devido, desde que

${ }^{255}$ Cf. PAULSEN, Leandro. Op. cit. (nota 56), P. 732. 


\section{os correspondentes rendimentos integrem as receitas tributáveis declaradas."}

(Acórdão $\mathrm{n}^{\circ}$ 06-24476 de 19.11.2009 - $2^{\circ}$ Turma da Delegacia da Receita Federal de Julgamento em Curitiba) ${ }^{256}$ (grifamos)

A constatação acima, quanto ao campo de abrangência do regime de retenção exclusiva, já pode ser adotada como um dos critérios que lhe justificam a existência, (i) seja com relação à ideia de tratamento especial que merecem as transações transnacionais, (ii) seja com relação à oferta de regras geralmente mais benéficas a tais contribuintes (pessoas físicas, pessoas jurídicas isentas ou beneficiários não-residentes), salvo os casos de isenção ou em hipóteses em que a tributação pela tabela progressiva seria menos gravosa, (iii) seja pelo fato de criar mecanismos que atuam na esteira de facilitadores da fiscalização de grandes operações (operações em massa, em função da curva crescente de aumento da população) e/ou dos movimentos de riqueza vislumbrados na sociedade, (iv) seja por razões de controle e fiscalização de movimentação de recursos em transações envolvendo pessoas jurídicas isentas e/ou o ingresso e a saída de recursos de não residentes (mecanismo de controle indutor de poupanças internas e da variação da moeda nacional no contexto internacional), (v) ou até mesmo pelo fato de que as pessoas físicas representam um contingente muito maior de contribuintes dentro do universo total de contribuintes submetidos à extensão da fiscalização.

Assim, como a renda sujeita a essa tributação não mais integrará a universalidade das demais rendas quando da apuração definitiva da base de cálculo do IR, pode-se dizer que se trata de um regime exclusivo e definitivo. O imposto recolhido, de forma antecipada e separada, não poderá ser utilizado para dedução do quantum devido quando daquela apuração, na data definida pelo legislador - entrega da declaração de ajuste anual do imposto de renda das pessoas físicas, ou entrega da declaração de rendimentos, no caso de pessoa jurídica isenta.

\footnotetext{
${ }^{256}$ Em outras decisões, a Receita Federal indica que a receita de JSCP deve ser incluída na base de cálculo da pessoa jurídica tributada com base no lucro presumido e, consequentemente, o IRF será tratado como antecipação do devido, deduzindo do valor apurado como imposto devido. Confira-se: Processos de Consulta

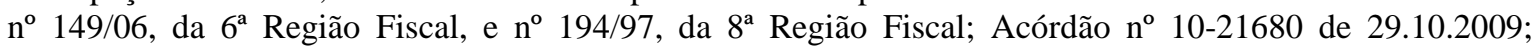
Acórdãos no 10-21361 e n ${ }^{\circ} 10-21362$, ambos de 15.10.2009, dentre muitos outros.
} 
Diversas razões orientam o processo legislativo quanto à definição desse tipo de tributação especial na fonte, de forma exclusiva e definitiva. Uma delas diz respeito àquelas de ordem prática e operacional, no sentido de possibilitar o recolhimento antecipado de receitas aos cofres do Estado e de facilitar a fiscalização não apenas em operações de massa, mas, também, em determinados fluxos e determinados pagamentos. Outras são de ordem extrafiscal, com a aplicação de alíquotas menos gravosas, no sentido de conferir tratamento especial a um determinado setor econômico (como se observa no regime de tributação próprio dos mercados financeiro e de capitais) ou de impulsionar o influxo de capitais estrangeiros, mediante regra de tributação mais benéfica em comparação àquelas vigentes para os contribuintes residentes e domiciliados no País.

No regime de tributação exclusiva, encontram-se as situações correspondentes às operações que resultam em apuração de ganhos de capital, tanto de residentes ${ }^{257}$ como, principalmente, de beneficiário não residente e, genericamente, às transações que envolvam operações financeiras. Observa-se que, neste regime, há um privilégio da tributação incidente sobre o capital em comparação àquela que recai sobre o trabalho.

Diante das diversas ocorrências em que o regime de retenção exclusiva ou definitiva do IRF aparece na legislação ordinária, será fundamental identificar a natureza específica do tipo de renda, de forma a justificar-lhe, na medida do possível, o tratamento especial e segregado. Assim, como exemplo, se tomarmos a tributação incidente sobre o $13^{\circ}$ salário, para a qual o legislador houve por bem tratar esses rendimentos como sujeitos à tributação exclusiva na fonte, esse procedimento parece indicar que poderia se tratar de mecanismo meramente tendente a facilitar o controle desses pagamentos pelas autoridades fiscais e até como forma de fiscalização para fins de incidência das contribuições previdenciárias, correspondendo, desse modo, a efetivo expediente de Política Tributária. Poderia se questionar, ainda, em se tratando de mais um dos rendimentos concedidos aos empregados assalariados (rendimentos derivados do trabalho), igualmente sujeitos à tributação pela tabela progressiva, que tais valores deveriam ser igual e conjuntamente tributados com os demais rendimentos tributáveis da pessoa física quando da apuração do IR. Voltaremos a este tema no subitem 1.20.2.

\footnotetext{
${ }^{257}$ Neste caso, não há retenção na fonte, mas apenas tributação pelo IR de forma separada e isolada pelo próprio contribuinte.
} 
Assim como o legislador dá tratamento especial a alguns rendimentos, classificados como isentos (doações, alienação de bens de pequeno valor, rendimentos de caderneta de poupança, lucros e dividendos, indenizações trabalhistas e, dentre outros, o próprio rendimento do trabalho até uma determinada faixa de isenção ${ }^{258}$ ), essa mesma legislação que disciplina a tributação do imposto de renda das pessoas físicas faz distinção entre (i) a renda ou proventos percebidos de fontes permanentes, como são os casos de rendimentos do trabalho assalariado, sujeito à tributação pela tabela progressiva, e (ii) os rendimentos decorrentes de transações eventuais e de caráter não permanente como são os ganhos de capital na alienação de bens e direitos, ganhos nos mercados de renda variável etc.

Sobre o regime jurídico a que a fonte pagadora estará submetida, é válida a transcrição da passagem abaixo em que MARY ELBE QUEIROZ ${ }^{259}$ assim aponta:

"Neste caso, a fonte pagadora assume, de acordo com a lei, o pólo passivo da relação jurídico-tributária, como responsável tributário (em substituição ao contribuinte), e, caso não cumpra com a respectiva obrigação, a qualquer momento, o Fisco poderá exigir dela o valor do imposto e as penalidades que forem cabíveis, excluindo-se a possibilidade de ser exigido o imposto do beneficiário.

A incidência do imposto esgota-se com a atividade da fonte pagadora, pois, os rendimentos submetidos a essa tributação, bem como o valor do respectivo imposto, não mais serão computados, pelo contribuinte, no momento do ajuste em função da periodicidade de tributação a que esteja submetido.

Tais valores serão apenas informados na declaração de rendimentos anual a ser apresentada, a fim de dar conhecimento ao Fisco dos fatos ocorridos e justificar possíveis alterações patrimoniais."

\footnotetext{
${ }^{258}$ A Medida Provisória n ${ }^{\circ}$ 528/11, convertida na Lei ${ }^{\circ} 12.469$, de 26/08/2011, alterou a Lei $\mathrm{n}^{\mathrm{o}} 11.482$, de $31 / 05 / 2007$, aumentando o limite mensal de isenção da tabela progressiva do IRPF de $R$ \$ $1.499,15$ para $R$ \$ 1.566,61, válido a partir de 01\%02/2011. Essa mesma MP 528/11 aumentou os limites de isenção para os exercícios seguintes, que, para o ano calendário de 2014, será de R \$1.787,77.

${ }^{259}$ Cf. QUEIROZ, Mary Elbe. Op. cit. (nota 90), P. 160.
} 
PAULO AYRES BARRETO ${ }^{260}$ apõe severas críticas quanto ao regime de tributação exclusiva na fonte, alegando sua inconstitucionalidade na medida em que não é possível compaginar essa modalidade de tributação com os princípios da generalidade e da progressividade, sendo vedada a segregação da renda auferida para sua tributação mediante critérios distintos.

O que releva destacar é que, diante do caráter definitivo que o imposto assume no regime de retenção exclusiva do IRF e, considerando que nem o rendimento sujeito a esse tratamento e tão menos o imposto ora retido e recolhido serão considerados na apuração do IR devido (tais valores são declarados tão-somente para fins de controle e informação), a fenomenologia da tributação exaure-se no ato de pagamento, crédito, remessa, entrega ou emprego realizado pela fonte. Significa dizer que a relação jurídica formada entre a fonte (terceiro obrigado ao recolhimento do tributo) e a União (sujeito ativo) e materializada pela incidência (definitiva) do tributo, esgota-se no exato instante em que o gravame é retido e recolhido. Os valores recolhidos sob este regime, de forma antecipada, não assumem a natureza de uma genuína antecipação, já que sua tributação é definitiva. Nesta ótica, a natureza jurídica dessas retenções exclusivas na fonte aproxima-se mais de um tributo propriamente dito do que de meras antecipações.

Respeitadas as argutas observações da doutrina quanto à desconformidade desse regime de retenção na fonte, sob a ótica dos princípios da progressividade, da generalidade e da igualdade, esta última isoladamente considerada e enquanto vetor da capacidade contributivo-econômica, enxergamos, também, que outras razões, igualmente de ordem constitucional, justificam a validade desse regime. Com efeito, respeitado o debate sobre sua constitucionalidade ou não, que é extremamente válido, queremos, aqui, identificar o regime jurídico próprio dessas retenções.

Na retenção exclusiva de fonte há um aperfeiçoamento completo do fato gerador do IR, na medida em que a tributação, antecipada, não depende de qualquer evento futuro para confirmar ou infirmar se, no final do período, haverá imposto a recolher ou a restituir. $\mathrm{O}$ fato gerador do IR é instantâneo e a mensuração de sua base de cálculo também, coincidentes ao evento originador do IRF. A natureza definitiva do imposto retido revela

${ }^{260}$ Cf. BARRETO, Paulo Ayres. Op. cit. (nota 156), P. 62. 
não uma mera antecipação, mas, sim, uma natureza tipicamente tributária. Com a concretização do fato gerador ocorrem três situações: formação da relação jurídica tributária; a fonte pagadora é transportada para a posição de sujeito passivo; e exclusão definitiva da responsabilidade do contribuinte.

Tanto é assim que, na hipótese de a fonte pagadora deixar ou omitir-se de realizar a retenção do IR, que é uma faculdade que a lei lhe autoriza, o rendimento pago, creditado, remetido, entregue ou empregado em favor de um determinado beneficiário, pessoa física ou jurídica, residente ou não residente será considerado líquido do imposto. Nessa condição, significa dizer que a fonte deverá recolher o imposto sobre uma base reajustada, técnica também conhecida como gross up. Numericamente, assim, teríamos: se a fonte devia o valor de 100, com retenção de $15 \%$, deveria ter entregue o valor de 85 , com retenção de 15 . Se por um lapso, entregou os mesmos 100, este valor será considerado líquido do imposto, o que implica dizer que a fonte deverá recolher 17,65 (aprox.) de imposto $^{261}$. Tendo em vista que a responsabilidade do contribuinte foi totalmente excluída (voltaremos a abordar esse tema no Capítulo III), o ônus do imposto será integralmente da fonte pagadora ${ }^{262}$.

\footnotetext{
${ }^{261}$ LUí́s EDUARDO SCHOUERI aborda essa situação revelando que, numa primeira relação, a fonte era, de fato, um mero agente de retenção. Somente quando deixa de efetuar a retenção e, por consequência, o próprio recolhimento do imposto, a fonte, numa segunda relação, assume a postura de sujeito passivo, na condição de responsável tributário stricto sensu (Cf. SCHOUERI, Luís Eduardo. Op. cit. (nota 04), P. 490).

${ }^{262}$ Neste sentido é a orientação contida em Soluções de Consulta exaradas pela Receita Federal, confira-se: "REAJUSTAMENTO DE BASE DE CÁLCULO. Estando determinado em sentença judicial o pagamento de valor de proventos líquido de imposto de renda, cumpre à fonte pagadora assumir o ônus do imposto incidente sobre a importância paga, e reajustar o rendimento bruto para sobre ele recair o imposto." (SRRF $6^{\mathrm{a}} \mathrm{RF} /$ Processo de Consulta $\mathrm{n}^{\mathrm{o}}$ 173/08 / Data da Decisão: 14.10.2008 - 05.11.2008); "REAJUSTAMENTO DA BASE DE CÁLCULO. TRIBUTAÇÃO NA DECLARAÇÃO DE AJUSTE ANUAL. A tributação pela pessoa física, na Declaração de Ajuste Anual, da base de cálculo reajustada e a compensação do imposto considerado ônus da fonte pagadora só é admissivel caso a fonte pagadora tenha efetuado o reajuste, assumindo efetivamente o ônus do imposto, e fornecido ao beneficiário o informe de rendimentos que evidencie o valor reajustado e o imposto correspondente. Só pode ser compensado, na Declaração de Ajuste Anual, o imposto efetivamente retido na fonte ou, no caso de reajustamento da base de cálculo, o imposto cujo ônus tenha sido realmente assumido pela fonte pagadora." (SRRF $7^{\mathrm{a}} \mathrm{RF} /$ Processo de Consulta $\mathrm{n}^{\mathrm{o}}$ 42/07 / Data da Decisão: 06.02.2007 - 29.05.2007); "FATO GERADOR.A fonte pagadora é responsável pela retenção e recolhimento do imposto de renda na fonte incidente sobre os valores tributáveis, pagos ou creditados em cumprimento de decisão judicial. O imposto incidente sobre os rendimentos tributáveis pagos em cumprimento de decisão judicial será retido na fonte, pela pessoa jurídica obrigada ao pagamento, no momento em que, por qualquer forma, o rendimento se torne disponível para o beneficiário. Quando se tratar de rendimento sujeito à aplicação da tabela progressiva, deverá ser utilizada a tabela vigente no mês do pagamento. Na falta de retenção, o rendimento colocado à disposição da pessoa física do beneficiário será considerado líquido, devendo proceder-se ao reajustamento da base cálculo, assumindo a fonte pagadora o respectivo ônus do imposto." (SRRF $1^{a} \mathrm{RF} /$ Processo de Consulta $\mathrm{n}^{\circ}$ 25/06 / Data da Decisão: 23.03.2006 - 14.06.2006). Vale dizer que essa interpretação parece ir ao encontro do artigo 128, do CTN,
} 
As situações enquadradas neste regime são muito diversas e a legislação que regula tais hipóteses é bastante esparsa. A Instrução Normativa (IN) SRF n ${ }^{\circ}$ 15/2001, publicada no D.O.U. de 08.02.2001, consolida as normas vigentes sobre a tributação das pessoas físicas pelo imposto de renda. Referida IN lista em seu artigo $5^{\circ}$ os rendimentos isentos ou não tributáveis; em seu artigo $6^{\circ}$, os rendimentos tributados exclusivamente na fonte; e, em seu $8^{\circ}$, os rendimentos sujeitos à tributação definitiva, grupo onde se enquadram, basicamente, os ganhos de capital e ganhos obtidos no mercado financeiro e de capital. Todos estes rendimentos não comporão a base de cálculo na Declaração de Ajuste Anual do Imposto de Renda da Pessoa Física (DIRPF) ${ }^{263}$.

QUE DETERMINA QUE O “responsável” é responsável pelo crédito tributário, revelando, no caso da fonte pagadora, que o ônus dos encargos moratórios (multa e juros) serão igualmente arcados por ela.

${ }^{263}$ Neste sentido, especificamente com relação aos rendimentos tributados exclusivamente na fonte, sem, contudo, querer exaurir o tema, confira-se a seguinte base legal, cuja redação ainda se encontra vigente, revelando a característica esparsa da legislação: Lei $\mathbf{n}^{\mathbf{0}}$ 8.134, de 27 de dezembro de 1990 [rendimentos recebidos acumuladamente; $13^{\circ}$ salário (não aplicável às antecipações); aplicações financeiras; resgate de quotas de fundos de ações ou clubes de investimento, excetuados os fundos de renda fixa e fundos de curto prazo - nessa legislação há previsão de que pagamentos não obrigatórios do imposto, efetuados durante o ano-base, não poderão ser deduzidos na DIRPF; pelo artigo $4^{\circ}$, da Lei $\mathrm{n}^{\circ} 11.312 / 06$ tais valores pagos ou retidos a maior poderão ser compensados na declaração anual de ajuste]; Lei $\mathbf{n}^{\mathbf{0}} \mathbf{8 . 3 8 3}$, de 30 de dezembro de 1991 [rendimentos produzido por aplicação financeira; ganhos líquidos nas operações de bolsa de valores, de mercadorias, de futuros e assemelhados]; Lei $\mathbf{n}^{\circ}$ 8.541, de 23 de dezembro de 1992 [os rendimentos auferidos pelas pessoas jurídicas, inclusive isentas e inclusive as tributadas pelo lucro real, em aplicações financeiras de renda fixa iniciadas a partir de $1^{\circ}$ de janeiro de 1993]; Lei $\mathbf{n}^{\circ} \mathbf{8 . 9 8 1}$, de 20 de janeiro de 1995 [(i) todo pagamento efetuado pelas pessoas jurídicas a beneficiário não identificado, ressalvado o disposto em normas especiais; (ii) os prêmios, exceto em dinheiro, distribuídos sob a forma de bens e serviços, através de concursos e sorteios de qualquer espécie; (iii) o rendimento produzido por aplicação financeira de renda fixa, a partir de $1^{\circ}$ de janeiro de 1995 - ressalvadas as hipóteses de isenção definidas no artigo 68 dessa Lei, rendimento, neste caso, (a) as operações conjugadas que permitam a obtenção de rendimentos predeterminados, realizadas nas bolsas de valores, de mercadorias, de futuros e assemelhadas, bem como no mercado de balcão; (b) as operações de transferência de dívidas realizadas com instituição financeira, demais instituições autorizadas a funcionar pelo Banco Central do Brasil ou com pessoa jurídica não-financeira; (c) os rendimentos auferidos pela entrega de recursos a pessoa jurídica, sob qualquer forma e a qualquer título, independentemente de ser ou não a fonte pagadora instituição autorizada a funcionar pelo Banco Central do Brasil; (d) as operações de mútuo e de compra vinculada à revenda, no mercado secundário, tendo por objeto ouro, ativo financeiro; (iv) os ganhos líquidos auferidos, a partir de $1^{\circ}$ de janeiro de 1995, em operações realizadas nas bolsas de valores, de mercadorias, de futuros e assemelhadas; (v) o rendimento auferido no resgate de quota de fundo de ações, de commodities, de investimento no exterior, clube de investimento e outros fundos da espécie; (vi) os rendimentos auferidos em operações de swap - para as hipóteses previstas nos itens (iii) a (v), desde que adquiridos/auferidos por beneficiário pessoa física ou jurídica, sendo importante destacar que, à época, a legislação previa que alguns desses rendimentos seriam tributados de forma definitiva inclusive para as pessoas jurídicas tributadas pelo lucro presumido e arbitrado essa orientação mudou, conforme se observa do artigo 55, da Instrução Normativa $\mathbf{n}^{0} 1.022$, de 5 de abril de 2010, tratando as retenções como antecipação do imposto devido, inclusive para as pessoas tributadas com base no lucro presumido e arbitrado]; Lei no 9.249, de 26 de dezembro de 1995 [(i) os juros sobre o capital próprio, pagos ou creditados e (ii) os rendimentos produzidos por aplicação financeira de renda fixa - em ambos os casos, quando auferidos por beneficiários pessoa física ou pessoa jurídica isenta]; Lei $\mathbf{n}^{\mathbf{0}}$ 9.430, de 27 de dezembro de 1996 [(i) sem prejuízo do disposto no art. 74 da Lei nº 8.981, de 20 de janeiro de 1995, os ganhos auferidos por beneficiário pessoa física ou pessoa jurídica isenta, nas demais operações realizadas em mercados de liquidação futura, fora de bolsa, serão tributados de acordo com 
No subitem 1.10.6. abordaremos como este regime jurídico do IRF se comporta com relação aos princípios constitucionais, analisando se este tratamento supostamente preferencial encontra proposições jurídicas, e não meramente econômicas, que o justifiquem ou, se, ao contrário, tende a dar ensejo a inconstitucionalidades.

Em arremate, atendendo à ideia de cedularização, o legislador infraconstitucional escolhe determinados rendimentos para os quais resolve dar tratamento específico, retirando-os da sistemática de apuração progressiva, universal e geral do IR, e os tributando separadamente. Assim como estes rendimentos não poderão ser reduzidos por meio da dedução de fatos-decréscimos legalmente autorizados, a lei atualmente vigente, de forma a balancear tal sistemática, adota, na maior parte dos casos, alíquotas fixas preferenciais, nominalmente inferiores às alíquotas máximas da tabela progressiva do IRPF. A verificação se a alíquota aplicada é benéfica dependerá da natureza de cada rendimento e do volume envolvido.

as normas aplicáveis aos ganhos líquidos auferidos em operações de natureza semelhante realizadas em bolsa; (ii) as importâncias pagas, creditadas, entregues, empregadas ou remetidas para o exterior pela aquisição ou pela remuneração, a qualquer título, de qualquer forma de direito, inclusive à transmissão, por meio de rádio ou televisão ou por qualquer outro meio, de quaisquer filmes ou eventos, mesmo os de competições desportivas das quais faça parte representação brasileira; (iii) os rendimentos recebidos por companhias de navegação aérea e marítima, domiciliadas no exterior, de pessoas físicas ou jurídicas residentes ou domiciliadas no Brasil]; Lei $\mathbf{n}^{\mathbf{0}}$ 9.532, de 10 de dezembro de 1997 [rendimentos produzidos pelas carteiras de fundos de investimentos auferidos por beneficiários pessoa física ou pessoa jurídica imune ou isenta]; Lei no 9.779, de 19 de janeiro de 1999 [(i) os rendimentos e ganhos de capital distribuídos por Fundo de Investimento Imobiliário ou auferidos na alienação ou no resgate de quotas desse Fundo e (ii) os rendimentos auferidos em qualquer aplicação ou operação financeira de renda fixa ou de renda variável, mesmo no caso das operações de cobertura (hedge), realizadas por meio de operações de swap e outras, nos mercados de derivativos - em ambos os casos, quando auferidos por beneficiário pessoa física ou pessoa jurídica isenta; (iii) os rendimentos do trabalho, com ou sem vínculo empregatício, e os da prestação de serviços, pagos, creditados, entregues, empregados ou remetidos a residentes ou domiciliados no exterior; (iv) ressalvadas as hipóteses a que se referem os incisos V, VIII, IX, X e XI do art. $1^{\circ}$ da Lei n ${ }^{\circ} 9.481$, de 13 de agosto de 1997, os rendimentos decorrentes de qualquer operação, em que o beneficiário seja residente ou domiciliado em país que não tribute a renda ou que a tribute à alíquota máxima inferior a vinte por cento, a que se refere o art. 24 da Lei $n^{\circ}$ 9.430, de 27 de dezembro de 1996]; Medida Provisória no 2.189-49, de 23 de agosto de 2001 [trata da tributação incidente sobre (i) os rendimentos auferidos no resgate de quotas dos fundos de investimentos, nos termos da referida lei; (ii) os rendimentos de aplicações financeiras auferidos por beneficiário estrangeiro]; Lei n⿳ 11.053, de 29 de dezembro de 2004 [benefícios ou resgates de valores acumulados de planos de caráter previdenciário]; Lei $\mathbf{n}^{\mathbf{0}} \mathbf{1 2 . 0 2 4}$, de 27 de agosto de 2009 [rendimentos e ganhos líquidos auferidos pelos Fundos de Investimento Imobiliário, em aplicações financeiras de renda fixa ou de renda variável]. 


\subsubsection{Regime de Retenção na Fonte como Antecipação do IR Devido}

Quanto ao regime de tributação na fonte como antecipação, mais largamente utilizado e que responde pela maior fatia de arrecadação de receitas federais a título de IRF $^{264}$, como já ventilamos, sua introdução para a tributação das pessoas físicas assalariadas deu-se, acreditamos, com a Lei n 2.354 , de 29.11.1954, que modificou a redação do Decreto-lei no 24.239, de 1947. Dada a peculiaridade da redação e no intuito de delimitação da extensão dos regimes jurídicos do IRF, vale a transcrição de alguns dispositivos, in verbis:

“Art. 10. Substitua-se o art. $5^{\circ}$ do Decreto $n^{o} 24239$, de 22 de dezembro de 1947, pelo seguinte e acrescente-se-lhe o $\$ 7^{\circ}$

"Art. $5^{\circ}$ Ressalvado o disposto nos $\$ 4^{\circ}$ e $5^{\circ}$ do art. 24. , serão classificados, na cédula $C$, os rendimentos do trabalho proveniente do exercício de empregos, cargos e funções, tais como vencimentos, soldo, subsídios ordenados, salários, percentagens, comissões, gratificações diárias, cotas-partes de multas, ajudas de custo, representações e quaisquer proventos ou vantagens pagos, sob qualquer título e forma contratual, pelos cofres públicos federais, estaduais ou municipais, pelas entidades autárquicas, paraestatais e de economia mista, pelas firmas e sociedades ou por particulares".

"§ $7^{\circ}$ Nos casos em que, além de remuneração fixa, perceber o contribuinte rendimentos variáveis especificados neste artigo, prevalecerá, quanto à totalidade desses proventos, o sistema de arrecadação nas fontes, exceto se os mesmos excederem de Cr\$10.000,00 (dez mil cruzeiros) mensalmente"."

“Art. 12. Acrescente-se ao art. 24. do Decreto $n^{\circ} 24.239$, de 22 de dezembro de 1947, os seguintes parágrafos:

$" § 4^{\circ}$ Os rendimentos do trabalho provenientes do exercício de empregos, cargos e funções, especificados no art. $5^{\circ}$ deste regulamento, quando inferiores a $\mathrm{Cr} \$ 10.000,00$ (dez mil cruzeiros) mensais, ficarão sujeitos ao desconto de

\footnotetext{
264 Considerando a arrecadação de agosto/2011, o IRF sobre rendimentos do trabalho, para qual se aplica o regime jurídico da retenção na fonte como antecipação, representou 57,89\% da arrecadação total a título de imposto de renda retido na fonte. Informação obtida através do site da Receita Federal do Brasil, localizado em 12/10/2011: http://www.receita.fazenda.gov.br/publico/arre/2011/Analisemensalago11.pdf.
} 
imposto na fonte, no ato do respectivo pagamento de acordo com o disposto no inciso $6^{\circ}$ do artigo $96^{\prime \prime}$.

"§ $5^{\circ}$ Serão deduzidas do imposto total, apurado na declaração, as importâncias descontadas pela forma indicada no parágrafo anterior, quando os contribuintes tiveram rendimentos de mais de uma fonte ou de outra natureza que não do trabalho, ou ainda perceberem rendimentos anuais superiores a Cr\$120.000,00 (cento e vinte mil cruzeiros)".

$" § 6^{o}$ Não caberá ao empregador responsabilidade alguma sobre as informações prestadas pelos seus empregados para controle dos seus rendimentos"."

Vê-se que, desde os primórdios, o regime jurídico do IRF sob a modalidade de antecipação já se apresentava com as características da sistemática atualmente em vigor, de maneira que os valores retidos/recolhidos de forma antecipada seriam utilizados no futuro, pelo contribuinte, quando da apuração do imposto devido (ocorrência do fato gerador). Mais especificamente, este momento, eleito pelo legislador como adequado para mensuração definitiva da base de cálculo e do quantum devido ${ }^{265}$, coincide com a data de entrega da declaração de ajuste anual pelas pessoas físicas e não exatamente com a data de ocorrência do IR, no final do exercício. Nada diferente do que se pratica hoje, conforme detalhado a seguir.

Atualmente, o regime jurídico do IRF, aqui chamado de "antecipação do devido", tem fundamento legal na Lei $n^{\circ} 7.713$, de 22.12.1988, portanto, já sob a égide da Constituição Federal de 1988, com as alterações promovidas por uma série de outras leis, em especial as Leis $\mathrm{n}^{\circ} 8.134 / 90, \mathrm{n}^{\circ} 8.383 / 91, \mathrm{n}^{\circ} 8.981 / 95$ e $\mathrm{n}^{\circ}$ 9.250/95. Passemos à análise do regime jurídico da tributação na fonte como "antecipação do devido", apoiados na legislação tributária em vigor.

Primeiramente, lembramos que a classificação por cédulas (ou cedularização) dos tipos de

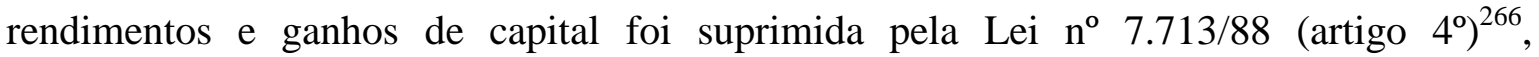

\footnotetext{
${ }^{265}$ Vale lembrar que a formação da base de cálculo é complexa, envolvendo o plexo de acontecimentos no decorrer do ano.

${ }^{266}$ Art. $4^{\circ}$ Fica suprimida a classificação por cédulas dos rendimentos e ganhos de capital percebidos pelas pessoas físicas.
} 
colocando todos os rendimentos percebidos por pessoas físicas em uma mesma classificação. Trata-se, em verdade, de uma falsa extinção, tendo em vista que, conforme vimos no subitem anterior, alguns rendimentos continuam sendo tributados separadamente, com alíquotas diferentes inclusive daquelas aplicadas ao final do período de apuração. Com isso, excetuadas as hipóteses submetidas ao regime jurídico do IRF com tributação exclusiva ou definitiva, não apenas os rendimentos do trabalho assalariado, mas, também, quaisquer outros decorrentes do produto do capital, do trabalho ou da combinação de ambos, independentemente da denominação, localização ou condição jurídica da fonte, da origem dos bens produtores da renda e/ou da forma de recepção desses rendimentos, passaram a ser tributáveis de forma igual para fins do IR.

$\mathrm{O}$ artigo $2^{\circ}$, da Lei $\mathrm{n}^{\mathrm{o}} 7.713 / 88^{267}$, trouxe o que chamamos de tributação em bases correntes, autorizando o recolhimento do IR de forma periódica, sem a necessidade de se aguardar o término do ano e a concretização do fato gerador. Redação idêntica foi adotada na Lei ${ }^{\circ} 8.134 / 90$ :

“Art. $2^{\circ} \mathrm{O}$ imposto de renda das pessoas físicas será devido à medida em que os rendimentos e ganhos de capital forem percebidos, sem prejuízo do ajuste estabelecido no artigo 11.

Art. $3^{\circ}$ O imposto de renda na fonte, de que tratam os artigos $7^{\circ}$ e 12 da Lei $n^{o}$ 7.713, de 22 de dezembro de 1988, incidirá sobre os valores efetivamente pagos no mês."

A tributação em "bases correntes" é aquela que permite a tributação das rendas e dos proventos à medida que vão sendo auferidos, aproximando-se do que se convencionou chamar de PAYE ("pay-as-you-earn”) conforme sistemática do IR britânico. Atualmente, os artigos $2^{\circ}$ a $6^{\circ}$, da Lei $n^{\circ} 9.250 / 95$, disciplinam sobre a obrigatoriedade e forma de apuração da incidência mensal do IR das pessoas físicas. Mais à frente voltaremos a tratar dos efeitos dessa tributação em "bases correntes” para as pessoas físicas.

267 Art. $2^{o}$ O imposto de renda das pessoas físicas será devido, mensalmente, à medida em que os rendimentos e ganhos de capital forem percebidos. Redação idêntica se observa no artigo $2^{\circ}$, da Lei $n^{\circ}$ $8.134 / 90$. 
Para as pessoas jurídicas tributadas pelo lucro real, a incidência mensal do IR é uma opção, embora a regra seja pela apuração trimestral (as pessoas jurídicas tributadas com base no lucro presumido ou arbitrado não gozam dessa faculdade). Nos termos da Lei $n^{\circ}$ 9.430/96, artigo $2^{\circ}$, a sistemática de apuração e pagamento do imposto pelas pessoas jurídicas tributadas pelo lucro real em periodicidade mensal é chamada de "pagamento por estimativa", mediante o levantamento de balancetes de suspensão e redução do imposto devido.

Diante dessa faculdade de recolhimento do IRPJ em bases mensais, haverá situações em que o imposto a recolher será igual a zero (suspensão) ou inferior (redução) ao montante apurado como imposto devido. Exemplificativamente, supondo que, no mês ou nos meses anteriores, a pessoa jurídica já tenha recolhido 800 e, no mês seguinte, tenha apurado 900 como imposto devido, o valor do imposto a recolher será de 100. Se no mês seguinte, apuraram-se os mesmos 900 como imposto devido, não haverá imposto algum a ser recolhido, tendo em vista que já existe recolhimento em montante igual (ou superior), i.e., os 800 de meses anteriores somados aos 100 do último mês totalizam 900 de imposto já recolhido.

Adicionalmente à instituição dessa linha de pagamento periódico do imposto, o legislador houve por bem definir que, especificamente para os contribuintes pessoas físicas, para mensuração da base de cálculo utilizada para essas antecipações, nenhuma dedução seria admitida, excetuadas as deduções a titulo de previdência social, pensão alimentícia e alimentos provisionais quando decorrentes de decisão judicial, o imposto pago no exterior e uma quantia específica calculada sobre o número de dependentes do contribuinte. Assim dispõe a Lei $n^{\circ} 9.250 / 95$, em seus artigos $4^{\circ}$ a $6^{\circ}$, modificada pelas Leis $n^{\circ} 11.727 / 08$ e $n^{\circ}$ $12.469 / 11$.

Causa estranheza a determinação definida nestes dispositivos, na medida em que as demais deduções (notadamente os gastos médicos e com instrução) legalmente descritas passam a ser admitidas unicamente à época da declaração de ajuste anual pelo contribuinte pessoa física, como se tratassem de dois impostos diferentes, com bases de cálculo distintas, quando, como já dissemos, o IRF é apenas uma forma de pagamento antecipado do IR das pessoas físicas. Neste sentido disciplinam os artigos $8^{\circ}$ e 12, ambos da Lei $n^{\circ}$ 9.250/95, 
com redação modificada pelas Leis $\mathrm{n}^{\circ} 11.324 / 06, \mathrm{n}^{\circ} 11.727 / 08, \mathrm{n}^{\circ} 12.213 / 10$ e $\mathrm{n}^{\circ}$ 12.469/11, ao informar sobre a apuração da base de cálculo do IRPF, arrolando, taxativamente, as deduções possíveis, ou, nas palavras de Luís CESAR SOUZA DE QUEIROZ $^{268}$, os fatos-decréscimos relevantes.

$\mathrm{O}$ procedimento estipulado naqueles dispositivos legais, especialmente no inciso $\mathrm{V}$, do artigo 12, da aludida Lei $n^{\circ} 9.250 / 95$, e que já constava da redação da Lei $n^{\circ} 7.713 / 88$ (artigo $5^{\circ}$ ), é que, assim como o próprio regime diz, o imposto retido antecipadamente será utilizado para dedução integral do imposto apurado no final do ano, quando da entrega da DIRPF (imposto devido). Deste confronto, poderá apurar-se saldo de imposto a recolher ou imposto a restituir, conforme o volume de antecipações realizadas no decorrer do ano calendário e conforme o volume de deduções autorizadas por lei a serem consideradas na declaração de ajuste anual.

Tais questões, entretanto, não passaram despercebidas pela doutrina. FERNANDO AURÉLIO ZILVETI teceu críticas à legislação atual do IRPF, ao arbitrar o que seria despesa, disciplinando um limite para as "despesas com educação", com grave ofensa ao conceito do mínimo existencial ${ }^{269}$.

Também merece atenção a crítica feita por MARY ELBE QUEIROZ ${ }^{270}$, que explica que esse regime do IRF não poderá ser admitido como um permissivo legal suficiente para autorizar a realização do fato gerador do IR a cada ingresso de valor, receita ou rendimento. Complementa que essas "antecipações" poderão ou não vir a se tornar imposto, explicando: se de fato, quando da entrega da DIRPF apurar-se saldo de imposto a recolher, o IRF recolhido anteriormente em "bases correntes" revestir-se-á de uma legítima antecipação; todavia, na hipótese de não ser apurado imposto a recolher, mas, ao contrário, apurar-se imposto a restituir, na medida em que as tais "antecipações" foram realizadas em montante superior ao valor do imposto devido, tais retenções ocorridas no passado (bases correntes) assumiriam a natureza de verdadeiros empréstimos compulsórios. Vale a transcrição:

\footnotetext{
${ }^{268}$ Cf. QUEIROZ, Luis Cesar Souza de. Op. cit. (nota 09), P. 247/248.

${ }^{269}$ Cf. ZILVETI, Fernando Aurélio. Op. cit. (nota 98), P. 44.

${ }^{270}$ Cf. QUEIROZ, Mary Elbe. Op. cit. (nota 90), P. 134/136.
} 
“Ora, nesse caso, é flagrante que os valores das "antecipações” pagas a maior ou indevidamente ao Fisco constituem-se em recolhimentos sem causa, verdadeiros empréstimos compulsórios a serem restituídos ao contribuinte sob pena de ilegalidade e locupletação ilícita de valores por parte da Fazenda Pública. Em se tratando de recolhimentos indevidos, eles terão, necessariamente, que ser restituídos, haja vista que não se revestem da natureza de IR, pois, caso fossem esse tributo, seriam devidos e não poderiam ser devolvidos por haverem extinto a respectiva obrigação tributária."

Vale destacar que o STF já teve a oportunidade de se manifestar no sentido de que tais antecipações não configuram empréstimo compulsório ${ }^{271}$. Para os casos de tributos recolhidos a maior ou recolhidos indevidamente, o CTN reserva disciplina específica para sua restituição (artigo 165, inciso I), sem que isso, no entanto, lhe retire a natureza tributária e o regime jurídico próprio dos tributos para fins de restituição.

Em que pese o entendimento estremado da autora, o mecanismo de pagamento titulado pelo IRF deve ser analisado à luz dos princípios constitucionais que regem a sistemática de tributação própria do IR. A este respeito, reafirmando algumas de nossas conclusões, veremos que a metodologia encampada pelo IRF encontra guarida na Constituição Federal e corresponde a um meio legal de o Estado angariar receitas para fazer frente aos gastos gerais na prestação de serviços públicos colocados à disposição da coletividade. Voltaremos a este tema, com arrimo no princípio da praticabilidade, trazendo outros argumentos geralmente sacados para justificação da tributação na fonte pelo IR.

\footnotetext{
${ }^{271}$ Neste sentido, confira-se: "3. Não ofendia a Carta decaída, tampouco configurava instituição irregular de empréstimo compulsório, a sistemática de recolhimento do imposto de renda, na fonte, mês a mês ou o seu pagamento trimestral, para posterior reajuste anual. 4." (STF, $2^{\mathrm{a}} \mathrm{T}$. RE 140.671/CE, Rel. Min. Ellen Gracie. DJ 13/08/2004). LUIS EDUARDO SCHOUERI ensina que os empréstimos compulsórios dependem de uma justificativa (causa) constitucionalmente prestigiada, sendo certo que, na não verificação dessa justificativa, não se fala em espécie tributária cujo regime jurídico corresponde a de um empréstimo compulsório. Tais justificativas constitucionais seriam aquelas definidas no artigo 148, da CF: (i) atender a despesas extraordinárias, decorrentes de calamidade pública, de guerra externa ou de sua iminência; ou, (ii) no caso de investimento público de caráter urgente de relevante interesse nacional. (Cf. SCHOUERI, Luis Eduardo. Op. cit. (nota 04), P. 198/200). RICARDO LOBO TORRES destaca que a característica mais marcante dos empréstimos compulsórios é ser uma prestação restituível. Lembra, todavia, que tais prestações pecuniárias têm natureza de um empréstimo forçado vinculado a atender uma necessidade pública específica (TORRES, Ricardo Lobo. Op. cit. (nota 25), P. 427/428).
} 
As Cortes Superiores de nosso País já se manifestaram sobre a viabilidade das antecipações do IR via retenções na fonte. Neste sentido, confira-se:

“TRIBUTÁRIO - IMPOSTO DE RENDA - HIPÓTESE DE INCIDÊNCIA AGRAVO REGIMENTAL - ANTECIPAÇÕES - RECOLHIMENTO POSSIBILIDADE. 1. O fato gerador do Imposto de Renda realiza-se no decorrer do ano-base ao qual se refere sua declaração (ato complexo). Ou seja, não ocorre ele no último dia do exercício financeiro em relação ao qual deve o contribuinte realizar a apuração do eventual quantum devido. 2. É no transcorrer do ano de referência que se verificam as disponibilidades econômicas e jurídicas que justificam a tributação da renda; podendo, por conseguinte, ser ela antecipada, de forma que sua apuração final poderá ser postergada para o ano seguinte. Precedentes. Agravo regimental provido."

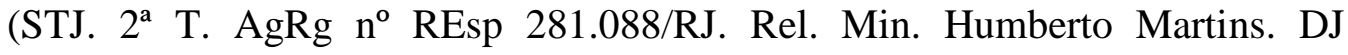
29/06/2007)

Focado exclusivamente na noção de disponibilidade jurídica e econômica, os julgadores parecem esquecer da aquisição de acréscimo patrimonial, imprescindível para configuração da hipótese tributária do IR. Queremos crer que a aquisição desse acréscimo patrimonial também se verifica no decorrer do ano, razão pela qual justifica-se do IRF como antecipação do imposto devido.

“IMPOSTO DE RENDA - ANTECIPAÇÃO - DECRETO-LEI N. 2.354/87.

$O$ imposto de renda tem como fato gerador a aquisição da disponibilidade econômica ou jurídica de renda (CTN, artigo 43, inciso I). No caso, a disponibilidade é adquirida pela pessoa jurídica ao longo do exercício social e pode o fisco exigir o seu pagamento antecipado, a exemplo, do que acontece com as retenções na fonte, no recebimento mensal de salários ou vencimentos. as antecipações do imposto de renda das pessoas jurídicas, previstas pelo Decreto-lei n. 2.354, de 24 de agosto de 1987 não ferem dispositivo do CTN. Recurso improvido."

(STJ. ${ }^{\text {a }}$ T. REsp n o 38.265-3/RJ. Rel. Min. Garcia Vieira. DJ 08/11/1993) 
Neste segundo julgado a aquisição de acréscimo patrimonial é também ignorada, apenas deixando claro que as retenções têm caráter de pagamento antecipado.

O que deve ser ressaltado é que, dos estudos traçados acima, quando definimos os matizes conceituais de "renda" e dos limites do fato gerador do IR, notadamente seus aspectos material, temporal e quantitativo, podemos afirmar que nessas antecipações, em verdade, não há a completa concretização do fato gerador, não se podendo falar, neste momento, em nascimento da relação jurídica tributária. Todavia, vale lembrar que as aquisições de disponibilidade econômica ou jurídica de rendas se constituem em fatos participantes do próprio aumento patrimonial, indicadores da circunstância de que cada um desses fatos está completo, tendo produzido aumento patrimonial $^{272}$, daí, ao lado da fundamentação constitucional que será investigada a seguir, justificar-se a tributação pelo IRF sobre tais rendimentos, como fatos-signos presuntivos de renda e reveladores de capacidade contributivo-econômica. Conforme veremos, apoiados nos princípios e valores defendidos na Constituição Federal, o recolhimento dessas antecipações, antes da ocorrência do fato gerador, procura encontrar suporte constitucional em outros dispositivos que não exclusivamente o artigo 153. Nestes casos, em um apontamento preliminar, não sendo possível falar-se em relação jurídica tributária, já que não houve o completo aperfeiçoamento do fato gerador, parece-nos temerária a conclusão de que a fonte exerceria o papel de substituto tributário, figura necessariamente atrelada ao nascimento da obrigação tributária.

\subsubsection{A Natureza Jurídica do IRF sob a ótica do CTN}

Conforme tivemos a oportunidade de tratar no Capítulo I, os deveres instrumentais não têm cunho patrimonial, já que seu descumprimento não gera, em favor do credor, um direito de indenização ou de reparação, por isso se diz que não há caráter patrimonial ou obrigacional (embora outra norma jurídica possa impor a aplicação de multa pecuniária).

Neste sentido, a par do disposto no artigo 113, do CTN, parece-nos difícil sustentar, por exemplo, que a retenção do IR corresponde a um simples dever instrumental, como quer

${ }^{272}$ Cf. OLIVEIRA, Ricardo Mariz de. Op. cit. (nota 171), P. 225. 
parcela da doutrina ${ }^{273}$. Mesmo que se diga que a retenção do tributo não decorra da ocorrência do fato gerador do IR, não há como afastar a ideia de que o IRF não tem por objetivo outra coisa que não o pagamento de tributo, mais ainda, como vimos nos casos contemplados pelo regime de retenção exclusiva na fonte, onde o montante retido é tratado de forma separada, assumindo natureza típica de imposto pago de forma definitiva. Ademais, a retenção na fonte tem origem em base legal e não em legislação tributária, como sói ocorrer com relação aos deveres instrumentais. A questão é extremamente relevante, na medida em que há uma preocupação com o princípio da legalidade.

Em discussão sobre o campo de inserção do $\S 3^{\circ}$, do artigo $7^{\circ}$, do CTN, os Professores RubEnS GOMES DE SousA e GERALDO ATALIBA ${ }^{274}$ travam oportuno debate sobre o tema. RUBENS GOMES DE SOUSA propunha-se a sustentar, apressadamente, que a fonte pagadora do imposto de renda estaria enquadrada no aludido dispositivo, sob o enredo de que se trataria de pessoa sujeita ao encargo de arrecadar tributos, por força de obrigação acessória. No momento seguinte, GERALDO ATALIBA corrige aquele primeiro pensamento, ao enxergar no dever acessório uma consequência inata da situação de sujeição em que ficam os administrados ante a administração tributária. RUBENS GOMES DE SOUSA concorda, destacando que o tal $\S 3^{\circ}$, do artigo $7^{\circ}$, do CTN, corresponde, de fato, a uma delegação de competência, ao passo que, no caso da fonte pagadora, está se impondo um dever, ao falar-se em “obrigação acessória”, utilizando a terminologia do Código.

A despeito das conclusões a que chegam sobre o alcance daquele dispositivo, o que releva destacar é que, ainda que superficialmente, aqueles respeitados Professores manifestam entendimento de que a retenção na fonte corresponderia a um dever instrumental.

A jurisprudência já teve a oportunidade de se manifestar sobre o tema, no sentido de que tanto as retenções do IR na fonte como as antecipações mensais do IRPJ e da CSLL não se caracterizam como tributos, mas, sim, revestem-se de "obrigações" de natureza acessória:

“4. O responsável tributário é aquele que, sem ter relação direta com o fato gerador, deve efetuar o pagamento do tributo por atribuição legal nos termos

\footnotetext{
${ }^{273}$ Cf. IBRAHIM, Fábio Zambitte. Op. cit. (nota 252), P. 56.

${ }^{274}$ Cf. SOUSA, Rubens Gomes de; ATALIBA, Geraldo; CARVALHO, Paulo de Barros. Comentários ao Código Tributário Nacional: Parte Geral. $2^{\mathrm{a}}$ ed. São Paulo: Quartier Latin, 2007. P. 95/96
} 
do artigo 121, parágrafo único, II, c/c 45, parágrafo único, do Código Tributário Nacional.

5. Tratando-se de obrigacão tributária acessória, tem-se que o sujeito passivo será a pessoa, contribuinte ou não, a quem a lei determine seu cumprimento, a qual, no caso sub examen, é o próprio contribuinte, que tem relação direta e pessoal com a situação configuradora do fato gerador do tributo - aquisição da disponibilidade econômica ou jurídica da renda ou do provento. Destarte, o inadimplemento do dever de recolher a exação na fonte, ainda que ocasione a responsabilidade do retentor omisso, não tem o condão de excluir a obrigação, do contribuinte, de oferecê-la à tributação, o que deveria ocorrer se tivesse havido o desconto na fonte." (grifamos)

(STJ. $1^{\text {a }}$ T. REsp 795.131/AL. Rel. Min. Luiz Fux. DJ 18/05/2006)

Respeitada as decisões sempre bem fundamentadas do Ministro Luiz Fux, hoje integrante do quadro de julgadores do STF, opinamos por divergir da decisão supra, tanto por chamar o terceiro obrigado ao recolhimento do IRF de responsável tributário, pois sequer houve o nascimento da relação jurídica tributária, como também por tratar a retenção na fonte como um "mero" dever instrumental.

“TRIBUTÁRIO. IMPOSTO DE RENDA. APURAÇÃO E PAGAMENTO DO TRIBUTO EM BASES MENSAIS, CONFORME SISTEMA INSTITUIDO PELA LEI-8383/91 E MANTIDO PELA LEI-8541/92. CORREÇÃO MONETÁRIA PELA UFIR. HONORARIOS ADVOCATICIOS.

1. A exigência de balanços mensais ou semestrais para efeito de apuração do imposto de renda e da contribuição social sobre o lucro e seu pagamento no mês seguinte ao da apuração se configura como antecipação desses tributos.

2. As antecipações não são tributo, mas sim obrigações de natureza acessória, que decorrem da legislação tributária, positivas ou negativas, nela prevista no interesse da arrecadação ou da fiscalização dos tributos (art-113, par-2 do CTN-66)." (grifamos)

(TRF da $4^{\text {a }}$ Região Fiscal. Turma de Férias. AMS 93.04.33786-0. Rel. João Surreaux Chagas. DJ 13/09/1995) 
Neste segundo julgado, o julgador afirma que o IRF, ou melhor, as antecipações, não são tributo, mas, sim, "obrigações acessórias" que decorrem da legislação tributária. Como vimos, a validade do IRF está vinculada, dentre outros, ao princípio da legalidade, i.e., deve ser obrigatoriamente veiculado por meio de lei. Sobre não ser tributo, parece-nos difícil sustentar tal afirmativa considerando que ao final do período de apuração, mais exatamente quando da entrega da DIRPF, a integralidade dos valores antecipados são deduzidos do IRPF devido. Se tais antecipações não fossem tributo, como seria possível o cotejo de valores de espécies diferentes? Talvez, o único cenário em que tal assertiva seria razoável é quando as antecipações excedem ao valor do imposto devido e, neste caso, para alguns autores, como é o caso da MARY ELBE QUEIROZ, assumiriam a natureza de uma penalidade, travestida de empréstimo compulsório, ainda assim dentro do grupo dos tributos.

Alinhado às premissas desenvolvidas no subitem 1.4.1., ressalta abordar que o caráter passageiro, próprio das obrigações, é identificável, pois, promovida a retenção e realizado o recolhimento do tributo correspondente àquela retenção, resolve-se o vínculo gerado, por exemplo, em um determinado pagamento sujeito ao IRF, entre a fonte pagadora e o sujeito ativo $^{275}$. Todavia, o mesmo não se pode dizer quando se trata, por exemplo, da entrega de declarações pela fonte pagadora sobre as retenções realizadas ou da guarda e manutenção desses documentos à disposição da fiscalização, revelando um comportamento de caráter permanente.

Queremos crer que o encargo acometido à fonte pagadora, nos termos do parágrafo único, do artigo 45, do CTN, não se reveste exclusivamente do figuro de um dever instrumental. Assume, em verdade, uma natureza híbrida, abrigando tanto obrigações de fazer ${ }^{276}$, como

\footnotetext{
${ }^{275}$ No caso do regime de retenção exclusiva na fonte, este vínculo se dissolve no exato momento da retenção, seguido do recolhimento do imposto. no regime de retenção na fonte por antecipação. Desde que o montante retido seja tempestiva e integralmente recolhido, aquele vínculo também não mais existirá, ao menos com relação ao pagamento/crédito/remessa/emprego/entrega que deu origem àquela retenção na fonte.

${ }^{276}$ MARY ELBE QUEIROZ elenca uma série de funções operacionais e administrativas da fonte pagadora, a saber: "i) a apuração da ocorrência do fato gerador do IR (se houve, ou não, pagamento de renda que se subsume à hipótese da lei tributária e constata que terceiro auferiu renda tributável); ii) a identificação do respectivo sujeito passivo (individualiza quem é o contribuinte, a pessoa que aufere e adquire a renda e seu benefício econômico); iii) a quantificação da matéria tributável (apurar a base de cálculo do tributo, valor bruto menos deduções da lei); iv) fazer o cálculo do IR devido (aplicar a alíquota progressiva cabível na situação pessoal do contribuinte); v) fornecer comprovante de rendimentos com o total do rendimento bruto pago pela fonte, o total retido a título de $I R$, e qual o rendimento líquido efetivamente recebido pelo beneficiário; vi) informar trimestralmente, na DCTF, os valores dos rendimentos brutos pagos e o valor do
} 
também uma obrigação de dar, correspondente à entrega, em favor dos cofres públicos, daquele exato montante retido contra o contribuinte.

Deve-se, contudo, atender tanto ao regime jurídico das obrigações principais, ainda que não se tenha verificado a plenitude dos aspectos da regra matriz, bem como dos deveres instrumentais, na medida em que encerra um conjunto de obrigações de fazer.

\subsubsection{Autorização Constitucional para o IRF}

Conforme já tivemos a oportunidade de apontar, a Constituição Federal fornece apenas as linhas gerais da noção conceitual de renda para fins de tributação do IR, cabendo ao legislador complementar, por força do disposto no artigo 146, inciso III, da CF, detalhar a sistemática de sua tributação em conformidade com o momento histórico e com as convicções sócio-econômicas vigentes. As linhas gerais fornecidas pela CF retratam a confirmação dos princípios e valores constitucionais, evitando a criação de amarras muito duras que, ou inviabilizariam a própria realização daqueles princípios, ou tornariam a tributação da renda por demais complexa, tornando inexequível sua operacionalização em virtude das situações de massa (número de contribuintes e volume de transações e operações alcançadas pela tributação do IR).

Acreditamos que não apenas a partir do indigitado artigo 146, inciso III, da CF, mas, também, dos artigos 157, inciso I, e 158, inciso I, ambos também da Magna Carta, já transcritos acima, fica assegurada a autorização, em âmbito constitucional, para a tributação, antecipada, na fonte.

Como vimos, ao analisar as diferentes acepções que a palavra "renda" aparece na Constituição Federal, RoBERTO QUIROGA MOSQUERA ${ }^{277}$ identifica, nos referidos artigos 157, inciso I, e 158, inciso I, "renda" como sinônimo de um somatório de rendimentos. Aponta, em seguida, que a noção constitucional de "renda" estampada no artigo 153, da

IR retido; vii) apresentar, anualmente, Declaração de Imposto sobre a Renda Retido na Fonte (DIRF), informando o nome dos beneficiários de rendimentos pagos pela fonte, o valor bruto dos valores pagos e o imposto que foi retido." (Cf. QUEIROZ, Mary Elbe. Op. cit. (nota 90), P. 395). Além dessa extensa lista, cabe à fonte pagadora identificar a precisa natureza do rendimento e, com base nisso, aplicar a alíquota correta, definida em lei para cada tipo de rendimento.

${ }^{277}$ Cf. MOSQUERA, Roberto Quiroga. Op. cit. (nota 125), P. 48/70 (52/53; 68). 
Magna Carta, é aclarada por exercício de uma definição denotativa, ao indicar as qualificações dos tipos de rendimentos com significação condizente para subsumir-se àquele conceito constitucional, quais sejam, rendimentos decorrentes do trabalho e do capital.

No entanto, vale lembrar, este mesmo autor, em outra oportunidade, sustenta que o IRF originar-se-ia de um fato gerador distinto daquele próprio do IR definido, constitucionalmente, nos moldes do artigo 153, da $\mathrm{CF}^{278}$, entendimento com o qual não concorda PAULO AYRES BARRETO ${ }^{279}$.

O Professor LUCIANO AMARO ${ }^{280}$, ao analisar a viabilidade de período de apuração mensal do IR, realça que, se a corrente encampada por aqueles que entendem que o imposto só poderia ser cobrado depois de aperfeiçoado o fato gerador periódico, ou seja, no final do período de apuração, o IRF teria que ser declarado inconstitucional, tese que é fortemente defendida por Mary Elbe QueIROZ. Conclui o Professor de Direito Tributário, da Faculdade de Direito da Universidade Mackenzie, que tal argumento não se sustenta, haja vista que a retenção na fonte encontra autorização não apenas na seara legal, a teor do disposto no artigo 45, parágrafo único do $\mathrm{CTN}$, mas, também, está prevista no seio constitucional, à guisa do disposto nos artigos 157, inciso I, e 158, inciso I. ROBERTO QUIROGA MOSQUERA $^{281}$ também identifica, nesses dispositivos, expressa autorização constitucional para a sistemática do IRF, tanto pelo regime de retenção exclusiva na fonte como pelo regime de retenção por antecipação.

Tal pensamento, todavia, não encontra fácil aceitação na doutrina. LUís CESAR SOUZA DE QUEIROZ $^{282}$ enfrenta o tema com afinco, esclarecendo que "não há óbice constitucional de se estabelecer uma sistemática de tributação antecipada na fonte por meio do IR" (destaques no original), desde que tal hipótese seja uma opção por parte do contribuinte ${ }^{283}$.

\footnotetext{
${ }^{278}$ Cf. MOSQUERA, Roberto Quiroga. Op. cit. (nota 210), P. 142/143.

${ }^{279}$ Cf. BARRETO, Paulo Ayres. Op. cit. (nota 156), P. 87/88.

${ }^{280}$ Cf. AMARO, Luciano. Op. cit. (nota 202), P. 41/46 (45).

${ }^{281}$ Cf. MOSQUERA, Roberto Quiroga. Op. cit. (nota 125), P. 48/70 (52/53; 68).

${ }^{282}$ Cf. QUEIROZ, Luis Cesar Souza de. Op. cit. (nota 09), P. 298/310.

${ }^{283}$ LUCIANO AMARO percorre caminho parecido, segregando que (a) a incidência exclusiva de fonte deveria ser opcional ao contribuinte ou obrigatória apenas em casos excepcionais, como no caso de rendimentos remetidos a beneficiários no exterior, (b) as hipóteses de retenção na fonte deveriam ser, em regra, ajustáveis
} 
Afirma que, para os casos de tributação definitiva e exclusiva na fonte, o que se tributa é rendimento e não renda; assevera que somente em circunstâncias extraordinárias é possível, constitucionalmente, admitir a tributação de um rendimento, por meio do IR, de forma isolada e definitiva. Como exemplo, o autor cita os casos de rendimentos auferidos por beneficiário não residente no País, situação em que o Fisco não terá condições de verificar a totalidade dos fatos-acréscimos e fatos-decréscimos que informam o conceito de renda ${ }^{284}$.

Já com relação ao IRF recolhido como antecipação do devido, Luís CESAR SOUZA DE QUEIROZ $^{285}$ conclui tratar-se de flagrante inconstitucionalidade, de forma que os artigos 157 e 158, ambos da CF, não teriam o condão de suplantar o disposto na Constituição Federal sobre a matéria relacionada ao IR, os princípios constitucionais e o conceito constitucional de "renda e proventos de qualquer natureza". Após valiosa ponderação dos princípios atinentes à matéria, pondera que os recursos recolhidos aos cofres públicos por meio da retenção na fonte correspondem a algo que não se confunde com renda.

MARY ELBE QUEIROZ ${ }^{286}$ admite que a sistemática do IRF e o reconhecimento da fonte pagadora como a pessoa que faz a retenção são acolhidos pela Constituição Federal, em seus artigos 157 a 159. Argumenta, contudo, que, em que pese tal sistemática ter sido reconhecida pelo legislador constituinte naqueles dispositivos retro citados em conjunto com o artigo $150, \S 7^{\circ}$, da $\mathrm{CF}$, essas "retenções e antecipações" estariam afrontando a legalidade, pois seriam realizadas antes mesmo da ocorrência do fato gerador do IR, antes mesmo de se saber se haverá base de cálculo positiva, portanto, tributável ${ }^{287}$.

Conforme passamos a expor no subitem seguinte, a solidificação dessa autorização, emanada pelos artigos 146, inciso III, 157, inciso I, e 158, inciso I, todos da CF, somente será possível se observados os princípios constitucionais, com a inolvidável ponderação do grau de priorização que o regime jurídico dos princípios demanda.

ao imposto apurado periodicamente, como de fato é, na maior medida possível. (Cf. AMARO, Luciano. Op. cit. (nota 202), P. 45.

${ }^{284}$ Cf. QUEIROZ, Luis Cesar Souza de. Op. cit. (nota 09), P. 290/297.

${ }^{285}$ Ibidem, Op. cit. (nota 09), P. 298/310.

${ }^{286}$ Cf. QUEIROZ, Mary Elbe. Op. cit. (nota 90), P. 389.

${ }^{287}$ Ibidem, Op. cit. (nota 90), P. 363. 


\subsubsection{O IRF e os Princípios Constitucionais}

Como vimos, a sistemática de pagamento antecipado pelo IRF, em seus dois regimes, levanta uma série de discussões, que, basicamente, giram em torno de dois grandes temas: (i) seu aspecto temporal propriamente dito, pelo simples fato de exigir tributo antes de ocorrida a consolidação de todos os aspectos da regra matriz do IR, ainda que, no regime de antecipação, os valores recolhidos mensalmente possam ser deduzidos do montante devido no final do período de apuração; e (ii) o tratamento diferenciado para algumas espécies de rendimentos específicos, como ocorre com relação aos ganhos de capital e receitas financeiras, tributados de forma isolada e com alíquotas (fixas) menores.

A proposta deste subitem é identificar se, para estes casos, existem justificativas constitucionais que atuam como vetores para validação daquelas sistemáticas, ou, ao contrário, se tais sistemáticas violam o sistema tributário nacional e ordenamento constitucional como um todo. Nesta hipótese, é necessária a criação de ajustes e ferramentas que assegurem os interesses do Fisco e a manutenção dos direitos e garantias individuais, especialmente a noção de mínimo existencial, da capacidade econômicocontributiva e da segurança jurídica, valendo-se, este último princípio, para o caso em enfoque, da praticabilidade como seu principal vetor.

Neste momento, surge a relevância de apurar a técnica de sopesamento ou ponderação dos princípios.

O Direito não está incólume às alterações e transformações que ocorrem ao seu redor nos planos social, político, econômico, cultural, religioso e ético. Não que isso, por um lado, traduza-se em uma norma jurídica mutável ou mesmo volúvel, sob pena de frontal prejuízo da segurança jurídica, da certeza do Direito, da boa fé e do princípio da mútua confiança que deve prevalecer entre Estado (Fisco, no nosso caso) e sociedade. Por outro lado, em que pese a respeitada opinião daqueles que vislumbram a Constituição como algo estático e não como um organismo vivo em constante transformação, parece-nos que a 
interpretação das normas deve atender a um mínimo de ingredientes de flexibilidade, proporcionalidade e razoabilidade ${ }^{288}$.

Não há como afastar a inexorável evolução das relações humanas e do surgimento de novas tecnologias e de novas atividades, gerando relações intersubjetivas antes não vislumbradas. Entretanto, é importante pautar que o Direito tem um norte dominante, que corresponde aos valores de um determinado Estado, como, por exemplo, a justiça, a segurança jurídica, a liberdade do povo e sua garantia pelo Estado, a paz, a igualdade, a solidariedade e a dignidade humana. A justiça, como queremos crer, é a fonte de tudo, é a

${ }^{288}$ Nesse sentido vide as respeitadas opiniões de: LARENZ, Karl. Metodologia da Ciência do Direito. $3^{\mathrm{a}}$ ed. Lisboa: [s.n.], 1997; e também MENDES, Gilmar. COELHO, Inocêncio Mártires. BRANCO, Paulo Gustavo Gonet. Curso de Direito Constitucional. $3^{\mathrm{a}}$ ed. São Paulo: Saraiva, 2008. P. 110/133. Confira-se, também, a seguinte decisão do Supremo Tribunal Federal onde se comenta sobre a flexibilização da interpretação constitucional, a fim de que seja conferida uma compreensão mais abrangente: "EMENTA: MANDADO DE INJUNÇÃO. GARANTIA FUNDAMENTAL (CF, ART. 5', INCISO LXXI). DIREITO DE GREVE DOS SERVIDORES PÚBLICOS CIVIS (CF, ART. 37, INCISO VII). EVOLUÇÃO DO TEMA NA JURISPRUDENNCIA DO SUPREMO TRIBUNAL FEDERAL (STF). DEFINIÇÃO DOS PARÂMETROS DE COMPETENNCIA CONSTITUCIONAL PARA APRECIAÇÃO NO ÂMBITO DA JUSTIÇA FEDERAL E DA JUSTIÇA ESTADUAL ATÉ A EDIÇÃO DA LEGISLAÇÃO ESPECÍFICA PERTINENTE, NOS TERMOS DO ART. 37, VII, DA CF. EM OBSERVÂNCIA AOS DITAMES DA SEGURANÇA JURÍDICA E À EVOLUÇÃO JURISPRUDENCIAL NA INTERPRETAÇÃO DA OMISSÃO LEGISLATIVA SOBRE O DIREITO DE GREVE DOS SERVIDORES PÚBLICOS CIVIS, FIXAÇÃO DO PRAZO DE 60 (SESSENTA) DIAS PARA QUE O CONGRESSO NACIONAL LEGISLE SOBRE A MATÉRIA. MANDADO DE INJUNÇÃO DEFERIDO PARA DETERMINAR A APLICAÇÃO DAS LEIS Nos 7.701/1988 E 7.783/1989. 1. SINAIS DE EVOLUÇÃO DA GARANTIA FUNDAMENTAL DO MANDADO DE INJUNÇÃO NA JURISPRUDÊNCIA DO SUPREMO TRIBUNAL FEDERAL (STF). 1.1. No julgamento do MI no 107/DF, Rel. Min. Moreira Alves, DJ 21.9.1990, o Plenário do STF consolidou entendimento que conferiu ao mandado de injunção os seguintes elementos operacionais: i) os direitos constitucionalmente garantidos por meio de mandado de injunção apresentam-se como direitos à expedição de um ato normativo, os quais, via de regra, não poderiam ser diretamente satisfeitos por meio de provimento jurisdicional do STF; ii) a decisão judicial que declara a existência de uma omissão inconstitucional constata, igualmente, a mora do órgão ou poder legiferante, insta-o a editar a norma requerida; iii) a omissão inconstitucional tanto pode referir-se a uma omissão total do legislador quanto a uma omissão parcial; iv) a decisão proferida em sede do controle abstrato de normas acerca da existência, ou não, de omissão é dotada de eficácia erga omnes, e não apresenta diferença significativa em relação a atos decisórios proferidos no contexto de mandado de injunção; iv) o STF possui competência constitucional para, na ação de mandado de injunção, determinar a suspensão de processos administrativos ou judiciais, com o intuito de assegurar ao interessado a possibilidade de ser contemplado por norma mais benéfica, ou que lhe assegure o direito constitucional invocado; v) por fim, esse plexo de poderes institucionais legitima que o STF determine a edição de outras medidas que garantam a posição do impetrante até a oportuna expedição de normas pelo legislador. 1.2. Apesar dos avancos proporcionados por essa construcão jurisprudencial inicial, o STF flexibilizou a interpretacão constitucional primeiramente fixada para conferir uma compreensão mais abrangente $\grave{a}$ garantia fundamental do mandado de injuncão. A partir de uma série de precedentes, o Tribunal passou a admitir solucões "normativas" para a decisão judicial como alternativa legítima de tornar a protecão judicial efetiva (CF, art. 5o, XXXV). Precedentes: MI no 283, Rel. Min. Sepúlveda Pertence, DJ 14.11.1991; MI no 232/RJ, Rel. Min. Moreira Alves, DJ 27.3.1992; MI no 284, Rel. Min. Marco Aurélio, Red. para o acórdão Min. Celso de Mello, DJ 26.6.1992; MI no 543/DF, Rel. Min. Octavio Gallotti, DJ 24.5.2002; MI no 679/DF, Rel. Min. Celso de Mello, DJ 17.12.2002; e MI no 562/DF, Rel. Min. Ellen Gracie, DJ 20.6.2003." (Decisão do Pleno do Supremo Tribunal Federal. MI 670/ES. Relator(a): Min. MAURÍCIO CORRÊA. Relator(a) p/ Acórdão: Min. GILMAR MENDES. D.J.e 31.10.2008. (grifamos) 
expressão mais pura e inabalável que se pode ter ou chegar a ter acerca da noção do que é o Direito e o que são cada um dos princípios que o informam ${ }^{289}$.

Os princípios, como dissemos, representam, em uma primeira e imediata análise, a consagração e juridicização daqueles valores em um Estado de Direito, os quais são colhidos de forma expressa na Constituição, ou de forma implícita, como sentimentos ou noções incrustados como bases sólidas no subconsciente de cada cidadão ${ }^{290}$. Por princípios temos a expressão de valores supremos, comportando-se como verdadeira norma jurídica, mesmo nos casos em que não são previstos de forma expressa ${ }^{291}$. Impregnados por essas cargas valorativas e altamente sujeitos a ponderações de subjetividade, os princípios exercem funções mais descritivas e menos prescritivas. Procura-se, ao invocar um determinado princípio, dimensionar ou circunscrever uma determinada gama de situações.

É justamente por causa dessa natureza menos rígida, seja porque não prescrevem tipos legais propriamente ditos, seja porque possuem um campo de abrangência mais lato, que os princípios se diferenciam das regras, as quais são mais rígidas e altamente prescritivas, devendo afastar considerações de ordem subjetiva ${ }^{292}$. Ao acontecimento de um dado fato previsto por uma regra deverá ser aplicada uma determinada consequência ${ }^{293}$, salvo se tratar de regra inválida perante o sistema.

É justamente porque estabelecem um estado ideal de coisas a ser buscado, que os princípios vinculam-se mais intensamente com os outros princípios, com os quais são mantidas relações de complementariedade, ratificando um dos ideais da Magna Carta, que é o dever de buscar ou preservar vários daqueles ideais ao mesmo tempo e ao tempo

\footnotetext{
${ }^{289}$ Cf. FARIA, Renato Vilela. Op. cit. (nota 100), P. 432 e ss.

290 “Assim, não obstante o caráter moral desses valores, o Direito os contempla muitas vezes expressamente, em suas normas, sejam elas princípios ou regras." (Cf. ROCHA, Paulo Victor Vieira da. Os Princípios da Legalidade e da Capacidade Contributiva na Valoração Aduaneira. in Revista de Direito Tributário Atual. Vol. 22. Coordenação: Prof. Alcides Jorge Costa, Prof. Luis Eduardo Schoueri e Prof. Paulo Celso Bergstrom Bonilha. São Paulo: IBDT/Dialética, 2008. P. 352).

${ }^{291}$ HeLENILSON CUNHA PONTES classifica os princípios como hierarquicamente superiores às demais normas, sejam elas normas de estrutura ou normas de conduta (Cf. PONTES, Helenilson Cunha. O Princípio da Proporcionalidade. São Paulo: Dialética, 2000. P. 26/27).

${ }^{292}$ Cf. ÁVILA, Humberto. Regra Matriz versus Princípios. in Direito Tributário - Homenagem a Paulo de Barros Carvalho. Coord. Prof. Luis Eduardo Schoueri. São Paulo: Quartier Latin, 2008. P. 69.

293 Assim é o caso da regra como fenômeno da tributação: a subsunção de um fato à hipótese tributária descrita abstratamente na norma (regra) provoca o nascimento da obrigação tributária, ensejando a exigência de tributo.
} 
todo $^{294}$. Significa dizer que os princípios constitucionais tributários entroncam-se e interpenetram-se de tal forma que é impossível obedecer a um só sem obedecer aos demais $^{295}$.

Outra diferença, mais relevante ainda, é quanto à eficácia em situações de conflito entre regras e princípios e entre cada um desses institutos considerados isoladamente (ou seja, conflitos entre regras e regras e entre princípios e outros princípios)

Como já dissemos outrora, o fato de um princípio prevalecer sobre o outro não significa que este último esteja fora ou descartado no sistema, como uma hipótese de revogação. Tanto é assim que, em outra situação concreta, este último princípio poderá prevalecer sobre aquele primeiro, invertendo suas posições. As regras, como vimos, aplicam sob a forma do "tudo ou nada"; os princípios, por sua vez, revelam uma dimensão de peso ou importância, que as regras não têm, fazendo com que um prepondere sobre outro ou outros, em uma análise caso a caso. Para as regras, em uma situação de conflito, uma delas terá que ser invalidada, devendo levar-se em conta não apenas as regras em si e seus atributos de hierarquia, generalidade, anterioridade e especialidade, mas, também, outras regras que possam ter sido criadas justamente para aplicação nessas hipóteses de conflito $^{296}$ e, por óbvio, os princípios constitucionais, expressos e implícitos.

Os princípios concretizam-se como valores e é neste exato sentido que se direciona sua finalidade, na proteção de um bem jurídico maior, tal como a justiça, a segurança jurídica, a paz, a dignidade humana ou a solidariedade. Por causa de seu grau de generalidade e distração é que os princípios admitem flexibilidade em sua aplicação, sob forte influência de subjetividade, ponderação e prudência por parte do intérprete e do aplicador ${ }^{297}$.

Em parecer jurídico sobre os efeitos no tempo decorrentes da anulação de incentivos fiscais, RICARDO LOBO TORRES ${ }^{298}$ toca neste ponto ao analisar a proteção da confiança e da boa-fé do contribuinte e de terceiros, da irrevisibilidade do lançamento e da

\footnotetext{
${ }^{294}$ Cf. ÁVILA, Humberto. Op. cit. (nota 292), P. 69.

${ }^{295}$ CARRAZZA, Roque Antonio. Op. cit. (nota 111), P. 429.

${ }^{296}$ Cf. ROCHA, Paulo Victor Vieira da. Op. Cit. (nota 290), . P. 354/355.

${ }^{297}$ Cf. FARIA, Renato Vilela. Op. cit. (nota 100), P. 432 e ss.

${ }^{298}$ Cf. TORRES, Ricardo Lobo. Anulação de Incentivos Fiscais - Efeitos no Tempo. in Revista Dialética de Direito Tributário. Vol. 121. São Paulo: Dialética, 2005. P. 127/146 (129).
} 
inalterabilidade dos critérios jurídicos adotados pela Administração. O professor carioca mostra que o valor principiológico da segurança jurídica agasalha, dentre outros, os princípios da legalidade e da proteção da boa-fé do contribuinte. Aduz, ainda, que não raras vezes tais princípios colocam-se em contradição, exigindo o recurso à técnica de ponderação de interesses para eliminar a antinomia e para garantir a harmonia do sistema jurídico. A tensão, no caso dos princípios, resolve-se pela ponderação, quando aquele que melhor se ajusta ao caso terá um peso maior, afastando-se a ideia de superioridade.

A preponderância de um princípio sobre o outro, por meio da técnica de ponderação de interesses, não implica a revogação daquele que, em uma situação concreta, apresentou um peso menor ${ }^{299}$.

Para Humberto ÁvilA ${ }^{300}$, é forte a distinção entre regras e princípios: as primeiras disciplinam mandamentos definitivos, aplicados por meio da subsunção, de forma que, havendo encaixe, deverá ser aplicada uma determinada consequência; os princípios, por sua vez, disciplinam deveres provisórios, aplicados por meio da ponderação. Para este autor, com relação às regras, o conflito ocorre no plano abstrato; para os princípios, a solução das antinomias se opera apenas no plano concreto.

O recurso à técnica de sopesamento ou ponderação entre princípios, em situações de tensão, é que permite uma convivência harmoniosa entre uma tributação materialmente justa e uma tributação substancialmente justa. O sopesamento mostra-se como instrumento plausível a indicar qual deles possui maior relevância ${ }^{301}$. Todavia, levando em conta que esta técnica pode criar encargos pecuniários, como se observa de forma patente nos casos do IRF, são essenciais, neste processo, a observância e o exame da proporcionalidade em sentido estrito (a medida não deve restringir excessivamente os direitos envolvidos, daí a importância de instrumentos de ajuste no fim do período de apuração do IR), da adequação (o meio escolhido deve ser apto para alcançar o fim pretendido, o que pode ser atingido com a obtenção de receitas antecipadas, o sucesso na diminuição das possibilidades de

\footnotetext{
${ }^{299}$ Cf. OLIVEIRA, Ricardo Mariz de. Op. cit. (nota 16). P. 221.

${ }^{300}$ Cf. ÁVILA, Humberto. A Teoria dos Princípios e o Direito Tributário. in Revista Dialética de Direito Tributário. Vol. 125. São Paulo: Dialética, 2006. P. 33/49 (36).

${ }^{301}$ Cf. SILVEIRA, Rodrigo Maito da. Tributação e Concorrência. in Série Doutrina Tributária Vol. IV. São Paulo: IBDT/Quartier Latin, 2011. P. 85/93.
} 
evasão, o melhor controle em operações específicas e a concessão de benefícios fiscais para determinados grupos de contribuintes ou determinadas atividades econômicas) e da necessidade (a medida escolhida, dentre as disponíveis, é a menos gravosa aos direitos envolvidos) ${ }^{302}$.

Pois bem.

Conforme tivemos a oportunidade de explicar, em sede do regime de retenção como antecipação, o aperfeiçoamento do fato gerador do IR se dá no exato momento da data final do período-base que o legislador elegeu como sendo o lapso temporal suficiente para medir se a aquisição de disponibilidade de renda (fato gerador instantâneo), no sentido de renda realizada, teve o condão de gerar acréscimo patrimonial passível de tributação. É só a partir dessa data que o imposto devido pelo contribuinte se torna exigível, i.e., somente a partir deste momento é que falamos em imposto devido. Qualquer exceção a essa regra, como é o caso do recolhimento do imposto retido de forma antecipada, que foi objeto de nossas análises, carece de uma justificativa suficiente para afastar alegações de ilegalidade ou inconstitucionalidade.

As justificativas existem, ora ratificando, ora reequilibrando-se com os princípios da realização da renda, da capacidade contributiva e, seu corolário, da igualdade. Com efeito, apoiadas nessas justificativas ou fundamentos justificadores, e desde que se estabeleçam ferramentas de ajustes como mecanismos de adequação aos princípios constitucionais ${ }^{303}$, tais exceções nada mais são que regras indutoras ou simplificadoras que buscam atender, em maior grau, a certos objetivos em detrimento de outros, sem, contudo, que essa sobreposição ofusque os valores ou a essência dos demais objetivos de forma permanente. Pelo contrário, o norte deve ser, sempre, no sentido de buscar o convívio harmônico e equilibrado de regras e normas que permitam a contínua manutenção financeira do Estado, ao mesmo tempo em que respeita as garantias individuais e os princípios constitucionais tributários, em especial, a legalidade, a capacidade contributiva e econômica e a igualdade.

\footnotetext{
${ }^{302}$ Cf. ÁVILA, Humberto. A distinção entre princípios e regras e a redefinição do dever de proporcionalidade. in Revista Diálogo Jurídico. Salvador, CAJ - Centro de Atualização Jurídica, v. I, $\mathrm{n}^{\circ} 4$, julho, 2001. Disponível em: http://www.direitopublico.com.br. Acesso em: 14.11.2011.

${ }^{303}$ Cf. AMARO, Luciano. Op. cit. (nota 202), P. 46.
} 
Citam-se, por exemplo, as conhecidas razões de comodidade fiscal e eficiência na e da função arrecadadora, permitindo não apenas que o recolhimento do tributo devido seja concentrado em uma única pessoa, em vez de diluir-se em um número infindável de contribuintes, mas, igualmente, por promover a diminuição da inadimplência e a otimização dos recursos públicos, financeiros e de pessoal, nos trabalhos de arrecadação, administração e fiscalização das receitas tributárias. Como já dissemos, tratar o tema da comodidade fiscal como uma vantagem exclusiva do Fisco é desconhecer o complexo de funções administrativas que permeiam a sistemática do IRF, antes e após o recolhimento antecipado do imposto. Tais justificativas, norteadas pelos ideais de simplificação, eficácia e eficiência, são, geralmente, vertidas em linguagem sob o rótulo de Praticabilidade ou princípio da praticabilidade ${ }^{304}$.

A praticabilidade pode ser traduzida como o conjunto de técnicas que visam viabilizar a adequada execução do ordenamento jurídico. Trata-se de autêntico princípio, do qual se observam as seguintes características: (i) elevado grau de generalidade e abstração, irradiando seus efeitos para outras normas, (ii) contempla valor considerado fundamental pela sociedade, no sentido de tornar exequíveis as leis tributárias e, com isso, a viabilização do atingimento do interesse público ${ }^{305}$.

A praticabilidade traz diversos benefícios ${ }^{306}$ :

${ }^{304}$ O próprio STF já captou a importância da praticabilidade, conforme se depreende do AI 746.875/MG (Rel. Min. Cármen Lúcia - DJe 27/10/2009), com citação de trecho do voto condutor exarado nos autos do RE 416.601 (Rel. Min. Carlos Velloso - Tribunal Pleno - DJ 30/09/2005): “O Direito não pode ignorar a realidade sobre a qual se aplica. O princípio da praticabilidade, tão bem trabalhado entre nós por MISABEL DERZI, jurisdiciza essa constatação elementar, que tampouco passa despercebida ao STF. Nos autos da Representação de Inconstitucionalidade $n^{\circ}$ 1.077/84, Rel. Min. MOREIRA ALVES, declarou a Corte que não se pode exigir do legislador mais do que 'equivalência razoável entre o custo real dos serviços e o montante a que pode ser compelido o contribuinte a pagar, tendo em vista a base de cálculo estabelecida pela lei e o quantum da alíquota por esta fixado'. Ora, é razoável supor que a receita bruta de um estabelecimento varie segundo o seu tamanho e a intensidade de suas atividades. É razoável ainda pretender que empreendimentos com maior grau de poluição potencial ou de utilização de recursos naturais requeiram controle e fiscalização mais rigorosos e demorados da parte do IBAMA (...)” (fl. 378)." (grifamos). Ainda sobre a relevância da praticabilidade, agora em uma situação de substituição tributária "para frente" do ICMS, o AI 655.401/MG (Rel. Min. Ricardo Lewandowski - Dje 19/10/2009), deita sua justificação sobre o princípio da praticabilidade.

${ }^{305}$ Cf. COSTA, Regina Helena. . Op. cit. (nota 06), P. 388/390.

${ }^{306}$ Cf. DERZI, Misabel Abreu Machado. Nota de Atualização. in BALEEIRO, Aliomar. Op. cit. (nota 06), P. 1253/1265. A despeito da infelicidade da expressão 'estado de necessidade', que, em um senso comum, pode trazer uma conotação desagradável, sua utilização, na doutrina alemã, alude à suposta oposição entre legalidade e 'praticidade', na medida em que o aparato administrativo e a capacidade financeira do Estado não oferece condições para solução e esclarecimento de cada fato tributário, bem como não há recursos financeiros suficientes para satisfazer as prestações. Por essa razão, i.e., esse 'estado de necessidade', 
a. no tocante ao uso de técnicas destinadas à execução de normas legais hierarquicamente superiores e proliferadas por meio de regulamentos, instruções normativas e portarias, a praticabilidade visa à facilitação da execução daquelas normas superiores e à simplificação da aplicação dos preceitos que tais normas superiores editam;

b. através do recurso a presunções e padronizações legais, asseguram-se, por meio da praticabilidade, a segurança jurídica, a uniformidade e a garantia e o fortalecimento do crédito tributário;

c. A noção de "custo versus benefício", tendo em vista o custo da máquina administrativa quanto à arrecadação e fiscalização (caso fosse cumprida rigidamente, i.e., caso a caso) é revelada pelo Estado de Necessidade Administrativa por ser desproporcional o volume do produto arrecadado. Some-se a isso a própria falta de pessoal, técnica e quantitativamente falando.

Sob a perspectiva do IRF a lista dos benefícios implementados pela praticabilidade é bastante extensa ${ }^{307}$ :

a. Agilidade e rapidez na arrecadação, tornando-a mais simples e econômica;

b. Facilitação para localizar e identificar a natureza específica de cada rendimento. Isso, dentre outros aspectos, permite que o Fisco gerencie manobras no sentido de determinar alíquotas específicas, fazendo as distinções necessárias que determinados tipos de rendimentos e determinadas situações exigem;

c. Otimização do controle no cumprimento das obrigações tributárias e dos correspondentes deveres instrumentais;

d. Melhor identificação dos beneficiários dos rendimentos;

e. Redução drástica do número de contribuintes a serem fiscalizados, ao menos com relação aos recolhimentos de imposto em bases correntes e nas situações abrangidas

MiSABEL ABREU MACHADO DERZI noticia que a jurisprudência alemã passa a adotar um modo de pensar 'tipificante', como um tentativa de apresentar uma solução a este impasse, por meio, por exemplo, da criação de pauta de valores, com uma prevalência da quantidade sobre a qualidade. Justifica-se, com isso, a noção trazida pela 'estado de necessidade' (bem como a validade da expressão), longe de uma referência fisiológica, mas como uma meta para a execução simplificadora da lei.

${ }^{307}$ Cf. QUEIROZ, Mary Elbe. Op. cit. (nota 90), P. 386/387. 
pelo regime de retenção exclusiva na fonte, onde é excluída a responsabilidade do contribuinte;

f. Maior eficiência da máquina arrecadadora, permitindo alocar melhor seu pessoal em outras searas da fiscalização e direcionar o planejamento estratégico da Administração em outras funções;

g. Redução dos eventos de sonegação, tendo em vista que deixar de efetuar as retenções em nada aproveita à fonte pagadora, pelo contrário, pode lhe trazer a imposição de penalidades, inclusive de natureza criminal $^{308}$;

h. Melhor equação entre o fluxo de caixa do Estado em contraposição com as necessidades e obrigações de periodicidade igualmente mensal, como, por exemplo, o pagamento de salários aos servidores públicos.

Além dos benefícios e vantagens destacados acima, vale ressaltar a enorme relevância que o produto coletado pelo IRF exerce no universo da arrecadação tributária total do Fisco. Conforme dados oficiais da Receita Federal do Brasil, para o período compreendido entre os meses de janeiro a setembro de 2011, o IRF representou 10,23\% do total arrecado a título de receitas federais. Considerando apenas os valores recolhidos a título de IR, esse percentual sobe para $33,81 \%$. Os dados mostram que o IRF tem se mostrado uma sistemática de arrecadação cada vez mais importante e eficiente. Em comparação ao mesmo período de 2010, o IRF decorrente de rendimentos do trabalho, mais atrelado, portanto, ao regime de retenção na fonte por antecipação, implicou um aumento de 10,33\%; para os rendimentos de capital, esse aumento foi superior a 30\%, possivelmente em função da aceleração na repatriação de divisas às matrizes estrangeiras por conta da crise econômica que assola o mundo ${ }^{309}$.

\footnotetext{
${ }^{308}$ MARY ELBE QUEIROZ comenta que, da perspectiva das pessoas físicas assalariadas, o IRF corresponde a um tributo quase que "insonegável" (Cf. QUEIROZ, Mary Elbe. Op. cit. (nota 90), P. 366.

${ }^{309}$ Cf. Análise da Arrecadação - Janeiro a Setembro de 2010. Brasília/DF. P. 8. Disponível em: http://www.receita.fazenda.gov.br/publico/arre/2011/ApresentacaoSet11.ppt\#503,8,Slide\%208. Acesso em 02/11/2011.
} 
Sobre essas justificativas, já apresentando outro viés da natureza jurídica da retenção na fonte do IR, que será abordado no Capítulo III, o jurista português Diogo FEIO ${ }^{310}$ assim elucida:

\begin{abstract}
"Neste elencar das características da substituição fiscal não podemos esquecer o facto de, muitas vezes, o aparecimento de um terceiro, a cumprir a obrigação de pagamento do imposto ao sujeito activo, ter como causas razões de mera ordem técnica. Esta conclusão acaba por ser completada se analisarmos algumas das principais vantagens da substituição fiscal. A substituição fiscal pode ter como efeito um pagamento mais rápido ao sujeito activo da relação jurídica de imposto, a redução do número dos sujeitos obrigados a pagar e a intervenção de alguém que não está interessado na evasão fiscal, o que cria maior segurança na arrecadação dos montantes devidos. É possível, pela enumeração destas vantagens, concluir que a substituição fiscal deve estar ao serviço da obrigação existente entre o contribuinte e o Estado, facilitando a posição deste último. Enfim, a substituição fiscal tem fundamentalmente por objectivo simplificar a intervenção da Administração Fiscal, que pretende, sem desfigurar o sistema, isto é respeitando os princípios fundamentais de Direito Fiscal, alcançar de forma mais célere e segura as receitas que tem o direito de receber." (g.n.)
\end{abstract}

Conforme já dissemos, a ideia de cobrança do imposto na fonte não é recente. BERHHARD GROSSFELD e JAMES D. BRYCE ${ }^{311}$, analisando o comparativo da história do imposto de renda no Reino Unido, na Alemanha e nos Estados Unidos, destacam que, à luz do histórico britânico, o então Primeiro Ministro, Addington Farnsworth, sagrou-se, nos idos de 1800, como o autor do ato normativo que criou o novo e moderno imposto de renda da forma como é conhecido nos dias de hoje. Em verdade, a nova "receita" trazida por Addington em muito se assemelhava ao imposto criado por seu antecessor, Willian Pitt, porém, dois novos ingredientes foram responsáveis pelo sucesso desse novo IR: (i) definição dos tipos de rendimentos passíveis de tributação, com foco na natureza específica

\footnotetext{
${ }^{310}$ Cf. FEIO, Diogo. A Substituição Fiscal e a Retenção na Fonte: O caso Específico dos Impostos sobre o Rendimento. Teses e Monografias I. Faculdade de Direito da Universidade do Porto. Porto: Coimbra Editora, 2001. P. 40/41. P. 57.

${ }^{311}$ Cf. GROSSFELD, Bernhard; BRYCE, James D. Op. cit. (nota 213) P. 219/220.
} 
de cada tipo de renda ou rendimento (cedularização); (ii) instituição da tributação/retenção na fonte.

Mais importante do que apurar o imposto em fontes específicas era a ideia de coletar o imposto na origem, seja onde fosse possível. O imposto era cobrado na origem no caso de anuidades, juros anuais, aluguéis, e salários de autoridades oficiais. O fator decisivo desse esquema era arrecadar o imposto no ponto onde a renda primeiramente emergia e se tornava visível. Por um lado, diminuía os encargos de fiscalização para o contribuinte em específico; por outro lado, tornou a evasão tributária mais improvável, já que o pagador normalmente não tinha qualquer incentivo para evitar, sob seu risco, os tributos do recebedor $^{312}$.

Observa-se, além do source concept, que a cedularização foi fator decisivo no aumento dos níveis de arrecadação, permitindo, inclusive, a redução de alíquota para determinados tipos de rendas.

A cedularização tem origem histórica como regra de exceção, ao destacar determinadas parcelas de uma regra geral de tributação, viabilizando maior transparência do Fisco. Atualmente, sua utilização está atrelada à ideia de captar diferentes tipos ou materialidades de riqueza. Assim como a retenção na fonte, a cedularização pressupõe a existência de uma justificativa que autorize sua instituição e manutenção. É o caso, por exemplo, dos países que excluem de sua tributação local os dividendos e juros remetidos em favor de beneficiários residentes ou domiciliados no exterior (outbound dividends and interests), por entender que tais valores só são tributáveis naquele outro Estado, em perfeito e mútuo respeito à soberania fiscal internacional. Há que se ver, no direito constitucional brasileiro, se tais justificativas existem tanto para o instituto da retenção na fonte como também para a cedularização própria do regime jurídico de retenção exclusiva na fonte.

\footnotetext{
312 Ibidem, Op. cit. (nota 213), P. 219/220. No original: "2. Even more important than assessing the tax on particular sources was the idea of collecting the tax - wherever possible - at the source. The tax was "stopped" at the source in case of annuities, yearly interests, rents, and salaries of public officials. The decisive factor of this scheme was to levy the tax at the point where the income first emerged and became visible. On the one hand this diminished the duties of disclosure for the particular taxpayer; on the other hand it made tax evasion more unlikely because the payor normally had no incentive to avoid, at his risk, the payee's taxes."
} 
Suportados, assim, pela análise percorrida sobre os princípios constitucionais, específicos ou não do IR e pelo ambiente jurídico e técnico em que se insere a sistemática antecipada de pagamento desse imposto, no momento de tributação do IRF não é possível aferir com precisão a capacidade contributivo-econômica do contribuinte. Ao receber um valor ou rendimento, é certo que, diante da construção jurídica de seu conceito, referido valor ou rendimento ainda não é "renda". Tal valor ou rendimento é um fato-signo presuntivo de renda, índice de capacidade contributiva, e induz à perspectiva de que o contribuinte pode vir a ter a renda, mas, a rigor, ainda não é renda.

Além do aspecto estrutural, a partir do qual pode ser analisada a capacidade contributiva, posto que verifica a capacidade dos contribuintes em suportar o ônus financeiro com a despesa gerada com o pagamento de tributo, há, também, uma perspectiva funcional. A capacidade contributiva, sempre que possível, deverá equilibrar a realização da isonomia, tributando igualmente os iguais e desigualmente os desiguais, bem como, harmonicamente, proporcionar a geração de receitas ao Estado a fim de dar continuidade às suas atividades pari passu aos acontecimentos da vida, seus compromissos e suas obrigações perante a sociedade.

Sob outra perspectiva, a segurança jurídica deve extrapolar os limites de proteção ao indivíduo de forma a atingir a sua função social. É dizer que há situações em que, para promover e favorecer a segurança jurídica, sacrifica-se a justiça estritamente individual, permitindo a manifestação de outros princípios e valores, como a solidariedade, a igualdade, a primazia do bem público sobre o particular e a justiça geral. É imprescindível que, neste exercício de ponderação de interesses, o sistema preveja dispositivos ou gatilhos que permitam essa flexibilização, evitando que a aplicação do Direito fique engessada ${ }^{313}$.

A segurança jurídica, materializada, como já dissemos, pelo ideal de simplificação do sistema jurídico, acaba por fornecer uma importante ferramenta aos contribuintes, por meio da sistemática do IRF, com drástica diminuição dos indivíduos sujeitos a efetuar um pagamento mensal do imposto e, consequentemente, na prestação de informações ao Fisco por meio dos deveres instrumentais.

${ }^{313}$ Cf. FARIA, Renato Vilela. Op. cit. (nota 100), P. 432 e ss. 
O princípio da universalidade, por sua vez, deve ser contraposto ao princípio da igualdade e seu corolário, a capacidade contributiva. Significa dizer que o legislador, ao definir regimes diferenciados para tributação do capital e do trabalho, como sói ocorrer com relação aos ganhos de capital e resultados decorrentes do mercado financeiro e de capitais, está, em verdade, colocando em relevo a igualdade, na medida em que se exige tributo diferente de contribuintes que se encontram em situações não equivalentes.

RICARDO MARIZ OLIVEIRA ${ }^{314}$ ensina que a generalidade não é equivalente à isonomia, mas se aproxima desta porque resulta em tratamento igual entre os patrimônios, de modo que, quanto ao IR, aquela não exclui esta última. Concordamos que generalidade não é equivalente à isonomia, todavia, preferimos dizer que, quanto ao IR, a generalidade objetiva realizar a isonomia na sua maior medida possível, sendo certo que outras razões poderão ser levadas em consideração, resultando em uma maior ou menor aproximação entre os conceitos de generalidade e isonomia.

Em outra perspectiva, o fato do IR conferir tratamento diferente entre pessoas físicas e pessoas jurídicas, aquelas primeiras tributadas com base na renda, entendida como o rendimento bruto deduzidas algumas despesas específicas, e estas últimas com base no lucro, não significa que o IR deixou de ser informado pela generalidade, apenas atendeu a outras razões que demandasse esse tipo de tratamento especial e aos diferentes perfis de contribuintes entre pessoas físicas e pessoas jurídicas.

A seu turno, a retenção na fonte pelo regime de "antecipação do devido" pressupõe um conjunto de pagamentos durante o lapso temporal que foi definido pelo legislador, sendo certo que, por ocasião daqueles pagamentos, a formação da base de cálculo do IR está em vias de produção. É justamente a natureza antecipatória desses pagamentos que, sem esquecer os limites constitucionais impostos pela capacidade contributiva e pela realização da renda, valida aqueles fundamentos justificadores ou indutores a que aludimos acima (eficiência, eficácia e comodidade das funções da Administração), aqui conjuntamente chamados de princípio da praticabilidade.

${ }^{314}$ Cf. OLIVEIRA, Ricardo Mariz de. Op. cit. (nota 16). P. 255. 
O crescimento populacional em escala geométrica e, consequentemente, do número de contribuintes, a complexidade gerada pelo cotidiano profissional, empresarial e corporativo, a inexistência de um aparato administrativo, físico, operacional e de pessoas, compatível com a aplicação e fiscalização da lei tributária, os altos custos decorrentes desse aparato administrativo, o atendimento simultâneo aos interesses do Fisco e dos contribuintes e a necessidade de busca de métodos simplificadores têm pressionando, cada vez mais, pela adoção da praticabilidade como regra, e não como exceção. Acredita-se, inclusive, que esta tendência deverá se acentuar de forma contínua e cada vez mais intensa, inclusive para situações ainda hoje não abarcadas por esta sistemática de simplificação. Trata-se inclusive de um processo não tão recente, conforme corrobora a inclusão do $\S 7^{\circ}$, ao artigo 150 da CF, por meio da Emenda Constitucional 3, de 1993.

MiSABEL ABREU MACHADO DERZI ${ }^{315}$ analisa com profundidade o princípio da praticidade ou praticabilidade ${ }^{316}$, afirmando que ele prestigia a igualdade e a capacidade contributiva, e objetiva evitar execuções muito complicadas da lei. Para a autora, apoiada nas lições do jurista alemão JOSEF ISENSSE, a praticabilidade é um princípio geral e difuso, sem formulação escrita, i.e., faz parte do rol de princípios implícitos na CF; a praticabilidade é o nome que designa a totalidade das condições que garantem uma execução eficiente e econômica das leis.

Para Misabel Abreu Machado DerZi, de forma a tornar a norma, legal ou infralegal, exequível, cômoda e viável, a praticabilidade informa que aquela mesma norma deve valer-se de abstrações generalizantes, tais como presunções, ficções, enumerações taxativas, somatórios e quantificações. A principal razão de ser da praticabilidade reside no fato de que o Direito Tributário enseja aplicação em massa de suas normas, a cargo da Administração, e de forma contínua. Igualmente, a praticabilidade torna-se imprescindível

${ }^{315}$ Cf. DERZI, Misabel Abreu Machado. Nota de Atualização. in BALEEIRO, Aliomar. Op. cit. (nota 06), P. 1249.

316 Misabel Abreu Machado Derzi dá preferência ao termo "praticidade". Respeitada sua posição, preferimos a palavra "praticabilidade", por trazer, etimologicamente, um significado ou conjunto de significação mais adequado à noção funcional exercida pelo Princípio da Praticabilidade. Assim é que por "praticidade" tem-se a característica de algo que é prático, i.e., de algo ou alguém habilidoso, experiente, traduzindo uma qualidade própria de uma pessoa, de um alguém que coloca em ação o conhecimento teórico, revelando, em suma, uma conduta humana. "Praticabilidade", por sua vez, é a qualidade ou característica do que é praticável, factível, exequível ou realizável. Revela, com isso, uma característica não de uma conduta humana, mas de uma situação ou conjunta de situações que objetivam dar condições para que algo seja realizado, executado. É substantivo que revela a possibilidade de algo ser feito ou de algo que pode acontecer (Cf. HOUAISS, Antônio; VILLAR, Mauro de Salles. Op. cit. (nota 34), P. 1536). 
nas hipóteses de fiscalização em massa, como ocorre com os tributos sujeitos a lançamento por homologação ${ }^{317}$.

Cita, como exemplo de norma constitucional em exercício da praticabilidade, o art. 150, $\S$ $7^{\circ}$, da CF, legitimando, segundo a autora, as antecipações de imposto, geralmente cobradas no interesse arrecadatório do Fisco, mas, também, em nome do combate à evasão, da otimização da fiscalização e da simplificação, tanto para o Fisco como para o contribuinte, do cumprimento das leis e dos procedimentos para apuração e recolhimento de imposto ${ }^{318}$.

Por meio de uma variedade de técnicas de presunções, simplificações, retenções, substituições, antecipações e outros tantos regimes facilitadores da execução do ordenamento jurídico como um todo, verifica-se que a praticabilidade está presente na função legislativa quando o legislador utiliza tais mecanismos com o objetivo de tornar exequível a própria vontade abstrata e genericamente prevista nas normas jurídicas ${ }^{319}$. Mais do que a efetiva subsunção do fato jurídico tributário ao antecedente da regra matriz ou a correta aplicação da hipótese tributária ao consequente, aqueles mecanismos que viabilizam a praticabilidade objetivam, em sua maior medida possível, atingir a teleologia da norma tributária ${ }^{320}$.

Sobre o tema, LUÍS CESAR SOUZA DE QUEIROZ ${ }^{321}$ admite o emprego da praticabilidade para tributação pelo IRF, de forma definitiva e isolada, para os casos de rendimentos pagos em favor de beneficiário residente ou domiciliado no exterior. O autor se mostra, todavia, absolutamente contrário à tributação na fonte para outras situações, como no caso de antecipação. Sobre o aludido artigo $150, \S 7^{\circ}, \mathrm{CF}$, norma que constitucionalizou a noção de fato gerador presumido, em que pese apontar que o STF já havia reconhecido a sua constitucionalidade para os fins específicos do $\mathrm{ICMS}^{322}$, o autor se coloca frontalmente

\footnotetext{
${ }^{317}$ Cf. DERZI, Misabel Abreu Machado. Nota de Atualização. in BALEEIRO, Aliomar. Op. cit. (nota 06), P. 1250 .

${ }^{318}$ Ibidem, Op. cit. (nota 06), P. 1250.

${ }^{319}$ Cf. GREGORIO, Ricardo Marozzi. Preços de Transferência - Arm's Lenght e Praticabilidade. in Série Doutrina Tributária Vol. V. São Paulo: IBDT/Quartier Latin, 2011. P. 271/274.

${ }^{320}$ Cf. ZILVETI, Fernando Aurélio. Simplicius Simplicissismus - os Limites da Praticabilidade diante do Princípio da Capacidade Contributiva. in Revista de Direito Tributário Atual no 22. São Paulo: IBDT/Dialética, 2008. P. 185.

${ }^{321}$ Cf. QUEIROZ, Luis Cesar Souza de. (nota 09), P. 310.

322 "EMENTA: TRIBUTÁRIO. ICMS. ESTADO DE SÃO PAULO. COMÉRCIO DE VEÍCULOS NOVOS. ART. 155, $2^{\circ}$, XII, B, DA CF/88. CONVÊNIOS ICM No 66/88 (ART. 25) E ICMS N 107/89. ART. 8, INC.
} 
contra a utilização deste dispositivo para fins do IR, por ofender aos princípios da igualdade e da capacidade contributiva objetiva e subjetiva, razão pela qual, em seu entendimento, não existe autorização, constitucional, para a tributação antecipada do IR.

Nos termos da decisão emanada pelo STF nos autos da ADIn 1.851-4/AL ${ }^{323}$, restou legitimado o artigo $150, \S 7^{\circ}$, da $\mathrm{CF}$, para os casos de substituição tributária "para frente" do ICMS, tratando o tal fato gerador presumido como sendo definitivo, i.e., não importa por qual valor a operação de circulação de mercadorias tenha ocorrido, sendo suficiente sua ocorrência. A constatação de diferença de valor entre a pauta fiscal fixada pelo Fisco e o valor efetivo da transação poderá resultar em prejuízo ou benefício para o Fisco. O menor grau de injustiça, neste caso, dependerá da maior participação do Estado na

XIII E $\S 4^{o}$, DA LEI PAULISTA $N^{o}$ 6.374/89. O regime de substituição tributária, referente ao ICM, já se achava previsto no Decreto-Lei $n^{\circ} 406 / 68$ (art. 128 do CTN e art. $6^{\circ}$, $\$ \$ 3^{\circ}$ e $4^{o}$, do mencionado decreto-lei), normas recebidas pela Carta de 1988, não se podendo falar, nesse ponto, em omissão legislativa capaz de autorizar o exercício, pelos Estados, por meio do Convênio ICM $n^{\circ} 66 / 88$, da competência prevista no art. 34, $\S 8^{\circ}$, do ADCT/88. Essa circunstância, entretanto, não inviabiliza o instituto que, relativamente a veículos novos, foi instituído pela Lei paulista $n^{\circ} 6.374 / 89$ (dispositivos indicados) e pelo Convênio ICMS $n^{o}$ 107/89, destinado não a suprir omissão legislativa, mas a atender à exigência prevista no art. $6^{o}$, $\$ 4^{o}$, do referido Decreto-Lei $n^{\circ}$ 406/68, em face da diversidade de estados aos quais o referido regime foi estendido, no que concerne aos mencionados bens. A responsabilidade, como substituto, no caso, foi imposta, por lei, como medida de política fiscal, autorizada pela Constituição, não havendo que se falar em exigência tributária despida de fato gerador. Acórdão que se afastou desse entendimento. Recurso conhecido e provido." (STF. Pleno. RE 213.396-5/SP. Rel. Min. Ilmar Galvão. DJ 01/12/2000).

323 "EMENTA: TRIBUTÁRIO. ICMS. SUBSTITUIÇÃO TRIBUTÁRIA. CLÁUSULA SEGUNDA DO CONVÊNIO 13/97 E $\$$ 6.$^{\circ}$ E 7. ${ }^{\circ}$ DO ART. 498 DO DEC. N. ${ }^{\circ} 35.245 / 91$ (REDAÇÃO DO ART. $1 .^{\circ}$ DO DEC. $N^{\circ}$ 37.406/98), DO ESTADO DE ALAGOAS. ALEGADA OFENSA AO \& 7. ${ }^{\circ}$ DO ART. 150 DA CF (REDAÇÃO DA EC 3/93) E AO DIREITO DE PETIÇÃO E DE ACESSO AO JUDICIÁRIO. Convênio que objetivou prevenir guerra fiscal resultante de eventual concessão do benefício tributário representado pela restituição do ICMS cobrado a maior quando a operação final for de valor inferior ao do fato gerador presumido. Irrelevante que não tenha sido subscrito por todos os Estados, se não se cuida de concessão de beneficio (LC 24/75, art. 2. ${ }^{\circ}$, INC. $2^{\circ}{ }^{\circ}$ ). Impossibilidade de exame, nesta ação, do decreto, que tem natureza regulamentar. A EC n. 03/93, ao introduzir no art. $150 \mathrm{da} C \mathrm{CF} / 88$ o $\$ 7 .^{\circ}$, aperfeiçoou o instituto, já previsto em nosso sistema jurídico-tributário, ao delinear a figura do fato gerador presumido $e$ ao estabelecer a garantia de reembolso preferencial e imediato do tributo pago quando não verificado o mesmo fato a final. A circunstância de ser presumido o fato gerador não constitui óbice à exigência antecipada do tributo, dado tratar-se de sistema instituído pela própria Constituição, encontrando-se regulamentado por lei complementar que, para definir-lhe a base de cálculo, se valeu de critério de estimativa que a aproxima o mais possível da realidade. A lei complementar, por igual, definiu o aspecto temporal do fato gerador presumido como sendo a saída da mercadoria do estabelecimento do contribuinte substituto, não deixando margem para cogitar-se de momento diverso, no futuro, na conformidade, aliás, do previsto no art. 114 do CTN, que tem o fato gerador da obrigação principal como a situação definida em lei como necessária e suficiente à sua ocorrência. O fato gerador presumido, por isso mesmo, não é provisório, mas definitivo, não dando ensejo a restituição ou complementação do imposto pago, senão, no primeiro caso, na hipótese de sua não-realização final. Admitir o contrário valeria por despojar-se o instituto das vantagens que determinaram a sua concepção e adoção, como a redução, a um só tempo, da máquina-fiscal e da evasão fiscal a dimensões mínimas, propiciando, portanto, maior comodidade, economia, eficiência e celeridade às atividades de tributação e arrecadação. Ação conhecida apenas em parte e, nessa parte, julgada improcedente." (grifamos) (STF. Pleno. ADI 1851/AL. Rel. Min. Ilmar Galvão. DJ 22/11/2002). 
fiscalização e verificação concreta dessas transações, mas, em tese, isso resultaria em custos excessivamente altos para o Estado.

Queremos crer que este entendimento, da forma como transcorrido no julgamento acima, não pode ser aplicado indistintamente ao caso do IR, caso contrário resultaria em tratar como definitivas todas as antecipações feitas sob a sistemática do IRF, podendo a Administração proceder a um ajuste final em nome da economicidade, eficiência e comodidade. Admitir isso, excetuadas as hipóteses de tributação definitiva e isolada, seria desconfigurar a natureza pessoal e progressiva do IR, inviabilizando a tomada da capacidade contributiva individual dos contribuintes. Daí a necessidade de aquelas antecipações serem igualmente consideradas ao final do período de apuração, deduzindo-se integralmente do imposto apurado como devido.

A um certo ponto de sua obra, após ilustrar que o STF legitimou a substituição tributária "para frente" do ICMS, Misabel Abreu Machado DeRzi questiona se uma norma hierarquicamente inferior poderia converter em presunção o que dispõe outra norma, de hierarquia superior. Noticia que a doutrina estrangeira costuma chamar esse efeito padronizante como um modo de pensar "tipificante", de forma a abandonar as peculiaridades de cada tributo ou de cada caso concreto por um padrão médio ou por uma média presumivel das operações ${ }^{324}$.

Informa que a doutrina alemã, após intenso exame dos seus efeitos e considerando a oposição gerada, em muitos casos, entre legalidade e praticabilidade, admitiu-se a preponderância do modo de pensar "padronizante" e um afrouxamento do princípio da legalidade, retomando a ideia de sopesamento a que nos referimos anteriormente. Concluise que a norma de pensar "padronizante", como sendo um dos vetores possíveis da praticabilidade, vem como tentativa de solução àquele impasse, em nome da economia administrativa, caso se direcionasse pela aplicação da norma tributária a cada caso individual concreto ${ }^{325}$.

\footnotetext{
${ }^{324}$ Cf. DERZI, Misabel Abreu Machado. Nota de Atualização. in BALEEIRO, Aliomar. Op. cit. (nota 06), P. $1256 / 1257$.

${ }^{325}$ Ibidem, Op. cit. (nota 06), P. 1262/1266.
} 
Esse modo de pensar "tipificante", através de um esquema, padrão ou, na linguagem do Professor GERD WILLI ROTHMANN ${ }^{326}$, um standard, objetiva uma padronização simplificadora, de forma a evitar a aplicação individual do Direito. A praticabilidade, por sua vez, ao ser empregada com relação ao IR, deverá estar alicerçada por outros dispositivos que permitam atender, antes de concluído o ciclo de formação do imposto, aos índices de pessoalidade e individualidade de cada contribuinte.

Dessa forma, é preciso, contudo, estabelecer limites e restrições à praticabilidade. Para sua aplicação não serão suficientes razões de conveniência ou de rentabilidade, fazendo-se imprescindível a caracterização do estado de necessidade ou que sua adoção não importe em situações de injustiça, tratando um pequeno número de contribuintes de uma determinada forma, em prejuízo de outro grupo de contribuinte em maior número ${ }^{327}$.

Nessa linha, apoiada na obra de Josef IsEnsse, Misabel Abreu Machado Derzi ${ }^{328}$ destaca algumas regras às quais tal esquema padronizante deve limitar-se:

- $\quad$ restringir-se ao mínimo necessário, proibindo-se os excesso;

- $\quad$ respeitar os direitos fundamentais, baseando-se em tipos que se formam de acordo com a representação daquilo que for normal;

- $\quad$ limitar-se a uma tributação pela média dos valores, vedando-se que o método se transforme em instrumento de política fiscal, de redistribuição de renda ou de benefícios e isenções tributárias;

- $\quad$ estabelecer critérios uniformes que não podem variar de repartição para repartição;

\footnotetext{
${ }^{326}$ Cf. ROTHMANN, Gerd Willi. O "Standard” Jurídico. São Paulo: Revista dos Tribunais Vol. 371, 1966. P. $12 / 15$.

${ }^{327}$ Regina HeLena Costa evidencia que, na medida em que o legislador deve buscar o ponto de equilíbrio entre justiça e praticabilidade, a praticabilidade deve realizar a justiça viável ou exequível, devendo ser observados os seguintes limites: (i) a veiculação da praticabilidade deve atender ao princípio da legalidade veiculação por lei - e observar os princípios da capacidade contributiva e da razoabilidade, bem como a repartição constitucional das competências tributárias; (ii) não podem ser adotadas presunções absolutas ou ficções para fins de instituição de obrigações tributárias; (iii) tais regras simplificadoras devem ser transparentes e opcionais, bem como devem apresentar as justificativas que lhe fundamentam, dentre outros (Cf. COSTA, Regina Helena. Op. cit. (nota 06), P. 398/406).

${ }^{328}$ Cf. DERZI, Misabel Abreu Machado. Nota de Atualização. in BALEEIRO, Aliomar. Op. cit. (nota 06), P. $1266 / 1267$.
} 
- $\quad$ fixar pautas de valores, somatórios ou presunções que devem obrigar a própria Administração, a qual, por imperativo do Estado de Direito, não pode deles se afastar;

- dar ampla publicidade aos padrões, esquemas e pautas de valores, os quais não podem constar de orientações internas secretas.

Sem prejuízo dos efeitos e consequências gerados em cada um dos regimes jurídicos do IRF, o emprego do princípio da praticabilidade, como vetor constitucional dessa sistemática de pagamento antecipado do IR, não pode ser analisado isoladamente, sob o risco de tratar este princípio como valor superior em toda e qualquer situação concreta em que o IRF ocorre.

A análise deve ser caso a caso. Isso, entretanto, não afasta a oportunidade de alinharmos algumas conclusões.

Primeiramente, no regime de retenção na fonte por antecipação, queremos crer que, ao lado de sua autorização constitucional, o legislador preocupou-se em fornecer as ferramentas de ajustes necessários para que, quando da apuração final, no caso de contribuintes pessoas físicas, o imposto apurado aproxime-se, na maior medida possível, dos ideais formados pelos princípios da progressividade, da capacidade contributivo-econômica e da noção do mínimo existencial. A praticabilidade exerce um papel fundamental, na medida em que, respeitados os contornos constitucionais e também a noção conceitual de renda, permite que, dentre muitas outras razões já apresentadas neste trabalho, o Fisco consiga acessar determinados rendimentos reveladores de capacidade contributiva e financeira, de signos presuntivos de renda, em periodicidade inferior ao prazo ordinário para apuração do IRPF. A retenção na fonte, neste caso, objetiva não apenas facilitar as providências por parte dos contribuintes e do Fisco (comodidade fiscal), mas, também, proporcionar receitas em periodicidade mensal, imprescindíveis para que o Estado promova gastos e pagamentos na mesma periodicidade, em perfeita harmonia entre o ciclo da atividade privada e o funcionamento da máquina pública nos diferentes níveis da Administração.

No regime de retenção exclusiva na fonte, a discussão sobre a sua constitucionalidade é mais nebulosa. Para o grupo dos beneficiários não residentes, há um claro indicativo de 
estado de necessidade, tendo em vista que o momento de remessa para o exterior é, em regra, o último instante em que o Fisco brasileiro poderá tributar aquela específica riqueza, sem prejuízo, contudo, em caso de descumprimento da obrigação legal de pagamento do imposto, de constranger o patrimônio da pessoa indicada por lei como responsável tributário lato sensu.

Esse estado de necessidade parece não se repetir com a mesma clareza quando o cenário é de um beneficiário residente no Brasil, devendo a análise, nestes casos, encontrar outros fundamentos de validade que o justifiquem.

Da discussão sobre o tema, uma questão se faz pertinente: Se o Fisco tem plenas condições de acessar aquela riqueza quando do término do período de apuração do IRPF, por que não tributá-la conjuntamente com as demais rendas, sob as mesmas alíquotas progressivas? A resposta como sendo para fins meramente arrecadatórios soa óbvia, fazendo-se necessário um processo de investigação mais cuidadoso.

De fato, é minimamente razoável concluir que, para os casos de retenção exclusiva na fonte, o elemento "estado de necessidade" não parece ser uma justificativa de fácil identificação, obrigando a uma análise caso a caso. Como se trata de casos diferentes, essa análise será concluída em nossos comentários no Capítulo IV.

De toda forma, tratar esse regime do IRF como uma sistemática opcional seria uma solução bastante prática para harmonização (i) dos benefícios, vantagens e prejuízos proporcionados com este regime de tributação exclusiva na fonte, via retenção, (ii) com os direitos e garantias fundamentais dos contribuintes seria.

A praticabilidade parece exercer uma função muito mais arrecadatória do que qualquer outra coisa. É certo afirmar que praticabilidade não se confunde com extrafiscalidade, mas também não é menos certo asseverar que o legislador determina, através deste regime de retenção exclusiva na fonte, um tratamento distinto entre os rendimentos produzidos pelo trabalho e os rendimentos derivados do capital, revelando um elemento de discrímen notadamente de conteúdo econômico. Há, certamente, um elemento indutor, na medida em que, regra geral, concede tratamento fiscal mais benéfico a determinadas atividades 
econômicas e aos beneficiários não residentes. Argumentos associados a políticas cambiais e à definição da taxa de juros também se destacam como critérios indutores, na medida em que estão associados a instrumentos de captação de divisas estrangeiras, tanto para o financiamento de investimentos operacionais (infraestrutura) como para fomento das poupanças internas de longo prazo.

A praticabilidade, como fundamento destes pagamentos antecipados de natureza estritamente tributária, deverá, sempre e obrigatoriamente, ser observada em consonância com outros dois princípios de igual valor, a razoabilidade e a proporcionalidade, e também aos postulados da necessidade e da adequação ao fim pretendido $^{329}$, valores estes que atuam tanto a favor como de forma limitadora às práticas do Fisco e dos contribuintes. Queremos crer que afirmar a preponderância da praticabilidade não significa se sobrepor ou anular a relevância do ciclo de formação do fato gerador do IR. É justamente nesse ambiente complexo que a praticabilidade se insere, tentando buscar simplicidade, eficiência e justiça fiscal, sem que um volumoso número de contribuintes seja submetido ao cumprimento de diversos deveres instrumentais e ao recolhimento, por ele próprio, de parcelas mensais de imposto.

\subsubsection{O IRF e o Aspecto Temporal}

A periodicidade é pressuposto para tributação da renda? Ou trata-se de uma concessão à praticabilidade? Assumindo que a praticabilidade deve prevalecer e, com isso, a periodicidade pode servir-lhe para orientar ou que deve ser considerado como um pressuposto da capacidade contributiva, qual seria o prazo razoável para apuração e recolhimento do IR? Em que medida a praticabilidade deve, se é que deve, a atender às necessidades do Fisco de arrecadar, sob o manto de um princípio de interesse publico?

Da mesma forma que o legislador escolhe o período em que deverá ser feita a apuração se houve aquisição de acréscimo patrimonial, deve-se compreender a eleição de outros momentos como suscetíveis para justificar o pagamento antecipado de imposto, como sói ocorrer nos casos do IRF.

${ }^{329}$ Cf. ÁVILA, Humberto. Op. cit. (nota 302). 
A natureza periódica é elemento essencial do IR. Ainda que seu fato gerador seja instantâneo, a formação da base de cálculo estabelece-se numa medida de tempo e não em um momento isolado. Significa dizer que essa formação ocorre em certo período de tempo e somente se consome ao término desse lapso ${ }^{330}$. Mas nem por isso podemos admitir que, apenas ao término desse período de formação, a relação jurídica entre sujeito passivo e Estado se instaura e ganha contornos de uma relação obrigacional. Como veremos mais adiante, a assunção da característica de imposto devido, e não meramente de natureza antecipatória, é mais uma questão associada ao elemento temporal eleito pelo legislador, do que por uma razão de materialização dos demais elementos que preenchem o fato gerador do IR, já analisados acima.

As realidades escolhidas pelo legislador como suficientes para gerar as hipóteses de retenção na fonte, com o consequente recolhimento e pagamento antecipado de imposto de renda, correspondem, efetivamente, a situações indicadoras de um rendimento disponível e realizado, em que foi gerado um possível aumento patrimonial (signo presuntivo de renda), e que, certamente, revelam a existência de uma capacidade contributivo-econômica.

O tema, todavia, não encontra consenso na doutrina.

PAUlo Ayres BARReto explica a imprescindibilidade de que o lapso temporal seja adequado para permitir um efetivo cotejo entre receitas, custos e despesas, uma vez que um prazo muito exíguo tende a comprometer até mesmo o conceito de renda. Ilustra que, caso se considere apenas as receitas verificadas em um único trimestre, em desproporção às despesas incorridas ao longo do ano, pode-se ensejar uma tributação sobre o patrimônio e não sobre o acréscimo patrimonial ${ }^{331}$.

LUCIANO AMARO postula que, se a apuração for realizada em períodos de apuração por prazos mais longos, os efeitos de pico tendem a ser neutralizados. Por esta razão, a adoção de períodos de apuração em prazos menores, por exemplo um mês, depende da adoção de técnicas de ajustes, sem olvidar o necessário respeito aos princípios constitucionais ${ }^{332}$.

\footnotetext{
${ }^{330}$ Cf. AMARO, Luciano. Op. cit. (nota 189), P. 348/349.

${ }^{331}$ Cf. BARRETO, Paulo Ayres. Op. cit. (nota 156), P. 80.

${ }^{332}$ Cf. AMARO, Luciano. Op. cit. (nota 202), P. 42/46.
} 
Sensibilizado com as lições de RUBEnS GOMES DE SousA (A Evolução do Conceito de Rendimento Tributável. RDP $\mathrm{n}^{\circ}$ 14, 1970. P. 339/340) que, com sutileza, revela a relação íntima entre o núcleo material da tributação do IR, associado à noção de acréscimo patrimonial e o elemento temporal, ROBERTO QUIROGA MOSQUERA afirma que, por menor que seja o lapso temporal adotado, ele nos permite verificar se houve ou não incrementos aos elementos patrimoniais, podendo esse período de tempo ser um ano, um mês, uma semana, um dia, uma hora ou um segundo. No interregno de tempo escolhido será possível averiguar se, num conjunto de direitos, houve decréscimo, acréscimo ou se houve manutenção do patrimônio anterior ${ }^{333}$.

Sacha Calmon Navarro Coelho aponta que, por razões de simplicidade e praticabilidade, o IRPF vem se tornando um imposto de "bases-correntes", com a prevalência da técnica do desconto na fonte, ainda que essas mudanças impliquem o sacrifício dos princípios da progressividade e da capacidade contributiva ${ }^{334}$.

A Constituição Federal não determina qual deva ser o período de tempo adequado, ainda que em vários de seus dispositivos se verifiquem referências à noção de um período anual, seja por meio da palavra "ano", seja com o termo "anual" ou suas variações tais como anos, plurianual etc. (artigos 5 , LXX, "b", 7, XXV, XXIX, "a" e "b", XXXIII, 8 , VIII,

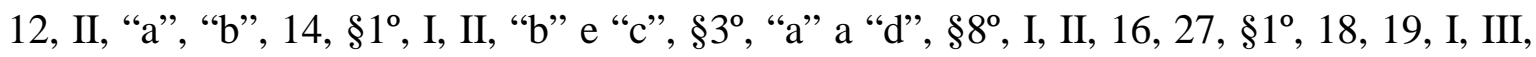

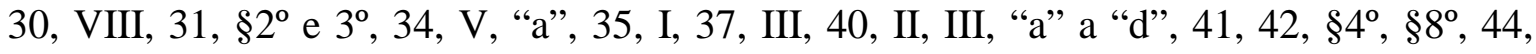
parágrafo único, $45, \S 1^{\circ}, 46, \S 1^{\circ}, \S 2^{\circ}, 48$, II, 49, IX, 52, parágrafo único, 57, $4^{\circ}, 58,71, \mathrm{I}$, $\S 4^{\circ}, 73, \S 1^{\circ}, \mathrm{I}, \mathrm{IV}, \S 3^{\circ}, 74, \mathrm{I}, 81, \S 1^{\circ}, 82,84, \mathrm{XXIII}, \mathrm{XXIV}, 87, \mathrm{III}, 89$, VII, 93, II, “b”, VI, 94, 95, 98, II, 101, 104, parágrafo único, 197, I, II, 111, §1 ${ }^{\circ}, 117,121, \S 2^{\circ}, 123$, parágrafo único, I, 128, §1 ${ }^{\circ}, \S 3^{\circ}, \S 5^{\circ}, \mathrm{I}$, “a”, $131, \S 1^{\circ}, 153, \S 2^{\circ}, \mathrm{II}, 165, \mathrm{I}, \S 1^{\circ}, \S 2^{\circ}, \S 4^{\circ}$ a $\S 9^{\circ}, \mathrm{I}, 166$, $\S 1^{\circ}, \mathrm{I}, \S 3^{\circ}, \mathrm{I}, \S 4^{\circ}, \S 6^{\circ}, \S 8^{\circ}, 167, \mathrm{I}, \S 1^{\circ}, 182, \S 4^{\circ}, \mathrm{III}, 183, \S 4^{\circ}, 184,189,191,192, \S 3^{\circ}, 201$,

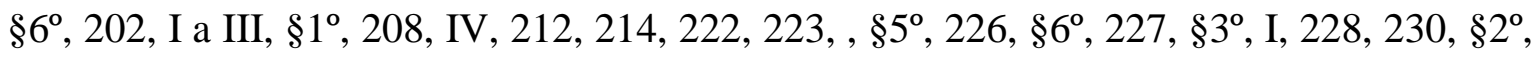

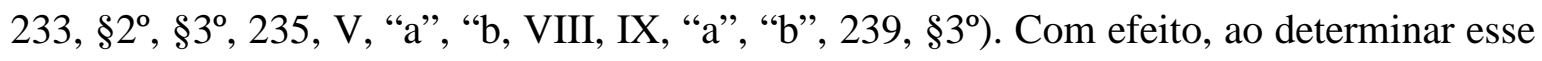
período de tempo, mormente quando inferior a um ano, o legislador infraconstitucional não

\footnotetext{
${ }^{333}$ Cf. MOSQUERA, Roberto Quiroga. Op. cit. (nota 125), P. 113/114.

${ }^{334}$ Cf. COELHO, Sacha Calmon Navarro. O Imposto de renda - Liber Amicorum in Honor do Prof. Paulo de Barros Carvalho. in Direito Tributário - Homenagem a Paulo de Barros Carvalho. Coord. Luís Eduardo Schoueri. São Paulo: Quartier Latin, 2008. P. 287.
} 
é livre, obrigando-se a fixar marcos (inicial e final) suficientes para a realização do confronto de entradas e saídas ${ }^{335}$.

Visceralmente contra a sistemática de pagamento definida pelo IRF, MARY ELBE QUEIROZ postula que, considerando tratar-se de fato gerador do tipo instantâneo, resta concluir que o nascimento da obrigação tributária se dá, para as pessoas físicas, no dia 31/12 de cada ano, ou, para as pessoas jurídicas, no mesmo dia 31/12 ou, na hipótese de tributação pelo regime de lucro real, no último dia de cada trimestre do ano civil ${ }^{336}$.

Por seu turno, a despeito de reconhecer que a tributação da renda na fonte encontra suporte constitucional ao menos em alguns casos, RiCARDo MARIZ DE OLIVEIRA é firme em afirmar que a técnica de arrecadação encampada pelo IRF, a todo rigor jurídico, não foi recepcionada no regime constitucional de 1988, porque ofende os princípios da universalidade, com a tributação de situações isoladas de aquisição de disponibilidade jurídica de renda ou provento, o que invariavelmente acaba por contrariar o princípio da progressividade. Este mesmo autor aponta que essa tributação de fatos isolados, antes da completude do fato gerador, i.e., antes do encerramento do período de apuração, pode implicar a desconsideração de fatores positivos e negativos que influenciarão na mutação patrimonial da massa universal de direitos que compõe aquele mesmo patrimônio ${ }^{337}$.

Como vimos, as ferramentas de ajuste ao término do período de apuração, associadas à ponderação de outras prioridades materializadas, grosso modo, no princípio da praticabilidade e no necessário respeito, na maior medida possível, aos demais princípios constitucionais, mormente à capacidade contributiva, à vedação da tributação com efeitos de confisco e à segurança jurídica, autorizam, a nosso ver, a adoção de período de tempo menores para apuração do IR via regime de retenção na fonte, como antecipação do imposto devido.

A análise sobre a relevância do aspecto material, no âmbito do IRF, torna-se mais palpável diante do regime de retenção na fonte por antecipação, já que, no regime de retenção exclusiva, o valor retido é tratado de forma definitiva, isolando-se das demais

\footnotetext{
${ }^{335}$ Cf. GONÇALVES, José Artur Lima. Op. cit. (nota 31), P. 185/186.

${ }^{336}$ Cf. QUEIROZ< Mary Elbe. Op. cit. (nota 90), P. 412.

${ }^{337}$ Cf. OLIVEIRA, Ricardo Mariz de. Op. cit. (nota 16), P. 493/500.
} 
quantificações de fatos-acréscimos e fatos-decréscimos verificados ao final do exercício. Significa dizer que, em razão de sua autonomia, no sentido de estarem desvinculados da declaração anual de ajuste, os valores retidos sob este regime adota, como aspecto temporal suficiente, um daqueles eventos (pagamento, crédito, entrega, remessa ou emprego) eleitos pelo legislador infraconstitucional como adequados para acionar o gatilho do IR exclusivo de fonte.

A esse respeito o STJ já se posicionou conforme se observa da decisões transcritas a seguir:

“TRIBUTÁRIO - IMPOSTO DE RENDA - HIPÓTESE DE INCIDÊNCIA AGRAVO REGIMENTAL - ANTECIPAÇÕES - RECOLHIMENTO POSSIBILIDADE.

1. O fato gerador do Imposto de Renda realiza-se no decorrer do ano-base ao qual se refere sua declaração (ato complexo). Ou seja, não ocorre ele no último dia do exercício financeiro em relação ao qual deve o contribuinte realizar a apuração do eventual quantum devido.

2. É no transcorrer do ano de referência que se verificam as disponibilidades econômicas e jurídicas que justificam a tributação da renda; podendo, por conseguinte, ser ela antecipada, de forma que sua apuração final poderá ser postergada para o ano seguinte."

(STJ. 2a Turma. AgRg no REsp no 281.088/RJ. Rel. Min. Humberto Martins. DJ 29/06/2007)

“TRIBUTÁRIO. IMPOSTO DE RENDA. PESSOA JURÍDICA. ANTECIPAÇÃO. DECRETO-LEI 2.354/87. O fato gerador do imposto de renda é a disponibilidade econômica ou jurídica que, no caso da pessoa jurídica, é adquirida no decorrer do exercício social, pelo que o Fisco pode exigir o recolhimento antecipado do tributo. Precedentes."

(STJ. REsp 37.532-0. Rel. Min. Américo Luz. DJU 10/04/1995)

Neste julgados, o STJ aponta que a disponibilidade da renda, no caso do lucro já que referente à pessoa jurídica, é adquirida ao longo do ano, justificando o recolhimento 
antecipado de tributos por meio de retenções na fonte. Nas duas decisões aqui referidas o julgador é uniforme ao apontar que a disponibilidade é verificada em bases correntes, sem, contudo, entrar no mérito se houve ou não aquisição de acréscimo patrimonial. No primeiro caso, mais recente, o julgador alude à ideia de que o fato gerador do IR seria complexo, não se verificando unicamente no último dia do exercício financeiro. conforme já tivemos a oportunidade de discorrer no presente trabalho, o fato gerador do IR é do tipo instantâneo, i.e., ocorre no último dia do ano.

“IMPOSTO DE RENDA - ANTECIPAÇÕES - DECRETO-LEI N. 2.354/87.

$O$ imposto de renda tem como fato gerador a aquisição da disponibilidade econômica ou jurídica de renda (CTN, artigo 43, inciso I). No caso, esta disponibilidade e adquirida pela pessoa jurídica ao longo do exercício social é pode o Fisco exigir o seu pagamento antecipado, a exemplo do que acontece com as retenções na fonte, no recebimento mensal de salários ou vencimentos. Recurso provido."

(STJ. $1^{\text {a }}$ T. REsp no 56.220/RS. Rel. Min. Garcia Vieira. DJ 06/02/1995)

No regime de retenção na fonte por antecipação, toma-se, como premissa, a verificação de quase todos os elementos necessários à ocorrência do fato gerador do IR, à exceção de apenas um, que é exatamente o aspecto que separa o IRF retido por antecipação do imposto pago na qualidade de imposto devido. Este aspecto é, como já apontamos, o aspecto temporal eleito pelo legislador como marco final para fins de mensuração do acréscimo patrimonial verificado até aquela data, o que não significa dizer que até aquele exato momento não houve acréscimo patrimonial, muito menos, que após aquele prazo, seja um mês, um trimestre ou um ano, não será possível aferir esse acréscimo.

Não se quer dizer que há necessário acréscimo patrimonial em todo e qualquer rendimento auferido pelo contribuinte do IR. O beneficiário, alvo da retenção na fonte, recebe rendimento, a partir do qual é possível aferir parte dos elementos suficientes para permitir averiguar se aquele rendimento atende aos pressupostos de aquisição (i) de sua disponibilidade e (ii) de acréscimo patrimonial, ao menos de sua presunção. Aquele rendimento é signo presuntivo de renda e indica que, possivelmente, ao término do período de apuração, haverá renda tributável, porém, jurídica e conceitualmente ainda não é renda. 
De toda forma, além de corresponder a uma riqueza nova e não apenas de uma recomposição do status quo patrimonial medido em um momento anterior, o beneficiário pode dispor dos recursos recebidos da forma que melhor lhe aprouver ${ }^{338}$.

O aspecto temporal, eleito pelo legislador, ainda que seja parte indissociável da hipótese tributária do IR, exerce importância dupla, em função das prévias retenções na fonte:

i. primeiramente, ao atender aos ideais de eficácia e eficiência da Administração no tocante à fiscalização e à arrecadação tributária, permite que sejam recolhidas antecipações aos cofres públicos, por ser ferramenta indispensável na gestão da máquina pública e no combate à evasão;

ii. precisamente em função daquelas antecipações e de forma a apurar a evolução patrimonial do contribuinte em um lapso temporal mais uniforme, abrindo espaço para a mensuração de eventual perda incorrida nesse período, vislumbra-se uma sistemática que autoriza a compensação das antecipações realizadas e eventual restituição. Sob essa perspectiva, assim como permite a derradeira mensuração do acréscimo patrimonial (se houver), culminando com o aperfeiçoamento do fato gerador do Imposto sobre a Renda - ferramenta de ajuste -, o aspecto material, concomitantemente, prestigia a mitigação dos efeitos maléficos em caso de rendimentos sazonais.

Ambas, tanto as datas definidas para fins de recolhimento antecipado do IRF como também a data definida como marco final para cálculo do acréscimo patrimonial no chamado período-base, com a apuração definitiva do imposto devido, correspondem a procedimentos técnico-legislativos. Tais procedimentos atendem a uma gama de justificativas de índole mais sócio-econômica e política do que jurídico-tributária propriamente dita, e permitem, não de uma maneira perfeita ou muito menos isenta de críticas, um maior equilíbrio entre os interesses do Fisco, da sociedade e dos contribuintes, assim como o convívio harmonioso da ampla rede de regras, normas e regimes de tributação associadas ao IR.

${ }^{338}$ Cf. MOSQUERA, Roberto Quiroga. Op. cit. (nota 125), P. 108/112. 
Já comentamos que, no regime de retenção na fonte por antecipação. o IRF recolhido de forma antecipatória não assume a natureza de imposto devido. Trata-se de forma de cálculo equivalente, porém os valores apurados correspondem a meras antecipações. Diferentemente do que sustentou Roberto QUIROgA MOSQUERA ${ }^{339}$, o IRF, especificamente sob o regime de retenção como antecipação, não é um algo autônomo, posto que está estritamente vinculado à declaração de ajuste anual. Tanto é assim que, repetimos, a legislação e a própria sistemática de apuração e declaração do IR, de forma definitiva, permitem não apenas a utilização daquelas antecipações para compensação com o imposto devido, mas, também, a restituição daqueles montantes retidos/recolhidos a maior, antecipadamente.

O IRF retido por antecipação tem sua origem na verificação dos princípios da capacidade contributiva e da realização da renda, assim como no preenchimento dos demais elementos caracterizadores do fato gerador do IR (à exceção do aspecto temporal definido pelo legislador). A análise sistemática e conjunta dessas observações é que permite apontar algumas conclusões acerca da natureza daqueles valores retidos:

a. Há a realização de uma disponibilidade, econômica ou jurídica;

b. Verifica-se a produção de acréscimo patrimonial a partir da realização daquela disponibilidade ${ }^{340}$, ou, nas palavras de RICARDO MARIZ DE OLIVEIRA, as aquisições de disponibilidade econômica ou jurídica de rendas e proventos não correspondem exatamente ao elemento temporal do fato gerador, mas se constituem em fatos participantes do próprio aumento patrimonial, indicadores da circunstância de que cada um desses fatos está completo, tendo produzido aumento patrimonial ${ }^{341}$;

c. Quando da apuração e declaração do imposto devido, vislumbra-se a garantia da possibilidade de o contribuinte utilizar aquele crédito retido, dada a natureza antecipatória do IRF - ferramenta de ajuste;

\footnotetext{
${ }^{339}$ Cf. MOSQUERA, Roberto Quiroga. Op. cit. (nota 210), P. 142.

${ }^{340}$ Oportuno esclarecer, todavia, que o acréscimo patrimonial a que nos referimos, medido em uma escala de tempo (mês) menor que aquela definida no aspecto temporal do fato gerador do IR (ano), é tomado, neste evento de retenção, de forma isolada; quando da apuração, poderá ser verificado que ainda há saldo de imposto a pagar ou, ao contrário, saldo de imposto a restituir; para ambas as situações, como já dissemos, o legislador fornece os meios e as ferramentas necessários para que se atinja o equilíbrio das relações entre Fisco e contribuinte.

${ }^{341}$ Cf. OLIVEIRA, Ricardo Mariz de. Op. cit. (nota 171), P. 225.
} 
d. Há a mensuração, em sua maior medida possível ${ }^{342}$, da capacidade contributiva do contribuinte, com ênfase em uma disponibilidade financeira;

e. A obrigatoriedade de recolhimento do IR decorre não apenas do atendimento a um mandamento legal, mas, também, da averiguação daqueles outros elementos mencionados nas letras acima. Esses fatores, associados às outras razões vinculadas ao princípio da praticabilidade exposto acima, é que determinam a obrigatoriedade de recolhimento do IR, ainda que não tenha se encerrado o ciclo de formação do seu fato gerador (base de cálculo complexa);

f. A garantia legal da retenção do montante do imposto a ser pago pela fonte pagadora permite que o ônus fiscal-financeiro atinja o patrimônio do contribuinte, único e exclusivo beneficiário da renda que lhe proporcionou um acréscimo patrimonial, ao mesmo tempo que permite a preservação patrimonial da fonte pagadora, definida, por lei, como devedora do imposto;

g. Em linha com o que foi apontado na letra "e" acima, justamente por decorrer de uma obrigação legal, a omissão por parte da fonte tem o condão de gerar não apenas a exigência do recolhimento do imposto (cujos recursos foram previamente retidos), mas, também, os demais encargos moratórios, inclusive com a aplicação de multa por descumprimento de obrigação legal de efetuar a retenção (correspondente ao imposto que assume a natureza antecipatória), sem prejuízo das demais penalidades aplicáveis de natureza não pecuniária.

Em linha com as conclusões arroladas acima, é possível depreender que a fonte deve cumprir a obrigação legal de recolher o IR (valendo-se, contudo, da faculdade da retenção do valor devido) em nome de terceiro, que corresponde ao recolhimento de IR vinculado exclusivamente à pessoalidade do contribuinte ${ }^{343}$. O descumprimento dessa obrigação

\footnotetext{
${ }^{342}$ Vale ponderar, contudo, de forma a tornar essa maior medida possível mais eficaz, que os dispêndios ou fatos-decréscimos com educação e gastos com despesas médicas incorridos no mês deveriam ser igualmente considerados para fins de apuração do quantum das retenções. Não se olvida, contudo, especialmente com relação aos gastos médicos, que essa possibilidade poderia inviabilizar a eficiência e a eficácia, próprios dessa sistemática de pagamento antecipado do IR, exigindo maior controle e fiscalização por parte das autoridades fiscais.

${ }^{343}$ Por isso não aceitarmos o posicionamento de SACHA CALMON NAVARRo CoÊLHO, que insiste em sua tese que a fonte pagadora é sujeito passivo direto, por estar pagando dívida própria, ainda que não tenha realizado o fato gerador. Para nós, a par das premissas traçadas sobre o fato gerador da obrigação tributária e a divisão insculpida pela ótica dualista da obrigação, não faz sentido a distinção veiculada pelo celebrado jurista mineiro (Cf. COÊLHO, Sacha Calmon Navarro. Sujeição Passiva Direta e Indireta - Substituição Tributária. in Grandes Questões Atuais do Direito Tributário. Vol. 13. Coord. Valdir de Oliveira Rocha. São Paulo: Dialética, 2009. P. 357 e ss).
} 
alheia gera a obrigatoriedade de recolhimento não apenas do IR outrora apurado, mas, também, do pagamento de multa, justamente, em ambos os casos, por se tratar de não observância de norma legal.

\subsubsection{Capacidade Contributiva e a Retenção}

O princípio da capacidade contributiva, chamado por alguns juristas de peso de princípio da capacidade econômica, com foco na ideia do mínimo existencial ${ }^{344}$, alude ao contribuinte ou de quem figura no polo passivo da relação jurídica tributária?

Conforme já tivemos a oportunidade de destacar, o princípio constitucional tributário em tela é do contribuinte e a ele se volta, e não a outros terceiros eleitos como pagadores de tributo alheio. São os direitos do contribuinte que deverão ser tutelados pelo princípio da capacidade contributiva, mas nem por isso tornam-se inconstitucionais ou não válidas as figuras do responsável tributário ou do substituto tributário, ou mesmo do agente de retenção, conforme o caso. Como teremos a oportunidade de demonstrar ao longo do presente trabalho, o instituto da retenção ratifica o princípio da capacidade contributiva, à medida que permite a transferência do ônus tributário da exata quantia dos valores $\operatorname{retidos}^{345}$.

A substituição tributária, como veremos, não exclui a figura ou a subjetividade do contribuinte, pelo contrário, a pressupõe, na medida em que releva verificar quem incorreu no fato gerador e de quem é a capacidade contributiva ${ }^{346}$. No caso da substituição tributária, apenas sua responsabilidade é excluída. A única tributação possível é aquela pretendida pela lei, de forma que a colocação de um terceiro na qualidade de responsável pelo recolhimento do imposto tem sempre de respeitar o princípio da capacidade contributiva, obrigando o legislador a encontrar e disponibilizar os meios necessários para que este terceiro não sofra uma diminuição patrimonial em virtude da prestação devida ao Estado por outrem. O terceiro, como veremos, substituto tributário ou agente de retenção, deve ter instrumento que lhe permita onerar o sujeito que causou o fato tributário, i.e., que

\footnotetext{
${ }^{344}$ Neste sentido KLAUS TIPKE (TIPKE, Klaus, e YAMASHITA, Douglas. Op. cit. (nota 99) ) e FERNANDO Aurélio Zilveti (ZILVETI, Fernando Aurélio. Op. cit. (nota 98), P. 36/37).

${ }^{345}$ Cf. FEIO, Diogo. Op. cit. (nota 310), P. 40/41.

${ }^{346}$ Ibidem, Op. cit. (nota 310), P. 63.
} 
realizou o verbo indicativo da titularidade de uma riqueza tributável ${ }^{347}$. Entendemos claramente que o instituto da retenção na fonte é instrumento que realiza com segurança e perfeição o princípio da capacidade contributiva, com a exata transferência do ônus financeira do encargo fiscal ao patrimônio do contribuinte.

${ }^{347}$ Ibidem, Op. cit. (nota 310), P. 63. 


\section{CAPÍTULO III - O ASPECTO SUBJETIVO DO FATO GERADOR DA OBRIGAÇÃO TRIBUTÁRIA}

Passamos à segunda parte de nosso trabalho, onde analisaremos a natureza jurídica da retenção na fonte do IR sob a perspectiva da fonte pagadora, de forma a verificar se a fonte assume a figura de um agente de retenção ou, ao contrário, na qualidade de legítimo sujeito passivo indireto, insere-se na posição de substituto tributário ou de responsável stricto sensu. Conforme veremos, a identificação precisa do figurino assumido pela fonte pagadora estará umbilicalmente ligada ao regime jurídico sob o qual a retenção é realizada.

Neste Capítulo III, apoiados nas premissas traçadas no capítulo inicial, onde abordamos as noções de antecedente e consequente e de relação jurídica tributária, nossos estudos serão direcionados, em um primeiro momento, para identificação do aspecto subjetivo da regra matriz. Em que pese nosso foco ser o sujeito passivo, a definição conceitual do sujeito ativo será relevante e servirá de ferramenta para uma possível aproximação com a figura do agente de retenção. No âmbito da sujeição passiva, estaremos diante da figura do contribuinte e do instituto da responsabilidade tributária, que nada mais é do que a condição de colocar uma pessoa como obrigada a pagar tributo, diretamente relacionado com o consequente da regra matriz ${ }^{348}$.

Delineados estes contornos, procuraremos detalhar as características fundamentais das figuras do agente de retenção e do substituto tributário, de forma a gerar ferramentas que nos permitam, no Capítulo IV, precisar qual roupagem veste a fonte pagadora em cada uma das situações de retenção na fonte analisadas neste trabalho.

348 Cf. DARZÉ Andréa M. Responsabilidade Tributária: solidariedade e subsidiariedade. São Paulo: Noeses, 2010. P. XXI. 


\subsection{Palavras Iniciais}

O exame e o estudo do tema "sujeição passiva tributária" desdobram-se em múltiplas correntes doutrinárias e decisões judiciais que só tendem a aumentar a confusão na cabeça do intérprete, que se vê perdido ao tentar se apoiar em um ou outro parâmetro que julga estar correto.

As manifestações jurisprudenciais por parte das Cortes Suprema e Superior de nosso País têm se mostrado titubeantes, ao tentar precisar critérios e parâmetros uniformes e harmônicos referentes às diversas relações da vida social vislumbradas pelo legislador complementar, no Código Tributário Nacional. Com isso, tomando-se, por exemplo, o tema da sujeição passiva, verifica-se, a partir daquele substrato jurisprudencial, que há razoável carência de uniformidade nos processos de identificação do suporte jurídico e legal de onde deve partir a formação dos conceitos como "responsabilidade tributária", "substituto tributário" ou "terceiro obrigado".

As situações concretas têm gerado um campo sobremodo fecundo de incertezas e contradições, ora com o Fisco, sem qualquer parâmetro, constituindo crédito tributário contra "terceiros", ora com o contribuinte ou o responsável tributário objetivando esquivarse da obrigação de pagar tributo ${ }^{349}$. Haverá situações que tais ocorrências poderão até gerar consequências de natureza criminal, sob a alegação de apropriação indevida de recursos de terceiros. É neste cenário que o estudo dos conceitos fornecidos pelas noções de responsável tributário, de substituto tributário e, como veremos, do agente de retenção mostra-se imprescindível.

$\mathrm{O}$ aspecto pessoal ou subjetivo do fato gerador da obrigação tributária diz respeito às pessoas físicas e/ou jurídicas que deverão participar dessa composição. Como vimos, no antecedente da regra matriz, onde se aloja o aspecto material, encontramos, também, o elemento subjetivo, em conexão com a figura do contribuinte. Por sua vez, instaurada a

${ }^{349}$ Ibidem, Op. cit. (nota 348), P. XXII. 
relação jurídica tributária, passa-se a abrigar o credor, chamado sujeito ativo, e o devedor, chamado sujeito passivo, que é a pessoa eleita pelo legislador para pagar o tributo ${ }^{350}$.

Note que, no âmbito do consequente da regra matriz, o aspecto subjetivo já não mais se restringe à figura do contribuinte. Este poderá reter a obrigação original de pagar o tributom, ao qual deu causa ao incorrer no fato gerador, assim como essa obrigação de pagamento do tributo poderá ser designada por lei a um terceiro, genericamente chamado de responsável tributário.

\subsection{Topologia do Código Tributário Nacional}

Partindo-se da estrutura organizacional do CTN, especificamente na parte que trata do escopo do presente trabalho, observa-se que o Título II leva o nome de Obrigação Tributária. O referido Título II é composto por cinco capítulos, da forma como segue:

- Capítulo I - Disposições Gerais

- Capítulo II - Fato Gerador

- Capítulo III - Sujeito Ativo

- Capítulo IV - Sujeito Passivo

- Capítulo V - Responsabilidade Tributária

IVES GANDRA DA SILVA MARTINS ${ }^{351}$ comenta que o título que trata da responsabilidade tributária talvez devesse constar como uma seção do capítulo referente ao sujeito passivo,

\footnotetext{
${ }^{350}$ TÉRCIO SAMPAIO FERRAZ JUNIOR, ao descrever sobre o elemento subjetivo do Direito, afirma que "em que pesem as dificuldades de fundamentação, as noções de sujeito jurídico, pessoa física e pessoa jurídica são correntes na dogmática (...) Nesses termos, o que chamamos de pessoa nada mais é do que feixe de papéis institucionalizados. Quando esses papéis se comunicam, isto é, o pai é simultaneamente o trabalhador em seu emprego, o pagador de impostos, o sócio de um clube, numa palavra, o agente capaz para exercer vários papéis e as atividades correspondentes (políticas, sociais, econômicas etc.), temos uma pessoa física. $O$ direito capta-a como conjunto comunicante de papéis institucionalizados. (...) As pessoas jurídicas podem ser públicas ou privadas. A classificação reporta-se à distinção entre direito público e privado. Depende, pois, do caráter das normas que compõem o estatuto. Pessoas jurídicas de direito público são, por exemplo, a União Federal, os Estados da Federação. Pessoas jurídicas de direito privado são, por exemplo, a empresa privada, as sociedades de modo geral. (...) As noções de pessoa física, jurídica e de sujeito são também ferramentas teóricas do jurista, com a ajuda das quais os agentes intervenientes na interação social podem ser juridicamente qualificados, tendo em vista a decidibilidade de conflitos." (Cf. FERRAZ JÚNIOR, Tércio Sampaio. Introdução ao Estudo do Direito. 4ª edição. São Paulo: Atlas, 2003. P. 154-157). Para fins do presente trabalho, sem querer nos alongarmos em demasia, o termo "pessoa" ou "pessoas" compreende pessoas físicas e pessoas jurídicas, necessariamente dotadas de personalidade jurídica.
} 
em vez de ser regrado como um capítulo à parte, autônomo. Esta consideração faz sentido tendo em vista que, conforme será exaustivamente analisada, a responsabilidade tributária (stricto sensu) é na verdade apenas um dos desdobramentos possíveis da sujeição passiva indireta.

Registre-se que os temas "sujeito ativo" e "sujeição passiva" foram muito bem inseridos no título que trata da obrigação tributária e da sequência do fato gerador, embora genuinamente este último instituto surja em momento anterior àquele primeiro, já que o fato gerador é causa da obrigação tributária.

\subsection{A Constituição Federal como Elemento Limitador}

Como vimos no Capítulo II, o conceito de "renda" não está exclusivamente contido no seio da Constituição Federal, mas, certamente, os principais contornos que tangenciam os seus limites estão impregnados no texto constitucional, não apenas em seu artigo 153, mas, tão importante quanto, nos princípios constitucionais explícitos e implícitos.

Com o aspecto subjetivo da regra matriz não é diferente. Se com o sujeito ativo a titularidade da capacidade tributária ativa decorre, na maioria dos casos, da própria condição da pessoa jurídica de direito público que tem a competência tributária para instituir o tributo, ou seja, sua definição advém basicamente da $\mathrm{CF}$, com o sujeito passivo este exame é mais criterioso ${ }^{352}$. Assim, o fato gerador tende a oferecer condições de colocar na condição de sujeito passivo ambas as partes envolvidas em uma relação obrigacional de direito privado, como, por exemplo, uma venda e compra de bem imóvel, onde é razoável afirmar que tanto comprador como vendedor teriam condições, e índice de capacidade contributiva, para arcar com o tributo ${ }^{353}$. No entanto, não raras vezes, a lei

\footnotetext{
${ }^{351}$ Cf. MARTINS, Ives Gandra da Silva. Direito Tributário 3. Comentários ao Capítulo V - Título II - Livro II, do CTN (artigos 128 a 138). São Paulo: Editor José Bushatsky, 1975. P. 238/239.

${ }^{352}$ Vale lembrar que cabe ao legislador infraconstitucional a definição do sujeito ativo (e do sujeito passivo também) de uma relação jurídica tributária; a competência tributária, por sua vez, tem seu molde definido exclusivamente na Constituição Federal (Cf. SCHOUERI, Luís Eduardo. Op. cit. (nota 26), P. 471).

${ }^{353} \mathrm{Em}$ tese, tudo depende do verbo escolhido pelo legislador como definidor do aspecto material, a partir do qual ter-se-á um ou outro sujeito como potencial contribuinte do tributo (Cf. DARZÉ Andréa M. Op. cit. (nota 348), P. 78). Este, todavia, não é o entendimento de José ARTUR LiMA GonÇALVES, que defende que somente uma dos lados da relação jurídica tributária apresenta elementos passíveis de mensuração de riqueza, sem qualquer margem de discricionariedade para o legislador (Cf. GONÇALVES, José Artur Lima. Op. cit. (nota 31), P. 187/190)
} 
define como sujeito passivo uma terceira pessoa, que não se confunde com o contribuinte, contudo, é obrigada ao recolhimento do tributo. E como vimos, especialmente após a definição da constitucionalidade do $\S 7^{\circ}$, do artigo 150 , da $\mathrm{CF}$, este recurso vem sendo cada vez mais utilizado, através do instituto do fato gerador presumido e da substituição tributária.

Além da problemática no tocante aos tipos de normas albergadas pela Constituição normas de estrutura e normas de $\operatorname{conduta}^{354}$-, quanto à posição que as regras constitucionais se colocam perante o mundo jurídico (melhor dizendo, perante as normas ordinárias ou infraconstitucionais), pretende-se, neste tópico, analisar os princípios constitucionais tributários, também enquadrados como elementos limitadores para identificação da pessoa que poderá incorrer no fato gerador da obrigação tributária (contribuinte).

Atentos à ideia de que o cerne do presente trabalho volta-se à figura de um terceiro eleito pela lei para pagamento de débito tributário alheio, dito, de forma genérica, "responsável tributário", almeja-se buscar os fundamentos constitucionais, sejam eles princípios ou garantias individuais, que justificam e conferem suporte à eleição e designação desse terceiro para o polo devedor da relação jurídica tributária.

\footnotetext{
354 TÉRCIO SAMPAIO FERRAZ JÚNIOR parece entender que na Constituição encontram-se apenas normas respeitantes à organização básica do Estado, ao reconhecimento e à garantia dos direitos fundamentais do ser humano e do cidadão, às formas, aos limites e às competências do exercício do Poder Público (legislar, julgar, governar) (FERRAZ JÚNIOR, Tércio Sampaio. Introdução ao Estudo do Direito. $4^{\mathrm{a}}$ edição. São Paulo: Atlas, 2003. P. 72-80). Sobre as regras de comportamento e as regras de estrutura, diz PAULO DE BARROS CARVALHO que as primeiras estão voltadas diretamente para o comportamento, para a conduta das pessoas, para as relações intersubjetivas entre essas e entre essas e o Estado. Para PAULO DE BARRos CARVALHO, a norma tributária é uma regra de comportamento. As normas de estrutura são dirigidas não às pessoas, mas ao próprio Poder Legislativo, eis que visam informar como outras normas deverão ser produzidas, sobre seus requisitos formais e como as demais normas deverão ser alteradas e desconstituídas (Cf. CARVALHO, Paulo de Barros. Fundamentos Jurídicos da Incidência. $8^{\mathrm{a}}$ ed. São Paulo: Saraiva, 2010. P. 61/63).
} 


\subsubsection{Posicionamento Doutrinário com Relação aos Limites Constitucionais para Eleição do Sujeito Passivo}

A literatura nacional é rica na mais diversa manifestação doutrinária ${ }^{355}$ sobre a extensão da liberdade do legislador ordinário na eleição do sujeito passivo da relação jurídica tributária e dos pressupostos que o sistema constitucional tributário nacional tem a nos oferecer. Três distintas correntes doutrinárias se destacam.

AlfREDO AUGUSTO BECKER ${ }^{356}$ capitaneava a corrente que atribui ao legislador infraconstitucional total liberdade para a escolha do sujeito passivo, independentemente de esses sujeitos guardarem alguma ligação com o fato gerador. Para tanto, deveriam ser respeitados dois critérios:

(i) o princípio da capacidade contributiva;

(ii) o ente tributante (pessoa jurídica de direito público) não poderia ser o próprio sujeito passivo da relação jurídica tributária, sob pena de o credor e o devedor figurarem, reciprocamente, em ambos os polos (ativo e passivo) da obrigação tributária (neste caso, estaria configurado o instituto da confusão, normatizado no artigo 381, do Código Civil - Lei no $10.406 / 02^{357}$ ).

GerAldo AtAliBA $^{358}$ entendia que o Brasil tem no Texto Magno todos os pressupostos da tributação. Para o jurista e pensador, o próprio conceito de tributo é, no Brasil, constitucionalmente pressuposto. Seguindo essa linha, RoQUE ANTONIO CARRAZZA 359 considera que nosso Texto Constitucional traz todo o arquétipo tributário.

\footnotetext{
${ }^{355}$ Cf. BECKER, Alfredo Augusto. Teoria Geral do Direito Tributário. $3^{a}$ edição. São Paulo: Lejus, 1998; Cf. ATALIBA, Geraldo, BARRETO, Aires Fernandino. Substituição e Responsabilidade Tributária. RDT 49:73-96; Cf. CARRAZZA, Roque Antonio. Curso de Direito Constitucional Tributário. $19^{\mathrm{a}}$ edição. $3^{\mathrm{a}}$ tiragem. São Paulo: Malheiros, 2003; Cf. BECHO, Renato Lopes. Sujeição Passiva e Responsabilidade Tributária. $1^{a}$ edição. São Paulo: Dialética, 2000; Cf. CARVALHO, Paulo de Barros. Sujeição Passiva e Responsáveis Tributários. Programa de Pós-Graduação em Direito - PUC/SP. São Paulo: Max Limonad, 1995. 2:259-287; Cf. SCHOUERI, Luís Eduardo. Op. cit. (nota 04), P. 472/517; Cf. DARZÉ Andréa M. Op. cit. (nota 348), P. 29/86.

${ }^{356}$ Cf. BECKER, Alfredo Augusto. Teoria Geral do Direito Tributário. $3^{\text {a }}$ edição. São Paulo: Lejus, 1998. P. $280 / 283$.

357 "Art. 381. Extingue-se a obrigação, desde que na mesma pessoa se confundam as qualidades de credor e devedor."

${ }^{358}$ Cf. ATALIBA, Geraldo, BARRETO, Aires Fernandino. Substituição e Responsabilidade Tributária. RDT 49. P. 73/96.

${ }^{359}$ Cf. CARRAZZA, Roque Antonio. Op. cit. (nota 111), P. 177/175.
} 
Conforme é possível depreender, ambos são ferozes defensores da supremacia da Constituição e, por enxergarem na Magna Carta a definição integral da hipótese tributária, reservando pouca ou quase nenhuma margem para o legislador ordinário, defendem que o sujeito passivo é aquele já definido na Constituição.

Filiando-se a essa corrente mais conservadora (na qual se enquadram GERALDO ATALIBA e Roque Antonio CARRAZZA), RenAto LOPES $\mathrm{BECHO}^{360}$, em sua notória visão constitucionalista, remonta à classificação dos tributos em "discriminados" e "não discriminados", afirmando que, para os primeiros, haveria pouca ou nenhuma liberdade para eleição do sujeito passivo pelo legislador infraconstitucional. Para os tributos "não discriminados", considerando ser omissa a definição de seu critério material, defende que haveria essa liberdade, contudo, de forma mitigada. O legislador ordinário estaria limitado, no entanto, pela própria definição desse aspecto material e dos demais elementos limitadores da Constituição.

PAUlO DE BARROS CARVALHO ${ }^{361}$ segue uma linha mais branda, a da liberdade mitigada. Cabe ao legislador infraconstitucional definir o sujeito passivo, desde que observados os limites da outorga constitucional e o grau de relacionamento do sujeito com o aspecto fático. O jurisfilósofo afirma, ainda, que apesar de a Constituição não traçar o arquétipo tributário (Regra Matriz da Incidência Tributária) em sua inteireza, o legislador infraconstitucional não poderá, nunca, se afastar dos limites e pressupostos previamente traçados pelo constituinte.

O artigo 146, III, “a”, da Constituição Federal, disciplina que a definição do fato gerador caberá à lei complementar, função essa primorosamente cumprida pelo CTN. No entanto, como é sabido, não apenas com relação ao capítulo da Constituição Federal que trata "Do Sistema Tributário Nacional”, o legislador complementar, ordinário e até mesmo no âmbito das normas infralegais não poderá criar norma jurídica em desatenção a qualquer pressuposto ou dispositivo da Magna Carta.

\footnotetext{
${ }^{360}$ Cf. BECHO, Renato Lopes. Sujeição Passiva e Responsabilidade Tributária. $1^{\text {a }}$ edição. São Paulo: Dialética, 2000. P. 77/78.

${ }^{361}$ Cf. CARVALHO, Paulo de Barros. Sujeição Passiva e Responsáveis Tributários. Programa de PósGraduação em Direito - PUC/SP. São Paulo: Max Limonad, 1995. 2:259/287.
} 
Como se vê, mesmo com relação a pressupostos constitucionais não expressamente previstos, como ocorre com relação a alguns valores e princípios, a definição do fato gerador e do contribuinte, assim como a designação do responsável tributário, deverão obrigatoriamente observar e respeitar os princípios constitucionais e as garantias e os direitos individuais. Se for o caso, inclusive, o legislador infraconstitucional deverá fornecer as ferramentas necessárias para que não ocorra dano econômico por parte do indivíduo (geralmente, o responsável tributário) em detrimento de outro (geralmente, o contribuinte).

\subsubsection{Limitações Constitucionais como Critérios Informadores da Condição de Contribuinte $^{362}$ e como Critérios para a Eleição do Sujeito Passivo}

As limitações constitucionais objetivam demarcar, delimitar, fixar fronteiras ou limites ao exercício do poder de tributar ou poder fiscal, caracterizando-se como instrumentos definidores ou demarcadores quanto ao que se pode e como pode ser tributado algo, não devendo ser entendidas como obstáculos ou vedações à própria competência ${ }^{363}$.

Não apenas os princípios veiculam limites quanto à definição dos contornos da regra matriz. Em especial, no nosso caso, não só o aspecto subjetivo, mas também as noções de competência tributária e de disposições infraconstitucionais que veiculam normas gerais em matéria tributária, em especial o CTN.

Como já dissemos, os princípios jurídicos são verdadeiros comandos balizadores do ordenamento, entendendo-se como princípios constitucionais aqueles consagrados expressa

\footnotetext{
${ }^{362}$ Registre-se que a mais alta jurisprudência de nosso País é firme no sentido de que as limitações ao poder tributar, impostas ao Estado, e os princípios constitucionais tributários existem e hão de existir em favor do contribuinte, com o objetivo de tutelar os direitos, deveres e garantias exclusivamente com relação aos contribuintes, e não de terceiros eleitos pelo legislador como responsáveis pelo pagamento do tributo. Nesse sentido confira-se: ADI-MC 712/DF, Tribunal Pleno do STF, Min. Rel. Celso de Mello, D.J. 19/02/1993; ADI-MC 2010/DF, Tribunal Pleno do STF, Min. Rel. Celso de Mello, D.J. 12/04/2002. Transcrevemos o mais recente: "Assiste, ao contribuinte, quando transgredidas as limitações constitucionais ao poder de tributar, o direito de contestar, judicialmente, a tributação que tenha sentido discriminatório ou que revele caráter confiscatório"

${ }^{363}$ Cf. AMARO, Luciano. Op. cit. (nota 69), P. 106/107.
} 
ou implicitamente no sistema e que têm por função inspirar a compreensão das regras jurídicas, informando o seu sentido e servindo de mandamento nuclear delas ${ }^{364}$.

Analisando a natureza dos princípios como colunas basilares de nosso ordenamento, sejam os princípios constitucionais, sejam os mais próximos à problemática em tela, os princípios constitucionais tributários, PAULO DE BARRos CARVALHO assevera que os princípios trazem consigo, dentre muitas outras acepções, dois significados de suma importância que terão o condão de distinguir entre o poder que um ou outro princípio poderá exercer sobre determinada questão. Assim, o professor identifica, em alguns princípios, um sentido de "valor" em contraponto a um caráter objetivo que, por vezes, se vislumbra mais presente em outras situações ${ }^{365}$.

Esse "valor", por sua vez, exercerá influência sobre as demais questões de direito, utilizando os princípios constitucionais como verdadeiros vetores de seu alcance, traduzindo, assim, a ideia de elemento limitador ao poder de tributar.

Neste momento, considerando que o fato gerador da obrigação tributária exerce importante papel na definição e identificação do contribuinte (o que deverá servir de argumento para afastar o posicionamento daqueles que querem anular a própria existência, a participação e a importância desse contribuinte) e do sujeito passivo da relação jurídica tributária, as análises focarão apenas os princípios que possuem íntima relação com o indivíduo que deu causa à subsunção desse fato gerador à hipótese abstrata prevista em lei: o princípio da legalidade, o princípio da capacidade contributiva, o princípio da vedação de tributo com efeito de confisco e a segurança jurídica.

A investigação de cada um desses princípios constitucionais é importante na medida em que deverão nortear os trabalhos do legislador no que se refere à definição do fato gerador de um determinado tributo e de quais sujeitos (pessoas) poderão ser apontados e

\footnotetext{
364 "Daí a definição de princípios como "deveres de otimização" aplicáveis em vários graus segundo as possibilidades normativas e fáticas: normativas, porque a aplicação dos princípios depende dos princípios e regras que a eles se contrapõem; fáticas, porque o conteúdo dos princípios como normas de conduta só pode ser determinado quando diante dos fatos." (Cf. ÁVILA, Humberto. Op. cit. (nota 302). P. 160).

${ }^{365}$ Cf. CARVALHO, Paulo de Barros. Op. cit. (nota 23), P. 191/197.
} 
relacionados na previsão abstrata da lei e quais poderão ocupar o polo passivo dessa relação jurídica tributária.

\subsubsection{O Princípio da Legalidade e a Competência Tributária}

Analisando as feições pelas quais o princípio da legalidade se desdobra, GERD WILLI ROTHMANN $^{366}$ informa que a tributação deve guardar conformidade com o fato, i.e., não pode a lei deixar, ao critério da administração, a diferenciação objetiva, devendo ela própria (a lei) realizar esta diferenciação, prevendo todos os aspectos do fato gerador, necessários à configuração da obrigação tributária.

LUÍs EDUARDO SCHOUERI ensina que o legislador deve dobrar-se às amarras do Direito Tributário, com destaque para o princípio da legalidade, de modo que, em matéria tributária, a Administração não pode, sob hipótese alguma, valer-se de um juízo de conveniência ou oportunidade, porquanto a cobrança do tributo é inexorável tão logo ocorra o fato gerador ${ }^{367}$.

Embora se afirme que o princípio da legalidade deverá nortear a condição de uma determinada pessoa como sendo contribuinte, no sentido de que só será contribuinte aquele que incorrer ou praticar o específico fato previsto de forma abstrata na lei, não se pode olvidar que a condição de sujeito passivo indireto, i.e., a pessoa eleita como pagador de tributo alheio (responsabilidade tributária), só será factível se expressamente prevista em lei. Caso contrário, o tributo deverá ser recolhido, naturalmente, pelo próprio contribuinte.

Nem a lei pode ferir os direitos e garantias dos contribuintes e de terceiros obrigados ao recolhimento de tributo devido por outrem, nem pode fazê-lo a Administração, cuja missão

\footnotetext{
${ }^{366}$ Cf. ROTHMANN, Gerd Willi. O Princípio da Legalidade Tributária. Temas Fundamentais do Direito Tributário. Atual. Antonio Roberto Sampaio Dória e Gerd Willi Rothmann. Belém: CEJUP, 1983. P. 77-120. ${ }^{367}$ Cf. SCHOUERI, Luís Eduardo. Contribuição ao Estudo do Regime Jurídico das Normas Tributárias Indutoras como Instrumento de Intervenção sobre o Domínio Econômico. Tese apresentada como parte dos requisitos para a inscrição em concurso de Professor Titular do Departamento de Direito Econômico e Financeiro, área de Legislação Tributária, da Faculdade de Direito da Universidade de São Paulo - USP. São Paulo: 2002. P. 310/313.
} 
não é outra coisa senão aplicar a lei tributária ou, nas palavras de MARIA DA GLÓRIA FERREIRA PINTO, a Administração deve movimentar-se nas malhas da legalidade ${ }^{368}$.

\subsection{Competência Tributária}

A competência tributária, classificada como um norma de estrutura ${ }^{369}$, está umbilicalmente ligada ao princípio da legalidade ${ }^{370}$ e tem por destinatário imediato o legislador. A Constituição define a competência de cada pessoa política e somente do texto constitucional derivam as parcelas do poder fiscal ${ }^{371}$. Ela se esgota na lei, tendo vista que qualquer procedimento no sentido de aumentar tributo, diminuí-lo, parcelar seu pagamento, isentá-lo, total ou parcialmente, remi-lo, anistiar suas infrações ou, até mesmo, não tributar deverá, sempre, buscar seu fundamento de validade em lei ${ }^{372}$.

Na medida em que competência tributária corresponde à aptidão para, por meio de lei, criar tributos, in abstracto, todos os elementos essenciais da norma jurídica tributária, tais como o aspecto material, os limites temporais e espaciais, os sujeitos ativo e passivo, a base de cálculo e a alíquota, deverão ser descritos ${ }^{373}$. Em suma, competência tributária corresponde à possibilidade de criar tributos, inovando a ordem jurídica por meio da expedição de regras tributárias ${ }^{374}$, e nisso a doutrina parece caminhar de forma uníssona ${ }^{375}$.

Outrossim, a competência se mostra importante na análise dos conceitos para verificar a própria extensão da competência outorgada às pessoas políticas, tendo em vista que ela representa, com base no critério da base econômica, por si só, uma limitação às

\footnotetext{
${ }^{368}$ Cf. CARRAZZA, Roque Antonio. Op. cit. (nota 111), P. 427.

${ }^{369}$ Cf. CARVALHO, Paulo de Barros. Op. cit. (nota 354), P. 62/63.

370 É preciso que se diga que a competência tributária também se conecta aos demais princípios constitucionais tributários, na medida em que encontra, nesses princípios, limites jurídicos ao seu exercício. Significa dizer que, e isto nos parece óbvio, que a atividade legiferante quanto à produção de norma tributária é uma atividade vinculada, não podendo, por exemplo, encerrar preceito que configure a criação de tributo com efeito de confisco ou que resulte em tratamento não isonômico entre contribuintes que se encontrem em situações equivalentes (CARRAZZA, Roque Antonio. Op. cit. (nota 111), P. 441/442).

${ }^{371}$ Cf. PAULSEN, Leandro. Op. cit. (nota 56), P. 35.

${ }^{372}$ Cf. CARRAZZA, Roque Antonio. Op. cit. (nota 111), P. 436/437.

${ }^{373}$ Ibidem, Op. cit. (nota 111), P. 439/441.

${ }^{374}$ Ibidem, Op. cit. (nota 111), P. 437/438.

${ }^{375}$ Cf. CARVALHO, Paulo de Barros. Op. cit. (nota 23), P. 269/270; também GiUliani FounrougE apoiado nas lições de BERLIRI (Cf. FONROUGE, C. M. Giuliani. Conceitos de Direito Tributário. Trad. da $2^{\mathrm{a}}$ edição argentina do livro "Derecho Financeiro" (Ediciones Depalma, Buenos Aires, 1970) por Geraldo Ataliba e Marco Aurélio Greco. São Paulo: Edições Lael, 1973. P. 37).
} 
possibilidades semânticas e sintáticas das palavras e expressões utilizadas para dar significado àqueles elementos essenciais da norma jurídica tributária ${ }^{376}$. Assim, com foco em nossa abordagem, quando o artigo 153, da CF, outorga competência para a instituição de imposto sobre a renda, impõe-se que se investigue o que é renda, o que, necessariamente, deve partir do próprio texto constitucional ${ }^{377}$.

Em aprofundado estudo sobre o tema, TÁCIO LACERDA GAMA sugere uma classificação entre sujeição passiva fraca e sujeição passiva forte: aquela primeira corresponderia ao conjunto de indivíduos que devem apenas ter ciência da existência de norma, sujeitando-se aos seus efeitos; esta, por sua vez, seria composta pelas pessoas obrigadas ao recolhimento do tributo. Diz, ainda, que somente as pessoas alcançadas pela noção de sujeição passiva forte teriam legitimidade para acionar o Poder Judiciário, no intuito de questionar sua validade $^{378}$. Em que pese o brilhantismo das lições de TÁCIO LACERDA GAMA, queremos crer que ao contribuinte sempre será reservado o direito de questionar a juridicidade da norma tributária, suspendendo ou afastando seus efeitos, mesmo quando o recolhimento do tributo é exigido de um terceiro (responsável tributário, genericamente falando). Mesmo quando sua responsabilidade é excluída de forma definitiva, não é de outra pessoa que não o contribuinte que o tributo gravará (e diminuíra) o patrimônio.

O que deve ser sobressaltado neste tópico é que a competência tributária, associada ao princípio da legalidade, mostra-se como índice seguro para delinear o conjunto de possibilidades colocadas à disposição do legislador para a definição completa dos contornos da sujeição passiva ${ }^{379}$. Se exercitada com estrita observância dos princípios e

\footnotetext{
${ }^{376}$ Cf. PAULSEN, Leandro. Op. cit. (nota 56), P. 37.

377 Neste sentido: "EMENTA: Imposto de renda. Incidência na fonte sobre o pagamento de férias não gozadas por servidor estadual em virtude de necessidade de serviço. - Saber se indenização é, ou não, renda, para o efeito do artigo 153, III, da Constituição, é questão constitucional, como entendeu o acórdão recorrido, até porque não pode a Lei infraconstitucional definir como renda o que insitamente não o seja. No caso, porém, ainda que se entendesse, como entende o recorrente, que o critério para caracterizar determinado valor como renda é legal, e que, no caso, teria havido ofensa ao artigo $3^{\circ}$ da Lei 7.713/88, esse entendimento não lhe aproveitaria, porquanto o Superior Tribunal de Justiça não conheceu do recurso especial, nestes autos, no qual se alegava, entre outras violações, a concernente a esse dispositivo legal, e dele não conheceu por entender que "não incide o imposto de renda sobre o pagamento de férias não gozadas por necessidade de serviço, em razão do seu caráter indenizatório". - Nesse sentido decidiu esta $1^{a}$ Turma, ao julgar o RE 195.059. Recurso não conhecido." (STF. 1ª T. RE 188.684-6/SP. Rel. Min. Moreira Alves. DJ 07/06/2002).

${ }^{378}$ Cf. GAMA, Tácio Lacerda. Competência Tributária. Fundamentos para uma teoria da nulidade, São Paulo: Noeses, 2009. P. 109.

${ }^{379}$ Cf. CARRAZZA, Roque Antonio. Op. cit. (nota 111), P. 437.
} 
normas constitucionais que pautam a criação de tributos, não apenas a legalidade, mas também a igualdade, a capacidade contributiva, a vedação à criação de tributo com efeito de confisco e a segurança jurídica, a competência tributária faz nascer, para os contribuintes, um estado genérico de sujeição, de forma que, realizado o fato gerador, não poderão esquivar-se da obrigação tributária. $\mathrm{O}$ mesmo vale para $\mathrm{o}$ tema da responsabilidade tributária, na medida em que, observados aqueles princípios constitucionais e as ferramentas de ajustes para que o ônus financeiro do encargo tributário recaia sobre o patrimônio do contribuinte, o terceiro estará legalmente obrigado ao recolhimento de tributo devido por outrem.

\subsubsection{O Princípio da Capacidade Contributiva}

O artigo 145, da Constituição Federal, ao determinar quais são as espécies tributárias passíveis de instituição pelos entes públicos tributantes, traduz, também, em seu parágrafo primeiro, um dos principais balisadores que deverão nortear a atividade exacional do Estado, verbis:

“Art. 145. A União, os Estados, o Distrito Federal e os Municípios poderão instituir os seguintes tributos:

I - impostos;

II - taxas, em razão do exercício do poder de polícia ou pela utilização, efetiva ou potencial, de serviços públicos específicos e divisíveis, prestados ao contribuinte ou postos a sua disposição;

III - contribuição de melhoria, decorrente de obras públicas.

$\S 1^{o} \underline{\text { Sempre que possível }}, \underline{\text { os impostos }}$ terão caráter pessoal e serão graduados segundo a capacidade econômica do contribuinte, facultado à administração tributária, especialmente para conferir efetividade a esses objetivos, identificar, respeitados os direitos individuais e nos termos da lei, o patrimônio, os rendimentos e as atividades econômicas do contribuinte." (grifamos)

LUÍS EDUARDO SCHOUERI afirma que o primeiro parâmetro a ser cogitado no estudo do sistema tributário brasileiro é o princípio da capacidade contributiva, já que se trata de um 
subprincípio ou vetor do princípio da solidariedade ${ }^{380}$. O autor traz, com clareza, a inteligência deste princípio: "a capacidade contributiva pressupõe a existência de uma riqueza, mas não qualquer uma, senão aquela que gera um saldo (disponível). Assim, não basta, para aferir a existência de capacidade contributiva, investigar os rendimentos de uma pessoa" 381 .

Em outras palavras, aproximando do escopo do presente estudo, é justamente o vínculo ou relação com o fato gerador, característica própria do contribuinte e, conforme descreveremos, do terceiro, na condição de obrigado ao recolhimento de tributo devido pelo contribuinte, que justifica a razão de o legislador defini-los como devedores do imposto $^{382}$, pois a vantagem ou resultado decorrente do fato econômico tributado é que permite o pagamento do tributo ao Fisco, validando a capacidade contributiva ${ }^{383}$. No caso do 'terceiro responsável', considerando que a vantagem ou resultado auferido é do contribuinte, ao terceiro deverá ser garantido, obrigatoriamente, o direito de ressarcir-se do imposto, evitando que o patrimônio desse terceiro seja diminuído, em vez do patrimônio do contribuinte, de quem efetivamente se está medindo a capacidade contributiva. A pessoa que deve ter seu patrimônio diminuído em razão de um fato revelador de riqueza, i.e., de capacidade contributiva, é o contribuinte, que é a pessoa que provoca ou causa tal fato e a ele lhe é atribuído um determinado proveito ou vantagem ${ }^{384}$.

Outros doutrinadores trataram do tema, aprofundando a análise para dar maior embasamento ao vínculo indissociável entre capacidade contributiva e contribuinte.

Ainda Luís EduARdo Schoueri, citando Klaus Vogel quando este discorria sobre o valor "justiça tributária", destaca que um imposto justo deve ser norteado pelo princípio da capacidade contributiva. A dosagem da repercussão tributária deve estar em estrita

${ }^{380}$ Cf. SCHOUERI, Luis Eduardo. Royalties e Assistência Técnica ao Exterior - Exigências da CIDE. Revista de Estudos Tributários. Ano VI. No 37. Porto Alegre: 2004. P. 144 e ss.

${ }^{381}$ Cf. SCHOUERI, Luis Eduardo. Op. cit. (nota 367), P. 340/342.

${ }^{382}$ ROQUE ANTONIO CARRAZZA sustenta que a capacidade contributiva é princípio específico e regula tão somente o regime jurídico dos impostos. Trata-se da chamada capacidade contributiva objetiva ou absoluta que, diferentemente da capacidade contributiva subjetiva, não leva em conta a capacidade ou condições econômicas reais do contribuinte, i.e., sua aptidão concreta e situacional (razões personalíssimas) de suportar a carga tributária (Cf. CARRAZZA, Roque Antonio. Op. cit. (nota 111), P. 437). Voltaremos a abordar este ponto mais à frente, colhendo, inclusive, posições doutrinárias em sentido contrário.

${ }^{883}$ Cf. NOGUEIRA, Ruy Barbosa. Op. cit. (nota 02), P. 145/147.

${ }^{384}$ Cf. ATALIBA, Geraldo; BARRETO, Aires F. Substituição e Responsabilidade Tributária. Revista de Direito Tributário. Cadernos de Direito Tributário. São Paulo: Revista dos Tribunais, n. 49, 1989. P. 73). 
conformidade com o nível de aptidão econômica demonstrado pelo sujeito que realizou o fato gerador, de forma que os valores repassados/entregues ao Estado correspondam a uma parcela daquela manifestação de riqueza ${ }^{385}$.

Decorre deste princípio que as pessoas, i.e., os contribuintes, devem contribuir para as despesas públicas na exata medida de sua capacidade para contribuir, de forma que não se deve exigir daqueles que só têm capacidade para sua própria subsistência ${ }^{386}$. Em outras palavras, os limites do mínimo existencial e, como veremos, da vedação ao tributo com efeito de confisco, devem ser preservados, de forma que, nas palavras de Vieira Andrade, embora envolva uma medida econômica, o tributo não corresponda a uma prestação negativa que subtraia recursos necessários para a própria subsistência e dignidade do $\operatorname{cidadão}^{387}$.

No esteio da terminologia empregada por Alfredo Augusto Becker, Ana Cláudia AKIE UTUMI conceitua a capacidade contributiva como "a capacidade econômica que algum sujeito possui, aferida por intermédio de fatos signos-presuntivos de riqueza, potencialmente tributáveis, já definidos na Constituição. O princípio da capacidade contributiva norteia toda a atividade de instituição e cobrança de impostos, sendo dirigido ao legislador e ao aplicador da norma tributária" (grifamos) ${ }^{388}$.

Em suas lições, RoQue ANTONIO CARRAZZA ensina que os impostos, quando ajustados à capacidade contributiva, permitem que os cidadãos cumpram seus deveres de solidariedade política, econômica e social, de forma que as contribuições pagas pelo grupo de contribuintes correspondem, na maior medida possível, às suas potencialidades econômicas. Este mesmo autor, ao traçar um paralelo com o princípio da igualdade, afirma que, nos impostos, estes objetivos são alcançados, considerando que, conforme apontamos nos casos do IRF, em alusão ao tratamento ofertado aos rendimentos do trabalho e aqueles derivados do capital, a capacidade contributiva das pessoas trata de modo igual os fatos

\footnotetext{
${ }^{385}$ Cf. DARZÉ Andréa M. Op. cit. (nota 348), P. 51.

${ }^{386}$ Cf. PAULSEN, Leandro. Op. cit. (nota 56), P. 64/65.

387 apud PAULSEN, Leandro. Op. cit. (nota 56), P. 65 (ANDRADE, Vieira. Os Direitos fundamentais na Constituição Portuguesa de 1976. $2^{\mathrm{a}}$ ed. Almedida. P. 388).

${ }^{388}$ Cf. UTUMI, Ana Cláudia Akie. Tese de Doutorado defendida na Universidade de São Paulo - Faculdade de Direito. O Regime Tributário Brasileiro do Imposto sobre a Renda de Não-Residentes. A Fonte como Critério de Conexão. São Paulo: 2006. Nota de rodapé $\mathrm{n}^{\circ}$ 120. P. 70. FD - Faculdade de Direito. Localização, em 10.10.2007: http://dedalus.usp.br:4500/ALEPH/POR/USP/USP/TES/FIND-ACC/3087757.
} 
econômicos que exprimem igual capacidade contributiva e, por oposição, de modo diferençado os que exprimem capacidade contributiva diversa ${ }^{389}$.

Necessário, também, avaliar se o princípio da capacidade contributiva, como elemento limitador da atividade do legislador infraconstitucional, ao estabelecer que os impostos terão caráter pessoal e deverão ser graduados segundo a manifestação de riqueza do fato jurídico, teria o condão de afastar a figura do responsável tributário, inserindo este em uma relação jurídica de natureza não tributária. Ressalte-se que este é um dos principais argumentos utilizados por boa parcela da doutrina (RENATO LOPES BECHO ${ }^{390}$, GERALDO AtAlibA $^{391}$, RoQue ANTONIO CARRAZZA ${ }^{392}$, obras já citadas) que defende que somente o contribuinte poderia ocupar o polo passivo das relações jurídicas tributárias.

A nosso ver, não se trata de uma questão de afastar o sujeito passivo indireto do polo passivo da obrigação tributária, mas, sim, de uma característica própria e exclusiva do contribuinte, que em nada interfere na identificação do sujeito que deverá figurar como responsável pelo pagamento do tributo. Tanto é assim que o parágrafo primeiro, do artigo 145, da Constituição Federal, fala em caráter pessoal em razão da capacidade do contribuinte e não do responsável ou substituto tributário.

Note que, ao se referir ao princípio da capacidade contributiva, RoQUE ANTONIO CARRAZZA refere-se a "fatos econômicos" para atendimento ao ditame constitucional da capacidade contributiva e não em características intrínsecas ao sujeito posto no polo passivo da obrigação tributária.

Complementando, e conforme já ventilamos acima, ROQUE ANTONIO CARRAZZA assevera que "a capacidade contributiva à qual alude a Constituição e que a pessoa política é obrigada a levar em conta ao criar, legislativamente, os impostos de sua competência é objetiva, e não subjetiva. É objetiva porque se refere não às condições econômicas reais de cada contribuinte, individualmente considerado, mas às suas manifestações objetivas

\footnotetext{
${ }^{389}$ Cf. CARRAZZA, Roque Antonio. Op. cit. (nota 111), P. 78/80.

${ }^{390}$ Cf. BECHO, Renato Lopes. Op. cit. (nota 360).

${ }^{391}$ Cf. ATALIBA, Geraldo, BARRETO, Aires Fernandino. Op. cit. (nota 384), P. 73/96.

${ }^{392}$ Cf. CARRAZZA, Roque Antonio. Op. cit. (nota 111), P. 177/175.
} 
de riqueza (ter um imóvel, possuir um automóvel, ser proprietário de jóias ou obras de arte, operar em Bolsa, praticar operações mercantis)" (destaques do próprio autor) ${ }^{393}$.

No mesmo sentido é o pensamento de MARIA RITA FerRaguT"394, que entende "que a capacidade contributiva determina que os impostos sejam graduados segundo a manifestação de riqueza do fato jurídico, possibilitando e, ao mesmo tempo, limitando a tributação".

Reservem-se os conceitos delineados acima, pois serão de grande valia para os contornos ao longo das considerações e conclusões que serão expostas no decorrer do presente trabalho. Mas antes, vejamos outros posicionamentos contrários ao exposto acima para ressaltar a importância da problemática do princípio da capacidade contributiva, enquanto elemento limitador da atividade do legislador infraconstitucional, ao eleger quem será o sujeito passivo da relação jurídica tributária.

SACHA CALMON NAVARRO COÊLHO ${ }^{395}$ entende que a capacidade contributiva à qual alude o indigitado artigo 145, parágrafo primeiro, da CF, é subjetiva, devendo levar em conta, portanto, a capacidade econômica real do contribuinte, i.e., sua aptidão concreta e específica de suportar a carga econômica do imposto. LEANDRO PAULSEN ${ }^{396}$ e JOSÉ MAURício CONTI ${ }^{397}$ também caminham nessa linha, afirmando que, diante dos extremos fornecidos pelo mínimo vital e da vedação de que a imposição tributária tenha efeito confiscatório, a capacidade contributiva é aplicável a todas as espécies, sendo certo, contudo, que encontra um campo de aplicação muito maior nos tributos com fato gerador não vinculado, como é o caso dos imposto.

\footnotetext{
${ }^{393}$ Cf. CARRAZZA, Roque Antonio. Op. cit. (nota 111), P. 78/80. Luís EdUARDo ScHOUERI esclarece que enquanto a capacidade contributiva subjetiva (ou relativa) se aplica a todos os tributos, no sentido de conhecer a situação real e pessoal do contribuinte, i.e., se ele tem condições ou não de suportar a carga tributária, sob o ponto de vista objetivo (ou absoluto), a capacidade contributiva funciona como critério a ser empregado para distinguir e identificar quem será o contribuinte (Cf. SCHOUERI, Luís Eduardo. (nota 04), P. 312/313).

${ }^{394}$ Cf. FERRAGUT, Maria Rita. Op. cit. (nota 03), P. 40.

${ }^{395}$ Cf. COÊLHO, Sacha Calmon Navarro. Comentários à Constituição de 1988: Sistema Tributário. $2^{\mathrm{a}}$ ed. Rio de Janeiro: Editora Forense, 1990. P. 90.

${ }^{396}$ Cf. PAULSEN, Leandro. Op. cit. (nota 56), P. 67.

${ }^{397}$ Cf. CONTI, José Maurício. Princípios da Capacidade Contributiva. São Paulo: Dialética, 1996. P. 65.
} 
RENATO LOPES BECHO tratou a questão da capacidade contributiva em pormenores. Sob sua visão constitucionalista e por que não dizer positivista e kelseniana do Direito e, mais detidamente, do Direito Tributário, também apoiado nos ensinamentos de PEREZ DE AyALA, entende que, em sistemas jurídicos onde se preconiza o princípio da capacidade contributiva, a utilização de presunções e/ou ficções jurídicas é inconstitucional, razão pela qual a figura do responsável tributário, chamado por ele de "sujeito passivo legal", não se enquadraria nos conceitos definidos pela Constituição. Para RENATO LOPES BECHO, o parágrafo primeiro do aludido artigo 145 teria como destinatário exclusivo o contribuinte, entendido como a pessoa que deu nascimento ao fato jurídico tributário descrito na hipótese de incidência ${ }^{398}$.

Por ora, tenha-se em mente que o princípio constitucional tributário é do contribuinte e a ele se volta, e não a outros terceiros eleitos como pagadores de tributo alheio. São os direitos do contribuinte que deverão ser tutelados pelo princípio da capacidade contributiva, mas nem por isso tornam-se inconstitucionais ou não válidas as figuras do responsável tributário ou do substituto tributário, conforme o caso.

\subsubsection{O Princípio da Vedação de Tributo com Efeito de Confisco}

$\mathrm{O}$ artigo 150 , inciso $\mathrm{IV}$, da $\mathrm{CF}$, determina que, às pessoas políticas com competência para tributar, é vedado utilizar tributos com efeito de confisco.

Primeiramente, é importante analisar o alcance da expressão "efeito de confisco". De fato, o que se veda não é confisco propriamente dito, mas sim os seus efeitos. Confisco é sanção ou medida de caráter sancionatório, que visa à absorção total ou parcial de propriedade privada, sem indenização. Seria equivocado dizer que é vedado o confisco; o que se proíbe é que se crie ou majore tributo cujo efeito seja equivalente ao de confisco $^{399}$. Trata-se de princípio que encerra não uma regra objetiva ou matemática, como é, por exemplo, a anterioridade, mas de critério informador da atividade do legislador, e igualmente dirigido ao intérprete e ao julgador, quando da aplicação do direito ${ }^{400}$.

\footnotetext{
${ }^{398}$ Cf. BECHO, Renato Lopes. Tributação das Cooperativas. $2^{\mathrm{a}}$ ed. São Paulo: 1999. Editora Dialética. P. 222.

${ }^{399}$ Cf. BARRETO, Aires. F. ISS na Constituição e na lei. $3^{\mathrm{a}}$ ed. São Paulo: Dialética, 2009. P. 17.

${ }^{400}$ Cf. AMARO, Luciano. Op. cit. (nota 69), P. 145.
} 
LEANDRO PAULSEN $^{401}$ mostra que os tribunais não definem com precisão o limite entre a garantia do direito de propriedade e o confisco pela tributação excessiva e que é verificado nas referências à tributação demasiadamente onerosa, insuportável, não razoável, que absorve a própria fonte da tributação etc. Indica, ainda, como referencial mais atual, o julgamento da ADIn 2.101-2/DF ${ }^{402}$, que ilustra justamente a noção da impossibilidade de uma injusta apropriação estatal de recursos, sem os quais o cidadão teria comprometido o exercício do direito de sua subsistência de forma digna, ou mesmo da prática de atividade profissional lícita. Referido julgado destaca, também, a noção de que a carga tributária deve ser analisada como um todo e não apenas como um tributo em específico, entendimento que já vinha sendo afirmado na doutrina ${ }^{403}$.

Com foco nos temas centrais da presente dissertação, tal qual a responsabilidade tributária, FRANCISCO J. MARTín JIMENEZ demonstra que, na hipótese de ao devedor não serem possíveis os eventos de reembolso ou de regresso em função do crédito que tem contra o contribuinte, o responsável acaba por assumir dívidas sem qualquer relação com os

${ }^{401}$ Cf. PAULSEN, Leandro. Op. cit. (nota 56), P. 224.

402 “A TRIBUTAÇÃO CONFISCATÓRIA É VEDADA PELA CONSTITUIÇÃO DA REPÚBLICA. - A jurisprudência do Supremo Tribunal Federal entende cabível, em sede de controle normativo abstrato, a possibilidade de a Corte examinar se determinado tributo ofende, ou não, o princípio constitucional da nãoconfiscatoriedade consagrado no art. 150, IV, da Constituição. Precedente: ADI 1.075-DF, Rel. Min. CELSO DE MELLO (o Relator ficou vencido, no precedente mencionado, por entender que o exame do efeito confiscatório do tributo depende da apreciação individual de cada caso concreto). - A proibição constitucional do confisco em matéria tributária nada mais representa senão a interdição, pela Carta Política, de qualquer pretensão governamental que possa conduzir, no campo da fiscalidade, à injusta apropriação estatal, no todo ou em parte, do patrimônio ou dos rendimentos dos contribuintes, comprometendo-lhes, pela insuportabilidade da carga tributária, o exercício do direito a uma existência digna, ou a prática de atividade profissional lícita ou, ainda, a regular satisfação de suas necessidades vitais (educação, saúde e habitação, por exemplo). A identificação do efeito confiscatório deve ser feita em função da totalidade da carga tributária, mediante verificação da capacidade de que dispõe o contribuinte considerado o montante de sua riqueza (renda e capital) - para suportar e sofrer a incidência de todos os tributos que ele deverá pagar, dentro de determinado período, à mesma pessoa política que os houver instituído (a União Federal, no caso), condicionando-se, ainda, a aferição do grau de insuportabilidade econômico-financeira, à observância, pelo legislador, de padrões de razoabilidade destinados a neutralizar excessos de ordem fiscal eventualmente praticados pelo Poder Público. Resulta configurado o caráter confiscatório de determinado tributo, sempre que o efeito cumulativo - resultante das múltiplas incidências tributárias estabelecidas pela mesma entidade estatal - afetar, substancialmente, de maneira irrazoável, o patrimônio elou os rendimentos do contribuinte. - O Poder Público, especialmente em sede de tributação (as contribuições de seguridade social revestem-se de caráter tributário), não pode agir imoderadamente, pois a atividade estatal acha-se essencialmente condicionada pelo princípio da razoabilidade." (STF. Pleno. ADIn 2010 MC/DF. Rel. Min. Celso de Mello. DJ 30/09/1999).

${ }^{403}$ Cf. MACHADO, Hugo de Brito. Op. cit. (nota 61), P. 47. 
princípios da capacidade contributiva, da igualdade, da progressividade, o que, invariavelmente, conduziria a uma clara situação confiscatória ${ }^{404}$.

Acolhemos tal ponderação em sua inteireza. A retenção na fonte, ferramenta sobre a qual repousa o presente estudo, é o instrumento genuíno que permite que, sob a perspectiva da fonte pagadora, aqueles princípios sejam observados de forma eficaz. Desse modo, transferir o ônus financeiro do encargo tributário ao contribuinte resultará em estrita observância da capacidade contributiva e, por consequência óbvia, da progressividade e da vedação ao efeito de confisco.

Em suma, em razão de seu grau de complementariedade, desrespeitar a capacidade contributiva equivale à instituição de tributo com efeitos de confisco $^{405}$. Trata-se igualmente de princípio direcionado exclusivamente à pessoa do contribuinte, mas nem por isso torna-se inadequado falar em "não efeito confiscatório" ao terceiro, obrigado a pagamento de tributo devido por outrem, na medida em que este terceiro não pode ter seu patrimônio diminuído em razão de uma vantagem ou proveito cujo beneficiário é o contribuinte.

\subsubsection{O Princípio da Segurança jurídica}

Como já dissemos, a segurança jurídica constitui-se como um sobreprincípio, veiculado no preâmbulo da Constituição Federal, que anuncia a noção de Estado de Direito a que estarão jungidas as relações jurídicas, conforme mencionado na parte inicial deste trabalho. Segurança jurídica traz, por si só, a noção de algo livre de perigo ou livre de risco, protegido, acautelado, garantido, de algo de que se pode ter certeza ou em que se pode confiar, daí sua estreita vinculação com a proteção da boa-fé, com a certeza do direito e da relação de confiança entre Fisco e contribuinte ${ }^{406}$.

Como sobreprincípio que é, a segurança jurídica se presta a fundamentar, no âmbito constitucional, outros princípios, tais como a legalidade, a anterioridade e a

\footnotetext{
${ }^{404}$ apud PAULSEN, Leandro. Op. cit. (nota 56), P. 228 (JIMENEZ, Francisco J. Martín. Ele Procedimiento de derivación de responsablidad tributaria. Valladolid: Lex Nova, 2000. P. 241/242).

${ }^{405}$ Cf. DARZÉ Andréa M. Op. cit. (nota 348), P. 53.

${ }^{406}$ Cf. PAULSEN, Leandro. Op. cit. (nota 56), P. 882/883.
} 
irretroatividade, de forma a garantir a certeza do direito no que tange não apenas à instituição ou majoração de tributos ${ }^{407}$, mas também à definição dos contribuintes e dos responsáveis tributários, bem como das ferramentas de compensação econômico-financeira existentes entre essas pessoas, como, por exemplo, o instituto da retenção na fonte, examinado no Capítulo II.

Com efeito, em que pese não concordarmos com a integralidade da decisão exarada no RE 603.191/MT, de relatoria da Min. Ellen Gracie e apesar de não fazer referência ao princípio constitucional em exame, entendemos que, em sede de identificação da pessoa responsável pelo pagamento de tributo devido por outrem, seja na condição de sujeito passivo, sob o figurino de substituto tributário, seja como mero colaborador do Fisco, na qualidade de agente de retenção, haverá respeito à segurança jurídica quando forem atendidas às seguintes condições:

- $\quad$ respeito às normas de competência, de tal forma que as hipóteses de retenção na fonte não se caracterizem como a criação de um novo tributo. Em tempo, na medida em que o legislador autoriza a compensação integral dos valores pagos/retidos de forma antecipada, resta patente que a técnica de retenção na fonte corresponde apenas a uma das formas de pagamento do imposto;

- $\quad$ respeito à capacidade contributiva e à vedação de tributação com efeito de confisco;

- $\quad$ respeito aos limites à própria instituição do dever de colaboração que asseguram o terceiro substituto contra o arbítrio do legislador, de tal forma que essa colaboração guarde estreita relação com os princípios da razoabilidade da proporcionalidade. Em outras palavras, não se pode impor a alguém, classificado como substituto tributário ou como agente de retenção, deveres inviáveis, excessivamente onerosos, desnecessários ou ineficazes;

- respeito ao artigo 128 , do $\mathrm{CTN}$, de tal forma que a responsabilidade tributária lato sensu - substituto tributário ou agente de retenção - esteja em contato indireto com o aspecto material da hipótese tributária;

- $\quad$ que seja assegurado ao substituto tributário ou ao agente de retenção a retenção do imposto ou o seu ressarcimento, de forma que sua função restrinja-se a um mero

${ }^{407}$ Cf. PAULSEN, Leandro. Op. cit. (nota 56), P. 882/883. 
dever de colaboração e, nunca, a um dever de contribuir para as despesas públicas, obrigação pertinente unicamente ao contribuinte.

Em suma, o terceiro, inserido na posição de responsável pelo recolhimento de tributo de outrem, não realiza o fato gerador nem é o titular da capacidade contributiva, razão pela qual não deve suportar o peso pecuniário da contribuição devido ao Estado-Fisco. Neste sentido, a segurança jurídica mostra-se como veículo que permite a efetivação dos demais direitos e garantias do contribuinte e, em especial, daqueles terceiros.

\subsubsection{O Papel da Lei Complementar}

É da própria dicção do artigo 146, da CF, que se extrai a função tricotômica da lei complementar, especificamente no sentido de que veicular normas gerais em matéria de legislação tributária não se confunde com as questões de conflito de competência ou de regular as limitações ao poder de tributar ${ }^{408}$. Parece-nos clara essa noção, especialmente levando em conta a redação do inciso III daquele dispositivo, que indica, em rol não taxativo, as matérias submetidas à reserva de lei complementar.

Assim é que, ao disciplinar na alínea "a", do inciso III, do aludido artigo 146, da CF, que caberá à lei complementar a definição, quanto aos impostos discriminados no texto constituição, dos respectivos fatos geradores (aspecto material), base de cálculo e

\footnotetext{
${ }^{408}$ Cf. SCHOUERI, Luís Eduardo. Op. cit. (nota 04), P. 68/72. Com propriedade, LUIS EdUARDO SCHOUERI descreve essa tríplice função:

$\ddot{y}$ dispor sobre conflitos de competência, i.e., firmar os limites até onde podem andar os legisladores federal, estadual, distrital ou municipal na instituição dos tributos que lhes tenham sido atribuídos pela própria Constituição, esclarecendo, nos casos em que duas ou mais competências pareçam coincidir, a quem cabe a competência;

$\ddot{y}$ regular as limitações constitucionais ao poder de tributar, o que se torna especialmente importante quando dispositivos constitucionais exijam algum tipo de esclarecimento ou complementação para sua própria eficácia (por exemplo: os requisitos para que uma entidade assistencial sem fins lucrativos seja imune a impostos), mas também relevante para a solução de casos conflituosos entre dispositivos constitucionais (por exemplo: no conflito entre legalidade e igualdade, a decisão sobre os limites do emprego da analogia); $e$

ÿ estabelecer normas gerais em matéria de legislação tributária, assegurando uma disciplina única, em âmbito nacional, para a matéria tributária, apesar da existência de diversas legislações editadas pelas pessoas jurídicas de direito público. Estas devem dobrar se ao que for previsto pela lei complementar."
} 
contribuintes, o CTN cumpre rigidamente aquela função de veicular normas gerais em matéria tributária ${ }^{409}$.

Na mesma linha, LUCIANO AMARO afirma que o balizamento ao poder de tributar se dá, também, por normas infraconstitucionais, que atuam no sentido de complementar o desenho do campo da competência tributária. Como exemplos, o autor cita as leis complementares - como é o caso do CTN -, as resoluções do Senado e os convênios ${ }^{410}$.

Com ênfase na noção de sujeição passiva, queremos crer que seu figurino jurídico não está limitado apenas pela Constituição Federal, como soam as vozes de RENATO LOPES BECHO $^{411}$ e de GERALDO AtAliba e Aires F. BARRETO ${ }^{412}$, que defendem a identificação do sujeito passivo estritamente no seio constitucional. Queremos crer que as disposições do CTN, exercendo sua função de lei complementar, encerram limitações e prescrições específicas quanto à definição da responsabilidade. Isto porque, a par da redação contida nos artigos 121 e 128, ambos do CTN, que serão analisados mais à frente, verifica-se que: (i) a despeito de a pessoa não ter provocado, produzido ou tirado proveito econômico do fato jurídico tributário, uma vez inserido no polo passivo da obrigação tributária, ele poderá assumir a função de sujeito passivo, e (ii) que a lei instituidora do tributo está autorizada a inovar em matéria de responsabilidade, diferentemente das prescrições específicas e rígidas contidas nos artigos 129 a 135, todos do CTN, desde que o terceiro eleito como sujeito passivo mantenha ou tenha vínculo com o fato gerador da obrigação tributária $^{413}$.

Comungamos, ainda, neste ponto, nas lições de PAUlo de BARRos CARVAlHO, para quem a Constituição Federal não aponta quem deva ser o sujeito passivo das exações, cabendo ao legislador infraconstitucional ,não apenas na identificação do contribuinte, mas também na

409 “TRIBUTO - RELAÇÃO JURÍDICA ESTADO/CONTRIBUINTE - PEDRA DE TOQUE. No embate diário Estado/contribuinte, a Carta Política da República exsurge com insuplantável valia, no que, em prol do segundo, impõe parâmetros a serem respeitados pelo primeiro. Dentre as garantias constitucionais explícitas, e a constatação não excluí o reconhecimento de outras decorrentes do próprio sistema adotado, exsurge a de que somente a lei complementar cabe "a definição de tributos e de suas espécies, bem como, em relação aos impostos discriminados nesta Constituição, a dos respectivos fatos geradores, bases de cálculo e contribuintes" - alínea "a" do inciso III do artigo 146 do Diploma Maior de 1988." (STF. Tribunal Pleno. RE 172.058/SC. Min. Rel. Marco Aurélio. DJ 13/10/1995)

${ }^{410}$ Cf. AMARO, Luciano. Op. cit. (nota 69), P. 106/109.

${ }^{411}$ Cf. BECHO, Renato Lopes. Op. cit. (nota 360), P. 63/64.

${ }^{412}$ Cf. ATALIBA, Geraldo; BARRETO, Aires F. Op. cit. (nota 384), P. 73/75.

${ }^{413}$ Cf. DARZÉ Andréa M. Op. cit. (nota 348), P. 69/70. 
definição de qual sujeito arcará com o peso da incidência fiscal, observar dois limites: a competência tributária e o grau de relacionamento da entidade com o evento fático ${ }^{414}$ - daí se dizer que, no IR, a fonte pagadora guarda íntima relação com o fato gerador.

Neste mesmo sentido são as posições de MARIA Rita FERRAGuT ${ }^{415}$ e AndrÉA M. DARZÉ $^{416}$, que desconhecem a existência de qualquer norma constitucional que tenha por escopo indicar, de forma precisa e completa, quem deva ser o sujeito passivo de uma relação jurídica tributária. Trata-se, pois, de matéria reservada à lei complementar ou à legislação infraconstitucional de uma maneira geral, caso o seu detalhamento não seja possível em sede de lei complementar ou ordinária.

\subsection{O Sujeito Ativo}

A alusão ao sujeito ativo traz implícita duas noções importantíssimas do Direito Tributário. A primeira é a competência tributária, que decorre da Constituição Federal, traduzindo o poder originário autorizador da divisão, entre as pessoas jurídicas de direito público, de instituição de tributos para fazer frente às despesas e gastos públicos. Outra noção é a que diz respeito à capacidade tributária ativa, definida na seara infraconstitucional, e que se refere à definição de qual entidade pública ou autarquia deverá figurar no polo ativo da relação jurídica tributária ${ }^{417}$, imiscuindo-se no poder de cobrar e receber tributos, bem como fiscalizar as atividades dos contribuintes no que tange à obrigatoriedade de recolher impostos, quando tais funções não são exercidas diretamente pela pessoa política instituidora de determinado gravame ${ }^{418}$.

\footnotetext{
${ }^{414}$ Cf. CARVALHO, Paulo de Barros. Op. cit. (nota 361), P. 278/279.

${ }^{415}$ Cf. FERRAGUT, Maria Rita. Op. cit. (nota 03), P. 30.

${ }^{416}$ Cf. DARZÉ Andréa M. Op. cit. (nota 348), P. 79.

${ }^{417}$ Cf. SCHOUERI, Luís Eduardo. Op. cit. (nota 04), P. 470/471.

${ }^{418}$ Nessa toada, alguns autores pecam pela falta de apego ao preciosismo técnico, deixando margem para situações onde essa diferença entre competência tributária e capacidade tributária ativa não fica clara. É o caso do advogado JORGE SAADI FILHO: "O sujeito ativo da obrigação tributária é o Poder tributante, qual seja, a pessoa jurídica de Direito Público competente para exigir o cumprimento de tal obrigação. Evidentemente que o CTN se refere às pessoas jurídicas de Direito público interno como a União, Estadosmembros, Distrito Federal ou Municípios, as quais podem exercer diretamente os atos privativos de suas competências ou, ainda, de forma indireta, quando delegam competência às entidades públicas instituídas pelas primeiras. A União é quem exerce tal competência pelo Território Federal." (Cf. FILHO, Jorge Saadi. Comentários Objetivos ao Código Tributário Nacional. São Paulo: Editora LTr, 1984. 194).
} 
Por ora, importante é ter em mente que o sujeito ativo, credor da relação jurídica tributária, será representado sempre por uma pessoa que exerça atividade de interesse público, independentemente de qual entidade esteja figurando no polo ativo dessa relação jurídica, e que se incumba de promover a cobrança e o recebimento dos tributos devidos, podendo ser o próprio Estado ou uma pessoa jurídica de direito privado, no âmbito da parafiscalidade $^{419}$.

Devem ser destacados os conceitos de competência (já abordado anteriormente) e capacidade tributária ativa, relacionada com as funções de cobrança, arrecadação e fiscalização de tributos, atividades exercidas pelo sujeito ativo. Assim, quando analisamos a natureza jurídica do IRF sob a ótica do CTN, nos deparamos com o debate entre os Professores Rubens Gomes de Sousa, Geraldo Ataliba e Paulo de Barros CARVALHO $^{420}$ quanto à extensão do disposto no $\S 3^{\circ}$, do artigo $7^{\circ}$, do $\mathrm{CTN}$, no sentido de que tal dispositivo corresponde, de fato, a uma delegação de competência, ao passo que, no caso da fonte pagadora, está se impondo um dever, falando-se em "obrigação acessória", utilizando a terminologia do Código.

Vimos, todavia, que a fonte pagadora, para os casos do IRF, exerce uma função híbrida, caracterizada tanto por uma obrigação de dar, na medida em que as parcelas retidas do

\footnotetext{
${ }^{419}$ Sobre o tema, dada a importância que atinem ao paralelo entre substituto tributário e Agente de Retenção, figuras que serão analisadas mais à frente, valiosas são as palavras de ROQUE ANTONIO CARRAZZA as quais reproduzimos em sua íntegra: "Normalmente, os tributos são arrecadados pela própria pessoa política que os instituiu. Se dermos revista em nossa realidade jurídica veremos que, no mais das vezes, a União arrecada os tributos que ela, por meio de lei, criou, o mesmo fazendo os Estados-membros, os Municípios e o Distrito Federal. Entretanto, a União, os Estados, os Municípios e o Distrito Federal podem - desde que o façam sempre através de lei própria - autorizar terceiras pessoas a procederem a cobrança tributária. Se o produto arrecadado volta para os cofres da pessoa tributante, ocorre o fenômeno jurídico que há nome "sujeição ativa auxiliar". O agente ativo atua, como lecionava o saudoso mestre Gian Antonio Micheli, "em nome e por conta da pessoa tributante". Já, quando uma entidade diversa daquele que criou o tributo vem a arrecadá-lo, ficando com o produto arrecadado para si, a dizer, para o implemento de suas finalidades, dizemos que estamos diante de uma situação de parafiscalidade. Juridicamente, a parafiscalidade é apenas a atribuição, mediante lei, da capacidade tributária ativa que a pessoa política faz a outra pessoa (pública ou privada), que, por vontade desta mesma lei, passa a dispor do produto arrecadado, para a consecução de sua finalidades." (grifamos) (CARRAZZA, Roque Antonio. Op. cit. (nota 111), P. 211 nota 44). Como se vê, se tomarmos a figura da fonte pagadora, RoQUE ANTONIO CARRAZZA a classificaria como um agente arrecadador auxiliar ou, utilizando a expressão adotada neste trabalho, Agente de Retenção. Todavia, a leitura da outra obra de autoria do mesmo autor revela que os tais auxiliares dos sujeitos ativos correspondem a figuras não existentes no Brasil; o autor aponta que tais "agentes auxiliares" são muito raras, possivelmente existentes em cidadelas da Itália (Cf. CARRAZZA, Roque Antonio. O Sujeito Ativo da Obrigação Tributária. São Paulo: Editora Resenha Tributária, 1977. P. 77/79)

${ }^{420}$ Cf. SOUSA, Rubens Gomes de; ATALIBA, Geraldo; CARVALHO, Paulo de Barros. Op. cit. (nota 274), P. 95/96
} 
contribuinte devem ser entregues/recolhidas aos cofres públicos, e por algumas obrigações de fazer, encerrando verdadeiras atividades administrativas, próprias da Administração Tributária, tais como apurar a ocorrência de fato gerador, identificar e individualizar o contribuinte, quantificar e calcular a matéria tributável e o próprio imposto devido e, de forma consolidadora, informar todas essas atividades em declarações trimestrais e anuais (DCTF e DIRF) ao Fisco. A rigor, a natureza híbrida da retenção na fonte é resumida em duas obrigações: recolher aos cofres públicos a parcela retida (obrigação de dar) e informar tais valores nas declarações a serem entregues ao Fisco - DIRF e DCTF (obrigação de fazer). As demais providências não correspondem a obrigações autônomas.

Quer se mostrar, com isso, que não raras vezes o sujeito ativo contará com o auxílio de terceiros nessas funções administrativas, em especial a fonte pagadora, integrando-se relações jurídicas entre o Estado (Fisco) e a própria fonte pagadora.

\subsection{Sujeição Passiva}

A sujeição passiva apresenta-se como um dos fenômenos jurídico-tributário mais interessante e complexo, seja pelo fato de que se desdobra em mais de um tipo de vínculo, seja porque esses diferentes tipos de vínculos ensejam, necessariamente, relações jurídicas de naturezas distintas (natureza jurídico-tributária, natureza privada ${ }^{421}$ ou mesmo uma natureza jurídico-administrativa). Assim é que, a partir do estudo da Teoria Dualista da obrigação tributária, chegamos à clara constatação da separação entre o dever, sabidamente alojado no antecedente da regra matriz, e a responsabilidade, esta última, atrelada ao conseqüente da norma ${ }^{422}$.

\footnotetext{
${ }^{421} \mathrm{O}$ advogado PAULO ROBERTO ANDRADE: "Afirmamos sem medo de errar que a sujeição passiva é o tema de direito tributário de sistematização mais nebuloso em doutrina e jurisprudência. Vigora, ainda hoje, indesejável dissenso terminológico na utilização dos termos responsabilidade, substituição, sujeição passiva direta e indireta, tratados promiscuamente ora como espécies de um mesmo gênero, ora como gêneros distintos." (Cf. ANDRADE, Paulo Roberto. O ISS e a Responsabilidade Tributária Prevista no art. $6^{o}, \S 2^{\circ}$, II, da Lei Complementar $n^{o}$ 116/03. Revista Dialética de Direito Tributário no 104. São Paulo: Dialética, 2004. P. 64).

${ }^{422}$ ANDRÉA M. DARZÉ adverte que a responsabilidade tem como núcleo comum o fato de ser sempre vista como enunciado prescritivo que interfere na obrigação de pagar tributo, revelando-se, pois, como tema diretamente relacionado ao conteúdo do consequente da regar matriz, mas especificamente do aspecto subjetivo (Cf. DARZÉ Andréa M. Op. cit. (nota 348), Introdução. P. XXI).
} 
Conforme já mencionamos, o artigo 121, do CTN, demarca que não raras vezes o tributo deverá ser arcado por um terceiro, diferente do contribuinte, e que não tenha relação/vínculo direto com o fato gerador da obrigação tributária. A obrigação de pagar o tributo decorre, nestes casos, de mera imposição legal e, conforme o caso, adicionalmente à previsão em lei, de um contato, indireto, ou com a situação que constitua o fato gerador ou com o próprio contribuinte.

Define o CTN como sujeitos passivos possíveis da relação obrigacional tributária o contribuinte, o qual deverá guardar relação pessoal e direta com o fato gerador (situação em que o aspecto subjetivo presente no antecedente da regra matriz confunde-se com aquele vislumbrado no consequente) e o responsável, pessoa diversa do contribuinte. Ora, nas palavras do próprio Código, não revestir a condição de contribuinte deve ser interpretado como não possuir relação, pessoal e direta, com o fato gerador, i.e., estar obrigado ao pagamento do tributo exclusivamente em razão de expressa disposição legal, mas não porque incorreu na tributação em si.

Assim é que o sujeito passivo, algumas vezes, confundir-se-á com a figura do contribuinte, situação em que a própria pessoa que incorreu no fato gerador é quem deverá pagar tributo próprio. Exemplos típicos, circunscritos ao universo da presente análise, são os casos para os quais o legislador não excepcionou mediante regra de retenção do tributo na fonte, como sói ocorrer com relação ao IR devido pela pessoa física que aliena um bem imóvel, nas hipóteses de ganho de capital, quando o imposto é pago, de forma definitiva, pelo próprio contribuinte. Noutras, o polo passivo da relação jurídica tributária será ocupado por pessoa diversa, recebendo o nome genérico de sujeito passivo indireto.

Por seu turno, o artigo 128, do CTN, disciplina, a nosso ver, uma não menos controvertida terceira forma de sujeição passiva tributária, com características diferentes do contribuinte e do responsável stricto sensu que, por si só, indicam a necessidade de sua classificação como uma espécie autônoma e independente ${ }^{423}$. Segundo esse artigo, o crédito tributário ${ }^{424}$

\footnotetext{
${ }^{423}$ LEANDRO PAULSEN parece entender de forma parecida, ainda que, para tanto, utilize nomenclatura diferente da que pretendemos estabelecer para o presente trabalho. PAULSEN propõe a classificação dos sujeitos passivos da seguinte forma; 1) Contribuinte; 2) Terceiros: 2.1) Substituto, que é o obrigado a apurar o tributo devido e a efetuar seu pagamento em caráter definitivo em lugar do contribuinte, normalmente mediante retenção e recolhimento, restando o contribuinte dispensado de efetuar a apuração e pagamento do tributo, mas, em lugar disso, o contribuinte simplesmente suporta a retenção (exemplo de substituto: a
} 
poderá ser atribuído à terceira pessoa, com a diferença que, neste caso, essa terceira pessoa deverá guardar algum tipo de vínculo com o fato gerador da obrigacão tributária por expressa definição legal.

A despeito da crítica referente à terminologia empregada para a nomenclatura deste Capítulo V, do CTN, pode parecer ousado afirmar que o legislador acaba por fornecer elementos característicos e próprios que não seriam aplicáveis às demais hipóteses de responsabilidade tributária disciplinadas nos artigos 129 a 135, todos do CTN.

Além do conjunto de questões que deverão ser levantadas na validação da classificação aqui em comento, contribuinte de um lado e, de outro lado, responsável tributário stricto sensu e substituto tributário, bem como a figura do agente de retenção, um primeiro problema que se coloca é a exata conceituação de cada uma dessas espécies e as características associadas à sujeição passiva indireta, tais como:

ð relação pessoal e direta com o fato gerador;

ð não revestir a condição de contribuinte;

ð terceira pessoa vinculada, indiretamente, ao fato gerador e qual a relevância e abrangência desse vínculo;

ð terceira pessoa vinculada ao contribuinte;

ð exclusão da responsabilidade do contribuinte;

ð atribuição de responsabilidade ao contribuinte de forma supletiva; e

ð agente de retenção.

instituição financeira relativamente ao imposto de renda devido sobre aplicações financeiras); 2.2) Retentor, que corresponde à situação semelhante ao do substituto, para os casos, porém, em que o imposto é retido não em caráter definitivo, mas como antecipação, tendo em vista que o tributo será posteriormente apurado pelo contribuinte, com a possibilidade de dedução das retenções (como exemplo cita o caso do empregador relativamente aos pagamentos feitos aos seus empregados); 2.3) Responsável, situação em que o terceiro responde com seu próprio patrimônio para os casos de inadimplência do contribuinte, do substituto ou do retentor. (Cf. PAULSEN, Leandro. Op. cit. (nota 56) P. 930).

${ }^{424}$ Aqui merece crítica o uso da expressão "crédito tributário", tendo em vista que, em sede do artigo 128, do CTN, albergando, como veremos, situação anterior à verificação de todos os elementos do fato gerador, não há se falar em "crédito tributário". Este somente se aperfeiçoa com o lançamento, que tem apenas o condão de declarar uma determinada obrigação tributária já ocorrida. Voltaremos a tratar deste ponto ao abordarmos as imprecisões técnicas impregnadas na redação do dispositivo em comento. 
Na medida do possível, e na ordem em que tais ocorrências surgirem, procuraremos, no âmbito de cada uma das classificações a seguir, abordar os aspectos conceituais e funcionais dos tópicos listados acima.

\subsubsection{Sujeição Passiva Direta - O Contribuinte da Obrigação Tributária}

Em sua exaustiva obra sobre o ISS, BERNARdo RIBEIRO DE MORAES, valendo-se das afirmações dos juristas argentinos ROBERTO TAMAGNO e DINO JARACH, conceitua a figura do contribuinte como toda pessoa que contribui, que dá ou paga contribuições, donativos, cotas ou impostos. Ensina que o contribuinte é o devedor do imposto com responsabilidade originária e que sua configuração resulta do simples fato de a pessoa estar nas condições previstas na hipótese tributária, i.e., estar em relação direta e imediata com o fato gerador do tributo, vale dizer, estar na condição de sujeito passivo direto ${ }^{425}$.

Não é demais ressaltar que, após apuradas as noções de antecedente e consequente da regra matriz vistas na parte inicial deste estudo, parece soar contraditório o uso da expressão "sujeição passiva direta" associada à figura do contribuinte.

Das palavras do Professor Luís EDUARDO SCHOUERI "conquanto o rigor normativo imponha a formulação de regra matriz em que a relação jurídica seja colocada no consequente da norma, e não no precedente ${ }^{, 26}$, e cientes de que o contribuinte se acomoda no antecedente daquela mesma regra matriz, mais precisamente no seio do aspecto material ${ }^{427}$, depreendemos que a utilização da expressão "sujeição passiva indireta", se válida ou não, fundamenta-se exclusivamente na ideia de trazer uma apresentação didática e útil ${ }^{428}$, sem, contudo, que isso implique desdizer as ideias nucleares construídas em torno do antecedente e do consequente.

\footnotetext{
${ }^{425}$ Cf. MORAES, Bernardo Ribeiro de. Doutrina e Prática do Imposto Sobre Serviços. $1^{\mathrm{a}}$ ed. $3^{\mathrm{a}}$ tiragem. São Paulo: Revista dos Tribunais, 1984. P. 440

${ }^{426}$ Cf. SCHOUERI, Luís Eduardo. Op. cit. (nota 367), P. 147.

427 Ibidem, Op. cit. (nota 367), P. 167.

${ }^{428}$ Cf. DE SANTI, Eurico Marcos Diniz. As Classificações no Sistema Tributário Brasileiro. in Justiça Brasileira. São Paulo: Max Limonad, 1998, P. 125/145.
} 
Com efeito, no bojo da "sujeição passiva indireta" iremos encontrar as figuras do responsável tributário e do substituto tributário, que correspondem às situações em que o sujeito passivo pagará tributo devido por outrem (o contribuinte).

Assim sendo, em linha com as premissas assumidas no início de nossas análises, mormente a teoria dualista da obrigação e os espectros conceituais do fato gerador e da obrigação tributária, o contribuinte está para a hipótese tributária, como pessoa que efetivamente promoveu o fato gerador (antecedente), assim como o responsável (ou o substituto) está para a relação jurídica tributária (consequente). Em que pese estes terceiros não terem incorrido no fato gerador, serão inseridos, por determinação legal, no polo passivo da relação jurídica tributária. Como dito anteriormente, o contribuinte poderá igualmente assumir a feição de sujeito passivo da relação jurídica tributária nas situações em que ele próprio ocupar a posição de devedor do tributo. Alerte-se, neste momento, que independente do fato de ocupar ou não o polo passivo da relação jurídica tributária, a pessoa que incorreu no fato gerador da obrigação tributária jamais abandona sua condição originária de contribuinte ${ }^{429}$.

O contribuinte é, com exclusividade, a figura que faz nascer a obrigação tributária por praticar uma determinada ação ou por se encontrar em determinada situação identificada abstratamente pelo legislador como suficiente para a incidência de tributos. Essa ação ou situação é o que chamamos de fato gerador. Somente e tão somente o contribuinte é quem tem aptidão pessoal para incorrer no fato gerador da obrigação tributária.

O estudo do silogismo do fenômeno da incidência tributária como relação jurídica tributária conduz à assertiva que, sem a ocorrência daquele fato gerador, i.e., sem a existência e a participação do contribuinte em um determinado evento do mundo fático, não há sequer o nascimento da obrigação tributária, composta por um credor (Estado) e um devedor. $\mathrm{O}$ antecedente e o consequente da regra matriz são frações indissociáveis e interdependentes; sua divisibilidade só é possível a partir de um corte metodológico (ou

\footnotetext{
${ }^{429}$ O Professor RUY BARBOSA NOGUEIRA chegou a firmar que: "Portanto, a qualidade de contribuinte é uma decorrência da realização do fato gerador, ou em outras palavras, a pessoa que realiza o fato previsto na lei como tributável adquire o status de contribuinte. Na literatura jurídica alemã, este fenômeno é chamado de Zurechnung, que poderíamos traduzir por responsabilidade pela conta ou quantia, por atributividade do débito, pois Zurechnungsfähigkeit é a responsabilidade pessoal ou imputabilidade." (destaques no original) (Cf. NOGUEIRA, Ruy Barbosa. Op. cit. (nota 02), P. 145).
} 
epistemológico) para fins exclusivamente didáticos. Significa dizer que a responsabilidade tributária, entendida em sua acepção lata, só tem lugar onde existe (ou existiu) um contribuinte e, posteriormente, uma obrigação tributária.

Essa é a exata noção que se extrai do artigo 121, do CTN, quando fala em "relação pessoal e direta com o fato gerador" e "não revestir a condição de contribuinte". No primeiro excerto, trata-se de situação exclusivamente atrelada à figura do contribuinte, mais especificamente, ao agir (ou não agir), ao ser e ao estar do contribuinte. Não revestir a condição de contribuinte quer dizer não ter essa aptidão de ser o ente que dá início ao fenômeno da incidência, não ter sequer a faculdade de incorrer, por seus próprios meios, na hipótese tributária ou na situação que constitua o fato gerador descrito na norma.

HUGO BARRETO SODRÉ LEAL enfrentou o tema com precisão, demonstrando que o termo 'pessoa' foi empregado para qualificar um vínculo de proximidade entre a pessoa e o fato, i.e., que o contribuinte se encontra presente no contexto de ocorrência do fato jurídico tributário. Afirma, contudo, que esse vínculo pessoal não é suficiente, sendo necessário que se trate de uma 'relação direta', no sentido de uma relação essencial, em linha reta, sem desvios. Conclui que a expressão 'relação pessoal e direta' significa a condição da pessoa que realiza o verbo de ação ou de estado, que consiste na conduta prevista no aspecto material da regra matriz ${ }^{430}$.

Assim é que, para ser qualificado como contribuinte, é necessário que participe diretamente da materialidade do tributo, realizando pessoalmente o verbo. Por um lado, saber se essa pessoa irá figurar no polo passivo da relação jurídica tributária é análise que foge à caracterização do contribuinte. Por outro lado, a pessoa vinculada indiretamente ao "fato gerador", que participa da compostura do suporte factual da tributação, sem, contudo, realizar o verbo, poderá ser definida como responsável tributário latu sensu, caso seja colocada no polo passivo da obrigação tributária ${ }^{431}$.

\footnotetext{
${ }^{430}$ Cf. LEAL, Hugo Barreto Sodré. Responsabilidade tributária na aquisição de estabelecimento empresarial. São Paulo: Quartier Latin, 2008. P. 34/35.

${ }^{431}$ Cf. DARZÉ Andréa M. Op. cit. (nota 348), P. 83.
} 


\subsubsection{Sujeição Passiva Indireta da Relação Jurídica Tributária}

Sobre a multiplicidade de pessoas inseridas na posição de responsável fiscal, genericamente falando, MANUEl CHASTAGNARET introduz o assunto afirmando que as primeiras observações sobre o tema da 'responsabilidade fiscal' já indicam a característica dominante do tema da responsabilidade, que se refere à ideia de que pode atingir todos os membros da sociedade, entes privados ou públicos, tanto as pessoas jurídicas quanto os indivíduos. Diz, ainda, que a responsabilidade pode ser pessoal ou atuar numa regra de benefício de ordem. Evidencia que essas acepções eram vistas desde o Código de Hamurabi, que já revelava a diversidade de fontes da responsabilidade. As ações que permitiam a Administração "colocar" uma pessoa que não o contribuinte de direito como responsável pelo tributo eram muito amplas, o que se explicava até pelo fato de que as pessoas atingidas por essas ações não formavam um conjunto uniforme, concluindo que a diversidade de situações implicava uma multiplicidade de terceiros responsáveis ${ }^{432}$. Como se vê, não é coisa nova a preocupação do Estado-Fisco com a garantia do crédito tributário.

Não há, absolutamente, como afastar a relevância da figura do contribuinte em uma relação jurídica tributária, inclusive nas situações em que o legislador, no exato instante da ocorrência do fato gerador, com o nascimento da obrigatória tributária, já elegeu um sujeito passivo diferente do contribuinte como obrigado à retenção e ao recolhimento do gravame, com a exclusão definitiva da responsabilidade do contribuinte.

\footnotetext{
${ }^{432}$ No original, com mais detalhes "Ces premières observations illustrent le caractère transversal du domaine de la responsabilité. Il concerne l'ensemble des membres du corps social, personnes privées ou personnes publiques. Il affecte aussi bien une collectivité qu'un individu. La responsabilité ne doit pas seulement s'entendre dans une acception négative et la revendication, fondée ou non, de responsabilité peut relever aussi de l'affirmation personnelle ou de la recherche d'avantages. Cette considération n'est pas nouvelle comme le montre le Code d'Hammourabi en matière de responsabilité médicale: 'Si un médecin a opéré quelqu'un d'un grave abcès avec une lampe de bronze et l'a guéri ou bien a ouvert la tempe de quelqu'un avec une lampe de bronze et lui a guéri l'ail, il recevra dix sicles d'argent'. Ce texte montre également la diversité des sources de la responsabilité : suivant les époques ou les territoires, les fondements de la règle diffèrent : ils ont souvent, et longtemps, été religieux avant de devenir plus matérialistes. (...) Les actions qui permettent à l'Administration fiscale de faire peser sur une personne distincte du contribuable des droits ou pénalités concernent un champ três étendu. En effet, les personnes visées par ces mécanismes ne forment pas un ensemble uniforme: la diversité des situations se traduit par une multiplicité de tiers responsables." (Cf. CHASTAGNARET, Manuel. De La Responsabilité Fiscale - Responsabilité de l'administration fiscale et responsabilité solidaire des tiers. Marseille: Presses Universitaires D'AixMarseille, 2003. P. 18 e 35).
} 
No âmbito de uma primeira tentativa de classificação dos diferentes sujeitos passivos indiretos, em que um terceiro é designado por lei para pagamento de tributo de outrem, tomando o aspecto temporal como ponto de partida, LUís EDUARDO SCHOUERI demonstra que este 'critério' não é suficiente para explicar a natureza do vínculo que este terceiro deve manter com o "fato gerador", utilizando a mesma dicção do artigo 128, do CTN. Demonstra, ainda, que, nos casos de substituição, o fato que dá nascimento ao vínculo surge antes ou, no máximo, ao mesmo tempo, da ocorrência do fato jurídico tributário. Por seu turno, nos casos de responsabilidade tributária stricto sensu, o vínculo poderá surgir até mesmo depois daquela concretização ${ }^{433}$.

Parece, assim, que o aspecto temporal, como elemento de discrímen para classificação dos sujeitos passivos indiretos explica a problemática apenas em parte ${ }^{434}$. A razão da expressão "fato gerador" vir, neste tópico, marcada entre aspas, tem fundamento, conforme se explica a seguir.

Se o aspecto temporal aparece como um critério de discrímen não suficientemente seguro e eficaz, parece-nos que, primeiramente, é preciso investigar, para identificação da natureza daquele vínculo, em qual sentido a indesejável expressão "fato gerador" foi empregada no artigo 128, do CTN, até mesmo como ferramenta para auxiliar na verificação se os artigos 129 a 135, do CTN, buscam naquele dispositivo sua regra geral de validade.

LUÍS EDUARDO SCHOUERI ensina que o "fato gerador" descrito no CTN corresponde a uma situação, que implica contemplar, também, além do aspecto material, os aspectos temporal e espacial, muito embora somente a partir do aspecto material é que será possível identificar uma tributação de outra ${ }^{435}$.

\footnotetext{
${ }^{433}$ Cf. SCHOUERI, Luís Eduardo. Op. cit. (nota 04), P. 480/481. O autor demostra que o vínculo está na exata medida da possibilidade, legalmente definida, que tem o terceiro de ressarcimento ou retenção perante o contribuinte.

${ }^{434}$ Queremos crer que, excetuado o caso do tutor, presente nos artigos 134, inciso II, e 135, inciso I, ambos do CTN, nas hipóteses previstas nos artigos 129 a 135, do CTN, a identificação do sujeito passivo indireto, como responsável tributário stricto sensu, se dá após a ocorrência do fato jurídico tributário e, em alguns casos, após a constituição do crédito tributário. Diferente é o caso do substituto tributário, descrito no artigo 128, do CTN, em que essa identificação opera-se no exato instante ou em momento anterior à concretização do fato gerador, i.e., a obrigação tributária já nasce com o substituto tributário definido.

${ }^{435}$ Cf. SCHOUERI, Luís Eduardo. Op. cit. (nota 04), P. 447.
} 
Todavia, quando um dispositivo legal refere-se ao "fato gerador", em que pese a penosa e problemática polivalência da expressão, parece-nos mais adequado entender que o uso daquela expressão objetivou, em verdade, referir-se à sua materialidade e não aos demais aspectos da hipótese tributária. O mesmo se diga, por exemplo, do artigo 146, inciso III, alínea "a", da CF, que autoriza o legislador complementar a veicular normas gerais tributárias para disciplinar, quantos aos impostos, sobre "fatos geradores, bases de cálculo e contribuintes". Ora, ainda que não exista um vínculo imediato entre os dispositivos legais aqui analisados, pensamos, em uma interpretação sistemática e teleológica da legislação tributária, que, nestes e noutros casos, quando o legislador utiliza a expressão "fato gerador" ele a emprega, de fato, em seu sentido nuclear, qual seja, busca apreender a materialidade (verbo) capaz de fazer nascer a obrigação tributária.

Já com essa primeira ponderação poderia se traçar um esboço de classificação dos sujeitos passivos indiretos, no qual aqueles, com vínculo indireto à materialidade da imposição, seriam agrupados como substitutos tributários e aqueles, com vínculo genérico à situação, mais propriamente um vínculo, direto ou indireto, à pessoa do contribuinte, pertenceriam ao grupo dos responsáveis tributários stricto sensu, previstos especificamente nos artigos 129 a 135 , do CTN.

Entretanto, defendendo as premissas assumidas no início deste trabalho, onde vimos que o aspecto subjetivo é visualizado, também, no antecedente, mais precisamente na pessoa do contribuinte como realizador do verbo denotativo da tributação, temos que o aspecto material poderá consolidar situações de contato tanto com o substituto tributário, em função da própria materialidade (pessoalidade) em si , como também com o responsável tributário stricto sensu, diante da identificação do aspecto subjetivo no antecedente.

ANDRÉA M. DARZÉ, ao passar sobre este tema, também aponta os inconvenientes inerentes à ambiguidade da expressão "fato gerador". Primeiramente, divide a responsabilidade tributária em dois grupos: o primeiro grupo corresponderia às prescrições específicas das Seções II, III e IV do Capítulo V, do Titulo II, do CTN - artigos 129 a 137 - e o segundo grupo ao próprio artigo 128, como norma inovadora na eleição de terceiro como sujeito passivo da obrigação tributária, desde que mantenha relação indireta com o "fato gerador". O que se vê, nessa classificação, é uma relação de autonomia daquele primeiro grupo em 
relação ao segundo, afastando, em princípio, a ideia de que o artigo 128 seria uma regra ou norma geral do tema 'responsabilidade tributária' ${ }^{436}$.

Após coligir essa classificação, a autora aponta que o vínculo existente entre aquele terceiro, definido como sujeito passivo da obrigação tributária, não corresponde a uma relação meramente econômica, mas, sim, a um vínculo jurídico que caracteriza a materialidade do tributo, i.e., sua conexão deve estar na realização do verbo pelo contribuinte.

Outro ponto relevante, ainda no âmbito que circunscreve ao artigo 128, é observar que, em alguns casos de responsabilidade tributária stricto sensu, como o do artigo 135, o legislador complementar não disciplinou, expressamente, norma que garanta, ao terceiro, regra de ressarcimento ou reembolso do ônus financeiro do tributo. Com efeito, assumindo que o artigo 128, juntamente com o artigo 121, materializam a função dualista da obrigação tributária, segregando o debitum (contribuinte) da obligatio (responsável ou substituto), os demais dispositivos que tratam da responsabilidade tributária haveriam de buscar no 128, como norma geral, o seu fundamento de validade, ao menos no que tange à possibilidade de ressarcir-se do tributo ou do crédito tributário, conforme o caso, perante o contribuinte $^{437}$. Sob outra perspectiva, no entanto, vale lembrar que a legislação não veda que o responsável tributário stricto sensu recomponha seu patrimônio junto ao contribuinte, ainda que, em alguns casos, isso não seja possível, por exemplo, no caso de uma sociedade ser incorporada. Diz-se, ainda, que as formas para que o responsável tributário stricto sensu possa recuperar o tributo pago em nome do contribuinte estão igualmente previstas em lei, contudo fora do âmbito do Direito Tributário (regra geral, através do exercício do direito de regresso, já no âmbito do direito privado).

Longe de querer inovar e de apresentar soluções definitivas às problemáticas apontadas acima, o que, além de sobremaneira pretencioso, refoge aos quadrantes do escopo deste trabalho, vale ponderar que, conforme a perspectiva com que se analisa, o artigo 128, do CTN, poderá ser enxergado ou como regra geral do tema 'responsabilidade tributária' ou como regra específica que permitirá ao legislador disciplinar novas hipóteses de

\footnotetext{
${ }^{436}$ Cf. DARZÉ Andréa M. Op. cit. (nota 348), P. 67/90 (69/71; 84; 87).

${ }^{437}$ Cf. SCHOUERI, Luís Eduardo. Op. cit. (nota 04), P. 510/511.
} 
"responsabilidade tributária", diferentes daquelas previstas nos artigos 129 a 135, do CTN. Como se viu, por um ângulo ou outro, o artigo 128 exerce importância para os demais dispositivos que tratam sobre responsabilidade tributária. Interessa-nos, por ora, manter a ideia de que, em sede das situações em que se exige tributo de pessoa diversa daquela que realiza o fato jurídico tributário, o responsável tributário stricto sensu e o substituto tributário são figuras diferentes com regimes jurídicos próprios.

Certo é que, desde que tenha ocorrido o aperfeiçoamento do fato gerador e o nascimento da obrigação tributária, a pessoa designada para pagamento do tributo sempre será efetivamente o sujeito passivo da relação jurídica tributária, seja ela um terceiro ou o próprio contribuinte ${ }^{438}$. O que se releva destacar, neste momento, além dos elementos característicos de cada uma daquelas duas classificações - responsável tributário stricto sensu e substituto tributário - são as razões que levam (ou que podem ou devam levar) o poder público a escolher outras pessoas, diversas daquelas que deram origem ao fato gerador, para levar recursos econômicos aos cofres do Estado.

Não apenas a partir do CTN, mas certamente de leis ordinárias editadas nas searas federal, estadual e municipal, observa-se que razões de ordem prática, de facilitação da máquina pública arrecadadora e da necessidade de mitigação dos riscos de insolvência físcal, têm motivado a cobrança de tributos contra pessoa diversa daquela que praticou/incorreu o/no fato gerador da obrigação tributária. Mais uma vez, estamos diante do que se convencionou chamar de princípio da praticabilidade, já abordado sob a perspectiva do IRF, cuja noção geral aplica-se também aos casos de responsabilidade tributária (acepção lata) por necessidade ou por interesse ${ }^{439}$.

Certamente, a causa mais relevante que se pode extrair do instituto da responsabilidade tributária, entendido em sua acepção mais abrangente, qual seja, a faculdade de atribuir a obrigação de recolhimento do tributo para uma terceira pessoa diferente do contribuinte, é

\footnotetext{
${ }^{438}$ JOSÉ MANUEL CARDOSO DA COSTA entende que: "O que o legislador tem em vista ao estender a pessoas diversas do sujeito passivo a obrigação do pagamento de determinados impostos, é um objetivo óbvio: o de reforçar a garantia do cumprimento da obrigação fiscal em certos casos em que é ou pode tornar-se problemático ou impossível fazer àqueles a sua cobrança." (Cf. COSTA, José Manuel Cardoso da. Curso de Direito Fiscal. Coimbra: 1970. P. 440). Vale manifestar crítica ao posicionamento no sentido de que o autor entende que o terceiro eleito como pagador do imposto não se qualificaria como sujeito passivo, o que, como vimos, não é a interpretação mais correta, ao menos sob a perspectiva do direito tributário nacional.

${ }^{439}$ Cf. DARZÉ Andréa M. Op. cit. (nota 348), P. 104/105.
} 
a finalidade arrecadatória, mediante garantia do crédito tributário. $\mathrm{O}$ bem jurídico tutelado pelo Direito Tributário não é outro senão a arrecadação.

MARIA RITA FERRAGUT ensina que, além da causa arrecadatória, existem outras finalidades que motivam o legislador tributário a valer-se (às vezes de forma abusiva) da responsabilidade tributária: conveniência, necessidade, a própria impossibilidade de adimplemento do crédito tributário, como se vislumbra no artigo 26, da Lei $\mathrm{n}^{\circ} 10.833 / 03$, e, por fim, a finalidade sancionatória. Propõe, ainda, ao classificar essas finalidades, que a conveniência e a necessidade seriam desdobramentos da finalidade arrecadatória ${ }^{440}$. Vale lembrar que a autora se posiciona no sentido de que ao legislador é outorgada muita liberdade na definição dos sujeitos passivos. Conforme já tivemos a oportunidade de comentar, há limites para estas definições; além dos princípios constitucionais, deve, na hipótese de não se referir a um dos casos específicos previstos nos artigos 129 a 135, do CTN, existir um vínculo com o fato gerador da obrigação tributária, para que se caracterize uma proximidade com o aspecto material da regra matriz.

Portanto, por conveniência, deve-se ter em mente os ideais de eficácia, praticidade, redução de custos e otimização da máquina pública. Com efeito, parece-nos perfeitamente razoável afirmar que o deslocamento da obrigação para o empregador (fonte pagadora), por exemplo, representa situação que claramente atende a estes ideais - em que pese já termos trabalhado estes conceitos no subitem 1.10.6. de forma mais detalhada, vale repisar algumas considerações:

a. Praticidade: permite que o recolhimento do tributo seja concentrado em uma única pessoa, em vez de diluir-se em um número infindável de contribuintes (operações de massa);

b. Eficácia: este ideal parece estar em posição indissociável dos consectários econômico-financeiros e administrativos associados às funções arrecadatória e fiscalizadora do Fisco, na qualidade de sujeito ativo. Por um lado, permite promover a diminuição da inadimplência. Sob outra perspectiva, autoriza que os agentes de fiscalização (i) possam direcionar seus trabalhos de auditoria em um número significativamente menor de sujeitos; (ii) que os órgãos de fiscalização possam

${ }^{440}$ Cf. FERRAGUT, Maria Rita. Op. Cit. (nota 03), P. 52/53. 
otimizar seu pessoal em outras funções. Ainda, como conseqüência, autoriza que se promova um enxugamento da pesada folha de pagamento da máquina estatal contudo, isso somente se tornará benéfico à sociedade à medida que reverter diretamente na diminuição da carga tributária como um todo.

Para os casos previstos nos artigos 129 a 135, do CTN, dentre as causas de sua existência encontramos: (i) necessidade, com foco nos artigos 129 a 133 - hipóteses de responsabilidade por sucessão -, tendo em vista a impossibilidade de exigência do cumprimento do crédito tributário frente ao contribuinte originário; e (ii) sancionatória, com foco nos demais artigos, para os casos de responsabilização por infração à legislação tributária ou a estatuto social, por ato ou omissão.

Para os casos de substituição tributária, atrelados à disciplina contida no artigo 128, do CTN, com razoável segurança, é possível ponderar que o princípio da praticabilidade, intimamente associado à ideia de eficácia e eficiência, revela-se como fundamento jurídico suficiente correspondente ao conjunto de condições que garantem uma execução adequada e econômica das leis.

Se adequadamente utilizado, este princípio terá o condão de atender a importantes necessidades do ordenamento jurídico, dentre as quais a possibilidade de torná-lo exequível, viável e ágil, que, em verdade, corresponde às propaladas eficácia e eficiência. Daí a relevância de serem observados os princípios da legalidade, vedação à instituição de tributo com efeito de confisco e da segurança jurídica, assim como zelar pela preservação do patrimônio do terceiro obrigado ao pagamento de débito alheio. Essa mesma segurança jurídica deverá ser equilibrada tanto sob a ótica da arrecadação tributária como também em proteção aos direitos do contribuinte e do terceiro.

\subsubsection{Responsável Tributário}

O CTN, no Capítulo V, do Título II de seu Livro Segundo, dedicou ao tema "responsabilidade tributária" onze artigos, subdividindo-os, à exceção de seu primeiro artigo, o 128, em três partes: (i) responsabilidade dos sucessores (artigos 129 a 133); (ii) 
responsabilidade de terceiros (artigos 134 a 135); e (iii) responsabilidade por infrações tributárias (artigos 136 a 138).

Analisando com propriedade a redação contida nos artigos 136 e 137, do CTN, chega-se à conclusão que ambos tratam de situações em que não se faz apropriado falar na figura de responsável tributário, mas sim em agente. Com isso, acompanhando de forma acertada o título dessa seção IV, os dispositivos em questão tratam de situações nas quais verificou-se uma infração tributária.

Em que pese o artigo 136 mencionar o termo "responsável" e, no mesmo sentido, o artigo 137 aludir, em seu inciso III, a sujeitos precisamente classificados como responsável tributário em outros dispositivos do CTN (mais especificamente nos artigos 134 e 135), somos da opinião que esses normativos que tratam da responsabilidade por infrações não se limitam exclusivamente à figura do responsável tributário (entendido na exata noção proposta no presente estudo). É dizer que a responsabilização, nos casos de infração à legislação tributária, poderá atingir qualquer um, tanto o contribuinte como também o sujeito passivo indireto, nas figuras aqui chamadas de responsável tributário stricto sensu e substituto tributário.

Mais ainda, MARIA RITA FERRAGUT ensina que, assumindo que este dispositivo trata das infrações definidas como sendo crime, faz-se relevante analisar o disposto no artigo 11, da Lei $\mathrm{n}^{\circ}$ 8.137/90, dispositivo que abarca não apenas o agente, mas, também, o partícipe ou mandante que tiver concorrido na prática delituosa ${ }^{441}$.

À guisa da extensão e do alcance dos artigos 136 e 137, ambos do CTN, parece-nos pacífico afirmar que estes dispositivos não se inserem (ou não se limitam) dentro da espécie responsabilidade stricto sensu. Sob este argumento, o exame destes artigos foge ao escopo de nossa abordagem.

Diferente não é o caso do artigo 138, do CTN, que disciplina o instituto da denúncia espontânea, aplicável indistintamente ao contribuinte, ao responsável tributário e ao

${ }^{441}$ Cf. FERRAGUT, Maria Rita. Op. Cit. (nota 03), P. 148. 
substituto tributário e, até mesmo, ao agente de retenção, como ente responsável pelo recolhimento de tributo.

Para Alfredo Augusto BeCKer ${ }^{442}$, o responsável legal tributário só surgiria quando ocorresse o fato da não satisfação do débito tributário devido pelo contribuinte de direito. AgOSTINHO SARTIN ${ }^{443}$, apoiado na classificação entre sujeitos passivos diretos e indiretos, pregava que, com relação a estes últimos, o fato de eles não terem uma relação pessoal e direta justificava a afirmação de que eles solviam dívida alheia.

Paulo de Barros CARVAlHo ${ }^{44}$, e nesse ponto é acompanhado por RenAto Lopes $\mathrm{BECHO}^{445}$, sustenta que a "responsabilidade tributária" é uma sanção administrativa, não se revestindo de uma roupagem essencialmente tributária. PAUlo DE BARRos CARvalho enxerga um timbre sancionatório na responsabilidade tributária, tendo em vista que pessoa diversa ao acontecimento do fato jurídico tributário é colocada como sujeito passivo da obrigação tributária, apresentando, assim, a natureza de uma sanção administrativa. Vale destacar, também, que o jurista constrói, no artigo 128, do CTN, uma regra ou enunciado geral que serve de suporte aos artigos 129 a 135. Aponta, ainda, que, na fixação da responsabilidade pelo "crédito tributário" (em que pese nalguns casos a responsabilidade não se estender aos encargos moratórios e punitivos), abre-se a seguinte classificação: um primeiro grupo seria "interno à situação tributária", verificado na própria estrutura daquele artigo 128; e, valendo-se das palavras iniciais do mesmo artigo 128 ("sem prejuízo do disposto neste Capítulo"), o segundo grupo seria "externo à situação tributária", desenrolando-se nas previsões contidas nos artigos 129 a $138^{446}$.

Neste segundo grupo, objeto do presente tópico, PAUlo DE BARros CARVAlHo diz que o legislador busca uma pessoa estranha aos limites factuais, quer de forma supletiva quer de forma exclusiva, para figurar como responsável pela prestação tributária, daí se dizer "externo à situação tributária". Diante dessa classificação, e considerando que não há um refazimento da regra matriz no sentido de 'comportar' essa pessoa estranha, o autor aponta

\footnotetext{
${ }^{442}$ Cf. BECKER, Alfredo Augusto. Op. Cit. (nota 356), P. 558.

${ }^{443}$ Cf. SARTIN, Agostinho. Sujeição Passiva e ICM. RDT 25-26:176-88.

444 Debates no IV Curso de Especialização em Direito Tributário da PUC/SP, in Destinatário Legal Tributário. EDP 30:288.

${ }^{445}$ Cf. BECHO, Renato Lopes. Op. cit. (nota 360), P. 148/153.

${ }^{446}$ Cf. CARVALHO, Paulo de Barros. Op. cit. (nota 361), P. 278/279.
} 
que a relação jurídica integrada pelo responsável (sujeito passivo alheio ao fato tributado) não corresponde a uma obrigação tributária, mas, sim, assume a natureza de sanções administrativas.

Após caminhar pelos artigos 130 a 134, PAUlo De Barros CARVAlHo conclui que a redação desses dispositivos denunciam, com força e expressividade, o timbre sancionatório nomeadamente em virtude de uma postura não zelosa, não diligente ou omissa por parte do terceiro (responsável), daí o animus puniendi da relação jurídica que se forma.

Na mesma linha, EdUARdo MARCIEL FERREIRA JARDIM ${ }^{447}$ reforça a necessidade de os sujeitos passivos estarem vinculados à materialidade do tributo. Já os responsáveis estariam atrelados a um ato passível de sanção ${ }^{448}$ :

Como dissemos, não pretendemos criticar um ou outro doutrinador, mas sim absorver aquilo que melhor se adapta aos conceitos delineados na presente dissertação. A partir do breve exame literário acima já é possível destacar alguns dos elementos que acreditamos que devem nortear a classificação de determinado indivíduo como sujeito passivo sob o figurino de "responsável tributário stricto sensu".

Note que, seguindo a doutrina de Paulo de Barros Carvalho, Eduardo Marciel FERREIRA JARDIM postula na inexistência de qualquer vínculo com a materialidade do fato gerador (e assim cremos que essa seja a inteligência do inciso II, do artigo 121, e também do 128, ambos do CTN, conforme expusemos anteriormente), mas fala também num possível contato, ainda que de forma indireta, com a pessoa do "contribuinte".

\footnotetext{
${ }^{447} \mathrm{E}$ assim diz: "Isto posto, entendemos que, à luz dos princípios sobranceiros que informam a ciência jurídica, aquelas pessoas desatreladas do fato jurídico tributário não podem, sequer por hipótese, assumir a condição de sujeitos passivos de obrigação tributária, sob pena de agredirmos as estruturas do sistema. Entretanto, podem ser elas responsabilizadas pela obrigação penal tributária, à medida que se enlaçaram com o contribuinte no cometimento de um ato omissivo ou comissivo suscetível de providência de cunho sancionatório." (Cf. JARDIM, Eduardo Marcial Ferreira. Manual de Direito Financeiro e Tributário. 2a edição. São Paulo: Saraiva, 1994. P. 200).

${ }^{448}$ Vale destacar que, em que pese a validade de parte das lições trazidas por EDUARDO MARCIAL FERREIRA JARDIM, cumpre apontar, por zelo ao correto emprego dos institutos jurídicos lapidados neste trabalho, que somente o contribuinte está em contato direto com a materialidade do tributo; quando muito, conforme veremos, o substituto tributário poderá desvelar este contato, de forma indireta, necessariamente. Por sua vez, o sujeito passivo é pessoa vinculada ao dever de pagar o tributo, que não obrigatoriamente tenha dado causa ao seu fato gerador.
} 
Assim, sumarizando as principais características examinadas acima, evidencia-se, nos artigos 129 a 135, todos do CTN, que essa "responsabilidade" do responsável tributário stricto sensu surge por outras razões que não um vínculo direto com o núcleo objetivo da situação tributada ${ }^{449}$ (ou seja, seu aspecto material) e, também, na quase totalidade dos casos, apenas com a ocorrência de um evento futuro (segundo fato), comissivo ou omissivo. Senão vejamos:

a. $\quad$ artigos 129 a 133: pensamos que a observação anterior é bastante clara, conforme constata o dispositivo que encabeça a seção II, que trata da responsabilidade dos sucessores ou responsabilidade por sucessão. O artigo 129, do CTN, é expresso ao afirmar que o disposto nesta seção aplica-se: (i) aos créditos tributários definitivamente constituídos; e (ii) aos créditos tributários em fase de constituição, desde que relativos à obrigação tributária já surgida até referida data ${ }^{450}$. Numa e noutra situação, conclui-se que a responsabilidade tributária só terá lugar em momento posterior ao surgimento da obrigação tributária. Como se vê, nos artigos 129 a 133, o fato que dá nascimento ao responsável tributário stricto sensu não se comunica com a materialidade que deu origem à tributação e, nalguns casos, surge até mesmo após a constituição do crédito tributário. No artigo 130, o segundo fato que origina a responsabilidade é uma transação de direito privado, materializada, por exemplo, em uma operação de compra - este segundo fato não se confunde com o fato jurídico tributário (primeiro fato) que era ser proprietário do bem imóvel, fato gerador do IPTU ou do ITR, já que o dispositivo se restringe a impostos. No artigo 131, por sua vez, a interpretação é bastante semelhante, com a diferença que, neste caso, abrange quaisquer bens adquiridos ou remidos - igualmente, o segundo fato

\footnotetext{
${ }^{449}$ Cf. CARVALHO, Paulo de Barros. Op. cit. (nota 361), P. 278/279.

${ }^{450}$ IVES GANDRA DA SILVA MARTINS ilustra bem essa situação ao comentar sobre o artigo 129, do Código Tributário Nacional, alegando que a aludida responsabilização pelos créditos tributários deverá ocorrer desde que, até essa data, os fatos geradores já tenham ocorrido (Cf. MARTINS, Ives Gandra da Silva. Op. cit. (nota 351), P. 246). Neste mesmo sentido, ALIOMAR BALEEIRO comentando, respectivamente, os artigos 129 e 130 , ambos do CTN: "Por outras palavras, a responsabilidade de terceiro, por sucessão do contribuinte, tanto pode ocorrer quanto às dividas fiscais deste, preexistentes, quanto às que vierem a ser lançadas ou apuradas posteriormente à sucessão, desde que o fato gerador haja ocorrido até a data dessa sucessão." E complementa: "Diz o C.T.N. que os adquirentes ficam subrogados nos créditos fiscais oriundos daqueles tributos, isto é, o sujeito passivo passar a ser o novo proprietário, foreiro, ou posseiro, em substituição ao anterior. O ressarcimento do adquirente por este é assunto entre ambos." (grifamos) (BALEEIRO, Aliomar. Op. cit. (nota 88)). Note que o autor utiliza a expressão "passa a ser", transmitindo a idéia de transformação, i.e., de uma relação jurídica caracterizada como "X" que se torna "Y".
} 
seria uma compra e venda, por exemplo, de um carro, cujo fato gerador do IPVA não é a transação privada, mas, sim, a condição de proprietário do bem (primeiro fato);

b. artigo 134: quando o dispositivo traz a expressão "impossibilidade", o legislador quer, em verdade, indicar uma relação de benefício de ordem. Assim, é necessário primeiro perquirir o patrimônio do contribuinte e esgotar os meios e vias disponíveis para verificação das condições econômicas do contribuinte a fim de ver satisfeito o crédito tributário. Somente se tais medidas restarem infrutíferas, ou seja, na impossibilidade de o contribuinte fazer frente àquele débito, é que os procedimentos de cobrança deverão ser redirecionados ao terceiro, na qualidade de responsável, desde que, é claro, seja observada sua intervenção ou omissão diante de um determinado dever legal. Nessa linha, o que deve ser ressaltado é que, se existe um procedimento anterior de exigência contra o contribuinte, conclusão óbvia é a de que este incorreu em um determinado fato gerador, dando nascimento à obrigação tributária, do contrário não seria aceitável nem mesmo possível falar em eventual exigência tributária ${ }^{451}$. Aqui, também, o vínculo do terceiro (responsável tributário stricto sensu) surge por razões estranhas ao aspecto material da regra matriz. Tais razões derivam ou de omissões ou de atos não diligentes ou com falha de zelo por parte das pessoas arroladas neste artigo. Quanto ao aspecto temporal, é válido ponderar o caso específico do tutor, cujo vínculo pode surgir antes mesmo da ocorrência do fato jurídico tributário, mas nem por isso significa dizer que este vínculo surge em função da realização do verbo que enseja a tributação;

c. artigo 135: este dispositivo trata de situações em que o ato ou fato é geralmente realizado em nome da pessoa jurídica - contribuinte - como único titular de direitos e obrigações. Ou seja, o contribuinte, ainda que por uma ação ou omissão de seus 'responsáveis' (gerentes, diretores, prepostos, representantes legais etc.), dá ensejo ao fato gerador, gerando contingência fiscal. Contudo, em razão da constatação de uma conduta culposa por parte de seus responsáveis (segundo fato), culpa em sentido estrito em quaisquer de suas modalidades, a responsabilidade tributária é atribuída/transferida ao sujeito que deu ensejo àquela infração. Significa dizer que, a

\footnotetext{
${ }^{451}$ Essa é a segurança jurídica que se extrai do princípio da legalidade e, mais ainda, da fenomenologia proporcionada pelo fato gerador da obrigação tributária, eleito pelo nosso principal diploma tributário como o momento único e exclusivo a partir do qual se desencadeiam diversas noções fundamentais de Direito Tributário, tais como a identificação do exato instante do nascimento da obrigação tributária, a identificação/determinação do sujeito passivo, dentre muitos outros (Cf. SCHOUERI, Luís Eduardo. Op. cit. (nota 26), P. 126.)
} 
exemplo do que foi apontado nas letras "a" e "b" anteriores, a definição da responsabilidade tributária ocorrerá após um evento futuro, que corresponderá à verificação e comprovação do ato culposo ${ }^{452}$.

É nesse sentido a posição de RUBEns GOMES DE SOUSA ${ }^{453}$, para quem a chamada responsabilidade por transferência ocorre quando a obrigação tributária, depois de ter surgido contra uma pessoa determinada, transfere-se, em virtude de um evento posterior, para pessoa diferente. E, de outro lado, a responsabilidade por substituição ocorre quando, em virtude de uma disposição expressa de lei, a obrigação tributária surge desde logo contra pessoa diferente daquela que esteja em relação econômica direta com o ato, o fato ou o negócio tributado. Nesse caso, é a própria lei que substitui o sujeito passivo direto por outro indireto.

Frise-se, entretanto, diferentemente da teoria clássica moldada por RUBENS GOMES DE SouSA, para a qual a substituição tributária é uma subclassificação da "responsabilidade tributária", por isso se fala em "responsabilidade por substituição", o entendimento que aqui se procura solidificar é no sentido de tais expressões ou institutos corresponderem a situações ou opções distintas, i.e., lograrem regimes jurídicos diferentes, como se fossem espécies de um mesmo gênero (responsabilidade latu sensu) e não uma subespécie de outra espécie. Ilustrativamente assim teríamos:

\footnotetext{
452 "A responsabilidade tributária substituta prevista no art. 135, III, do CTN, imposta ao sócio-gerente, ao administrador ou ao diretor de empresa comercial depende da prova, a cargo da Fazenda Estadual, da prática de atos de abuso de gestão ou de violação da lei ou do contrato e da incapacidade da sociedade de solver o débito fiscal." (STJ, AgReg no AG nº 246475/DF, $2^{\mathrm{a}} \mathrm{Turma}^{\mathrm{O}} \mathrm{Re}^{\mathrm{a}} \mathrm{Min}^{\mathrm{a}}$. NANCY ANDRIGHI, D.J. de 01/08/2000).

${ }^{453}$ Cf. SOUSA, Rubens Gomes de. Op. cit. (nota 21), P. 71/72.
} 


\section{Figura 3}

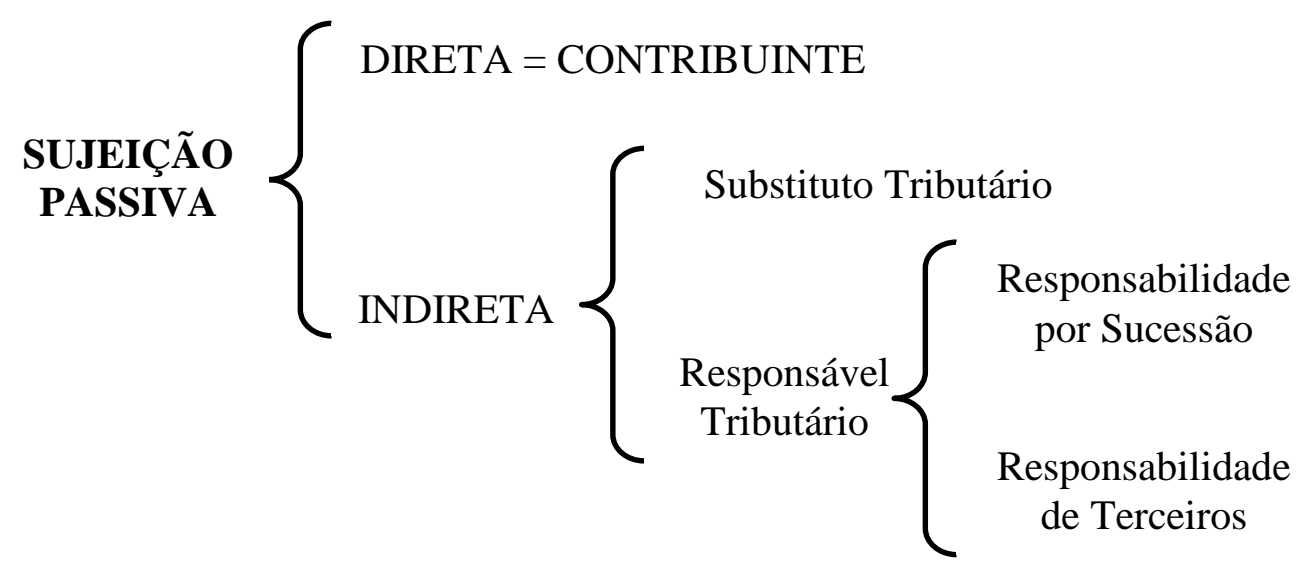

Mais à frente, voltaremos a apontar outros critérios que fundamentam a classificação identificada na ilustração acima, bem como trataremos da figura do agente de retenção, que não corresponde nem ao responsável tributário stricto sensu nem ao substituto tributário.

Cumpre ressaltar que, nos casos de responsabilidade tributária stricto sensu, valendo-se aqui dos artigos 124 e 128, do CTN, como fundamentos de validade, e dada a regra geral da natureza jurídica solidária da sujeição passiva ${ }^{454}$, o estudo sobre o afastamento, a solidariedade ou mesmo a subsidiariedade da responsabilidade do contribuinte deve ser examinado caso a caso. Sem nos alongarmos muito, já que uma análise detalhada escapa ao escopo deste trabalho, esclarecemos que, no caso da solidariedade, a manutenção do contribuinte no polo passivo da relação jurídica tributária dependerá ou de previsão legal expressa ou de relação que revele a existência de "interesse comum". Como se vê, essa é mais uma situação que deve ser considerada como argumento válido para a adoção do artigo 128 como norma geral para a responsabilidade tributária stricto sensu prevista nos artigos 129 a 135 daquele mesmo Diploma Legal Tributário.

\subsubsection{Substituição Tributária}

Traçando um paralelo acerca da classificação predominante no País no que se refere ao tema "responsável tributário", SACHA CALMON NAVARRo CoÊLHO assevera que este sujeito será definido ou pela transferência do dever, o que pressupõe que há um dever

${ }^{454}$ Cf. SCHOUERI, Luís Eduardo. Op. cit. (nota 04), P. 492. 
preexistente, ou por substituição da pessoa que realizou o fato gerador e que deveria ser o sujeito passivo. $\mathrm{O}$ jurista mineiro assim $\operatorname{arremata}^{455}$ :

\begin{abstract}
"Isto posto, cabe frisar que, nos casos de responsabilidade tributária por transferência, existe uma cláusula jurídica que imputa ao responsável o dever de pagar o tributo em lugar do contribuinte. $O$ que se transfere é o dever jurídico, que migra total ou parcialmente do contribuinte para o responsável. Diferentemente, nos casos de substituição tributária, a pessoa que pratica o fato gerador não chega a ser contribuinte. A lei imputa diretamente o dever de pagar o tributo ao responsável tributário. O que se substitui, portanto, é a pessoa que, tendo praticado o fato gerador, deveria ser o sujeito passivo." (destaques no original)
\end{abstract}

A linha de argumentação tracejada no presente tópico confronta-se com a posição de SACHA CALMON NAVARRo CoÊLHo, para quem a pessoa que pratica o fato gerador não chega sequer a ser contribuinte, entendimento que, como já dissemos, não reflete a origem do fato correspondente à realização do verbo pertinente ao mecanismo concernente ao nascimento da tributação, tampouco às noções de antecedente e consequente definidas para os fins do presente estudo, além de desdizer o próprio conteúdo contido no princípio da capacidade contributiva.

Os conceitos acima delineados servem não somente para identificar as situações em que o sujeito passivo será chamado de responsável tributário stricto sensu, mas, certamente, para caracterizar as outras ocorrências previstas pelo legislador complementar e ordinário, tais quais o substituto tributário ou o agente de retenção, diante das quais estarão o intérprete e o aplicador do Direito. Assim, vitais são as seguintes noções:

a. Com suporte na corrente dualista, a obrigação tributária corresponde ao desencadeamento dos efeitos da subsunção dos conceitos individuais identificados no fato jurídico tributário aos conceitos gerais verificados na previsão abstrata definida em lei, gerando o dever (Schuld) de pagar tributo, o que Alcides Jorge Costa

\footnotetext{
${ }^{455}$ Cf. COELHO, Sacha Calmon Navarro. Comentários ao Código Tributário Nacional. Coordenação Carlos Valder do Nascimento. Rio de Janeiro: Editora Forense, 1997. 282.
} 
chamou de "dever positivo de uma prestação de dar"456. Diante da instauração da relação jurídica tributária, forma-se, no consequente da regra matriz, a responsabilidade pelo pagamento do tributo (Haftung; obligatio), com a solidificação do vínculo patrimonial e prestacional entre os polos ativo (credor ou sujeito ativo) e passivo (sujeito passivo ou devedor) ${ }^{457}$;

b. com foco nos impostos, tendo o Imposto sobre a Renda como alvo do presente trabalho, o contribuinte é a única pessoa que guarda relação direta com a sua materialidade, i.e., a partir de sua capacidade contributiva pessoal é que deverá ser exercida a função mensuradora (aspecto quantitativo; base de cálculo) da incidência;

c. diferentemente do que se vê com relação ao responsável tributário, cuja caracterização depende, na maioria dos casos, de evento futuro (o segundo fato) e, em alguns casos, após a constituição do crédito tributário, a definição do substituto tributário atenderá a critérios observáveis no exato momento da realização do aspecto material da tributação - conforme veremos, este critério aplica-se também ao agente de retenção;

d. o sujeito passivo indireto (ou, em outras palavras, o terceiro eleito para pagamento de débito tributário de outrem) guarda algum tipo de vínculo ou com o aspecto material da regra matriz ou com o contribuinte que deu causa aquele mesmo fato gerador, conforme o caso.

Há outros critérios diferenciadores que poderão e deverão ser considerados para identificação de uma ou outra espécie do gênero sujeição passiva indireta, assim como se faz necessário o estudo de outros posicionamentos existentes na doutrina pátria que não se coadunam com as premissas aqui assumidas. Acredita-se, que, por desconsiderarem a relevância da função do fato gerador da obrigação tributária, em especial o seu objeto nuclear (aspecto material) e, em igual relevância, as noções do antecedente e consequente da regra matriz, estes posicionamentos culminam em conclusões e classificações diferentes daquelas que pretendemos alcançar no presente trabalho.

\footnotetext{
${ }^{456}$ Cf. COSTA, Alcides Jorge. Op. cit. (nota 05), P. 31 e ss.

${ }^{457}$ MOACYR PEREIRA JUNIOR lembra que os elementos estruturais de uma relação jurídica são as pessoas sujeito ativo e sujeito passivo - e a prestação que as interliga, sendo que a falta de qualquer um desses elementos implica na inexistência de relação jurídica. Voltando mais detidamente para o espectro do Direito Tributário, seria afirmar que, nos casos em que falta a prestação contra o contribuinte, a relação jurídica tributária se forma exclusivamente na figura do substituto tributário (Cf. PEREIRA JUNIOR, Moacyr. Comentários ao Código Tributário Nacional. Volume 5. Coordenadores Hamilton Dias de Souza, Henry Tilbery, Ives Gandra da Silva Martins. São Paulo: Editora Resenha Tributária, 1978/1979. P. 263).
} 


\subsubsection{Breve Panorama da Doutrina Estrangeira}

Em suas lições o jurista argentino HeCTOR VILLEGAS ${ }^{458}$ procurou traçar um breve panorama sobre a diversidade de correntes doutrinárias que existem sobre os sujeitos passivos da relação jurídica tributária. Assim registrou o autor:

ð Corrente Majoritária: admite que os sujeitos passivos se dividem em duas grandes categorias: contribuintes (devedores a título próprio) e responsáveis (devedores a título alheio). Capitaneados pelo mestre italiano MARIO PUGLIESE, filiam-se, também, a essa corrente Giuliani Fonrouge, Flores Zavala, Gustavo Ingrosso, FRANCISCO DE LA GARZA;

ð $\quad \underline{2^{a} \text { Corrente: }}$ liderada por A.D. GIANNINI, só considera sujeito passivo o contribuinte, ou seja, quem manifesta o fato imponível. Todas as outras pessoas ficariam excluídas como sujeitos passivos. À primeira vista, essa corrente tem grande aceitação entre os adeptos da Teoria Monista da relação obrigacional;

ð $\quad 3^{\mathrm{a}}$ Corrente: considera que há dois sujeitos passivos: contribuintes e substituídos. HECTOR VILlEgas afirma que essa seria a posição mais aceita entre os autores ibéricos: do lado da Espanha, Blanco Ramos e Jose Luis Perez de Ayala, e em Portugal, José MANUEl CARDOSO DA COSTA. CORTÊS DOMIGUEZ parece caminhar na mesma linha, ao afirmar que o sujeito passivo da obrigação tributária é o realizador do fato imponível e, para contornar a suposta contradição contida na legislação tributária espanhola, aponta que o contribuinte e o sujeito passivo são sempre a mesma pessoa, salvo os casos de substituição, quando, segundo o jurista espanhol, há dois obrigados, o sujeito passivo stricto sensu (contribuinte) e o substituto ${ }^{459}$;

ð $\quad \underline{4}$ Corrente: posição defendida por ANTONIO BERLIRI, para quem só é sujeito passivo quem deve entregar ao Estado o objeto da obrigação. Com algumas variações, filiamse também a essa corrente AlLORIO e CleBER GIARDINO;

\footnotetext{
${ }^{458}$ Cf. VILlEGAS, Hector B. Curso de Direito Tributário. Trad. Roque Antonio Carrazza. São Paulo: 1980. Editora Revista dos Tribunais. Também Hector VILlEgAS no mesmo sentido: Cf. VILLEGAS, Hector B. Destinatário Legal Tributário - Contribuinte e sujeitos passivos da obrigação tributária. Revista de Direito Público no 30. Julho/Agosto de 1974. Editora Revista dos Tribunais.

459 apud FONROUGE, C. M. Giuliani. Op. cit. (nota 375), P. 97.
} 
$\quad \underline{5^{\mathrm{a}} \text { Corrente: }}$ distingue as pessoas entre devedor, contribuinte e responsável, posição à qual, guardadas algumas diferenças, filiam-se VICTOR BOMPANI e TESORO;

ð $\underline{6}^{\mathrm{a}}$ Corrente: GIOvANI INGROSso fala em cinco possíveis sujeitos passivos: contribuinte, substituto, responsável, representante e arrecadador;

ð $\quad 7^{\mathrm{a}}$ Corrente: DINO JARACH fala em contribuintes e diferentes tipos de responsáveis, a saber: responsáveis por substituição, responsáveis por solidariedade e responsáveis por garantia;

ð $\underline{8^{a} \text { Corrente: }}$ amplamente difundida no Brasil, classifica os sujeitos em passivos diretos e indiretos. A essa corrente se filiam RubEns Gomes DE SousA, Aliomar BAleEIro, Gilberto de UlhôA CANTO.

GiUliani FounRouge descreve que o sujeito do tributo (o contribuinte) é o sujeito da obrigação, porém, em certos casos, a lei atribui a condição de obrigado (a satisfazer uma prestação) a pessoa diferente do contribuinte. Por essa circunstância, esse terceiro exercerá uma função somatória ao contribuinte, numa atuação paralela, ou poderá substituí-lo integralmente. Apoiado nas lições de EZIO VANONI, o autor entende ser supérflua a discussão se o sujeito da obrigação é o devedor do tributo ou é o responsável pelo pagamento do tributo, argumento com o qual concorda SAINZ DE BUJANDA. Em consequência, GIULIANI FOUNROUGE conceitua o sujeito passivo da obrigação tributária como a pessoa individual ou coletiva a quem a lei determina o cumprimento da prestação e que pode ser tanto o devedor originário (o contribuinte) ou um terceiro, responsável ou substituto $^{460}$.

Luis PeREZ DE AyAla, a seu turno, entende que o sujeito passivo do tributo é aquele a quem se atribui a condição de sujeito passivo da correspondente obrigação (material) tributária, sendo que dentro desta categoria incluem-se duas possibilidades: o contribuinte e o substituto do contribuinte. O responsável pelo tributo corresponderia a uma pessoa que não se reveste da condição de sujeito passivo da obrigação tributária, mas que era chamado para o seu cumprimento - o responsável não participa do fato gerador, mas ele deve guardar uma relação formal com a Administração Fazendária ou uma relação de outro tipo com o sujeito passivo ${ }^{461}$.

\footnotetext{
${ }^{460}$ Cf. FONROUGE, C. M. Giuliani. Op. cit. (nota 375), P. 97/99.

${ }^{461}$ Cf. AYALA, Jose Luis Perez de. Op. cit. (nota 48), P. 165/179.
} 
Para Manuel Pires e Rita CALÇAda PiRes, sujeito passivo, em sentido jurídico, é o devedor do imposto, i.e., a pessoa que tem a obrigação de realizar a prestação em que consiste o imposto. Em sentido econômico, sujeito passivo é a pessoa que suporta a carga fiscal e a diminuição patrimonial resultante do pagamento do imposto, mediante o fenômeno da transferência (repercussão) do imposto. Com base na legislação portuguesa sobre o assunto, examinando as pessoas que se encontram colocadas na situação de obrigadas à realização do imposto, o autor as classifica em (i) sujeitos originários, que se referem às pessoas obrigadas desde o início e que podem ser tanto o contribuinte como os substitutos, diferenciando-se, estes dois, pelo fato de que somente aos primeiros se verificam os pressupostos do imposto; e (ii) sujeito não originários ou supervenientes, entre os quais se inserem os sucessores ou, num caso particular, pessoas que assumem a dívida do imposto. Os juristas portugueses anotam, ainda, que os responsáveis, obrigados em virtude de mandamento legal, não se qualificam como sujeitos passivos mas como garantidores do cumprimento da obrigação fiscal ${ }^{462}$.

\subsubsection{Outras Divergências Doutrinárias e Teorias sobre o Responsável Tributário e sobre o Substituto Tributário}

Fundado no critério econômico, RUBEnS GOMES DE SoUSA ${ }^{463}$ dizia que o sujeito passivo era quem tirava uma vantagem econômica de determinado ato, fato ou negócio jurídico. Entendia que a existência do sujeito passivo indireto estava relacionada com os ideais de "necessidade e interesse" do Estado, cobrando tributo de outra pessoa por mero capricho administrativo e instrumental.

A ideia retratada por RubEns Gomes DE SOUSA de que o sujeito passivo é aquele quem sofre a repercussão financeira ${ }^{464} \mathrm{em}$ virtude do fato jurídico tributário é evidenciada com frequência na jurisprudência nacional ${ }^{465}$.

\footnotetext{
${ }^{462}$ Cf. PIRES, Manuel ; PIRES, Rita Calçada. Op. cit. (nota 51), P. 232/234.

${ }^{463}$ Cf. SOUSA, Rubens Gomes de. Op. cit. (nota 21).

${ }^{464}$ MARIA RITA FERRAGUT ensina que a repercussão econômica consiste no ônus financeiro suportado pelo sujeito em função do pagamento do tributo, e que pode ou não ser transferido a uma terceira pessoa. Não se confunda com a incidência jurídica, resultado do ato de aplicação de normas (Cf. FERRAGUT, Maria Rita. Op. cit. (nota 03), P. 42). Conforme já tivemos a oportunidade de esclarecer, a incidência jurídica no fato
} 
Em parecer jurídico tratando da sujeição passiva em caso de taxa rodoviária única, GERALDO ATALIBA $^{466}$ destacou que o sujeito passivo deve ser definido e escolhido pela lei e que a sujeição passiva deverá recair em pessoa que esteja de alguma forma ligada à atuação desenvolvida pelo Estado, i.e., ligado à atividade de cobrança do tributo. Pensamos que, em vez de estar ligado à mera atividade de cobrança, por respeito ao rigor técnico que se exige do estudo, melhor seria dizer estar ligado, ainda que de forma indireta, à materialidade da tributação, o que, em momento subsequente ou de forma simultânea, dará origem à exigência do imposto devido.

Neste contexto, em Aula Magna realizada em 08/12/1973, no IV Curso de Especialização em Direito Tributário pela Faculdade de Direito da Pontifícia Universidade Católica de São Paulo $^{467}$, HeCTOR VILLEGAS trouxe valiosas lições trazidas que, sem sombra de dúvidas, influenciaram sobremaneira a doutrina de GERALDO ATALIBA, RUBENS GOMES DE SousA e tantos outros. Confira-se:

ð o indivíduo eleito pelo legislador para o pagamento do ônus tributário é chamado de “destinatário legal tributário", expressão de autoria do próprio jurista argentino. Assim define o autor: "É a pessoa que se encontra na situação concreta escolhida pela lei como hipótese de incidência tributária, e que deve sofrer, por via legal, o peso econômico da prestação tributária, que é conseqüência de sua configuração.";

escolhido pelo legislador como suficiente para nascimento da obrigação e incidência da tributação é atributo exclusivo do contribuinte.

${ }^{465} \mathrm{Na}$ seara administrativa: Acórdão no $104-20.392,1^{\circ} \mathrm{CC}, 4^{\mathrm{a}}$ Câmara, sessão em 02/12/2004; Acórdão $\mathrm{n}^{\text {o }}$ 102-47.614, $1^{\circ} \mathrm{CC}, 2^{\mathrm{a}}$ Câmara, sessão em 26/05/2006 - transcrevemos este último: "ANTECIPAÇ̃O DO IMPOSTO - RESPONSABILIDADE DO CONTRIBUINTE - DECLARAÇÃO DE AJUSTE ANUAL - A falta de retenção pela fonte pagadora do imposto de renda sobre rendimentos do trabalho com vínculo empregaticio, no regime de antecipação, não exonera o beneficiário e titular dos rendimentos, sujeito passivo direto da obrigação tributária. Deve o contribuinte, como titular da disponibilidade econômica destes rendimentos, oferecê-los à tributação do imposto de renda na Declaração de Ajuste Anual ainda que não tenha havido a tributação destes rendimentos na fonte. A substituição da responsabilidade tributária do contribuinte para a fonte pagadora, nos casos de falta de retenção do IRPF, somente ocorre nas hipóteses de incidência expressamente determinadas em Lei. Recurso negado." ( $1^{\circ}$ CC. $2^{\mathrm{a}}$ Câmara. Acórdão no $102-$ 47.614. Sessão de 26 de maio de 2006). Na seara judicial: REsp n ${ }^{\circ} 573.052 / S C, 2^{a}$ Turma do STJ, Rel. Min Eliana Calmon. D.J. em 18/04/2005: “O regulamento do imposto de renda e outros dispositivos legais impõem à fonte pagadora a responsabilidade pela retenção e antecipação do recolhimento do imposto de renda, mas não dispensa o contribuinte da obrigação de pagamento."

${ }^{466}$ Cf. ATAliBA, Geraldo. Sujeição Passiva. Sujeição direta e indireta - Responsabilidade tributária Destinatário legal tributário - Aspecto Pessoal da Hipótese de incidência. Revista de Direito Público nº 29. Editora Revista dos Tribunais, Maio/Junho de 1974. P. 245/251.

${ }^{467}$ Cf. VILLEGAS, Hector. Op. cit. (nota 10), P. 271/294. 
ð diz-se "destinatário" porque a carga econômica do tributo está destinada a ele, mas se vai efetivamente suportar esse ônus econômico (casos de retenção e direito de regresso) já não seria um problema jurídico propriamente dito (a leitura da exposição realizada por HECTOR VILLEGAS evidencia uma certa contradição neste ponto, quando o autor fala da importância da juridicização da retenção na fonte);

ð diz-se legal, pois a carga econômica do tributo deriva da lei e não do efeito de uma translação, como ocorre nos casos dos chamados impostos indiretos ${ }^{468}$ ou dos tributos, cuja sistemática de apuração e recolhimento comporta o repasse do ônus fiscal para a etapa seguinte, como é o caso do ICMS e do IPI ${ }^{469}$, mediante o uso da conta gráfica entre débitos e créditos (assegurado pelo princípio constitucional tributário da não cumulatividade).

O magistério de HeCTOR VillegAS, ainda que não seja incorreto, pode parecer excessivo. Talvez, preferível seria utilizar a classificação proposta no próprio CTN e, a partir daí, fazer as adaptações e os ajustes necessários. Assim é que existem o contribuinte e o responsável tributário que, por sua vez, se desdobra em responsável stricto sensu e substituto. Lembre-se que o sujeito passivo, associado ao consequente da regra matriz, poderá ser tanto o próprio contribuinte como também um terceiro eleito pelo legislador, sob o figurino de responsável (stricto sensu) ou substituto tributário.

\footnotetext{
${ }^{468}$ Não é escopo do presente trabalho definir se é ou não é jurídica a classificação dos impostos em diretos e indiretos. Assume-se, de qualquer forma, que tributos indiretos são aqueles que repercutem economicamente de forma que o ônus é suportado por um terceiro que possua relação com o contribuinte.

469 Assim reza o disposto no artigo $153, \S 3^{\circ}$, II, e no artigo 155, §2º I, ambos da Constituição Federal. Ressalte-se que a jurisprudência é pacífica no sentido de considerar a natureza desses impostos como sendo do tipo indireto: "TRIBUTÁRIO. ICMS. RESTITUIÇÃO E COMPENSAÇÃO. TRIBUTO INDIRETO. REPASSE DE ENCARGO FINANCEIRO AO CONSUMIDOR FINAL. ART. 166 DO CTN. PRECEDENTES. 1. O tributo examinado (ICMS) é de natureza indireta. Apresenta-se com essa característica porque o contribuinte real é o consumidor da mercadoria objeto da operação (contribuinte de fato) e a empresa (contribuinte de direito) repassa, no preço da mercadoria, o imposto devido, recolhendo, após, aos cofres públicos o imposto já pago pelo consumidor de seus produtos. Não assume, portanto, a carga tributária resultante dessa incidência. 2. No caso sub examine, ainda que sob pretexto de obter exclusivamente o creditamento dos valores questionados, não se pode negar que a verdadeira pretensão da recorrente é obter a restituição das importâncias indevidamente recolhidas, a título de ICMS, em razão da majoração da alíquota do imposto, de $17 \%$ para 18\%, que teve sua inconstitucionalidade declarada pelo STF. 3. Aplica-se a regra do art. 166 do CTN que exige a comprovação de que o contribuinte de direito não repassou ao contribuinte de fato o encargo financeiro do tributo, ou, no caso de tê-lo transferido a terceiro, de que está por este autorizado a pleitear a repetição do indébito. 4. Agravo regimental não-provido." (grifamos) (STJ. $1^{\text {a }}$ T. AgRg no Ag 925.488/SP. Rel. Min. José Delgado. DJe 16/04/2008). Neste mesmo confira-se em: AgRg no Ag 853.712/SP (STJ - $1^{\text {a }}$ Turma - Rel. Min. José Delgado - D.J.e 05/06/2008); REsp 411.478/PR (STJ $1^{\text {a }}$ Turma - Rel. Min. Luiz Fux - D.J. 28/10/2002); AgRg no REsp 433.171/RS (STJ - $1^{\text {a }}$ Turma - Rel. Min. José Delgado - D.J. 23/09/2002).
} 
No que se refere à chamada sujeição passiva indireta, a doutrina largamente difundida por Geraldo Ataliba e por Rubens Gomes DE SousA reitera a seguinte classificação: a) responsabilidade tributária via substituição, situação na qual a própria lei substitui um sujeito passivo por outro, i.e., a obrigação tributária já nasce com um sujeito passivo eleito pelo legislador, diferente do contribuinte; e b) responsabilidade tributária via transferência, que dizia que o sujeito passivo surgia em momento posterior ao nascimento da obrigação tributária e se operacionalizava de três formas (solidariedade/sucessão/responsabilidade). Dizia, ainda, que o contribuinte era aquele que cumpre a obrigação própria e o responsável, a obrigação alheia.

AlFRedo Augusto BecKeR ${ }^{470}$ afirma que, se o Estado tem a faculdade de eleger o pagador do tributo, está-se diante do substituto legal tributário e não do responsável legal tributário. Por sua vez, Rubens Gomes de SousA ${ }^{471}$ e Alfredo Augusto Becker ${ }^{472}$, aproximando-se daquela primeira corrente ilustrada por HECTOR VILLEGAS, classificam os sujeitos passivos em contribuintes e responsáveis, e estes últimos em responsáveis propriamente ditos e substitutos.

PAUlO DE BARros CARVALho ${ }^{473}$, como vimos, sustenta que o responsável assume obrigação de natureza sancionatória (sanção administrativa). Para os casos próprios do artigo 128, o autor ensina que o terceiro eleito como sujeito passivo integra uma efetiva relação jurídica tributária, posto que unido, indiretamente, ao núcleo objetivo da situação tributada.

Com singular ineditismo, RENATO LOPES BECHO ${ }^{474}$ traz a divisão entre "sujeitos passivos constitucionais" e "sujeitos passivos legais". Assim, coloca, de um lado, o contribuinte como único sujeito passivo eleito pelo constituinte e que tem contato direto com o fato descrito na norma constitucional de incidência. De outro lado, os responsáveis e substitutos, exclusivamente para os casos em que houver omissão por parte do legislador constituinte no que tange à eleição do sujeito passivo. Os sujeitos passivos legais, na visão

\footnotetext{
${ }^{470}$ Cf. BECKER, Alfredo Augusto. Op. cit. (nota 356), P. 558/559.

${ }^{471}$ Cf. SOUSA, Rubens Gomes de. Op. cit. (21).

${ }^{472}$ Cf. BECKER, Alfredo Augusto. Op. cit. (nota 356), P. 559.

${ }^{473}$ Cf. CARVALHO, Paulo de Barros. Op. cit. (nota 361), P. 278/279.

${ }^{474}$ Cf. BECHO, Renato Lopes. Op. cit. (nota 360), P. 85/109.
} 
do autor, albergariam as hipóteses de sujeição passiva da pessoa que não se encontrava ligada ao fato imponível por uma relação direta, por um ato próprio.

Ainda, acerca das formas em que se expressa a responsabilidade tributária, MARIA RITA FERRAGUT $^{475}$ traz uma classificação quíntupla, dividindo em (i) substituição; (ii) solidariedade; (iii) sucessão; (iv) responsabilidade de terceiro; e (v) responsabilidade por infrações.

Examinando a figura do substituto passivo tributário, Alfredo Augusto BeCKeR ${ }^{476}$ chegou a quatro importantes conclusões:

$1^{\mathrm{a}}=>$ não existe qualquer relação jurídica entre o substituído e o Estado. O substituído não é sujeito passivo da relação jurídica tributária, nem mesmo quando sofre a repercussão jurídica do tributo, em virtude de o substituto legal tributário exercer o direito de reembolso do tributo ou de sua retenção na fonte;

Ainda que nos casos de substituição tributária, foco de nossas atenções, a responsabilidade do contribuinte é excluída de plano, não há como afastar a relação jurídica que se formou a partir de um ato ou fato próprio do contribuinte, cuja materialidade, em função de suas características pessoais, atendeu à norma contida na hipótese tributária. O fato gerador se concretiza neste momento, conectado à capacidade contributiva do contribuinte, ainda que, neste mesmo momento, a lei atribua a responsabilidade do pagamento do tributo à terceira pessoa.

Em tempo, em ambos os regimes de retenção na fonte, o direito de exercer o reembolso do tributo, seja a título de restituição via entrega da DIRPF, seja em procedimento administrativo específico, será do contribuinte. O substituto tributário ou o agente de retenção farão jus ao reembolso na hipótese de terem recolhido aos cofres públicos uma quantia maior que aquela que foi previamente retida.

\footnotetext{
${ }^{475}$ Cf. FERRAGUT, Maria Rita. Op. cit. (nota 03), P. 55/56.

${ }^{476}$ Cf. BECKER, Alfredo Augusto. Op. cit. (nota 356), P. 529-530.
} 
$2^{\mathrm{a}} \Rightarrow>$ em todos os casos de substituição legal tributária, mesmo naqueles em que o substituto tem, perante o substituído, o direito de reembolso do tributo ou de sua retenção, o único sujeito passivo da relação jurídica que se reveste de natureza tributária é o substituto;

Conforme veremos adiante, mais especificamente no item 1.16., ainda que o agente de retenção "substitua" o contribuinte na função de recolhimento do imposto, ainda que lhe seja reservado o direito de retenção do imposto, o agente de retenção, ao exercer uma função administrativa, não chega a ocupar o polo passivo da relação jurídica tributária.

$3^{\mathrm{a}}=>$ o substituído não paga 'tributo' ao substituto. A prestação jurídica do substituído que satisfaz o direito do substituto (casos de retenção e reembolso) não é de natureza tributária, mas sim de natureza 'privada';

O substituído, i.e., o contribuinte, não "paga" nada ao substituto. O que ocorre é que uma parte do montante que seria destinada ao contribuinte é retida pelo substituto, que a utiliza para pagamento do imposto gerado com este mesmo pagamento.

$4^{\mathrm{a}}=>$ nos países cuja Constituição normatizou o princípio da capacidade contributiva, como é o caso do Brasil, o legislador, ao criar o substituto legal tributário, está obrigado a, simultaneamente, criar a repercussão jurídico-econômica do imposto sobre o substituído, outorgando ao substituto o direito de reembolso ou de retenção na fonte.

Em parecer tratando da inconstitucionalidade do ILL - Imposto sobre o Lucro Líquido, previsto no artigo 35, da Lei no 7.713/88, IVES GANDRA DA SILVA MARTINS aponta que, no direito pátrio, há apenas duas espécies de pagador de tributos, o contribuinte e o substituto, estando este no lugar daquele, por imposição legal, transferência de responsabilidade ou sucessão. Afirma que todo responsável é sempre substituto, na medida em que substitui o contribuinte, assumindo a responsabilidade de pagamento que competia ao verdadeiro gerador da obrigação tributária ${ }^{477}$.

\footnotetext{
${ }^{477}$ Cf. MARTINS, Ives Gandra da Silva. Inconstitucionalidade do Artigo 35 da Lei 7.713/88. in Imposto de Renda - Questões Atuais e Emergentes. Coord. Valdir de Oliveira Rocha. São Paulo: Dialética, 1995. P. $75 / 76$.
} 
ALCIDES JORGE COSTA ${ }^{478}$ também traz breve arrazoado de algumas classificações, no tocante ao tema da substituição tributária, que podem ser apontadas da seguinte forma:

- Parte da doutrina estrangeira sustentava que a substituição é uma forma especial de execução contra terceiros, determinada por lei (MARio Pugliese, Tesoro e BLUMENSTEIN);

- $\quad$ Outros entendiam que o chamado substituto não deveria ser considerado um devedor do tributo, mas um simples intermediário que promove a arrecadação por conta do Estado (BUHLER, QUARTA, BOINDI), chamado, neste caso, por alguns, de agente de retenção;

- Há ainda aqueles que enxergam na substituição uma representação ex lege (UCKMAR);

- Uma pequena parcela, capitaneada por BODDA, sustenta que a substituição em direito tributário pode ser reconduzida ao instituto geral da substituição, de larga aplicação tanto no direito substantivo como no processual;

- $\quad$ Por fim, A.D. GiAnNini traz o entendimento de que a substituição é uma figura típica do direito tributário ${ }^{479}$, sem, contudo, nada explicar o que propôs com essa afirmação.

Em suas sempre bem pontuadas críticas ao CTN, LUCIANO AMARO ${ }^{480}$ assevera que a classificação proposta pelo legislador infraconstitucional é sofrível, dificultando sobremaneira a vida do hermeneuta. O tributarista continua, em suas lições, informando que este mesmo Código optou pela "pobre" classificação dos sujeitos passivos em “contribuintes" e "responsáveis", nos moldes de seu artigo $121^{481}$. A espécie "responsáveis" agruparia todas as formas de sujeição passiva indireta.

\footnotetext{
${ }^{478}$ Cf. COSTA, Alcides Jorge. Op. cit. (nota 05), P. 59/60.

${ }^{479}$ Em artigo com título sugestivo, confira-se: RODRIGUES, Walter Piva. A Substituição tributária é Instituto Típico do Direito Tributário. in Direito Tributário - Homenagem a Alcides Jorge Costa. Coordenação Luís Eduardo Schoueri. São Paulo: Editora Quartier Latin, inverno de 2003. P. 239

${ }^{480}$ Cf. AMARO, Luciano. Op. cit. (nota 69), P. 307/310.

481 A bem da verdade, considerando que a figura do "substituto tributário" é uma classificação autônoma, com características próprias que a diferenciam do "responsável tributário", a imprecisão técnica começa no próprio artigo 121, do CTN, que deveria elucidar o tema, reservando espaço especial para essa terceira forma de sujeito passivo. Tal constatação não escapou do olhar clínico e exemplarmente técnico de LEANDRO PAULSEN: "Optou o legislador, no caput do art. 121 do CTN, por uma simplificação terminológica, o que não contribui para a exata compreensão das diversas posições passivas e identificação dos regimes que lhe são próprios." (Cf. PAULSEN, Leandro. Op. cit. (nota 56), P. 930).
} 
Em verdade, largamente apoiada nas lições de RUBENS GOMES SouSA, a doutrina pátria, antes mesmo do surgimento do CTN, já classificava a chamada sujeição passiva indireta da seguinte forma:

(ii) sujeição passiva por substituição, que corresponderia às situações nas quais o sujeito escolhido pelo legislador incumbido de pagar o tributo seria conhecido desde já, i.e., desde o exato instante do nascimento da obrigação tributária. Nestes casos, por razões diversas, o legislador optaria por "ignorar" o contribuinte e inserir, na posição de sujeito passivo, o substituto tributário; e

(iii) sujeição passiva por transferência, em sentido diverso, o "novo" sujeito passivo eleito pelo legislador não seria identificável e conhecido de plano, i.e., a obrigação de efetuar o pagamento de determinado imposto nasce na figura do próprio contribuinte e, em razão de um evento futuro (segundo fato), desloca-se para uma outra pessoa. RUBENS GOMES SOUSA ${ }^{482}$ entendia que essa classificação se desdobrava em três subespécies: a sucessão, a solidariedade e a responsabilidade.

Como se vê, a doutrina diverge muito sobre o tema e qualquer posição adotada tende a encontrar ferozes críticas de juristas e pensadores do mais alto escalão de nossa literatura.

Toda essa divergência doutrinária pode causar insegurança jurídica aos sujeitos de direito. A ausência de contornos jurídicos sobre os conceitos de responsável tributário stricto sensu e de substituto tributário, ou, de forma mais genérica, sobre os tipos ou modalidades de sujeição passiva indireta, pode levar a conclusões equivocadas e consequências injustas, ao incluir um terceiro qualquer no polo negativo da relação jurídica tributária, às vezes, totalmente desamparado de qualquer tutela do Direito.

Tomando como exemplo o recente julgado exarado pelo STF, de relatoria da Min. Ellen Gracie (RE n 603.191/MT. Tribunal Pleno. DJe 05.09.2011), verifica-se não apenas a confusão dos conceitos, mas, também, a não diferenciação da posição do contribuinte conforme o regime jurídico em que a retenção de tributo na fonte ocorre.

${ }^{482}$ Cf. SOUSA, Rubens Gomes de. Op. cit. (nota 21), P. 92/93. 
Destacou-se nessa decisão que a relação contributiva, i.e., a relação entre 'contribuinte $\mathrm{x}$ fisco', sempre será preservada, ainda que a satisfação da obrigação da obrigação tributária do contribuinte seja facilitada e assegurada pelo regime de substituição tributária e assim complementa:

"A relação contributiva é preservada, sendo que a satisfação da obrigação do contribuinte é facilitada e assegurada pelo regime da substituição tributária. A segunda relação instituída (substituto x fisco), de certo modo, serve à primeira (contribuinte $x$ fisco). O retentor não é um devedor do tributo, e sim um obrigado ao recolhimento, conforme esclarece Joachim Lang na obra Steuerrecht (Köln, Verlag Dr. Otto Schmidt KG, $19^{a}$ ed., 2008, p. 178).

Portanto, diferentemente do que a consideração isolada do termo “substituição” poderia levar a crer, não há o alijamento do contribuinte. Sua obrigação não é excluída, tampouco amesquinhada, o que já era destacado por Dino Jarah, em sua obra El Hecho Imponibli: Teoria general Del Derecho Tributário Sustantivo (Aleledo-Perrot, $2^{a}$ ed., 1971, p. 29).

Por força da substituição tributária, o que ocorre, isto sim, é que o contribuinte deixa de tomar a frente quanto à apuração e ao recolhimento, surgindo tais deveres diretamente para o substituto, que, no entanto, procede ao recolhimento em nome do contribuinte.

A validade de tal mecanismo pressupõe que não se olvide seu caráter meramente instrumental, em que o substituto figura como simples colaborador do Fisco. Substitui o contribuinte no ato de efetuar o pagamento, mas não na obrigação de contribuir para as despesas públicas."

(trecho do voto da Min. Rel. Ellen Gracie) (grifamos)

Ao misturar conceitos como 'retentor', 'substituição tributária' e cimples colaborador do Fisco', o julgado acaba por desconsiderar as diferenças existentes nas diferentes situações em que a retenção na fonte ocorre, em especial confrontando os regimes de "retenção exclusiva de fonte" e "retenção como antecipação do devido". Procuramos demonstrar, no regime de retenção exclusiva na fonte do IR, que a responsabilidade do contribuinte é totalmente excluída, mesmo nas situações em que a fonte deixa de recolher o tributo. Tanto é que, nestes casos, agrava-se a responsabilidade da fonte pagadora, na medida em que, 
sobre o rendimento pago, creditado, entregue, remetido ou empregado em favor do beneficiário (contribuinte) o IRF será exigido sobre uma base de cálculo reajustada (gross up), tomando aquele valor como se já estivesse líquido da retenção. Não há como dizer que, nestes casos, a responsabilidade do contribuinte não foi excluída, situações típicas em que a fonte passa a ocupar o polo passivo da relação jurídica tributária

Sob outra perspectiva, para os casos em que a retenção na fonte ocorre sob o regime de antecipação, como se vislumbra com relação ao IR ou à contribuição previdenciária ao INSS, não há, em absoluto, como afastar a responsabilidade do contribuinte, a quem competirá, ao término do período de apuração, a verificação se há saldo de tributo a recolher ou a ser restituído. Todavia, conforme detalharemos no item 1.16., nestes casos nos parece mais adequado falar-se em agente de retenção em vez da tradicional idea de substituição tributária.

Assim, quando acontecer de uma norma jurídica dizer "pague" para outra pessoa, que não o contribuinte (ou, na linguagem de HECTOR VILLEGAS, destinatário legal tributário), estaremos diante da sujeição passiva indireta, situação em que um terceiro deverá pagar tributo em nome e devido pelo contribuinte. Somente a partir das características peculiares do fato gerador, em especial seu aspecto material, e da relação jurídica tributária instaurada é que será possível classificar os sujeitos passivos indiretos em substitutos ou em responsáveis.

\subsubsection{Imprecisão Técnica e Terminológica do artigo 128, do Código Tributário Nacional}

Questões de terminologia entre os conceitos podem gerar algum tipo de discussão e, mesmo assim, dadas as premissas assumidas, as partes divergentes podem estar com a razão, sem que, com isso, ofusquem a razão alheia. A problemática a ser tratada neste tópico parece não corresponder a uma simples divergência terminológica, mas, sim, a uma imprecisão técnica da legislação e que, a nosso ver, pode gerar confusão e levar a interpretações que nem sempre correspondem à realidade dos fatos. 
Registre-se que o artigo 128, do CTN, em que pese utilizar a expressão responsabilidade e em que pese ser a norma inaugural do capítulo que trata da "Responsabilidade Tributária" naquele Código, é o dispositivo legal que, queremos crer, na realidade, trata das principais características do instituto da substituição tributária. Assim também é a visão da doutrina, mas que, fugindo dessa suposta ausência de critério ao incluir este artigo como ponto de partida de uma outra figura jurídica, o responsável tributário propriamente dito, classifica essa espécie como sendo o responsável por substituição ${ }^{483}$.

Como restou demonstrado, a doutrina clássica faz a classificação dos chamados responsáveis tributários em responsáveis por substituição e responsáveis por transferência. Essa classificação se deve, em muito, à própria literalidade do CTN que colocou todas as formas de sujeição passiva indireta dentro de um único subgrupo. Queremos crer que a noção de sujeição passiva indireta é o gênero e os responsáveis tributários (stricto sensu) são apenas uma de suas espécies.

Sobre a distinção desses dois institutos, em Conferência publicada pelo I.B.D.F., GILBERTO DE UlHÔA CANTO ${ }^{484}$ fez primorosa exposição:

“A lei não basta ao surgimento da obrigação tributária. Quando há uma ligação comum dos interessados, ao mesmo fato gerador, então, se verifica a responsabilidade solidária. Mas, há outras figuras de transferência. Há por exemplo, a sucessão, que os senhores sabem perfeitamente de que se trata, e que não é apenas a "mortis causa” mas também a "inter vivos”. O sucessor, de acordo com tais ou quais disposições legais peculiares, assume a responsabilidade que, numa obrigação tributária já criada, competia ao seu sucessor. A substituição é outra das modalidades amplas de modificação do sujeito passivo. Ocorre quando a lei elege para sujeito passivo uma pessoa diferente daquela que figura na relação econômica que justificaria e que justificou a incidência. Um exemplo bem típico de substituição é o do imposto

\footnotetext{
483 Sob o olhar do jurista mais atento ao preciosismo do correto emprego de conceitos e da adequada terminologia das palavras (ditas institutos jurídicos), como já foi apontado, a geografia do CTN, considerando a disposição dos artigos que tratam da obrigação tributária, da sujeição passiva e também da responsabilidade, guarda algumas imperfeições.

${ }^{484}$ Cf. CANTO, Gilberto de Ulhôa. Obrigação Tributária: seus pressupostos e elementos. Conferência publicada pelo I.B.D.F. Rio de janeiro: 1958. P. 108.
} 
de renda cobrado na fonte. Assim o que incide sobre dividendos de ações ao portador. A lei desconhece totalmente os beneficiários do rendimento ${ }^{485}$. Por motivos de ordem prática, fixa um sujeito passivo que toma o lugar do sujeito passivo lógico, que é o beneficiário do rendimento, e impõe o recolhimento do tributo à parte, que não recebeu o rendimento, mas, pelo contrário o pagou"

O responsável tributário, alvo de nossas observações no subitem anterior, deverá, nos moldes do artigo 121, do CTN, distinguir-se do contribuinte, sendo certo que a sua condição, de responsável, deverá decorrer de uma situação que não um fato que esteja em contato, ainda que indireto, com o aspecto material da regra matriz. Quando muito poderá guardar alguma forma de contato, direto ou indireto, com a pessoa do contribuinte.

\subsubsection{Repercussão Econômica do Tributo - Outro Critério Diferenciador}

Em seu magistério, o Professor da Universidade Nacional de Córdoba, HeCtoR VILLEGAS $^{486}$, afirmou que, em sede de substituição tributária, o chamado destinatário legal tributário, que corresponde ao sujeito que dá causa ao fato gerador (restrito, portanto, nestes casos, ao plano abstrato), fica fora da relação jurídica tributária:

“Então, quando ocorre esta situação jurídica, o destinatário legal tributário fica marginalizado, fica fora da relação jurídica tributária - mas continua sofrendo, nos seus bens, o impacto econômico de tributo, e o sofre por uma norma legal: a norma legal que concede o reembolso ao substituto. É claro que o montante que o substituído restituiu ao substituto - que pagou o título sem nada ter a ver com a hipótese de incidência - não tem o caráter jurídico de tributo." (g.n.)

Com a ressalva de que se trata de doutrina estrangeira, transportando tais lições para o universo brasileiro cumpre apontar discordância ao pensamento do renomado jurista

\footnotetext{
${ }^{485}$ Destaque-se, desde já, a despeito da validade dos comentários trazidos por GILBERTO DE ULHÔA CANTO, uma das maiores referências nacionais em tributação pelo Imposto sobre a Renda, não concordamos com a afirmação de que a lei desconhece totalmente a figura do contribuinte, nem antes nem após a ocorrência do fato gerador. Nem mesmo o legislador infra-legal desconhece ou descuida dessa relação, conforme se depreende do Ato Declaratório Normativo no 1, de 2002, que será melhor examinado no Capítulo IV.

${ }^{486}$ Cf. VILLEGAS, Hector. Op. cit. (nota 467), P. 277.
} 
argentino que, ao fazer comparação entre o responsável substituto e o responsável solidário, acaba por desconsiderar a redação do artigo 128, do CTN, falando em vínculo daquele com o destinatário legal tributário, quando, na verdade, pela leitura da lei, em se tratando de substituto tributário, o vínculo, indireto, será sempre com o fato gerador (aspecto material). Eventual vínculo com o contribuinte será indiferente para fins da classificação de substituto tributário aqui proposta.

Ainda, ao tratar das similitudes entre substituto e responsável, HeCTOR VILLEGAS explica que "em ambos os casos ficam os dois liberados do peso econômico do tributo. Porque, em ambos os casos, uma norma lhes concede a faculdade de ressarcir-se, reembolsar-se.".

Também, aqui, o professor argentino parece não levar em consideração as diferentes formas de reembolso do ônus econômico do tributo no Brasil. As modalidades de reembolso e de direito de regresso exercem função diferenciadora entre os institutos da responsabilidade tributária stricto sensu e da substituição tributária.

Com efeito, nos casos de responsabilidade tributária stricto sensu, as formas existentes, para que o contribuinte promova a reparação do patrimônio do responsável, encontram guarida na própria legislação, contudo, em âmbito externo ao Direito Tributário ${ }^{487}$. Tratase de situação resguardada pelo direito privado, como é o caso do direito de regresso contra o contribuinte que, na qualidade de devedor originário do tributo, deixou de recolhê-lo por qualquer razão que seja ${ }^{488}$.

Os casos de substituição tributária comportam cenários bastante diferentes, daí a relevância em identificar uma e outra situação de forma a prestigiar os seus efeitos e as suas consequências. Assim é que, em alguns casos, conforme veremos no capítulo seguinte, essa forma de recuperação do ônus financeiro gerado pelo tributo pode se dar por meio do

\footnotetext{
${ }^{487}$ Nada impede, todavia, que essas formas fossem tratadas no próprio CTN.

${ }^{488}$ Situações existirão em que esse reembolso poderá ficar prejudicado, como, por exemplo, nos casos de tributos devidos pelo de cujus, via sucessão ou na circunstância de extinção de empresas. Nas demais situações, tributos devidos pelos filhos, tutelados, curatelados, massa falida, alienantes de bens imóveis, dentre outros, contudo pagos por terceiros (pais, tutores, curadores, síndico, adquirentes de bens imóveis), restará, como sempre houve de existir, o direito à ação de regresso ou, ainda, que o tributo devido seja pago com recursos provenientes do patrimônio do contribuinte originário, de forma a permitir e a possibilitar que estes terceiros transfiram o ônus tributário suportado por meio de alguma forma de restituição ou indenização.
} 
instituto da retenção. Todavia, o mecanismo de reembolso via retenção na fonte nem sempre será integrado pela figura do substituto tributário, havendo situações em que a figura do agente de retenção é que se faz presente. O que releva destacar, como critério de discrímen, é que, nestes casos, a ferramenta de recomposição do patrimônio deste terceiro (substituto tributário ou agente de retenção, que será melhor explorado no tópico seguinte) encontra regulamentação no próprio CTN.

Importante chamar a atenção, neste momento, que a análise de questões jurídicas não deve ser feita, sob hipótese alguma, de forma isolada do sistema jurídico e do complexo de normas que informam o Direito. Não pairam dúvidas de que, sobre este tema, o jurista deverá lançar mão dos métodos sistemático e teleológico da legislação tributária.

Com efeito, a natureza jurídica do substituto tributário, apresentada no referido artigo 128, do CTN, traz elementos que permitem sua individualização das demais espécies de sujeitos passivos, bem como a identificação de seu conceito. Ainda que esse dispositivo forneça a quase totalidade dos elementos conceituais da substituição tributária, é imperioso ressaltar que se trata de construção doutrinária, tendo em vista que o legislador não foi expresso nesse sentido $^{489}$.

Logo no início da redação do artigo 128, o legislador determina que "sem prejuízo do disposto neste Capítulo" deverão ser aplicados os efeitos pertinentes à regra da substituição tributária. Pensamos que, em total sintonia com o rigor técnico que se almeja alcançar, mais acertado seria dizer "sem prejuízo do disposto neste Título" (Título II - Obrigação Tributária), daí sim fazendo referência expressa aos artigos 113 e 114, que tratam respectivamente da obrigação tributária e do fato gerador, bem como no já citado artigo 121, inciso I, todos do CTN, com foco na figura do contribuinte,

A título de definição de seu alcance conceitual, temos que o substituto tributário é espécie de sujeito passivo indireto, cujo fundamento legal de validade está contido no artigo 128,

\footnotetext{
${ }^{489}$ Sobre o tema, BRANDÃO MACHADO pondera: "XIII. O conceito de substituição tributária não vem definido em nosso direito positivo. É construção teórica consolidada doutrinariamente a partir das idéias de Ernst Blumenstein, o primeiro autor, no mundo, que apreendeu e explicou o fenômeno jurídico da substituição." (Cf. MACHADO, Brandão. Adicional do Imposto de Renda dos Estados. Repertório IOB de Jurisprudência $n^{\circ}$ 18: 1989. P. 294).
} 
do CTN. O substituto tributário necessariamente deverá estar em contato indireto com o aspecto material (núcleo do fato gerador) e, em virtude de lei, sua origem deriva ou antes ou no exato momento em que o contribuinte realiza o verbo desencadeador da obrigação tributária. Significa dizer que o substituto tributário participa do aperfeiçoamento do fato gerador, sem, contudo, assumir a posição de contribuinte, já que não é a sua capacidade contributiva que está sendo medida.

Ainda, como características marcantes de seu regime jurídico, vale anotar que o legislador prevê expressamente, na própria lei de onde derivou sua condição de substituto tributário, as formas e/ou instrumentos por meios dos quais será ressarcido pelo contribuinte, como, por exemplo, nos casos de retenção na fonte - é justamente este instrumento técnico que permite, juridicamente, que o substituto suporte o ônus tributário gerado por um ato do contribuinte. Na substituição tributária, a responsabilidade do contribuinte é excluída por completo, i.e., somente o substituto responde pelo pagamento do tributo e pelas consequências de seu inadimplemento ou descumprimento de deveres instrumentais, de modo que, em razão do substituto assumir o lugar que deveria ser do contribuinte, já que assume este lugar “na largada”, o Estado não pode voltar-se contra o substituído ${ }^{490}$.

\subsection{O Agente de Retenção}

Em continuidade à abordagem anterior, verifica-se que a única hipótese prevista (e aqui identificada) de uma suposta substituição tributária, além da regra geral delineada no artigo 128, seria o artigo 45, ambos do CTN, verbis:

“Art. 45. Contribuinte do imposto é o titular da disponibilidade a que se refere o artigo 43, sem prejuízo de atribuir a lei essa condição ao possuidor, a qualquer título, dos bens produtores de renda ou dos proventos tributáveis.

Parágrafo único. A lei pode atribuir à fonte pagadora da renda ou dos proventos tributáveis a condicão de responsável pelo imposto cuja retencão $e$ recolhimento lhe caibam." (g.n.)

${ }^{490}$ Cf. RODRIGUES, Walter Piva. Substituição Tributária. São Paulo: Quartier Latin, 2004. P. 76/77; 
A norma corresponde à regra que torna clara quem é o contribuinte do fato gerador do Imposto sobre a Renda, assim como explicita, no entendimento de boa parcela da doutrina, a regra de substituição tributária. Como é sabido, já amplamente abordado no Capítulo II $^{491}$, quem dá ensejo ao fato gerador é aquele que aufere renda ou proventos de qualquer natureza (aspecto material). Desse modo, o próprio legislador da norma tributária, sem precisar recorrer a eventuais ferramentas do direito privado, já fornece os meios necessários para o devedor recuperar o ônus fiscal (financeiro) incorrido por conta e ordem do contribuinte. Portanto, a ferramenta disponibilizada pelo legislador tributário é o instituto da retenção, aplicável tanto ao substituto tributário como também à figura do agente de retenção.

Ora, ao autorizar a fonte a fazer essa retenção, o legislador está, na verdade, autorizando que esse terceiro, no caso a fonte, repasse o ônus fiscal ao contribuinte, mediante a dedução do valor do imposto do montante cuja titularidade é do próprio contribuinte.

Sem sombra de dúvida, esse terceiro (a fonte) guarda íntimo vínculo com o fato gerador, mais precisamente com o seu aspecto material, tendo em vista que é o pagamento ${ }^{492}$ que dá ensejo à 'aquisição da disponibilidade econômica ou jurídica da renda ou provento de qualquer natureza' por parte do beneficiário (contribuinte). A fonte "participa" do aperfeiçoamento do fato gerador, situação que, acreditamos, juntamente com outras características apontadas neste trabalho, deve servir como critério para classificar o terceiro ou como substituto tributário ou agente de retenção, mas nunca como responsável tributário stricto sensu.

Nos casos de retenção na fonte do imposto sobre essa renda, essa mesma renda (ou proventos de qualquer natureza) não se origina de outra pessoa que não a própria fonte pagadora.

\footnotetext{
${ }^{491}$ Em outras palavras, e em consonância com a redação do artigo 43, do CTN, o contribuinte é aquele que tem a disponibilidade econômica ou jurídica da renda, entendida como a qualidade que esse sujeito "tem de usar, gozar e dispor de seus bens (no caso, a renda), ou seja, que ele (contribuinte-proprietário) pode consumir, alienar, gravar, enfim, dar qualquer destinação, a seu bel prazer, o seu direito" (Cf. MELLO, Gustavo Miguez de. O Fato Gerador do Imposto sobre a Renda e Proventos de Qualquer Natureza. Coord. Ives Gandra da Silva Martins. Centro de Estudo de Extensão Universitária e Resenha Tributária. São Paulo: 1986).

${ }^{492}$ Lembrando, os eventos que acionam o gatilho da retenção na fonte no IR são o pagamento, o crédito, a remessa, a entrega ou o emprego de um determinado rendimento.
} 
Outras situações existem à saciedade, normatizadas por leis ordinárias, como é o caso, por exemplo, da "responsabilidade" do tomador de serviços, para as hipóteses em que o legislador deslocou essa obrigação para um terceiro que não o contribuinte (prestador dos serviços). Nossa abordagem, contudo, tratará exclusivamente dos casos de IR.

Ainda sobre a forma como essa repercussão econômica do tributo se translada, PAULO DE BARROS CARVALHO fez a seguinte observação:

“Essa repercussão econômica é prestigiada pelo Direito, de modo que ela tem a sua expressão jurídica. Apenas, não é contemplada no âmbito do Direito Tributário, uma vez que o Direito Tributário se extingue com a própria extinção da obrigação tributária.

Assim sendo, eu diria que essa repercussão econômica tem expressão jurídica, porque a ordem jurídica prevê, disciplina e prestigia a repercussão econômica de certos tributos, muito embora não deva ser estudada no campo do Direito tributário, mas sim em outros ramos do Direito." ${ }^{493}$

Por conseguinte, consoante os apontamentos dos célebres juristas aqui em comento, o instituto da retenção, enquanto fenômeno econômico, ao ser juridicizado pelo legislador tributário (tanto no CTN, quanto pelo legislador ordinário nas searas federal, estadual e municipal), passa a ter relevância para o universo do Direito, sem, contudo, integrar a relação jurídica tributária. Em outras palavras, participa do aperfeiçoamento da relação de

493 Cf. CARVAlHO, Paulo de Barros. Op. cit. (nota 10), P. 282. Nesta mesma Aula Magna, o Professor GERALDO ATALIBA afirmou que "os fenômenos econômicos não têm a menor importância para o jurista, a não ser na medida em que a lei os traga para o mundo do Direito, já reduzidos à categoria jurídica." (Cf. ATALIBA, Geraldo. Op. cit. (nota 10), P. 281.) Em parecer datado de 10.02.1993, IVES GANDRA DA SILVA MARTINS, apoiado nas palavras do então Ministro JOSÉ CARLOS MOREIRA ALVES, sintetizadas por VitTORINO CASSONE e CARlos TOLEDO DE ABREU FILHO, expunha que se um fato econômico produz consequências no mundo do direito é porque esse fato é (ou será) necessariamente jurídico, valendo a conclusão que a disponibilidade será sempre jurídica (Cf. MARTINS, Ives Gandra da Silva. A Hipótese de Imposição do Imposto Sobre a Renda e Proventos de Qualquer Natureza. A Convivência de Regimes Jurídicos Distintos para a Apuração do "Quantum Debeatur" Concernente ao Referido Tributo - Opinião Legal. in Imposto de Renda - Estudos. São Paulo: Resenha Tributária, 1993. P. 09/25). Neste mesmo sentido são as lições de LUIS EDUARDO SCHOUERI que, ao tratar da definição conceitual de disponibilidade econômica da renda, assim disse: "A pedra-de-toque, aqui, é que um conceito econômico, uma vez contemplado pelo legislador, torna-se jurídico." (Cf. SCHOUERI, Luis Eduardo. Op. cit. (nota 113), P. 262). 
crédito e débito entre sujeito ativo (substituto ou agente de retenção) e sujeito passivo (contribuinte), respectivamente.

Nossa tarefa, a seguir, não é apenas identificar as características que qualificam a figura do agente de retenção, mas também identificar aquelas que o individualizam do substituto tributário. Estes fundamentos serão imprescindíveis para verificar sob qual figurino a fonte pagadora se apresenta em cada um daqueles regimes jurídicos de retenção na fonte que analisamos no Capítulo II.

Primeiramente, devem ser ressaltadas a importância e a validade teórica e prática da corrente doutrinária ${ }^{494}$ que sustenta que a fonte pagadora, independentemente de estar em conexão com o fato gerador (aspecto material), corresponde a um agente de retenção. Conforme avançaremos, diante das balizas conceituais levantadas sobre o fato gerador e os sujeitos que integram uma relação jurídica de natureza tributária, a figura do agente de retenção, para alguns casos que envolvam a retenção na fonte do IR, parece explicar de forma mais adequada a qualificação do terceiro (fonte pagadora) colocado na posição de pagador do imposto. Diante do contexto em que a figura do agente de retenção é examinada, genuinamente própria dos casos que envolvam retenção na fonte, e considerando a delimitação do presente trabalho, o foco de nossas análises, de forma a identificar a extensão conceitual desta figura, será concentrado nos estudos sobre a retenção na fonte do $\mathrm{IR}^{495}$.

\footnotetext{
${ }^{494}$ Cf. MACHADO, Brandão. Op. cit. (nota 489), P. 296/297. Em outra perspectiva, em que pese a utilização da expressão "agente da retenção na fonte", RICARDO LOBO TORRES entende que essa figura seria uma espécie de substituto tributário (Cf. TORRES, Ricardo Lobo. Op. cit. (nota 25), P. 265/266). O Juiz LEANDRO PAULSEN chama o agente de retenção de substituto e este de retentor (Cf. PAULSEN, Leandro. Op. cit. (nota 56), P. 930).

${ }^{495}$ A ideia de um agente arrecadador não é nova entre nós. À época do período imperial, vigeu entre nós as coletorias federais. Tratavam-se de repartições locais arrecadadoras que sucederam às Coletorias de Rendas Gerais do período imperial. Eram também chamadas de Coletorias de Rendas Federais e Coletorias para Arrecadação das Rendas Federais. As Coletorias eram subordinadas às Delegacias Fiscais do Tesouro Nacional, mas a orientação técnica cabia à Diretoria (depois Departamento) de Rendas Internas. Ao longo dos anos, o sistema de coletorias foi se ampliando e cobrindo todo o território nacional, chegando a ultrapassar o número de duas mil repartições. Foi o maior aparelho arrecadador montado no hemisfério sul e um dos maiores do mundo, se não tiver sido o maior. Na década de 1960 passaram a se denominar Exatorias Federais (Lei n. 4.503, de 1964) e passaram a ser subordinadas ao Departamento de Arrecadação, através de suas Delegacias Regionais e Seccionais. Com a implantação do sistema de arrecadação pela rede bancária, deixaram de ter atribuições e passaram a ser extintas. Uma boa parte, porém, foi transformada em 1968 nos Postos da Receita Federal, hoje Agências da Receita Federal. Informação disponível no sítio eletrônico da Receita Federal do Brasil: http://www.receita.fazenda.gov.br/Memoria/administracao/reparticoes/1822a1970/colet federais/default.asp. Acesso em 15/11/2011.
} 
Atendo-nos a esse objetivo, exporemos comentários de outros juristas que trataram do mesma assunto.

Em certa oportunidade, RICARDO MARIZ DE OLIVEIRA ${ }^{496}$ afirmou que "o sistema arrecadatório de tributação na fonte é uma opção política do legislador, tendo por escopo a racionalização e eficiência da arrecadação ${ }^{497}$ (assim, é preferível cobrar de apenas um sujeito passivo o imposto sobre a folha de salários, ao invés de multiplicar a cobrança pelo número de assalariados), ou se apresenta como a única forma de tornar possível a aplicação da lei, quando o contribuinte se encontra no exterior e, por conseqüência, fora do império da lei brasileira". ${ }^{498}$

Seguindo a linha de raciocínio de interpretação do Direito como um sistema uno e indivisível, a partir da perquirição legislativa e doutrinária, conforme já tivemos a oportunidade de analisar, o IRF está sujeito a dois diferentes regimes de retenção, a saber: a) retenção exclusiva na fonte; e b) retenção como antecipação do imposto devido. Sob este enfoque, profícuas as assertivas de HUGO DE BRITO MACHADO ${ }^{499}$ : "Em qualquer dessas duas formas de incidência do imposto de renda na fonte o débito continua sendo do contribuinte, enquanto a responsabilidade pelo pagamento do imposto é atribuída à fonte pagadora da renda."

\footnotetext{
${ }^{496}$ Cf. OLIVEIRA, Ricardo Mariz de. Parecer: A Sujeição Passiva da Fonte Pagadora de Rendimento, quanto ao Imposto de Renda Devido na Fonte. Revista Dialética de Direito Tributário no 49. São Paulo: Dialética, 1999. P. 88/105.

${ }^{497}$ Em sentido contrário, RENATO LOPES BECHO assim se posiciona a respeito da racionalização e eficiência da arrecadação como instrumentos para informar a hipótese de incidência tributária: "É que esses dados pouco importam para a ciência do Direito. Para ela, o que vale é a identificação de uma norma constitucional e outra, distinta mas ligada umbilicalmente àquela, infraconstitucional. Por outro giro verbal, o que nos interessa é identificar na Constituição Federal determinados sujeitos passivos tributários e observar que o legislador escolheu outras pessoas, colocando-as no pólo passivo. Diante disso, o cientista vai verificar a licitude dessa conduta, utilizando para isso os instrumentais que sua ciência lhe disponibiliza." $\mathrm{O}$ autor informa, ainda, que rechaça todas as declarações que tentam justificar quaisquer temas da sujeição passiva como sendo facilitador do trabalho do Fisco ou como medida de comodidade administrativa. RENATO LOPES BECHO sustenta que esses dados não interessam à Dogmática Jurídica. (Cf. BECHO, Renato Lopes. Op. cit. (nota 360), P. 115).

${ }^{498}$ Outras situações, por sua vez, parecem ter uma finalidade meramente antecipatória do produto da arrecadação, como parecem ser os casos de retenção do ISS na fonte, pelo tomador dos serviços, nas hipóteses taxativas elencadas pela Lei Complementar $\mathrm{n}^{\circ}$ 116/2003.

${ }^{499}$ Cf. MACHADO, Hugo de Brito. O Contribuinte e o Responsável no Imposto de Renda na Fonte. Revista Dialética de Direito Tributário no 70. São Paulo: Dialética, 2001. P. 109/116.
} 
Com ênfase na legislação tributária federal e, principalmente, no Parecer Normativo COSIT n ${ }^{\circ}$ 01/2002, a partir da análise de casos e testes práticos, verifica-se que, nesses dois regimes do IRF, mormente os de retenção por antecipação, proporcionam diferentes situações, tais como:

(i) fonte pagadora faz a retenção mas deixa de proceder ao recolhimento do tributo;

(ii) fonte pagadora não faz a retenção nem o recolhimento do tributo;

(iii) fonte pagadora faz a retenção, porém não fornece o comprovante de retenção ao contribuinte-beneficiário;

(iv) fonte pagadora deixa de efetuar a retenção em virtude de decisão judicial;

(v) fonte pagadora faz a retenção, porém o recolhimento do imposto é realizado de forma não tempestiva.

Veremos, a seguir, que o tal agente de retenção pode assumir diferentes conotações, ora como um ente mecânico, que definitivamente não guarda qualquer relação, mesmo que indireta, com o fato gerador, ora como um ente que exerce uma função administrativa, já que, em contato com a materialidade da tributação, auxilia nas funções de apuração da ocorrência do fato gerador, identificação e individualização do contribuinte, quantificação da matéria tributária e cálculo do imposto, além de ter que prestar tais informações ao Fisco através de declarações (DCTF e DIRF, especificamente no caso do IR).

Em um primeiro exemplo, podemos citar uma instituição financeira privada que procede aos pagamentos referentes à remuneração de servidores públicos, ou seja, os pagamentos que darão ensejo à ocorrência do fato gerador do IR não são feitos pela fonte pagadora, no caso, o próprio Estado. Diferentemente das situações nas quais aqui nos debruçamos, o banco (instituição financeira privada) sequer participa, ainda que indiretamente, do nascimento da obrigação tributária; é apenas um ente intermediário que possibilita a realização de uma série de pagamentos, valendo-se, para isso, de recursos financeiros disponibilizados pelo agente empregador, no caso o próprio Estado. A função do banco é tão somente pegar aqueles recursos repassados pelo Estado (fonte pagadora) e dividi-los em quantas contas bancárias forem o número de empregados (beneficiários); a retenção na fonte, associada àquela mecânica, decorre de mandamento legal, já que quem faz o 
pagamento é o Estado, o banco apenas organiza a colocação dos dinheiros em "escaninhos" diferentes.

Com isso, sob a perspectiva da instituição financeira privada, a relação jurídica tributária não chega a existir entre ela e o Estado, prevalecendo apenas uma relação operacional com o contribuinte e com os beneficiários dos dinheiros. A instituição financeira privada exerce, assim, uma das possíveis formas de qualificação do agente de retenção, cumprindo, neste caso, uma relação mecânico-obrigacional, de natureza estritamente administrativa ${ }^{500}$.

Frise-se que, exclusivamente sob essa perspectiva 'mecânica', o conceito de "agente de retenção" não se confunde com aquele ventilado por PIROSKA E. SoOS (vide subitem 1.1.) quando da análise comparativa entre taxation at the source e withholding tax. $\mathrm{O}$ "agente de retenção" a que PIROSKA E. Soos alude é a própria fonte pagadora, aproximando-se do entendimento de BRANDÃO MACHADO que, categoricamente, valendo-se dos ensinamentos de ERnst Blumenstein, quando da análise do Direito Tributário suíço e alemão, chama a fonte pagadora, notadamente nos casos de retenção do imposto de renda na fonte, de mero agente de retenção, sequer assumindo a condição de sujeito passivo ${ }^{501}$.

Arrimado no estudo pioneiro de ERNST BLUMENSTEIN sobre o tema da substituição tributária, BRANDÃO MACHADO ${ }^{502}$ conclui, após trabalhosa investigação, que a função da fonte pagadora não seria a de um sujeito passivo, historicamente classificada como substituto tributário, mas, sim, de mero agente arrecadador. Identifica, preliminarmente, que a noção da fonte como substituto tributário decorre de um legado das fortes influências que o direito pátrio sempre sofreu das legislações italiana e espanhola, as quais introduziram a figura do substituto como fonte pagadora da renda. Tal influência, como se sabe, repercutiu no CTN, mais precisamente em seu artigo 45.

BRANDÃO MACHADO explica que a fonte exerce uma função auxiliar da administração fazendária, incumbindo-se de coletar tributos que incidem sobre rendimentos que ela paga

\footnotetext{
${ }^{500}$ Em que pese adotar classificação inversa à nossa, chamando o agente de retenção de substituto e este de retentor, LEANDRO PAULSEN traz exemplo semelhante, referindo-se igualmente às instituições financeiras, relativamente ao imposto devido sobre aplicações financeiras (Cf. PAULSEN, Leandro. Op. cit. (nota 56), P. 930).

${ }^{501}$ Cf. MACHADO, Brandão. Op. cit. (nota 489), P. 296/297.

502 Ibidem, Op. cit. (nota 489), P. 296/297.
} 
a terceiros. $\mathrm{O}$ autor vê na fonte, que retém tributo de terceiro, um executor de uma tarefa, de uma obrigação legal de fazer, da mesma natureza de tantas outras tarefas administrativas que o Estado impõe aos particulares, ou que estes assumem com ordem dele, como é o caso dos tabeliães, dos concessionários de serviço público. Para BRANDÃO MACHADO, o substituto tributário executa uma obrigação própria, o que não acontece no caso da retenção na fonte.

Vale tecer alguns comentários às lições colhidas acima.

De fato, a fonte exerce uma função auxiliar ao Estado, disso não restam dúvidas e já apontamos acima o conjunto de obrigações de fazer acometidas à fonte, que culminam no recolhimento de dinheiro aos cofres públicos e na prestação de informações declaratórias ao Fisco. Todavia, vimos também que a natureza jurídica da fonte, sob a ótica do CTN, assume uma função híbrida, na medida em que necessariamente implica uma obrigação de dar, com a entrega dos recursos retidos, i.e., o recolhimento, aos cofres do Estado. Ou seja, não se trata de uma mera obrigação legal de fazer como tantas outras tarefas administrativas impostas pelo Estado aos particulares.

Outro ponto que merece a devida observação é a afirmação de que a fonte não se reveste da roupagem de um substituto, já que não realiza uma obrigação própria. Da análise das figuras possíveis de sujeitos passivos indiretos, e também dos conceitos de antecedente e consequente da regra matriz e, especialmente, com fulcro na teoria dualista da obrigação, ainda que, na substituição, a sujeição passiva já nasça com a terceira pessoa, vinculada ao núcleo objetivo da tributação, tal obrigação, como vimos, não é própria desse terceiro, no caso a fonte pagadora, mas, sim, desde a ocorrência do fato gerador, do contribuinte. Tanto é assim que a própria lei, de forma a preservar-lhe o patrimônio, já disciplina as ferramentas de reembolso do imposto devido pelo contribuinte, no caso em tela, o instituto da retenção na fonte, bem como a capacidade contributiva medida é do beneficiário da renda e não da fonte. Apenas a responsabilidade do contribuinte é excluída, não o seu debitum; não fosse assim, não haveria fundamento para transferir, para o patrimônio do contribuinte, a dedução do ônus financeiro do tributo. 
Isso, entretanto, não afasta a validade e a aplicabilidade da teoria do agente de retenção para os casos do IRF, salvo onde a figura do substituto tributário parece adequar-se melhor. Nesse sentido, vale lembrar que, para o nascimento da figura do substituto tributário, são necessários alguns requisitos, sendo alguns deles: (i) a existência de uma relação obrigacional tributária, pressupondo a ocorrência do fato gerador; (ii) a exclusão completa da responsabilidade do contribuinte.

De fato, com foco nos regimes jurídicos do IRF, analisados no Capítulo II, em situações em que não há o aperfeiçoamento do fato gerador em sua plenitude, onde os pagamentos mensais assumem a natureza de meras antecipações e, também, considerando que, ao final do período de apuração, o contribuinte deve apurar, de forma definitiva, se há ou não imposto a recolher, respondendo, inclusive, por eventual retenção não realizada pela fonte, nota-se, com clareza, que sua responsabilidade nunca foi excluída, mas apenas mantida em forma latente, diferida para a data de entrega de sua DIRPF ${ }^{503}$. O critério temporal diz respeito ao momento em que se instaura o vínculo obrigacional e surge a relação jurídicotributária entre os sujeitos ${ }^{504}$, o que significa que, para o regime de retenção na fonte por antecipação, este vínculo definitivo não surge nos eventos de retenção (pagamentos, crédito, remessa, entrega ou emprego do rendimento). Difere, no entanto, do regime de retenção exclusiva na fonte, onde não é necessário aguardar o término do período de apuração, tendo em vista a condição definitiva do imposto retido e recolhido. No caso da retenção na fonte por antecipação, parece-nos clara a aplicação dos estudos de BRANDÃO MACHADO, segundo o qual a fonte estaria cumprindo uma função meramente administrativa, auxiliando o Fisco no recolhimento dos pagamentos mensais obrigatórios devidos pelos contribuintes.

LUÍS EDUARDO SCHOUERI acompanha, sem ressalvas, o estudo arguto do mestre BRANDÃO MACHADO, apontando que o sujeito passivo é o contribuinte e a fonte, mero agente retentor. Somente nas hipóteses em que deixa de efetuar a retenção é que a fonte assume o papel de sujeito passivo, sendo certo que a sujeição, neste caso, teria surgido não em virtude do fato jurídico tributário, mas, como sói ocorrer nos casos típicos de responsável

\footnotetext{
${ }^{503}$ Os limites definidos periodicamente serão analisados no Capítulo IV, com ênfase ao PN COSIT $n^{\circ}$ 01/2002.

${ }^{504}$ Cf. QUEIROZ, Mary Elbe. Op. cit. (nota 90), P. 125.
} 
tributário stricto sensu, de um segundo fato, posterior ao fato gerador, qual seja, o evento de não retenção ${ }^{505}$.

RICARDO MARIZ DE OLIVEIRA ${ }^{506}$ chegou a afirmar ser um erro atribuir à fonte pagadora a natureza de mero agente de arrecadação, como, por exemplo, no caso de uma instituição financeira autorizada a arrecadar tributos devidos por terceiro.

Em sentido contrário, VALENTINO APARECIDO ANDRADE ${ }^{507}$, apoiado na salutar doutrina trazida pelo prestigiado Professor de Direito Tributário da Universidade Nacional de Córdoba, HeCTOR VILLEGAS ${ }^{508}$, entende que " a figura do agente de retenção, a quem a Lei normalmente atribui a condição de sujeito passivo do tributo, cabendo-lhe nesse caso reter dinheiro do contribuinte, para recolhê-lo ao Fisco", decorre do disposto no próprio artigo 121, inciso II, do CTN. Em outras palavras, VALENTINO APARECIDO ANDRADE classifica o agente de retenção como um legítimo responsável tributário.

Sobre o tema, PAUlo DE BARRos CARVALHO parece aproximar-se da ideia do agente de retenção:

“(...) quando se faz referência a entregas de dinheiros ao Estado, comportamento que realiza a prestação pecuniária, é sumamente importante salientar que a quantia entregue deve sair do patrimônio do sujeito passivo. Do contrário, não teremos tributo, mas outro tipo de relação jurídica. É o caso do 'imposto de renda na fonte'. Não cremos existir relação jurídica tributária entre União e a empresa que retém, mas tão-somente uma obrigação estabelecida pelo legislador federal, com a finalidade de facilitar o cumprimento da prestação, a cargo do verdadeiro sujeito passivo (a pessoa

\footnotetext{
${ }^{505}$ Cf. SCHOUERI, Luis Eduardo. Op. cit. (nota 04), P. 488/490.

${ }^{506}$ Cf. OLIVEIRA, Ricardo Mariz de. Op. cit. (nota 496), P. 88/105.

507 Cf. ANDRADE, Valentino Aparecido. O Agente de Retenção no Imposto de Renda Incidente sobre Rendimentos Pagos em Cumprimento de Decisão Judicial. Revista Dialética de Direito Tributário no 106. São Paulo: Dialética, 2004. P. 100/111.

${ }^{508}$ Em hercúleo trabalho, HECTOR VILLEGAS estudou a fundo essa singular figura do agente de retenção, analisando sua natureza jurídica em diversos sistemas positivos do Direito. Observou que essa figura ímpar ora é tratada como sujeito passivo, como deveras ocorre em países como Argentina e México, ora é tratada como uma espécie de funcionário público, caso, por exemplo, da Venezuela (Cf. VILLEGAS, Hector. Retenção de Tributos - Agentes de Retenção e Agentes de Percepção. Revista de Direito Tributário no 6. 1978. P. 67/83).
} 
física que teve parte de seu dinheiro retido pela fonte pagadora). É por isso que é dever, de conteúdo patrimonial, há penalidades pecuniárias que garantem ao Estado o cumprimento dessa prestação por parte das pessoas jurídicas que devam promover a retenção."509

RENATO LOPES BECHO chama fonte de sujeito ativo auxiliar: “(...)a retenção de tributos não transforma o agente retentor em contribuinte do tributo, não sendo o caso de substituição tributária, mas sim de agente em colaboração com a Administração. Isto porque o agente de retenção não participa da norma jurídico-tributária, não há uma materialidade tributária descrita como reter valores a título de tributo." 510

Este também é o pensamento de FÁBIO ZAMBITTE IBRAHIM, que vê na figura do agente de retenção uma explicação mais adequada para as hipóteses de retenção do IR e do custeio previdenciário. Para este autor, a doutrina se limita a repetir o senso comum sobre o tema, qualificando a retenção na fonte como mera forma alternativa de substituição tributária. Afirma que, entre agente de retenção e substituição tributária, a semelhança se limita a ambos os casos corresponderem a mecanismos legislativos para a garantia da arrecadação estatal, mas que, nos casos de retenção na fonte, por não haver alteração do polo passivo da relação exacional, não há como se falar em substituição tributária, o que não apenas inviabilizaria o direito de restituição por parte do contribuinte, mas, também, comprometeria a aplicabilidade da identificação do real beneficiário nos casos de isenções e imunidades ${ }^{511}$.

LUís CESAR SOUZA DE QUEIROZ ${ }^{512}$ mistura os conceitos e qualifica a fonte pagadora como substituto tributário, que atua como mero agente arrecadador e repassa aos cofres públicos quantia equivalente àquela originariamente devida pelo contribuinte. Declara que a substituição tributária é fenômeno jurídico que decorre da coexistência de duas normas de conduta de natureza diversa e inconfundível: (i) uma norma jurídica tributária, que determina a obrigação de, a título de tributo, o contribuinte entregar certo valor em

${ }^{509}$ Cf. CARVALHO, Paulo de Barros. Teoria da norma tributária. São Paulo: Max Limonad, 1998. P. 89, nota 48.

${ }^{510}$ Cf. BECHO, Renato Lopes. Op. cit. (nota 360), P. 122; 191.

${ }_{511}$ Cf. IBRAHIM, Fábio Zambitte. Op. cit. (nota 252), P. 56/57.

${ }^{512}$ Cf. QUEIROZ, Luis Cesar Souza de. Op. cit. (nota 09), P. 298/299. 
dinheiro ao Estado-Fiscal ou permitir que esse mesmo Estado-Fiscal dele retire certa importância; em ambos os casos o Estado-Fiscal estará representado pelo substituto tributário, como mero agente arrecadador; (ii) e uma segunda norma, de natureza jurídica administrativo-fiscal, que determina em seu consequente a obrigação de o substituto tributário (que atua como órgão meramente arrecadador) entregar (repassar) ao Estado o dinheiro recebido ou retido do contribuinte. Faz, ainda, as seguintes observações:

“a) a relação jurídica tributária somente se estabelece entre o contribuintesubstituído (sujeito passivo tributário) e o Estado-Fiscal (sujeito ativo tributário);

b) o contribuinte-substituído é o titular da capacidade contributiva objetiva, a qual é elemento característico da espécie tributária imposto;

c) o contribuinte-substituído é quem possui a riqueza, da qual parcela alíquota - será entregue ao Estado-Fiscal a título de tributo;

d) a obrigação tributária do contribuinte-substituído estará cumprida quando ele tiver entregue certo valor ao substituto tributário ou quando o substituto tributário tiver retirado do contribuinte-substituído o referido valor, conforme dispuser a norma tributária;

e) o Estado-Fiscal (sujeito ativo tributário), na relação jurídica tributária, é representado por seu agente arrecadador, o substituto tributário;

f) na relação administrativo-fiscal, o substituto tributário, que está obrigado a dar (repassar) o valor entregue pelo contribuinte-substituído ou retido do contribuinte-substituído, é o sujeito passivo administrativo-fiscal, enquanto o Estado-Fiscal é o sujeito ativo administrativo-fiscal." (destaques no original).

Como se vê, a despeito de o autor chamar a fonte de substituto tributário, com função de agente arrecadador, a argumentação adotada enquadra-se perfeitamente aos contornos conceituais do agente de retenção, definidos pela doutrina coligida acima, não se confundindo, pois, com a definição típica de substituto tributário, posto que, no caso do IRF, ao menos no regime de retenção por antecipação, a fonte não assume a condição de sujeito passivo da relação jurídica tributária. 
A fonte pagadora, na qualidade de agente de retenção é, a nosso ver, uma extensão (longa manus) da função tributante do Estado, correspondendo à função residualmente administrativa.

A obrigação da fonte pagadora, seja como substituto tributário, seja como agente de retenção, é providenciar, mediante uma série de obrigações de fazer já mencionadas neste trabalho, o recolhimento antecipado ou definitivo do tributo (obrigação de dar). A retenção do tributo na fonte, é verdade, traduz-se como ferramenta utilizada como mecanismo para transferência do ônus tributário/financeiro para o contribuinte, ou seja, autoriza que aquele terceiro não sacrifique patrimônio próprio para fins de pagar tributo devido por outrem. $\mathrm{O}$ recolhimento do tributo mediante a sua prévia retenção não é outra coisa senão a reafirmação e/ou ratificação do princípio da capacidade contributiva, cujo corolário é a igualdade, que deve funcionar não apenas como balizas norteadoras da tributação, mas, também, como limites constitucionais ao poder de $\operatorname{tributar}^{513}$. Até aqui temos os traços de semelhança entre as figuras do substituto tributário e do agente de retenção.

Com foco no contribuinte, sua relação com o Estado subsiste (parte final do artigo 128, do CTN), uma vez que só ao final do período de apuração é que se aperfeiçoará o fato gerador do IR, na condição de pessoa que realiza este fato gerador da obrigação tributária. O ônus financeiro do tributo, repassado ao contribuinte por meio da dedução dos valores a receber, correspondente ao exato montante pago pela fonte a título de IRF, será utilizado pelo contribuinte quando da entrega de sua DIRPF, o que constitui mais um argumento que mantém a vinculação de sua responsabilidade.

Ademais, fazendo valer os estritos termos do princípio da capacidade contributiva, ao menos em sua maior medida possível, as características pessoais do contribuinte serão novamente levadas em consideração ao findar-se o período de apuração, a partir do qual passamos a falar em pagamento do imposto devido. Neste momento, todos aqueles pagamentos de natureza antecipatória serão igualmente considerados, revelando a íntima vinculação entre o conjunto de eventos que, encadeados, perfazem a base de cálculo do fato gerador do IR (fato gerador instantâneo e base de cálculo complexa). Ao término do período de apuração, aqueles pagamentos são trazidos para dentro da universalidade que

${ }^{513}$ Neste mesmo sentido confira-se SCHOUERI, Luis Eduardo. Op. cit. (nota 113), P. 262/264. 
deverá mensurar a capacidade econômica do contribuinte, ou seja, tais pagamentos antecipados, cujo ônus financeiro foi continuamente repassado, serão utilizados como créditos para fins de cálculo do chamado imposto devido ou de eventual saldo de imposto a restituir.

Em outras palavras, os valores retidos a título de IR, pagos antecipadamente, serão utilizados como créditos do contribuinte e consolidados em sua Declaração, e nunca do terceiro (fonte pagadora).

Não há dúvidas de que, em sede desses pagamentos por antecipação através do IRF, a figura do contribuinte em nenhum momento se afasta ou se exclui por completo. Desconsiderar esses eventos ocorridos antes do término do período de apuração é desprezar o princípio da capacidade contributiva e da igualdade e a própria natureza do fato gerador do IR, que consiste em uma série de eventos encadeados entre si, ocorridos e tomados em um determinado período de tempo.

Distancia-se, pois, o agente de retenção do substituto tributário na medida em que aquela figura não "substitui" o contribuinte na relação jurídica tributária, em que pese responsabilizar-se pelo recolhimento antecipado do imposto, nos precisos termos da lei. Por isso, apoiados nas lições de BRANDÃO MACHADO ${ }^{514}$, reafirmamos que a fonte exerce uma função jurídico-administrativa. Frise-se que, da análise do aspecto temporal do IR nos casos de retenção na fonte por antecipação, não há se falar em relação jurídica tributária, pois, como se viu, o fato gerador do IR ainda não se aperfeiçoou e os pagamentos antecipados constituem meras antecipações. Essa responsabilidade, alerte-se, não é de natureza tributária, mas, sim, administrativa, na medida em que corresponde a uma função auxiliadora da máquina estatal e, por se tratar de uma obrigação legal, seu descumprimento encerra a aplicação de penalidades. Aliás, o tema penalidades pode ser utilizado como outra característica marcante do agente de retenção, tendo em vista que os casos de retenção e não repasse aos cofres públicos implicam em penalidades até mesmo de natureza criminal. Este ponto será analisado em seguida.

${ }^{514}$ Cf. MACHADO, Brandão. Op. cit. (nota 489), P. 294/296. 
O agente de retenção é, em suma, um terceiro, necessariamente em contato com o aspecto material da regra matriz, obrigado ao recolhimento de tributo devido por outrem, cujo vínculo com o núcleo objetivo da tributação lhe autoriza, legalmente, a reembolsar-se do ônus financeiro do encargo tributário, por intermédio do instituto da retenção na fonte. $\mathrm{O}$ agente de retenção surge em situações em que não houve o nascimento da obrigação tributária, exercendo, assim, uma função estritamente administrativa de auxílio ao Estado, sem que, com isso, fique afastada a responsabilidade tributária do contribuinte, que permanece, nestes casos, como o único sujeito passivo da relação jurídica tributária.

\subsubsection{Análise do Tema sob a Ótica das Penalidades Aplicáveis}

Outro argumento que deve ser apontado para fazer prevalecer o magistério de BRANDÃO MACHADO $^{515}$, no que tange ao agente de arrecadação ou agente retentor ${ }^{516}$, refere-se à aplicação de penalidades. Todavia, algumas ressalvas devem ser colocadas.

Para os sujeitos passivos eleitos para cumprimento de sua atividade prestacional, o legislador é claro ao tratar dos efeitos tributários em caso de não recolhimento do tributo. Este efeitos, frisem-se, são de natureza tributária (recolhimento do tributo acrescido dos correspondentes encargos moratórios).

Como vimos, o agente de retenção distancia-se da natureza precipuamente tributária do sujeito passivo, mas isso não significa que o descumprimento do dever da fonte corresponderá ao descumprimento de uma mera obrigação acessória, que, como vimos, encerra, também, uma obrigação de dar.

Em apertada síntese, quando se trata de descumprimento de obrigação tributária por parte do sujeito passivo, ou seja, mera falta de recolhimento do tributo, afastadas as hipóteses de dolo, fraude e simulação de que cuidam os artigos 135 a 137, do CTN, a legislação é clara no sentido de que esta conduta corresponde tão-somente a uma simples infração tributária, ensejando apenas a aplicação de penalidades de natureza pecuniária, i.e., multa e juros moratórios.

\footnotetext{
${ }^{515}$ Cf. MACHADO, Brandão. Op. cit. (nota 489), P. 294/296.

${ }^{516}$ Ou simplesmente retentor (Cf. PAULSEN, Leandro. Op. cit. (nota 56), P. 930).
} 
De outra sorte são os casos em que a fonte pagadora promove a retenção contra o contribuinte e, por qualquer razão que seja, deixa de efetuar o recolhimento do imposto aos cofres públicos. Para estes casos, entendendo tratar-se de conduta que oferece maior grau de lesividade, o legislador houve por bem tipificar tais práticas como crime, conforme o disposto no artigo $2^{\circ}$, inciso II, da Lei $\mathrm{n}^{\circ} 8.137 / 90$, verbis:

“Art. $2{ }^{\circ}$ Constitui crime da mesma natureza:

(...)

III - deixar de recolher, no prazo legal, valor de tributo ou de contribuição social, descontado ou cobrado, na qualidade de sujeito passivo de obrigação e que deveria recolher aos cofres públicos;

Pena - detenção, de 6 (seis) meses a 2 (dois) anos, e multa."

Estamos diante das diferenças observáveis a partir dos espectros dos subsistemas do Direito Tributário Penal e do Direito Penal Tributário, ambos voltados ao estudo das infrações às normas que regulam as relações jurídicas tributárias, situados, entretanto, em campos distintos conforme a essência da infração, do potencial lesivo causado ou, em alguns casos, da natureza própria das sanções aplicadas.

Sem nos estendermos muito sobre este tema, o que releva destacar é que o bem jurídico tutelado pelo Direito Tributário Penal é o Erário, ou, em outras palavras, a manutenção do nível de arrecadação. A norma jurídica que trata do binômio infração/sanção a uma regra fiscal sempre irá buscar seu fundamento de validade na desobediência a uma norma tributária, i.e., que regula a relação jurídica entre Fisco (credor) e devedor do tributo.

Por outro lado, o subsistema do Direito Penal Tributário tipifica a conduta lesiva como um delito/crime, com o necessário exame do elemento da culpabilidade. Em havendo ofensa ou nocividade aos valores de uma sociedade, as sanções poderão assumir a forma pecuniária (multas) ou traduzir-se em uma medida de segurança (penas privativas de liberdade). 
Em suma, é o grau de nocividade (potencial lesivo) das condutas praticadas que definirá se estamos diante de uma infração administrativa (fiscal) ou de um crime (delito fiscal). Essa medida de gravidade ou nocividade é definida por critérios de política criminal e vertido na linguagem competente, mormente a Lei no 8.137/90.

Queremos crer que a conduta da fonte de não ter recolhido o imposto (previamente retido) difere-se das hipóteses em que, por exemplo, o contribuinte ou o responsável, por questões diversas (falta de recursos ou por algum lapso), deixa de pagar o tributo, muito mais por razões da maior nocividade entre aquela primeira situação e esta última, do que por razões de classificação entre agente de retenção ou sujeito passivo indireto, na qualidade de substituto tributário. Este ponto, há que se concordar, revela uma coerência mais clara para classificação da fonte como agente de retenção, considerando que, diferentemente da regra geral dos efeitos gerados para o sujeito passivo em mora, a fonte, que retém e não recolhe, incorre em crime contra a ordem tributária.

Todavia, parece- nos mais acertado afirmar que o fator "penalidades" não seria um critério eficaz para classificar uma situação como típica substituição tributária ou se seria caso de agente de retenção. Em ambas as situações é clara a existência de valores devidos a título de tributo, ainda que, em um dos regimes de retenção na fonte, os pagamentos antecipados assumam a natureza de meras antecipações. Ocorre que, naquela primeira situação (retenção sem o recolhimento do imposto), há manifesta apropriação de recursos de terceiros (locupletamento ilícito), conduta grave que deve ser seriamente reprovada e que mereceu tratamento diferenciado, culminando com sua tipificação como crime. Mas isso, a nosso ver, não quer dizer que o agente de retenção ocupa uma posição ou classificação especial; significa dizer que o sujeito passivo, em suas diversas espécies, ou até mesmo o contribuinte, poderá assumir a feição de agente ao incorrer em crime contra a ordem tributária, da mesma forma como ocorre com o caso da fonte aqui comentado.

A jurisprudência esmagadora do STJ trilha no sentido de que a apropriação indébita, tipificada como crime pelo artigo 168-A, do Código Penal, específico para o caso de contribuições previdenciárias, se consuma com o simples não recolhimento, no prazo legal, 
das contribuições descontadas dos empregados ${ }^{517}$. O artigo $2^{\circ}$, inciso II, da Lei $\mathrm{n}^{\circ}$ 8.137/90, alberga os crimes de apropriação indébita tanto de contribuições como de impostos. Com isso, analogamente, é de se concluir que os casos de retenção do IR e não recolhimento dos valores retidos aos cofres públicos resultariam igualmente em conduta delituosa, tipificada como crime.

Todavia, como se denota de julgados mais recentes sobre o tema, a leitura isolada desses dispositivos parece não dar conta da complexidade que tais enunciados escondem.

Assim é que chamamos a atenção para uma leitura mais moderna de decisões do STJ, no sentido de que não basta a simples mora tributária para que se resulte em conduta criminalizada. Esta postura desserve ao propósito estatal de dinamizar a arrecadação tributária por meio da fonte pagadora (que está imaculada no princípio da praticabilidade) e transforma a Ação Penal em instrumento de coação da dívida ativa. Ademais, e sem querer entrar nesse mérito, alguns julgados afirmam que tratar o crime de apropriação indébita de forma isolada seria confirmar uma inaceitável responsabilidade penal objetiva, colocando em pé de igualdade a pessoa que promoveu a retenção regularmente e prestou as informações ao Fisco em DCTF (ensejando uma cômoda lavratura de autuação), mas que, por um lapso, perdeu o prazo de recolhimento do tributo anteriormente retido, e o sujeito que, valendo-se de ardis e artimanhas, oculta fatos relevantes e procura efetivamente locupletar-se daqueles dinheiros retidos dos contribuintes. Em suma, observa-se a necessidade de caracterização da intenção do agente em querer apropriar-se dos valores retidos.

É o que se deduz de algumas decisões cujos trechos são transcritos a seguir. Observa-se que as Cortes Superiores parecem dar início a um novo estágio jurisprudencial, no sentido

517 "PENAL. PROCESSUAL PENAL. RECURSO ESPECIAL. APROPRIAÇÃO INDÉBITA PREVIDENCIÁRIA. ART. 168-A DO CP. DOLO GENÉRICO. RECURSO PROVIDO.

1. A Terceira Seção desta Egrégia Corte, por unanimidade, pacificou o entendimento de que o crime previsto no art. 95, alínea $d$, da Lei ${ }^{\circ}{ }^{\circ} 8.212 / 91$, revogado com o advento da Lei $n^{\circ}$ 9.983/00, que tipificou a mesma conduta no art. 168-A do Código Penal, se consuma com o simples não-recolhimento das contribuições previdenciárias descontadas dos empregados no prazo legal. (AgRg no REsp 1.070.139/PE, Rel. Min. JANE SILVA, Desembargadora Convocada, Sexta Turma, DJ 2/2/09)

2. Recurso especial conhecido e provido para cassar a ordem de habeas corpus e determinar o prosseguimento da ação penal." (STJ. REsp no 1.107.297/PE. Rel. Min Arnaldo Esteves Lima. DJe 31/08/2009) 
de segregar aquelas pessoas (fonte pagadora) que notoriamente agem com intuito doloso de se apossar, em benefício próprio, dos valores anteriormente retidos, daqueles outros que optam por investir tais recursos na própria sociedade, às vezes com a finalidade de pagar salários ou credores, em detrimento do mandamento legal de recolher tais valores aos cofres públicos ou que, simplesmente, se atrasaram no recolhimento aos cofres públicos porque se encontravam em situação de dificuldade financeira. Confira-se:

"AGRAVO REGIMENTAL. RECURSO ESPECIAL. CRIME DE APROPRIAÇÃO INDÉBITA DE CONTRIBUIÇÃO PREVIDENCIÁRIA. TIPO PENAL (ART. 168-A DO CP). DOLO ESPECÍFICO. NECESSIDADE DE A DENÚNCIA DESCREVER A INTENÇÃO DE SE FURTAR AO RECOLHIMENTO TRIBUTÁRIO.

O tipo do art. 168-A do Código Penal, embora tratando de crime omissivo próprio, não se esgota somente no "deixar de recolher", isto significando que, além da existência do débito, haverá a peça acusatória de demonstrar a intenção específica ou vontade deliberada de pretender algum benefício com a supressão ou redução, já que o agente "podia e devia" realizar o recolhimento. Agravo provido para também prover o recurso especial, de modo a reconduzir a sentença de rejeição da denúncia."

(STJ. AgRg no REsp nº 695.487/CE. Rel. Min. Maria Thereza de Assis Moura. DJe 30/11/2009)

“(...)

11. É de inegável relevo assinalar que o colendo Supremo Tribunal Federal parece ter assimilado a tese de que o crime de apropriação indébita previdenciária (art. 168-A do CPB) não é de mera conduta, mas sim de resultado, isto é, o bem jurídico tutelado pela norma penal é a arrecadação das contribuições devidas ao INSS, tanto que o parcelamento (moratória individual) suspende a punibilidade desse crime e a quitação da dívida a extingue; em outras palavras, a figura típica não se esgota no simples ato ilícito de não-recolhimento ou não-repasse das contribuições descontadas dos salários dos empregados, o que basta à configuração do ilícito administrativo e expõe o infrator à execução fiscal. 
(...)

13. Ao que se percebe, admitir-se que o parcelamento da divida suspenda e que o seu pagamento extinga a punibilidade desse crime não se harmonizariam, data venia, com a compreensão de que se trataria de crime de mera conduta, porque assim se estaria deixando de punir um ilícito penal caracterizado e consumado; na verdade, essas decisões do STF evidenciam que, não tendo havido, por parte do agente, a intenção de se apropriar dos valores descontados dos seus empregados e devidos ao INSS, não se aperfeiçoa a figura criminal típica do art. 168-A do CPB.

14. Reitera-se, portanto, que o crime de apropriação indébita previdenciária somente ocorre quando se demonstra ter o agente atuado com o ânimo de apropriar-se dos valores descontados dos salários dos empregados, ou seja, com o ânimo de converter em coisa própria, mediante o cometimento de ato ilícito, os bens (valores) de terceiro (INSS) que detinha provisoriamente em seu poder; assinalo que o agente tem a posse justa dos valores descontados dos salários dos empregados e que essa mesma posse somente se torna posse injusta quando (e se) ocorrer a deliberada conversão desses valores em coisa própria.

15. Cumpre lembrar que apropriar-se significa precisamente alguém tornar próprio ou fazer sua a propriedade um bem alheio de que tem a posse justa, mediante a prática de ato ilícito, como a doutrina jurídica leciona, sem discrepância, quanto ao crime de apropriação indébita (art. 168 do CPB).

16. É fora de dúvida que a prática da apropriação indébita (art. 168 do CPB) exige que o agente tenha a intenção específica de se apoderar da coisa móvel de outrem, de se tornar ilegalmente o seu dono; não há razão jurídica para se dar ao crime de apropriação indébita previdenciária (art. 168-A do CPB) configuração diversa, quer por causa do próprio nomen juris, quer por causa da sua posição tópica, que por causa dos elementos que se requerem em ambos os tipos (posse justa de coisa móvel de outrem e apropriação).

17. A dificuldade de demonstração do dolo específico não é escusa jurídica e nem legítima para se implantar a responsabilidade penal objetiva no crime do art. 168-A do CPB, cabendo ao órgão da acusação evidenciar, pela análise da conduta do agente, a sua intenção (animus) de se apropriar (sibi habendi) da 
coisa alheia (rem) de que tem a posse justa, neste caso, os valores descontados dos empregados e não repassados ao INSS, em manifesto abuso da sua condição de depositário.

18. Consciente de que este voto dissente da orientação seguida nesta Turma Julgadora, peço licença ao ilustrado Ministro ARNALDO ESTEVES LIMA para dele divergir respeitosamente, o que faço louvando o seu lúcido entendimento manifestado em sentido contrário ao que agora afirmo; dest'arte, voto pelo improvimento do recurso." (grifamos)

(STJ. REsp No 1.107.297/PE. Rel. Arnaldo Esteves Lima. Voto Vista: Min. Napoleão Nunes Maia Filho. DJe 31/08/2009)

É inegável que o critério das penalidades aplicáveis é argumento válido como potencial fator de qualificação da figura do agente de retenção, em contraposição ao substituto tributário. Os comentários tecidos acima objetivam, contudo, ponderar sobre o fato de que a maior penalização aos casos de não recolhimento de tributos retidos na fonte, onde, atualmente, parece exigir-se o animus de apropriação por parte da fonte pagadora, revelam que este tratamento punitivo está diretamente associado ao grau de lesividade das condutas praticadas e não em função da classificação dos sujeitos em agente de retenção ou substituto tributário. Como se viu, em se verificando que a fonte não tinha a intenção de se apropriar dos valores retidos, a orientação poderá ser no sentido de que ambas as situações podem não gerar responsabilização penal em função do mero não recolhimento dos tributos. 


\section{CAPÍTULO IV - DEBATE SOBRE OS DIFERENTES CENÁRIOS DE APLICAÇÃO PRÁTICA DO IRF}

Com foco nos regimes próprios do IRF, vimos que ora ele assume a característica de "exclusivo de fonte", ora como "antecipação do devido". A relevância dessa divisão, e considerando os estudos que fizemos sobre o agente de retenção e o substituto tributário, é que dela decorrem diferentes consequências, tanto para a fonte pagadora, na qualidade de terceiro obrigado ao pagamento de tributo devido por outrem, quanto para o próprio contribuinte e, em alguns casos, para uma figura intermediária que não se confunde nem com a fonte pagadora nem com o contribuinte.

Proliferam as situações de irregularidades e fiscalizações no que se refere à exigência e à cobrança do IR e, não raras vezes, são lavradas autuações contra pessoas que ou já tiveram sua responsabilidade excluída ${ }^{518}$, ou que já diligenciaram nos exatos termos da lei, contudo, foram prejudicadas por evento posterior (caso da fonte que regularmente faz a retenção e o recolhimento do imposto e acaba sendo lesada pela prestação de informação de forma incorreta pelo contribuinte quando da entrega, por exemplo, da DIRPF ${ }^{519}$ ).

Preocupada com essas situações, a Receita Federal do Brasil (à época sob o nome de Secretaria da Receita Federal) editou o Parecer Normativo COSIT (Coordenação-Geral do Sistema de Tributação) $n^{\circ}$ 01, de 24 de setembro de 2002 - Anexo. Apoiados no posicionamento que aqui se procura solidificar, acreditamos que a Receita Federal do

518 “IMPOSTO DE RENDA NA FONTE - RETENÇÃO NA FONTE - FALTA DE RECOLHIMENTO RESPONSABILIDADE - Não se estende ao beneficiário do rendimento, que suportou o ônus do imposto retido na fonte, o descumprimento à legislação de regência cometido pela fonte pagadora responsável pela retenção e recolhimento aos cofres públicos do valor descontado. Desta forma, a falta de recolhimento do imposto de renda retido sujeitará a fonte pagadora da remuneração ao lançamento de ofício $e$ às penalidades da lei." (Acórdão no 104-22794. 1 CC. $4^{\text {a }}$ Câmara. Formalizado em 12.12.2007).

519 "SUBSTITUIÇÃO TRIBUTÁRIA - RESPONSABILIDADE EXCLUÍDA - A fonte pagadora tendo cumprido as disposições legais no que se refere a retenção do Imposto de Renda na Fonte incidente sobre rendimentos do trabalho assalariado e outros e tendo fornecido o Comprovante de Rendimentos Pagos e de Retenção de Imposto de Renda computando, inclusive, a Ajuda de Custo paga pelo exercício de Mandato Parlamentar, não pode ser responsabilizada pelo erro ou omissão praticado pelo sujeito passivo da obrigação tributária quando da apresentação da Declaração Anual de Ajuste." (Acórdão nº 102-45044, $1^{\text { }}$ CC, $2^{a}$ Câmara, sessão em 19/09/2001). 
Brasil, através da COSIT, foi feliz na edição do referido PN, guardados alguns comentários de ordem técnica quanto à redação utilizada.

A seguir, além de analisarmos situações específicas descritas ou não naquele PN, apontaremos um esboço ou uma tentativa de construir uma regra geral do regime jurídico aplicável aos dois regimes de retenção na fonte, destacando os itens específicos do PN pertinentes a cada situação. Antes, porém, analisaremos algumas "condições gerais" definidas naquele PN.

\subsection{O Parecer Normativo COSIT nº 01, de 2002 - Regras Gerais}

Além das regras específicas para cada um dos regimes jurídicos próprios do IRF, o PN COSIT $n^{\circ}$ 01/2002 traz informações de regras aplicáveis às situações em geral da sistemática de pagamento do IRF, bem como informações sobre o tratamento da sujeição passiva tributária existente em nosso ordenamento jurídico.

Inicialmente vale observar o tópico "Sujeição passiva tributária geral", abordado em seus parágrafos 2 a 7 (Anexo). Acreditamos que a disciplina trazida pelo PN apenas esclarece o que já estava definido em lei, tornando mais didática as situações vislumbradas em cada um dos cenários, não havendo, assim, falar-se em ofensa ao princípio da legalidade.

Como primeira observação, em oposição à redação contida no parágrafo 4, diante dos conceitos aqui construídos, em especial a classificação proposta para os sujeitos passivos tributários indiretos, de fato a fonte pagadora substitui o contribuinte quanto à obrigação de recolher o tributo de forma antecipada, todavia, jamais sob a roupagem de responsável tributário stricto sensu. Como vimos, essa figura depende de um acontecimento futuro (o segundo fato) para dar nascimento à sua condição de responsável. A responsabilidade tributária (acepção lata) da fonte pagadora surge no exato instante em que ocorre o pagamento, crédito, remessa, entrega ou emprego, momentos eleitos pelo legislador como suficientes para o nascimento da obrigação de recolhimento do IRF.

Logo, como queremos crer, a fonte pagadora poderá assumir a condição ou de substituto tributário ou de agente de retenção, mas não de um responsável tributário stricto sensu. 
Uma segunda observação (parágrafo 6), já em estrita conexão com cada um dos regimes jurídicos do IRF analisados, reporta-se à condição definida sobre a responsabilidade da fonte pagadora, que poderá ser exclusiva, para as hipóteses de retenção exclusiva de fonte, ou subsidiária, para os casos de antecipação do imposto devido, tudo em isso nos termos do artigo 128, do CTN.

Vale apontar, ainda, com foco no referido parágrafo 6, que a responsabilidade acometida à fonte pagadora é quanto ao recolhimento do imposto e não quanto à sua retenção. A retenção da fonte corresponde a um mecanismo cuja faculdade é outorgada à fonte pagadora como forma de neutralizar o impacto financeiro decorrente de sua responsabilidade pelo recolhimento de tributo devido por outrem e, com isso, evitar qualquer lesão ao seu patrimônio em benefício do contribuinte. Corrobora essa assertiva o fato de que, se por alguma razão ou lapso a fonte deixar de reter o imposto na fonte, presume-se que o rendimento foi pago líquido, devendo-se, neste caso, proceder ao recolhimento do IRF, inclusive dos encargos moratórios (multa e juros), cujo ônus será da fonte pagadora, conforme preceitua o parágrafo 17 do mesmo PN (Anexo).

Como já apontamos no item 1.16., independentemente de se considerar como critério de discrímen entre agente de retenção ou substituto tributário, fato é que as situações que envolvam retenção de tributos, desacompanhadas de seu recolhimento, caracterizam-se como crime, tipificadas como apropriação indébita. Com o IRF não é diferente, aplicandose essa regra para ambos os regimes. Vale anotar, contudo, que a parte final do parágrafo 17 aplica-se somente ao regime de "antecipação do devido", tendo em vista que, no regime do IRF "exclusivo de fonte", a retenção do imposto é tratada de forma definitiva e isolada, não se comunicando com a apuração ao final do período de apuração, valendo o mesmo para o próprio rendimento submetido àquele regime de retenção.

Levando em conta a elucidação de RUY BARBOSA NOGUEIRA ${ }^{520}$, segundo o qual se uma série de relações sociais com características fáticas comuns, para ser adequadamente regulada, exige normas apropriadas a esse objetivo, é porque a natureza comum desses fatos requer uma normatividade especial, podemos concluir que assim parecem ser os

${ }^{520}$ Cf. NOGUEIRA, Ruy Barbosa. Op. cit. (nota 02), P. 36. 
casos, se não de todos, mas da quase a totalidade das hipóteses do IRF. Tendo isso em vista, pode-se ventilar a ideia de construção de regras gerais no sentido de moldar o regime jurídico do IRF nas sistemáticas de retenção como "antecipação do devido" e retenção como "exclusivo de fonte".

\subsection{O Regime Jurídico do IRF como "antecipação do devido"}

Como tivemos a oportunidade de analisar, este regime traz como principal marca a situação de o fato gerador do IR ainda não ter se aperfeiçoado completamente, justamente pelo elemento "aspecto temporal" corresponder a momentos, eleitos pelo legislador, diferentes. Assim, o momento em que o IRF é devido é anterior ao momento em que se dará a apuração definitiva do IR, logo se afirmar, com larga segurança, que os valores recolhidos a título de IR caracterizam-se como legítimas antecipações. Antes de descrevermos as principais características do regime do IRF como "antecipação do devido", vejamos como o PN COSIT n 01/2002 tratou o tema cujo teor passamos a transcrever, juntamente com nossas ponderações:

“IRRF. ANTECIPAÇÃO DO IMPOSTO APURADO PELO CONTRIBUINTE. RESPONSABILIDADE.

Quando a incidência na fonte tiver a natureza de antecipação do imposto a ser apurado pelo contribuinte, a responsabilidade da fonte pagadora pela retenção e recolhimento do imposto extingue-se, no caso de pessoa física, no prazo fixado para a entrega da declaração de ajuste anual, e, no caso de pessoa jurídica, na data prevista para o encerramento do período de apuração em que o rendimento for tributado, seja trimestral, mensal estimado ou anual. IRRF. ANTECIPAÇÃO DO IMPOSTO APURADO PELO CONTRIBUINTE. NÃO RETENÇÃO PELA FONTE PAGADORA. PENALIDADE.

Constatada a falta de retenção do imposto, que tiver a natureza de antecipação, antes da data fixada para a entrega da declaração de ajuste anual, no caso de pessoa física, e, antes da data prevista para o encerramento do período de apuração em que o rendimento for tributado, seja trimestral, mensal estimado ou anual, no caso de pessoa jurídica, serão exigidos da fonte pagadora o imposto, a multa de ofício e os juros de mora. 
Verificada a falta de retenção após as datas referidas acima serão exigidos da fonte pagadora a multa de ofício e os juros de mora isolados, calculados desde a data prevista para recolhimento do imposto que deveria ter sido retido até a data fixada para a entrega da declaração de ajuste anual, no caso de pessoa física, ou, até a data prevista para o encerramento do período de apuração em que o rendimento for tributado, seja trimestral, mensal estimado ou anual, no caso de pessoa jurídica; exigindo-se do contribuinte o imposto, a multa de ofício e os juros de mora, caso este não tenha submetido os rendimentos à tributação."

Após a leitura das "ementas" acima, descritas no introito do PN, os parágrafos 11 a 16 detalham o tema da responsabilidade da fonte pagadora. Com foco nas datas fixas para apuração do imposto devido, momentos em que surge a obrigação tributária do contribuinte, pessoa física ou jurídica, de recolher o IR devido, o legislador define de quem é a responsabilidade pelo recolhimento do tributo ou dos encargos moratórios (multa e juros) para os casos em que não houve a retenção.

Pensamos que o legislador acertou na definição da sistemática de responsabilidade pelas antecipações (que não se caracteriza como imposto, ainda) e pelos encargos moratórios. Ainda que se tenha como cristalina a regra de que o fato gerador do IR ocorre no último dia do período de apuração, quando sua base de cálculo é finalmente construída, certo é que, no caso de pessoa física, é somente na data de entrega de sua DIRPF que o contribuinte se torna obrigado ao recolhimento do imposto, se devido. Os parágrafos 12 e 13 dão conta dessa situação, ressaltando a relevância em identificar o momento em que foi verificada a falta de retenção do IRF, se antes ou após os prazos fixados no parágrafo 12 (entrega da DIRPF, se pessoa física, ou no encerramento dos períodos de apuração, mensal, trimestral ou anual, se pessoa jurídica).

Isto se deve ao fato de que a DIRPF é o instrumento definido pelo legislador como próprio para o fim de apuração do IR devido. Através de um programa gerador eletrônico, disponível virtualmente, o contribuinte terá condições de quantificar o imposto a ser pago, caso seja apurado algum valor a pagar. A declaração de ajuste anual é o instrumento onde são informados, além da relação de bens adquiridos ou alienados ou de dívidas assumidas 
durante o ano onde, todos os rendimentos auferidos no ano ${ }^{521}$, bem como as despesas relevantes (fatos-decréscimos) ou não, permitindo, com isso, a apuração final e definitiva do IR. Não há outro momento em que o contribuinte possa realizar essa apuração, o que significa dizer que não existem condições suficientes para que o contribuinte proceda à apuração do quantum devido no último dia do exercício, momento em que se aperfeiçoa o fato gerador.

Mais certo seria dizer que somente na data de entrega da DIRPF é que o contribuinte se torna apto a recolher qualquer imposto, se houver, assim como somente nesta data é que será possível verificar se há ou não saldo a restituir.

Os casos específicos dos artigos 157, inciso I, e 158, inciso I, ambos da CF, na medida em que os Estados, o Distrito Federal e os Municípios são os próprios empregadores, correspondem a exemplos típicos onde se aplicam as condições do regime jurídico do IRF como "antecipação do devido", de forma que tais pessoas políticas, ainda que intermediadas por meio de bancos estatais ${ }^{522}$, atuam sob a égide do figurino de agentes de retenção $^{523}$.

Disto decorre que a data final para entrega da DIRPF, geralmente no último dia do mês de abril do exercício seguinte àquele em que foram realizadas as antecipações, é tomada como marco divisor para definição tanto da responsabilidade pelo recolhimento tanto do IRF como dos encargos moratórios. Para melhor clareza, estruturamos a linha do tempo a seguir, conforme ilustra a Figura 4:

\footnotetext{
${ }^{521}$ Apenas lembrando, os rendimentos isentos, tributados de forma definitiva (como são, por exemplo, os ganhos de capital) e os rendimentos tributados exclusivamente na fonte são apenas arrolados na DIRPF, com a finalidade única de informar às Autoridades Fiscais e compor o total da variação patrimonial do contribuinte, ainda que, contudo, tais acréscimos fujam do alcance do IRPF quando da apuração final e definitiva do IR.

${ }_{522}$ Mesmo na hipótese desses pagamentos serem operacionalizados por instituições financeiras privadas, o figurino aplicável será de um agente de retenção, já que neste caso a retenção se daria não por um contato indireto com a materialidade do fato gerador, mas, sim, por uma função mecânico-administrativa, derivada de um mandamento legal.

${ }_{523}$ Este, todavia, não parece ser o entendimento de LEANDRO PAULSEN, que considera que, nesses casos, tais pessoas políticas atuam como substitutos tributários (Cf. PAULSEN, Leandro. Op. cit. (nota 56), P. 431).
} 
Figura 4

Responsabilidade do Contribuinte pelo recolhimento do imposto e dos

Evento gerador encargos, calculados a partir dessa data

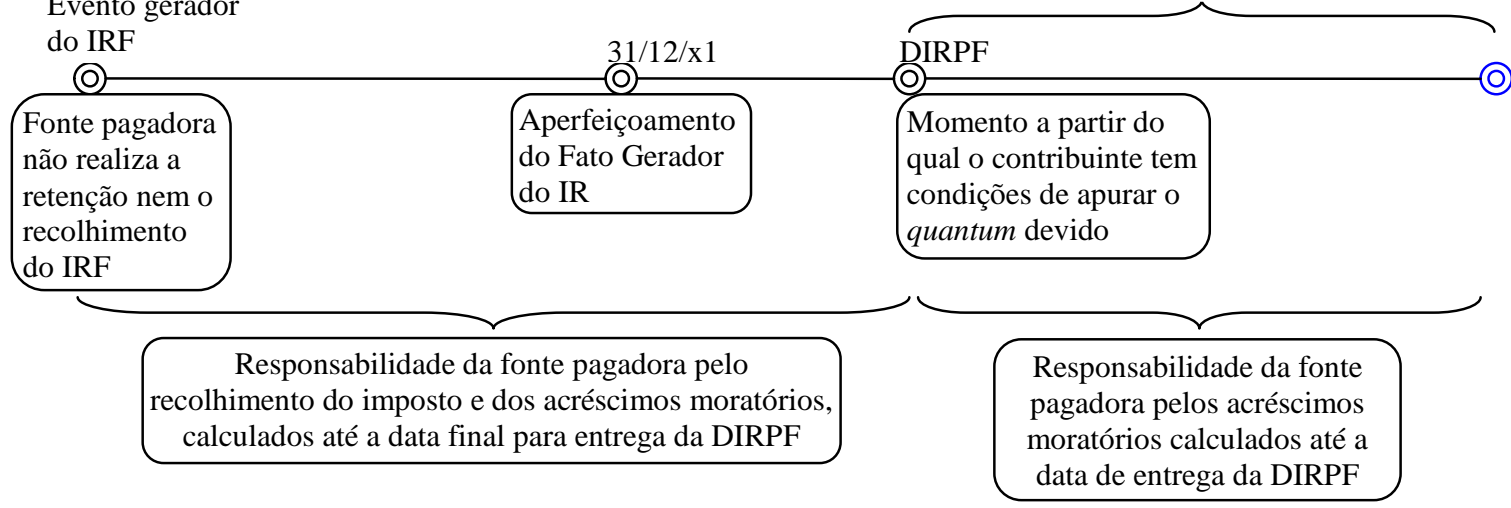

Diante do fato de que tais antecipações não assumem a natureza de imposto, já que não se aperfeiçoou o ciclo de formação do fato gerador, conclui-se que a obrigação tributária não surgiu, não se falando, pois, em relação jurídica tributária. A fonte pagadora, como vimos, não assume a condição de sujeito passivo (e muito menos de responsável tributário, conforme indicado no PN COSIT $n^{\circ}$ 01/2002), mas de um mero agente de retenção, obrigada, contudo, a proceder a tais recolhimentos antecipados sob a condição de um dever de natureza administrativa, auxiliar às funções fiscalizatória e arrecadatória por parte do Estado-Fisco.

À fonte pagadora, contudo, de forma a afastar qualquer prejuízo ao seu patrimônio próprio, é-lhe garantido o direito (trata-se de uma faculdade e não de uma responsabilidade ou obrigação) de retenção do imposto do próprio rendimento a ser pago ao beneficiário que, em princípio, o receberá já líquido (deduzido) do IRF.

Vale destacar que, mesmo que sua responsabilidade tributária (acepção lata) seja supletiva, nos termos da parte final do artigo 128, do CTN, a fonte pagadora, sob o figurino do agente de retenção, não terá essa responsabilidade afastada antes da data final para entrega da DIRPF, ainda que, entre o período compreendido entre a data final do exercício fiscal e a entrega da declaração anual de ajuste, o fato gerador do IR já tenha ocorrido. Isto porque antes daquela data, entrega da DIRPF, ao contribuinte não são disponibilizadas condições suficientes para apuração, com precisão e rigor, do quantum do imposto devido. 
A definição daqueles períodos de tempo, em que se destacam parcelas de responsabilidade do agente de retenção e do contribuinte, em estrita conexão com a DIRPF, atende substancialmente aos ditames do princípio da praticabilidade, como uma sistemática prática que permite uma fácil execução da lei tributária, ao mesmo tempo em que se respeita aos princípios da capacidade contributivo-econômica e da segurança jurídica, não exigindo, do contribuinte, algo que ele não teria condições de entregar ou fazer, já que o próprio Estado-Fisco definiu, como procedimento hábil e único, que a apuração definitiva do IR seja realizada através do programa gerador virtual denominado DIRPF.

A ênfase no perfil da responsabilidade do agente de retenção, como subsidiária à responsabilidade do contribuinte, pode ser assim ilustrada:

\section{Figura 5}

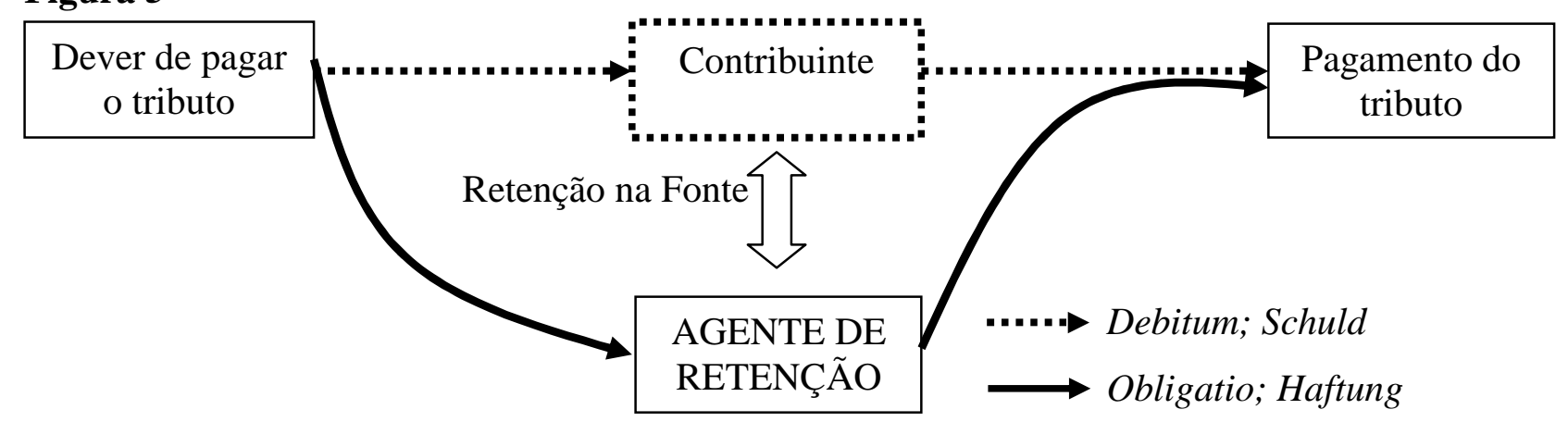

A ilustração acima mostra que a figura do contribuinte continua em estado latente, ou seja, na hipótese de o agente de retenção deixar de efetuar a retenção e o recolhimento do imposto, a responsabilidade tributária do contribuinte poderá ser alcançada, conforme um daqueles momentos específicos identificados na linha do tempo desenhada na Figura $4^{524}$.

\footnotetext{
524 “IRPF - RESPONSABILIDADE TRIBUTÁRIA - Em se tratando de imposto em que a incidência na fonte se dá por antecipação daquele a ser apurado na declaração de ajuste anual, não existe responsabilidade tributária concentrada, exclusivamente, na pessoa da fonte pagadora." ( $1^{\circ}$ CC. $4^{a}$ Câmara. Acórdão no $104-$ 20.392. Sessão de 2 de dezembro de 2004); "IRPF - PRELIMINAR - ERRO DE IDENTIFICAÇÃO DO SUJEITO PASSIVO - RESPONSABILIDADE DA FONTE PAGADORA - O contribuinte do imposto de renda é o adquirente da disponibilidade econômica ou jurídica da renda ou de proventos de qualquer natureza A responsabilidade atribuída à fonte pagadora tem caráter apenas supletivo, não exonerando o contribuinte da obrigação de oferecer os rendimentos à tributação." (CARF. $3^{\text {a }}$ Seção de Julgamento. Acórdão no 3401-00.061 - 4 Câmara / 1" Turma Ordinária. Sessão de 07 de maio de 2009). Adicionalmente, vale transcrever algumas passagens do voto da julgadora relatora Ana Neyle Olímpio Holanda: "Dessarte, no tocante aos rendimentos auferidos mensalmente, embora a sua tributação se dê à medida que foram percebidos, devem ser submetidos ao ajuste anual. Isto porque, somente ao final de cada exercício fiscal, estabelecido pela legislação tributária como o período de doze meses do ano, é possível definir a renda a ser submetida de forma "definitiva" à tributação, após efetuadas as deduções autorizadas por lei.
} 
Para as pessoas jurídicas, este regime aplica-se a qualquer receita, desde que submetida à retenção na fonte. Sob a perspectiva das pessoas físicas, o regime do IRF aqui analisado aplica-se a quaisquer rendimentos recebidos decorrentes do produto do capital, do trabalho ou da combinação de $\operatorname{ambos}^{525}$, independentemente de sua denominação, localização ou condição jurídica ou mesmo da nacionalidade da fonte, da origem dos bens produtores da renda e da forma de percepção das rendas ou proventos, bastando, para a incidência do imposto, o benefício do contribuinte por qualquer forma e a qualquer título ${ }^{526}$. Os exemplos de rendimentos mais característicos desse regime são os valores recebidos como salário ou cuja natureza esteja intimamente vinculada à verba salarial. Neste regime

Com efeito, embora a aquisição da disponibilidade econômica ou jurídica dos rendimentos se dê mensalmente, sendo tais rendimentos submetidos à tributação à medida que foram sendo percebidos, tais recolhimentos são apenas antecipações do que for devido na declaração anual de rendimentos, pois que o fato gerador do imposto sobre a renda das pessoas físicas, salvo nos casos de tributação definitiva, somente se perfaz ao final de cada ano calendário, submetendo-se, o conjunto dos rendimentos à tributação pela tabela progressiva anual.

Este é o entendimento do Superior Tribunal de Justiça, no Recurso Especial $n^{\circ}$ 584.195/PE, de lavra do Relatos Ministro Franciulli Netto, cujo excerto se transcreve: (...)

Desta forma, depreende-se que, o melhor entendimento para as normas que regem a tributação do IRPF é a de que a legislação determinou a obrigatoriedade, durante o ano-calendário, de o sujeito passivo submeter à tributação os determinados rendimentos de forma antecipada, cuja apuração definitiva somente se dará quando do acerto por meio da declaração de ajuste anual.

Sob esse pórtico, tem-se que a responsabilidade da fonte pagadora não pode ser entendida como infinita e indeterminadamente no tempo e no espaço. Há que se ter um termo final a esta responsabilidade e, este termo final, materializa-se quando da entrega da declaração de ajuste anual, oportunidade em que o sujeito passivo direto da obrigação tributaria está obrigado a informar todos os rendimentos percebidos no anocalendário, apurando se há saldo de imposto a pagar ou valor a ser restituído.

Portanto, após a data da entrega da declaração de ajuste anual, incabível a constituição de crédito tributário através do lançamento de imposto de renda na fonte na pessoa jurídica pagadora dos rendimentos. O lançamento, a titulo de imposto de renda - pessoa física - , se for o caso, há que ser efetuado em nome do sujeito passivo direto da obrigação tributária, ou seja, o beneficiário e titular da disponibilidade jurídica e econômica do rendimento, exceto no regime de exclusividade do imposto na fonte. A falta de retenção do imposto de renda na fonte pela fonte pagadora não exonera o beneficiário dos rendimentos da obrigação de incluí-los, para fins de tributação, na declaração de ajuste anual, do contrário a inclusão deverá ser efetuada de oficio pela autoridade fiscal.

Este tem sido o entendimento da Câmara Superior de Recursos Fiscais do Ministério da Fazenda, órgão uniformizador da jurisprudência dos Conselhos de Contribuintes, o que fica demarcado no Acórdão CSRF/01-05.026, de 09/08/2004, em Recurso Especial no Acórdão $n^{\circ}$ 106-128.643, cujo entendimento se resume na ementa a seguir transcrita (...)" Nesse sentido a própria Súmula 12 do CARF e outras decisões: "Súmula CARF no 12: Constatada a omissão de rendimentos sujeitos à incidência do imposto de renda na declaração de ajuste anual, é legítima a constituição do crédito tributário na pessoa física do beneficiário, ainda que a fonte pagadora não tenha procedido à respectiva retenção"; CARF - $2^{\mathrm{a}}$ Seção de Julgamento. Acórdão 2801-00.579. $1^{\text {a }}$ Turma Especial. Sessão em 17 de junho de 2010; STJ. 2a Turma. REsp 1058771/RS. DJe 31/08/2009.

${ }_{525}$ Nos termos do artigo 43 , do CTN, e do artigo $3^{\circ}, \S 1^{\circ}$, da Lei $n^{\circ} 7.713 / 88$ e alterações.

${ }^{526}$ Nos termos artigo $3^{\circ}, \S^{\circ}$, da Lei $n^{\circ} 7.713 / 88$ e alterações. 
enquadram-se todos e quaisquer rendimentos, salvo aqueles tratados como isentos ou como sujeito à tributação exclusiva de fonte, que passamos a analisar na sequência ${ }^{527}$.

\subsection{O Regime Jurídico do IRF "exclusivo de fonte”}

No regime de retenção do IR exclusivamente na fonte, a característica mais marcante é o fato de que tanto o montante retido como o rendimento submetido a essa sistemática não se comunicam com a disponibilidade da renda e o acréscimo patrimonial, se houver, adquirido ao final do ano, quando da apuração conclusiva do IR por meio da DIRPF. Seguindo a mesma metodologia adotada acima, passemos, primeiro, pela identificação da disciplina contida no PN COSIT n ${ }^{\circ} 01 / 2002$.

“IRRF. RETENÇÃO EXCLUSIVA. RESPONSABILIDADE.

No caso de imposto de renda incidente exclusivamente na fonte, a responsabilidade pela retenção e recolhimento do imposto é da fonte pagadora."

Este regime de retenção na fonte vem detalhado nos parágrafos 8 a 10 do PN (Anexo). O parágrafo 9 sinaliza quase todas as características que a fonte pagadora assume no regime do IRF "exclusivo de fonte", as quais comentamos a seguir. O parágrafo 10, por sua vez, traz como exceção as hipóteses em que a obrigação de recolhimento do imposto (e logicamente sua retenção) é afastada em função da existência de ordem judicial nesse sentido impetrada pelo contribuinte, por entender que sobre aquele determinado rendimento não incide o IR. Trataremos desses casos em subitem apartado.

Diante do que foi analisado sobre antecedente e consequente da regra matriz, fato gerador da obrigação tributária, conceito de renda, entrelaçamento dos princípios constitucionais, especialmente a capacidade contributivo-econômica, vedação de imposto com efeito de confisco e segurança jurídica como vetor da praticabilidade, é possível traçar o perfil do regime jurídico próprio do IRF como "exclusivo de fonte" a partir das seguintes características:

${ }^{527}$ Nos termos artigo $6^{\circ}$, da Lei $n^{\circ} 7.713 / 88$ e alterações. 
i. Os momentos definidos pelo legislador para retenção do imposto e sua apuração definitiva são coincidentes, logo, atendem ao pressuposto do aspecto temporal, componente da regra matriz, permitindo o aperfeiçoamento do fato gerador do IR;

ii. Com a ocorrência cabal do fato gerador (já que prescinde de qualquer evento posterior para identificação do quantum devido), forma-se uma relação jurídica de natureza tipicamente tributária, em que a responsabilidade pelo recolhimento do imposto é determinada, por lei, a outra pessoa que não o contribuinte, que foi quem auferiu uma vantagem econômica (renda). A fonte pagadora, neste caso, substitui o contribuinte (polo passivo) no contexto de uma relação jurídica tributária, assumindo típica função de um substituto tributário;

iii. O IR retido de forma definitiva assume a natureza de imposto devido, e não de uma mera antecipação, já que não se comunica com outros rendimentos e outras retenções de forma a definir o quantum devido. O IRF neste caso é autônomo com relação à DIRPF;

iv. Na qualidade de sujeito passivo que substitui o contribuinte, no âmbito da relação jurídica tributária quanto à obrigatoriedade de pagar/recolher o imposto devido, a fonte pagadora torna-se, exclusivamente, a única responsável pelo recolhimento do imposto. Excetuadas as hipóteses de medida judicial afastando incidência do IR sobre um determinando rendimento e, consequentemente, a retenção do IRF, a exigência por parte do Estado-Fisco nunca poderá direcionar-se contra o contribuinte, que teve sua responsabilidade excluída de forma definitiva, i.e., já no consequente da regra matriz só há se cogitar da figura da fonte pagadora;

v. O valor do rendimento recebido pelo contribuinte deverá ser informado em sua DIRPF (apenas para fins de controle), independentemente de a fonte pagadora ter efetuado a retenção ou não. Tanto é que, nessa segunda hipótese, a responsabilidade da fonte pagadora sobre o recolhimento é aplicável a qualquer momento, seja antes, seja após o prazo final para entrega da DIRPF, justamente em função da exclusividade de sua responsabilidade. 


\section{Figura 6}

$1^{\text {a }}$ Relação (ANTECEDENTE)

\begin{tabular}{|c|c|c|c|}
\hline Contribuinte & $\begin{array}{c}\text { FATO } \\
\text { GERADOR }\end{array}$ & $\begin{array}{l}\text { OBRIGAÇÃO } \\
\text { TRIBUTÁRIA }\end{array}$ & $\begin{array}{c}\text { Dever de pagar } \\
\text { o tributo }\end{array}$ \\
\hline
\end{tabular}

$2^{\mathrm{a}}$ Relação (CONSEQUENTE)

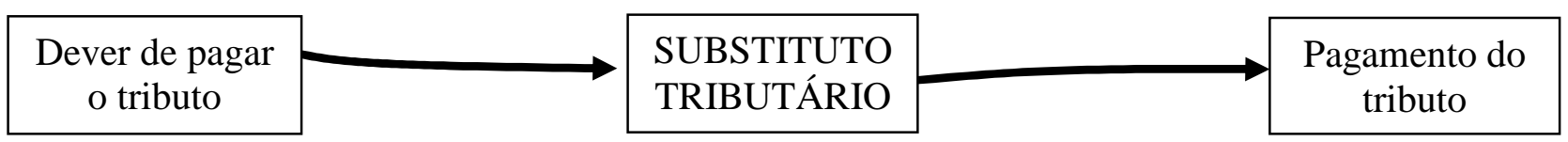

Do esquema acima, diferente do desenho do regime do IRF como "antecipação do devido" (Figura 5), é possível concluir que:

a. Há duas relações: na primeira, o antecedente indica que o contribuinte incorreu no fato gerador do IR, ao auferir rendimento revelador de capacidade contributivoeconômica e financeira e, portanto, evidencia signo presuntivo de renda. Na segunda relação, o consequente, portanto no âmbito de uma relação jurídica tributária, tem-se a fonte pagadora como sujeito passivo indireto, na qualidade de substituto tributário;

Sobre essa primeira conclusão, pertinente é a transcrição de trecho do voto da Min. Ellen Gracie, relatora da já citada decisão exarada nos autos do RE nº 603.191/MT. Apoiada nas lições da jurista italiana Andrea Parlato, identifica-se a presença de duas normas na substituição tributária, todavia, sob uma ótica diferente daquela apresentada acima, verbis:

\section{“(..)}

4. Em qualquer das modalidades de substituição tributária, sempre estaremos diante de pelo menos duas normas: a) a norma tributária impositiva, que estabelece a relação contributiva entre o contribuinte e o fisco; b) a norma de substituição tributária, que estabelece a relação de colaboração entre outra pessoa e o fisco, atribuindo-lhe o dever de recolher o tributo em lugar do contribuinte." 
Da leitura íntegra do voto depreende-se que a posição de devedor e responsável pelo recolhimento do tributo do contribuinte é mantida, chamado, neste caso, de substituo tributária. O julgado, contudo, trata de hipótese de retenção de contribuição previdenciária pelo regime de antecipação, não aplicável, portanto, a nosso ver, ao figurino da substituição tributária.

Queremos crer que, na hipótese de retenção do IR pelo regime exclusivo de fonte, a relevância do contribuinte encerra-se no exato momento de ocorrência do fato gerador, já que neste momento é que são tomadas as características próprias do contribuinte, sua capacidade contributiva e sua pessoalidade.

b. a figura do contribuinte é totalmente excluída do consequente porque a responsabilidade tributária é, neste regime, exclusivamente da fonte pagadora.

O regime jurídico aqui analisado corresponde, regra geral, à tributação aplicável aos rendimentos apurados nos mercados financeiro e de capitais, ou seja, corresponde, apenas a título exemplificativo, ao regime de retenção do IRF pertinente às aplicações financeiras (renda fixa e variável) e aos rendimentos produzidos pelas carteiras de fundos de investimentos. Este também é o regime geral para toda e qualquer remessa, entrega, emprego ou pagamento de rendimento para beneficiário não residente no País. Em algumas situações, sob o argumento da "necessidade", a RFB exige o imposto do procurador do beneficiário não residente, manifestando, como veremos, interpretação peculiar sobre a tributação pelo IR sobre tais transações internacionais.

\subsection{Outros Casos}

Examinadas as regras gerais dos regimes jurídicos pertinentes a cada uma das duas sistemáticas de pagamento do IRF, analisamos, a seguir, situações especiais que ou não atendem à totalidade das características principais acima detalhadas ou não se enquadram em nenhum dos perfis definidos acima ou, ainda, que simplesmente retratam situações especiais com regimes jurídicos específicos. 


\subsubsection{Responsabilidade tributária no caso de não retenção por força de decisão judicial}

Há situações em que a responsabilidade da fonte pagadora é afastada em função de uma determinação judicial, sob a alegação de que sobre tais rendimentos não deve incidir o IRF. Situação típica são os casos de rescisão de contrato de trabalho quando uma parte dos valores recebidos pela pessoa física tem suposta natureza indenizatória, não havendo, portanto, tributação pelo IR, já que sequer haveria se falar em presunção de aquisição de um acréscimo patrimonial.

O PN COSIT n 01/2002 reservou os parágrafos 18 a 22 sobre o tema. Transcrevemos apenas o parágrafo 19:

"19. Caso a decisão final confirme como devido o imposto em litígio, este deverá ser recolhido, retroagindo os efeitos da última decisão, como se não tivesse ocorrido a concessão da medida liminar. Nesse caso, não há como retornar a responsabilidade de retenção à fonte pagadora. O pagamento do imposto, com os acréscimos legais cabíveis, deve ser efetuado pelo próprio contribuinte, da seguinte forma:

a)tratando-se de rendimento sujeito à antecipação, considera-se vencido o imposto na data prevista para a entrega da declaração, no caso de pessoa física, ou na data prevista para o encerramento do período de apuração em que o rendimento for tributado, seja trimestral, mensal estimado ou anual, no caso de pessoa jurídica;

b)tratando-se de rendimento sujeito à tributação exclusiva, considera-se vencido o imposto no prazo originário previsto para o recolhimento do imposto que deveria ter sido retido.

19.1. A multa de mora fica interrompida desde a concessão da medida judicial até o trigésimo dia de sua cassação, nos termos do $\$ 2^{\circ}$ do art. 63 Lei $n^{\circ} 9.430$, de 1996:

"Art. 63.

(...) 
$\S 2^{o}$ A interposição da ação judicial favorecida com a medida liminar interrompe a incidência da multa de mora, desde a concessão da medida judicial, até 30 dias após a data da publicação da decisão judicial que considerar devido o tributo ou contribuição."

19.2. No caso de pagamento após o prazo referido no subitem anterior, a contagem da multa de mora será reiniciada a partir do trigésimo primeiro dia, considerando, inclusive e se for o caso, o período entre o vencimento originário da obrigação e a data de concessão da medida judicial.

19.3. Em qualquer hipótese, os juros de mora serão devidos sem qualquer interrupção desde o mês seguinte ao vencimento estabelecido na legislação do imposto." (grifamos)

Por conseguinte, os casos de não retenção por força de medida judicial aplicam-se a ambos os regimes. Suprimida a decisão judicial, por quaisquer razões, há o restabelecimento da obrigação de recolher o imposto, só que, neste caso, a responsabilidade tributária é direcionada exclusivamente para o contribuinte. No regime do IRF como "antecipação do devido", trata-se de uma situação normal, já que a responsabilidade da fonte pagadora é supletiva, retroagindo seus efeitos para a data de entrega da DIRPF, i.e., deverá ser tomada essa data para cálculo dos acréscimos legais sobre o imposto devido. Como se vê da redação do parágrafo 19, a exceção corre por conta do IRF como "exclusivo de fonte", que corresponde à única situação em que haverá o direcionamento da responsabilidade tributária para o contribuinte, retroagindo seus efeitos para desde o momento em que ocorreu o fato gerador.

\subsubsection{Gratificação Natalina e Participação nos Lucros e Resultados}

Já mencionamos, neste trabalho, que a gratificação natalina ou subsídio de Natal, popularmente conhecido como décimo terceiro salário ( $13^{\circ}$ salário), é modalidade de rendimento cuja tributação é realizada exclusivamente na fonte. Mencionamos, também, que essa sistemática de tributação sobre o $13^{\circ}$ salário indicaria mera preocupação arrecadatória de olho nos recolhimentos das contribuições previdenciárias. 
A verdade é que, como efetivo expediente de Política Tributária, considerando que o $13^{\mathrm{a}}$ salário corresponde a mais um dos rendimentos concedidos aos empregados assalariados (rendimentos derivados do trabalho), igualmente sujeitos à tributação pela tabela progressiva, caso o legislador não houvesse conferido tratamento tributário específico para aqueles rendimentos, o contribuinte acabaria sendo lesado.

Criado pela Lei $\mathrm{n}^{\mathrm{o}} 4.090$, de 13/07/1962, regulamentada pelo Decreto $\mathrm{n}^{\mathrm{o}} 57.155$, de 03/11/1965 e alterações posteriores, o $13^{\circ}$ salário deve ser pago ao empregado em duas parcelas até o final do ano, no valor correspondente a 1/12 (um doze avos) da remuneração para cada mês trabalhado. O $13^{\circ}$ salário caracteriza-se, a rigor, como uma gratificação atípica, que não é decorrente de um serviço propriamente dito (pro labore). O fato de dispor a lei que este $13^{\circ}$ vencimento deverá ser pago em dezembro, não permite concluir que deverá integrar a remuneração daquele mês.

Trata-se, a nosso ver, de procedimento de extremo acerto, na medida em que considerando os recolhimentos do IR em bases correntes, levando em conta as antecipações realizadas ao longo do ano, bem como a uniformidade dos rendimentos auferidos ao longo de um exercício fiscal, a lógica de um sistema assentado em tributação com tabela progressiva e antecipações na fonte é que, ao final do exercício fiscal, quando da apuração definitiva do IR devido, não sejam apuradas diferenças a maior (saldo a pagar) nem a menor (saldo a restituir). Na hipótese de os rendimentos decorrentes do $13^{\mathrm{a}}$ salário serem adicionados aos rendimentos de dezembro, mesmo que fosse diluído nos dois meses em que essa gratificação é paga, haveria distorção na sistemática desejada pelo legislador, que culminaria na exigência de antecipações em montante superior ao valor efetivamente devido, gerando ou aumentando o saldo de IR a restituir, quando da entrega da DIRPF pelo contribuinte.

Não acontece isso com o $13^{\circ}$ salário. Ainda que pagos conjuntamente com o salário devido no mês, tais rendimentos, a gratificação natalina de um lado e o salário ordinário de outro, são tributados isoladamente um do outro, sendo certo que somente ao salário ordinário são autorizadas as deduções dos fatos-decréscimos com previdência oficial e dependentes. Por ter sido tributado exclusivamente na fonte, o IRF calculado sobre o $13^{\circ}$ salário não pode ser utilizado na apuração final do IR. 
Desta forma, o $13^{\circ}$ vencimento não pode ser agregado aos vencimentos, rendimentos e vantagens recebidos no mês de dezembro, sobrepondo-se uns aos outros para fins de tributação, sob pena de atingir teto de tributação diferente daquele experimentado pelo contribuinte, de forma uniforme, ao longo do ano.

Por sua vez, temos os rendimentos destacados a título de Participações nos Lucros e Resultados (PLR), os quais, nos termos do artigo $3^{\circ}$, $\S 5^{\circ}$, da Lei $n^{\circ} 10.101$, de 2000, são tributadas na fonte, em separado dos demais rendimentos recebidos no mês, como antecipação do IR devido na DIRPF.

A primeira observação a ser feita é que, da mesma sorte que a gratificação natalina, tais rendimentos são tributados de forma isolada, mediante a aplicação da tabela progressiva do IR, sem, contudo, qualquer dedução pelos fatos-decréscimos legalmente admitidos no mês. A diferença com o $13^{\circ}$ salário é que tanto o IRF poderá ser deduzido do imposto apurado como devido na DIRPF, como também os rendimentos de PLR deverão ser incluídos na base de rendimentos tributáveis.

A teor do disposto no artigo $7^{\circ}$, inciso $\mathrm{XI}$, da $\mathrm{CF}$, os rendimentos derivados dos planos de PLR adotados pelas empresas com seus empregados não constituem parte integrante da remuneração dos trabalhadores, daí não se exigir o recolhimento das contribuições sociais patronais sobre tais valores. Por se tratar de um instituto cuja adoção é facultativa, o cumprimento ao mandamento constitucional por empresas e trabalhadores encontra validade na medida em que proporciona integração entre o capital e o trabalho. O bem jurídico buscado pelo texto constitucional é a possibilidade de percepção de valores "adicionais" através da participação nos lucros da empresa, com a melhoria de sua condição social, aproximando a posição dos trabalhadores daquela ocupada pelos empreendedores, acionistas, sócios ou titulares de um determinado empreendimento ou negócio.

Assim é que os valores distribuídos a título de PLR não possuem natureza de remuneração e nem de rendimentos do trabalho. Ao contrário, tais valores decorrem da condição do trabalhador de partícipe do empreendimento, ao menos de seu sucesso, já que em caso de 
perdas o trabalhador não será obrigado a injetar capital para manutenção da saúde financeira do negócio.

Como se vê, é clara a natureza desses rendimentos como sendo derivados do capital, daí, a nosso ver, não ser correto o tratamento fiscal semelhante aos rendimentos do trabalho, tal qual ocorre com o salário. Se aos dividendos, espécie de rendimento derivado do lucro, foi concedido o benéfico fiscal da isenção, aos rendimentos derivados do PLR deveria, ao menos, prevalecer a sistemática de tributação exclusivamente na fonte, mediante a adoção de alíquotas preferenciais e reduzidas.

\subsubsection{IRF sobre o Ganho de Capital do Não Residente}

A Lei $n^{\circ} 9.249 / 95$, em seu artigo $18^{528}$, estabelece que o ganho de capital por contribuinte não residente será tributado de acordo com as regras aplicáveis aos residentes no País.

Com foco em transações realizadas exclusivamente por residentes ou domiciliados no exterior, o legislador brasileiro, preocupado, talvez, com uma potencial "janela" de evasão fiscal sobre o IRF incidente sobre os ganhos de capital apurados nessas operações, publicou a Lei $\mathrm{n}^{\circ} 10.833 / 03$, cujo artigo 26 assim disciplina, verbis:

"Art. 26. O adquirente, pessoa física ou jurídica residente ou domiciliada no Brasil, ou o procurador, quando o adquirente for residente ou domiciliado no exterior, fica responsável pela retenção e recolhimento do imposto de renda incidente sobre o ganho de capital a que se refere o art. 18 da Lei $n^{\circ} 9.249$, de 26 de dezembro de 1995, auferido por pessoa física ou jurídica residente ou domiciliada no exterior que alienar bens localizados no Brasil."

RICARDO MARIZ DE OLIVEIRA destaca que por força dessa norma passou a ser possível a incidência da tributação brasileira se ambas as partes de um negócio jurídico forem não

\footnotetext{
528 "Art. 18. O ganho de capital auferido por residente ou domiciliado no exterior será apurado e tributado de acordo com as regras aplicáveis aos residentes no País."
} 
residentes, desde que o objeto dessas tributação seja o ganho de capital relativo a um bem, tangível ou intangível, situado no território nacional ${ }^{529}$.

Em uma primeira análise, a leitura do normativo retrocitado pode causar dúvida ao intérprete mais (ou menos) atento. Considerando o deslocamento da obrigação de retenção e recolhimento do imposto contra o procurador, a redação não se mostra nem um pouco clara, não especificando se essa suposta responsabilidade seria do procurador do adquirente ou do procurador do alienante.

Frise-se que a Exposição de Motivos da Medida Provisória $n^{\circ} 135 / 2003^{530}$ que, após diversas alterações, foi convertida na Lei nº 10.833/03, não oferece muita ajuda.

Apoiado na redação do parágrafo único, do artigo 45, do CTN, e no artigo 128, do CTN, considerando a necessidade de o substituto tributário ter um vínculo indireto com o aspecto material do fato gerador e, para o caso em específico, ter contato direto com a fonte pagadora, não parece fazer muito sentido atribuir essa responsabilidade para outro procurador que não o do adquirente. Essa é a conclusão, a nosso ver correta, a que chega RICARDO MARIZ DE OLIVEIRA ${ }^{531}$.

Preliminarmente é fundamental averiguar qual o aspecto material (aspecto nuclear) envolvido para o fato gerador do IRF sobre ganhos de capital de não-residente.

Conforme se depreende do artigo 18, da Lei $\mathrm{n}^{\circ}$ 9.249/95, ao mencionar que tais ganhos serão tributados conforme as regras aplicáveis internamente, i.e., aplicáveis aos residentes no País, o legislador nos remete às hipóteses de tributação dos ganhos de capital previstas localmente.

${ }^{529}$ Cf. OLIVEIRA, Ricardo Mariz de. Tributação Internacional de "Goodwill” e Intangíveis. in Revista de Direito Tributário Atual. Vol. 26. Coord. Ricardo Mariz de Oliveira, Luis Eduardo Schoueri e Fernando Aurélio Zilveti. São Paulo: Dialética-IBDT, 2011. P. 29/47 (42).

530 "21. O art. 24 tem por objetivo reduzir a possibilidade de não pagamento pelo contribuinte não-residente do imposto de renda incidente sobre os ganhos de capital apurados na alienação de seus bens localizados no Brasil, pois atualmente cabe ao alienante a apuração e recolhimento do tributo, o que dificulta a fiscalização do cumprimento da obrigação tributária, sobretudo pela não-residência do contribuinte em território nacional." Quando de sua conversão o dispositivo foi renumerado para o artigo 26.

${ }^{531}$ Cf. OLIVEIRA, Ricardo Mariz de. Op. cit. (nota 529). P. 29/47 (42/43). 
Assim é que o artigo 117, do Regulamento do Imposto de Renda (Decreto no 3.000/99 $\mathrm{RIR} / 99)^{532}$, descreve sobre o momento ("alienação de bens ou direitos de qualquer natureza") e as hipóteses em que essa materialidade ganha contorno de relevância para fins do Direito Tributário e, principalmente, para o Imposto sobre a Renda ${ }^{533}$.

Por dedução lógica, considerando a hipótese tributária do IR, contribuinte do imposto é o beneficiário da renda ou proventos de qualquer natureza (os ganhos de capital se enquadram nesse segundo grupo). Portanto, desnecessárias são outras explicações no sentido de identificar, para o caso concreto em tela, que o beneficiário, dito contribuinte, é o alienante de tais bens ou direitos.

532 “Art. 117. Está sujeita ao pagamento do imposto de que trata este Título a pessoa física que auferir ganhos de capital na alienação de bens ou direitos de qualquer natureza (Lei $n^{\circ} 7.713$, de 1988, arts. $2^{\circ}$ e $3^{\circ}$, $\$ 2^{\circ}$, e Lei $n^{\circ} 8.981$, de 1995, art. 21).

$\S 1^{\circ} \mathrm{O}$ disposto neste artigo aplica-se, inclusive, ao ganho de capital auferido em operações com ouro não considerado ativo financeiro (Lei $n^{\circ} 7.766$, de 1989, art. 13, parágrafo único).

$\$ 2^{\circ}$ Os ganhos serão apurados no mês em que forem auferidos e tributados em separado, não integrando a base de cálculo do imposto na declaração de rendimentos, e o valor do imposto pago não poderá ser deduzido do devido na declaração (Lei $n^{o} 8.134$, de 1990, art. 18, $\$ 2^{\circ}$, e Lei $n^{o} 8.981$, de 1995, art. 21, $\$ 2^{\circ}$ ). $\S 3^{\circ} \mathrm{O}$ ganho de capital auferido por residente ou domiciliado no exterior será apurado e tributado de acordo com as regras aplicáveis aos residentes no País (Lei no 9.249, de 1995, art. 18).

$\S 4^{\circ} \mathrm{Na}$ apuração do ganho de capital serão consideradas as operações que importem alienação, a qualquer título, de bens ou direitos ou cessão ou promessa de cessão de direitos à sua aquisição, tais como as realizadas por compra e venda, permuta, adjudicação, desapropriação, dação em pagamento, doação, procuração em causa própria, promessa de compra e venda, cessão de direitos ou promessa de cessão de direitos e contratos afins (Lei $n^{\circ} 7.713$, de 1988, art. $3^{\circ}, \S 3^{\circ}$ ).

$\S 5^{\circ}$ A tributação independe da localização dos bens ou direitos, observado o disposto no art. 997."

${ }_{533}$ Sobre o tema assim comenta ANA CLÁUDIA UTUMI: "Este é o primeiro ponto a se destacar no regime de tributação dos ganhos de capitais - estes são sempre oriundos da alienação de bens ou direitos de qualquer natureza. não são, assim, resultados do trabalho, do capital, nem da combinação de ambos. $O$ ganho de capital é o acréscimo patrimonial verificado quando existe a alienação, a disposição ou a liquidação de determinado bem ou direito. É justamente o que encontramos se buscarmos a significação dessa locução em dicionários jurídicos." Neste ponto a autora traz os conceitos das expressões "ganho de capital" e "ganho". Mais à frente continua: "O ganho de capital, definido como diferença positiva entre o valor da alienação ou realização de determinado bem ou direito e seu custo de aquisição, não é uma inovação da legislação brasileira. Várias são as legislações ao redor do mundo que reconhecem este tipo e o submetem à tributação pelo imposto sobre a renda. Para que ocorra o ganho de capital, é essencial, assim, que exista a realização do bem ou direito, realização esta que pode ser total ou parcial. (...) Portanto, o critério material do imposto de renda sobre o ganho de capital das pessoas não-residentes é "auferir ganho de capital", assim entendido como a diferença positiva entre o valor de alienação e o custo de aquisição de determinado bem ou direito, objeto da alienação. $O$ ganho de capital é , assim, a mensuração do acréscimo patrimonial do não-residente, nas transações em que este alienar bens ou direitos localizados no Brasil." (Cf. UTUMI, Ana Cláudia Akie. Op. cit. (nota 386), P. 153/157. Também nesse sentido, confira-se: XAVIER, Alberto. Direito Tributário Internacional do Brasil. $6^{\mathrm{a}}$ ed. Rio de Janeiro: 2005. Editora Forense; TILBERY, Henry. A tributação dos ganhos de capital, 1978 nas vendas de participações societárias pelas pessoas físicas. São Paulo: 1978. Editora Resenha Tributária / I.B.D.F. 139 p. FD - Faculdade de Direito. Localização, em 31.10.2008: http://dedalus.usp.br:4500/ALEPH/POR/USP/USP/DEDALUS/FULL/0017395. 
Como já se afirmou, idealmente, o tributo deveria ser recolhido/pago por aquela pessoa que teve contato íntimo e pessoal com o fato gerador da obrigação tributária, i.e., pelo indivíduo que incorreu/praticou em um determinado fato da vida, escolhido pelo legislador como suficiente para dar nascimento à obrigação tributária, e, consequentemente, à relação jurídica tributária.

Também não é novidade lembrar que, por razões de praticabilidade e eficiência fiscal ${ }^{534}$, não raras vezes, notadamente para os casos do IRF, o legislador tende a eleger para figurar como responsável pelo recolhimento do imposto a própria fonte pagadora.

Em uma transação que envolva a alienação de bem ou direito, com apuração de ganho de capital, as únicas pessoas em contato com o fato gerador da obrigação tributária originada são o comprador e o vendedor, e somente este último, na qualidade de contribuinte, guarda relação íntima, pessoal e direta com esse fato gerador.

Nesse cenário, seria impensável imaginar a atribuição do ônus tributário a pessoa diversa do alienante e do adquirente. Causa, no mínimo, estranheza a regra jurídica contida no artigo 26, da Lei $n^{\circ}$ 10.833/03, ao atribuir a obrigação de retenção e recolhimento do IRF ao procurador, que, nos termos do artigo 128 , do CTN, é figura totalmente alienígena à relação jurídica tributária.

Com efeito, há que se analisar a extensão dos poderes outorgados ao procurador, o qual deverá ser minimamente constituído para a prática da própria operação de compra e venda

\footnotetext{
${ }^{534}$ Sobre as ferramentas de política fiscal utilizadas pelo Estado veja comentário do Professor espanhol LUIS M. AlONSO GONZÁLEZ: "Debe subrayarse la enorme preocupación sentida por el Estado Moderno desde su mismo nacimiento para allegar los recursos necesarios para el cumplimiento de sus fines. Posiblemente pueda incluso trazarse un indudable paralelismo entre la validez recaudatoria creciente y la ampliación de las necesidades de la sociedad que han de ser cubiertas por el Estado, sobre todo cuando este toma la forma de um Estado Social e Intervencionista. Pues bien, para obtener más recursos puede ampliarse el número de los obligados al pago, pero también hay que asegurarse de que tales sujetos cumplan sus obligaciones tributarias. Com la sustitución se alcanzan vários objetivos que redundan en una mayor eficacia recaudatoria. Se facilita enormemente la gestión de los tributos. Este logro se manifiesta especialmente en la sustitución con retención. En la misma retención a cuenta actúa como una obligación accesoria de una obligación tributaria principal. Además, la retención en la fuente tiene una doble consecuencia. De un lado, una importante reducción del número de sujetos com los que debe entenderse la Administración Fiscal, pues ésta se dirige contra el retenedor y no contra los que sufren retención en los haberes satisfechos por el sustituto retenedor." (Cf. GONZÁLEZ, Luis M. Alonso. El Sustituto: Primier Acercamiento a un Sujeto Pasivo Conflictivo. Revista de Derecho Financeiros y de Hacienda Pública. Madrid: 1990. EDERSA Editoriales de Derecho Reunidas, S.A. P. 130).
} 
do bem localizado no Brasil. O procurador deverá reunir condições suficientes para ser legitimamente qualificado como substituto tributário. Em respeito ao princípio da capacidade contributiva, não há como exigir do mandatário, qualificado como fonte pagadora, a "retenção" de valores a título de IR se sequer teve contato com a transação financeira realizada entre adquirente e alienante ${ }^{535}$.

Tome-se, por hipótese e por mero exercício de elucubração, a situação em que ambas as partes não se encontram em território nacional e a transação financeira de compra e venda de bens ou direitos seja realizada e operacionalizada fora do País, o que inviabiliza qualquer forma de controle fiscalizatório por parte das autoridades públicas nem mesmo por parte dos procuradores constituídos no Brasil, tanto pelo alienante quanto como pelo adquirente.

Como será possível determinar o valor de alienação? E a forma como o pagamento ocorreu e outras condições relevantes do negócio? Somente a partir desses dados será possível apurar o ganho de capital, se houver. E mais, considerando o cenário hipotético acima, como deverá proceder o procurador para fins de retenção do imposto se, na realidade, nem mesmo haverá trânsito de recursos financeiros no País? Como "reter" de algo que, aos olhos fiscais, não existe? É até mesmo impróprio falar-se em "retenção" pois somente se retém alguma coisa de algo que previamente pertence ao domínio do retentor. Em determinadas condições, poderia se chegar ao absurdo do procurador ter que recolher o imposto por meio da utilização de recursos próprios, em frontal desrespeito às normas constitucionais e legais que dão suporte à sistemática de retenção na fonte, em seus diferentes regimes.

Situações como essas, nas quais o legislador não se ateve às bases conceituais predispostas no CTN para instruir a atividade legislativa, vitimam determinadas pessoas (no caso em tela, terceiros constituídos e outorgados como procuradores) a ficar totalmente à margem da tutela oferecida pelo Direito e do alcance do próprio princípio da segurança jurídica.

A análise, contudo, diante da nova regra de tributação trazidas pelo artigo 26 , da Lei $\mathrm{n}^{\circ}$ 10.833/03, na qual restou regulamentada a competência de o Fisco brasileiro tributar as

${ }^{535}$ Cf. OLIVEIRA, Ricardo Mariz de. Op. cit. (nota 529). P. 29/47 (42/43). 
situações em que a análise (se determinado rendimento é tributável), deve ser caso a caso, passando pela ponderação dos critérios da fonte de produção (source of production) e fonte de pagamento (source of payment).

O Professor GERD WILLI ROTHMANN é autor de excelente artigo sobre o tema ${ }^{536}$. Identifica, inicialmente, duas situações no referido artigo 26: uma possível e outra ilegítima. Antes de analisar tais situações e identificar, se possível, o regime jurídico cabível ao dispositivo, é imprescindível tratar dos institutos que versam sobre os elementos de conexão.

Diante dos limites de jurisdição para tributar a renda, i.e., diante do conflito que possa existir entre a legislação brasileira e a legislação estrangeiras para determinar qual país é competente para arrecadar o IR, a análise não deve restringir-se às normas locais mas, principalmente, deve valer-se das definições contidas em tratados internacionais para evitar a dupla tributação, em especial quanto aos elementos de conexão. Nas lições de AlBERTO XAVIER, os elementos de conexão são os elementos que, determinando a "localização" de uma situação da vida num certo ordenamento tributário, tem como efeito típico determinar o âmbito de aplicação das leis desses ordenamento a essa mesma situação ${ }^{537}$.

GERD WiLLI ROTHMANN ensina que, para efeitos do IRF sobre os ganhos de capital aqui em análise, devem ser analisados os seguintes elementos de conexão: domicílio e residência (os rendimentos são sempre tributados no Estado do domicílio ou residência do contribuinte, independentemente do Estado em que foram auferidos), fonte de rendimento e situação do bem (este último constitui modalidade de aplicação do princípio da territorialidade - locus rei sitae - , pelo qual o elemento de conexão dominante é o lugar de situação de bem, como sói ocorrer nos casos de alienação de bens imobiliários) ${ }^{538}$.

Interessa-nos a análise do elemento "fonte de rendimento". GERD WILLI ROTHMANN lembra que a expressão tem duas acepções: (i) fonte de produção (também conhecida como fonte econômica ou objetiva), que indica o lugar em que é exercida a atividade onde são

\footnotetext{
${ }^{536}$ Cf. ROTHMANN, Gerd Willi. Tributação Internacional sem Sujeito Passivo: uma Nova Modalidade do Imposto de Renda sobre Ganhos de Capital? in Grandes Questões Atuais do Direito Tributário. Vol. 10. Coord. Valdir de Oliveira Rocha. São Paulo: Dialética, 2006. P. 106/161.

${ }^{537}$ Cf. XAVIER, Alberto. Op. cit. (nota 534) P. 252.

${ }^{538}$ Cf. ROTHMANN, Gerd Willi. Op. cit. (nota 536). P. 110/116.
} 
utilizados os fatores de produção ou em que se situam os bens ou direitos de que provém a renda; e (ii) fonte de pagamento (também chamada de fonte financeira ou subjetiva), correspondente à origem dos recursos pagos ao beneficiário residente no Exterior.

Historicamente reconhecido entre os Estados tributantes, conforme se depreende da leitura de tratados internacionais para evitar a dupla, mormente naqueles celebrados entre Estados industrializados (chamados de exportadores de capital) e países em desenvolvimento ou "emergente" (conhecidos como importadores de capital), a tributação na fonte sobre os ganhos de capital exige não apenas que o bem se localize no território do Estado legitimado a tributar mas, também, que a fonte pagadora nele resida. Até então, com suporte nos artigos 682 e 685, ambos do Regulamento do Imposto de Renda (RIR Decreto $n^{\circ} 3.000 / 99$ ), a legislação pátria sobre a tributação dos ganhos de capital (já que esse é campo de abrangência do artigo 18, da Lei $\mathrm{n}^{\circ}$ 9.249/95) exigia a presença cumulativa daqueles dois elementos de conexão - fonte de produção e fonte de pagamentos - e essa era, e ainda parece ser, a posição dominante na doutrina ${ }^{539}$.

Diante da nova sistemática empreendida pelo artigo 26, da Lei $\mathrm{n}^{\mathrm{o}} 10.833 / 03$, vale consignar que a legislação brasileira passou a inovar em matéria de tributação internacional sobre ganhos de capital. A depender da extensão dos poderes outorgados ao mandante e da análise de cada caso, ao atribuir a responsabilidade tributária ao procurador (provavelmente do adquirente), caracterizado, dessa forma, como substituto tributário, poderá haver situações onde se configura um desprezo pelo elemento de conexão relativo à fonte de pagamento, na medida em que, numa operação de compra e venda entre não residentes, os recursos financeiros sequer transitarão pelo Brasil.

\subsubsection{Beneficiário Não Identificado}

Guardadas as devidas proporções, o fato gerador do IR está associado a alguma forma de disponibilidade que, por sua vez, pressupõe o princípio da realização, i.e., uma renda disponível que possa ser empregada, utilizada e/ou aproveitada, associando-se, portanto, a

\footnotetext{
${ }^{539}$ Cf. XAVIER, Alberto. Op. cit. (nota 534). P. 511; Cf. ROTHMANN, Gerd Willi. Op. cit. (nota 536). P. 111/116, 130/133; Cf. MUSA, Simone Dias; PRADO, Marcos Vinícius Passarelli. A Tributação dos Ganhos Auferidos por Não-residentes na Alienação de Bens Localizados no Brasil - Análise do artigo 26 da Lei $n^{o}$ 10.833/03. in Revista Dialética de Direito Tributário n 156. São Paulo: Dialética, 2008. P. 109/121 (111).
} 
um dos atributos do conceito de "domínio" sobre um bem ou direito (conceito extraído do Direito Privado), sem, contudo, que, necessária e obrigatoriamente, ocorra a entrega de moeda ou de recursos financeiros. Assumindo este raciocínio como correto e verdadeiro, como explicar o IRF nos moldes definidos pelo artigo 61, da Lei $\mathrm{n}^{\mathrm{o}} 8.981 / 95^{540}$, regulamentado pelo artigo 674, do RIR/99?

Como é sabido, trata-se da hipótese de pagamento a beneficiário não identificado, com a aplicação de retenção na fonte à alíquota de $35 \%$, sobre o total do pagamento efetuado. $\mathrm{O}$ dispositivo, queremos crer, aparenta ter instituído modalidade de pagamento do IR pela fonte pagadora diferente dos regimes jurídicos identificados acima, não sendo apropriado, portanto, falar-se em agente de retenção e substituto tributário conforme definidos acima, pelos seguintes argumentos:

- não há um substituído, tendo em vista que se trata de beneficiário não identificado;

- tanto na perspectiva da substituição como do agente de retenção, a capacidade contributiva levada em conta é a do substituído, o que não ocorre no caso em tela;

- as figuras do agente de retenção e do substituto tributário exigem, como elemento de validade, o instrumento do desconto (retenção) de uma parcela do rendimento disponibilizado ao beneficiário, de forma a permitir que a fonte tenha seu patrimônio recomposto, transferindo o ônus financeiro do tributo para quem de direito, ou seja, o contribuinte. Para os casos de pagamento a beneficiário não identificado, a fonte pagadora deverá pagar o IR com recursos próprios, calculado com base no montante do pagamento efetuado;

- o "fato gerador" do dispositivo em tela não é "auferir renda ou proventos de qualquer natureza”, mas, sim, a realização de um pagamento em favor de um beneficiário não identificado.

\footnotetext{
540 “Art. 61. Fica sujeito à incidência do imposto de renda exclusivamente na fonte, à alíquota de 35\%, todo pagamento efetuado pelas pessoas jurídicas a beneficiário não identificado, ressalvado o disposto em normas especiais.

$\S 1^{\circ}$ A incidência prevista no caput aplica-se, também, aos pagamentos efetuados ou aos recursos entregues a terceiros ou sócios, acionistas ou titular, contabilizados ou não, quando não for comprovada a operação ou a sua causa, bem como à hipótese de que trata o $\$ 2^{\circ}$, do art. 74. da Lei $n^{\circ} 8.383$, de 1991.

$\S 2^{\circ}$ Considera-se vencido o imposto de renda na fonte no dia do pagamento da referida importância.

$\S 3^{\circ} \mathrm{O}$ rendimento de que trata este artigo será considerado líquido, cabendo o reajustamento do respectivo rendimento bruto sobre o qual recairá o imposto."
} 
O caso do artigo 61, da Lei $n^{\circ} 8.981 / 95$, é hipótese em que a capacidade contributiva medida é da própria fonte pagadora, porém a disponibilidade da renda é do beneficiário. Este, por sua vez, possui a disponibilidade de uma riqueza nova, bem como o domínio sobre aquele bem. Embora haja a efetiva realização da renda, a "regra tributária" não alcança o seu patrimônio, mas sim o de outra pessoa, no caso, a fonte.

Pelos argumentos aqui apontados verifica-se que o regime jurídico da norma tributária examinada equivale a uma hipótese de penalidade ${ }^{541}$. O que se "tributa" não é renda, mas, sim, a conduta da pessoa jurídica, tendo em vista sua deliberação em realizar um pagamento e não identificar o beneficiário, daí a justificativa de uma alíquota sobremodo mais elevada.

\subsubsection{Aplicações Financeiras de Renda Variável}

Em linhas gerais, as aplicações financeiras de renda variável podem ser conceituadas como aquelas cuja remuneração não pode ser dimensionada pelo investidor no momento da aplicação, caracterizando-se, assim, pela imprevisibilidade de sua remuneração e pelo risco assumido pelo investidor ${ }^{542}$.

Os ativos negociados no mercado de renda variável são os valores mobiliários ${ }^{543}$, o ouro, ativos financeiros e, também, as debêntures, que corresponde a um valor mobiliário de renda fixa.

O tratamento fiscal do ganho líquido obtido pelo beneficiário em uma operação de renda variável dependerá, fundamentalmente, do local de negociação dessa operação, se em ambiente bursátil, i.e., os mercados de bolsa de valores, de mercadorias e de futuros

\footnotetext{
${ }^{541}$ Essa é a mesma conclusão a que chegam os tributaristas Antonio Airton Ferreira, Juliana M. O. Ono, Luiz Martins Valero, Marcos Shigueo Takat, Marcos Vinícius Neder de Lima e Victor Hugo I. de Mello Castanho (Cf. Regulamento do Imposto de Renda 1999 - anotado e comentado: atualizado até 30 de abril de 2009. FERREIRA, Antonio Airton; ONO, Juliana M. O; VALERO, Luiz Martins; TAKATA, Marcos Shigueo; LIMA, Marcos Vinícius Neder de; CASTANHO, Victor Hugo I. de Mello. Vol. 2: Tributação na Fonte e Sobre Operações Financeiras e Administração do Imposto. 12a ed. São Paulo: Fiscosoft, 2009. P. 1669/1671) ${ }^{542}$ Cf. Manual de Tributação no Mercado Financeiro. Coord. Paulo Marcelo de Oliveira Bento. $1^{\mathrm{a}}$ ed. $2^{\mathrm{a}}$ tiragem. São Paulo: Saraiva, 2011. P. 107 e seguintes.

${ }^{543}$ A Lei $n^{\circ} 10.303 / 01$, alterou a redação do artigo $2^{\circ}$, da Lei $n^{\circ} 6.385 / 76$, ampliando significativamente o conceito de valores mobiliários, abrigando quaisquer títulos ou contratos de investimento coletivo, tais como cotas de fundos de investimento, bônus de subscrição, contratos derivativos etc.
} 
(BM\&FBOVESPA) ou assemelhados, como é o caso dos mercados de balcão organizado, ou fora da bolsa de valores. Ademais, mesmo que ocorram em ambiente fora de bolsa, mas desde que realizadas no contexto dos mercados financeiro e de capitais, algumas situações, tais como operações realizadas no mercado de liquidação futura e alienação de participações societárias por pessoa jurídica, receberão o tratamento fiscal pertinentes às aplicações de renda variável.

Com efeito, focado nas hipóteses de retenção na fonte, importa-nos as operações com ativos negociados em ambiente bursátil ou que recebam o tratamento tributário de renda variável.

Assim, como regra geral, temos que os ganhos líquidos auferidos nos mercado de bolsa e balcão organizado, inclusive operações day trade, estão sujeitos à incidência do IR, devendo ser apurado e recolhido pelo próprio contribuinte. Todavia, para essas situações, por meio do artigo $2^{\mathrm{o}}, \S 1^{\mathrm{o}}$, da Lei $\mathrm{n}^{\mathrm{o}} 11.033 / 04^{544}$, regulamentado pelo artigo 52 , da

\footnotetext{
544 “Art. $2^{\circ} \mathrm{O}$ disposto no art. $1^{\circ}$ desta Lei não se aplica aos ganhos líquidos auferidos em operações realizadas em bolsas de valores, de mercadorias, de futuros, e assemelhadas, inclusive day trade, que permanecem sujeitos à legislação vigente e serão tributados às seguintes alíquotas:

I - 20\% (vinte por cento), no caso de operação day trade;

II - $15 \%$ (quinze por cento), nas demais hipóteses.

$\S 1^{\circ}$ As operações a que se refere o caput deste artigo, exceto day trade, sujeitam-se à incidência do imposto de renda na fonte, à alíquota de $0,005 \%$ (cinco milésimos por cento) sobre os seguintes valores:

I - nos mercados futuros, a soma algébrica dos ajustes diários, se positiva, apurada por ocasião do encerramento da posição, antecipadamente ou no seu vencimento;

II - nos mercados de opções, o resultado, se positivo, da soma algébrica dos prêmios pagos e recebidos no mesmo dia;

III - nos contratos a termo:

a) quando houver a previsão de entrega do ativo objeto na data do seu vencimento, a diferença, se positiva, entre o preço a termo e o preço à vista na data da liquidação;

b) com liquidação exclusivamente financeira, o valor da liquidação financeira previsto no contrato;

IV - nos mercados à vista, o valor da alienação, nas operações com ações, ouro ativo financeiro e outros valores mobiliários neles negociados.

$\S 2^{\circ} \mathrm{O}$ disposto no $\S 1^{\circ}$ deste artigo:

I - não se aplica às operações de exercício de opção;

II - aplica-se às operações realizadas no mercado de balcão, com intermediação, tendo por objeto os valores mobiliários e ativos referidos no inciso $I V$ do $\S 1^{o}$ deste artigo, bem como às operações realizadas em mercados de liquidação futura fora de bolsa.

$\S 3^{\circ}$ As operações day trade permanecem tributadas, na fonte, nos termos da legislação vigente.

$\S 4^{\circ}$ Fica dispensada a retenção do imposto de que trata o $\$ 1^{\circ}$ deste artigo cujo valor seja igual ou inferior a $R \$ 1,00$ (um real).

$\S 5^{\circ}$ Ocorrendo mais de uma operação no mesmo mês, realizada por uma mesma pessoa, física ou jurídica, deverá ser efetuada a soma dos valores de imposto incidente sobre todas as operações realizadas no mês, para efeito de cálculo do limite de retenção previsto no $\$ 4^{\circ}$ deste artigo.

$\S 6^{\circ}$ Fica responsável pela retenção do imposto de que tratam o $\$ 1^{o}$ e o inciso II do $\S 2^{o}$ deste artigo a instituição intermediadora que receber diretamente a ordem do cliente, a bolsa que registrou as operações
} 
Instrução Normativa RFB $\mathrm{n}^{\circ} 1.022 / 10$ (IN RFB $\mathrm{n}^{\circ} 1.022 / 10$ ), foi criada uma nova modalidade de retenção na fonte sobre tais operações, exceto as operações de day trade e swap. Essa nova hipótese de IRF passou a incidir à alíquota de $0,005 \%$ (cinco milésimos por cento).

O que se observa é que essa nova modalidade de IRF intitulou-se como efetiva ferramenta de fiscalização, nos moldes como empreendido pela extinta CPMF, cobrada à alíquota de 0,38\%. O caráter fiscalizatório fica evidente não apenas em razão da imaterialidade de sua alíquota mas, especialmente, pelo fato de que sua base de cálculo, variável conforme a operação realizada, em alguns casos sequer corresponde ao efetivo ganho auferido pelo contribuinte $^{545}$.

Em qualquer hipótese, o IRF de $0,005 \%$ é tratado como antecipação do imposto devido. Todavia, sob a perspectiva do contribuinte pessoa física, para quem os rendimentos são tributados sob o regime de retenção exclusiva de fonte, este IRF "fiscalizador" poderá qualificar-se como imposto pago (retido) indevidamente, já que, especificamente para as operações realizadas no mercado à vista, a alíquota de $0,005 \%$ incidirá sobre o valor da alienação, ainda que tenha sido apurada perda pelo contribuinte na operação. Fica facultado ao contribuinte, entretanto, solicitar a restituição do IRF.

Diferente é o IRF aplicável às operações day trade, à alíquota de 1\%. Nestes casos, a base de cálculo será sempre o rendimento auferido, independentemente do mercado onde o ativo foi negociado (à vista, a termo, futuro ou de opções). Adicionalmente, nos termos do artigo $8^{\circ}, \S 2^{\circ}$, da Lei $n^{\circ} 9.959 / 00$ e do artigo $54, \S 4^{\circ}$, da IN RFB $n^{\circ} 1.022 / 10$, para fins de mensuração da base de cálculo desse IRF de $1 \%$, admite-se a compensação de perdas incorridas em operações day trade, realizadas no mesmo dia. Outrossim, eventual saldo de

\footnotetext{
ou entidade responsável pela liquidação e compensação das operações, na forma regulamentada pela Secretaria da Receita Federal do Ministério da Fazenda.

$\S 7^{\circ} \mathrm{O}$ valor do imposto retido na fonte a que se refere o $\$ 1^{\circ}$ deste artigo poderá ser:

I - deduzido do imposto sobre ganhos líquidos apurados no mês;

II - compensado com o imposto incidente sobre ganhos líquidos apurados nos meses subseqüentes;

III - compensado na declaração de ajuste se, após a dedução de que tratam os incisos I e II deste parágrafo, houver saldo de imposto retido;

IV - compensado com o imposto devido sobre o ganho de capital na alienação de ações.

$\S 8^{\circ} \mathrm{O}$ imposto de renda retido na forma do $\S 1^{\circ}$ deste artigo deverá ser recolhido ao Tesouro Nacional até o $3^{\circ}$ (terceiro) dia útil da semana subseqüente à data da retenção." (grifamos)

${ }^{545}$ Cf. Manual de Tributação no Mercado Financeiro. Op. cit. (nota 541). P. 123/124.
} 
IRF remanescente no final do ano e não deduzido do imposto incidente sobre os ganhos líquidos apurados no mês, não poderá ser compensado com o IR devido sobre ganhos líquidos auferidos no ano seguinte, devendo, neste caso, ser objeto de pedido de restituição.

\subsubsection{Prêmios Distribuídos em Dinheiro ou em Bens}

Em atenção ao disposto no $\mathrm{PN} \mathrm{n}^{\circ}$ 93/74, a distribuição de prêmios a funcionários e representantes comerciais da pessoa jurídica como ferramenta de incentivo à produtividade, não depende de qualquer autorização por parte do Ministério da Justiça. A obrigatoriedade de autorização prévia se reporta somente às situações nas quais a distribuição dos prêmios está associada ao fator sorte ou azar, ou seja, quando a premiação é realizada através de sorteio, vale-brinde, concurso ou operação assemelhada.

Igualmente são os prêmios concedidos em competições desportivas, artísticas, científicas e literárias que, nos termos do $\mathrm{PN} \mathrm{n}^{\circ}$ 173/74, por estarem atrelados exclusivamente ao esforço da pessoa contemplada ou à sua habilidade ou melhor desempenho, são tributados como rendimentos do trabalho. Ou seja, em se tratando de beneficiário pessoa jurídica, será aplicável o IRF à alíquota de 1,5\%; sendo o beneficiário pessoa física, a tributação aplicável será aquela da tabela progressiva, com o ajuste final na DIRPF. Nestes casos, quando o prêmio é pago em bens ou em espécie, o artigo 994, do RIR, determina que os rendimentos sejam avaliados em dinheiro, pelo valor que tiverem na data da percepção.

Nas decisões colacionadas a seguir, verifica-se que a premiação deu-se em razão de esforço pessoal do contemplado, seja em razão de sua habilidade técnica ou física, seja em razão de seu esforço em prol da empresa na qual trabalhava:

“Ementa: PRÊMIO EM DINHEIRO. PESSOA FÍSICA. PESSOA JURÍDICA. O pagamento feito à pessoa física, como prêmio pela qualidade do trabalho realizado em determinada área do conhecimento, está sujeito à retenção do imposto de renda na fonte nos termos do art. 620 do RIR/1999. Contudo, caso o beneficiário do pagamento seja pessoa jurídica, não há retenção de imposto de renda na fonte, se não houver prestação de serviço em benefício da entidade 
pagadora.

(Processo de Consulta n ${ }^{\circ}$ 176/11. SRRF da 9 $9^{a}$ Região Fiscal) (grifamos)

"Ementa: Rendimentos tributáveis na fonte $e$ na declaração anual de ajuste.

O prêmio instituído pelo consulente para os funcionários que completarem 10, 20 ou 30 anos de serviços ininterruptos na empresa não possui natureza indenizatória e como tal está sujeito à incidência do imposto de renda na fonte e na declaração de ajuste anual. A verba paga, a título de indenização, a funcionário demitido sem justa causa, em função do Programa de Desligamento Especial, instituído pela empresa, não se enquadra no conceito de incentivo à demissão voluntária, estando sujeita à tributação mensal e na declaração de ajuste anual.

(Processo de Consulta $n^{\circ}$ 70/05. SRRF da $1^{\text {a }}$ Região Fiscal

"Ementa: PRÊMIOS PAGOS A ATLETA.

Os valores das gratificações, prêmios, participações, pagos a atleta profissional em decorrência dos resultados obtidos em competições esportivas possuem caráter remuneratório e estão sujeitos à incidência do imposto de renda, na fonte e na declaração. Se os prêmios forem entregues a pessoa física não-residente no Brasil, sujeitam-se à incidência exclusiva na fonte à alíquota de $25 \%$.

(Processo de Consulta $\mathrm{n}^{\circ}$ 15/02. COSIT) (grifamos)

“Ementa: DISTRIBUIÇÃO DE PRÊMIO EM DINHEIRO INCIDÊNCIA.

A distribuição de prêmios em dinheiro, outorgados pela avaliação do desempenho dos participantes, assume o aspecto de remuneração do trabalho, assalariado ou não-assalariado, conforme haja ou não vínculo empregatício entre o beneficiário e a fonte pagadora. APURAÇÃO DO IMPOSTO. Os valores pagos aos beneficiários, pessoas físicas residentes no país, com ou sem vínculo empregatício, estão sujeitos à incidência do imposto de renda na fonte, calculado com base na tabela progressiva mensal. Devido a ausência de previsão legal, não estão sujeitos à incidência do imposto de renda 
na fonte os valores pagos às pessoas jurídicas domiciliadas no Brasil, a título de prêmio em dinheiro. Os prêmios, conquistados em concursos, pagos, creditados, entregues, empregados ou remetidos a beneficiários (pessoas físicas ou jurídicas) residentes ou domiciliados no exterior, sujeitam-se à incidência do imposto de renda na fonte à alíquota de $15 \%$ (quinze por cento).

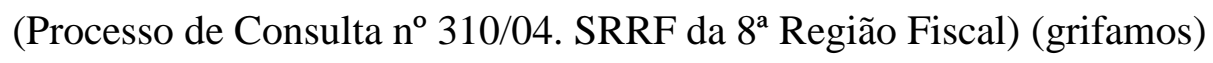

Em se tratando de prêmios distribuídos por meio de concursos e sorteios, o RIR guarda norma específica para prêmios em dinheiro (artigo 676) e prêmios em bens e serviços. Para o primeiro caso, será aplicável o IRF à alíquota de 30\% e, no segundo caso, o IRF será de $20 \%$. Em ambos os casos o regime de retenção será exclusivo de fonte. Apenas a título ilustrativo, confira-se a decisão abaixo:

\section{"Ementa: DISTRIBUIÇÃO GRATUITA DE PRÊMIO - "Kit Torcida" INCIDÊNCIA.}

A distribuição gratuita de prêmios mediante sorteio, na forma de "Kit Torcida", submete-se à tributação pelo imposto de renda na modalidade fonte à alíquota de 20\%, cabendo à pessoa jurídica que proceder à distribuição de prêmios efetuar o pagamento do imposto, sem aplicação do reajustamento da base de cálculo. APURAÇÃO E RECOLHIMENTO. Tratando-se de regime de tributação exclusiva na fonte, se o montante apurado resultar inferior a $R \$$ 10,00 (dez reais), deverá ser adicionado ao imposto apurado nas próximas distribuições de prêmios, até que o total seja igual ou superior a $R \$ 10,00$ (dez reais), devendo ser recolhido no prazo estabelecido para o último período de apuração.

(Processo de Consulta $n^{\circ}$ 156/04. SRRF da $8^{\circ}$ Região Fiscal) (grifamos e destacamos)

HIROMI HigUCHI ${ }^{546}$ demonstra, todavia, especificamente com relação aos prêmios concedidos sem a interferência do fato sorte ou azar, i.e., sem a realização de sorteio ou concurso, que a Receita Federal tem demonstrado interpretação uniforme para ambas as

\footnotetext{
546 Cf. HIGUCHI, Hiromi. HIGUCHI, Fábio Hiroshi. HIGUCHI, Celso Hiroyuki. Imposto de Renda das Empresas - Interpretação e Prática. $33^{\mathrm{a}}$ ed. São Paulo: IR Publicações Ltda., 2008. P. 514/518.
} 
situações, de forma que qualquer modalidade de premiação, mesmo naquelas que dependem do esforço ou da habilidade individual do contemplado, os prêmios têm sido alvo de tributação exclusiva de fonte. $O$ tributarista explica que a confusão estaria atrelada à infeliz redação do artigo 677, já que a palavra 'concurso' teria sido utilizada com o sentido de 'sorteio', onde entra o fator sorte e azar.

Vejamos algumas decisões nesse sentido:

\section{"Ementa: PARTICIPAÇÃO DE PESSOAS FÍSICAS EM COMPETIÇÕES TELEVISIVAS PREMMIOS PAGOS EM BENS.}

Os prêmios em bens, obtidos no programa de televisão intitulado "Roleta Russa", que visa aferir a capacidade humana em diversas áreas (conhecimentos gerais, raciocínio, lógica, intelecto, agilidade, improvisação, habilidades físicas elou artísticas), sujeitam-se à incidência do imposto de renda, à alíquota de vinte por cento, exclusivamente na fonte, calculado sobre o valor do bem na data da distribuição.PREAMIOS PAGOS EM DINHEIRO. Os prêmios em dinheiro outorgados à pessoas físicas em decorrência da avaliação do desempenho demonstrada no programa de televisão intitulado "No Vermelho", ainda que mediante assunção de dívidas contraídas pelos participantes, assumem o aspecto de remuneração do trabalho nãoassalariado, estando sujeitos à incidência do imposto de renda na fonte, calculado mediante a aplicação da tabela progressiva.

(Processo de Consulta n ${ }^{\circ}$ 48/03. SRRF da $8^{\text {a }}$ RF - Aduaneira) (grifamos)

Neste caso, a decisão é expressa no sentido de que a premiação, tanto em bens como em dinheiro, decorre da habilidade e/ou do melhor desempenho do participante. A obtenção do prêmio depende única e exclusivamente dos conhecimentos do participante de um concurso e de sua capacidade de dar respostas corretas e rápidas. Não é em razão de estar participando de um concurso que o fator sorte e azar está sempre presente. O participante pode até ter sorte ou azar em função de uma pergunta que lhe foi sorteada para a qual pode ter maior ou menor facilidade, mas a capacidade de respondê-la foge desses fatores, dependendo somente de sua memória, seu raciocínio e seu intelecto. 
"Ementa: No caso de concurso para escolha de projeto arquitetônico, $\underline{\text { a }}$ premiacão feita à qualidade dos projetos melhor classificados não se confunde com a remuneração ou os honorários que são pagos posteriormente ao arquiteto contratado para prestação dos serviços. Destarte, o pagamento do prêmio enseja retenção do IRPF pelo código 0916 do Mafon/2008, a título de prêmio distribuído sob a forma de bens, por meio de concurso." (Processo de Consulta $n^{o}$ 238/09. SRRF da $9^{a}$ Região Fiscal) (grifamos e destacamos)

Neste segundo caso, parece ser clara que a diretriz que definiu a premiação, no âmbito de um concurso, vincula-se à qualidade de sua apresentação, i.e., está intimamente associado com a habilidade profissional do contemplado, não existindo razão para que tal prêmio, seja em bens seja em dinheiro, seja tributado em separado de seus honorários profissionais.

A falta de uniformidade em algumas instâncias da RFB pode trazer prejuízos tanto ao contribuinte, com a tributação exclusiva de fonte sobre prêmios que, em razão do seu montante, estariam isentos ou sujeitos a alíquotas menos gravosas, como também à fonte pagadora, cuja responsabilidade tributária poderá ter uma exposição maior do que aquela definida, por exemplo, no âmbito do regime de retenção como antecipação do devido. 


\section{Conclusões}

1. A identificação dos fatos econômicos juridicizados pela norma tributária, traduzindo-se, portanto, como fatos jurídicos, que geram a renda tributável e dos fatos que, isoladamente, revelam meros signos-presuntivos de renda, mas que indicam índice de capacidade contributivo-econômica e financeira, ilustra que o legislador escolheu diferentes momentos (aspecto temporal) determinantes para que o IR seja pago. O IRF, definido em lei como sistemática de recolhimento do IR de forma antecipada, antes do término do período de apuração, altera o aspecto temporal principal da regra matriz do IR, revelando, contudo, maior preocupação com um conjunto de princípios, expressos e implícitos, da Constituição Federal em comparação com a subsunção de um fato concreto à hipótese abstrata definida em lei.

A eleição desses momentos distintos, todavia, indica que o legislador priorizou aspectos econômicos em relação a determinações e conceitos jurídicos impregnados ao nosso ordenamento jurídico-tributário constitucional. Não chega a caracterizar uma função estritamente arrecadatória, na medida em que há uma forte preocupação com os princípios e valores constitucionais, em especial a segurança jurídica e a proteção da confiança que devem reger a relação entre Estado-Fisco, contribuinte e terceiros obrigados ao pagamento do imposto, e o princípio da praticabilidade, imprescindível para a boa execução das leis tributárias e do bom cumprimento das obrigações fiscais impostas aos contribuintes e responsáveis tributários.

2. A identificação da natureza jurídica da retenção na fonte do Imposto Sobre a Renda está intimamente associada às diferentes hipóteses em que essa retenção ocorre, quais sejam: a retenção como antecipação do imposto devido e a retenção exclusiva na fonte. Em cada uma dessas classificações há características suficientemente abrangentes e particulares que permitem identificar o regime jurídico que lhes é pertinente.

3. Para tanto, qualquer análise nesse sentido deve partir dos princípios constitucionais que guardam maior contato e mais se identificam à hipótese tributária do IR e aos propósitos para os quais acreditamos que direcionam, ou devem direcionar, as políticas atreladas à tributação da renda das pessoas físicas e jurídicas, a saber: a legalidade, a igualdade, por meio de seu vetor a capacidade contributiva, a vedação de instituição de imposto com efeito de confisco e a segurança jurídica, ao realizar a noção do 
mínimo existencial. Além da gama de princípios constitucionais que regem o sistema tributário nacional, o IR demanda, ainda, a presença, simultânea, de outros princípios específicos para sua formulação: a universalidade, a generalidade e a progressividade.

A generalidade é tomada como um vetor da realização do primado da igualdade, de forma que o imposto deve tratar por igual todo e qualquer contribuinte que tenha obtido um aumento patrimonial sujeito à tributação pelo IR, independentemente de quaisquer outras circunstâncias externas ao contexto da hipótese tributária. A universalidade refere-se ao alcance do conjunto de todas as espécies de rendas e de todas as espécies de proventos, independentemente de sua origem e de sua fonte de produção. O princípio da progressividade, por sua vez, está vinculado quase que exclusivamente a um dos aspectos quantitativos da regra matriz: a alíquota. Desde que associada aos princípios da generalidade e da universalidade, a progressividade se mostrará como um vetor eficiente, permitindo a realização da capacidade contributiva na hipótese tributária do IR.

4. A tributação na fonte opõe-se a alguns desses princípios, ora com maior intensidade contra a capacidade contributiva, ora contra a universalidade, ora contra a generalidade. Todavia, tendo em vista que esse conjunto de regras deve ser considerado englobadamente, o que se vê, na sistemática de pagamento do IRF, são exceções condicionadas e justificadas à verificação desses e outros princípios em maior ou menor grau de importância, relativizando-se uns entre os outros, por meio da técnica do sopesamento, própria dos princípios.

Com isso, tanto a universalidade poderá permitir a existência de diferentes tipos de tributação em razão do tipo de renda, como a praticabilidade poderá estabelecer uma zona de prioridade, na medida em que a exigência de recolhimentos antecipados ou a aplicação de alíquotas preferenciais (i) permitirá a simplificação dos processos de arrecadação e fiscalização, nessa ordem, (ii) promoverá um ambiente de comodidade e segurança às pessoas envolvidas (contribuinte e fonte pagadora), (iii) bem como resguardará a manutenção da máquina estatal de forma salutar e, na maioria das vezes, não agressiva àquelas mesmas pessoas, seja por meio de recolhimentos antecipados, seja por meio do cumprimento de obrigações acessórias.

5. Nesse sentido, em busca de um conceito de renda, vital para os propósitos percorridos na presente dissertação, vale apontar que a Constituição Federal, através dos princípios ali enraizados, traz apenas uma noção de renda (aproximação tipológica), evidenciando que a palavra "renda" carece de uma maior amplitude. 
Renda é um tipo para o qual a Constituição Federal mantém um núcleo mínimo semântico, do qual o legislador infraconstitucional não poderá se afastar, sem, contudo, a existência de travas ou limites, salvo com relação àquele núcleo, que é a exata medida que impede que a definição do conceito de renda possa ficar à mercê do legislador infraconstitucional, de forma livre ou sem a existência de contornos mínimos. Referido núcleo é composto pelo conjunto de significação proposto e informado pelos princípios constitucionais, específicos e não específicos do IR, que impedem que se chame de renda aquilo que, em linguagem e senso comuns, não é. Apoiado na redação do artigo 43, do CTN, o conceito de renda vale-se das teorias da renda-produto e da renda acréscimo patrimonial, em que o legislador ordinário dá uma maior preferência aos casos de acréscimo patrimonial, conforme se depreende da leitura dos incisos I e II daquele mesmo artigo 43.

6. A complexidade do IR se deve, em grande parte, à circunstância de que seu fato gerador deve atender a três condições: realização da renda, acréscimo patrimonial medido em um determinado período de tempo e aquisição de disponibilidade econômica e/ou jurídica, esta última indissociável da primeira (realização). Somente quando atendidas essas características de forma conjunta é que o IR se torna devido. Tais condições correspondem aos próprios aspectos material, temporal e quantitativo de sua regra matriz.

7. Como fato gerador instantâneo que é, o fato gerador do IR somente se materializa quando todos os seus aspectos ali estiverem presentes. Significa dizer que não basta apurar se existe uma renda tributável ou o quantum dessa renda tributável representa em termos de aquisição de um acréscimo patrimonial, sem que tais expedientes estejam dentro de um contexto temporal. O tal confronto de fatos-acréscimos e fatos-decréscimos perde qualquer significado jurídico comparativo sem a noção de um período de tempo. A indissociabilidade desses aspectos deve ser dura de tal forma que, não identificada a presença de um deles, não estaremos diante do fato gerador do IR, ainda que, como é sabido, existam autorizações constitucionais para tributar em momentos distintos do marco final daquele lapso temporal, como são os casos do IRF.

8. A relação entre a aquisição desse acréscimo patrimonial e o aspecto temporal do fato gerador do IR nos conduz a concluir que este exato momento poderá ser qualquer um, desde que após verificada a materialidade que lhe dá ensejo, qual seja, a aquisição de uma disponibilidade econômica ou jurídica que se traduza na realização de um acréscimo patrimonial. De fato, o que se vê é o deslocamento desse momento para uma data futura, 
permitindo, com isso, a mensuração da evolução ou mutação patrimonial, computada em prazos predefinidos que a lei estabelece, mediante a comparação de um mesmo patrimônio mensurado em momentos diferentes.

Por se tratar de um conceito eminente e essencialmente dinâmico, a noção de patrimônio sempre estará vinculada à sua variabilidade no tempo, i.e., a algum parâmetro temporal de comparação. Vale dizer que essa variabilidade atingirá exatamente o aspecto quantitativo do fato gerador do IR, permitindo afirmar que, em que pese tratar-se de um fato gerador instantâneo, a formação de sua base de cálculo é bastante complexa. É durante aquele intervalo de tempo que se apura a base de cálculo, valendo-se, para isso, de complexas fórmulas com adições, exclusões, deduções, presunções, cálculos de valores adicionais etc.

9. Os casos de IRF, especificamente com relação ao regime de antecipação, revelam hipóteses em que o pagamento do imposto é antecipado em comparação à data em que ocorre o aperfeiçoamento do fato gerador. Excetuando-se assim à regra geral pertinente ao aspecto temporal do IRPF, deve(m) ser identificada(s) a(s) justificativa(s) de ordem constitucional que autoriza(m) o Estado-Fisco a constranger o patrimônio do contribuinte antes do término do período de apuração.

10. O IRF não corresponde a uma espécie tributária autônoma, com hipótese tributária própria e distinta do IR das pessoas físicas e jurídicas. O IRF é mera técnica de pagamento antecipado do IR devido pelas pessoas físicas e jurídicas e atende, na maior medida possível, aos moldes definidos pelo fato gerador do IR.

11. Em estudos de Direito Comparado, a evolução do IRF, desde suas formas mais primitivas, costuma ser analisada sob dois conceitos: a) o primeiro desses conceitos é chamado de "taxation at the source", que pode ser entendido, em tradução livre, como a "tributação na origem" ou "tributação na fonte (pagadora)"; b) a segunda forma de manifestação de tributação sobre a renda foi identificada como sendo o "withholding tax" imposto retido na fonte -, que corresponde, na verdade, a uma modalidade mais globalmente conhecida e de mais fácil identificação, tanto nas operações internas de cada país, como nas relações jurídico-tributárias entre os países, regularmente normatizadas, em muitos casos, pelos acordos internacionais para evitar a dupla tributação.

12. Em um contexto global, tanto a sistemática de retenção na fonte do IR como a tributação de determinados rendimentos em separado de outros são ferramentas largamente 
utilizadas pelos países desenvolvidos e pelos países em desenvolvimento, como é o caso do Brasil.

13. A tributação diferenciada para tipos de rendas ou de rendimentos de naturezas distintas caracteriza um sistema de tributação em cédulas, seja através da aplicação de alíquotas menores ou de isenções, seja através da autorização de certas deduções, proporcionando a redução das bases tributáveis. A cedularização nada mais é do que a escolha de determinadas realidades pinçadas pelo legislador que, por revestirem características próprias, demandam tratamento separado das demais hipóteses ou da regra geral. Assim é que os ganhos de capital são tributados à parte, da mesma forma como as pessoas jurídicas possuem tratamento em separado de seus acionistas pessoas físicas. $\mathrm{O}$ "regresso" à cedularização constitui uma tendência mundial, misturado aos ingredientes da proporcionalidade e da progressividade e corresponde a uma prática cujo ideal é buscar a tributação mais próxima possível da realidade, sem, contudo, descuidar da capacidade contributiva e do princípio da "renda líquida" que, necessariamente, devem informar a tributação do imposto de renda.

14. Partindo para as conclusões sobre a classificação proposta entre os sujeitos (terceiros) eleitos como responsáveis pelo pagamento de tributo alheio, já que nem todos assumem a natureza de um legítimo ou genuíno sujeito passivo, vale destacar que se procurou assentar a ideia de que ao referir-se à expressão "fato gerador", parece mais adequado entender que seu uso objetivou, em verdade, reportar-se à sua materialidade e não aos demais aspectos da hipótese tributária. Esta é a leitura que deve ser feita a partir do artigo 128, do CTN.

15. O substituto tributário é espécie de sujeito passivo indireto, que tem no artigo 128, do CTN, seu fundamento legal de validade e que, necessariamente, deverá estar em contato indireto com o aspecto material (núcleo do fato gerador) e, em virtude de lei, sua origem deriva ou antes ou no exato momento em que o contribuinte realiza o verbo desencadeador da obrigação tributária, participando, desta forma, do aperfeiçoamento do fato gerador.

Ainda, como características marcantes de seu regime jurídico, o legislador prevê, na própria lei de onde derivou sua condição de substituto tributário, as formas e/ou instrumentos por meio dos quais será ressarcido pelo contribuinte, como, por exemplo, nos casos de retenção na fonte - é justamente este instrumento técnico que permite, juridicamente, que o substituto suporte o ônus tributário gerado por um ato do contribuinte. Na substituição tributária, a responsabilidade do contribuinte é excluída por completo, i.e., 
somente o substituto responde pelo pagamento do tributo e pelas consequências de seu inadimplemento ou descumprimento de deveres instrumentais. O substituto tributário assume, "na largada", o lugar que teria sido do contribuinte, de modo que o Estado não pode voltar-se contra o substituído.

16. O agente de retenção, figura analisada genuína e essencialmente a partir dos casos que envolvam retenção na fonte, é identificado sob duas formas:

a) Em um primeiro caso, por exemplo, podemos citar uma instituição financeira privada que procede aos pagamentos referentes à remuneração de servidores públicos, hipótese em que sequer participa, ainda que indiretamente, do nascimento da obrigação tributária, amoldando-se como um mero ente intermediário que possibilita a realização de uma série de pagamentos, valendo-se, para isso, de recursos financeiros disponibilizados pelo agente empregador, no caso o próprio Estado. Com isso, sob a perspectiva da instituição financeira privada, a relação jurídica tributária não chega a existir entre ela, instituição financeira, e o Estado, prevalecendo apenas relações operacionais entre ela e a fonte pagadora e entre ela e os beneficiários dos dinheiros (contribuintes). A instituição financeira privada exerce, assim, uma das possíveis forma de qualificação do agente de retenção, cumprindo, neste caso, uma relação mecânico-obrigacional, de natureza estritamente administrativa.

b) Idêntica expressão é utilizada pelo tributarista BRANDÃO MACHADO ${ }^{547}$, que, categoricamente, valendo-se dos ensinamentos de Ernst Blumenstein, quando da análise do Direito Tributário suíço e alemão, chama a fonte pagadora, notadamente nos casos de retenção do imposto de renda na fonte, de mero agente de retenção, sequer assumindo a condição de sujeito passivo.

17. A fonte pagadora, na qualidade de agente de retenção é, a nosso ver, uma extensão (longa manus) da função tributante do Estado, correspondendo a função residualmente administrativa.

O agente de retenção distancia-se do substituto tributário na medida em que, dentre outras razões, a relação do contribuinte com o Estado subsiste (parte final do artigo 128, do CTN), tendo em vista que só ao final do período de apuração é que se aperfeiçoará o fato gerador do IR. O agente de retenção não "substitui" o contribuinte na relação jurídica tributária, em que pese responsabilizar-se pelo recolhimento antecipado do imposto. Quando ocorre a retenção, nos casos em que se fala em agente de retenção

${ }^{547}$ Cf. MACHADO, Brandão. Op. cit. (nota 489), P. 296/297. 
(próprio dos casos de retenção por antecipação), não há se falar em relação jurídica tributária, pois, como se viu, o fato gerador do IR ainda não se aperfeiçoou e os pagamentos realizados com base nos valores retidos constituem meras antecipações. $\mathrm{O}$ agente de retenção exerce uma função jurídico-administrativa, i.e., sua responsabilidade não é de natureza tributária, mas, sim, administrativa, na medida em que corresponde a uma função auxiliadora da máquina estatal e, por se tratar de uma obrigação legal, seu descumprimento encerra a aplicação de penalidades.

18. O agente de retenção é, em suma, um terceiro, necessariamente em contato com o aspecto material da regra matriz, obrigado ao recolhimento de tributo devido por outrem, cujo vínculo com o núcleo objetivo da tributação lhe autoriza, legalmente, a reembolsar-se do ônus financeiro do encargo tributário, através do instituto da retenção na fonte. O agente de retenção surge em situações em que não houve o nascimento da obrigação tributária, exercendo, assim, uma função estritamente administrativa de auxílio ao Estado, sem que, com isso, fique afastada a responsabilidade tributária do contribuinte, que permanece, nestes casos, como o único sujeito passivo da relação jurídica tributária.

19. A retenção do tributo na fonte traduz-se como ferramenta utilizada para transferência do ônus tributário/financeiro para o contribuinte, evitando que aquele terceiro sacrifique patrimônio próprio para fins de pagar tributo devido por outrem. O recolhimento do tributo mediante a sua prévia retenção não é outra coisa senão a re-afirmação e ratificação do princípio da capacidade contributiva, cujo corolário é a igualdade, que devem funcionar não apenas como balizas norteadoras da tributação, mas, também, como limites constitucionais ao poder de tributar.

20. Por fim, em busca da identificação dos regimes jurídicos próprios às hipóteses de retenção na fonte do IR, no regime de retenção na fonte por antecipação toma-se como premissa a verificação da quase todos os elementos necessários à ocorrência do fato gerador do IR, à exceção de apenas um, que é exatamente o aspecto que separa o IRF retido por antecipação do imposto pago na qualidade de imposto devido. Trata-se do aspecto temporal, eleito pelo legislador como marco final para fins de mensuração do acréscimo patrimonial verificado até aquela data, o que não significa dizer que até aquele exato momento não houve acréscimo patrimonial.

O beneficiário, alvo da retenção, na fonte, recebe rendimento, a partir do qual é possível aferir parte dos elementos suficientes para permitir averiguar se aquele rendimento atende aos pressupostos de (i) aquisição de sua disponibilidade e (ii) aquisição 
de acréscimo patrimonial, ao menos de sua presunção, revelando signo presuntivo de renda.

O aspecto temporal, eleito pelo legislador, parte indissociável do fato gerador do IR, exerce importância dupla, em função das prévias retenções na fonte:

(i) primeiramente, ao atender aos ideais de eficácia e eficiência da Administração no tocante à fiscalização e à arrecadação tributária, permite que sejam recolhidas antecipações aos cofres públicos, ferramenta indispensável na gestão da máquina pública e no combate à evasão;

(ii) precisamente em função daquelas antecipações e de forma a apurar a evolução patrimonial do contribuinte em um lapso temporal mais uniforme, abrindo espaço para a mensuração de eventual perda incorrida nesse período, vislumbra-se uma sistemática que autoriza a compensação das antecipações realizadas e eventual restituição, se assim for o caso, assim como permite a derradeira mensuração do acréscimo patrimonial (se houver) culminando com o aperfeiçoamento do fato gerador do Imposto sobre a Renda - ferramenta de ajuste -, ao mesmo tempo que mitiga os efeitos maléficos em caso de rendimentos sazonais.

21. Suportados pelo PN COSIT $n^{\circ} 01 / 2002$ e por ampla rede de decisões administrativas e judiciais nesse sentido, temos que, no regime jurídico do IRF como "antecipação do devido", diante do fato de que as antecipações não assumem a natureza de imposto, já que não se aperfeiçoou o ciclo de formação do fato gerador, é de se concluir que a obrigação tributária não surgiu, não se falando, pois, em relação jurídica tributária. A fonte pagadora, como vimos, não assume a condição de sujeito passivo, mas de um mero agente de retenção, obrigada, contudo, a proceder a tais recolhimentos antecipados sob a condição de um dever de natureza administrativa, auxiliar às funções fiscalizatória e arrecadatória por parte do Estado-Fisco.

Vale destacar que, mesmo que sua responsabilidade tributária (acepção lata) seja supletiva, nos termos da parte final do artigo 128, do CTN, a fonte pagadora, sob o figurino do agente de retenção, não terá essa responsabilidade afastada antes da data final para entrega da DIRPF, ainda que, no período compreendido entre a data final do exercício fiscal e a entrega da declaração anual de ajuste o fato gerador do IR já tenha ocorrido e se aperfeiçoado. Isto porque, antes daquela data, entrega da DIRPF, ao contribuinte não são disponibilizadas condições operativas suficientes para apuração e declaração, com precisão e rigor, do quantum do imposto devido. 
A definição daqueles períodos de tempo onde se destacam parcelas de responsabilidade do agente de retenção e do contribuinte, em estrita conexão com a DIRPF, atende substancialmente aos ditames do princípio da praticabilidade, como uma sistemática prática que permite uma fácil execução da lei tributária. Concomitantemente, são respeitados os princípios da capacidade contributivo-econômica e da segurança jurídica, não exigindo, do contribuinte, algo que ele não teria condições de entregar ou fazer, já que o próprio Estado-Fisco definiu, como procedimento hábil e único, que a apuração definitiva do IR seja realizada através do programa gerador virtual denominado DIRPF.

22. O regime do IRF como "antecipação do devido" corresponde a sistemática mais largamente utilizada e responde pela maior fatia de arrecadação de receitas federais a título de IRF. Nesta sistemática, a tributação, em "bases correntes”, ocorre à medida que os rendimentos vão sendo auferidos.

23. No regime de retenção exclusiva (e definitiva) do IRF o legislador destaca um determinado tipo de rendimento para que ele seja tributado separadamente das demais rendas (ou rendimentos) do contribuinte. Assim é que, valendo-se de metodologia que atenda ao efeito da cedularização das rendas e dos rendimentos, por se tratar de situações que, geralmente, demandam tratamento separado, o legislador escolhe, discricionariamente, as espécies de rendimentos que passarão a pertencer a esse grupo especial.

24. A característica mais marcante desse regime é o fato de que tanto o montante retido como o rendimento submetido a essa sistemática não se comunicam com a disponibilidade da renda e o acréscimo patrimonial, se houver, adquirido ao final do ano, quando da apuração conclusiva do IR por meio da DIRPF. Outrossim, sobre o regime de retenção exclusiva na fonte, é possível apontar as seguintes conclusões:

25. Na retenção exclusiva de fonte há um aperfeiçoamento completo do fato gerador do IR, na medida em que a tributação, antecipada, não depende de qualquer evento futuro para confirmar ou infirmar se, no final do período haverá imposto a recolher ou a restituir. O fato gerador do IR é instantâneo e a mensuração de sua base de cálculo também, já que os momentos definidos pelo legislador para retenção do imposto e sua apuração definitiva são coincidentes, logo, atendendo-se ao pressuposto do aspecto temporal. A natureza definitiva do imposto retido revela não uma mera antecipação mas, sim, uma natureza tipicamente tributária (o imposto é definitivo). Com a concretização do fato gerador, há a 
formação da relação jurídica tributária, com a fonte pagadora transportada para a posição de sujeito passivo, substituindo o contribuinte e excluindo definitivamente sua responsabilidade. 


\begin{abstract}
ANEXo
Parecer Normativo $\mathrm{n}^{\circ} 1$, de 24 de setembro de 2002

DOU de 25.9.2002

Imposto de Renda Retido na Fonte - IRRF.

DESPACHO DO SECRETÁRIO

Em 24 de setembro de 2002

Aprovo.

EVERARDO MACIEL

ANEXO

PARECER NORMATIVO No 1, DE 24 DE SETEMBRO DE 2002
\end{abstract}

\title{
IRRF. RETENÇÃO EXCLUSIVA. RESPONSABILIDADE.
}

No caso de imposto de renda incidente exclusivamente na fonte, a responsabilidade pela retenção e recolhimento do imposto é da fonte pagadora.

\section{IRRF. ANTECIPAÇÃO DO IMPOSTO APURADO PELO CONTRIBUINTE. RESPONSABILIDADE.}

Quando a incidência na fonte tiver a natureza de antecipação do imposto a ser apurado pelo contribuinte, a responsabilidade da fonte pagadora pela retenção e recolhimento do imposto extingue-se, no caso de pessoa física, no prazo fixado para a entrega da declaração de ajuste anual, e, no caso de pessoa jurídica, na data prevista para o encerramento do período de apuração em que o rendimento for tributado, seja trimestral, mensal estimado ou anual.

\section{IRRF. ANTECIPAÇÃO DO IMPOSTO APURADO PELO CONTRIBUINTE. NÃO RETENÇÃO PELA FONTE PAGADORA. PENALIDADE.}

Constatada a falta de retenção do imposto, que tiver a natureza de antecipação, antes da data fixada para a entrega da declaração de ajuste anual, no caso de pessoa física, e, antes da data prevista para o encerramento do período de apuração em que o rendimento for tributado, seja trimestral, mensal estimado ou anual, no caso de pessoa jurídica, serão exigidos da fonte pagadora o imposto, a multa de ofício e os juros de mora. 
Verificada a falta de retenção após as datas referidas acima serão exigidos da fonte pagadora a multa de ofício e os juros de mora isolados, calculados desde a data prevista para recolhimento do imposto que deveria ter sido retido até a data fixada para a entrega da declaração de ajuste anual, no caso de pessoa física, ou, até a data prevista para o encerramento do período de apuração em que o rendimento for tributado, seja trimestral, mensal estimado ou anual, no caso de pessoa jurídica; exigindo-se do contribuinte o imposto, a multa de ofício e os juros de mora, caso este não tenha submetido os rendimentos à tributação.

\section{IRRF RETIDO E NÃO RECOLHIDO. RESPONSABILIDADE E PENALIDADE.}

Ocorrendo a retenção e o não recolhimento do imposto, serão exigidos da fonte pagadora o imposto, a multa de ofício e os juros de mora, devendo o contribuinte oferecer o rendimento à tributação e compensar o imposto retido.

\section{DECISÃO JUDICIAL. NÃO RETENCÃO DO IMPOSTO. RESPONSABILIDADE.}

Estando a fonte pagadora impossibilitada de efetuar a retenção do imposto em virtude de decisão judicial, a responsabilidade desloca-se, tanto na incidência exclusivamente na fonte quanto na por antecipação, para o contribuinte, beneficiário do rendimento, efetuando-se o lançamento, no caso de procedimento de oficio, em nome deste.

Dúvidas têm sido suscitadas no âmbito da Secretaria da Receita Federal acerca da responsabilidade tributária, no caso de pagamento de rendimentos sujeitos ao imposto de renda na fonte. Com vistas a solucionar a questão, no presente parecer serão abordados os seguintes pontos: a caracterização da responsabilidade da fonte pagadora à luz da Lei $\mathrm{n}^{\circ}$ 5.172, de 25 de outubro de 1966 - Código Tributário Nacional (CTN); o tratamento tributário nos casos de imposto de renda retido exclusivamente na fonte e de imposto retido na fonte por antecipação do devido na declaração da pessoa física ou, no caso de pessoa jurídica, do devido no encerramento do período de apuração em que o rendimento for tributado, seja trimestral, mensal estimado ou anual; quais as multas aplicáveis à fonte pagadora, na hipótese de não-retenção do imposto, e ao contribuinte pelo não-oferecimento do rendimento à tributação; a responsabilidade tributária no caso de não-retenção por força de decisão judicial; e imposto retido e não recolhido.

Sujeição passiva tributária em geral 


\section{Dispõe o art. 121 do CTN:}

"Art. 121. Sujeito passivo da obrigação principal é a pessoa obrigada ao pagamento de tributo ou penalidade pecuniária.

Parágrafo único. O sujeito passivo da obrigação principal diz-se:

I - contribuinte, quando tenha relação pessoal e direta com a situação que constitua o respectivo fato gerador;

II - responsável, quando, sem revestir a condição de contribuinte, sua obrigação decorra de disposição expressa de lei."

3. Como visto, a sujeição passiva na relação jurídica tributária pode se dar na condição de contribuinte ou de responsável. Nos rendimentos sujeitos ao imposto de renda na fonte o beneficiário do rendimento é o contribuinte, titular da disponibilidade econômica ou jurídica de renda, a que se refere o art. 43 do CTN.

4. A fonte pagadora, por expressa determinação legal, lastreada no parágrafo único do art. 45 do CTN, substitui o contribuinte em relação ao recolhimento do tributo, cuja retenção está obrigada a fazer, caracterizando-se como responsável tributário.

5. Nos termos do art. 128 do CTN, a lei, ao atribuir a responsabilidade pelo pagamento do tributo à terceira pessoa vinculada ao fato gerador da obrigação tributária, tanto pode excluir a responsabilidade do contribuinte como atribuir a este a responsabilidade em caráter supletivo.

6. A fonte pagadora é a terceira pessoa vinculada ao fato gerador do imposto de renda , a quem a lei atribui a responsabilidade de reter e recolher o tributo. Assim, o contribuinte não é o responsável exclusivo pelo imposto. Pode ter sua responsabilidade excluída (no regime de retenção exclusiva) ou ser chamado a responder supletivamente (no regime de retenção por antecipação).

7. No caso do imposto de renda, há que ser feita distinção entre os dois regimes de retenção na fonte: o de retenção exclusiva e o de retenção por antecipação do imposto que será tributado posteriormente pelo contribuinte. 


\section{Retenção exclusiva na fonte}

8. Na retenção exclusiva na fonte, o imposto devido é retido pela fonte pagadora que entrega o valor já líquido ao beneficiário.

9. Nesse regime, a fonte pagadora substitui o contribuinte desde logo, no momento em que surge a obrigação tributária. A sujeição passiva é exclusiva da fonte pagadora, embora quem arque economicamente com o ônus do imposto seja o contribuinte.

10. Ressalvada a hipótese prevista nos parágrafos 18 a 22, a responsabilidade exclusiva da fonte pagadora subsiste, ainda que ela não tenha retido o imposto.

\section{Imposto retido como antecipação}

11. Diferentemente do regime anterior, no qual a responsabilidade pela retenção e recolhimento do imposto é exclusiva da fonte pagadora, no regime de retenção do imposto por antecipação, além da responsabilidade atribuída à fonte pagadora para a retenção e recolhimento do imposto de renda na fonte, a legislação determina que a apuração definitiva do imposto de renda seja efetuada pelo contribuinte, pessoa física, na declaração de ajuste anual, e, pessoa jurídica, na data prevista para o encerramento do período de apuração em que o rendimento for tributado, seja trimestral, mensal estimado ou anual.

\section{Responsabilidade tributária na hipótese de não-retenção do imposto}

12. Como o dever do contribuinte de oferecer os rendimentos à tributação surge tãosomente na declaração de ajuste anual, no caso de pessoa física, ou, na data prevista para o encerramento do período de apuração em que o rendimento for tributado, seja trimestral, mensal estimado ou anual, no caso de pessoa jurídica, ao se atribuir à fonte pagadora a responsabilidade tributária por imposto não retido, é importante que se fixe o momento em que foi verificada a falta de retenção do imposto: se antes ou após os prazos fixados, referidos acima. 
13. Assim, se o fisco constatar, antes do prazo fixado para a entrega da declaração de ajuste anual, no caso de pessoa física, ou, antes da data prevista para o encerramento do período de apuração em que o rendimento for tributado, seja trimestral, mensal estimado ou anual, no caso de pessoa jurídica, que a fonte pagadora não procedeu à retenção do imposto de renda na fonte, o imposto deve ser dela exigido, pois não terá surgido ainda para o contribuinte o dever de oferecer tais rendimentos à tributação. Nesse sentido, dispõe o art. 722 do RIR/1999, verbis:

Art. 722. A fonte pagadora fica obrigada ao recolhimento do imposto, ainda que não o tenha retido (Decreto-Lei $n^{\circ}$. 5.844, de 1943, art. 103).

13.1. Nesse caso, a fonte pagadora deve arcar com o ônus do imposto, reajustando a base de cálculo, conforme determina o art. 725 do RIR/1999, a seguir transcrito.

"Art. 725. Quando a fonte pagadora assumir o ônus do imposto devido pelo beneficiário, a importância paga, creditada, empregada, remetida ou entregue, será considerada líquida, cabendo o reajustamento do respectivo rendimento bruto, sobre o qual recairá o imposto, ressalvadas as hipóteses a que se referem os arts. 677 e 703, parágrafo único (Lei n ${ }^{\circ} .4 .154$, de 1962 , art. $5^{\circ}$. e Lei $n^{\circ} .8 .981$, de 1995, art. 63, § $\left.2^{\circ}\right)$."

14. Por outro lado, se somente após a data prevista para a entrega da declaração de ajuste anual, no caso de pessoa física, ou, após a data prevista para o encerramento do período de apuração em que o rendimento for tributado, seja trimestral, mensal estimado ou anual, no caso de pessoa jurídica, for constatado que não houve retenção do imposto, o destinatário da exigência passa a ser o contribuinte. Com efeito, se a lei exige que o contribuinte submeta os rendimentos à tributação, apure o imposto efetivo, considerando todos os rendimentos, a partir das datas referidas não se pode mais exigir da fonte pagadora o imposto.

\section{Penalidades aplicáveis pela não-retenção ou não-pagamento do imposto}

15. Verificada, antes do prazo para entrega da declaração de ajuste anual, no caso de pessoa física, ou, antes da data prevista para o encerramento do período de apuração em que o rendimento for tributado, seja trimestral, mensal estimado ou anual, no caso de pessoa jurídica, a não-retenção ou recolhimento do imposto, ou recolhimento do imposto após o prazo sem o acréscimo devido, fica a fonte pagadora, conforme o caso, sujeita ao 
pagamento do imposto, dos juros de mora e da multa de ofício estabelecida nos incisos I e II do art. 44 da Lei no 9.430, de 27 de dezembro de 1996 (art. 957 do RIR/1999), conforme previsto no art. $9^{\circ}$ da Lei ${ }^{\circ} 10.426$, de 24 de abril de 2002, verbis:

Lei $\mathrm{n}^{\mathrm{o}} 10.426$, de 2002

"Art. $9^{\circ}$ Sujeita-se às multas de que tratam os incisos I e II do art. 44 da Lei n 9.430, de 27 de dezembro de 1996, a fonte pagadora obrigada a reter tributo ou contribuição, no caso de falta de retenção ou recolhimento, ou recolhimento após o prazo fixado, sem o acréscimo de multa moratória, independentemente de outras penalidades administrativas ou criminais cabíveis.

Parágrafo único. As multas de que trata este artigo serão calculadas sobre a totalidade ou diferença de tributo ou contribuição que deixar de ser retida ou recolhida, ou que for recolhida após o prazo fixado."

$\mathrm{RIR} / 1999$

"Art. 957. Nos casos de lançamento de ofício, serão aplicadas as seguintes multas, calculadas sobre a totalidade ou diferença de imposto (Lei n ${ }^{\circ}$ 9.430, de 1996, art. 44):

I - de setenta e cinco por cento nos casos de falta de pagamento ou recolhimento, pagamento ou recolhimento após o vencimento do prazo, sem o acréscimo de multa moratória, de falta de declaração e nos de declaração inexata, excetuada a hipótese do inciso seguinte;

II - de cento e cinqüenta por cento, nos casos de evidente intuito de fraude, definido nos arts. 71, 72 e 73 da Lei $\mathrm{n}^{\mathbf{0}}$ 4.502, de 1964, independentemente de outras penalidades administrativas ou criminais cabíveis.

Parágrafo único. As multas de que trata este artigo serão exigidas (Lei nº 9.430, de 1996, art. $\left.44, \S 1^{\circ}\right)$ :

I - juntamente com o imposto, quando não houver sido anteriormente pago;

II - isoladamente, quando o imposto houver sido pago após o vencimento do prazo previsto, mas sem o acréscimo de multa de mora;

(...)."

16. Após o prazo final fixado para a entrega da declaração, no caso de pessoa física, ou, após a data prevista para o encerramento do período de apuração em que o rendimento for tributado, seja trimestral, mensal estimado ou anual, no caso de pessoa jurídica, a responsabilidade pelo pagamento do imposto passa a ser do contribuinte. Assim, conforme 
previsto no art. 957 do RIR/1999 e no art. $9^{\circ}$ da Lei $n^{\circ} 10.426$, de 2002, constatando-se que o contribuinte:

a)não submeteu o rendimento à tributação, ser-lhe-ão exigidos o imposto suplementar, os juros de mora e a multa de ofício, e, da fonte pagadora, a multa de ofício e os juros de mora;

b)submeteu o rendimento à tributação, serão exigidos da fonte pagadora a multa de ofício e os juros de mora.

16.1. Os juros de mora devidos pela fonte pagadora, nas situações descritas nos itens "a" e "b" acima, calculam-se tomando como termo inicial o prazo originário previsto para o recolhimento do imposto que deveria ter sido retido, e, como termo final, a data prevista para a entrega da declaração, no caso de pessoa física, ou, a data prevista para o encerramento do período de apuração em que o rendimento for tributado, seja trimestral, mensal estimado ou anual, no caso de pessoa jurídica.

16.2. A pessoa jurídica sujeita à tributação do imposto de renda com base de cálculo estimada, a que se refere o art. $2^{\circ}$ da Lei $n^{\circ} 9.430$, de 1996 , que não tenha submetido à tributação os rendimentos sujeitos à retenção na fonte que devam ser incluídos na base de cálculo estimada, fica sujeita à multa isolada prevista no inciso IV do $\S 1^{\circ}$ do art. 44 da referida Lei, e caso não inclua tais rendimentos na apuração anual, ser-lhe-ão exigidos o imposto suplementar, os juros de mora e a multa de ofício.

\section{Imposto retido e não recolhido}

17. Ocorrendo a retenção do imposto sem o recolhimento aos cofres públicos, a fonte pagadora, responsável pelo imposto, enquadra-se no crime de apropriação indébita previsto no art. 11 da Lei $\mathrm{n}^{\circ}$ 4.357, de 16 de julho de 1964, e caracteriza-se como depositária infiel de valor pertencente à Fazenda Pública, conforme a Lei no 8.866, de 11 de abril de 1994. Ressalte-se que a obrigação do contribuinte de oferecer o rendimento à tributação permanece, podendo, nesse caso, compensar o imposto retido.

\section{Responsabilidade tributária no caso de não-retenção por força de decisão judicial}


18. Por fim, resta identificar a responsabilidade tributária na hipótese em que a fonte pagadora se vê impedida de reter o imposto de renda ao pagar determinado rendimento a contribuinte, devido a um provimento judicial, normalmente uma medida liminar.

19. Caso a decisão final confirme como devido o imposto em litígio, este deverá ser recolhido, retroagindo os efeitos da última decisão, como se não tivesse ocorrido a concessão da medida liminar. Nesse caso, não há como retornar a responsabilidade de retenção à fonte pagadora. O pagamento do imposto, com os acréscimos legais cabíveis, deve ser efetuado pelo próprio contribuinte, da seguinte forma:

a)tratando-se de rendimento sujeito à antecipação, considera-se vencido o imposto na data prevista para a entrega da declaração, no caso de pessoa física, ou na data prevista para o encerramento do período de apuração em que o rendimento for tributado, seja trimestral, mensal estimado ou anual, no caso de pessoa jurídica;

b)tratando-se de rendimento sujeito à tributação exclusiva, considera-se vencido o imposto no prazo originário previsto para o recolhimento do imposto que deveria ter sido retido.

19.1. A multa de mora fica interrompida desde a concessão da medida judicial até o trigésimo dia de sua cassação, nos termos do $§ 2^{\circ}$ do art. 63 Lei nº 9.430, de 1996:

"Art. 63.

(...)

$\S 2^{\circ} \mathrm{A}$ interposição da ação judicial favorecida com a medida liminar interrompe a incidência da multa de mora, desde a concessão da medida judicial, até 30 dias após a data da publicação da decisão judicial que considerar devido o tributo ou contribuição."

19.2. No caso de pagamento após o prazo referido no subitem anterior, a contagem da multa de mora será reiniciada a partir do trigésimo primeiro dia, considerando, inclusive e se for o caso, o período entre o vencimento originário da obrigação e a data de concessão da medida judicial.

19.3. Em qualquer hipótese, os juros de mora serão devidos sem qualquer interrupção desde o mês seguinte ao vencimento estabelecido na legislação do imposto.

20. Em relação às ações ajuizadas a partir de $1^{\circ}$ de maio de 2001 , independentemente de se tratar de imposto de renda incidente exclusivamente na fonte ou sujeito à antecipação, o termo inicial dos juros de mora é contado a partir da data do vencimento originário da 
obrigação, por força do que estabeleceu o art. 55, §1º I, da Medida Provisória $\mathrm{n}^{\circ}$ 2.158-35, de 24 de agosto de 2001.

21. Existindo provimento judicial que impeça a fonte pagadora de reter o imposto de renda incidente na fonte, de forma exclusiva ou por antecipação, será efetuado lançamento de oficio em nome do contribuinte beneficiário do rendimento, quando a obrigação de tributar o rendimento já estiver caracterizada.

22. Não tendo ocorrido o trânsito em julgado da sentença, para evitar a decadência, o lançamento deve ser efetuado, ficando sobrestada a cobrança e execução do imposto lançado, enquanto não sobrevier decisão definitiva.

À consideração superior.

JORGE HENRIQUE BACKES

AFRF

MARIA DAS GRAÇAS PATROCÍNIO OLIVEIRA

AFRF

De acordo.

REGINA MARIA FERNANDES BARROSO

Coordenadora-Geral de Tributação 


\section{BIBLIOGRAFIA}

AMARO, Luciano. Direito Tributário Brasileiro. 13 ${ }^{\text {a }}$ edição. São Paulo: Saraiva, 2007.

AMARO, Luciano. Imposto sobre a Renda e Proventos de Qualquer Natureza. in O Fato Gerador do Imposto sobre a Renda e Proventos de Qualquer Natureza. Coord. Ives Gandra da Silva Martins. São Paulo: Centro de Estudos de Extensão Universitária e Resenha Tributária, 1986. P. 388 e ss.

AMARO, Luciano. Questões Sobre a Periodicidade da Apuração do Imposto de Renda. in Imposto de Renda e ICMS - Problemas Jurídicos. Coord. Valdir de Oliveira Rocha. São Paulo: Dialética, 1995.

AMED, Fernando José e NEGREIROS, Plínio José Labriola de Campos. História dos Tributos no Brasil. São Paulo: 2000. Edições SINAFRESP. Nobel. 326 p.

ANDRADE, André Martins. Efeitos Jurídicos da Inconstitucionalidade do Imposto de Renda sobre o Lucro Líquido - ILL. in Imposto de Renda - Questões Atuais e Emergentes. Coord. Valdir de Oliveira Rocha. São Paulo: Dialética, 1995.

ANDRADE, Paulo Roberto. O ISS e a Responsabilidade Tributária Prevista no art. $6^{o}$, $\S 2^{\circ}$, II, da Lei Complementar $n^{o} 116 / 03$. Revista Dialética de Direito Tributário $\mathbf{n}^{0} 104$. São Paulo: Dialética, 2004.

ANDRADE, Valentino Aparecido. O Agente de Retenção no Imposto de Renda Incidente sobre Rendimentos Pagos em Cumprimento de Decisão Judicial. Revista Dialética de Direito tributário no 106. São Paulo: Dialética, 2004.

ATALIBA, Geraldo. Hipótese de Incidência Tributária. $6^{\text {a }}$ edição. $5^{\text {a }}$ tiragem. São Paulo: Malheiros, 2004. 
ATALIBA, Geraldo. Sujeição Passiva. Sujeição direta e indireta - Responsabilidade tributária - Destinatário legal tributário - Aspecto Pessoal da Hipótese de incidência. Revista de Direito Público no 29. Editora Revista dos Tribunais, Maio/Junho de 1974.

ATALIBA, Geraldo, BARRETO, Aires Fernandino. Substituição e Responsabilidade Tributária. RDT 49.

Aula Magna - Exposição de VILlEGAS, Hector. Destinatário Legal Tributário Contribuinte e sujeitos passivos na obrigação tributária. Revista de Direito Público. Julho/Agosto de 1974. Editora revista dos Tribunais $-n^{\circ} 30$

AULT, Hugh J. Comparative Income Taxation: A Structural Analysis. The Netherlands: 1997. Kluwer Law International.

ÁVILA, Humberto. A distinção entre princípios e regras e a redefinição do dever de proporcionalidade. in Revista Diálogo Jurídico. Salvador, CAJ - Centro de Atualização Jurídica, v. I, nº 4, julho, 2001. Disponível em: http://www.direitopublico.com.br. Acesso em: 14.11.2011.

ÁVILA, Humberto. A Teoria dos Princípios e o Direito Tributário. in Revista Dialética de Direito Tributário. Vol. 125. São Paulo: Dialética, 2006.

ÁVILA, Humberto. Regra Matriz versus Princípios. in Direito Tributário - Homenagem a Paulo de Barros Carvalho. Coord. Prof. Luis Eduardo Schoueri. São Paulo: Quartier Latin, 2008.

ÁVILA, Humberto. Sistema Constitucional Tributário. $3^{\text {a }}$ ed. São Paulo: Saraiva, 2008.

ÁVILA, Humberto. Teoria da igualdade tributária. São Paulo: Malheiros, 2008.

AYALA, Jose Luis Perez de. Derecho Tributário I. Serie IV - Tratados de Derecho Financeiro y de Hacienda Publica. Vol. XIII. Madrid: Editorial de Derecho Financeiro, 1968. 
BALEEIRO, Aliomar. Direito Tributário Brasileiro. $11^{\mathrm{a}}$ ed. Rio de Janeiro: Editora Forense, 2002.

BALEEIRO, Aliomar. Limitações Constitucionais ao Poder de Tributar. Atualizadora: Misabel Abreu Machado Derzi. 8ª ed. Rio de Janeiro: Editora Forense, 2010

BARBOSA, Rui. Oração aos Moços. Ed. Popular anotada. Rio de Janeiro, Fundação Casa de Rui Barbosa, 1980.

BARRETO, Aires. F. ISS na Constituição e na lei. $3^{\text {a }}$ ed. São Paulo: Dialética, 2009.

BARRETO, Paulo Ayres. Imposto Sobre a Renda e Preços de Transferência. São Paulo: Dialética, 2001.

BASTOS, Celso Ribeiro. Comentários ao Código Tributário Nacional. Vol. 2. $3^{\mathrm{a}}$ ed. Coord. Ives Gandra da Silva Martins. São Paulo: Saraiva, 2002

BECHO, Renato Lopes. Sujeição Passiva e Responsabilidade Tributária. $1^{\mathrm{a}}$ edição. São Paulo: Dialética, 2000.

BECHO, Renato Lopes. Tributação das Cooperativas. 2a ed. São Paulo: Dialética, 1999.

BECKER, Alfredo Augusto. Teoria Geral do Direito Tributário. $3^{\mathrm{a}}$ edição. São Paulo: Lejus, 1998.

BLUMENSTEIN, Ernst. Sistema di Diritto delle Imposte. Trad. Italiana. Milão: Ed. Giuffrè, 1954.

BOITEUX, Fernando Netto. A Tributação na Fonte dos Dividendos Recebidos - o Conselho de Contribuintes e o Judiciário. Revista Dialética de Direito Tributário no 132. São Paulo: Dialética, 2006. 
CANTO, Gilberto de Ulhôa. A Aquisição da Disponibilidade e o Acréscimo Patrimonial no Imposto sobre a Renda. in Imposto de Renda - Conceitos, Princípios e Comentários. Coord. Ives Gandra da Silva Martins. São Paulo: Editora Atlas, 1996.

CANTO, Gilberto de Ulhôa; SOUZA, Antônio Carlos Garcia; MUNIZ, Ian de Porto Alegre. Imposto sobre a Renda e Proventos de Qualquer Natureza. in O Fato Gerador do Imposto sobre a Renda e Proventos de Qualquer Natureza. Coordenação Ives Gandra da Silva Martins. Centro de Estudos de Extensão Universitária e Resenha Tributária. São Paulo: 1986.

CANTO, Gilberto de Ulhôa. Obrigação Tributária: seus pressupostos e elementos. Conferência publicada pelo I.B.D.F. Rio de janeiro: 1958.

CANTO, Gilberto Ulhôa. Estudos e Pareceres de Direito Tributário - Imposto de Renda. São Paulo: Revista dos Tribunais, 1975.

CARRAZZA, Roque Antonio. A natureza meramente interpretativa do art. 129 a Lei $n^{o}$ 11.196/05, o imposto de renda, a contribuição previdenciária e as sociedades de serviços profissionais. in Revista Dialética de Direito Tributário no 154. São Paulo: Dialética, 2008.

CARRAZZA, Roque Antonio. Curso de Direito Constitucional Tributário. $19^{\mathrm{a}}$ edição. $3^{\mathrm{a}}$ tiragem. São Paulo: Malheiros, 2003.

CARRAZZA, Roque Antonio. Imposto sobre a renda: perfil constitucional e temas específicos. $2^{\mathrm{a}}$ ed. São Paulo: Malheiros, 2006.

CARRAZZA, Roque Antonio. O Sujeito Ativo da Obrigação Tributária. São Paulo: Editora Resenha Tributária, 1977.

CARRIÓ, Genaro R. Notas sobre Derecho y Lenguaje. $4^{\circ}$ ed. Buenos Aires: Editora Abeledo-Perrot, 1990. 
CARVALHO, Paulo de Barros. Fundamentos Jurídicos da Incidência. $8^{\mathrm{a}}$ ed. São Paulo: Saraiva, 2010.

CARVAlHO, Paulo de Barros. Curso de Direito Tributário. 23 $3^{\text {a }}$ edição. São Paulo: Saraiva, 2011.

CARVALHO, Paulo de Barros. Teoria da norma tributária. São Paulo: Max Limonad, 1998.

CARVALHO, Paulo de Barros. Sujeição Passiva e Responsáveis Tributários. Programa de Pós-Graduação em Direito - PUC/SP. São Paulo: Max Limonad, 1995.

CHANCELLOR, Thomas. Imputed Income and the Ideal Income Tax. 67 Or. L. Ver. 561 (1998). in Federal Income Tax Anthology. CARON, Paul L.; BURKE, Karen C.; MCCOUCH, Grayson M.

CHASTAGNARET, Manuel. De La Responsabilité Fiscale - Responsabilité de l'administration fiscale et responsabilité solidaire des tiers. Marseille: Presses Universitaires D’Aix-Marseille, 2003.

COÊLHO, Sacha Calmon Navarro. Curso de Direito Tributário Brasileiro. Rio de Janeiro: Editora Forense, 2001

COÊLHO, Sacha Calmon Navarro. Comentários ao Código Tributário Nacional. Coordenação Carlos Valder do Nascimento. Rio de Janeiro: Editora Forense, 1997.

COÊLHO, Sacha Calmon Navarro. Comentários à Constituição de 1988: Sistema Tributário. $2^{\text {a }}$ ed. Rio de Janeiro: Editora Forense, 1990.

COÊLHO, Sacha Calmon Navarro. Sujeição Passiva Direta e Indireta - Substituição Tributária. in Grandes Questões Atuais do Direito Tributário. Vol. 13. Coord. Valdir de Oliveira Rocha. São Paulo: Dialética, 2009. P. 357 e ss. 
COELHO, Sacha Calmon Navarro. O Imposto de renda - Liber Amicorum in Honor do Prof. Paulo de Barros Carvalho. in Direito Tributário - Homenagem a Paulo de Barros Carvalho. Coord. Luís Eduardo Schoueri. São Paulo: Quartier Latin, 2008.

COMISSÃO DE REFORMA DO MINISTÉRIO DA FAZENDA. Evolução do Imposto de Renda no Brasil. Rio de Janeiro: 1966. 25:5/6.

COMPARATO, Fábio Konder. Essai d'Analyse Dualiste de l'Obligation en Droit Privé. Paris: Librairie Dalloz, 1964.

CONTI, José Maurício. Princípios da Capacidade Contributiva. São Paulo: Dialética, 1996.

CORREA, Walter Barbosa. Subsídios para o Estudo da História Legislativa do Imposto de Renda no Brasil. in Imposto de Renda: conceitos, princípios, comentários. Coord. Ives Gandra da Silva Martins e Alcides Jorge Costa. $2^{a}$ ed. São Paulo: Atlas, 1996.

COSTA, Alcides Jorge. Contribuição ao Estudo da Obrigação Tributária. Edição Especial para a Jornada de Direito Tributário em Homenagem ao Professor Alcides Jorge Costa. São Paulo: IBDT, 2003.

COSTA, Alcides Jorge. Conceito de Renda Tributável. in Estudos sobre o Imposto de Renda (Em Memória de Henry Tilbery). Coord. Ives Gandra da Silva Martins. São Paulo: Editora Resenha Tributária, julho/1994.

COSTA, Alcides Jorge. Noção de Tributo. Imposto. Taxa. Contribuição. Preços Públicos. Noção de Direito Tributário. in Curso de Direito Tributário. São Paulo: s.d. Editora FIESP.

COSTA, Alcides Jorge. Imposto sobre a Renda: a Aquisição da Disponibilidade Jurídica ou Econômica como seu Fato Gerador - Limite de sua Incidência. Revista de Direito Tributário no 40. Vol. 11. São Paulo: 1987. 
COSTA, Regina Helena. Praticabilidade e Justiça Tributária. São Paulo: Malheiros, 2007

DARZÉ Andréa M. Responsabilidade Tributária: solidariedade e subsidiariedade. São Paulo: Noeses, 2010

Debates no IV Curso de Especialização em Direito Tributário da PUC/SP, in Destinatário Legal Tributário. EDP 30:288.

DERZI, Misabel Abreu Machado. Princípio de cautela ou não paridade de tratamento entre o lucro e o prejuízo. in Estudos de Direito Tributário em Homenagem á Memória de Gilberto Ulhôa Canto. Rio de Janeiro: Editora Forense, 1998.

DE SANTI, Eurico Marcos Diniz. As Classificações no Sistema Tributário Brasileiro. in Justiça Brasileira. São Paulo: Max Limonad, 1998,

DINIZ, Maria Helena. Curso de Direito Civil Brasileiro. V. 2 - Teoria Geral das Obrigações. $22^{\mathrm{a}}$ ed. Revista e atualizada. São Paulo: Saraiva, 2007

DINIZ, Maria Helena. Dicionário Jurídico Universitário. $1^{\text {a }}$ ed. São Paulo: Saraiva, 2010

EMORY, Meade. The Early English Income Tax: A Heritage for the Comtemporary. Philadelphia: 1965. The American Journal of Legal History. Volume 9. Temple University School of Law.

FALCÃO, Amílcar de Araújo. Fato gerador da obrigação tributária. $4^{\mathrm{a}}$ ed. São Paulo: Editora Revista dos Tribunais, 1976.

FARIA, Renato Vilela. Noções de Justiça Fiscal e o Planejamento Tributário. in Revista de Direito Tributário Atual. Vol. 23. Coord. Alcides Jorge Costa, Luis Eduardo Schoueri e Paulo Celso Bergstrom Bonilha. São Paulo: Dialética-IBDT, 2009 
FEIO, Diogo. A Substituição Fiscal e a Retenção na Fonte: O caso Específico dos Impostos sobre o Rendimento. Teses e Monografias I. Faculdade de Direito da Universidade do Porto. Porto: Coimbra Editora, 2001.

FERRAGUT, Maria Rita. Responsabilidade tributária e o Código Civil de 2002. 2a ed. São Paulo: Noeses, 2009.

FERRAZ JÚNIOR, Tércio Sampaio. Introdução ao Estudo do Direito. $4^{\mathrm{a}}$ edição. São Paulo: Atlas, 2003.

FERRAZ, Tércio Sampaio. Obrigação Tributária Acessória e Limites de Imposição. in Teoria Geral da Obrigação Tributária - Estudos em Homenagem ao Professor Souto Maior Borges. São Paulo: Malheiros, 2005

FILHO, Jorge Saadi. Comentários Objetivos ao Código Tributário Nacional. São Paulo: Editora LTr, 1984.

FONROUGE, C. M. Giuliani. Conceitos de Direito Tributário. Trad. da $2^{\mathrm{a}}$ edição argentina do livro "Derecho Financeiro" (Ediciones Depalma, Buenos Aires, 1970) por Geraldo Ataliba e Marco Aurélio Greco. São Paulo: Edições Lael, 1973.

GAMA, Tácio Lacerda. Competência Tributária. Fundamentos para uma teoria da nulidade. São Paulo: Noeses, 2009.

GONÇALVES, José Artur Lima. Imposto sobre a Renda - Pressupostos Constitucionais. $1^{\mathrm{a}}$ ed. $2^{\mathrm{a}}$ tiragem. São Paulo: Malheiros, 2002

GONZÁleZ, Luis M. Alonso. El Sustituto: Primier Acercamiento a un Sujeto Pasivo Conflictivo. Revista de Derecho Financeiros y de Hacienda Pública. Madrid: 1990. EDERSA - Editoriales de Derecho Reunidas, S.A.

Grande Dicionário Larousse Cultural da Língua Portuguesa. São Paulo: Editora Nova Cultural, 1999. 
GRECO, Marco Aurélio. Dinâmica da Tributação e Procedimento. São Paulo: Editora Revista dos Tribunais, 1979.

GREGORIO, Ricardo Marozzi. Preços de Transferência - Arm's Lenght e Praticabilidade. in Série Doutrina Tributária Vol. V. São Paulo: IBDT/Quartier Latin, 2011

GROSSFELD, Bernhard; BRYCE, James D. A Brief Comparative History of the Origins of the Income Tax in Great Britain, Germany an the United States.

HIGUCHI, Hiromi. HIGUCHI, Fábio Hiroshi. HIGUCHI, Celso Hiroyuki. Imposto de Renda das Empresas - Interpretação e Prática. 33 a ed. São Paulo: IR Publicações Ltda., 2008.

HINTSANEL, L. Attribution of income to permanent establishment under EC Law. In: European Taxation - Amsterdam - Vol. 43 (2003) $n^{\circ} 4$.

HOLMES, Kevin. The Concept of Income - A multidisciplinary analysis. Doctoral Series 1 - Academic Council. Amsterdam, The Netherlands: IBFD Publications BV, February 2000.

HOUAISS, Antônio; VILlAR, Mauro de Salles. Dicionário Houaiss da língua portuguesa. Instituto Houaiss de Lexicografia e Banco de Dados da Língua Portuguesa S/C Ltda. Rio de Janeiro: Objetiva, 2009.

IBRAHIM, Fábio Zambitte. A Retenção na fonte como obrigação instrumental: aplicações no custeio previdenciário. Niterói/RJ: Impetus, 2008.

IRS. Internal Revenue Service Data Book, 2010. October $1^{\text {st }}, 2009$ to September $30^{\text {th }}$, 2010. P. 3. Disponível em http://www.irs.gov/pub/irs-soi/10databk.pdf. Acesso em $02 / 11 / 2011$. 
JARACH, Dino. Aspectos da hipótese de incidência tributária. Revista de Direito Público $n^{\circ} 17$. P. 287:304.

JARACH, Dino. O Fato Imponível. in Teoria Geral do Direito Tributário Substantivo. São Paulo: Editora Revista dos Tribunais, 1989.

JARDIM, Eduardo Marcial Ferreira. Manual de Direito Financeiro e Tributário. $2^{\mathrm{a}}$ edição. São Paulo: Saraiva, 1994.

KOCH, Alfred P. e MOORE, Carl L. Income Taxes and Their Impact on the Individual since 1913. TAXES - The Tax Magazine, by Benjamin M. Becker: 1954. Mahoning Law Library Associaton.

LEAL, Hugo Barreto Sodré. Responsabilidade tributária na aquisição de estabelecimento empresarial. São Paulo: Quartier Latin, 2008.

MACHADO, Brandão. Adicional do Imposto de Renda dos estados. Repertório IOB de Jurisprudência n ${ }^{\circ}$ 18: 1989.

MACHADO, Brandão. Breve Exame Crítico do Art. 43 do CTN. in Imposto de Renda Conceitos, Princípios e Comentários. Coord. Ives Gandra da Silva Martins. São Paulo: Editora Atlas, 1996.

MACHADO, Hugo de Brito. Curso de Direito Tributário. $21^{\mathrm{a}}$ ed. revista, atualizada e ampliada. São Paulo: Malheiros, 2002

MACHADO, Hugo de Brito. O Contribuinte e o Responsável no Imposto de Renda na Fonte. Revista Dialética de Direito Tributário no 70. São Paulo: Dialética, 2001. P. 109116.

MANDÊTTA, Savério. Impostos, taxas e contribuições: resenha histórica do regime fiscal no Brasil. São Paulo: s.d. Colíbras. P. 557 e ss. 
Manual de Tributação no Mercado Financeiro. Coord. Paulo Marcelo de Oliveira Bento. $1^{\text {a }}$ ed. $2^{\mathrm{a}}$ tiragem. São Paulo: Saraiva, 2011.

MARTINS, Ives Gandra da Silva. Parecer: O Fato Gerador do Imposto sobre a Renda e a Aquisição de Disponibilidade Econômica ou Jurídica que implique Acréscimo Patrimonial - Inteligência do artigo 43 do Código Tributário Nacional - Ilegalidade de Pretendida Incidência sem Ocorrência de Acréscimo. Revista Dialética de Direito Tributário no 137. São Paulo: 2007. Editora Dialética. P. 108:117.

MARTINS, Ives Gandra da Silva. Comentários ao Código Tributário Nacional. $2^{\circ}$ volume. $3^{\text {a }}$ ed. São Paulo: 2002. Editora Saraiva.

MARTINS, Ives Gandra da Silva. Direito Tributário 3. Comentários ao Capítulo V Título II - Livro II, do CTN (artigos 128 a 138). São Paulo: Editor José Bushatsky, 1975.

MARTINS, Ives Gandra da Silva. Inconstitucionalidade do Artigo 35 da Lei 7.713/88. in Imposto de Renda - Questões Atuais e Emergentes. Coord. Valdir de Oliveira Rocha. São Paulo: Dialética, 1995.

MELLO, Gustavo Miguez de. O Fato Gerador do Imposto sobre a Renda e Proventos de Qualquer Natureza. Coordenação Ives Gandra da Silva Martins. Centro de Estudo de Extensão Universitária e Resenha Tributária. São Paulo: 1986.

MELO, José Eduardo Soares de. Curso de Direito Tributário. São Paulo: Dialética, 2002

MIRANDA, Pontes de. Tratado de Direito Privado - Parte Geral - Tomo I. Campinas/SP: Editora Bookeseller, 1999.

MORAES, Bernardo Ribeiro de. Doutrina e Prática do Imposto Sobre Serviços. $1^{a}$ edição.

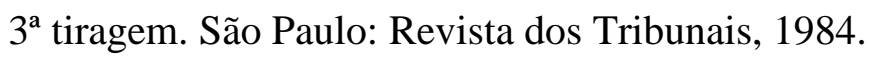

MOSQUERA, Roberto Quiroga. Renda e proventos de qualquer natureza - o imposto e o conceito constitucional. São Paulo: Dialética, 1996. 
MOSQUERA, Roberto Quiroga. Tributação no Mercado Financeiro e de Capitais. São Paulo: Dialética, 1998.

MUSA, Simone Dias; PRADO, Marcos Vinícius Passarelli. A Tributação dos Ganhos Auferidos por Não-residentes na Alienação de Bens Localizados no Brasil - Análise do artigo 26 da Lei $n^{\circ}$ 10.833/03. in Revista Dialética de Direito Tributário $\mathbf{n}^{\circ}$ 156. São Paulo: Dialética, 2008. P. 109/121

NOGUEIRA, Ruy Barbosa. Curso de Direito Tributário. 15ª ed. São Paulo: Saraiva, 1999.

OLIVEIRA, Ricardo Mariz de. Fundamentos do Imposto de Renda. São Paulo: Quartier Latin, verão de 2008.

OLIVEIRA, Ricardo Mariz de. Parecer: A Sujeição Passiva da Fonte Pagadora de Rendimento, quanto ao Imposto de Renda Devido na Fonte. Revista Dialética de Direito Tributário no 49. São Paulo: Dialética, 1999.

OLIVEIRA, Ricardo Mariz de. Princípios Fundamentais do Imposto de Renda. in Direito Tributário - Estudos em Homenagem a Brandão Machado. São Paulo: Dialética, 1998.

OLIVEIRA, Ricardo Mariz de. Tributação Internacional de "Goodwill” e Intangíveis. in Revista de Direito Tributário Atual. Vol. 26. Coord. Ricardo Mariz de Oliveira, Luis Eduardo Schoueri e Fernando Aurélio Zilveti. São Paulo: Dialética-IBDT, 2011. P. 29/47

PAULSEN, Leandro. Direito Tributário: Constituição e Código Tributário à Luz da doutrina e da jurisprudência. 11 ${ }^{\mathrm{a}}$ ed. Porto Alegre: Livraria do Advogado; EMAFE.

PEDREIRA, José Luiz Bulhões. Imposto Sobre A Renda - Pessoas Jurídicas. Vol. 1. Rio de Janeiro: Justec-Editora Ltda., 1979. 
PEREIRA JUNIOR, Moacyr. Comentários ao Código Tributário Nacional. Volume 5. Coordenadores Hamilton Dias de Souza, Henry Tilbery, Ives Gandra da Silva Martins. São Paulo: Editora Resenha Tributária, 1978/1979.

PIRES, Manuel; PIRES, Rita Calçada. Direito Fiscal. $4^{\mathrm{a}}$ ed. Coimbra: Almedina, 2010

POLIZELLI, Victor Borges. O Princípio da Realização da Renda e sua Aplicação no Imposto de Renda de Pessoas Jurídicas. Dissertação apresentada como parte dos requisitos para habilitação ao título de Mestre em Direito, sob a orientação do Prof. Dr. Luís Eduardo Schoueri, na subárea de Legislação Tributária, integrada ao Departamento de Direito Econômico e Financeiro da Faculdade de Direito da Universidade de São Paulo - USP. São Paulo: 2009.

PONTES, Helenilson Cunha. O Princípio da Proporcionalidade. São Paulo: Dialética, 2000

PONTES, Helenílson Cunha. Revisitando o Tema da Obrigação Tributária. in Direito Tributário - Homenagem a Alcides Jorge Costa. Vol. 1. Coordenação Luís Eduardo Schoueri. São Paulo: Quartier Latin, inverno de 2003.

PONTES, Helenilson Cunha. Sistema Tributário, Carga Tributária e Capacidade Contributiva. Grandes Questões Atuais do Direito Tributário. $8^{\circ}$ Volume. Coord. Valdir de Oliveira Rocha. São Paulo: Dialética, 2004.

PUGLIESE, Mario. Instituciones de Derecho Financeiro. Trad. Espanhola. México: Editorial Porrúa, 1976.

QUEIROZ, Luís Cesar Souza de. Imposto sobre a renda: requisitos para uma tributação constitucional. Rio de Janeiro, Forense. 1996

QUEIROZ, Mary Elbe. Imposto sobre a renda e proventos de qualquer natureza. Barueri/SP: Manole, 2004 
Regulamento do Imposto de Renda 1999 - anotado e comentado: atualizado até 30 de abril de 2009. FERREIRA, Antonio Airton; ONO, Juliana M. O; VALERO, Luiz Martins; TAKATA, Marcos Shigueo; LIMA, Marcos Vinícius Neder de; CASTANHO, Victor Hugo I. de Mello. Vol. 2: Tributação na Fonte e Sobre Operações Financeiras e Administração do Imposto. 12a ed. São Paulo: Fiscosoft, 2009.

ROCHA, Paulo Victor Vieira da. Os Princípios da Legalidade e da Capacidade Contributiva na Valoração Aduaneira. in Revista de Direito Tributário Atual. Vol. 22. Coordenação: Prof. Alcides Jorge Costa, Prof. Luis Eduardo Schoueri e Prof. Paulo Celso Bergstrom Bonilha. São Paulo: IBDT/Dialética, 2008.

ROCHA, Paulo Victor Vieira da. A Proporcionalidade na Tributação por Fato Gerador Presumido (Artigo 150, $\$ 7^{\circ}$, da Constituição Federal). Dissertação apresentada como parte dos requisitos para habilitação ao título de Mestre em Direito, sob a orientação do Prof. Dr. Luís Eduardo Schoueri, na subárea de Legislação Tributária, integrada ao Departamento de Direito Econômico e Financeiro da Faculdade de Direito da Universidade de São Paulo - USP. São Paulo: 2010. Acesso em 28.12.2011. Disponível em: http://www.teses.usp.br/teses/disponiveis/2/2133/tde-06072011-164915/).

Receita Federal do Brasil (sítio eletrônico) Acesso em 23.10.2011.

Disponível em: http://www81.dataprev.gov.br/sislex/paginas/23/1923/4682.htm. Acesso em 12/10/2011. Disponível em: http://www.receita.fazenda.gov.br/publico/arre/2011/Analisemensalago11.pdf. Acesso em 02/11/2011. Análise da Arrecadação - Janeiro a Setembro de 2010. Brasília/DF. P. $8 . \quad$ Disponível em: http://www.receita.fazenda.gov.br/publico/arre/2011/ApresentacaoSet11.ppt\#503,8,Slide\% 208.

Acesso em 15/11/2011. Disponível em: http://www.receita.fazenda.gov.br/Memoria/administracao/reparticoes/1822a1970/colet fe derais/default.asp.

RODRIGUES, Silvio. Curso de Direito Civil. 25a ed. São Paulo: Saraiva, 2004. 
RODRIGUES, Walter Piva. Substituição Tributária. São Paulo: Quartier Latin, 2004.

RODRIGUES, Walter Piva. A Substituição tributária é Instituto Típico do Direito Tributário. in Direito Tributário - Homenagem a Alcides Jorge Costa. Coordenação Luís Eduardo Schoueri. São Paulo: Quartier Latin, inverno de 2003.

ROLIM, João Dácio. A Compensação de Prejuízos Fiscais - Condições de Juridicidade e Necessidade - O Direito Comparado e o Direito Brasileiro. in Imposto de Renda e ICMS - Problemas Jurídicos. Coord. Valdir de Oliveira Rocha. São Paulo: Dialética, 1995.

ROLIM, João Dácio. O Conceito de Renda e Proventos de Qualquer Natureza: Alguns Casos Concreto - Adições e Exclusões ao Lucro Real. in Imposto de Renda - Questões Atuais e Emergentes. Coord. Valdir de Oliveira Rocha. São Paulo: Dialética, 1995

ROTHMANN, Gerd Willi. O Princípio da Legalidade Tributária. Temas Fundamentais do Direito Tributário. Atual. Antonio Roberto Sampaio Dória e Gerd Willi Rothmann. Belém: CEJUP, 1983. P. 77-120.

ROTHMANN, Gerd Willi. Prefácio In Planejamento Tributário: Análise de Casos. Organizador Leonardo Freitas de Moraes e Castro. São Paulo: MP Ed., 2010

ROTHMANN, Gerd Willi. O “Standard” Jurídico. São Paulo: Revista dos Tribunais Vol. $371,1966$.

ROTHMANN, Gerd Willi. Tributação Internacional sem Sujeito Passivo: uma Nova Modalidade do Imposto de Renda sobre Ganhos de Capital? in Grandes Questões Atuais do Direito Tributário. Vol. 10. Coord. Valdir de Oliveira Rocha. São Paulo: Dialética, 2006.

RUSSO, Pasquale. Os Princípios Fundamentais (Título Original: I Principi Fondamentali - Capítulo do livro "Manuale di Duitto Tributario: parte generale”, Milano: Giuffrè, 2002, 
p. 39-73). Tradução de Dalton Dallazem. in Princípios e Limites da Tributação. Coord. Roberto Catalano Botelho Ferraz. São Paulo: Quartir Latin, 2005

SARTIN, Agostinho. Sujeição Passiva e ICM. Revista de Direito Tributário no 25-26. 1983.

SCHOUERI, Luis Eduardo. Direito Tributário. São Paulo: Saraiva, 2011

SCHOUERI, Luis Eduardo. O Mito do Lucro Real na Passagem da Disponibilidade Jurídica para a Disponibilidade Econômica. in Controvérsias Jurídico-Contábeis (Aproximações e Distanciamentos). Coord.s Roberto Quiroga Mosquera e Alexsandro Broedel Lopes. São Paulo: Dialética, 2010.

SCHOUERI, Luis Eduardo. Imposto de Renda e os Lucros Auferidos no Exterior. in Grandes Questões Atuais de Direito Tributário - vol. 7. Coord. Valdir de Oliveira Rocha. São Paulo: Dialética, 2003.

SCHOUERI, Luís Eduardo. Fato Gerador da Obrigação Tributária. in Direito Tributário - Homenagem a Alcides Jorge Costa. Vol. 1. Coordenação Luís Eduardo Schoueri. São Paulo: Quartier Latin, inverno de 2003.

SCHOUERI, Luis Eduardo. Contribuição ao Estudo do Regime Jurídico das Normas Tributárias Indutoras como Instrumento de Intervenção sobre o Domínio Econômico. Tese apresentada como parte dos requisitos para a inscrição em concurso de Professor Titular do Departamento de Direito Econômico e Financeiro, área de Legislação Tributária, da Faculdade de Direito da Universidade de São Paulo - USP. São Paulo: 2002.

SCHOUERI, Luís Eduardo. Discriminação de competências e Competência Residual. in Direito Tributário - Estudos em Homenagem a Brandão. Coordenação Luís Eduardo Schoueri e Fernando Aurélio Zilveti. São Paulo: Dialética, 1998.

SCHOUERI, Luis Eduardo. Royalties e Assistência Técnica ao Exterior - Exigências da CIDE. Revista de Estudos Tributários. Ano VI. № 37. Porto Alegre: 2004. 
SILVA, De Plácido e. Vocabulário Jurídico Conciso. Atualizadores Nagib Salibi Filho e Gláucia Carvalho. $2^{\mathrm{a}}$ ed. Rio de Janeiro: Forense, 2010.

SILVA, Mauro. Direito ao Desenvolvimento e Fonte de Pagamento: em Busca dos Fundamentos Jurídicos para a Divisão Estatal do Poder de tributar a Renda. Direito Tributário Atual no 19. Coord. Alcides Jorge Costa, Luis Eduardo Direito Schoueri, Paulo Celso B. Bonilha. São Paulo: 2005. Dialética. 384 p.

SILVA, Volney Zamenhof de Oliveira. Código Tributário Nacional - Comentado, Anotado e Atualizado. Campinas/SP: 2002. Lex Editoras. 786 p.

SILVEIRA, Ricardo Maitto da. O Princípio da Realização da Renda no Direito tributário Brasileiro. Revista de Direito Tributário Atual no 21. São Paulo: Editora Dialética / I.B.D.F., 2007.

SILVEIRA, Rodrigo Maito da. Tributação e Concorrência. in Série Doutrina Tributária Vol. IV. São Paulo: IBDT/Quartier Latin, 2011.

SMITH, Adam. Lectures on Justice, Police, Revenue and Arms. 1956. P. 239:240.

SOBRINHO, José Wilson Ferreira. Imunidade Tributária. Porto Alegre: Editora Sergio Antonio Fabris Editor, 1996.

SOOS, Piroska E. The Origins of Taxation at Source in England. Amsterdam, The Netherlands: 1997. IBFD Publications.

SOUSA, Rubens Gomes de. A evolução do conceito de rendimento tributável. in Revista de Direito Público, vol. 14.

SOUSA, Rubens Gomes de. Compêndio de Legislação Tributária. $2^{\mathrm{a}}$ ed. Rio de Janeiro: Edições Financeiras S/A, 1954. 
SOUSA, Rubens Gomes de; ATALIBA, Geraldo; CARVALHO, Paulo de Barros. Comentários ao Código Tributário Nacional: Parte Geral. 2a ed. São Paulo: Quartier Latin, 2007.

THURONYL, Victor. The Concept of Income. 46 Tax. L. Ver. 45 (1990). in Federal Income Tax Anthology. CARON, Paul L.; BURKE, Karen C.; MCCOUCH, Grayson M. P.

TILBERY, Henry. Comentários aos artigos 43 a 45 do Código Tributário Nacional, atualizados por José Ruben Marone. in Comentários ao Código Tributário Nacional: Volume I. Coord. Ives Gandra da Silva Martins. $3^{\text {a }}$ Ed. São Paulo: Saraiva, 2002. P. 328 e ss.

TILBERY, Henry. A tributação dos ganhos de capital nas vendas de participações societárias pelas pessoas físicas. São Paulo: 1978. Editora Resenha Tributária / I.B.D.F. 139 p. FD - Faculdade de Direito. Localização, em 31.10.2008: http://dedalus.usp.br:4500/ALEPH/POR/USP/USP/DEDALUS/FULL/0017395.

TILBERY, Henry. Imposto sobre a Renda e Proventos de Qualquer Natureza (artigos 43, 44 e 45). in Comentários ao Código Tributário Nacional - Vol. 1. Coords. Hamilton Dias de Souza; Henry Tilbery; Ives Gandra da Silva Martins. Editora Bushatsky, 1975

TIPKE, Klaus, e YAMASHITA, Douglas. Justiça Fiscal e Princípio da Capacidade Contributiva. São Paulo: Malheiros Editores, 2002.

TORES, Ricardo Lobo. Curso de Direito Financeiro e Tributário. $17^{a}$ edição. Rio de Janeiro; São Paulo: Editora Renovar, 2010.

TORRES, Ricardo Lobo. O Princípio da Tipicidade no Direito Tributário. Direito Tributário Atual $\mathbf{n}^{\mathbf{0}}$ 18. Coord. Alcides Jorge Costa, Luis Eduardo Direito Schoueri, Paulo Celso B. Bonilha. São Paulo: Dialética, 2004. 
TORRES, Ricardo Lobo. Anulação de Incentivos Fiscais - Efeitos no Tempo. in Revista Dialética de Direito Tributário. Vol. 121. São Paulo: Dialética, 2005.

UTUMI, Ana Cláudia Akie. Tese de Doutorado defendida na Universidade de São Paulo Faculdade de Direito. O Regime Tributário Brasileiro do Imposto sobre a Renda de NãoResidentes. A Fonte como Critério de Conexão. São Paulo: 2006. FD - Faculdade de $\begin{array}{llll}\text { Direito. } & \text { Localização, } & \text { em } & \text { 10.2007: }\end{array}$ http://dedalus.usp.br:4500/ALEPH/POR/USP/USP/TES/FIND-ACC/3087757.

ZILVETI, Fernando Aurélio. Capacidade Contributiva e Mínimo Existencial. in Direito Tributário - Estudos em Homenagem a Brandão Machado. Coordenação: Prof. Luis Eduardo Schoueri e Prof. Fernando Aurelio Zilveti. São Paulo: Dialética, 1998.

ZILVETI, Fernando Aurélio. O Princípio da Realização da Renda. in Direito Tributário Homenagem a Alcides Jorge Costa. Coordenação Luís Eduardo Schoueri. São Paulo: Quartier Latin, inverno de 2003.

ZILVETTI, Fernando Aurélio. Progressividade, justiça social e capacidade contributiva. in Revista Dialética de Direito Tributário n ${ }^{\circ 6}$. São Paulo: Dialética, 2002

ZILVETI, Fernando Aurélio. Simplicius Simplicissismus - os Limites da Praticabilidade diante do Princípio da Capacidade Contributiva. in Revista de Direito Tributário Atual no 22. São Paulo: IBDT/Dialética, 2008.

VANONI, Ezio. Natureza e Interpretação das Leis Tributárias (Título Original: Natura ed Interpretazione Delle Leggi Tributairie) Tradução de Rubens Gomes de SOUSA. São Paulo: Edições Financeiras S.A., 1932.

VILLEGAS, Hector. Retenção de Tributos - Agentes de Retenção e Agentes de Percepção. Revista de Direito Tributário no 6, 1978.

VILLEGAS, Hector B.. Curso de Direito Tributário. Trad. Roque Antonio Carrazza. São Paulo: Editora Revista dos Tribunais, 1980. 
XAVIER, Alberto. Direito Tributário Internacional do Brasil. $6^{\text {a }}$ ed. Rio de Janeiro: Forense, 2004.

$* * * * * * *$ 